



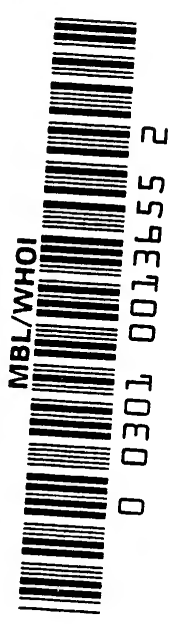


CRYPTOGAMIC BOTANY 
PRINTED BY

SPOTTISWOODE AND CO., NEW-STREET SQUARE LONDON 
Ace. "s28

M.B.L.

A HANDBOOK

$\mathrm{OF}$

\title{
CRYPTOGAMIC BOTANY
}

BY

ALFRED W. BENNETT, M.A., B.Sc., F.L.S.

LECTLRER ON BOTANY AT ST THOMAS'S HOSPITAL

$\mathrm{AND}$

GEORGE MURRAY, F.L.S.

SENIOR ASSISTANT, DEPARTMENT OF BOTANY, BRITISH MUSEUM

AND EXAMINER IN BOTANY, GLASGOW UNIVERSITY

WITH $3 \% 8$ ILLUSTRATIONS

\author{
LONDON \\ L O NGMANS, GRE E N, A N D CO. \\ AND NEW YORK : 15 EAST $16^{\text {th }}$ STREET \\ I 889
}




$$
\begin{aligned}
& 24 \\
& 2490
\end{aligned}
$$




\section{P R E F A C E.}

IN presenting to the botanical public this 'Handbook of Cryptogamic Botany,' the result of the labour of several years, the authors are deeply sensible of its inevitable defects. In traversing so wide a field, it is impossible that a single worker, or even two, can be practically acquainted with more than a comparatively small portion of it. It is necessary, therefore, to consult a literature, the extent of which, even for a single year, is appalling, and in which it is often difficult to distinguish between trustworthy and untrustworthy observations. The attempt has, notwithstanding, been made by the authors to acquaint themselves with the contents of every important publication of recent years bearing on Cryptogamic Botany, and issued in English, French, German, Italian, or Latin. It is beyond hope but that inaccuracies have crept in, or that observations which should have been noted have escaped attention. We shall be grateful to workers and writers who will inform us of any such inaccuracies or omissions, and especially to those who will kindly supply us, with a view to future editions, with copies of papers containing records of new and original observations or theories. Those relating to Vascular Cryptogams, Muscineæ, Algæ, and Schizophyceæ should be directed to Mr. Bennett ; those relating to Fungi, Mycetozoa, and Schizomycetes to Mr. Murray; these being the portions of the work actually written respectively by each of us, although we hold ourselves severally responsible for the whole contents of the volume.

So rapidly are facts accumulating, and new views of affinity being promulgated, that it may be necessary to change one's opinion on some points even in the interval between the printing of the earlier and later sheets of a volume like this ; and this must be held to account for any 
slight discrepancies that may be apparent between the general scheme of classification contained in the Introduction, and the details as carried out in the work itself.

We have also to acknowledge the permission given by the publishers of the following, works for electros to be taken from the illustrations contained in them, viz. :-De Bary, 'Comp. Morph. und Biol. der Pilze, Mycetozoen, und Bacterien,' and 'Vorlesungen über die Bacterien'; Sachs, 'Lehrbuch der Botanik' ; Goebel, 'Grundzüge der Systematik'; Luerssen, 'Die Kryptogamen'; Schenk, 'Handbuch der Botanik'; Zopf, 'Die Spaltpilze' : Hauck, 'Die Meeresalgen'; Reinke, 'Lehrbuch der Botanik' ; Thomé, 'Lehrbuch der Botanik'; Le Maout et Decaisne, 'Traité Général de Botanique'; Solms-Laubach, 'Einleitung in die Palæophytologie.'

Of the remaining illustrations, many have been taken from nature ; others have been copied from the illustrations of previous works, especially from Cooke's 'British Freshwater Algæ'; and for others we have to thank the courtesy of the Councils of the Royal and Linnean Societies, and the publishers of the 'Annals of Botany.'

In those branches of Cryptogamic Botany which have not been the immediate object of our own researches, we have freely consulted experts in these several departments, and have received from all the greatest kindness and most valuable assistance. In particular we wish to express our obligations in this respect to Mr. W. Carruthers, Pres. L.S., F.R.S. ; Mr. J. G. Baker, F.R.S. ; Professor F. O. Bower, F.L.S. ; Dr. R. Braithwaite, F.L.S. ; Mr. E. M. Holmes, F.L.S. ; and Mr. G. C. KAROP, F.R.M.S.

December, 1888 .

ALFRED W. BENNET'T, 6 PARK Village East, London, N.W.

GEORGE MURRAY,

British Museum (Naturai. History), Cromwell RoAd, London, S. IV. 


\section{CONTENTS.}

INTRODUCTION

PAGE

FIRST SUBDIVISION : VASCULAR CRYPTOGAMS . . . IO

Heterosporous Vascular Cryptogams . . . . 2 I

CLASS I. RHIZOCARPEE

„, II. SElaginellace. . . . . . . . 38

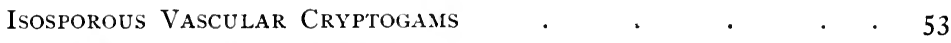

CLASS III. LYCOPODIACE. . . . . . . . $\quad .53$

„, IV. FILICES .

" V. OPHIOGLOSSACE.E . . . . . . . . 95

" VI. EQUISETACE.E . . . . . . . .

Fossil Vascular Cryptogams . $\quad . \quad$. $\quad . \quad$. 114

SECOND SUBDIVISION : MUSCINE 2 . . . . ${ }^{132}$

ClaSS VII. MUSCI .

„, Vili. Hepatic.E. . . . . . . . . 156

Fossil Muscineæ

THIRD SUBDIVISION : CHARACE.E • • • . . 173

ClasS IX. CHARACE.E. . . . . . . . 173

Fossil Charace.

FOURTH SUBDIVISION : ALGE

CLASS X. FLORIDEÆ .

" XI. CONFERVOIDE. HETEROGANE . . . . . 219

„, XII. FUCACE.E • • . . . . . . . 228

", XIII. PHAOSPORE .

", xiv. CONJUGat.e. . . . . . . .

„, XV. CONFERVOIDE $Æ$ ISOGAME . . . . . . 272

", xvi. Multinucleatie . . . . . . . 280

", XVII. CCENOBIE $/$. . . . . . . $29 \mathrm{I}$

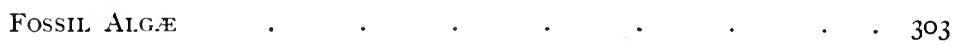


FIFTH SUBDIVISION : FUNGI • • • • . . . $\quad$ • 305

Group I. Phycomycetes . $\quad . \quad+\quad \cdot \quad \cdot \quad \cdot \quad \cdot 323$

CLASS XVIII. OOMYCETES • . . . . . . . . 323

, XIX. ZYGOMYCETES . . . . . . . 335

Group II. SPOROCARPEÆ

ClASS XX. ASCONYCETES • . . . . . 353

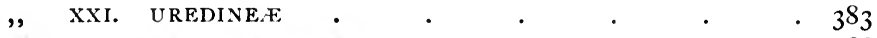

, XXII. BASIDIONYCETES . . . . . . . . 388

SIXTH SUBDIVISION : MYCETOZOA . . . . . . 401

CLASS XXIII. MYXOMYCTES • . . . . . . 40I

, XXIV. ACRASIE.E . . . . . . . . 405

SEVENTH SUBDIVISION : PROTOPHYTA • • • • 407

Group I. SChizophyce. . . . . . . . 408

CLASS XXV. PROTOCOCCOIDE.モ . . . . . . 409

,, XXVI. DIATOMACEA. . . . . . . . 4 . 49

, XXVII. CYANOPHYCE. . . . . . . . 426

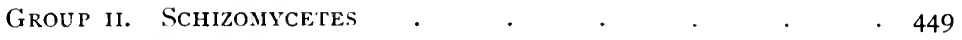

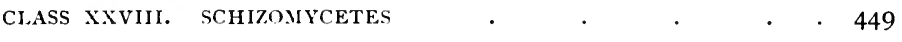

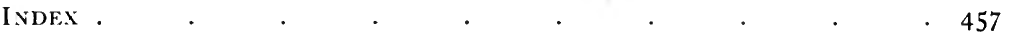

\section{Errata}

Page II, line 22, for oophnre read oophyte

" II, , 22, for sporophoie riad sporophyte

", 122, description of fig. 94, for Haulea read Hawlea

", 186, line io, for CFNoBife read CENobie.s.

", 187, , 12, for Mlesocarpea, Desmidiece read Mesocarpacea, Desmidiacea

", 187, lines 19, 24, for Desmidieæ read Desmidiaceæ

", 187, line 26, for Mesocarpeæ read Mesocarpaceæ

", 190, ", 4, for Desmidieæ read Desmidiaceæ

", 208, last line, for HYPN A:ACE.t read HYPNEACE.F

"209, line $\mathrm{I}$, for $\mathrm{H}$ ypnaea read Hypnea

" 209, , 4, for Rytiphlaa read Rytiphlœa

"2 23 , description of fig. 191, line $\mathrm{I}$, for corymlosa read corymbifera

"250, ," ,", ,223, ,2, for propagules read sphaceles

"280, line 6 from bottom, for '̈asycladacea read Dasycladaceæ

:296, last line, for polyhedra read polyhedra

," $31 \mathrm{x}$, description of fig. 271, line 1 , for Lib. read de By.

", 313, ," ," ,' 275, ,, I, for Portulacea read Portulaca

, 3rg', line 3, omit full stop after Johow

" 326 , description of fig. 287 , line 3 , also last line of page, for Portulacea read Portulack

, 335, line 2, insert comma after Pythium

", 343, ", 5 from bottom, for Tremellini read Tremellinea

," $381, ., 13$, for Barenetski reai Baranetzki 


\section{HANDBOOK}

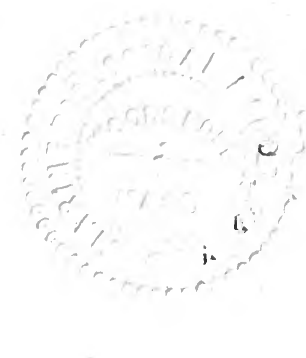

TO

\section{CRYPTOGAMIC BOTANY.}

\section{INTRODUCTION.}

No general handbook to Cryptogamic Botany has appeared in the English language since the Rev. M. J. Berkeley's in 1857. Since then this department of botanical science has gone through little less than a revolution. Not only has the number of known forms increased enormously, but additions of great importance have been made to our knowledge of structure by the use of the microscope, and to the genetic connection of different forms by the careful following out of the lifehistory of particular species. The present work is an attempt to bring within the reach of botanists, and of the public generally who are interested in the study of nature, an acquaintance with the present state of our knowledge in this branch of science. It is not intended to replace in any way the numerous excellent handbooks or monographs which exist of special farnilies or groups. Its scope is quite different. Neglecting the minor differences by which genera, or in many cases even orders, are distinguished from one another, the aim of the authors has been to bring before the reader the main facts of structure, of development, and of life-history, which mark the larger groups, contrasting them with one another, and referring only to the broader lines of demarcation within those groups. It is hoped that the work will be found useful to the beginner as well as to the more advanced student.

One great difficulty in our work has been to observe a due proportion in the space allotted to the different groups; and this has been increased by the necessity for a very different mode of treatment in the higher and the lower forms. Of the Vascular Cryptogams-more nearly allied in many respects to Phanerogams than to the lower Cryptogamsour knowledge is, with some exceptions, as minute and exhaustive as that 
of Flowering Plants ; and it is improbable that any living forms remain ta be discovered differing in any material point of structure from those cready known. Here, therefore, we are able to discuss systems of çassification which claim something like finality; and the difficulty of the compiler of a handbook is the enormous amount and the minute detai of the material to his hand, from which he has to cull those portions which seem suitable for his object. In order not to extend this portion of the work beyond due limits, it has been necessary frequently to practise rigid compression-beyond, probably, what many of our readers specially interested in these groups would have desired. The same remarks apply, to a large extent, to the Muscineæ. But in the Thallophytes, and especially in the lower Algæ and Chlorophyllous Protophyta, the case is very different. From the extremely minute size of many of these, and the much smaller extent to which they have been studied, new forms are constantly being discovered, and important additions are yearly being made to our knowledge of their life-history and of their structure. It is highly probable that among these groups, as well as in some of the orders of Fungi, forms will yet be discovered which cannot be assigned to any type at present known, gaps in the lifehistory of many species will yet be filled up, and organisms hitherto placed in widely separated families will ultimately be found to be phases in one cycle of development. We have therefore, in this branch of our subject, brought before our readers every fact of importance known to us which is vouched for by observers in whom we have confidence; and the classification here submitted is a purely tentative one. In the Algæ, the Fungi, and the Protophytes, we do not attempt an exhaustive erumeration of orders or families which shall include every known organism, but describe in detail only those types which are of greater importance, and of which our knowledge is more complete.

Something must be said on the classification adopted. In the Vascular Cryptogams and in the Muscineæ this proceeds on generally recognised lines, in which there is not much room for difference of opinion. But a very different treatment seemed necessary of the Thallophytes, and of the relationship to one another of the Algæ and Fungi, and of the different orders within each of these groups. Here the systems proposed are almost as numerous as the original investigators, and it has been necessary to choose that which appeared to the authors to bring together those organisms which are most nearly related to one another. Whether these two familiar terms represent a natural bifurcation in the classification of the lower organisms, is a question which has been very variously answered by different observers and theorisers. About fifteen years ago a system of classification of the Thallophytes was pro- 
posed, on authority entitled to the highest respect, ${ }^{1}$ which altogether abolished the bifurcation into Algæ and Fungi. On this system the sole character made use of in their primary classification was the mode of reproduction. First came the Protophyta, in which no sexual mode of reproduction is known, followed by three primary classes (in ascending order)-the Zygosporeæ, Oosporeæ, and Carposporeæ-distinguished solely by the degree of complexity of the sexual process. Each of these four classes was then divided into a series containing chlorophyll and a series not containing chlorophyll, the former including the organisms hitherto known as Algæ, the latter those hitherto known as Fungi.

In support of this view it was urged, with great plausibility, that, reproduction being the most important event in the life-history of a plant, the mode in which this is brought about must become fixed in each group by heredity; while such a subordinate character as the presence or absence of chlorophyll is seen, in the higher plants, to be entirely without importance in determining affinity. But a little consideration will show that it is unsafe to apply the same rule to more highly and to less highly organised forms. In the higher forms of life the mode of sexual reproduction becomes, in its main features, absolutely fixed ; and throughout the vast range of Angiosperms - as in the higher animalsthere is entire uniformity in this respect in all important points; while in external morphology, and in the mode in which they obtain their livelihood, there is the greatest diversity, even within a narrow circle of affinity. In the animal kingdom we may point, as an illustration of this law, to the existence of such a family as the Cetacea among Mammalia; among flowering plants we have only to consider such phenomena as the occurrence of parasitism, insectivorous habits, or the suppression of chlorophyll, in individual genera dispersed through a large number of natural orders. Even in subsidiary characters connected with the process of reproduction there is not the uniformity that might have been expected. While such an apparently subordinate point as the number of cotyledons in the embyro is so constant as to give its name to primary divisions of Phanerogams, a character which might have been supposed to be much more important (but which, it is instructive to observe, is connected with the mode in which the germinating embryo receives its nutriment) - viz. the presence or absence of endosperm - is not always constant, even within narrow limits. The first necessity of a nascent organism is to live; and hence it is not surprising to find that in the lower forms of life the one character which remains most constant within wide circles of affinity is the mode of life. In the course of development

' See Sachs's Text-book of Botany, 2nd English edition, p. 244. 
of the higher forms nature may be said to have tried a variety of experiments in the mode of reproduction ; on the whole there is a continual advance, but still by no means infrequent fallings back to simpler modes ; and unless this law of retrogression is taken into account, any system of classification must be pro tanto imperfect and misleading.

If these considerations have any weight, it is not surprising that, although the system of classification of Thallophytes above alluded to has been adopted by a few authorities in this country and on the Continent, it has not met with general acceptance. The adoption of its leading principle, that ' in each class Fungi have diverged as ramifications from various types of Algæ,' ' is seen to lead to such startling results as the collocation in the same class of Spirogyra and Mucor, of Volvox and Peronospora, of Callithamnion and Agaricus. It may, on the contrary, be safely asserted that several of the most important groups among Fungi (take, for example, the Uredineæ and the Basidiomycetes) display no traces of genetic affinity with any known class of Algæ ; and if, on the other hand, we have forms like Saprolegnia and Chytridium among Fungi, or Leptothrix and Beggiatoa among Protophyta, which betray strong indications of a degraded affinity with groups of Algæ, this by no means contradicts the general law that Fungi as a class form an altogether independent series.

Retrogression may take the form of the suppression of either the vegetative or the reproductive organs; and wherever you have one of these sets of organs displaying strong development, while the other set of organs is very feeble or altogether wanting, you have prima facie evidence of retrogression. Of this examples will be given in the sequel.

While, therefore, we adopt the Protophyta as a primary class, with the general limits proposed by Sachs, we have no hesitation in reverting to the time-honoured division of the higher Thallophytes into the two great groups of Algæ and Fungi.

The classification of Fungi adopted is that of de Bary, consisting of a main series (called the series of the Ascomycetes), composed as follows : (I) Peronosporeæ (with Ancylisteæ and Monoblepharis), (2) Saprolegnieæ, (3) Mucorini or Zygomycetes, (4) Entomophthoreæ, (5) Ascomycetes, (6) Uredineæ; and of divergent groups as follows : (7) Chytridineæ, (8) Protomyces and Ustilagineæ, (9) Doubtful Ascomycetes (Saccharomyces, \&c.), (го) Basidiomycetes.

The groups $\mathrm{I}-4$ are Phycomycetes, and 7 and 8 of the second series go with them; while 9 stands in relation to 5 , and 10 to 6 ; and they are 
so considered together in the linear series in which they come in the book. The Phycomycetes approach the Algæ (Chlorophyceæ) very nearly ; and the other groups of Fungi bear a relation to the Phycomycetes which seems to negative any supposition of their independent connection with algal forms.

One other point had to be decided, whether to commence at the bottom or at the top of the series. Had our purpose been to construct theoretically a genealogical tree for the lower forms of vegetable life, the former course must necessarily have been pursued, and in the laboratory there is no doubt much to be said in favour of proceeding from the simple to the more complicated types. But to the general student, 'from the known to the unknown' is a very sound principle. And, among flowerless plants, not only are the higher types far the best known to the ordinary observer, but they are also those about the life-history of which we have the greatest certainty of knowledge. We have been confirmed in our belief of the correctness of this decision by observing that in the last edition of Huxley and Martin's 'Elementary Biology' these authors have (in the zoological section) abandoned the ascending for the descending order.

The question of terminology is one of the greatest stumbling-blocks to the student of cryptogamy. Not only are new terms being constantly introduced, many of them quite needlessly or from an erroneous idea of structure; but some that are in continual everyday use are employed in different senses by different writers of repute. The first requisite in a terminology, after accuracy, is simplicity; and to this end we have, wherever possible, used anglicised instead of Latin and Greek forms. Many of the terms which we employ throughout this volume-such as sporange, archegone, antherid, conobe, sclerote, epiderm, \&c.-will probably be accepted at once; and it seems strange that the awkward and uncouth foreign forms of these words should have held their ground so long. With others there will no doubt be greater hesitation; but we hope to see all, or nearly all, of the anglicised forms we have used gradually introduced into all English works on cryptogamic botany, and the same principle possibly extended in other cases where we have not ventured to apply it.

A striking instance of the uncertainty which still surrounds cryptogamic terminology is afforded by the various senses in which different writers use the everyday term 'spore.' Le Maout and Decaisne and Asa Gray speak of spores as 'the analogues of seeds ;' Berkeley describes the unfertilised oospheres of Fucus as spores; Vines includes under the term all reproductive cells produced either asexually or sexually; while Sachs defines a spore as a reproductive cell produced 
either directly or indirectly by an act of fertilisation, reserving the term 'gonidium' for those which are produced without any previous act of impregnation. It is obvious that one practical defect of this last suggestion is that it may necessitate a perpetual change of terminology as our knowledge advances. Every fresh extension of the domain of sexual fecundation-and it is probable that many such will. take place-will involve the removal of a fresh series of reproductive cells from the category of gonidia to that of spores, even though they may not be the immediate result of an act of fertilisation. Again, if the spores of ferns and mosses are the indirect result of impregnation, it is difficult to say why the term should not ultimately include all reproductive bodies whatever, except the spores of the 'apogamous ferns' with which Farlow and de Bary have recently made us acquainted, and of other similar abnormal productions, which are certainly not the result of impregnation, direct or indirect.

It seems a sounder principle-and is certainly more convenient to the student-to base a system of terminology on facts which can be confirmed by actual observation, rather than on unproved hypotheses. We propose, therefore, as the basis of our terminology, to restore the term spore to what has been in the main hitherto its ordinary signification, and to restrict its use to any cell produced by ordinary processes of vegetation, and not directly by a union of sexual elements, which becomes detached for the purpose of direct vegetative propagation. The spore may be the result of ordinary cell-division or of free-cell-formation. In certain cases (zoospore) its first stage is that of a naked primordial mass of protoplasm. In rare instances it is multicellular, breaking up into a number of cells (polyspore, composed of merispores, or breaking up into sporids).

The simple term spore will, for the sake of convenience, be retained in Muscineæ and Vascular Cryptogams ; but in the Thallophytes it will generally be used in the form of one of those compounds to which it so readily lends itself, expressive of the special character of the organ in the class in question. Thus, in the Protophyta we have chlamydospores; in the Myxomycetes, sporangiospores; in the Saprolegnieæ and many Algæ, zoospores; in the Uredineæ, teleutospores, acidiospores, uredospores, and sporids; in the Basidiomycetes, basidiospores; in the Ascomycetes (including Lichenes), ascospores, polyspores, and merispores; in the Diatomaceæ, auxospores; in the Edogoniaceæ, androspores ; in the Florideæ, tetraspores; and others belonging to special groups. The cell in which the spores are formed will, in almost all cases, be called a sporange; and this term will be compounded in the same way as spore. 
In describing the heterosporous Vascular Cryptogams it is usual to speak of the spores which give rise to the female prothallium and those which give birth to antherozoids as 'macrospores' and 'microspores' respectively. The first of these terms is doubly objectionable : firstly, etymologically, the proper meaning of $\mu$ ak ós being not 'large,' but 'long ;' and secondly, from the close similarity in sound of the two terms, an inconvenience, especially in oral instruction, which every teacher must have experienced. Seeing that the correct and far preferable terms megaspore and microspore are used by Berkeley, Areschoug, Carpenter, and others, it is difficult to understand how 'macrospore' can ever have got into general use ; and these terms, together with megasporange and microsporange, will be used in the following pages. For similar reasons megazoospore is always used instead of 'macrozoospore.'

The male organs of fecundation are so uniform in their structure throughout Cryptogams that very little complication has found its way into their terminology. The cell or more complicated structure in which the male element is formed is uniformly known among Cormophytes as well as Thallophytes as an antherid; the fecundating bodies are almost invariably naked masses of protoplasm, provided with vibratile cilia, endowed with apparently spontaneous motion, and bearing the appropriate name of antherozoids or 'spermatozoids.' The former of these is perferable for two reasons; from its etymological connection with antherid, and because the use of terms compounded from 'sperm' should, for reasons to be detailed presently, be avoided for male organs. In only two important groups, Florideæ and Ascomycetes, are the fecundating bodies destitute of vibratile cilia and of spontaneous motion : in the former case they are still usually termed 'antherozoids;' in the latter 'spermatia,' and their receptacles 'spermogonia.' In order to mark the difference in structure from true antherozoids, it is proposed to designate these motionless bodies in both cases pollinoids; the term 'spermogone' is altogether unnecessary, the organ being a true antherid.

A satisfactory terminology of the female reproductive organs presents greater difficulties, from the much greater variety of structure, and the larger number of terms already in use. The limits we have placed to the use of the term 'spore' and its compounds require the abandonment of 'oospore' for the fertilised ovum or oosphere in its encysted state (enclosed in a cell-wall), anterior to its segmentation into the embryo ; and this is the most important change involved in the terminulogy of the present volume.

In devising a term which shall include all those bodies which are the immediate result of impregnation, it was necessary to take two points specially into account. Firstly, the term must be capable of 
defence on etymological grounds ; and secondly, it must, like 'spore,' be suited for ready combination. After much consideration we have decided on adopting the syllable sperm. No doubt the objection will present itself that the Greek $\sigma \pi \epsilon^{\prime} \rho \mu \alpha$, like the Latin 'semen,' while originally meaning the ultimate product of fertilisation, came afterwards to signify the male factor in impregnation; and hence, in zoology, terms derived from these roots are used for the male fertilising bodies. But the objection applies to a much smaller extent to phyto-terminology, and the use in the proposed sense of the syllable 'sperm' is justified by the universal employment in phanerogamic botany of such terms as 'gymnosperm,' 'angiosperm,' 'endosperm,' and ' perisperm.' Of cryptogamic terms, where the syllable is used in the reverse sense, 'sperm-cell,' for antherozoid or pollen-grain, has never come into general use in this country ; 'spermatozoid ' is easily replaced by 'antherozoid ;' 'spermogonium' is simply a peculiar form of antherid, and 'spermatium' has already been referred to. Accepting this term as the least open to objection of any that could be proposed, it will be found to supply the basis of a symmetrical system of terminology, which will go far to redeem the confusion that at present meets the student at the outset of his researches. For the unfertilised female protoplasmic mass the term oosphere is already in general use; and, though not all that could be desired, it is proposed to retain it. The entire female organ before fertilisation, whether unicellular or multicellular, is designated by a set of terms ending in gone, such as archegone and carpogone, again-following existing analogy.

The term reproduction itself is often far too vaguely employed by botanical writers. We propose to limit its use, in accordance with its etymology, to the production of a new individual, that is, to a process of impregnation; all cases of non-sexual multiplication being described as propagation.

The object of the writer of a handbook is to gather up and to collate material already existing, winnowing, to the best of his judgment, the wheat from the chaff. Except, therefore, where original observations may have been made by the compiler himself, it will contain nothing new. In compiling from the writings of the original observers it was thought best, as far as possible, to use their own words, and this will account for the frequent close resemblance in the following pages of the descriptions contained to those in such works as de Bary's 'Comparative Anatomy of the Phanerogams and Ferns,' the 'Comparative Morphology and Biology of the Fungi, Mycetozoa, and Bacteria,' by the same writer, the scheme of which has been mainly adopted in outline, and Goebel's 'Outlines of Classification and Special Morphology.' Admirable, on 
the whole, as are the translations of these works by which the Clarendon Press has enriched English scientific literature, it is the original work rather than the translation that we have in all cases followed. We wish here to express the great obligation under which we lie to these writers, and to acknowledge the extent to which we have borrowed from them. In the chapter on Fossil Vascular Cryptogams we have, to a considerable extent, followed Graf zu Solms-Laubach's excellent 'Einleitung in die Palæophytologie,' though with some modifications. To the description of each group or family we have appended a bibliography of the researches on which that description is founded ; these having again been consulted, wherever possible, in the original language. 


\section{FIRST SUBDIVISION. VASCULAR CRYPTOGAMS.}

The Vascular Cryptogams include all the highest forms of cryptogamic life, and constitute a well-marked group of plants intermediate between the Gymnosperms, or lowest division of Flowering Plants, and the lower or Cellular division of Flowerless Plants. From the former they differ mainly in the mode in which fertilisation is effected; from the higher forms of the latter in the much greater differentiation of tissues. The term 'vascular' Cryptogams is, however, strictly speaking, correct only to a limited degree. Although the arborescent and fruticose species display as well-marked a differentiation of their tissues as Flowering Plants, into epidermal tissue, 'vascular' bundles, and fundamental tissue, and the bundles consist of distinct xylem and phloem (without any intermediate cambium, as in Gymnosperms), it is only rarely, as in that group of Flowering Plants, that the xylem is composed of vessels in the true sense of the term.

The Vascular Cryptogams and the highest families of Cellular Cryptogams are distinguished from Flowering Plants by an obvious Alternation of Generations between Sexual Generation or Oophyte, and Non-sexual Generation or Sporophyte. The former is a small and purely cellular structure, usually of very temporary duration, the purpose of which is to bear the sexual organs of reproduction, male antherids and female archegones, the structure of which is uniform in all essential characters throughout the class, and which are borne on a cellular expansion, the prothallium. This prothallium may be either monoecious or dicecious - that is, the male and female organs may be borne on the same or on different prothallia. The act of fertilisation consists in the impregnation of an oosphere, a naked mass of protoplasm contained within the central cell of the archegone, by one or more antherozoids, minute masses of protoplasm endowed with spontaneous motion by means of vibratile cilia, which escape from the cells of the antherid and penetrate to the central cell of the archegone. The immediate result of the impregnation of the oosphere is that it invests itself 
with a cell-wall of cellulose, and thus becomes an oosperm, which develops into the embryo, and finally into the sporophyte, which is often of great size and extended length of life. It is this that is commonly known in popular language as the Fern, Club-moss, \&c. On it are produced, without any process of fertilisation, the spores, which are always single cells, protected by two or three coats, and giving rise on their part, when they germinate, to the oophyte. This is the cycle of development in the Isosporous families of Vascular Cryptogams. In the Heterosporous families there are produced (always on the same plant) two different kinds of spore, differing very greatly in size-larger megaspores and smaller microspores. The former produce female prothallia, that is, those which bear archegones only; the latter male prothallia, bearing antherids only, or even antherozoids, without the intervention of a male prothallium or antherid. The spores are always endogenous structures, produced by free-cell-formation within a spore-case or sporange, which again, in the heterosporous families, is a megasporange or a microsporange, according as it contains megaspores or microspores. The sporanges are often collected into groups known as sori, and these may again be enclosed within special chambers, sporocarps or conceptacles. Various kinds of vegetative propagation, similar to those of Flowering Plants, also occur on both oophyte and sporophyte; and in certain exceptional cases either the oophore or the sporophore may be entirely suppressed, constituting the phenomena of apogamy and apospory respectively. These will be described especially under Ferns, where they are of the most common occurrence.

It may be useful in this place to compare the structure of the organs of reproduction and the phenomena of impregnation in Vascular Cryptogams with those of Phanerogams, and to endeavour to trace the requisite homologies, ${ }^{1}$ although these cannot be fully understood without some knowledge of the details of structure described under the separate families. It has been usual to compare the pollen-grain of Phanerogams with the antherozoid of Vascular Cryptogams; but this is not strictly accurate. The essence of the act of fecundation consists in the coalescence of the protoplasmic contents of an active (male) and of a passive (female) cell. The protoplasmic endoblast or cell-contents in each case must, therefore, be homologous ; that is, the antherozoid with the protoplasmic contents of the pollen-grain which, in Flowering Plants, is brought into contact with the embryonic vesicle by means of the pollen-

1 Hofmeister was the first to point out these homologies in his Vergleich. Unters. über Keimung u.s.zu. der höheren Kryptogamen (see the Ray Society's translation, On the Germination, Ecc., of the Higher Cryptogamia, p. 438). They have since been traced out more completely by Hanstein, Celakovsky, and others. 
tube ; or probably the more correct homology is that of the nucleus of the antherozoid with the 'generative' nucleus of the pollen-grain. The most important difference between Cryptogams and Phanerogams lies in the mode in which this contact between the male and female elements is brought about. In Flowering Plants it takes place by the penetration into the embryo-sac, through the micropyle of the ovule, of the extension of the inner coat of the pollen-grain known as the pollen-tube, excited into activity by the viscid secretion of the stigma. The pollen-grain has therefore in the first place' to be conveyed from the anther to the stigma ; and the various parts of the flower of Flowering Plants are all more or less concerned, directly or indirectly, with arrangements for facilitating the conveyance of pollen. In Flowerless Plants, on the contrary, contact between the male and female elements is effected by the protoplasmic contents escaping from the male cells and coming directly into contact with the oosphere in consequence of an independent power of motion imparted to these naked masses of protoplasm (antherozoids) by the vibratile cilia with which they are provided. This impregnation always takes place in water or moisture, and no external agency is needed to bring it about. Hence the absence from all Flowerless Plants of any conspicuous compound organ analogous to the flower of Phanerogams. The true homology of the pollen-grain of Phanerogams appears to be with the microspore of the heterosporous Vascular Cryptogams, notwithstanding the fact that the contents of the microspore break up into a number of antherozoids, each capable of impregnating an oosphere ; while the pollen-grain, as a rule, emits only a single pollen-tube. Here, as in other phenomena, we are guided to the true homology by comparing the highest Cryptogams with the lowest Phanerogams, the Gymnosperms, which form a connecting link between them and Angiosperms. In all Gymnosperms, as in some Angiosperms, the pollen-grain is divided into several cells, only one of 'which (very much larger than all the rest) emits a short pollen-tube. The large fertile cell in the pollengrain of Gymnosperms corresponds to the larger fertile portion of the nicrospore of Selaginellaceæ, to the entire contents of the microspore of Marsileaceæ, to the terminal cell of the germinating filament in Salviniaceæ, and to the antherid of the isosporous Vascular Cryptogams. In Angiosperms the sterile cells of the pollen-grain of Gymnosperms appear to be sometimes entirely suppressed, and the pollen-grain becomes unicellular. The contents of the pollen-grain of Angiosperms, together with the intine or inner coating of the grain, are therefore homologous with the antherid of Cryptogams. Seeing that the motile antherozoids have to be conveyed to the oosphere through the medium of water, it is convenient for both antherid and archegone to be freely 
exposed to the action of moisture at the time of maturity. Hence, in all the isosporous Vascular Cryptogams, by far the largest portion of the product of germination of the hermaphrodite spore is the cellular tissue or prothallium (reduced to a comparatively small size in the Lycopodiaceæ and Ophioglossaceæ), on which are borne both the antherids and the archegones. In the heterosporous Salviniaceæ the male prothallium is reduced to a simple unseptated germinating filament; and in Marsileaceæ it altogether disappears. In Selaginellaceæ it takes the form of the small sterile cells at one extremity of the microspore ; in Gymnosperms, of the sterile cells of the pollen-grain; in Angiosperms it is almost entirely suppressed. The contents of the pollen-grain corre-

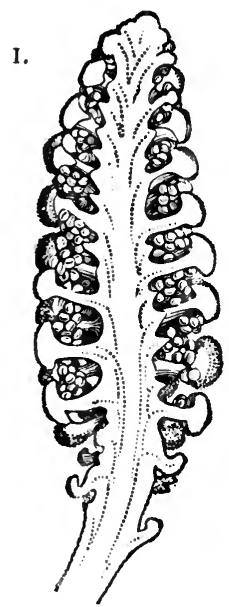

FIG. 1.-I., male catkin of Zamia (Cycadeæ). II. III., antheriferous scale and pollen-sacs.

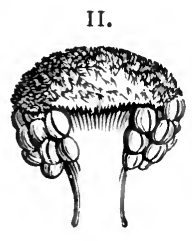

III.

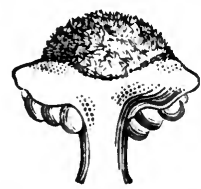

Fig. 2.-Peltate scale of Equisetum, with sporanges $\mathrm{sg}$. (After Sachs.)

sponding to the antherozoids, the pollen-grain itself becomes homologous with the microspore, the pollen-sac or anther-cell to the microsporange. Even in external appearance the pollen-sacs of Coniferæ and Cycadeæ bear a striking resemblance to the sporanges of some Vascular Cryptogams. The modes of formation of the pollen-grains within the pollensac and of spores within the sporange, from an original archespore, are identical in their main features.

Turning now to the female organs of reproduction, we must trace the homology of these back from the product of the union of the two elements, which in all the higher plants, whether flowering or flowerless, niay be termed the oosperm, developing later into the embryo. In 
Flowering Plants this is the product of the action of the contents of the pollen-grain on the protoplasnic embryonic or germinal vesicles; in the higher Flowerless Plants, of the action of the antherozoid on the oosphere, or protoplasmic contents of the central cell of the archegone. The naked masses of protoplasm known as the germinal vesicles (or perhaps rather that one only which is ultimately fecundated) are therefore unquestionably homologous with the naked mass of protoplasm known as the oosphere. In Vascular Cryptogams the central cell which contains the oosphere is a portion of an archegone which is borne on a prothallium resulting from the germination of a spore or of a megaspore, as the case may be. To understand the homologies with the higher Phanerogams we must again have recourse to the intermediate Gymnosperms. In
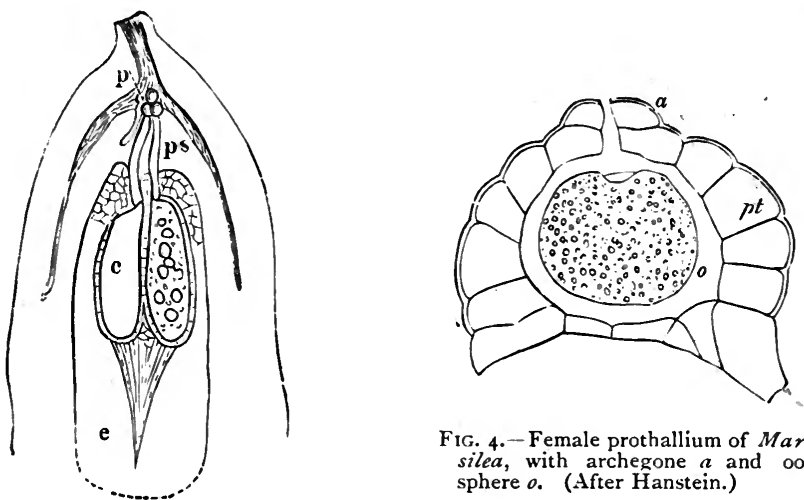

FIG. 4.-Female prothallium of Marsilea, with archegone $a$ and oosphere $\boldsymbol{o}$. (After Hanstein.)

FIG. 3.-Fertilisation of Abies (Coniferæ). $\not$, pollen-grains ; $p s$, pollen-tube ; $\ell$, embryosac ; $c$, secondary embryo-sac or corpusculum. $(\times 60$.

this class the female elements are not directly developed in the interior of the embryo-sac, but within certain chambers produced within the embryo-sac, the secondary embryo-sacs or 'corpuscula, the homologues of the central cell of the archegone. In connection with them there have been detected other structures comparable to the neck and the canal-cells of the archegone. The object of the peculiar structure of the archegone and the deliquescence of the canal-cells being to facilitate the passage of the motile antherozoids to the oosphere, these are no longer wanted when impregnation is effected by means of a pollentube. The archegone (except the central cell) is therefore reduced to a rudimentary condition in Gymnosperms, and disappears altogether in Angiosperms, where the embryonic vesicles are produced directly within 
the embryo-sac, the homologue of the megaspore. The nucellus of the ovule must then be regarded as corresponding to the megasporange; but it is difficult to carry the homology further. In Filices and Lycopodiaceæ an hermaphrodite prothallium usually exposes both kinds of sexual organ to the action of moisture ; in Equisetaceæ we find a normal differentiation into male and female prothallia, but produced from one kind of spore only ; in the heterosporous families the differentiation is carried back to the spores and sporanges, and the female prothallium is altogether a subordinate product, and never has any separate existence apart from the megaspore, within which it is more or less concealed, only that part which bears the archegones being exposed. In Angiosperms it has been suggested that we have a rudiment of the female prothallium surviving in the peculiar 'antipodal cells' found within the embryo-sac in certain natural orders; but the homology is doubtful. In the Selaginellaceæ we find also the rudiments of two other structures which characterise the ovule of Flowering Plants. The sterile tissue which occupies the lower part of the megaspore in this order is probably the first appearance of the endosperm (albumen) which is found in the seed of a large number of Flowering Plants; the purpose in both cases being the same, to provide the embryo with nutritive material during the early stages of its growth. In all Phanerogams the young embryo is borne on a longer or shorter pedicel of cellular structure, the suspensor or proembryo, which, again, we find for the first time in the same order of Cryptogams.

In all the isosporous Vascular Cryptogams the sexual generation or oophyte has an independent existence distinct from the spore which produced it ; while in the heterosporous families the prothallium recedes more and more into the background, existing only within the megaspore ; and at the same time the male organs or antherids become more rudimentary in structure. In Gymnosperms the female prothallium and the antherids (as distinct from the antherozoids) have become much reduced, and in Angiosperms have completely disappeared. While, therefore, in Characeæ alternation of generations disappears by the suppression of the non-sexual generation which bears the spores, in Phanerogams the same result is brought about by an exactly opposite process, the suppression of the sexual generation or prothallium with its antherids and archegones, and the coalescence of male and female elements takes place within the non-sexually produced embryo-sac of the ovule, which corresponds to the megaspore.

The life-history and general structure of the various organs in Vascular Cryptogams may now be described more in detail.

The immediate product of the germination of the spore or megaspore 
is always a prothallium, which is usually a green plate of tissue lying flat on the soil, very commonly lobed or reniform in shape, sometimes microscopic, but often quite visible to the naked eye, from $\frac{1}{4}$ to $\frac{1}{2}$ an inch in diameter, and constituting, with its organs of reproduction, the oophore, oophyte, or sexual generation. The prothallium usually disappears as soon as the non-sexual generation has firmly rooted itself in the soil ; but in Gymnogramme (Filices) it attains a larger size, and continues its existence for a considerable time, producing a succession of reproductive organs. The oophyte never becomes differentiated into stem and leaves, as in the Muscineæ, nor does it contain any vascular tissue. It usually consists of only a single layer of cells filled with chlorophyll, except a marginal cushion, where there are several layers. Here it puts out into the soil numerous colourless elongated cells, the organs of attachment, or rhizoids, ${ }^{1}$ among which, or scattered over the whole of the under surface and margin, are the archegones and antherids. True vegetative budding takes place but rarely on the prothallium; but it sometimes, in certain Filices, exhibits apogamy, the sporophore springing directly from it, without the intervention of the sexual organs. In some Lycopodiaceæ and in the Ophioglossaceæ the prothallium is subterranean, destitute of chlorophyll, and cylindrical or tuberous. In the Hymenophyllaceæ (Filices) it is often filiform. In the isosporous families the prothallium is most commonly monœcious, less often diœcious. In the heterosporous families it is far less fully developed. That which arises from a megaspore is very small, formed within the spore, and at no period maintains an independent existence; while that developed within a microspore is still more rudimentary.

The archegones of Vascular Cryptogams are produced on the prothallium, usually on the under side of the cushion. Each archegone consists of a swollen basal portion or venter, and a neck, usually composed of four longitudinal rows of cells; the venter is buried in the tissue of the prothallium, the neck alone projecting above it. The archegone originates from a superficial cell of the prothallium, which divides by a tangential wall into an inner and an outer cell; the latter then develops, by further divisions, into the four rows of cells constituting the neck, which is, therefore, always comparatively short. The inner cell puts out a protuberance between the neck-cells, which is first of all separated as the neck-canal-cell, and below it a small portion is again separated from the lower larger cell as the ventral canal-cell; the

1 These organs are frequently termed root-hairs; but it is better to confine this term to the epidermal appendages (trichomes) of the roots of Phanerogams and of the sporophyte generation of Vascular Cryptogams, between which and true rhizoids there is a functional rather than a morphological homology. 
lowermost portion of the lowest cell remains of a comparatively large size, and is the central cell containing the oosphere. When mature, the two canal-cells deliquesce into mucilage, which swells up considerably, drives apart the four apical lid-cells or stigmatic cells of the neck, and is ejected; an open canal being thus formed to allow the access of the antherozoids to the oosphere, which always takes place in moisture, the ejected mucilage assisting also in this process.

The antherids appear as roundish papillæ on the margin, or dispersed over the under surface of the prothallium; in some cases they are imbedded in its tissue. Each antherid consists of a comparatively small number of cells ; when mature the cell-walls are ruptured under water, and from each escapes a swarming antherozoid. The antherozoids are spirally coiled threads of protoplasm, the body of which is formed from the nucleus of the mother-cell, with a number of fine vibratile cilia on the anterior coils. There is generally attached to each antherozoid, as it escapes from its mother-cell, a vesicle of protoplasm containing starch-grains, formed out of the cytoplasm of the mother-cell, which, adhering to one of its posterior coils, is dragged along with it during its swarming, but becomes detached before its entry into the neck of the archegone. In the heterosporous families the antherid is of very simple structure, and is either produced directly within the microspore, or after the preliminary formation of a few cells, which must be regarded as a rudimentary prothallium.

The form and size of the non-sexual generation or sporophyte vary within very wide limits, from the filmy, moss-like Hymenophyllaceæ (Filices) to the arborescent tree-ferns (Filices), and must be described more in detail under the various families. It arises in the archegone, from the oosperm or fertilised oosphere. The first effect of impregnation is that the oosphere invests itself with a cell-wall of cellulose, thus becoming the oosperm, which then divides into a small number of undifferentiated cells, in which condition it is known as the embryo. In the earliest subsequent divisions of the embryo may be recognised the rudiments of the first root, of the first leaf or cotyledon, and of the apex of the stem; while at the same time a lateral outgrowth termed the foot is formed at the bottom of the venter, and draws from the prothallium the first nourishment for the young plant. The venter at first grows vigorously, enveloping the embryo, until this latter finally protrudes free, leaving the foot still attached to it for some time as a nutritive organ. The primary root soon disappears, and in some Hymenophyllaceæ, and in Salvinia and Psilotum, is not followed by others ; but in the great majority of cases other true ruots succeed in acropetal succession, and the prothallium then disappears. The cotyledon always 
remains small; the first stem bends upwards, and other leaves of a more complicated structure appear on it.

The roots of Vascular Cryptogams usually arise in acropetal succession on the stem (in some ferns on the leaf-stalk), and branch either monopodially or dichotomously. There is never one preponderating root continucus in a downward direction with the main stem corresponding to the tap-root in Flowering Plants. They are distinguished from the roots of Flowering Plants by the lateral roots springing, not from the procambium, but from the innermost cortical layer of the mother-root. They are abundantly covered with root-hairs, trichomic formations by means of which the nutritive materials are absorbed from the soil. They possess a true root-cap. Salvinia (Rhizocarpeæ) and Psilotum (Lycopodiaceæ) are altogether rootless, as also are a few Hymenophyllaceæ (Filices), the function of roots being performed by underground branches of the stem.

The degree of development of the stem varies within very wide limits. In the tree-ferns it is of erect habit, and attains great height and considerable thickness. In many herbaceous ferns the internodes of the erect stem are altogether suppressed, while the underground portion forms an elongated rhizome. In the existing Lycopodiaceæ, and in some Selaginellaceæ the very elongated creeping stem is mainly above ground ; in the rootless forms, like Psilotum, branches of the stem bending down into the soil perform the function of roots. In some paludose species belonging to the Rhizocarpeæ the stem is almost entirely suppressed, and in Salvinia the whole plant floats on the surface of the water. The mode of branching is either monopodial or dichotomous; the leaves do not usually produce buds and branches in their axils, as in Flowering Plants.

In all the larger species the stem displays a distinct differentiation of tissues into the three systems, fundamental, epidermal, and 'vascular' or fascicular. The so-called vascular bundles are closed, like those of Monocotyledons-that is, they contain no formative cambium ; and they are usually but not always concentric, the phloem portion surrounding the xylem portion in the form of a phloem-sheath. Each bundle, or a group of bundles, is again very frequently surrounded by a single layer of strongly sclerenchymatous cells belonging to the fundamental tissue, the vascular bundle-sheath, where it encloses a single, or plerome-sheath, while it surrounds a group of bundles. The prevalent, though not the exclusive form of thickening in the xylem is that of scalariform tracheides; true vessels formed from the coalescence of cells are rare; in the phloem sieve-tubes are of common occurrence. Potonié holds that there is no sharp differentiation between the xylem and phloem portions 
of the 'vascular' bundles of Vascular Cryptogams, and prefers for them the terms hadrome and leptome respectively. According to Van Tieghem, the secondary tissues, like those of Flowering Plants, proceed normally from two concentric generating layers - an external one in the cortex, forming bark outwardly and secondary cortex inwardly, and an inner one in the central 'vascular' cylinder intercalated in the liber and in the xylem of the primary 'vascular' bundles, producing secondary liber outwardly and secondary xylem inwardly. The epiderm is in most cases abundantly provided with trichomic appendages of various kinds.

The size and form of the leaves are extremely various. In Lycopodium, Selaginella, and some other genera, they are very small, unsegmented, and lanceolate, not unlike those of mosses, and form a dense imbricated clothing to the stem ; in Psilotum they are altogether rudimentary ; in the Equisetaceæ they are reduced to divisions or teeth of a membranous sheath; in Isoëtes (Selaginellaceæ), Pilularia (Rhizocarpeæ), and Phylloglossum (Lycopodiaceæ), they are long, narrow, and awl-shaped. In some ferns the barren and fertile leaves differ from one another in appearance, and especially in the degree of division of the lamina. In Salvinia they are of two kinds, one floating on the surface of the water and entire, the other submerged, very finely divided, and performing the function of a root ; in Azolla (Rhizocarpeæ) they are floating and bilobed. In some genera of Filices and their allies the leaves are quite entire ; in the Hymenophyllaceæ they are very delicate, consisting of only a single layer of cells, and in the smaller species closely resemble those of the foliose Hepaticæ; while in most ferns they are of considerable (in the tree-ferns of gigantic) size, with well-marked petiole, rachis, and lamina, and distinguished by the great extent to which the lamina is divided. In most cases (except the Hymenophyllaceæ) they are abundantly provided with stomates. The tissue beneath the epiderm consists of a parenchymatous mesophyll containing abundance of chlorophyll, the portion of which adjacent to the upper epiderm is frequently developed as palisade-parenchyme. This mesophyll is permeated by 'vascular' bundles or veins, which branch off from the cauline bundles, and are distinguished, in the majority of ferns, by their dichotomous mode of branching, in contrast to the reticulate anastomosing in Dicotyledons, and the parallel arrangement in most Monocotyledons. Among Gymnosperms a similar arrangement is presented by Salisburia and Stangeria. The floral metamorphosis of the leaves of Flowering Plants does not occur in Vascular Cryptogams, nor their special agglomeration round the organs of reproduction as in mosses.

The mature sporange, theca, or spore-case, is usually a roundish 
capsule borne on a stalk, of small size and simple structure. Its morphological value varies greatly, and will be referred to more particularly under the separate families. In the majority of Filices the sporanges are trichomic structures, and are collected into groups or sori, which are 'always located in connection with a 'vascular' bundle on the under side or margin of the leaf. In the Marattiaceæ they spring from a hypodermal mass of tissue. In the Ophioglossaceæ a segment of a leaf is transformed into sporanges. In Selaginella and Lycopodium they arise from the growing point of the stem above the axil of a leaf. In Psilotum they are sunk in the extremity of branchlets of a peculiar form. In the Salviniaceæ they are enclosed in receptacles or sporocarps, which are themselves modifications of divisions of the leaf. The mode of formation of the spores closely corresponds to that of the pollen-grains in Flowering Plants. The spore-forming tissue can always be traced back to a single cell or a row or layer of cells, the archespore, which may be distinguished at a very early period from the remaining cellular tissue by the nature of its contents. From this proceeds the sporogenous tissue, which afterwards becomes the mother-cells of the spores by perfectly regular divisions, the details of which differ in the different families. This is surrounded by one or more layers of cells, the tapetal cells or tapete, and the whole is enclosed in the wall of the sporange, itself composed of one or more layers of cells. In the heterosporous families the distinction between megaspores and microspores is manifested only at a comparatively late period in their development. In the isosporous families the spores are always strictly unicellular, very commonly elliptical or reniform in shape. The coat always consists of two separable layers-an outer cuticularised exospore, often elevated into warts or other prominences ; and an inner endospore, composed of cellulose, which bursts through the exospore on germination, producing the germ-filament, which develops by cell-division into the prothallium. In the megaspores of the heterosporous families these are further protected on the outside by a third separable, greatly hardened layer, the epispore. The mode in which the spores escape from the sporange differs in the different families.

A purely vegetative mode of propagation by means of gemmæ or bulbils borne on the sporophyte occurs especially in Filices and Equisetaceæ; on the oophyte vegetative propagation is less common.

The classification of Vascular Cryptogams is attended with considerable difficulty. None of the systems as yet produced have much clain to be regarded as natural ; and, until some doubtful points are cleared up connected with fossil forms which may be links between existing families, the primary distinction into Heterosporons and Isosporous 
Vascular Cryptogams is so convenient, that we have decided to adhere to it, without dogmatising as to its permanent retention. In the boundaries of the families, again, there is equal room for diversity of opinion. Whether to retain the Psiloteæ under Lycopodiaceæ, and the Isoëteæ under Selaginellaceæ, and whether to regard the true Filices, the Marattiaceæ, and the Ophioglossaceæ as constituting one, two, or three classes, are points on which there is much to be said in favour of classifications different from that which we have decided to adopt.

LITERATURE.

Thuret-(Zoospores and Antherids) Ann. Sc. Nat., vol. xiv., I850, p. 214; and vol. xvi., p. 5.

Hofmeister-Germination, Development, and Fructification of the Higher Cryptogams, Ray Soc., I 862.

Schacht-Die Spermatozoiden, Braunschweig, I 864.

Dippel-(Fibrovasc. Bundles) Ber. Deutsch. Naturf. u. Aerzte, 1865.

Nägeli u. Leitgeb-(Root) Nägeli's Beitr. z. wiss. Bot., I867.

Kny-(Prothallium) Sitzber. Ges. Naturf. Freunde, Berlin, I 868.

Millardet - (Prothallium) 1869.

Russow-Vergleich. Unters., Petersburg, 1872.

Janczewski - (Archegone) Bot. Zeit., I872; p. 418.

Goebel - (Sporangia) Bot. Zeit., I880 and I88I.

Sadebeck- Die Gefässkryptogamen, I 880 .

Prantl -Morphologie der Gefässkrypt., 1881 .

Van Tieghem-Bull. Soc. Bot. France, I883, p. I69.

Potonié-(Vasc. Bundles) Jahrb. Bot. Gart. Berlin, 1883 .

Leitgeb - (Spores) Ber. Deutsch. Bot. Gesell., I883, p. 246.

Celakovsky-Pringsheim's Jahrb. f. wiss. Bot., xiv., I884, p. 29 r.

Bower-(Leaf) Proc. Roy. Soc., xxxvii., I884, p. 6I.

Rabenhorst-Crypt. Flora Deutschland, Vasc. Crypt., by Luerssen, I884-88.

De Bary-Comparative Anatomy of Phanerogams and Ferns, I884.

Klein - (Dehiscence of Sporange) Bull. Soc. Bot. France, 1884, p. 292.

Leclerc du Sablon-(Spores) Ann. Sc. Nat., vol. ii., 1885, p. 5.

Campbell - (Antherozoids) Ber. Deutsch. Bot. Gesell., I887, p. 120.

Baker - Handbook to Fern Allies, 1887.

\section{HETEROSPOROUS VASCULAR CRYPTOGAMS.}

\section{Class I.-Rhizocarpeæ.}

The Rhizocarpeæ or Hydropterideæ constitute a class composed of only a small number of genera, none of which includes more than a few species. They grow submerged in or floating on water, and derive their name from the circumstance that the non-sexual organs of propagation are produced in the radicular region, or near the base of the leaves. 
The spores are of two kinds, one of which is many hundred times larger than the other. The larger spores, or megaspores, produced in megasporanges, are female; the smaller spores, or microspores, produced

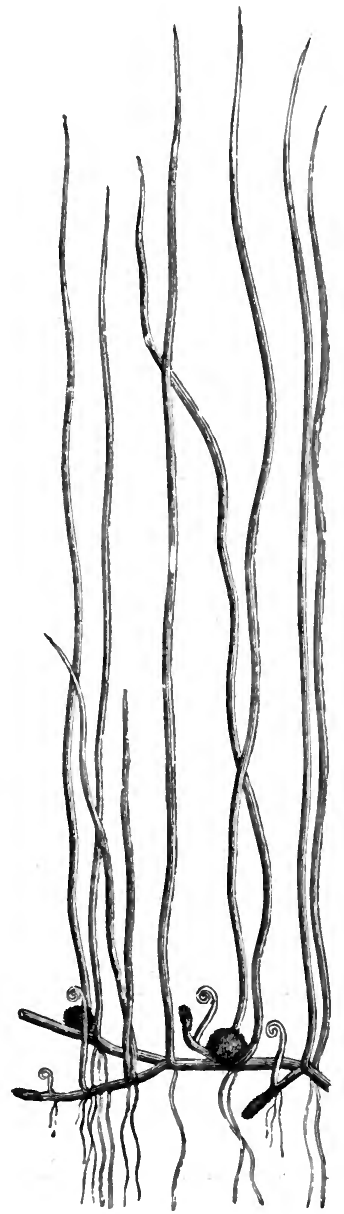

FIG. 5.-Pilularia globulifera L., with fructification, natural size. (After Luerssen.)

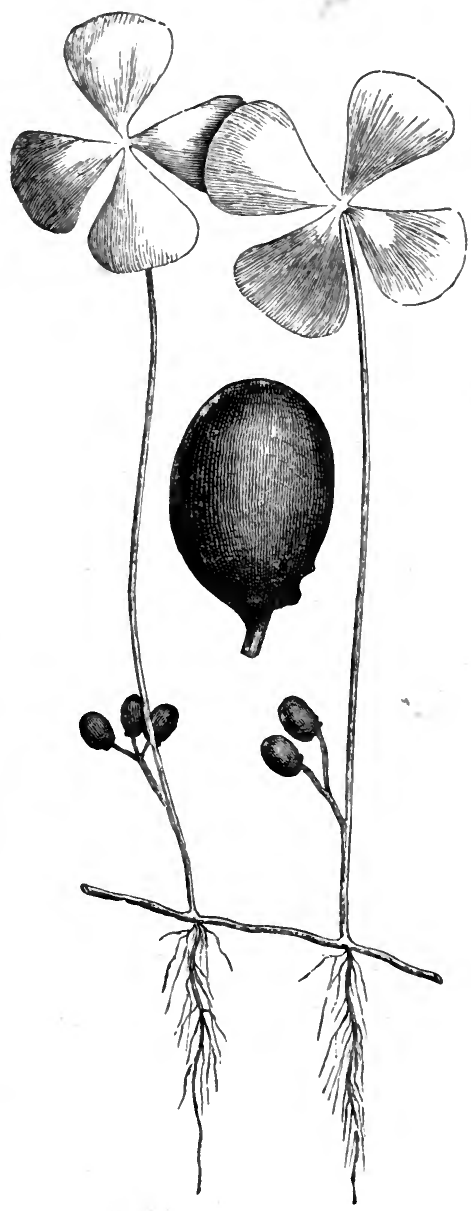

FIG. 6.-Marsilea quadrifolia L., with fructification, natural size, and fructification enlarged. (After Luerssen.)

in microsporanges, are male. The megaspore is not completely spherical, but has a distinct apical protuberance, which at the period of maturity is enveloped in a thick firm layer termed the epispore, formed by the 
hardening of mucilage derived from the disorganisation and deliquescence of a portion of the contents of the sporange. The female prothallium is formed within the apical papilla of the megaspore, and is exposed by the bursting of the enveloping epispore. It never completely frees itself from the megaspore, and is usually altogether destitute of chlorophyll. It bears one or more archegones, differing from one another in smaller points of structure in the different genera. The microspores do not give birth to a male prothallium, nor even to antherids, in the sense in which the terms are employed elsewhere in

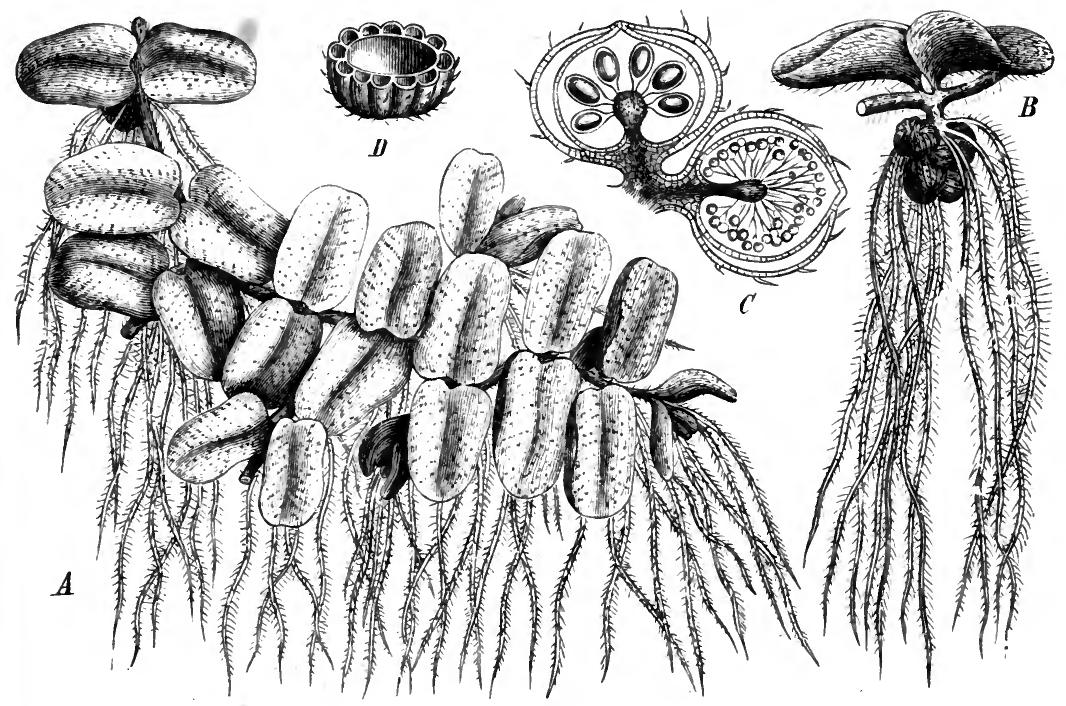

FIg. 7.-Salvinia natans L. $A$ and $B$ natural size, the latter with two aërial leaves and submerged fertile leaves ; $C$, two sporocarps, slightly magnified and diagrammatic, one containing a few megasporanges, the other a large number of microsporanges; $D$, section of empty sporocarp, slightly magnified. (After Luerssen.)

Vascular Cryptogams ; the contents divide more or less directly into the parent-cells of the antherozoids, which, accompanied by peculiar vesicles attached to them, reach and impregnate the oosphere contained in the central cell of the archegone.

The external form of the sporophyte or non-sexual generation varies widely in the different genera. The growth of both stem and root is always the result of successive divisions from a single apical cell. The stem is extremely abbreviated in Salvinia (Schreb.) and Azolla (Lam.) ; procumbent and creeping in Marsilea (L.) and Pilularia (L.). It is traversed 
by closed concentric 'vascular' bundles, each surrounded by its bundlesheath, and the branching is always monopodial. The roots-except in Salvinia, which is rootless-are fibrous, are furnished with a root-cap, and branch monopodially. The leaves also vary greatly in form. In Pilularia they are erect, cylindrical, and setiform : in Marsilea (L.) the lamina consists of several distinct leaflets at the extremity of a more or less elongated petiole. In both these genera the vernation is circinate. In Azolla the leaves are deeply bifid. Salvinia is remarkably heterophyllous. While the majority of the leaves retain an ordinary leaf-like

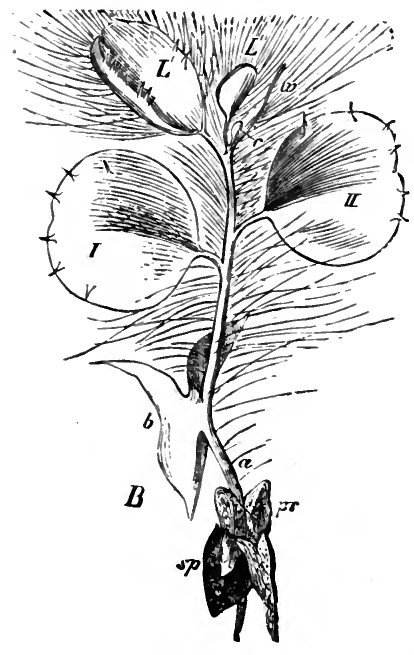

FIG. 8.-Salvinia natans L. Young plant still attached to the prothallium $p r$, and megaspore $s p$. $b$, scutiform leaf; $I$ and $I I$, first and second leaves ; $L^{\prime}$ and $L^{\prime \prime}$, later aërial, and $w$, submerged leaf of the first whorl. (After Pringsheim, $\times 20$.) habit, others develop into coriaceous scutiform structures, while others again divide into a number of capillary segments, which perform the function of roots, and at the same time bear the non-sexual propagating organs.

The fructification is of a more complicated structure than in other classes of Vascular Cryptogams. In Salvinia it springs from the lower teeth of the submerged leaves; in Azolla from the pendent section of the deeply bipartite leaf, or rather of one particular leaf; in Pilularia it stands Beside and beneath the leaves ; in Marsilea (L.) on the under side of the petiole, or of the base of the leaf itself. The Rhizocarpeæ are always monœcious, the two kinds of sporange being produced on the same individual, and usually in close proximity. The structure and degree of complexity of the fructification differ in the different genera. The sporanges are always associated together in groups. Each of these groups, known as a sorus or sporocarp, is a closed capsule-like chamber, which is of epidermal or trichomic origin, its wall or indusium, often considerably hardened, being an extension of the epiderm. Each sporocarp is regarded by Celakorsky as the homologue of the integumented ovule of Flowering Plants. In the Salviniaceæ the sporocarp is unilocular; in the Marsileaceæ it is plurilocular, and the wall indurated into a hard shell. Each sporocarp may contain sporanges of one kind only or of both kinds; in the former case male and female sporocarps are often associated together in 
groups. The megasporanges are often considerably larger than the microsporanges.

In the early stages of their development no difference is exhibited between the megasporanges and microsporanges. In both cases the sporange originates in a papilla placed on the placenta, which divides first into an upper and a lower cell, the latter developing, by repeated transverse septation, into the pedicel, the former into the body of the sporange, and dividing. ultimately into a large central tetrahedral archespore, surrounded by a layer which almost immediately breaks up into two layers of tapetal cells or mantle-layers. The archespore further divides into sixteen spore-mother-cells, and each of these into four special spore-cells arranged tetrahedrally. A difference is now manifested according as the sporange is to develop into a mega- or a microsporange. In the latter case each of the sixty-four cells develops into a microspore, while the tapetal cells become disorganised, and changed into the frothy mucilage which subsequently hardens and encloses the spores. In the former case only one of the sixty-four cells develops into a megaspore, growing rapidly at the expense of the others, and ultimately filling up the cavity of the sporange. The remaining sixtythree spore-cells, as well as the tapetal cells, become disorganised, and deliquesce into a frothy mucilage which envelops the ripe megaspore, ultimately hardening into the epispore, which splits to allow the emergence of the prothallium. In Azolla the mucilage of the microsporanges forms the peculiar massula which will be described later.

A more detailed description requires the division of the Rhizocarpeæ into the two orders Salviniacea (Salvinia and Azolla) and Marsileacea (Marsilea and Pilularia), which are, perhaps, not in reality very nearly related to one another.

\section{ORDER I.-SAlviniacee.}

The female prothallium of Salvinia is formed within the apical papilla of the megaspore. The protoplasm in this papilla appears to separate from that of the rest of the spore, and then breaks up by free-cell-formation into several portions, which remain for a time unclothed with cellulose ; subsequently they secrete cell-walls, and form a tissue, which breaks through the cell-wall of the papilla, and forces its way through the epispore, which splits into a three-lobed body. The prothallium, when it first emerges from the epispore, has a somewhat triangular form, with an elevated ridge along its median line, and two wing-like appendages, subsequently forced apart by the growth of the embryo, which hangs down on each side of the spore. It contains a considerable amount of 
chlorophyll, but never loses its connection with the megaspore, even after the commencement of the germination of the sporophyte. The first archegone makes its appearance on the elevated dorsal ridge of the prothallium, and subsequently two others are formed, one on each side of the first. If one of these is fertilised no more archegones are produced, and the prothallium ceases growing. But if no impregnation has taken place the prothallium continues to grow, and produces from one to three additional rows, each consisting of from three to seven archegones. In Azolla the prothallium has the form of a slightly convex

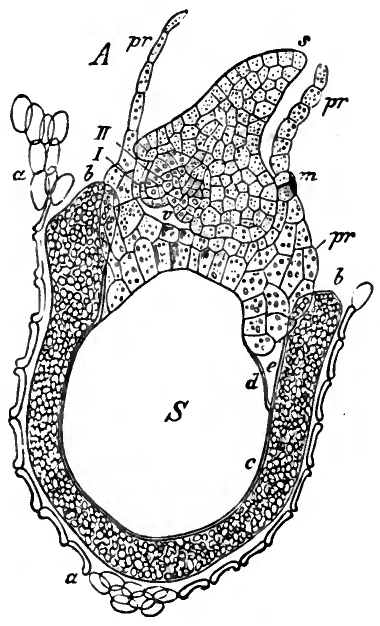

FIG. 9.-Salvinia natans. Longitudinal section through megaspore and prothallium. $a$, wall of sprrange; $b$, epispore, formed of hardened mucilage: $c$, coat of spore; $d$, diaphragm separating prothallium from spore-cavity; $p r$, prothallium; $m$, neck of archegone ; $I, I I$, first two leaves of embryo; $s$, scutiform leaf or cotyledon. (After Pringsheim, $x$ 70.) disc, consisting, in its central part, of several layers of cells, at the margin of only one. A single archegone is first formed, near the centre of the prothallium. If this

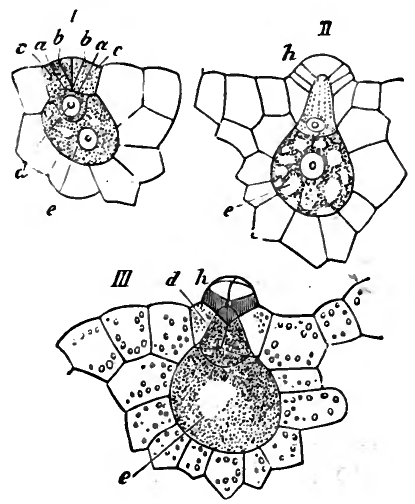

FIG. ro.-Archegone of Salvinia natans in three stages. $a, b, c$, divisions in the neck-cells ; $\boldsymbol{d}$, neck-canal-cell : $e$, oosphere ; $h$, neck-cells. (After Pringsheim, $x_{150}$.)

is fertilised, no others are formed; if not, it is followed by a few others.

The archegone of Salvinia is a nearly globular cavity, its venter being completely buried in the tissue of the prothallium. The central cell is at first somewhat elliptical, its axis lying obliquely to the surface of the prothallium. Its apex is at first covered by four cells belonging to the epiderm, arranged in the form of a cross. Each of these four neck-cells divides by transverse septa into a row of three cells, the four rows thus forming a short neck. The large central cell now elongates upwards and forces its way between the lowermost four cells of the neck, and its 
conical point becomes cut off by a septum, forming the neck-canal-cell. Below this a second very small portion of the central cell is again cut off to form the ventral canal-cell, so that the canal now consists of two cells. These two cells become transformed into mucilage, which escapes by forcing apart the four apical or stigmatic cells, leaving an open canal In the meantime the protoplasm of the large basal portion of the central cell has become transformed by contraction into the oosphere. The archegone is now ready for impregnation, the antherozoids reaching the oosphere through a funnel-shaped depression in the epispore and the open canal. After fertilisation the canal again closes up by the expansion of the stigmatic cells. The archegone of Azolla resembles that of Salvinia in all essential points.

The male prothallium of Salvinia is reduced to a mere rudiment. The microspores lie imbedded in a mass of hardened, granular, frothy mucilage, formed by the disorganisation of the tapetal cells. They do not escape from this mucilage, but the endospore of each develops into a tubular filament which pierces through the mucilage and the wall of the sporange. The extremity of this filament which projects outside the sporange is curved, and becomes cut off by a septum. The lower and larger of the two cells thus formed is regarded as a rudimentary prothallium ; the terminal cell, which again divides into two,

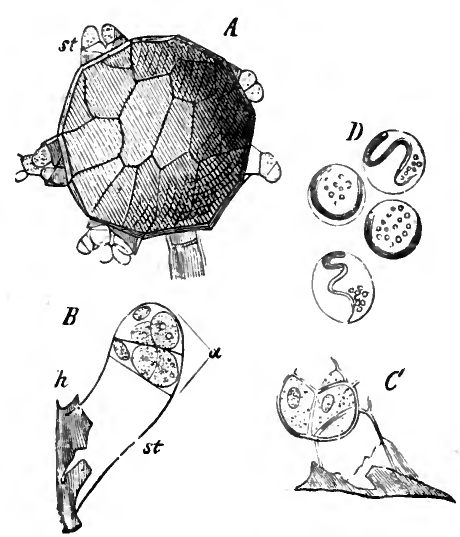

FIG. Ir.-Salvinia natans. $A$, microsporange, with microspore-tubes st. $(\times 100)$.$B , microspore-tube (\times 200)$ with closed, $C$ with empty antherid. $D$, antherozoids $(\times 600)$. (After Pringsheim.)

as a rudimentary antherid. The protoplasm of each of the two antheridial cells divides into four, and each of these eight masses of protoplasm escapes as an antherozoid. Each antherozoid is a corkscrewlike coil of protoplasm, bearing vibratile cilia of great length at its broader extremity. To the same extremity is attached a vesicle, composed of a portion of the protoplasm of the antheridial cells which was not used up in the formation of the antherozoids, and which does not leave the antherozoid during the period of its 'swarming.'

The development of the multicellular embryo from the fertilised oosperm has been very carefully followed out in Salvinia. The first segmentation is by a nearly vertical wall (at right angles to the surface of the prothallium) into two somewhat unequal portions, each of which 
again divides by a septum nearly at right angles to the first one. Further divisions then take place. Out of the posterior of the first two segments (the one immediately beneath the mouth of the archegone) is formed the foot of the young plant, by which it is attached to and derives its nutriment from the prothallium. From the anterior of these two segments is derived a peculiar foliar structure, differing from all the subsequent leaves, the cotyledon or scutiform leaf, by the growth of which the terminal bud of the stem becomes directed downwards. No root whatever is produced. Azolla is stated to have a second cotyledon. Both stem and root (in Azolla) are developed from a single apical cell, which is rounded in front and pointed below. The primary meristem-layers are differentiated, as in Flowering Plants, into plerome, periblem, and dermatogen.

The mature sporophyte differs considerably in appearance in the two genera, but always floats on the surface of the water. The very short stem is erect or horizontal, and the branching of both stem and root (in Azolla) is monopodial. The root, stem, and leaf-stalk are each traversed by a single concentric 'vascular' bundle of simple structure, containing spiral and annular tracheides. The leaves of Azolla are very crowded, and are placed in two rows on the dorsal side of the stem; but in some species they have the appearance of standing in four rows. They are of delicate membranous texture, and are always deeply bifid, one lobe being submerged and the other floating. The floating lobe of each" leaf has a remarkable cavity, covered by a double epidermal layer, with the exception of a narrow orifice which opens into the cavity. This cavity is formed during the growth of the leaf by a more rapid growth of the epiderm than of the subjacent tissue, and is itself clothed with an epidermal layer. The cavities are frequently occupied by well-developed colonies of Nostoc-filaments. Salvinia is remarkably heterophyllous (see figs. 7, 8). The first leaf of the young plant is the scutiform or peltate leaf already mentioned, which is produced near the base of the stem. It is coriaceous in texture and sagittate in form. Next are produced, also singly, two ovate aerrial leaves. All the subsequent leaves are arranged in whorls of three, two of which are aërial, with flat, ovate, or orbicular lamina, floating on the surface of the water; while the third or submerged leaf at once branches into long slender filiform segments, which hang down into the water and perform the function of roots. The leaves of adjacent whorls are placed alternately, so that the mature plant has two rows of ventral submerged, and four rows of dorsal aërial leaves. Each leaf has a single definite apical cell in Salvinia, but not in Azolla. The leaves of both genera are furnished with stomates, which, according to Strasburger, differ considerably, both in structure and 
appearance, from those of Flowering Plants. Those of Salvinia are remarkably small, and are inserted about halfway up the epidermal cells, which are eight or nine times their height. Air-pores occur also in the submerged leaves. The very simple roots of Azolla are of endogenous origin. The root-cap originates from a single cell ; in A. Caroliniana (Willd.) the cap is eventually thrown off, leaving the root-tip naked.

The sporanges are enclosed in unilocular sporocarps, formed two together or in larger numbers; in Salvinia on the youngest teeth of the submerged leaves, in Azolla on the pendent submerged lobe of the deeply bifid leaves, and only on the lowermost leaf of each shoot. The leaf-segment which is destined to become fertile first of all develops into a columel or placenta, to which the sporanges are attached. An annular wall, the rudiment of the indusium, then becomes elevated from the base of the columel, eventually overtops its apex, closes up, and thus forms the wall of the sporocarp. The sporocarp of Salviniaceæ is therefore a metamorphosed portion of a leaf, and corresponds to a sorus in the Hymenophyllaceæ (Filices), with the difference that in the latter the envelope remains open in the form of a cup, while in the former it closes completely over the sorus, as in Cyathea (Filices). The indusium is much more strongly developed than that of ferns, and completely envelops the sorus; it consists of two layers of cells, the

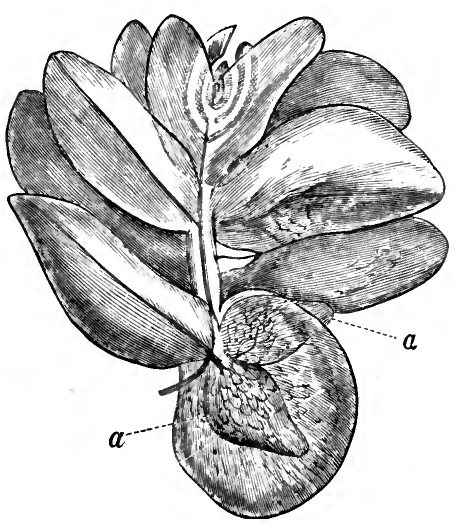

Fig. 12.-Fertile shoot of Azolla filiculoides Lam., with two female sporocarps, $a(\times 27)$. (After Strasburger.) walls of which are, in Azolla, strongly lignified in the upper part. Each sporocarp contains one kind of sporange only; but both kinds always occur on the same individual, and may even spring from the same metamorphosed leaf. In Salvinia the megasporanges are considerably larger than the microsporanges, and the number of the latter in a sporocarp is greater (see fig. 7). In Azolla the number of microsporanges in a sporocarp is about forty, while the female sporocarps contain only a single megasporange, and consequently only a single megaspore, enveloped first in the wall of the sporange, and then in the greatly hardened indusium. The microsporanges are nearly globular capsules, with long slender pedicels, the wall consisting, when mature, of a single layer of cells. The megasporanges are pear-shaped, with much shorter and 
stouter pedicels, and arise from the apex of the columel. In the formation of the pedicels of the megasporanges longitudinal cell-division takes place, as well as transverse. The mode of formation of the spores within each kind of sporange has already been described in general terms, after the preliminary separation of a single external layer of cells which develops into the wall of the sporange. The sixty-four microspores appear to be disposed without any arrangement in the cavity of the microsporange. A large nucleus lies at the end of the megaspore which is nearest the apex of the sporange. Before fertilisation both kinds of sporange become detached from their pedicels, and are carried

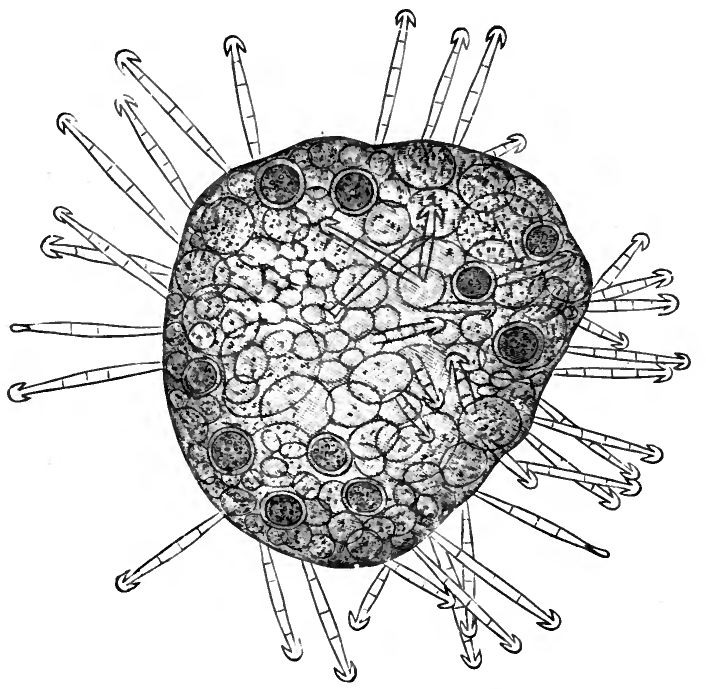

Fig. 13.-Massula of Azolla Caroliniana Willd. (×240). (After Strasburger.)

up to the surface of the water in the spring by the surrounding masses of Algæ. The epispore then splits above the apex of the megaspore into three lobes, between which the emerald-green prothallium forces itself, and impregnation is effected. In Azolla the epispore assumes a still more striking form. In the microsporanges it has the appearance of a large-celled tissue, and breaks up into two or more spherical masses called massula, each of which envelops a number of microspores, and has a distinct coat. In some species, but not in all, the surface of these masses is covered with hair-like appendages, barbed at the apex, the glochids, by means of which, after emerging from the sporange, and when floating on the surface of the water, they attach themselves to the 
floating megaspores. The roundish megaspore, which does not nearly fill up the sporange, is completely covered by a very thick warty layer of hardened frothy mucilage, its epispore, which projects far above the apex, and separates, in its upper part, into either three or nine large pear-shaped masses of the same substance, terminating in a tuft of fine threads. These bodies constitute a floating apparatus for the megaspore, the fine threads floating on the surface of the water, and suspending beneath them the float-corpuscles, either three in number or more numerous, containing abundance of air-cavities, and the megaspores, to which the microspores are attached by their glochidiate processes.

The two genera of Salviniaceæ, Salvinia and Azolla, each incluce but a small number of species, all annual plants, widely distributed over the globe, especially in its warmer regions. Those of Azolla form green or red floating patches of considerable size, with the habit of a Jungermannia. No economical application is known of either genus.

\section{ORDER 2.-MARSILEACEÆ.}

The female prothallium attains here a much smaller degree of development than in the Salviniaceæ. It arises within the apical papilla of the megaspore, the protoplasm of which breaks up into several cells, which remain for a time unclothed with cellulose, and only subsequently constitute a tissue containing a small quantity of chlorophyll. Even after this the prothallium still remains for some time completely enclosed within the apical papilla of the megaspore, being covered by the epidermal layers of the apex of the spore itself, and shut off from the spore-cavity within and below by a diaphragm which is attached to the internal coat of the spore. By the further growth of the prothallium the epidermal layers of the apical papilla are broken through, and the dorsal ridge of the prothallium projects into the funnel formed by the absence at this spot of the thick outer layers of the epispore. The diaphragm subsequently arches convexly, and the prothallium is pushed further outwards, but still lies as a hemispherical mass in the funnelshaped opening.

In those species which have hitherto been examined each prothallium produces only a single archegone. Even before the prothallium breaks through the megaspore, the large central cell may be recognised in it, covered only by four cells arranged in a cross, which form at the same time the apex of the prothallium. From these are developed the more or less projecting neck and the stigmatic cells of the archegone. As in Salviniaceæ, a neck-canal-cell is separated from the central cell, which pushes up between the neck-cells, as well as a smaller ventral canal-cell; 
the lower and larger portion of the protoplasmic cell-contents contract . ing into an oosphere. If the archegone remains unfertilised the prothallium continues to grow into a comparatively large chlorophyllous structure with rhizoids.

The male prothallium and antherids are reduced to a still more

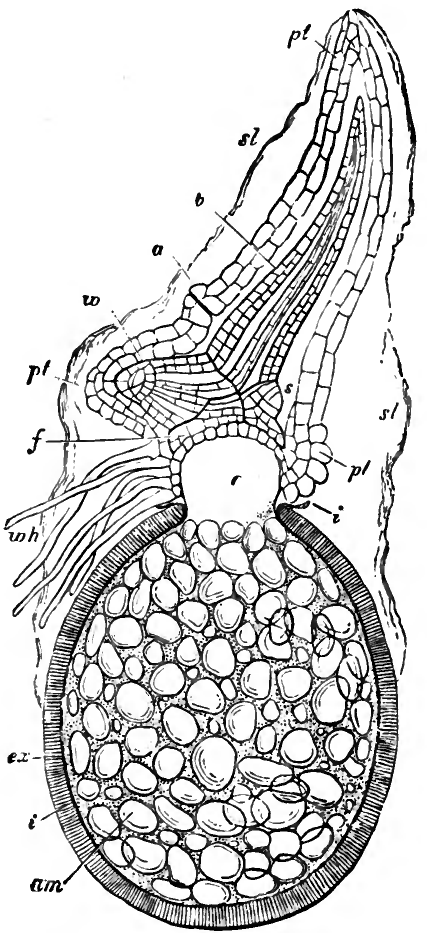

Fig. 14.-Marsilea salvatrix L. Longitudinal section through megaspore, prothallium, and embryo. am, starch grains ; $i$, inner ccat ; $e x$, epispore : $c$, space beneath diaphragm; $p t$, prothal. lium; $w$ h, its rhizoids ; $a$, archegone; $f$ foot ; $w$, root of embryo ; $b$, coty. ledon; $s l$, mucilaginous envelope of megaspore. (After Goebel, $\times$ 6o.)
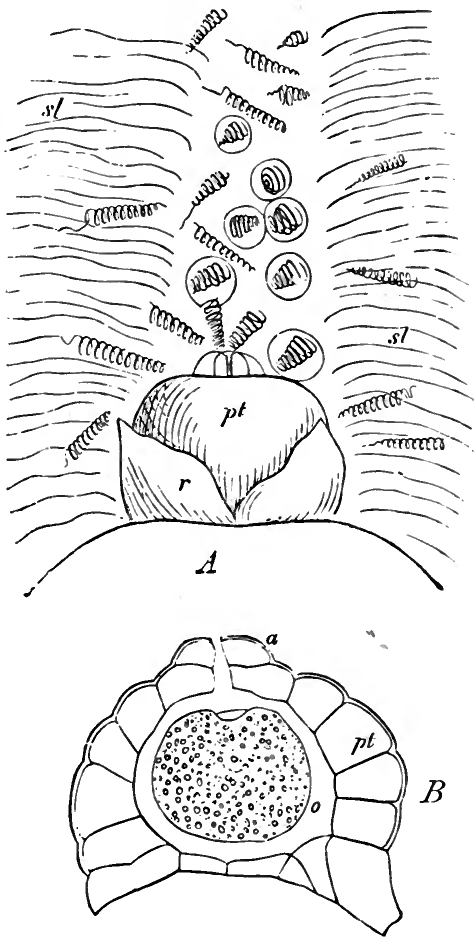

Fig. 15.-Marsilea salvatrix. A, prothallium $p t$, projecting from ruptured coat $r$ of megaspore ; $s l$, layers of mucilage forming funnel, with antherozoids. $B$, vertical section of prothallium $p t ; 0$, oosphere ; $a$, stigmatic cells. (After Goebel, greatly magnified.)

rudimentary condition than in the Salviniaceæ. The contents of the microspore divide into three cells, one of which (the prothallium) remains sterile, the other two constituting the antherid. The contents of each of these two cells again divide into sixteen antherozoid-mothercells. From the nucleus of each of these is formed an antherozoid; 
these bodies are therefore developed entirely within the microspore, while the microspores themselves are set free completely from the sporange. As in the Salviniaceæ, the whole of the contents of the mother-cell is not used up in the formation of the antherozoid ; a portion remains behind in the form of a roundish turbid lump consisting of protoplasm and starch-grains, which gradually becomes clearer, and attaches itself, in the form of a vesicle, to the antherozoid, which in Pilularia becomes soon detached, but in Marsilea remains attached to the antherozoid during the greater portion of the period of 'swarming.' When the antherozoids are mature the exospore of the microspore bursts at its apex, and the endospore swells up into a hyaline bladder,

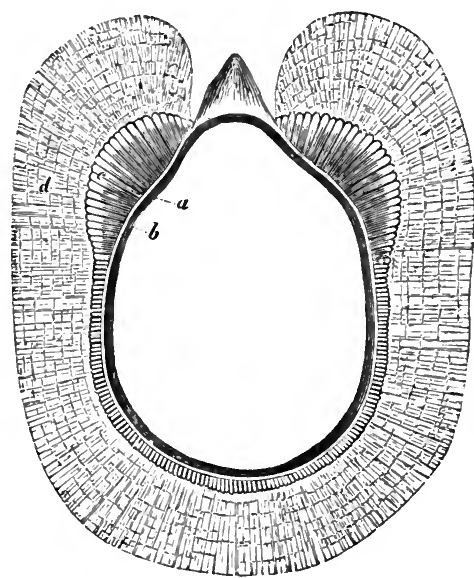

FIG. 16.--Pilularia globulifera L. Longitudinal section of megaspore. $a$, coat of spore; $b, c$, $d$, the three layers of the epispore. (After Luerssen, magnified.)

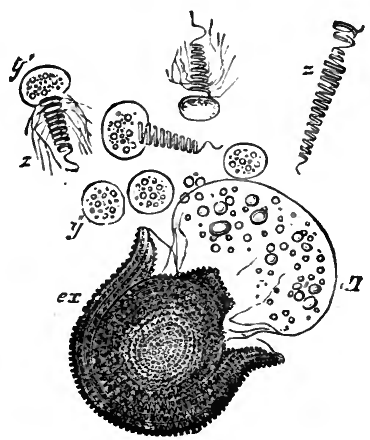

Fig. 17.-Marsilen salvatrix. Microspore discharging antherozoids. $e x$, exospore; $d l$, endospore ; $z z$, antherozoids; $y y$, their vesicles with starchgrains. (After Goebel, × 350.)

which finally bursts to allow of the escape of the antherozoids with their vesicles. In Pilularia the antherozoid consists of only four or five coils with a few vibratile cilia; in Marsilea it is of considerable length, the shape of a corkscrew, and consists of twelve or thirteen coils, the vibratile cilia being also of great length. The antherozoids collect, in large numbers, in the funnel-shaped depression of the epispore of the megaspore above the prothallium (see fig. I 5), and force themselves, through the neck of the archegone, to its central cell.

In its early stages the development of the oosperm or impregnated oosphere corresponds to that of Salviniaceæ. After becoming invested with a cell-wall of cellulose, the first segmentations give rise to the 
parent-cells of the first root, of the young stem, of the first leaf or cotyledon, and of the foot by which the young embryo is attached to the prothallium. In Marsilea a second cotyledon is formed from the fourth octant of the lower half of the embryo. The layer of tissue surrounding the central cell becomes double after impregnation; a few grains of chlorophyll are formed in it, and its outer cells develop into long rhizoids, which are especially luxuriant if no fertilisation has taken place.

The sporophyte of the Marsileaceæ differs very widely in external form in the two genera ; but its internal structure agrees in its essential features with that of the Salviniaceæ. The stem, root, and leaves all originate from a single apical cell, which always divides into three rows. The stem is procumbent on damp soil or at the bottom of stagnant water, and is traversed by a single central 'vascular' cylinder filled with fundamental tissue, each bundle consisting of a central xylem with spiral or scalariform tracheides, surrounded by a phloem with large sieve-tubes and sieve-plates, and the whole enclosed in a brown sclerenchymatous bundle-sheath, composed of a single layer of cells with wavy lateral walls. A single 'vascular' bundle traverses each root and leaf-stalk; in the lamina of the leaf of Marsilea this branches into a dichotomous venation. The fundamental tissue abounds, in both genera, in large schizogenous intercellular cavities, as is usually the case with waterplants. Those of Marsilea form a complete intercommunicating system. In those of Pilularia are remarkable spiral hairs. The leaves develop basifugally, as in Salviniaceæ; they are formed in two alternating rows on the dorsal side of the stem; but, as in Salviniaceæ, it is not every segment of the stem that produces a leaf. In this respect the Rhizocarpeæ agree with Filices, and differ from Equisetaceæ and Muscineæ. The leaves are circinate in vernation, resembling in this respect true ferns only. Tannin-sacs occur in the petiole. In Marsilea (see fig. 6) all the leaves except the first, which is filiform and destitute of a lamina, have a very long slender petiole and a four-lobed lamina; they are larger when growing in water than on dry land. M. quadrifolia (L.) has stomates on both surfaces of the aërial, on the upper surface only of the floating leaves. The stomates are depressed in the tissue of the leaf by the growth of the adjoining epidermal cells over the guard-cells. The mesophyll of the aërial leaves is characterised by the presence of rows of sclerenchymatous cells. In Pilularia the petiole is elongated and quilllike, and entirely destitute of a lamina (fig. 5).

The sporocarp or conceptacle of the Marsileaceæ is an even more complicated structure than that of the Salviniaceæ. In Pilularia it is a roundish, shortly-stalked capsule springing from the axil of a leaf-stalk 
on the procumbent stem. According to Juranyi, each sporocarp is the result of the coalescence of two segments of bifid leaves. The wall of the sporocarp is very thick and hard, and consists of several layers of cells forming a sclerenchymatous tissue. It is divided by vertical walls into compartments, varying from two to four in the different species. Each compartment has, at least in its young state, an opening at the apex, and is therefore not of endogenous origin, but rather a depression in the surface. In each compartment there is, on the side which forms its outside wall, a cushion-like placenta, formed from superficial cells, and resting on a 'vascular' bundle. To this placenta are attached a number of stalked sporanges of both kinds, constituting a sorus; the megasporanges are chiefly below, and the microsporanges above. 'The remainder of each compartment is occupied by a delicate thin-walled parenchyme. When mature the sporocarp splits from the apex downwards into as many valves as it has compartments; and each sporange dehisces by the expansion of the gelatinous mass resulting from the dissolution of the tapetal cells.

The sporocarps of Marsilea are capsules with somewhat the shape of a bean, a longer or shorter pedicel, and a very hard sclerenchymatous wall. They spring, usually in clusters, from the petiole of an ordinary leaf.

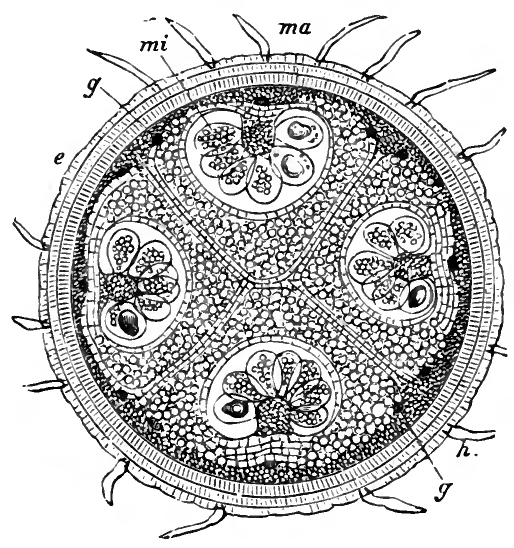

FIG. 18.-Transverse section of sporocarp of Pilularia globulifera. mi, microsporanges; $m a$, megasporanges; $e$, wall of sporocarp ; $g$, parenchyme. (After Goebel, magnified.)

The pedicel runs along the dorsal edge of the sporocarp, and gives off lateral veins right and left which branch dichotomously and run to the ventral edge. The ripe sporocarp has a bilaterally symmetrical structure, and is divided by transverse walls into two rows of compartments, each of which has, when young, a narrow opening on the ventral side. Each compartment contains a single sorus, consisting of a few megasporanges in the centre, with a larger number of microsporanges on each side. As in Pilularia, a large portion of the cavity of each compartment is occupied by a succulent parenchyme.

The development of the sporanges commences, in both genera, with the swelling up of some of the epidermal cells of the part which ultimately becomes the placenta. These cells divide several times 
obliquely-not horizontally, as in Salviniaceæ-into three rows of segments, until ultimately a convex septum cuts off a triangular apical cell, which at length becomes the tetrahedral archespore. From this is separated the mantle-layer of tapetal cells; further divisions take place both in these and in the rows of cells of which the wall of the sporange is composed, and the archespore divides by successive bipartitions into sixteen spore-mother-cells, each of which produces four spores in the ordinary way. The pedicel of the sporange consists at first of three rows of cells, the number being subsequently increased by further longitudinal divisions. The tapetal cells become gradually disorganised, and form a granular mucilage, filling up the interstices between the mother-cells of the spores, which is subsequently employed in the production of the epispore or gelatinous envelope of the spore. The differentiation of the two kinds of spore now commences. In the microsporanges all the sixty-four microspores reach maturity, each special mother-cell or rudimentary spore becoming invested, while still within the mother-cell, with its permanent cell-wall, while the walls of the sixteen mother-cells disappear. In the megasporanges, on the other hand, one of the four special mother-cells in each of the sixteen tetrads displays at first a greater vigour of growth than the other three. Of these sixteen sistercells fifteen gradually become abortive, only one reaching maturity and developing into a perfect megaspore. During their development and disappearance all the rudimentary spores are furnished with spiny protuberances, by which they are attached to one another. As the megaspore increases in size its coat becomes hard and brown ; and it is ultimately invested by a gelatinous epispore consisting of three distinct layers (fig. 16). The innermost of these is a mucilaginous coat, which is often folded, and ultimately forms a papilla above the apex of the mature spore. Outside this is a thicker layer of a soft prismatic substance, and external again to this a third still thicker but less clearly organised envelope. The two outer layers are wanting at the apex of the spore, where there is a funnel-shaped depression exposing the papilla belonging to the innermost layer of the epispore. Down this funnel the antherozoids pass to impregnate the oosphere within the archegone produced on the prothallium within the apical papilla of the megaspore.

The processes by which both kinds of spore escape from the very hard shell of the sporocarp are very remarkable. In Pilularia globulifera (L.) the ripe sporocarp lies above or beneath the surface of the damp soil. It splits from its apex downwards into four valves, and exudes a tough hyaline mucilage derived from the parenchymatous tissue within each compartment. This mucilage accumulates on the ground; and into it both kinds of spore escape after the rupture of the 
sporanges. Fertilisation takes place within the drop of mucilage, which then gradually disappears, and the impregnated megaspore lies on the damp ground, to which it becomes attached by the rhizoids put out from the prothallium until the first root of the embryo penetrates into the soil. In Marsilea the processes are somewhat similar. The excessively hard, almost stony, shell of the sporocarp gives way slightly at its ventral edge as it lies in water, and the water penetrates into the interior. This causes the succulent parenchymatous tissue in each compartment to swell up, and splits the shell along the whole of the ventral edge into two valves. Between these valves the contents are gradually forced out; the compartments still remain closed, each enclosing a sorus, and are attached in two rows to the cartilaginous cushion or sorophore which ran along the ventral edge of the sporocarp, and which now becomes detached at one end, and exposed in the form of a string many times longer than the sporocarp itself ; by the absorption of water it has increased enormously in size, to something like 200 times its original dimensions, and the sori are thus placed at a considerable distance from one another. Ultimately the walls of the sori or original compartments of the sporocarp disappear; the walls of the sporanges burst, both
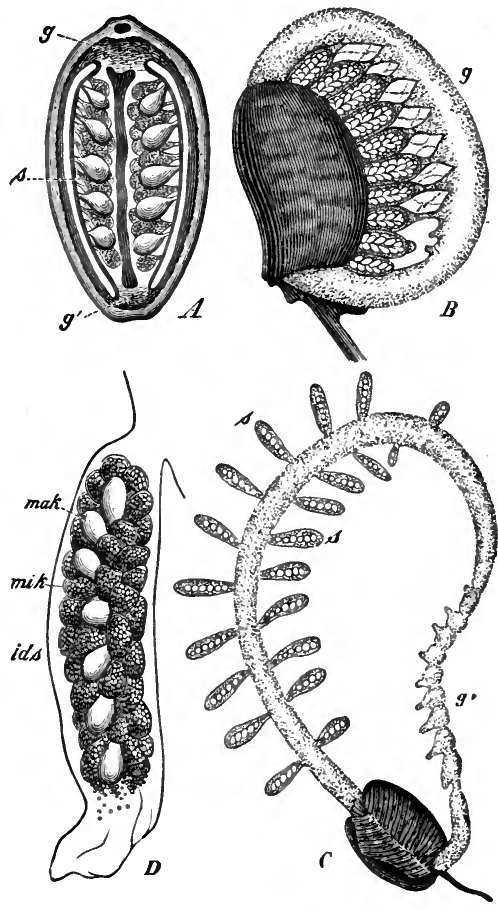

Fig. 19.-Sporocarp of Marsilea saliatrix. A, transverse section. $B$, swollen and bursting, showing sorophore $\left(\times 2 \frac{1}{6}\right)$. $C$, sporocarp (natural size), with sorophore fully extended, and sori attached. $D$, section of sorus $(\times 6) ; i d s$, indusium; mik, microsporanges; $m a k$, megasporanges. (After Hanstein.) kinds of spore escape, and fertilisation is effected on the damp soil.

All the species of both genera of Marsileaceæ are marsh or aquatic perennial plants, mostly natives of the warmer temperate and tropical countries. The number of species of Pilularia is small, of Marsilea about forty. The leaves of Marsilea, when growing in the air, display a sensitiveness to light, folding up in the evening and expanding in the morning, similar to those of many Leguminosæ and other Flowering 
Plants. The sporocarps of M. Drummondii (Br.), and probably of some other species, are eaten by the natives of Australia under the name of nardoo.

\section{LiteratuRE.}

Bischoff-Die Rhizocarpeen und Lycopodiaceen, Nuremberg, 1828.

Mettenius-Beitr. zur Kenntniss der Rhizocarpeen, I846; Linnæa, 1847, p. 260 ; and Beitr. zur Botanik, Heft I, I853; Plantæ Tinneanæ.

Meyen-Nov. Art. Acad. Cæsar-Leopold., vol. xviii., pt. I, p. 253.

Hofmeister-Ueb. Keimung der Salvinia, Abhandl. Sächs. Gesell. Wiss. 1857, p. 665 .

Pringsheim-(Salvinia) Jahrb. f. wiss. Bot., vol. iii., I863, p. 484.

Hanstein-Ueb. eine neuholländische Marsilia, Monber. Berl. Akad., 1862, p. I83 ;

Befruchtung u. Entwickelung der Marsilia, Jahrb. f. wiss. Bot., vol. iv., I865,

p. 107 ; Pilulariæe generatio cum Marsilia comparata, Bonn, I866.

Braun-(Marsilia and Pilularia) Monber. Akad. Wiss. Berlin, 1870, p. 653, and I872, p. 668.

Russow-Vergleich. Unters., Petersburg, 1872 ; and Hist. u. Entwick. d. Sporen-

frucht v. Marsilia, Dorpat, 1877 .

Strasburger-Ueber Azolla, Jena, I87j.

Juranyi-Ueb. d. Entwick. d. Sporangien u. Sporen v. Salvinia, Berlin, I873 ; and

(Pilularia) Sitzber. Ungar. Akad. Wiss., I 879 (see Bot. Centralbl., vol. i., I881, p. 207).

Berggren-(Azolla) Rev. Sc. Nat., I88I, p. 2 I.

Heinricher-(Spores of Salvinia).Sitzber. Akad. Wiss. Wien, vol. lxxxv., I882, p. 494. Goebel-(Pilularia) Bot. Zeit., I882, p. 77 I.

\section{Class II.-Selaginellaceæ.}

This class is composed of two genera only, Selaginella (Spring) and Isoëtes (L.), resembling one another in the general facts of their lifehistory, but differing widely in external appearance, and each constitutıng a monotypic order. We have, again, as in Rhizocarpeæ, two kinds of spore; the megasporanges and microsporanges are of very similar appearance, and are produced in connection with the leaves. The female prothallium, produced within the megaspore, is a more completely endogenous structure than in any other class of Cryptogams, and is altogether destitute of chlorophyll. From the occurrence in both genera of a foliar structure known as the ligule, the term 'Ligulatæ' is sometimes given to the class; but the character is unsatisfactory, and it will be best to treat the two orders Selaginellea and Isoëtece separately. 


\section{Order I.-Selaginelleæ.}

In the genus Selaginella, the sole representative of the order, the prothallium appears to be already completely formed by the time the megaspore is mature, but occupies only the apical portion of the cavity of the spore; the basal portion is still filled by an undifferentiated mucilaginous protoplasm, which subsequently develops into a cellular tissue, the secondary prothallium, or, as it is termed by some writers, the endosperm. In some species, at least, this structure is separated by a diaphragm from the true prothallium. The prothallium always produces a number of archegones, sometimes as many as thirty, which arise in centrifugal succession on the exposed portion of the prothallium, the one formed first being at the apex. The archegone originates by division of a superficial cell in a direction parallel to the surface ; the outer of these two then divides into four cells, and each of these again breaks up by tangential division into two. These form the neck of the archegone, which therefore consists of four rows, each composed of two cells. The lower of

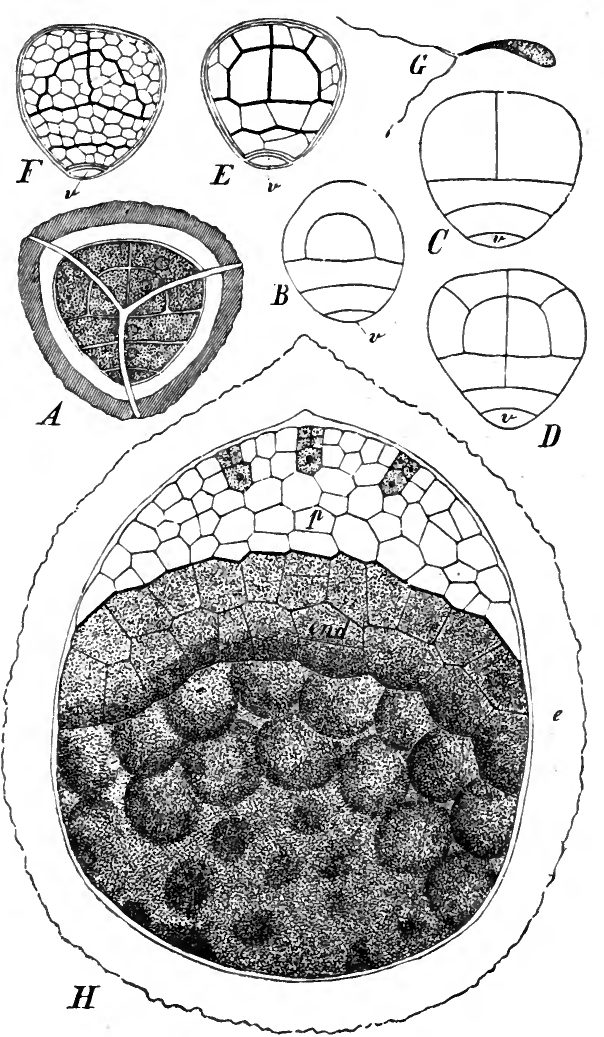

Frg, 20. $-A-F$, stages in the division of the microspore of Selaginella caulescens Spr. $v$, sterile cell; $G$, antherozoid ( $\times$ r 400$) ; H$, vertical section of megaspore of $S$. Martensii Spr. ; $p$, prothallium with three archegones; end, endosperm; $e$, exospore $(x+165)$. (After Pfeffer.)

the two original cells becomes the venter of the archegone, and puts out a slender prolongation between the neck-cells, which is separated as the neck-canal-cell. Another very small portion is subsequently separated 
as the ventral canal-cell, and the protoplasm of the larger and lower portion rounds itself off into the oosphere. The two canal-cells then deliquesce into mucilage, leaving an open passage for the entrance of the antherozoids.

The microspores, spherical orange or bright red bodies, remain in a dormant condition through the winter, and undergo further development in the spring. The contents then divide, first of all by a transverse wall of cellulose near one end into two cells of very unequal size. The smaller one of these does not divide further, and remains sterile; it is regarded as the last degraded vestige of a male prothallium. The contents of the larger of the two cells, which may be regarded as an antherid, then break up into from four to eight primordial cells, and each of these divides again into four mother-cells of antherozoids; but it is uncertain whether all the cells are fertile. The antherozoids are coiled up into a helix, and are furnished at the anterior end with two long fine cilia. The antherozoid is in all cases derived from the nucleus of the mother-cell ; a central vacuole, invested with a delicate membrane, often remains attached to its posterior end during 'swarming.' The 'swarming' condition continues for about half to three-quarters of an hour.
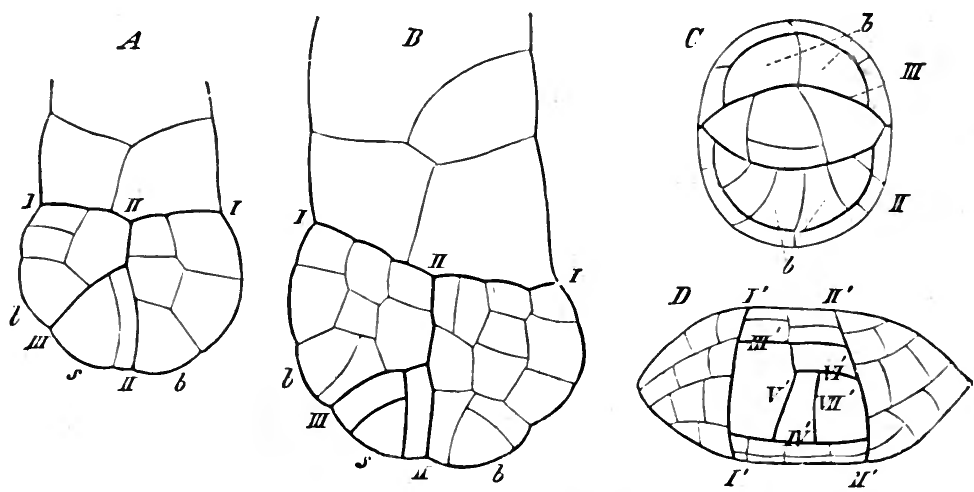

FIG. 21. - Formation of embryo and suspensor in S. Martensii, showing order of formation of dividing walls. (After Pfeffer.)

In the formation of the embryo the first division of the oosperm differs from that in Rhizocarpeæ and in Filices in taking place at right angles to the axis of the archegone. It is thus divided into two superposed halves, from the lower of which is developed the embryo itself; from the upper half a structure almost peculiar to this order, consisting 
of a small number of large cells, known as the suspensor, or pro-embryo, from its apparent homology with the structure which goes by this name in Flowering Plants. By the elongation of the suspensor and the compression and absorption of the adjacent cells, the lower portion of the oosperm is forced into the endosperm, from which it appears to derive nutriment, dividing, both previously and subsequently, into a small-celled tissue. This tissue undergoes a large amount of differentiation before the embryo emerges from the megaspore, the rudiments of all the principal parts of the sporophyte making their appearance at this early stage. The mother-cell of the embryo divides into two by an oblique wall. From one of the two cells thus formed originate the stem and one of the cotyledons, from the other the foot and the other cotyledon. The rudimentary stem has a two-edged apical cell, from which segments are cut off alternately right and left. An inner mass of tissue soon becomes differentiated as the procambium of the axial 'vascular' bundle, the peripheral tissue as dermatogen and periblem. The stenbud, or plumule, with its first leaves (subsequent to the cotyledons), finally grows erect from the apex of the megaspore as the embryo increases in length. 'The formation of the first root begins later between the foot and the suspensor ; its apical cell is formed from an inner cell of the older segment ; the first layer of its root-cap originates from the splitting into two layers of the overlying dermatogen; the later layers of the root-cap are formed from the apical cell of the root.

The sporophyte differs greatly in appearance in the two orders. In Selaginella the stem is always slender, erect or procumbent, with distinct internodes, and lengthening rapidly by monopodial branching, which very often has a dichotomous appearance from the vigorous growth of the lateral branches. These lateral branches, with their ramifications, frequently develop in a single plane, giving the system the appearance of a compoundly pinnate leaf; all the branches and leaves displaying a distinctly dorsiventral character. The stem has an epiderm composed of elongated prosenchymatous cells, without stomates, but containing a considerable amount of chlorophyll in remarkably large grains. The fundamental tissue consists of elongated thin-walled cells with oblique septa, fitting closely together without intercellular spaces, and-endowed with the power of long-continued growth both in length and diameter. 'In the absence of small intercellular spaces the stem of Selaginella resembles that of mosses ; but, on the other hand, each 'vascular' bundle is surrounded by a large air-cavity, traversed by trabecules, rows of cells connecting the bundle with the surrounding fundamental tissue. The entire cortex has a tendency to become dark brown with age from partial sclerosis. When 
the cells of which these trabecules are composed are round, they form a loose spongy parenchyme surrounding the bundle, and sharply differentiated from the firm compact fundamental tissue. The stem has one or more cauline 'vascular' bundles, which may be traced in the

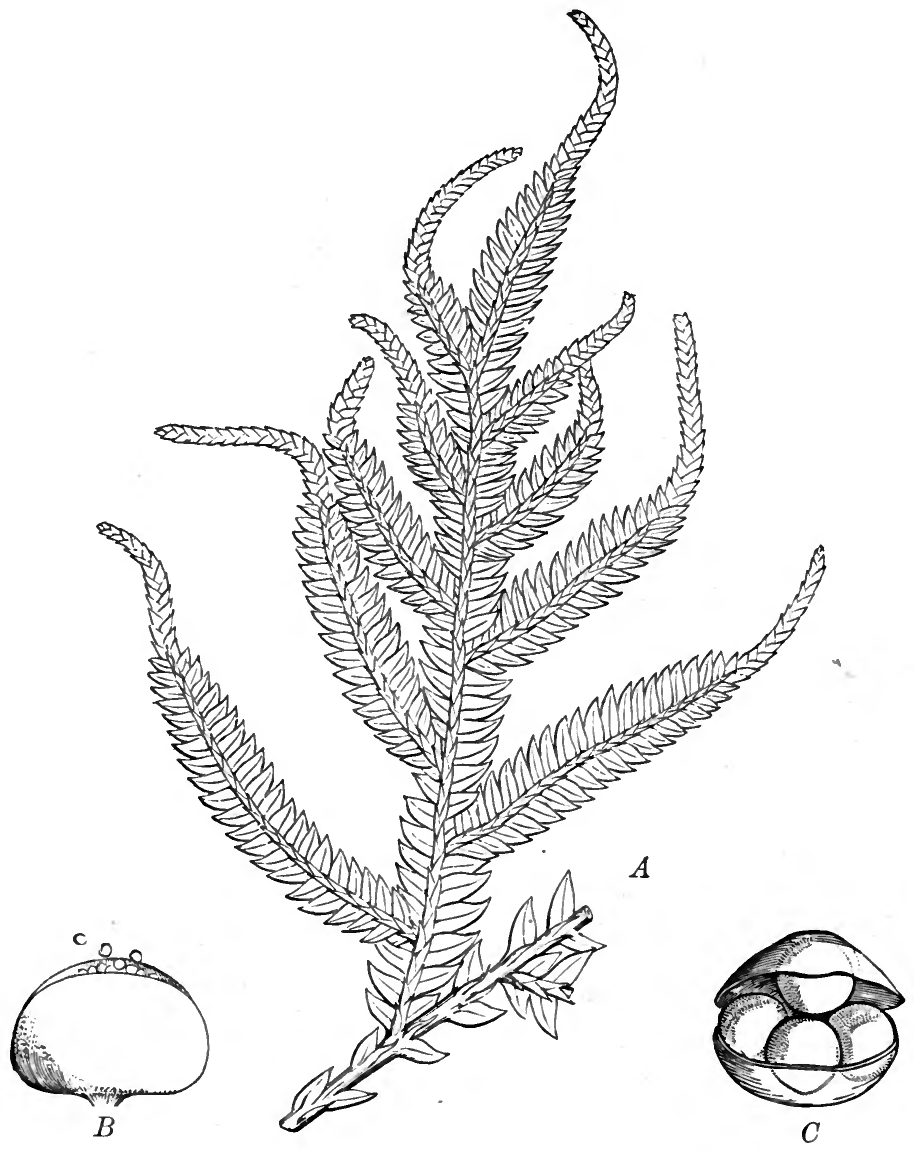

FIG. 22. - Selaginella inaqualifolia Spr. $A$, branch (natural size); $B$, microsporange; $C$, megasporange

procambial condition to the apex of the stem close beneath the apical cell and above the youngest leaves; the separate bundles which descend from the leaves (leaf-trace-bundles) only unite with the cauline ones at a later period. The bundles are usually ribbon-shaped, and are concen- 
tric and closed. In the centre is the xylem, consisting chiefly of scalariform and reticulate tracheides; this is completely surrounded by the
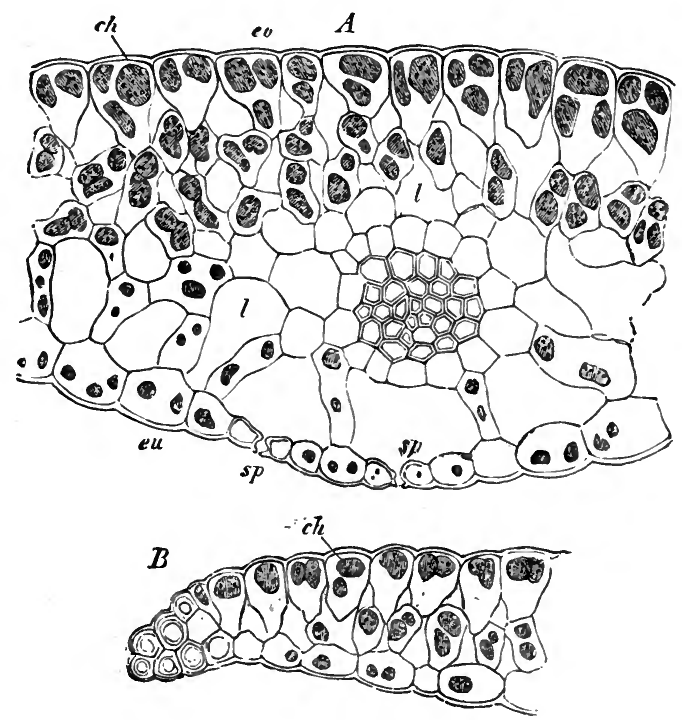

FIG. 23.-Transverse section through leaf of $S$. inaqualifolia. ch, chlorophyll-bodies; co, upper epiderm ; $e u$, lower epiderm; $s p$, stomates; $l$, air-cavity surrounding vascular bundle and traversed by trabecules. (After Goebel, magnified.)

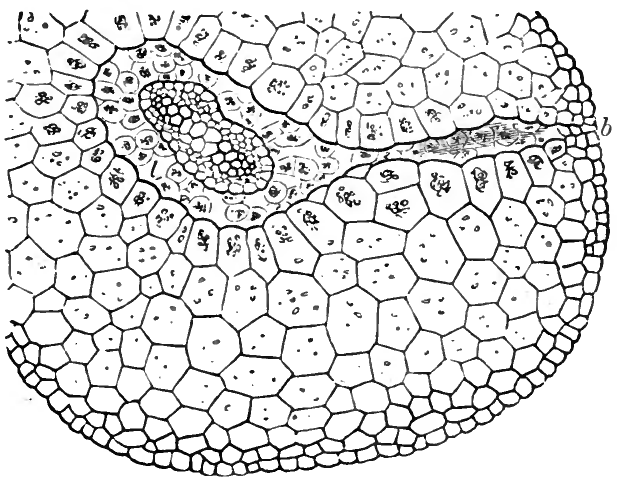

FIG. 24.-Transverse section of stem of $S$. denticulata Lk. $b$, air-cavity surrounding 'vascular' bundle. (After Goebel, magnified.)

thin-walled phloem. The primary elements of the xylem, very narrow spiral tracheides, are formed at the angles of the bundle, and from them 
the development and lignification of the tracheides advance centripetally. The external layer of phloem is itself surrounded by two or three parenchymatous layers, constituting a bundle-sheath, belonging to the fundamental tissue, but within the large air-cavity. The mode of apical growth varies in the different species. In some the apex of the stem is occupied, as in Isoëtes, by a group of equivalent merismatic cells; while in others there are two co-ordinate apical cells side

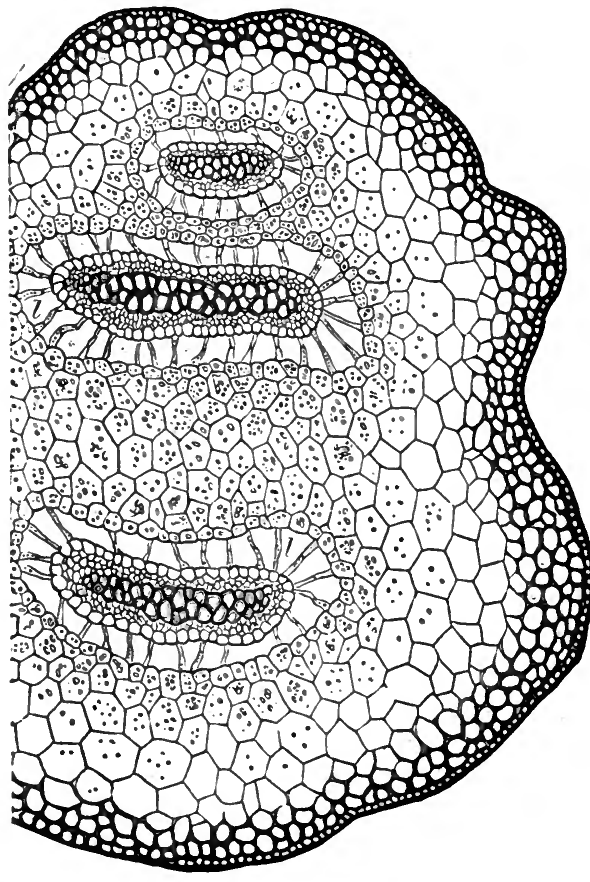

FIG. 25. -S. inaqualifolia; transverse section of stem ( $\times$ 150). (After Sachs.)

by side, or a single one, which may be two-sided or three-sided.

The leaves are simple and unbranched, and are traversed by a single 'vascular' bundle. They are always of small size, resembling those of Lycopodium, awl-shaped and acuminate, or ending in a delicate awn, and usually with a cordate base. The greater number of species are heterophyllous, the sterile leaves having two different forms; those on the ventral or shaded side of the obliquely ascending stem are larger than those on the dorsal side exposed to the light. They are always in four rows, one dorsal and one ventral leaf forming a pair. On the upper side of the leaf near its base is the peculiar structure known as the ligule, from the presence of which the class has sometimes been called 'Ligulatæ.' The fertile leaves are uniform in size, and differ somewhat in shape from the sterile, forming a compact square terminal spike. The sporange springs from the upper surface below the ligule. In some species the epiderm is alike on the two sides of the leaf; in others it differs. The epidermal cells contain chlorophyll, as is the case in ferns, and frequently have beautifully serpentine lateral walls ; in some species they are so greatly thickened that the cell-cavity disappears alto- 
gether. The chlorophyll, both in the epidermal cells and in the mesophyll, is collected into large lumps, in which are grains of starch. Stomates occur in the under, rarely also in the upper surface. The mesophyll consists of a loose spongy parenchyme ; when the leaves are very small it is developed only as a single layer surrounding the central 'vascular' bundle, and is altogether suppressed near the margins, where the upper and lower epiderm are in actual contact.

True roots occur in all known species belonging to the order. In some species of Selaginella a structure known as the rhizophore intervenes between the stem and the root. The rhizophores resemble roots in general appearance, but are destitute of a root-cap. They may spring either from the dorsal side of the stem only, near the base of a branch, bend round and then grow downwards, or two may spring from each fork, one on the dorsal, the other on the ventral side, the former of which usually remains undeveloped in the form of a small protuberance, while the latter grows to the normal size. Their origin is very near the growing point, and they appear to be formed in the same way as the branches. Unlike the roots, they are exogenous structures. After apical growth has ceased, the end of the rhizophore, which is still very short, swells up into a spherical form ; its cell-walls become thicker, and the first rudiments of the true root originate in the interior of the swelling, but do not break through the surface until the rhizophore has increased considerably in length by intercalary growth, and its swollen end has penetrated the soil, where its apical cells deliquesce into mucilage, through which the true roots reach the ground. In some species the rhizophores are frequently transformed into leafy shoots, which at first manifest some deviations from the normal structure of aërial shoots, but afterwards present the ordinary structure, and may even bear sporanges. The rhizophore is not, however, universal in Selaginelia. In many species the roots spring directly from the lowest fork of the stem, and branch monopodially before they reach the ground. They originate, like those borne by the rhizophores, near the growing point. All the roots branch copiously, the planes of the successive branchings crossing one another at right angles. They have a single apical cell, but this soon ceases to give off segments, and the subsequent increase in length is chiefly due to intercalary growth.

Both kinds of sporange are shortly stalked nearly spherical capsules (fig. 22), closely resembling those of Lycopodium in appearance and structure, except in their being heterosporous. They are collected into dense spikes at the extremity of somewhat metamorphosed leafy shoots. The lower portion of each spike in some species consists of megasporanges, the upper portion of microsporanges, and the former may be 
reduced to only one. Each fertile leaf or sporophyll subtends only a single sporange, which is borne on the stem above the leaf-axil. The sporanges are of considerable size in proportion to that of the leaf, and are formed from a group of superficial cells at the growing point of the stem. They make their nirst appearance as flat, afterwards spherical or

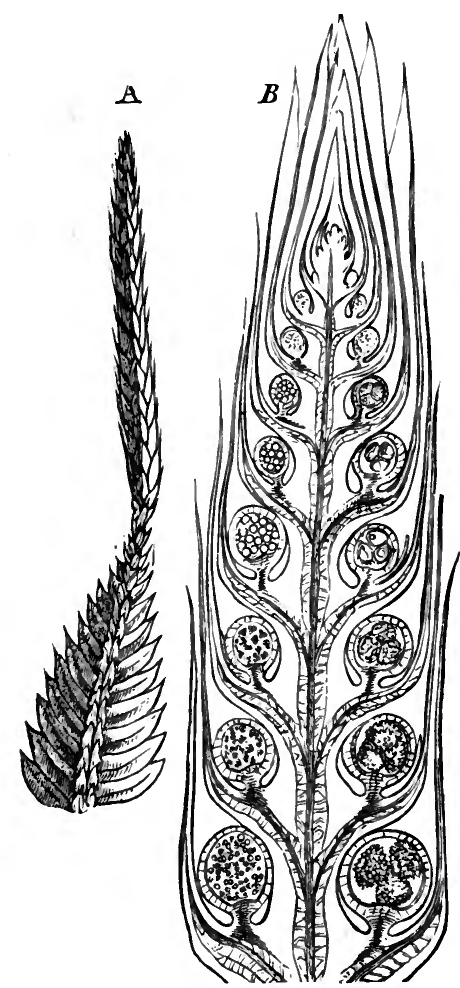

FIG. 26. $-A$, fertile branch of $S$. incequali. folia (half natural size). $B$, longitudinal section of upper part. showing microsporanges and megasporanges. (After Goebel, magnified.) club-shaped, swellings, completely covered by the epiderm, which subsequently forms, by tangential divisions, the wall of the sporange, composed of three layers. By subsequent growth the sporange

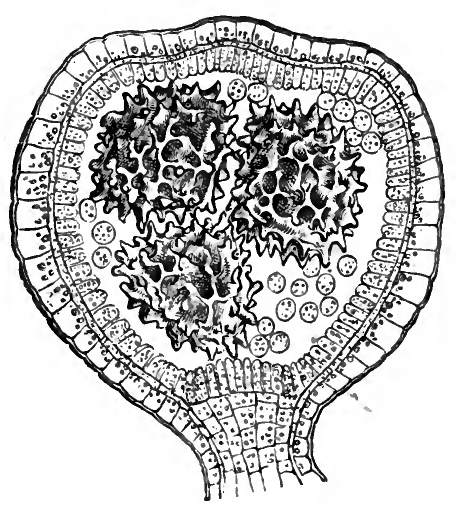

FIG. 27.-Section of megasporange of $S$. incequalifolia, showing double wall of sporange, layer of tapetal cells, and megaspores. (After Goebel, magnified.)

comes to be placed in the axil or even on the base of the leaf. The 'vascular' bundle of the leaf passes beneath the sporange without sending a branch into it. As in the other heterosporous families, the two kinds of sporange present no differentiation in their early stages. The archespore is the terminal hypodermal cell of an axial row. This divides into the sporogenous tissue surrounded by the layer of tapetal cells formed from the innermost of the layers of cells into which the wall of the sporange divides. In the megasporanges one of the spore-mothercells grows more vigorously than the rest, which gradually abort. In this 
privileged cell are formed four spores, the number usually present in the mature megasporange. The microspores are formed in the same way as in the other heterosporous families. After falling out of the sporange they frequently adhere together in fours. The microspore has three coats-endospore, exospore, and epispore-of which the innermost is composed of cellulose. The coat of the megaspore is also treble, and the epispore is not unfrequently beautifully granulated and spiny. The dehiscence of both kinds of sporange is caused by the unequal contraction of the epidermal cells. The microsporanges are 2-valved, the megasporanges 3-4-valved.

The genus Selaginella (Spring) includes above 300 species, spread over the whole globe, but most abundant in the tropics. Many species resemble Lycopodium very closely in habit, but are more moss-like, and the leaves generally more delicate ; in others the stem is erect, and they reach the magnitude of small shrubs. Several species are favourite objects of cultivation from the beautiful metallic lustre of the leaves. They are readily propagated non-sexually, a small fragment of the stem producing a new plant if kept warm and moist on loose earth, owing to the production of adventitious roots in the angle formed by the branching of the 'vascular' bundle of the leaf from that of the stem. No economical use is known of any species either of Selaginella or Isoëtes.

\section{ORDER 2.-ISOËTEÆ.}

In the single genus Isoëtes the general phenomena of the life-history correspond to those of Selaginella, but with some important differences. Some weeks after the escape of the megaspore from the decaying megasporange its cavity becomes filled, by free-cell-formation, with a number of naked primordial cells, which gradually fill up the whole cavity of the endospore, and then become converted into a cellular tissue by the investment of each with a cell-wall of its own. The endospore at the same time thickens, and separates into several layers with a finely granular structure. The epispore, or outer layer of the coat of the megaspore, now splits at its apex by a three-rayed fissure, exposing the endospore, which also subsequently disappears, and a portion of the spherical prothallium is thus laid open. At its exposed apex appears the first archegone, which is followed by others if the first is not fertilised. The archegones resemble those of Selaginella, except that each of the rows which constitute the neck is composed of four instead of two cells.

The microspores are yellowish grey, and of the form of the quadrant of a sphere. The antherozoids are very long, slender, and attenuated 
at both ends, where they are provided with two tufts of very long cilia ; in some species they are remarkably large. Their period of 'swarming' does not last more than about five minutes.

The stem of Isoëtes is distinguished by its extraordinarily restricted

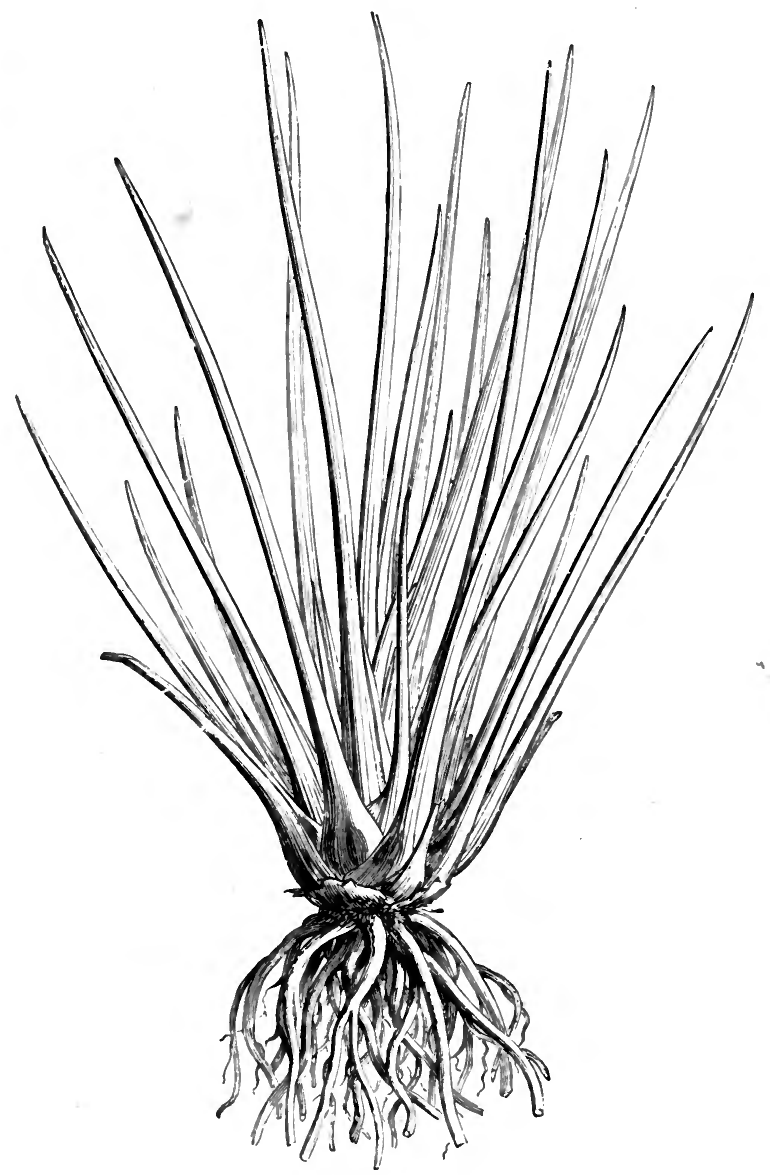

FIG. 28.-Isoëtes lacustris L. (natural size).

growth in length, and the complete absence of branching, as well as by a remarkable secondary increase in thickness. It is completely covered by the bases of the leaves, leaving no part exposed. Its upper portion has the form of a shallow funnel, with the apex depressed in its centre. 
The long-continued increase in thickness which distinguishes this genus alone among Vascular Cryptogams-except possibly Botrychium (Filices) - is dependent on an internal layer of meristem which surrounds the axial 'vascular' cylinder, and continually produces new layers of paren-
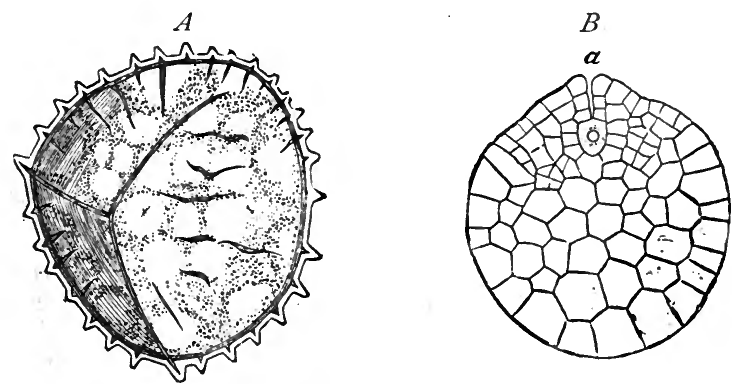

FIG. 29. $-A$, megaspore of Isoëtes acustris L. $B$, prothallium ; $\alpha$, archegone ( $\times$ about 50 ). (After Hofmeister.)

chyme on the outside. This takes place especially in either two or three directions, so that a corresponding number of projecting masses of tissue are formed, which slowly die off on the outside ; and between them lie the same number of furrows meeting on the ventral side of the stem, which has hence the appearance of a laterally elongated plate or
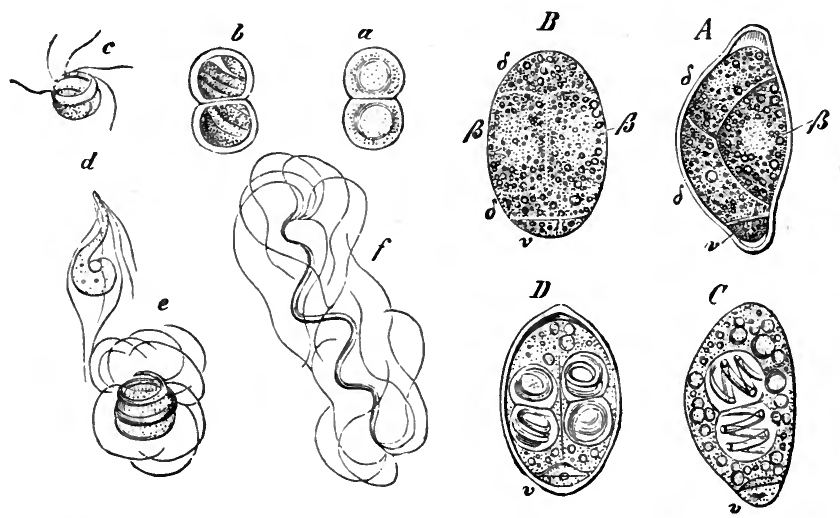

FIG. 30. -1 . lacustris. $A-D$, microspore, showing stages in formation of antherid and antherozoids $(\times 580)$. $z$, sterile cell ; $a-d$, stages in formation of antherozoid $\left(\times{ }_{580}\right) ; e, f$, mature antherozoid $(\times 700)$. (After Millardet.)

disc. In these furrows are produced a large number of rows of roots in acropetal succession. In the stem is a single cauline axial bundle composed of short reticulate and spiral tracheides, surrounded by a rudimentary phloem without sieve-tubes. From this axial bundle there 
proceeds a branch into each leaf and one into the root. The layer of meristem which surrounds the axial bundle increases chiefly in the centrifugal direction, fresh layers thus formed replacing the outer ones, which continually die off. The secondary long-enduring increase in thickness of the stem is chiefly due to increase in thickness of the cortical tissue, though new xylem-elements are also produced. The mode of apical growth differs from that in most species of Selaginella. There is no single apical cell, the apex of the stem being occupied by a group of equivalent merismatic cells.

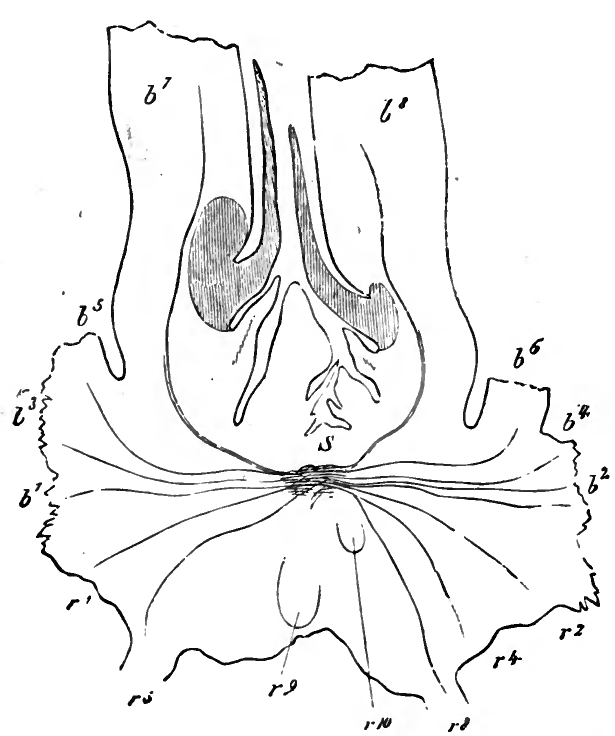

FIG. 3r.-Longitudinal section of stem of I. lacustris. $b-b^{\mathrm{a}}$, leaves; $r^{2}-r^{10}$, roots: the ligules are shaded $(\times 30)$. (After Hofmeister.)

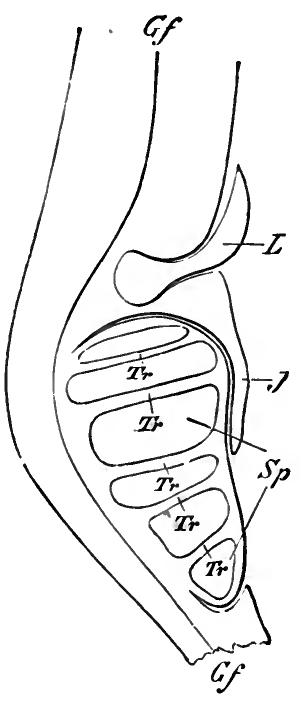

FIG. 32.-Longitudinal section through lower portion of leaf of I. lacustris (diagrammatic). $L$, ligule; $\mathcal{F}$, indusium; $S p$, microsporange ; $T r$, trabecules; $G f$, vascular bundle of sporophyll. (After Goebel.)

The leaves of Isoëtes are very elongated, cylindrical, and quill-shaped, and are arranged in a complicated phyllotaxis on the very short stem. They are segmented into a basal portion, the sheath or glossopode, and an apical portion, the lamina. The sheath is nearly triangular in form with a very broad insertion, and does not completely embrace the stem. $I_{i}$ is convex behind and concave in front, where it bears the sporange in a large depression known as the fovea ; the margin of this depression rises in the form of a thin membranous outgrowth, the veil or indusium, which, in many species, extends above and beyond the sporange. Above 
the fovea, and separated from it by a ridge called the saddle, is a smaller depression, the foveola, the lower margin of which forms a lip-like structure, the labium, and from its base rises a narrow membranous acuminate structure, the ligule, with a cordate base, and usually projecting above the foveola. The sheath passes above into the lamina, which is narrow and thick, almost cylindrical, but flattened in front, contains chlorophyll, and is traversed by four wide longitudinal air-cavities, segmented by transverse septa. A rosette of these fertile leaves or sporophylls is produced annually, but between these whorls are alternate whorls of phyllades, or imperfec: leaves, consisting, in the submerged species, of only a small lamina with no sheath, while in the terrestrial species they are reduced to mere scales. Stomates occur in the paludose and terrestrial, but not in the submerged species. Scattered spiral tracheides are found in the parenchymatous base of the leaf. The fundamental tissue, which
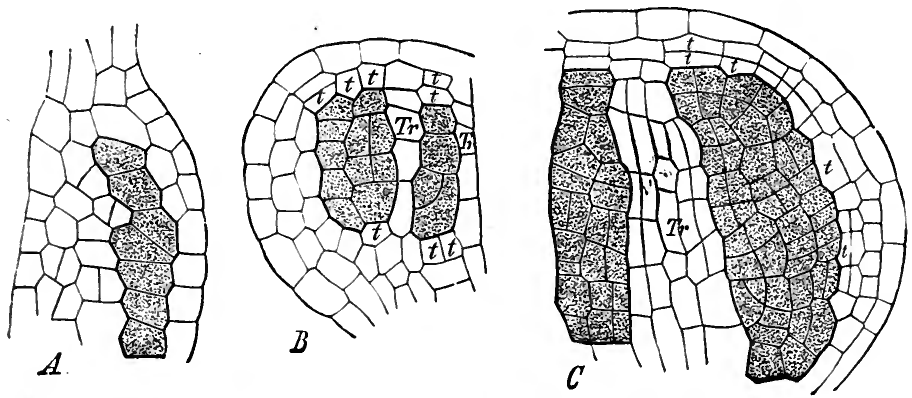

FIG. 33.-Developmen: of microsporange of $I$. lacustris. $t$, tapetal cells; $T r$, trabecules: the archespore and sporogenous cells derived from it are shaded. (After Goebel, magnified.)

is not separated from the single 'vascular' bundle by a bundle-sheath, has a strong tendency to become sclerenchymatous, especially beneath the epiderm and in the sheath. The very simple bundle which occurs in each leaf is stated by Russow to be collateral, the xylem and phloem lying side by side.

The roots spring from the furrows of the stem, and resemble, in structure and mode of branching, those of Selaginella. There is no rhizophore.

The sporanges of Isoëtes do not make their appearance until the third year after germination. Each sporophyll bears only a single sporange, which is undoubtedly a product of the leaf, and is situated below the ligule in the fovea, to which it is attached by a narrow base. The outer leaves of the fertile rosette produce megasporanges only, the inner leaves microsporanges only. Both kinds of sporange originate from a group of cells at the base of the leaf. The archespore is derived 
from a hypodermal layer of cells. In the formation of the microsporange the archespore-cells elongate in a direction at right angles to the surface, and divide by transverse walls. Some of these rows of cells are then arrested in their growth, lose their abundant protoplasm, and divide into elongated tabular cells constituting the trabecules, which cross the sporange from the dorsal to the ventral side. The remaining cells develop into the mother-cells of the microspores, an external layer having been previously separated as tapetal cells. In the development of the megasporange the processes are the same as far as regards the formation of the tapetal cells and the trabecules; the mature sporange may contain either four or a much larger number of megaspores. The mode of development of the megaspores presents perhaps the closest analogy to that of the secondary embryo-sacs of Gymnosperms that occurs in any order of Vascular Cryptogams; and the same remark applies to the formation of the microsporanges and pollen-sacs. Both kinds of sporange are indehiscent, the spores escaping. only by the decay of the tissue.

In both kinds of spore the epispore is frequently granulated, tuberculate, or echinate ; and in some species there are two kinds of microspore differing from one another in this respect.

One or two species of Isoëtes display the phenomenon of apogamy in various degrees. In extreme cases the formation of the megasporange is arrested at a very early stage, and its place supplied by a wegetative shoot, which becomes detached and develops into an independent plant.

The number of species of Isoëtes is about fifty, the greater part inhabitants of the warmer portions of the globe. They somewhat resemble Pilularia in general habit. Some species are aquatic and entirely or partially submerged, other paludose, and a very few terrestrial ; and they present corresponding differences in the structure of their tissue, presence of stomates, \&c.

\section{Literature.}

Von Mohl-(Stem of Isoëtes) Linnæa, I840, p. I81.

Braun-Ueber Isoëtes, Monber. Berlin Akad. Wiss., I 863.

Hofmeister-Entwick. d. Isoëtes lacustris, Abhandl. Sächs. Gesell. Wiss., I865.

Pfeffer-Entwick. d. Keims Selaginella, in Hanstein's Bot. Abhandl., iv., r87 r.

Tchistchakoff-(Isoëtes) Nuov. Giorn. Bot. Ital., I873, p. 207.

Bruchmann-Wurzeln v. Lycopodium u. Isoëtes, 1874 .

Hegelmaier-Bot. Zeit., 1874, p. 481.

Goebel-(Apogamy of Isoëtes) Bot. Zeit., I879, p. I.

Mer-(Sporange of Isoëtes) Compt. Rend., xlii., I88I, p. 310 ; and Bull. Soc. Bot.

France, I881, pp. 72, Io9.

Kienitz-Gerloff-(Embryo of Isoëtes) Bot. Zeit., I881, pp. 761, 785 .

Vines-(Isoëtes) Annals of Botany, vol. ii., 1888, p. 117. 


\section{ISOSPOROUS VASCULAR CRYPTOGAMS.}

\section{Class III.-Lycopodiaceæ.}

The Lycopodiaceæ are a comparatively small group of plants comprised in only four genera, differing from one another greatly in habit, but agreeing in the prevalence of a dichotomous rather than of a monopodial mode of branching in both stem and root, though this is by no means universal. Growth is effected by a group of equivalent cells in the growing point, never (except in Psilotum, Sw.) by a single apical cell. The leaves are always of small size and entirely undivided ; in Psilotum they are reduced to mere scales, and this genus is also entirely rootless; while in Phylloglossum (Kze.) the underground stem is tuberous. The sporanges and spores are of one kind only; the spore produces on germination (where this has been observed) a green or colourless prothallium, which carries on a much more independent existence than is the case in the heterosporous orders, and bears, in the cases which have been examined, both archegones and antherids. The position of the sporanges varies. In the Lycopodiex it corresponds to that of the Selaginelleæ, on the upper side of the base of the leaf, or they are crowded on special erect branches ; and here the sporanges are unilocular ; while in the Psilotex they are plurilocular, and are grouped on the main stem or on short lateral branches. Further details are best described under the heads of the two orders into which the Lycopodiaceæ may be divided. In the monøcious prothallium the Lycopodiaceæ approach the Ophioglossaceæ ; while in the structure of the sporophyte they display a remarkable resemblance to the heterosporous Selaginellaceæ.

\section{Order I.-LycopodieÆ.}

In this order are included two genera of very different habit: Lycopodium (L.), with nearly roo known species ; and Phylloglossum (Kze.), with only one. The form and appearance of the oophyte vary greatly even in the different species of the typical genus Lycopodium. The gernination of the spores of L. inundatum (L.) has been described as follows by de Bary :-The endospore bursts in the form of a nearly spnerical vesicle through the exospore, which splits into three valves; the germinating filament which originates in this way then divides by a septum into a basal cell, which undergoes no further change, and a larger apical cell, which divides into two rows of segments; each segment further divides by a tangential wall into an inner and an outer cell, so that 
the young prothallium now consists of an axial row of four short ce!ls, the basal and apical cells, and two lateral rows. The cells contain a few grains of chlorophyll. The formation of the sexual organs was not observed. The mature oophyte of L. annotinum (L.) presents several important differences. The prothallium is underground and of a yellowish-white colour, destitute of chlorophyll, and consists of a tuberous mass with cushion-like ridges on the upper side and a few small rhizoids. On its upper side and completely imbedded in the tissue are a number of antherids, consisting of cavities covered by one or more layers of cells,

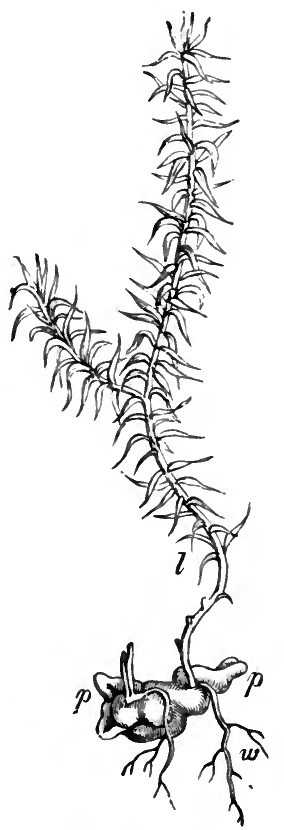

FIG. 34.-Young plant of Lycopoditum annotinum L. $p$, prothallium; $w$, root (natural size). (After Fankhauser.) and containing a large number of mother-cells of antherozoids. 'The antherozoids themselves appear to be minute bodies consisting of only a few coils, and probably with two cilia. The archegones have not been actually observed, but are evidently borne on the same prothallium

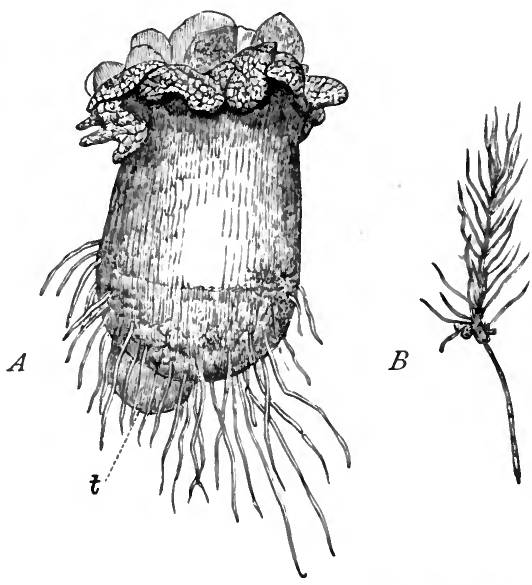

FIG. 35. $-A$, prothallium of $L y$ copodium cernuum L. ; $t$, tuberous outgrowth $(\times 25)$. $B$, young plant of $L$. cernutum $\left(x_{2}\right)$. (After Treub.)

as the antherids, and in close contiguity with them, apparently on the upper side, in the depressions between the ridges. Only one archegone appears to be fertilised on each prothallium. The young sporophyte has no foot, its place being supplied by a tuberous swelling with roothairs. A very different type of prothallium is presented, according to Treub, by L. cernuum (L.). It consists of a short cylindrical axis half immersed in the soil, containing chlorophyll in its exposed portion, and putting out rhizoids from its lower end. The upper extremity bears a tuft 
of small leaf-like lobes, beneath which are the archegones and antherids on the same prothallium, and buried in its tissue. Each antherid arises from a single superficial cell, which divides by a transverse septum into an outer stigmatic cell, subsequently splitting up into three, and a basal cell in which the antherozoids are formed. The archegone has a very short neck, consisting of three rows of cells. While the prothallium displays greater differentiation than is the case elsewhere in Vascular Cryptogams, the embryo or young sporophyte is, on the contrary, of very simple structure, and entirely parenchymatous. A cotyledon is formed at one end, but there is no primary root, or other differentiation of organs. In L. Phlegmaria (L.) the prothallium is cylindrical, without chlorophyll, and branches freely. The rhizoids proceed from a super-

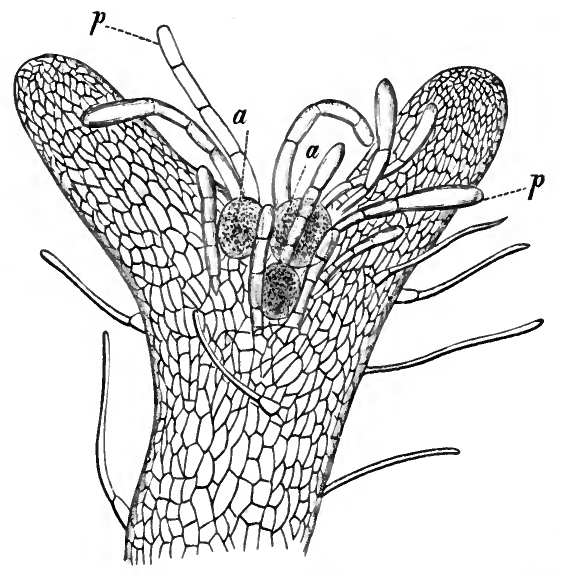

FIG. 36.-Prothallium of L. Phlegmaria L. Bifurcate branch bearing antherids, $a$, and paraphyses, $p$ ( $\times$ 9o). (After Treub.)

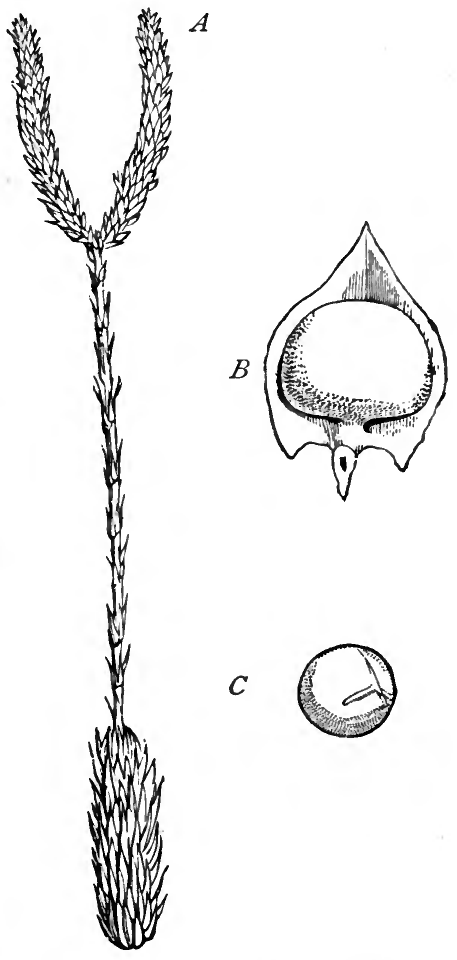

FIG. 37.-Lycopodium clavatum L. $A$, sporangiferous branch (natural size); $B$, sporange and subtending leaf (greatly magnified) ; $C$, spore, showing lines of fissure (still more magnified).

ficial layer, which also branches laterally, by which means fresh prothallia are constantly being formed without any production of sexual organs. The archegones and antherids are borne on the upper surface of the prothallium, and are always accompanied by paraphyses, barren tubular cells of rare occurrence among Vascular Cryptogams. The 
antherids are scattered or in groups, and produce biciliated antherozoids. The archegones appear later than the antherids on the thickened extremities of the same branches. They project above the surface of the prothallium, and have from three to five canal-cells. In the formation of the sporophyte it is possible that we have a transition between Vascular Cryptogams and Muscineæ. The oosphere divides by a wall vertical to the axis of the archegone into two cells, of which the one nearest the neck becomes the suspensor, while the other is the mothercell of the embryo. The first root is but slightly endogenous. The cells of the prothallium of all known species of Lycopodium are liable to be infested by an endophytic Pythium, the zoospores of which have very probably been taken for antherozoids. The oophyte of Phylloglossum

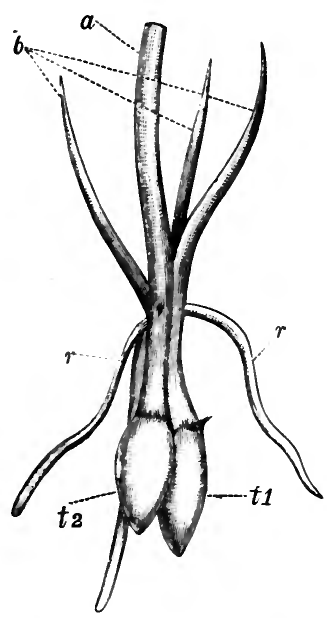

FIG. 38.-Phylloglossum Drum. mondii Kze. l, leaves ; $r$, roots ; $t_{1}$, old tuber; $t_{2}$, new tuber: $a$, sporangiferous axis $\left(x_{3}\right)$. (After Bower.) is unknown. Of the development of the sporophyte of the Lycopodieæ very little is known in its early stages.

In the typical genus Lycopodium the sporophyte resembles Selaginella in habit. The stem of most species is procumbent, extending in the case of L. clavatum (L.) to several feet, and putting out here and there a few roots into the soil. Less vigorous branches rise erect, and are sporangiferous. The procumbent species display a tendency to bilateralness,, especially in the structure of the axial 'vascular' bundle. In other species the much shorter stem grows erect, and puts out roots from its lower portion, which in some cases grow downwards through the tissue of the stem, emerging only as a tuft at its base. In some of these erect species, especially in the tropics, the stem is stout and shrubby. One or two species of Lycopodium have climbing stems; a few are epiphytic. The sporophyte of Phylloglossum, its only known condition, has a striking resemblance to the embryonic condition of Lycopodium. The erect unbranched stem is very short, rising into a slender scape, which bears at its extremity a spike of sporanges, and at its base a rosette of long subulate leaves; otherwise the stem bears only a few very rudimentary leaves. The plant is reproduced by adventitious shoots consisting of a tuber with a leafless rudimentary bud.

As far as has been at present observed, the growing end of the stem of Lycopodium has no single apical cell, and the same is true of the leaves and of the roots. The growing point of the stem corresponds 
closely with that of Gymnosperms. It is composed of a small-celled primary meristem, in which no differentiation can be detected into

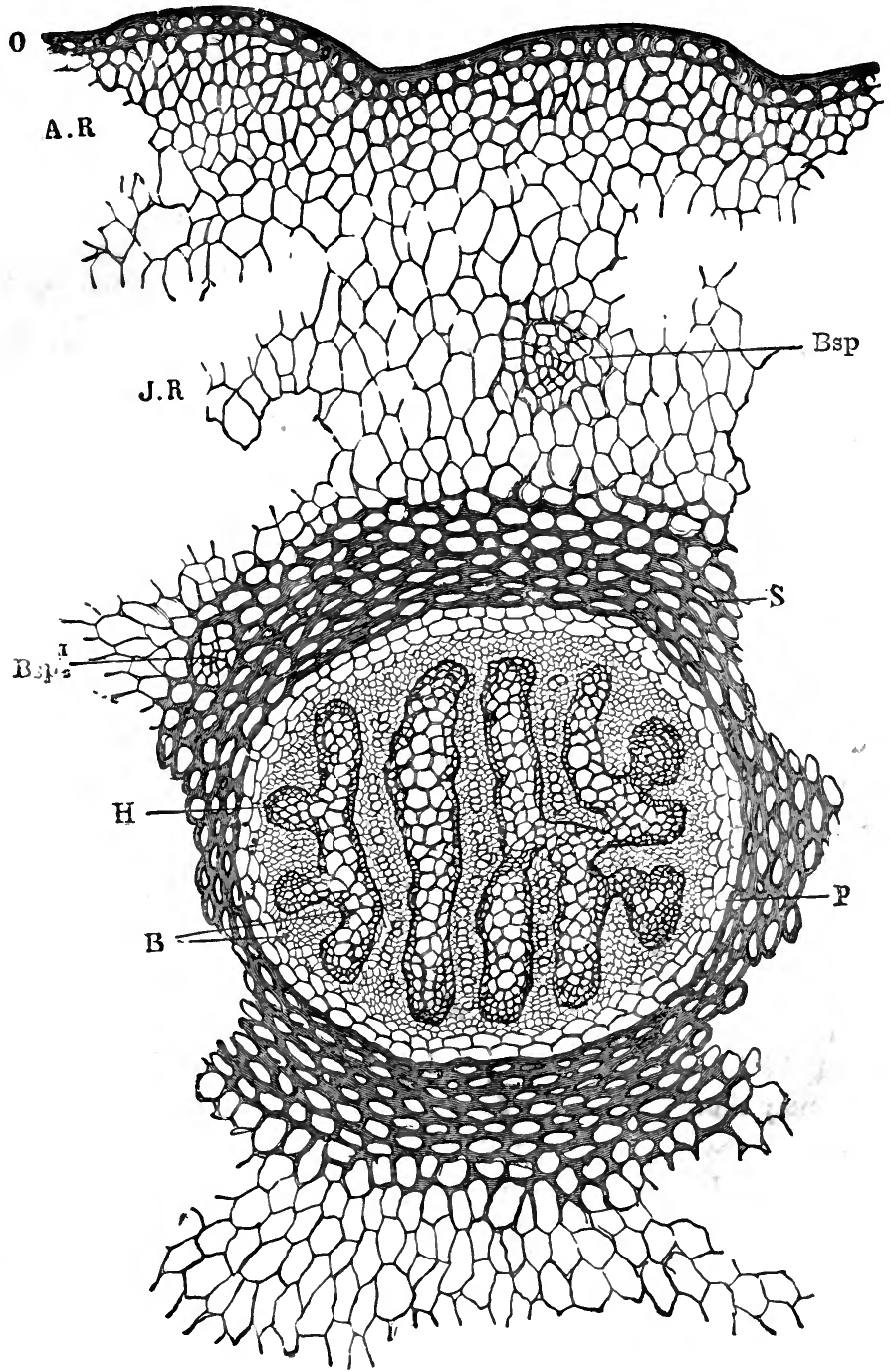

F1G. 39.-Transverse section of stem of $L$. annotinum. O, epiderm; A R, outer cortex ; J R, inner cortex : $S$, sclerotised fundamental tissue; $P$, vascular bundle-sheath; $H$, xylem; $B$, phloemportion of axial vascular cylinder; Bsp, leaf-traces (magnified). 
dermatogen and periblem, the rudiments of the 'vascular' bundle penetrating nearly to its apex. In some species it projects in the youngest leaves in the form of a low cone ; in others the apex is flat. As in Flowering Plants, the leaves and rudiments of the shoots do not arise from single cells, but from groups of cells which include both the outermost and the subjacent layers of the primary tissue of the growing point.

The branching of the stem of Lycopodium is either monopodial or dichotomous in its origin ; but in the latter case one of the bifurcations usually greatly exceeds the other in vigour of growth. The branches are never placed in the axils of leaves, as in Flowering Plants, but usually arise from the stem above a leaf, but without any definite relation to it. In several species two new growing points of equal strength appear side by side on the flat apical surface, and continue to develop dichotomously. In others the rudiment of the new branch takes the form of a lateral protuberance on the greatly elevated cone of growth. On the stems of many species the small leaves are so closely packed that the internodes are completely suppressed.

The internal structure of the stem of Lycopodieæ presents several peculiarities. The cells of the fundamental tissue are sometimes uniformly thin-walled, but usually the inner layers in particular have thicker walls, and the cells are prosenchymatous, or even have their walls strongly sclerotised, reminding one of the sclerenchymatous layer in ferns; but they are never coloured brown. The axial 'vascular' cylinder is separated from the cortical fundamental tissue by a strongly developed bundle-sheath, composed of from one to three layers of cells. Aircavities and mucilage- and gum-passages sometimes occur in the fundamental tissue of the stem and the leaves. The 'vascular' bundles themselves present a striking peculiarity in Lycopodium, forming in the stem and root a single axial cylinder, usually with a circular outline. In this compound bundle are plates or bands of xylem, which are either completely isolated, or coalesce in various ways so as to form figures which are divided into two similar halves by an axial longitudinal section. The cylinder may therefore be described as displaying a bilateral symmetry. If transverse sections are made at different heights in the stem, the xylem presents different figures, in consequence of the bands anastomosing in their course. The elements of these xylem-bands are, like those of ferns, tracheides pointed at both ends, and increasing in breadth towards the interior, the most common form of thickening being pitted or scalariform rather than annular or spiral ; the latter are found only at the outer edges of the bands. The whole mass of xylem-bands is surrounded by a narrow-celled phloem, containing, in the larger species, sieve-tubes. Between the outer edges of the xylem-bands and the 
periphery lie the bast-like cells known as 'protophloem-elements.' Within the bundle-sheath the phloem is surrounded by several layers of larger cells, corresponding to the phloem-sheath of ferns. Though the sclerotised tissue is much less developed than in ferns, the axial 'vascular' bundle is, in the stouter species of Lycopodium, surrounded by a ring of fibres composed of several layers. The axial bundle is cauline, and may be followed out, in a rudimentary condition, to very near the apex. In Phylloglossum the short stem is traversed by a single narrow bundle, which is very weak, and has no scalariform, only a few spiral and annular tracheides.

The roots of Lycopodium originate on the outside of the axial cylinder ; their internal structure is similar to that of the stem. In the erect species they have their origin at a considerable height in the stem, whence they strike downwards through its fundamental tissue, in which they sometimes even branch dichotomously, and emerge in the form of a tuft at the base of the greatly thickened stem. In the creeping and climbing species they emerge separately, and dichotomise in the soil in intercrossing planes. The epiderm of the root is often strongly cuticularised. In Phylloglossum the underground portion of the stem consists of two ovoid tubers of different age (see fig. $3^{8}$ ), which are destitute of the least trace of 'vascular' bundles. From above these tubers spring a few adventitious roots, which are of endogenous origin, do not branch, and each of which has a single concentric axial bundle.

The leaves are very small in most species of Lycopodium, and invariably narrow, simple, and sessile; sometimes with a long apiculus. They are sometimes adpressed to the stem with the exception of the free apex; more often they are entirely free. In some species the form and size of the leaves vary greatly even on the same individual plant, and these heterophyllous species often display more or less of a bilateral structure. The phyllotaxis is sometimes verticillate, sometimes spiral, or both arrangements occur together in the same species. In the verticillate species the leaves are either decussate, or in whorls of three, four, or more ; on creeping stems they are usually placed on a transverse zone oblique to the axis; and the number of leaves in a whorl varies even on the same branch. The small and extremely variable divergences of the leaves in the species with spiral phyllotaxis are very remarkable. Each leaf is always penetrated by a single central 'vascular' bundle without any lateral branches; it is of very simple structure, and is in connection with the axial cylinder of the stem. In L. albidum (Bak.) the leaves are membranous, and quite destitute of chlorophyll. The epiderm is provided with stomates, either on the under surface only or on both surfaces, and frequently collected into groups. The fundamental 
tissue is sometimes furnished with air-cavities and gum-passages, usually in connection with the 'vascular' bundle. In some of the heterophyllous species these occur only in the sporangiferous or fertile leaves. In Phylloglossum the leaves all spring from the base of the scape (see fig. $3^{8)}$; they are narrow and subulate, about half an inch in length, and penetrated by a single 'vascular' bundle. They are colourless in their basal half, green in their apical half, and have stomates only in the green part. In a large number of species of Lycopodium all the leaves serve the purpose of nutrition only, and the sporanges are borne in the axils of ordinary leaves. But in the remaining species of Lycopodium, and in Phylloglossum, the leaves which subtend the sporanges are greatly modified, being of a membranous texture and colourless. In these species the sporanges with their subtending leaves are usually collected into spike-like 'inflorescences,' which may be short, erect, bifurcate branches, as in L. clavatum, or an elongated naked scape, as in Phylloglossum.

The sporanges of Lycopodium are seated each on the base of a leaf which has frequently undergone more or less metamorphosis (see fig. $37, B$ ) ; by displacement they may subsequently become axillary. They are kidney-shaped, and are attached at their broader side by a short thick pedicel. They are unilocular, and dehisce by a fissure across the apex in the longest diameter. In all the Lycopodiaceæ the outer walls of the epidermal cells of the sporange are composed of pure cellulose, while the inner and side walls are lignified. Dehiscence takes place by the outer face of these cells contracting more than their inner face in dry air. The small and numerous spores are sphero-cubical, the exospore being marked in a variety of ways. On germinating the exospore splits by three fissures which meet in a point at the apex of the spore, the endospore projecting between the three valves thus formed. The sporange originates as a prominence from a group of superficial cells at the base of the leaf. The original cells from which it is formed are few in number; the central one of these gives rise to the archespore. The wall of the sporange ultimately consists of from two to four layers of cells; the innermost of these forms the layer of tapetal cells. The mother-cells of the spores become separated from one another, and invest themselves with very thick cell-walls; from each is developed four spores, and the exospore becomes elevated into warts, spines, \&c., before the walls of the mother-cells have become absorbed. In Phylloglossum the sporanges are also unilocular, and are placed in the axil of short triangular apiculate metamorphosed leaves ; and a large number are collected into a spike-like 'fructification' at the extremity of a naked scape. They dehisce by a vertical longitudinal fissure. The spores 
are excessively minute, and have three radiating lines meeting at the apex. Their germination is unknown.

In most species of Lycopodium vegetative propagation takes place by means of axillary bulbils, which become detached; and in some, adventitious buds are also produced lower down on the stem. L. cernuum produces similar gemmæ or bulbils on the root. Phylloglossum is propagated by the lateral budding of its underground tubers, in a manner somewhat similar to our native species of Orchis.

The species of Lycopodium are scattered over the whole globe from the polar to the equatorial regions, the greater number growing on elevated ground or in swamps; some are epiphytic. The monotypic Phylloglossum Drummondii (Kze.) is a native of swamps in Australia and New Zealand. Several species of Lycopodium have an ancient use as cathartics. The spores are used in the manufacture of pills, and have the property, from the large quantity of oil which they contain, of keeping the hands dry when dipped in water. Those of L. clavatum are collected in large quantities, especially in Northern Germany, for pyrotechnic purposes. The British species are popularly known as 'clubmoss' and 'stagr's-horn moss.'

\section{Order 2.-PSILOTEE.}

This order is composed of the two very small tropical genera Psilotum (Sw.) and Tmesipteris (Bernh.), of the latter of which very little is known, it never having been examined in the living state.

The stem is erect, and is penetrated, in Psilotum, by a cauline 'vascular' bundle of very simple structure, which is circular on transverse section, and is surrounded by a bundle-sheath. It always branches dichotomously. Psilotum is entirely rootless, the function of roots being performed by remarkable underground branches of the stem, which dichotomise like the aërial shoots. These underground shoots have a three-sided apical cell, and are entirely destitute of a root-cap. Those only which are nearest the surface have a few whitish subulate rudimentary leaves ; these may turn upwards, develop chlorophyll, and become ordinary aërial shoots. Those branches which strike deeper into the soil are slenderer, and the rudiments of leaves are reduced to groups of a few cells which remain buried in the tissue, not projecting above the surface. They resemble true roots in their single axial 'vascular' cylinder. Psilotum triquetrum (Sw.) produces minute gemmæ or bulbils, which remain dormant for a time, and from which the plant not unfrequently makes its appearance apparently spontaneously in orchid-and palm-houses. The leaves of Tmesipteris are erect, elliptical, 


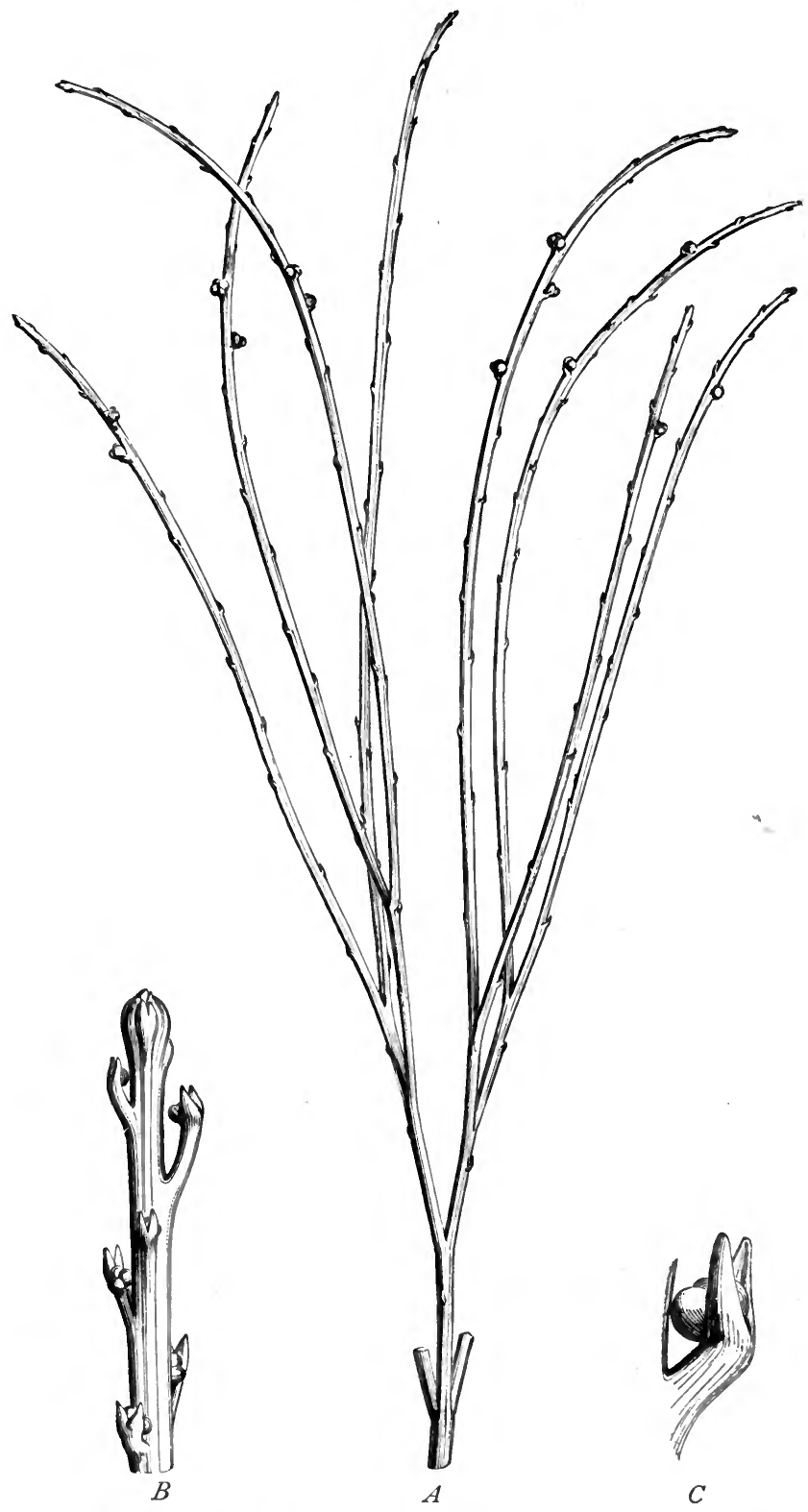

Fig. 40.-Psilotum triquetrum Sw. $A$, fertile branch (natural size); $B$, portion of the same (magnified); $C$, smaller portion an $\ddagger$ sporange (still more magnified). 
and apiculate, and are penetrated by a single 'vascular' bundle ; those which subtend the sporanges are much smaller, and apparently deeply bifid, in consequence of their becoming connate at their base in pairs. In Psilotum the leaves are reduced to mere scales without any 'vascular' bundle.

The sporanges of the Psiloteæ differ from those of the Lycopodieæ in not being formed in connection with the leaves, and in being plurilocular. They are collected into spikes which are formed at the growing point of a primary shoot. In Tmesipteris each spike usually consists of two sporanges only, situated in the fork between two connate or one bifid fertile leaf ; they are oblong and bilocular, and dehisce by two vertical slits; the spores are very minute, oblong, and curved. In Psilotum the sporanges are collected into groups of three or four on special short lateral branches, each in the axil of a rudimentary leaf, and forming a loose spike. They are turbinate in form, and are divided into three compartments, less often into two or four ; each locule dehisces by a vertical fissure. The germination of the spores and the oophyte generation are entirely unknown in the order.

Psilotum consists of two spe-

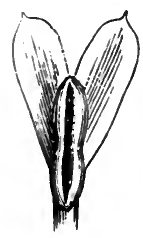

$B$

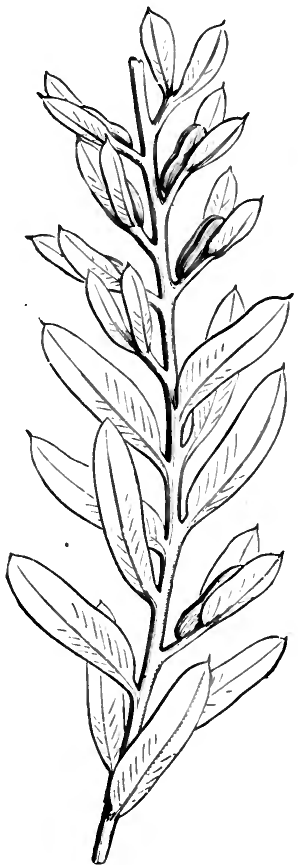

At

FIG. 4r.-Tmesipteris tannensis Bernh. $A$, portion of branch (natural size); $B$, sporange and subtending leaves (magnified). cies, natives of the tropical regions of both hemispheres, having the appearance of small branching nearly leafless shrubs; Tmesipteris of a single known species, epiphytic on the trunks of tree-ferns, with a pendulous habit, in the Southern Hemisphere.

\section{LITERATURE.}

Spring-Monograph des Lycopodiacées in Mém. Acad. Roy. Belgique, I 842 and 1849 .

Cramer-(L. Selago) in Nägeli u, Cramer's Pflanzenphys. Unters. Heft i., 1855.

De Bary-(Germination) Naturf. Gesell. Freiburg, 1858.

Mettenius-(Phylloglossum) Bot. Zeit., 1867, p. 97.

Payer-Botanique Cryptogamique, 1868.

Juranyi-(Psilotum) Bot. Zeit., 1871, p. 177.

Hegelmaier-Bot. Zeit., 1872, pp. 798 et seq., and 1874, p. 773 . 
Fankhauser-(Prothallium) Bot. Zeit., I873, p. I.

Strasburger-Bot. Zeit., I873, pp. 8I et seq.

Bruchmann-Ueb. Wurzeln v. Lycopodium u. Isoëtes, 1874 .

Beck-(Prothallium) Oesterr. Bot. Zeitschr., 1880, p. 341.

Bertrand-(Psilotum) Compt. Rend., xcvi., I883, pp. 390, 5 18 ; (Phylloglossum) do., xcvii., I883, pp. 504 et seq.

Solms-Laubach-(Psilotum) Ann. Jard. Bot. Buitenzorg, I884, p. I39, and 1886, pp. $217,233$.

Treub-(Prothallium) Ann. Jard. Bot. Buitenzorg, I884, p. 307, and I886, p. 87 ; see Nature, xxxi., I885, p. 31 7 , and xxxiv., I886, p. 145.

Galloway-(Spores) Bull. Torrey Bot. Club, I885, p. 55.

Bower-(Phylloglossum) Proc. Roy. Soc., xxxviii., 1885, p. 445.

Bruchmann-(do.) Bot. Centralbl., xxi., I885, pp. 23, 309.

Treub-(Prothallium) Ann. of Bot., i., I887, p. I 19.

Goebel-(Prothallium) Bot. Zeit., I887, pp. I6I, 177.

\section{Class IV.-Filices.}

Ferns (under which term the Ophioglossaceæ are also included in popular language) are by far the most numerous and best known class of Vascular Cryptogams. In some families, however, as the Marattiaceæ and Schizæaceæ, much yet remains to be made out with regard to the history of development, and their exact position in the ${ }_{\text {-circle of }}$ affinity must remain for a time doubtful.

The germinating spore develops into the prothallium by the bursting of the cuticularised exospore, and the rapid growth and division of the contents of the endospore into a plate of cells. Before germination the contents of the spore become invested with a new cellulose membrane. But the tabular prothallium does not always result directly from the contents of the spore. In the Hymenophyllaceæ the spore undergoes division, even before the rupture of the exospore, into three cells, one of which only attains great development, dividing by transverse septa, and branching until it greatly resembles the protoneme of a moss; the flat prothallia then springing from lateral shoots. In most of the Polypodiaceæ, which include by far the greater number of the genera of ferns, and in the Schizæaceæ, the contents of the spore develop directly into a short segmented filiform protonemal structure, which expands at the apex into a cordate or reniform plate of tissue, consisting at first of only a single layer of cells. If a single apical cell is present, it soon disappears, and is replaced by a growing point situated in a depression at the anterior end of the prothallium, behind which a cushion, several layers in thickness, is formed by tangential cell- 
divisions. The prothallium is most commonly monœcious, though the sexual organs may not appear at the same time, and is strictly bilateral or dorsiventral, the result, according to Leitgeb (Sitzber. Akad. Wiss. Wien, lxxx., I880, p. 20r), of the action of light. The archegones

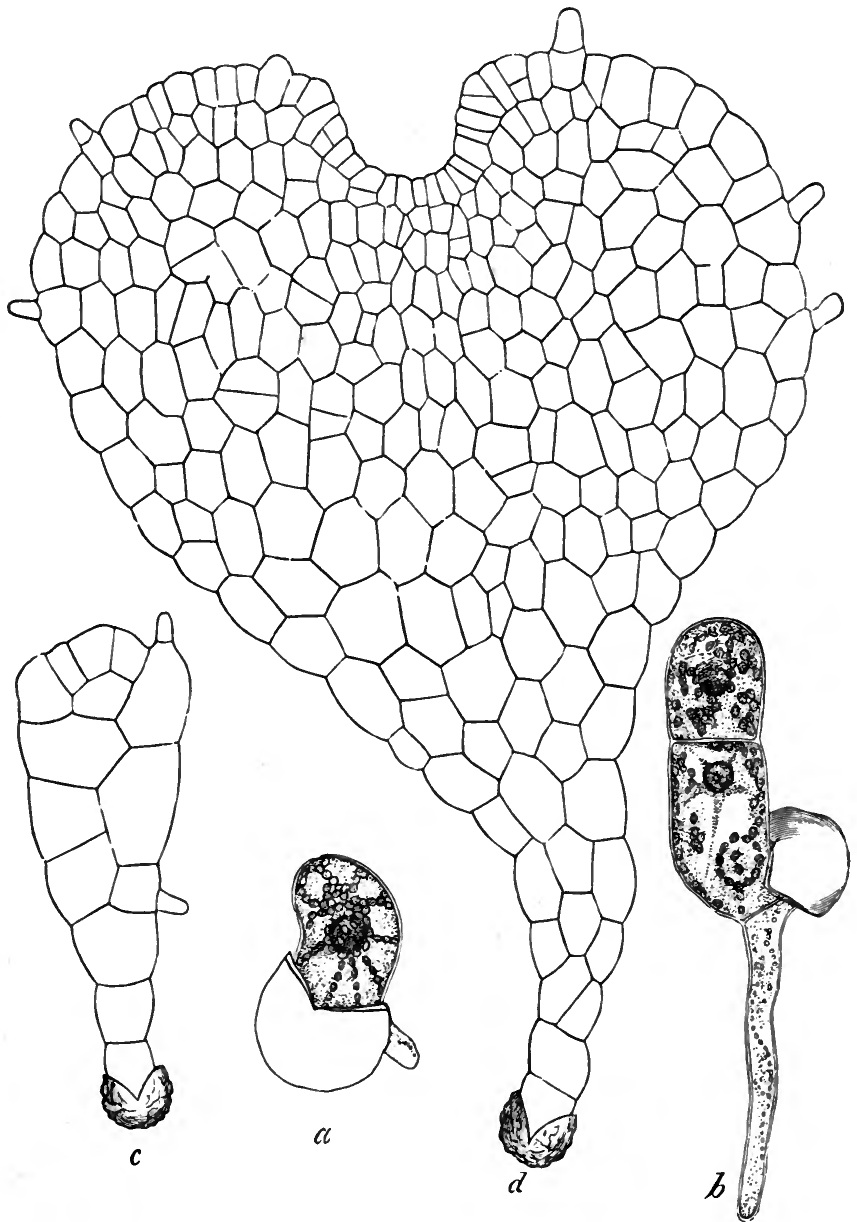

FIG. 42.-Germination of prothallium of fern, with exospore still attached. $a, b$, Dicksonia antarctica Lab. (x 240); $c, d$, Aspidium filix-mas Sw. ( $\times$ I 20). (After Luerssen.)

are found exclusively (except in Marattiaceæ) on the under side of the cushion. Rhizoids are produced in large numbers on the under side of another part of the cushion; the antherids also on the under side among the rhizoids, or less often on the margin. In Gymnogramme 
leptophylla (Desv.) the prothallium is many-lobed, and the archegones and antherids are produced on separate conical tuber-like outgrowths

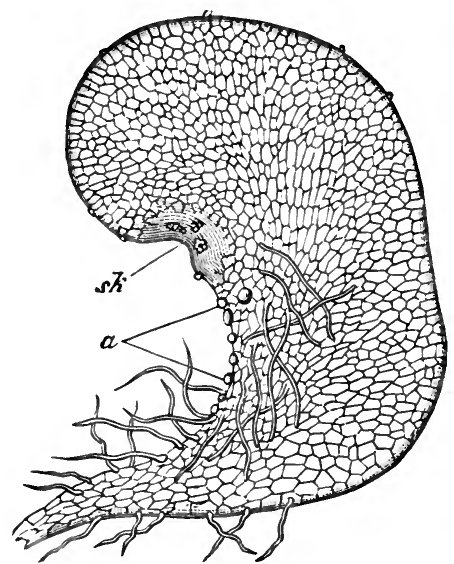

Fig. 43.-Under side of prothallium of Aneimia Phyllitidis Sw. sk, cushion, with archegones; $a$, antherids and rhizoids $(\times 25)$. (After Bauke.) from its under side, which penetrate into the soil, where they are perennial, and may give birth by budding to new prothallia, while the sporophyte generation is annual. The prothallium is occasionally, in the Hymenophyllaceæ, reduced to a single row of cells terminating in an antherid, or even to a single cell. Campbell has detected continuity of protoplasm in the cells of the prothallium of Struthiopteris germanica (L.). In the Osmundaceæ the prothallium springs directly from the spore without any intermediate protoneme, a plate of cells being formed on germination by longitudinal and transverse divisions; the first rhizoid is formed out of a posterior cell. The ribbon-shaped prothallium of Osmunda (L.) is characterised by the presence of a midrib composed of several layers of cells running along its whole
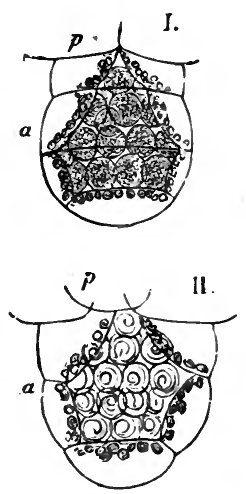

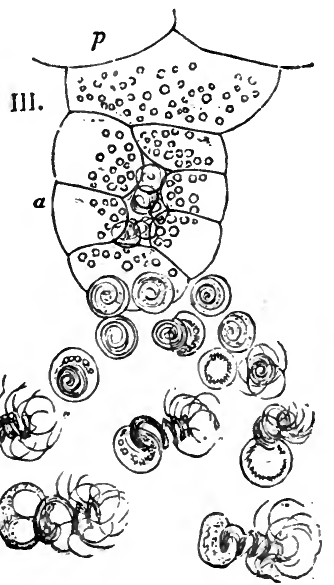

FIG. 44.-Antherid of Adiantum capillus-Veneris L., in different stages. $\phi$, prothallium; $a$, antherid ; $s$, antherozoids; $b$, vesicle with starch-grains $(\times 500)$. length. The archegones are produced on the under surface on this midrib; the antherids either on the margin or on the under surface with the exception of the midrib. An approach towards a higher type of organisation is indicated by the tendency of the prothallium to become diøcious in the Osmundaceæ, and in Struthiopteris (L.). All the spores from the same sporange sometimes produce male prothallia, i.e. such as bear antherids only, the 
archegones being produced later, and in smaller numbers, on female prothallia; or the same prothallium may produce first antherids and subsequently archegones, when it may be termed proterandrous. This is remarkably the case also in Gymnogramme. In Cystopteris fragilis (Bernh.) (Polypodiaceæ) Campbell states that there are two kinds of prothallium, a smaller male and a larger hermaphrodite. The prothallium of ferns is sometimes propagated vegetatively by the production of adventitious shoots from single marginal cells, which become detached and form independent prothallia. This takes place especially in Hymenophyllaceæ and in Osmunda, but occurs also in Polypodiaceæ,
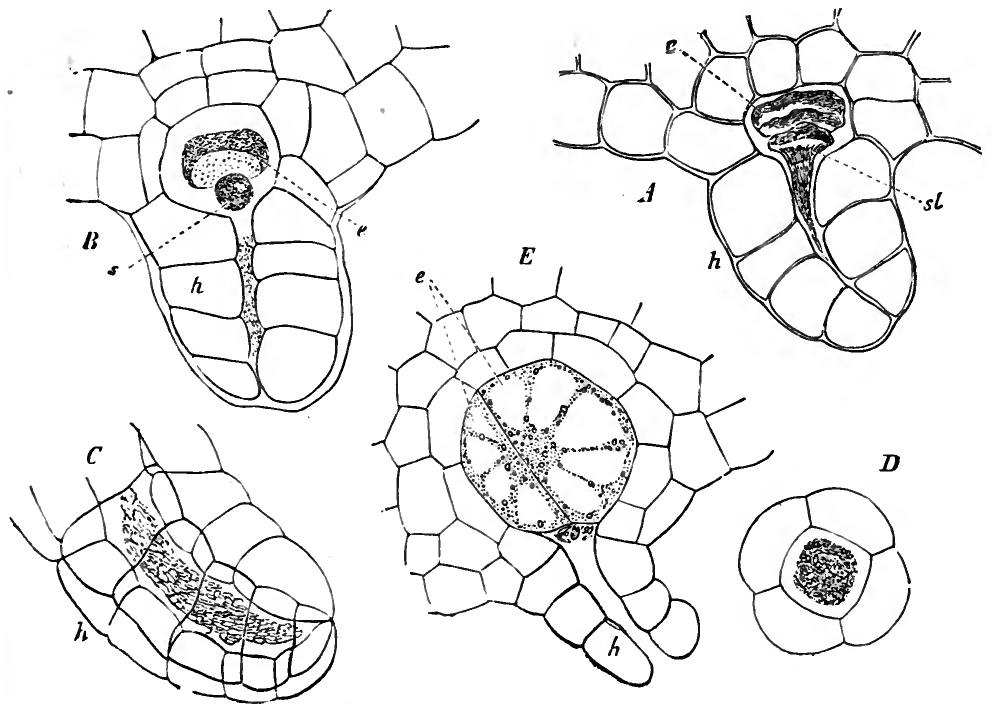

FIG. 45.-Archegone of Adiantum capillus-Veneris, in various stages. $A, B, C, E$, in longitudinal, $D$, in transverse section; $h$, neck; $s l$, canal-cells converted into mucilage ; $s$, ventral canal-cell; $e$, oosphere ; in $E$ divided into a 2 -celled embryo ( $\times 800$ ). (After Goebel.)

abundantly in Gymnogramme (see Cramer, Denkschr. Schweiz. Naturf. Gesell., I880). The prothallium of Vittaria (Sm.) produces peculiar stalked bulbils.

The antherids of ferns are small papilliform projections on the under side or margin of the prothallium (very rarely on the upfe: side), produced among the rhizoids, and of similar origin, i.e. from a single superficial cell ; in the Hymenophyllaceæ they are produced also on the protonemal filaments. The protuberance becomes separated by a septum from the parent superficial cell, and then sometimes divides at once into the parent-cells of the antherozoids. But more often the 
papilla divides first of all into a central cell surrounded by a single layer of peripheral cells. These last are barren, but contain chlorophyll ; while the central cell divides still further, each derivative nearly cubical cell then producing a flat spirally-coiled antherozoid contained within a vesicle, or 'special parent-cell.' In no case is the number of antherozoids produced by a single antherid very considerable. The function of the peripheral cells appears to be to absorb water violently when the antherid is mature, in consequence of which they swell up considerably and rupture the central cells, thus causing the escape of the parent-cells of the antherozoids. From each of these is then discharged, by the bursting of its delicate cell-wall, an antherozoid consisting of a flat band of protoplasm coiled spirally three or four times, and bearing at its anterior end

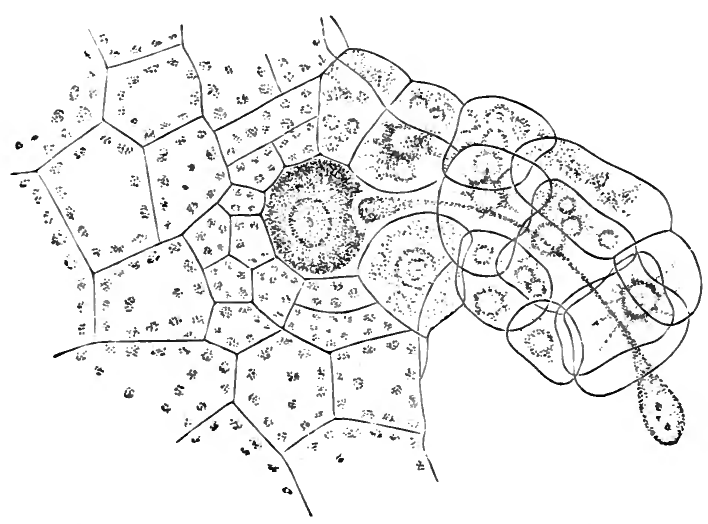

Fig. 46.-Archegone of Pteris serrulata L. at the moment of the expulsion of the mucilage $\left(\times 35^{\circ}\right)$. (After Strasburger.)

a number of fine cilia (fig. 44). To its posterior end is frequently attached for a time a vesicle containing starchgrains, which is probably the remains of the special parentcell of the antherozoid. As in other Vascular Crypto. gams, the body of the antherozoid appears to be formed from the nucleus of

the mother-cell, the cilia from the cell-protoplasm.

The archegones are produced on the under side of the cushion of the prothallium, but in much smaller numbers than the antherids. Like them, each archegone is derived from a single superficial cell, which at first bulges only slightly, and is first divided into three cells by two tangential walls. The lowermost of these three, or basal cell, divides further, and takes its share in the formation of the venter, or swollen part of the archegone, which is altogether imbedded in the prothallium. The outermost of the three cells develops into the neck-wall, or outermost wall of the neck of the archegone, dividing at first into four cells, from which the four rows of cells which constitute the neck are formed by oblique septa. Since the neck grows more rapidly on the anterior side, i.e. the side nearest to the apex of the prothallium, and hence becomes convex on that side, the number of cells is also larger in the 
anterior rows of the neck, the usual number being six, while there are seldom more than four in the concave posterior side. From the middle one of the three primary cells arises the whole of the axial row of cells of the archegone, consisting of the central cell and the canal-cells. During the development of the neck this middle cell becomes pointed upwards, and forces itself between the neck-cells ; this pointed portion becomes divided off by a septum, and now forms the single neck-canalcell, which lengthens as the neck lengthens. The large central cell now breaks up into an upper and smaller ventral canal-cell and a much larger lower cell, the protoplasmic contents of which subsequently become rounded off, and constitute the oosphere. According to Campbell, the ventral canal-cell is wanting in Struthiopteris germanica (L.). The walls of the canal-cells swell up and become converted into mucilage, and finally this thin mucilage, together with the protoplasm of the canal-cells, is expelled from the open neck. The antherozoids are retained by the mucilage, and collect in large numbers before the archegone; a number of them force themselves into the canal of the neck, and of these some eventually reach the oosphere, and coalesce with it, entering it at a light-coloured spot near the neck, which is termed the receptive spot. After impregnation the neck closes up. It is very rare for more than one archegone to be fertilised on the same prothallium, and the enormous majority of prothallia perish without producing any sporophyte generation.

The ordinary course of the alternation of generations is occasionally interrupted by apogamy or by apospory, the suppression respectively of the oophyte or of the sporophyte generation. The former has been observed especially in Pteris serrulata (L. fil.), the latter in particular varieties of Athyrium filix-fœemina (Bernh.), and of Polystichum angulare(Willd.). In apogamy the non-sexual fern-plant springs directly from the prothallium without the intervention of a fertilised archegone. In apospory a prothallium is produced on the surface of the frond, either in the locality where the sorus would normally be found, or less often elsewhere, and may assume unusual forms, sometimes that of a solid cylindrical body, but bears normal archegones and antherids. Bower classifies the various forms of substitutionary or correlative growths connected with the suppression of the sporophyte generation under three heads, viz.(I) simple prolification; (2) sporophytic budding; (3) apospory. The first hardly occurs among ferns. The second is illustrated by the familiar formation of bulbils in species of Asplenium (L.), Cystopteris (Bernh.), \&c., in which the formation of the buds cannot be directly correlated with arrest of spore-formation. In apospory we get a more or less complete sporal arrest, but this may vary in degree. In some instances 
the substitutionary growths which accompany the arrest of spore-formation are restricted to the sporanges themselves. These are replaced by 'pseudo-bulbils' of a pear-like form, presenting but little resemblance to ordinary prothallia, but demonstrating their oophytic character by producing antherids. In other examples the prothalloid growths are by no means restricted to the sporange ; they may either arise from the sorus itself, or may appear at points quite distinct from the sori, and even on fronds which bear no sori at all. There is here a distinct transition from

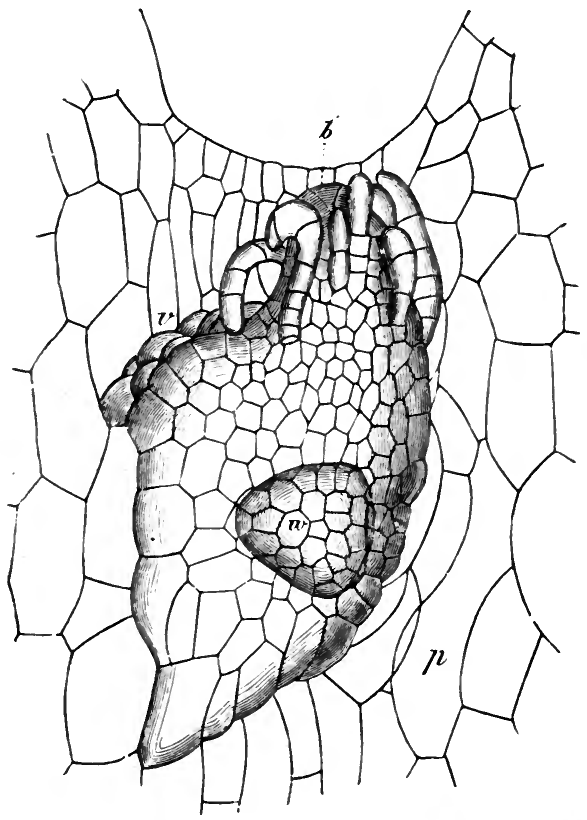

Fig. 47.-Apogamous shoot of Pteris sermulata, on the under side of the prothallium $p ; b$, first leaf; $z$, apex of stem; $w$, rudiment of first endogenous root $(\times 80)$. (After de Bary.)

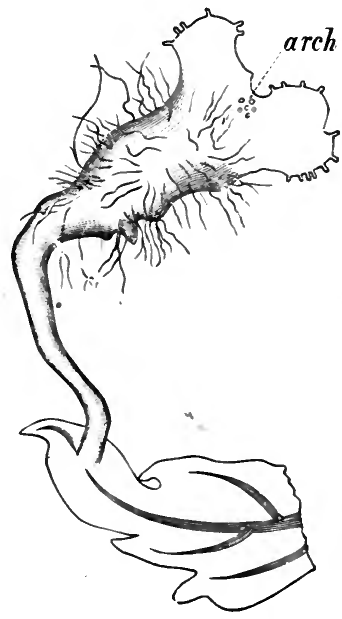

Fig. 48.-Prothalloid growth of Poly. stichum angulare Willd. var. pul. cherrima, originating from surface of frond ; arch, archegone ( $x_{10}$ ). (Afier Bower.)

sporophyte to oophyte without the intervention of spores. Comparatively little is known about the oophyte generation in the Hymenophyllaceæ, but it would appear as if apogamy were a very common, perhaps even normal occurrence in some species of Trichomanes (Sm.); and here the two phenomena have even been observed on the same individual, the oophyte and sporophyte generation succeeding one another without the production of either spores or sexual organs.

The fertilised oosphere or oosperm becomes immediately invested 
with a cell-wall of its own, and develops by cell-division into the embryo, from which springs the young sporophyte, commonly known as the fern-plant. The first division-wall in the oosperm is always nearly vertical; and two others follow, at right angles to it and to each other, dividing the oosperm into octants. From the anterior of the two original halves are derived the growing point of the stem, and the cotyledon or first leaf ; from the posterior half the foot by which it is attached to the prothallium, and the first root. Until the differentiation of the first leaf and the fixed root, the embryo remains imbedded in the surrounding tissue of the prothallium, which grows with its growth. The primary root is always small ; in the Hymenophyllaceæ it disappears early, and in many

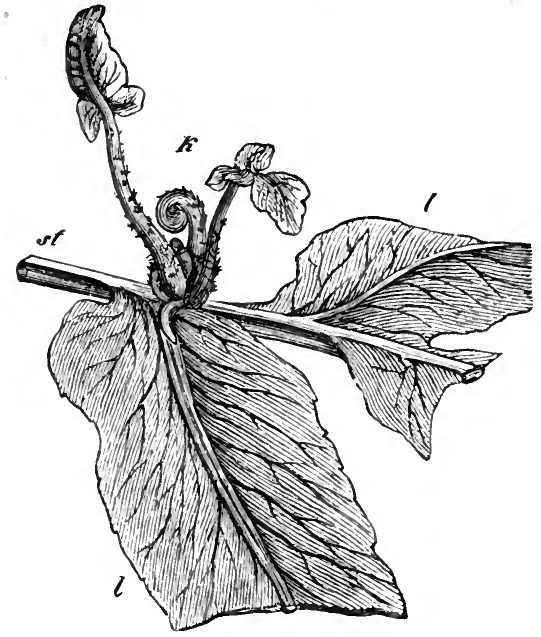

FIG. 49.-Asplenium decussatum; adventitious bud, $k$, already rooting (natural size).

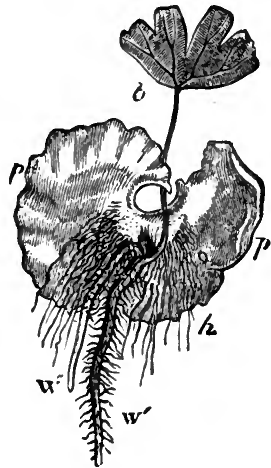

FIG. 50.-Young sporophyte of Adiantum capillus-Veneris still attached to prothallium $p ; b$, first leaf; $w^{\prime}, w^{\prime \prime}$, Ist and 2nd root; $h$, rhizoids of prothallium $(\times 30)$. (After Goebel.)

species of Trichomanes no subsequent roots are formed, their place being supplied by underground branches.

The mature fern varies in size from that of the 'filmy ferns,' species of Hymenophyllum not above an inch in height, with delicate mosslike habit, to the stately 'tree-ferns' of the Southern Hemisphere (Cyatheaceæ and Dicksonia, L'Herit.), fifty or sixty feet in height. The stem is either ascending and vertical, or creeping on or beneath the surface of the soil, or occasionally scandent (Lygodium, Sw.), often very short with undeveloped internodes, and the leaves so crowded that frequently no portion of the stem-then often called a caudex-remains exposed ; while in the creeping and climbing species the leaves are often 
separated by long internodes. The ultimate roots are always adventitious ; that is, there is no predominant axial root which is a prolongation downwards of the main axis of the plant, as in many Dicotyledons and some Monocotyledons. They are usually very numerous, especially in tree-ferns, arising in acropetal succession, and completely clothing the lower part of the stem, or, where this is suppressed, the leaf-stalks, as in the case of the common 'male fern' (Aspidium filix-mas, Sw.). The ultimate branches of the root are furnished with a root-cap as in Flowering Plants. The leaves, or, as they are more commonly called, 'fronds,' are invariably stalked, and are remarkable in many species, especially when they attain a large size, for the great extent to which subdivision of the lamina is carried; in some tree-ferns they attain a length of from six to ten feet. In the filmy ferns they consist, as in Muscineæ, of only a single layer of cells penetrated by distinct 'vascular' bundles. Stomates, similar in structure to those of Flowering Plants, occur abundantly both on the under side of the leaf and on the leaf-stalk, except in the Hymenophyllaceæ. The leaves exhibit very little metamorphosis compared to those of Flowering Plants. Most usually all the leaves are alike in form and extent of division, and even nearly so in size ; but in some species only certain of the leaves, sporophylls, are fertile, and these then show a more or less well-marked difference from the barren leaves, as in our 'hard fern' (Lomaria spicant, Desv.) and 'parsley fern'(Cryptogramme crispa, R. Br.). In the 'elk's-horn fern' (Platycerium alcicorne, Desv.), commonly grown in cultivation, the leaves are alternately broad thalluslike barren plates, closely applied to the surface on which the plant grows, and long erect dichotomously branched fertile leaves. The leaves (except the first, which spring from the prothallium) are circinate in vernation, both the principal rachis and the midrib of the pinnæ (when the leaf is pinnate) being rolled up on their upper side-owing to the more rapid growth of the cells on the under than those on the upper surface-and only slowly unroll as the development of the leaf advances. The young leaves, and the rachis and petiole of mature leaves, are generally more or less completely clothed with pales or ramenta, flat brown scale-like trichomes or outgrowths of the epiderm. These are often glandular, and sometimes contain crystals of oxalate of lime. They serve as a protective mantle to the young stem and leaves, and also as a reservoir of moisture. Capitate, glandular, and other more ordinary kinds of hair are also of frequent occurrence. In the typical ferns the sporanges are also trichomic in their origin. They are collected into groups or sori (fig. 58), usually formed in connection with a 'vascular' bundle. In unilamellar leaves these sori are placed on the edge, in all others almost invariably on the under side of the leaf, especially of its 
apical portion, and they then assume a great variety of shapes-circular, reniform, crescent-shaped, linear, or they are concealed beneath the revolute margin of the leaf. The sorus may or may not be covered by a membrane called the indusium, an outgrowth of the epiderm. In the

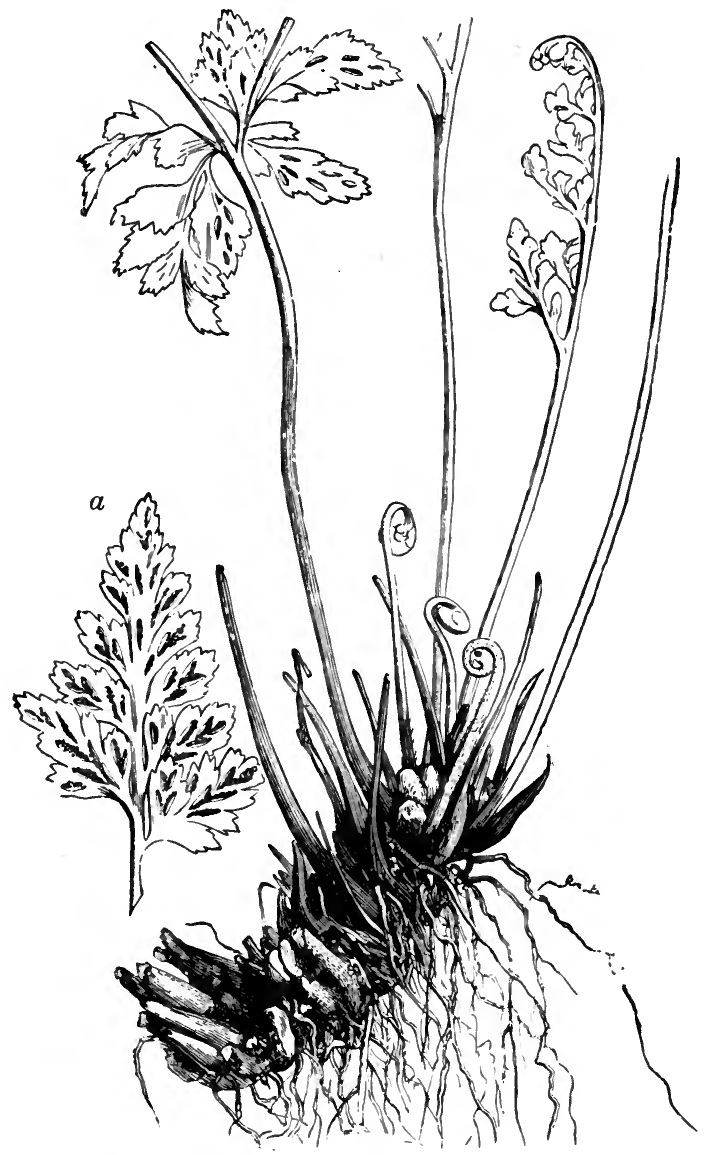

FIG. 51.-Asplenium Adiantum-nigrum L. ; rhizome with fronds showing circinate vernation (natural size). $a$, under side of fertile pinnule (magnified).

Cyatheaceæ they assume the form of a cup; in the Hymenophyllaceæ they are situated at the extremity of a vein at the apex or margin of a pinna. In some instances, as in our native 'flowering' or 'royal fern' (Osmunda regalis, L.), the sori completely consume, in the course of their 
development, the parenchyme of the fertile (apical) part of the leaf, giving the appearance of a panicled or thyrsoid inflorescence. The sporange is usually stalked, and has an elliptical form, or that of a battledore or racket-bat. The sides are commonly thin and membranous, and the sporange dehisces either longitudinally or transversely, generally from the elasticity of an annulus or ring of brown thick-walled cells running along or across it. The position of this annulus, and its more or less complete development or entire absence, are useful characters in the subdivision of the class. In the Marattiaceæ the sporanges are of altogether different origin, being developed from hypodermal masses of cells; and transitional forms occur between the two. The spores are

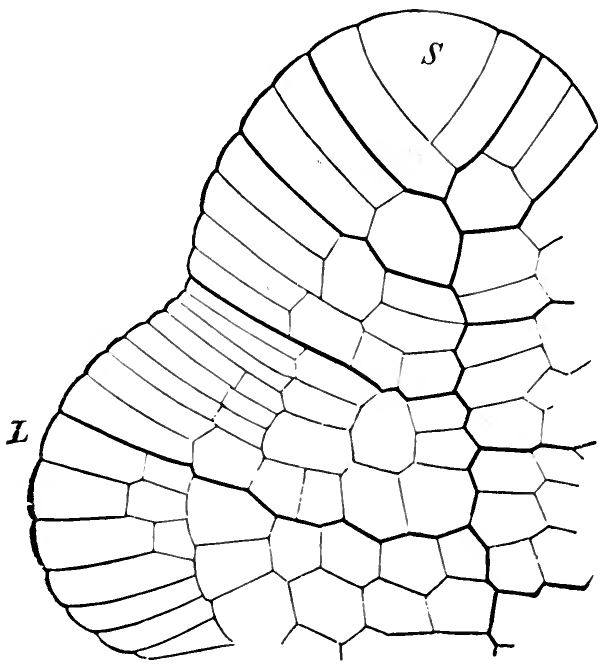

Fig. 52.-Diagram of tip of leaf of Ceratopteris thalic. troides Brongn. $S$, apical cell ; $L$, lateral lobe of leaf. (After Kny.) minute, very commonly reniform, or often nearly cubical, resembling pollengrains in structure, usually furnished with two coats, an exospore and endospore, the latter of which is sometimes double, and the former generally marked with papillæ, reticulations, \&c.

A more minute description must now be given of the structure and peculiarities of the various organs.

'The great distinguishing feature which characterises the development of the stem of ferns, as contrasted with that which occurs in all Flowering Plants (Gymnosperms and Angiosperms), is the presence of a single apical cell, from which the whole of the growing point or apical meristem originates, and which may therefore be recognised as the parent-cell of the whole of the tissue subsequently formed. This apical cell is usually wedge-shaped in creeping stems with a bilateral structure, a three-sided pyramid in erect or ascending stems. The growing apex of the stem is frequently completely hidden in the youngest leaf-bud, but in other species there is a considerable intervening space. In some Hymenophyllaceæ leafless prolongations of the stem assume the appearance and the function of roots. As contrasted with Flowering Plants, especially Exogens, the stem of ferns is characterised by the small extent to which it branches ; 
and this is true not only of the erect columnar stem of tree-ferns, but also of the creeping or erect stem of smaller species. Axillary branching is very rare, if it ever actually occurs ; the terminal branching is always dichotomous, never sympodial. The fundamental tissue of the stem and leaf-stalk consists, in many species, entirely of thin-walled parenchyme. In others, and especially in tree-ferns, portions of it undergo a change in the great thickening and brown colouring of the cell-walls, the cells becoming at the same time prosenchymatous. In

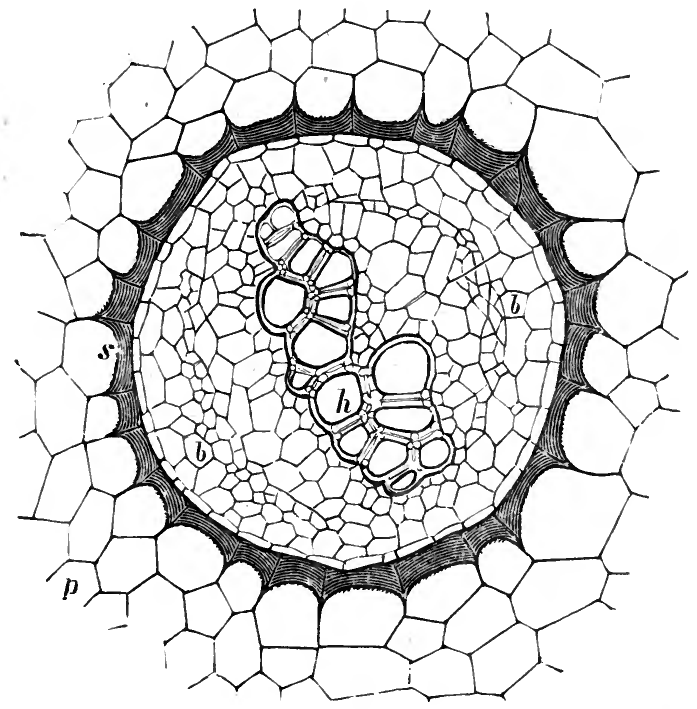

FIG. 53.--Transverse section of 'vascular' bundle of Polypodizcm leiorhizum Wall. $p$, fundamental tissue; $s$, sclerenchymatous sheath $; b$, phloem ; $h$, xylem $(\times 200)$. (After Luerssen.)

this sclerenchyme of the fundamental tissue the sclerosis may take place in

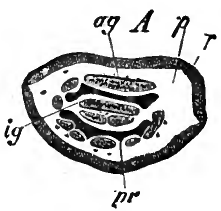

FIG. 54.-Transverse section of stem of Pteris aquilina L. $r$, epiderm; $p$, fundamental tissue ; $p r$ sclerenchymatous sheath; ig, vascular bundle; ag, outer network (somewhat magnified).

individual isolated cells ; more often the cells so affected are united into con-

spicuous bands or sheaths. In many Polypodiaceæ and Osmundaceæ the entire cortex assumes eventually a dark colour. In the common brake (Pteris aquilina, L.) two thick sclerenchymatous bands of this description lie between the inner and outer 'vascular' bundles, while another continuous layer immediately underlies the epiderm. The firmness and solidity of the stem of tree-ferns are mainly due to strongly developed sclerenchymatous cylinders which form complete sheaths surrounding the 'vascular' bundles. The 'vascular' bundles themselves are always closed or destitute of cambium; in the stem, except in Osmiunda, and usually in the leaves, they are concentric, consisting of a central xylem-portion entirely enveloped in a layer of phloem ; in. the stem and leaves of Osmunda, and in the leaves of some other ferns, they are collateral, the xylem and phloem portions lying side by 
side. Besides a few narrow spiral tracheides, lying at definite points of the transverse section, the xylem consists mainly of scalariform tracheides, i.e. of tracheides with bordered pits which usually have the appearance of transverse clefts, their ends being mostly obliquely truncate or fusiform and pointed. True vessels occur but rarely in ferns ; e.g. in Pteris aquilina and in the rhizome of Athyrium filix-fœmina, where they are also scalariform. Between the tracheides lie narrow thin-walled cells which contain starch in winter. In the phloem, in addition to narrow parenchymatous cells, are sieve-tubes with welldeveloped sieve-plates, but forming true callus only in a small number of cases; and at the circumference narrow bast-like thick-wall prosenchyme. Each individual bundle is usually immediately enclosed in a single distinct layer of narrower cells, the vascular bundle-sheath or endoderm; this layer, which probably originates from the fundamental tissue, displays a strong tendency for its walls to become brown and suberised. In very young stems and those which permanently remain very slender, as in many Hymenophyllaceæ, there is a single axial bundle. But in stouter stems and leaf-stalks the central bundle is replaced by a network of anastomosing bundles, presenting, in typical cases, a cylinder of considerable diameter, by which the fundamental tissue is separated into an outer cortical and an inner medullary portion; but isolated scattered bundles also arise in addition. The principal bundles which constitute this cylindrical network mostly have the form of broad plates with the margins curved outwards, each surrounded by its thick firm brown sclerenchyme-sheath; they usually present the appearance of an interrupted ring near the periphery, but in Osmundaceæ the ring is more continuous. From the margins of these cauline bundles spring the more slender filiform bundles which pass into the leaves, the number of openings in the meshes of the cauline 'vascular' cylinder corresponding to that of the leaves. In the leaf-stalk the bundles may either run separately or may coalesce into plates. Terletzki (Pringshein's Jahrb., I 884, p. 452) has detected continuity of protoplasm between the cells in the parenchyme of the rhizome in several species of fern; the intercellular spaces also contain protoplasm which is in connection with that of the cells. In the aquatic genus Ceratopteris the stem contains large air-cavities. Elongated tannin-sacs occur in the parenchyme of the stem and leaf-stalk of many ferns, especially in the neighbourhood of the 'vascular' bundles. Gum- and mucilage-cells are also of frequent occurrence. Incrustations of calcium carbonate are not infrequent on the leaves. Round stalked glands occur in the fundamental tissue of the stem and leaves of Aspidium filix-mas. 
The leaves of ferns stand either in two rows on the stem, or less often in a single dorsal row, or the phyllotaxis is more complicated and spiral ; they are never opposite or whorled. Each leaf originates from a superficial cell of the growing point distinguished by a stronger swelling of its outer cell-wall. The petiole is the first part of the leaf formed; the lamina then begins to appear at its apex, and itself develops from the base to the apex. In many ferns the leaves of the mature plant are characterised by the extraordinary slowness of their development. In old plants of Pteris aquilina the formation of the leaf commences fully two years before it begins to unfold; at the commencement of the second year only the leaf-stalk is as yet in existence ; during the summer of the second year the lamina begins to develop at the apex of the rod-like petiole, and may be found hidden beneath the long hairs in the form of a minute disc. It then begins to bend downwards at its apex, and continues for a time in a pendent condition. It is only in the spring of the third year that the elongation of the leafstalk forces the lamina above the surface of the soil, and that the latter begins to unfold. In Aspidium filix-mas the development is almost as slow. The basifugal development of the lamina itself is also extremely slow in many ferns, the lower portions having long been fully formed while the apex is still unfolding. In several genera, as Gleichenia (Sm.) and Mertensia (Willd.), a periodical interruption occurs of the apical growth, this intermittent development even extending over several years. In Lygodium the primary pinnæ remain unfolded after the formation of a pair of pinnæ of the second order, while the rachis of the leaf grows without limit and resembles a twining stem, climbing in some cases to the height of fifty or one hundred feet, the pinnæ themselves presenting the appearance of leaves. In the anomalous Ceratopteris thalictroides, which grows in water, the ultimate segments of the leaves are swollen up in a pod-like manner. Goebel has shown (Ann. Jard. Bot. Buitenzorg, vii., I 887) that in the heterophyllous ferns, such as Platycerium alcicorne and several species of Polypodium (L.), one form of leaf is specially adapted, directly or indirectly, for the supply of nutriment to the plant, and is sometimes furnished with special aquiferous tissue. The stipular structures of the Marattiaceæ are quite peculiar among Vascular Cryptogams. The leaves of ferns not unfrequently display a tendency to branch dichotomously at the apex, but in other cases the branching appears to be monopodial. The leaf-stalk has frequently the power of producing adventitious leaf-buds (see fig. 49). In Struthiopteris germanica these develop into long underground stolons covered with scale-leaves, which at length rise above the surface, and bear at their apex a rosette of ordinary leaves. Nephrolepis (Sch.) is also furnished 
with remarkable stolons, the extremities of which swell up into tubers ; but it is uncertain whether they belong to the stem or the root. In other cases adventitious leaf-buds are borne on the upper surface of the lamina or in the axils of the leaves. In Woodwardia radicans (Sm.) and some other species, the long drooping leaves may root in the soil and put up new shoots. The veins in the leaves of the great majority of ferns do not anastomose, but divide repeatedly dichotomously. Their 'vascular' bundles differ, in some cases, from those of the stem in being collateral, the xylem facing the upper, the phloem the under surface of the leaf.

With the exception of some species of Trichomanes, all ferns have true roots, characterised, like those of Vascular Cryptogams generally, and of Flowering Plants, by the presence of a true root-cap, composed of several layers of cells, and by the tendency of the epidermal cells to develop into long unsegmented filaments or root-hairs, by which the nutriment is absorbed from the soil. These proceed in acropetal succession from the creeping underground stem or rhizome, or, where the stem is erect, very short, and densely covered with leaves, from the leafstalks. In tree-ferns the lower part of the erect stem is densely covered with a thick felt-like envelope of slender roots, which give a broad base to the stem. Like the stem, the tissue of the root develops from a single apical cell. The branching is always monopodial. The lateral rootlets arise in acropetal succession on the outside of the primary 'vascular' bundle. The root is traversed by a single axial cylinder formed by the coalescence of 'vascular' bundles.

The epiderm of the leaves of those ferns which are not unilamellar differs in no essential respect from that of Flowering Plants, but its cells contain a larger quantity of chlorophyll. The epiderm of the under side only is abundantly provided with stomates, which are usually of quite the ordinary structure. In some cases, as Aneimia (Sw.), they present the peculiar appearance of the two guard-cells being entirely enclosed within a single epidermal cell. Those of Kaulfussia (Bl.) (Marattiaceæ) are very large, and of peculiar structure.

The sporanges of ferns are rounded, ovoid, or pear-shaped capsules, seated on long stalks in the Polypodiaceæ and Cyatheaceæ, sessile in the other orders. When mature, the wall of the capsule consists, except in the Marattiaceæ, of a single layer of cells, a particular row of which, running longitudinally, transversely, or obliquely round the capsule, usually undergoes special development, and is known as the annulus; but the annulus may be entirely wanting, as in the Marattiaceæ, or its place may be taken by the special development of an apical or lateral group of cells, as in the Osmundaceæ. Where there is 
an annulus the sporange dehisces by a fissure at right angles to it ; in the Marattiaceæ it opens by an apical pore. The dehiscence is due to unequal contraction in drying of the unequally thickened portions of the cell-walls of the annulus. On one side of the sporange of a considerable number of ferns are two, three, or four cells of peculiar form, with lignified cell-walls, the lip-cells, between which the dehiscence always begins, and which appear to guide its direction. These cells together are sometimes called the 'stomium.' Among the spo-

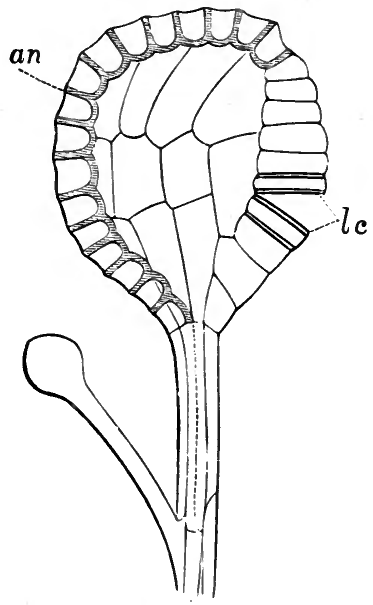

FIG. 55.-Sporange of Aspidium filixmas, showing annulus an, lip-cells lc, and paraphyse attached to stalk. (After Kündig, greatly magnified.)

ranges are frequently slender segmented filaments, or paraphyses. In some Polypodiaceæ there is a Fig. 56 . - Development of sporange of Asple. single (rarely more than one) out-
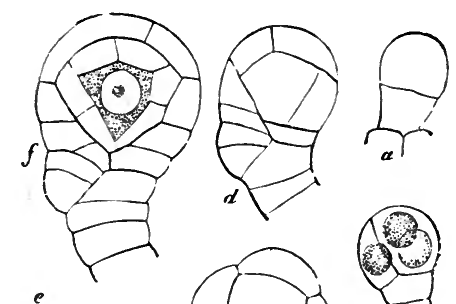
growth from the stalk of the sporange, resembling a capitate hair, and sometimes septated internally. It is regarded as a paraphyse, and may probably be an undeveloped sporange. The entire sorus may be covered by the recurved margin of the leaf, or by a true indusium belonging to the epiderm, or by a false indusium, consisting of an outgrowth of the hypodermal tissue, composed of several layers of cells. In Enterosora (Bak.), from British Guiana (Polypodiaceæ), the sporanges spring from the base of spherical chambers in the under surface of the 
leaf, which open only by a narrow slit. Although the sori usually originate on the veins of a leaf, and only on the under side of the lamina, this is not always the case. In Olfersia they spring from both surfaces of the lamina by the side of the midrib; and in this and other species of Acrosticheæ from the mesophyll as well as the veins. In the Hymenophyllacєæ they are enclosed in a cup-like indusium, and are attached to the apex of the veins, which projects beyond the margin of the leaf. The spot on the fertile vein which bears a sorus is known as the placenta or receptacle. In the Polypodiaceæ, and probably also in the Cyatheaceæ, each sporange originates from a single epidermal cell, which swells up considerably, and is cut off from the rest of the leaf by a septum. This mother-cell of the sporange subsequently divides by another septum into a basal cell which develops into the pedicel, and an apical cell which becomes the capsule. The pedicel usually consists ultimately of three rows of cells produced by longitudinal and transverse divisions. The nearly hemispherical mother-cell of the capsule first divides, by four successive oblique walls, into four parietal and a nearly cubical central cell, the archespore. In the parietal cells further divisions follow at right angles to the surface; while from the archespore are formed four tabular segments parallel to the parietal cells, which again divide by walls vertical to the surface into one or two layers of tapetal or mantle-cells, constituting together the tapete. The row of cells in the wall of the sporange which constitute the annulus are the result of divisions at right angles to the surface of the sporange; their outer walls bulge out and project above the surface. The tapetal cells ultimately disappear, and the whole of the space within the wall of the capsule is occupied by a fluid, in which float the mother-cells of the spores formed by successive bipartitions of the archespore, and normally sixteen in number in the Polypodiaceæ and Schizæaceæ. In these families the formation of the spores takes place in the following way. Each of the sixteen spore-mother-cells divides into four by two successive bipartitions of the protoplasmic contents, preceded by corresponding divisions of the nuclei. Sixty-four spores are thus normally formed in each sporange. They then invest themselves with a cell-wall, which is usually double, consisting of an inner coat, or endospore, generally but not always composed of cellulose, and sometimes itself consisting of two layers, and an outer brown cuticularised exospore, provided with ridges, papillæ, warts, or other elevations. Leitgeb states that in Osmunda and some other genera there is no true endospore ; while in Onoclea (L.), according to Campbell, there are three coats. The spores of the Osmundaceæ and Hymenophyllaceæ contain chlorophyll. Another mode of spore-formation, more analogous to what takes place 
in the formation of the pollen of Flowering Plants, occurs sometimes in the two orders just named, and invariably in the Cyatheaceæ, Osmundaceæ, and Hymenophyllaceæ. Each spore-mother-cell divides at once by cell-walls of cellulose into four compartments, sometimes called 'special mother-cells'; within each of these compartments the spores become invested with their permanent cell-walls, both the walls of the original mother-cells and their septa being then absorbed. The spores formed in this way have a rounded cubical shape, while those produced in the mode first described are bilateral, and very commonly kidneyshaped. In the Schizæaceæ and Osmundaceæ the sporanges are not strictly trichomic in their arigin, being formed, before the differentiation of the epiderm, each from a single cell, which may be regarded as the rudiment of a leaf-branch. In both these orders the number of spores produced in a sporange is much larger than in the Polypodiaceæ; in this and in other respects they manifest an approximation to the Marattiaceæ and Ophioglossaceæ. The sporanges of Marattiaceæ are altogether endogenous in their origin, being developed from an internal mass of tissue, and are destitute of an annulus. On the dehiscence of the normal sporange the spores are at first attached to the annulus, and are detached and thrown to a distance by its sudden return to its original position. The spores of many Polypodiaceæ retain their vitality and power of germination for a long period, and require a longer or shorter period of rest before germination ; those of the Hymenophyllaceæ, on the other hand, often begin to germinate while still enclosed in the sporange. In Scolopendrium (Sm.), according to Beck (Verhandl. Zool.-Bot. Ges. Wien, 1879), the exospore does not burst, but decays at the spot where the germinating filament emerges.

The non-sexual propagation of ferns takes place chiefly by means of the adventitious buds already described, which appear on the lamina or petiole of the leaf (fig. 49). As a normal phenomenon it is, however, confined to a small number of species known in cultivation as viviparous or bulbiferous ferns, such as Asplenium bulbiferum (Forst.) and Cystopteris bulbifera (Bernh.). The occasional vegetative propagation of the prothallium has also been already described.

Ferns are distributed over the whole globe, from the equator to the arctic zone ; and, from the ease of their culture and the beauty of their forms, are favourite objects of cultivation. They are most abundant in moist warm climates, and hence enter largely into the composition of all insular floras. In the tropics a large number of species are epiphytic ; and it is only there, and in the islands of the Southern Hemisphere, that they attain the size of tree-ferns. One or two species are annual, and a single one, Ceratopteris thalictroides, is aquatic, while a very few have a 
climbing habit. The number of species which are at the present time applied to any economical purpose is extremely small. The common brake, Pteris aquilina, is largely used throughout Northern Europe for forage purposes, and for the stuffing of rough beds and pillows. The socalled ' male fern,' Aspidium filix-mas, has a very ancient repute as a vermifuge, and is still occasionally employed for that purpose, as also are several other species to a less extent in different parts of the globe, either for a similar purpose or as astringents and mucilages. In several species, especially tropical, the stem contains sufficient starch to be esculent. The number of known species of ferns is at present estimated at about $3, \infty 00$, but it is constantly and rapidly increasing. They are arranged in a comparatively small number of genera, the limits of which are often extremely difficult to define.

\section{Literature.}

Mettenius-Filices Hort. Bot. Lipsiensis, 1856.

Hofmeister-Abhandl. Sächs. Gesell. Wiss., vol. v., I857 ; and Pringsheim's Jahrb. wiss. Bot., 1863, p. 278.

Wigand-Botanische Untersuchungen, 1854.

Newman-History of British Ferns, 4th ed., 1865.

Reess-(Sporange) Pringsheim's Jahrb. wiss. Bot., 1867, p. 217.

Strasburger-(Fertilisation) ibid., 1869, p. 390.

Kny-(Antherid) Monber. Akad. Wiss. Berlin, 1869, p. 416 ; and Pringsheim's Jahrb. wiss. Bot., r869, p. I.

Hooker and Baker--Synopsis Filicum, 1868.

Goebel-(Prothallium of Gymnogramme) Bot. Zeit., 1877, pp. 671 et seq.

Weiss-(Bundle-sheath) Flora, 1880, p. 119.

Cramer-(Fertilisation) Denkschr. Schweiz. Naturf. Gesell., I880.

Haberlandt-(Vascular Bundles) Sitzber. Akad. Wiss. Wien, lxxxiv., I88I, p. I2 I. Lachmann-(Root-organs) Compt. Rend., xcviii., r884, p. 833 ; and ci., I885, p. 592. Klein-Bot. Zeit., 1884, pp. 577 et seq.

Schmidt-(Dehiscence of Sporange) Flora, I885, pp. 451, 471, and 1887, pp. 177, 202 ; and Ber. Deutsch. Bot. Ges., r886, p. 396.

Campbell-(Prothallium) Bot. Gazette, 1885, p. 355.

Thomæ-(Leaf-stalk) Pringsheim's Jahrb. wiss. Bot., 1886, p. 99.

Goebeler-(Pales) Flora, 1886, pp. 451 et seq.

Gardiner and Ito-(Mucilage-cells) Ann. of Bot., i., I887, p. 27.

Campbell-(Struthiopteris germanica) Mem. Boston Soc. Nat. Hist., I887, p. 17.

Kindig-(Sporange) Hedwigia, 1888, p. I.

The following classification of the Filices into families or orders follows partly the plan proposed by Mettenius, partly that adopted in Hooker and Baker's 'Synopsis Filicum.' It must, however, be distinctly borne in mind that the divisions are of very unequal value. The first three are closely allied to one another; the Hymenophyllaceæ show con- 
siderably greater divergence ; the affinity of Osmundaceæ and Schizæaceæ with the typical ferns is more remote ; while the Marattiaceæ exhibit so many points of divergence that some high authorities have removed them altogether from the Filices.

\section{ORder I.-PolypodiaceE.}

This order includes by far the largest number of genera and species, and may be regarded as the typical family of ferns. The sporanges arise out of single epidermal cells, and have usually long pedicels ; they

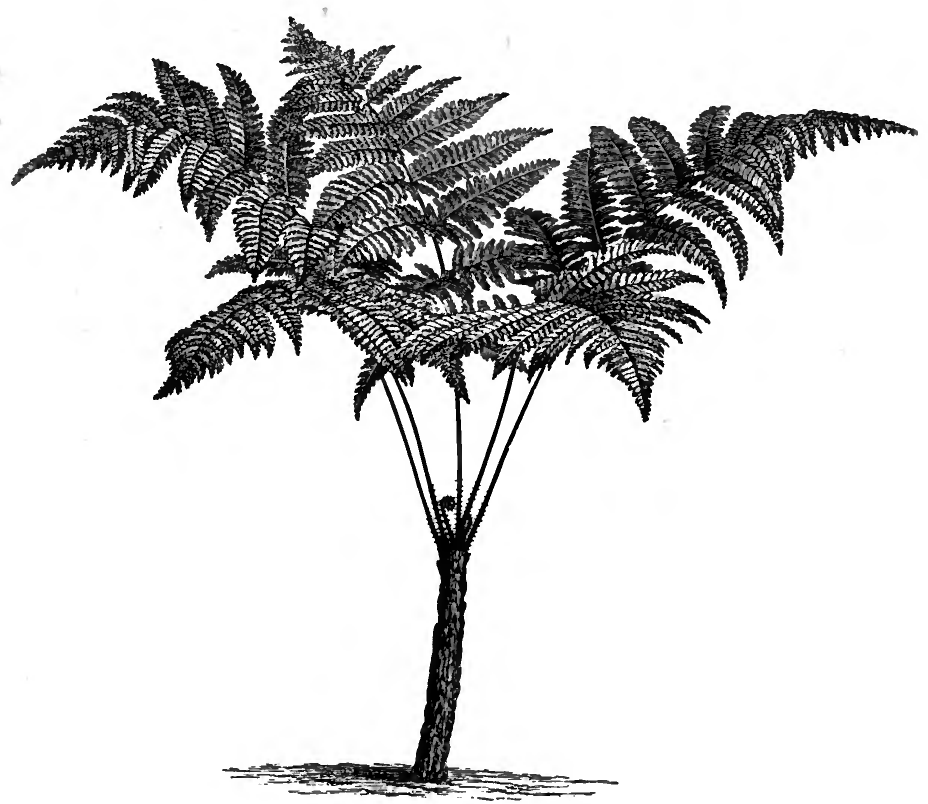

FIG. 57.-Alsophila aculeata Klotzsch, a tree-fern (reduced).

have an incomplete vertical annulus, and consequently dehisce transversely. The sori vary greatly in size and form, and usually consist of a large number of sporanges. They are seated on the under side of the divided or undivided leaf, upon the veins ; much less often (Acrosticheæ) also on the upper surface or in connection with the mesophyll; they are usually covered by an indusium in the Asplenieæ, Aspidieæ, and Davallieæ, but not in the Acrosticheæ or Polypodieæ. In the great majority of species all the leaves are ultimately fertile; but in some genera (Gymnogramme (Desv.), Lomaria (Willd.), Platycerium (Desv.), \&c.) 
there are species with barren and fertile leaves, differing from one another in habit and in degree of segmentation; in other heterophyllous

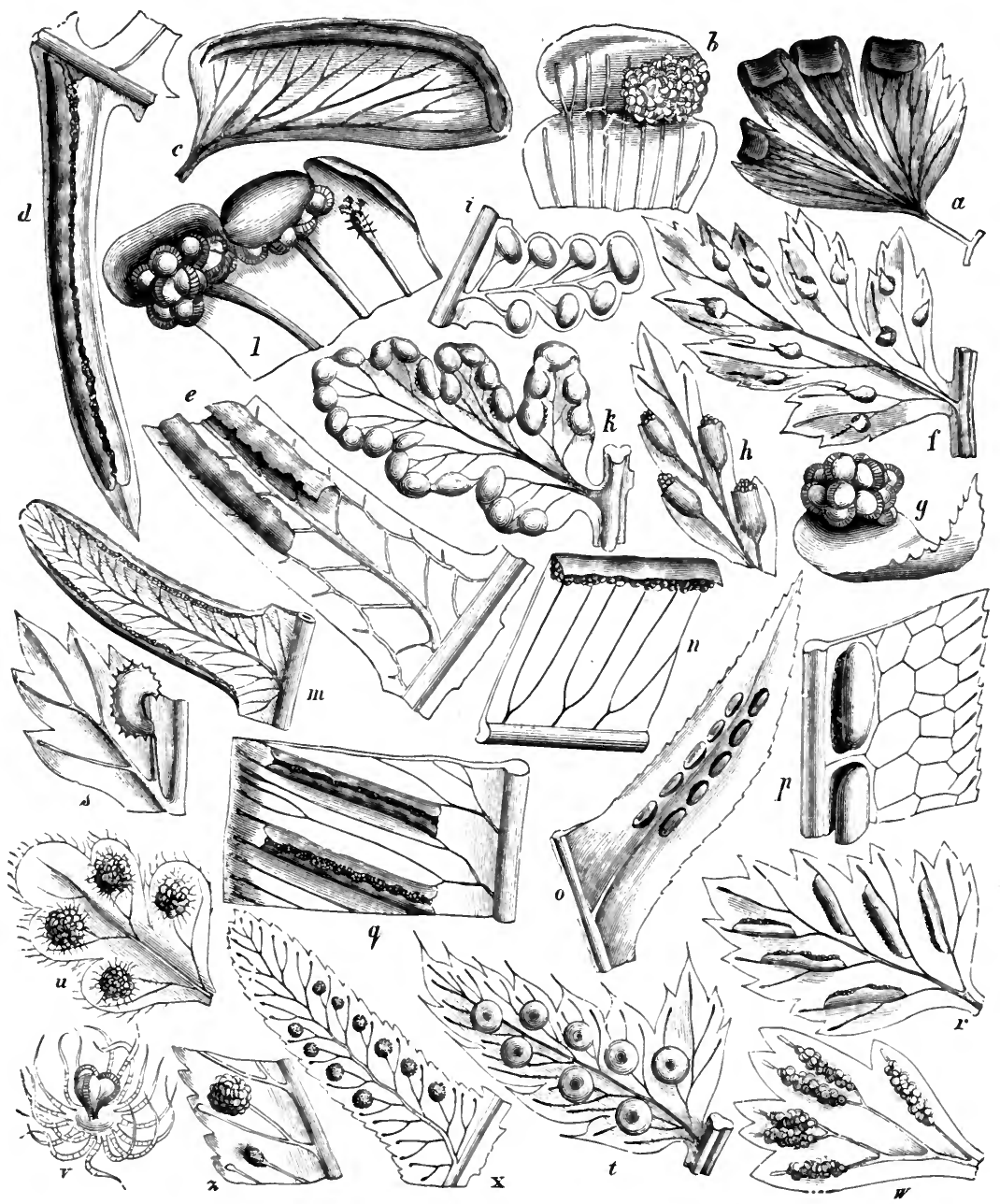

FIG. 58.- Sori of Polypodiaceæ (variously magnified). a, b, Adiantum;, , Lindsaya; d, e, Blechnum; $f, g, C y$ stopteris ; $h, i$, Davallia; $k, l$, Cheilanthes; $m, n$, Pteris; $0, p$, Woodwardia; $q$, Scolopendrium; r, s, Asplenium; $t$, Aspidium; u, v, Woodsia; $v$, Gymnogramme; $x$, z, Polypodium. (After Luerssen.)

ferns (species of Polypodium) both forms of leaf are fertile. A few of the Polypodieæ are arborescent (Dicksonia L'Herit.). 
Principal genera:-Adiantum (L.), Cheilanthes (Sw.), Pellæa (Link), Pteris (L.), Lomaria (Willd.), Blechnum (L.), Woodwardia (Sm.), Doodia (R. Br.), Asplenium (L.), Scolopendrium (Sm.), Aspidium (Sw.), Nephrodium(Rich.), Lastrea (Presl), Nephrolepis (Sch.), Polypodium(L.), Nothoclæna (R. Br.), Gymnogramme (Desv.), Hermonitis (L.), Vittaria (Sm.), Acrostichum (L.), Platycerium (Desv.), Onoclea (L.), Woodsia (R. Br.), Ceterach (Adans.), Dicksonia (L'Herit.), Davallia (Sm.), Cystopteris (Bernh.), Lindsaya (Dry.).

\section{Order 2.-Cyatheacee.}

This order is not distinguished from the Polypodiaceæ by any very clear lines of demarcation. The sporanges are epidermal and shortly stalked; they have a complete oblique eccentric annulus. The sori are seated on a receptacle or placenta which often projects considerably ; they are naked, or are more often enclosed in a cup-shaped indusium or 'involucre,' which sometimes forms a closed cup opening by a transverse fissure ; the sporanges are densely crowded in the sorus. The greater number of the tree-ferns belong to this family (fig. 57). The leaves are often very large (five to ten feet in length), and

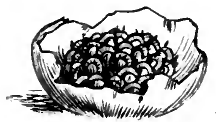

FIG. 59.-Sorus of Cyathea with open indusium (mag. nified). usually compoundly pinnate, forming a rosette at the summit of the columnar unbranched arborescent stem, which is densely covered with aërial roots, especially in its lower portion, and is marked in a diamond pattern by the scars of fallen leaves. In some species, in addition to the ordinary cylinder of 'vascular' bundles, there are a number of accessory bundles distributed through the medulla and cortex, forming a delicate open network. Crystals of calcium oxalate are not uncommon in the epidermal cells.

Principal genera :-Cyathea (Sm.), Hemitelia (Br.), Alsophila (R. Br.).

\section{Orner 3.-Gleicheniacee.}

The sporanges are epidermal and sessile, with a broad complete transverse annulus running nearly horizontally, and hence with vertical dehiscence. The sori are naked, on the under side of ordinary leaves, and usually consist of only three or four sporanges. The stem is a slender creeping rhizome ; the leaves are usually very large, and with peculiar buds or 'innovations' on the lamina.

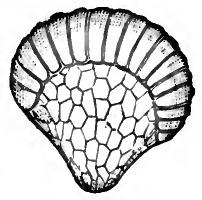

Fig. 6o.-Sporange of Gleichenia (magnified).

Principal genera:-Gleichenia (Sm.), Mertensia (Willd.). 


\section{ORDER 4.-HyMENophyllaceE. .}

The oophyte generation is known but in a very few species of Hymenophyllaceæ. Where it has been observed (some species of Hymenophyllum and Trichomanes) it differs from that of other ferns, and is usually filiform, closely resembling the protoneme of a moss, but somewhat coarser. Antherids appear to be produced at the middle of these filaments, and archegones at their extrenity. But apogamy is much more common in the Hymenophyllaceæ than in any other family of ferns, and it is doubtful whether it does not even occur regularly in some species. Bulbils or gemmæ are produced abundantly on the prothallium, consisting of a small number of cells, and borne on pedicels or sterigmas. They germinate with extreme slowness. In Trichomanes

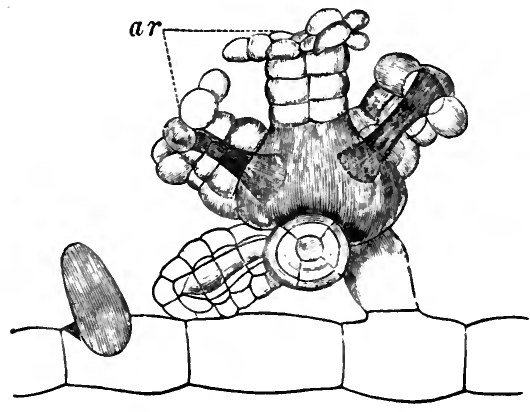

FIG. 6I.-Archegoniophore of Trichomanes pyxidiferum L., bearing five archegones, ar, of different ages ( $x$ I75). (After Bower.) pyxidiferum (L.) the prothallium is frequently an aposporous growth, derived from imperfect arrested sporanges, or even from cells of the placenta. The archegones are borne on peculiar structures, known as archegoniophores, massive outgrowths of the prothallium, each archegoniophore bearing either a single archegone or several. The archegoniophore is usually a multicellular structure, and the venters of the archegones are imbedded in its tissue. $\mathrm{T}$. alatum (Sw.) is habitually apogamous, and is possibly never reproduced sexually. Aposporous prothallia spring in great numbers from all parts of the frond, often quite independent of the sori, and are more flattened and ribbon-like in structure than those of most Hymenophyllaceæ. They produce large numbers of stalked gemmæ. Archegones have never been observed in this species, and the antherids are imperfect, and apparently functionless The spores are multicellular before germination. The archegones differ from those of other ferns in having a perfectly straight neck.

The sporanges have a complete horizontal or oblique annulus (incomplete in Loxsoma, R. Br.), and hence dehisce by a vertical fissure. They are borne on a prolongation of the fertile vein, the columel, which projects beyond the margin of the leaf, and is enclosed in the cup-shaped indusium. The columel or placenta elongates by intercalary growth, and the sporanges are produced on it in a spiral line in basifugal succes- 
sion. In Hymenophyllum (L.) and Trichomanes (Sm.) the sporanges are sessile and biconvex, and are attached to the columel by one of their convex faces ; the annulus, projecting in the form of a cushion, separates the two convexities, and is usually oblique, dividing the circumference into two unequal portions : in Loxsoma they are pear-shaped and dis-

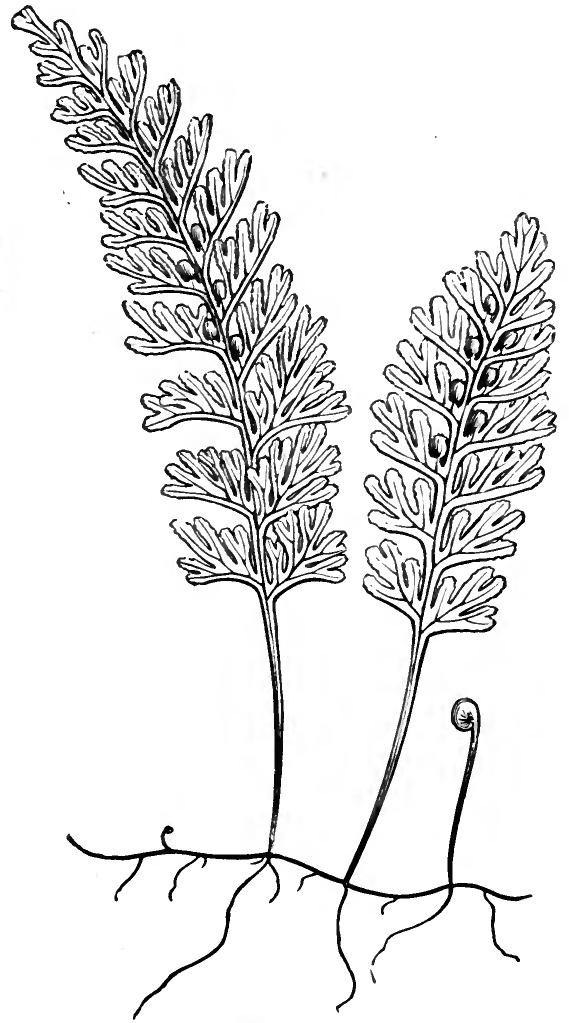

FIG. 62.-Hymenophyllum tunbridgense (natural size). tinctly stalked. Paraphyses occur only in a few species of Hymenophyllum. The mesophyll of the leaf consists, in the two larger genera, of only a single layer of cells, and the leaves have hence a filmy and

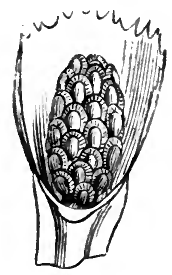

Frg. 63.-Hymenophyllum; ; sporanges exposed (magnified).

moss-like appearance ; but in Loxsoma there are several layers of cells, and the leaf is then provided with stomates. The stem is generally creeping and mostly very slender, and is penetrated by a single axial 'vascular' bundle. Many species of Trichomanes are rootless; and the stem is then densely clothed with root-hairs, and slender ramifications of the stem assume the appearance and function of true roots. Even the ordinary branches of the stem have often been long formed before their leaves emerge from a rudimentary condition. In some species of Trichomanes the fructification is confined to special fertile leaves.

The Hymenophyllaceæ include but three genera, of which Loxsoma comprises a single species only, of creeping habit, native of New 


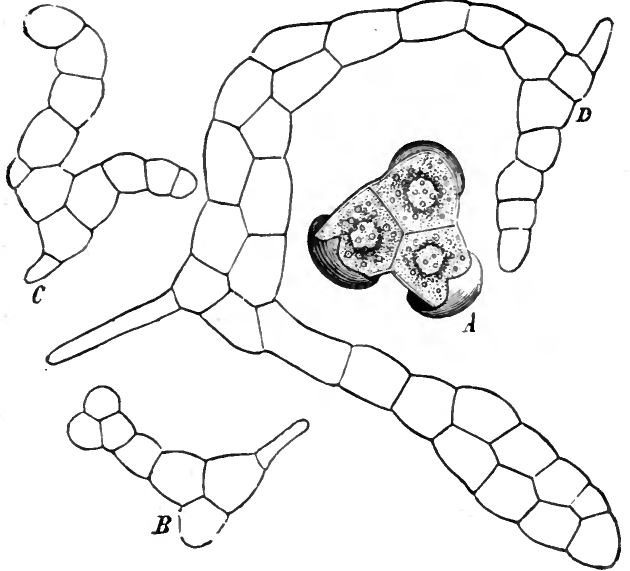

Fig. 64.-A, germinating spore and prothallium of Hymeno. phyllum; $B, C, D$, stages in development of prothallium ( $x$ I20). (After Luerssen.)

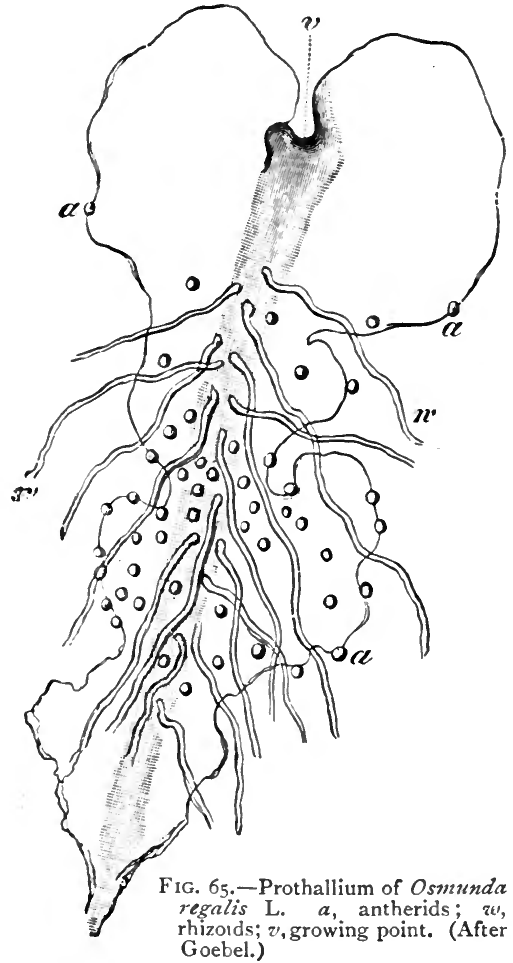

Zealand ; Hymenophyllum and Trichomanes nearly roo species each, exceedingly delicate and graceful ferns, growing mostly on the trunks of trees and damp rocks, often within reach of the spray of waterfalls, in the moister and warmer parts of the globe. The smaller species of Hymenophyllum are known as 'filmy ferns.' 'The Hymenophyllaceæ may be regarded as the simplest and are probably the oldest family of ferns, and possibly form a connecting link between the Muscineæ and the Vascular Cryptogams.

\section{LITERATURE.}

Mettenius-Ueber die Hỳmenophyllaceen, 1864 .

Janczewski and Rostafinski - (Prothallium) Mém. Soc. Nat. Sc. Cherbourg, xix., 1875 .

Goebel-(Germination) Ann. Jard. Bot. Buitenzorg, vii., I887, p. 57.

Prantl- Untersuchungen zur Morphologieder Gefässkryptogamen, Heft I. Bower-Annals of Botany, vol. i., I887, pp. 183 and 269.

\section{Order 5.-Osmundacee.}

The prothallium of the Osmundaceæ is characterised by its strong tendency to propagate itself vegetatively, by means of adventitious shoots, and is commonly diœcious, springing directly from the spore. It is usually ribbonshaped, with a well-defined midrib 
The sessile or shortly stalked, roundish, but unsymmetrical sporanges are not strictly epidermal in their origin. They bear on one side of their apex a modified annulus in the form of a group of cells of peculiar form, and dehisce vertically on the other side. Todea (Willd.) presents no

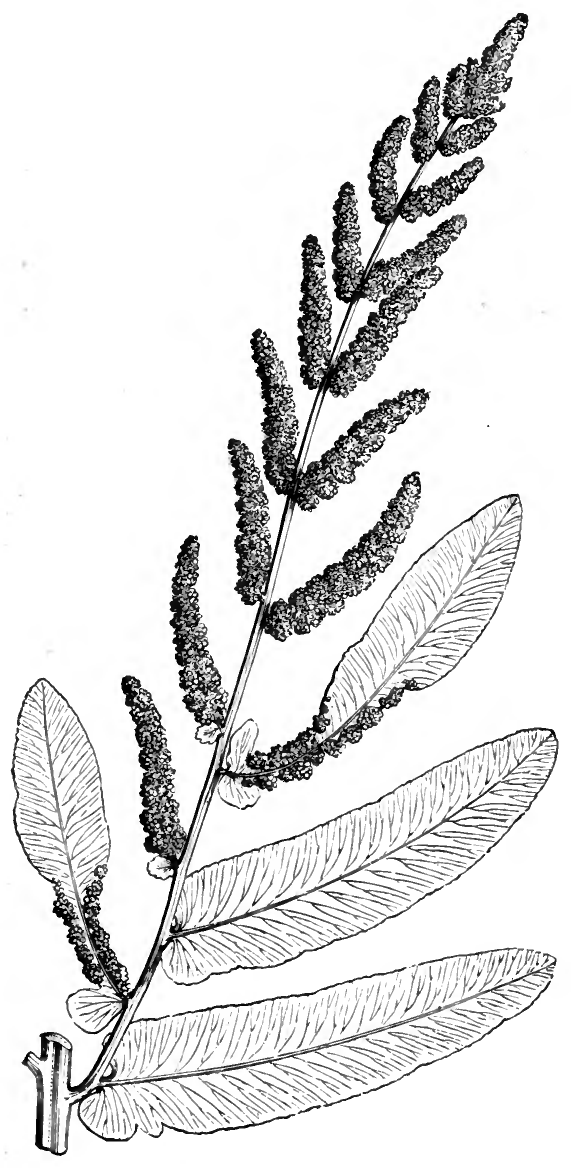

Fig. 66.-Osmunda regalis $\mathrm{L}$. Portion of frond (natural size). difference between the fertile and sterile leaves; while in Osmunda(L.)thefructification has the appearance of a continuous or interrupted panicle,

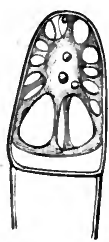

Fig. 67.-Mucilage-gland from Osmunda regalis (magnified). (After Gardiner.)

from the entire absorption of the mesophyll of the fertile part of the leaf. In some species of Todea the leaf consists of only a single layer of cells. In Osmunda there are

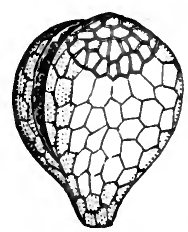

Fig. 68.-Sporange of Osmunda (magnified).

abundant mucilage-cells at the base of the leaf-stalk. The 'vascular' bundles of the stem are collateral, as contrasted with the concentric bundles of typical ferns, and their course bears more resemblance to that in Gymnosperms and in Dicotyledons. In the structure of the leaves, and in the structure and development of the growing point, Osmundaceæ exhibit a transitional condition between the typical ferns 
and the Marattiaceæ. The young leaves (in Osmunda cinnamomea, Lu, and Todea superba, Col.) present the remarkable peculiarity of their apex being occupied by a well-marked triangular-conical apical cell.

The family includes only a very small number of species, comprised

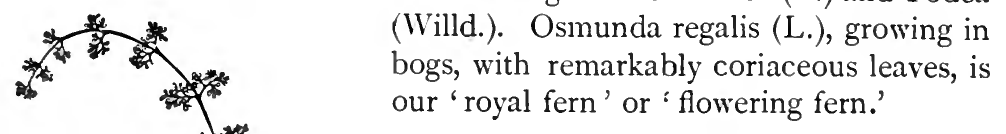
in the two genera Osmunda (L.) and Todea (Willd.). Osmunda regalis (L.), growing in bogs, with remarkably coriaceous leaves, is our 'royal fern' or 'flowering fern.'

\section{LITERATURE.}

Bower-Proc. Roy. Soc., xxxvii., I 884 , p. 42 ; and Quart. Journ. Micr. Sc., 1885, p. 75.

Gardiner and Ito-Annals of Botany, vol. i., 1887, p. 27 .

\section{ORDER 6.-SCHIZFACEE.}

The ovoid or pear-shaped sessile sporanges are not strictly epidermal in their origin. The apex of the sporange is occupied by a cap-like zone of cells of peculiar form, and the dehiscence is vertical. In the genera Aneimia (Sw.) and Schizæa (Sm.) the fertile leaves have the paniculate appearance of an Osmunda. In Schizæa and Lygodium (Sw.) the sporanges are seated in two rows on the under side of very narrow pinnæ; and in Lygodium each sporange is enclosed in a pocket-shaped indusium. In Aneimia the two lowermost pinnæ form a long-stalked panicle, from which the mesophyll has disappeared. In Aneimia and Lygodium the sporanges spring originally from the margin of the leaf, but are eventually placed in the course of development on its under side. In Mohria (Sw.) they are placed on the back of the leaf, and are conFIG. 69.-Lygodium palmatum Sw. (reduced). cealed by its recurved margin. The differentiation of tissues, both in the mesophyll of the leaf and in the 'vascular' bundles, is very slight. The stem is in general but feebly developed, and seldom branches; the leaf-stalk is penetrated by only a single 'vascular' bundle. The peculiar position of the stomates in some species of Aneimia has already been described. 
The family of Schizæaceæ comprises a small number of species, included in five genera, of which Mohria (Sw.) and Trochopteris (Gardn.) are monotypic. Aneimia (Sw.) and Schizæa (Sm.) resemble the Osmundaceæ in their paniculate appearance. All the species of Lygodium (Sw.) present the appearance of climbing stems, from the peculiar structure and mode of growth of the leaves already described. The family is confined to the warmer parts of the globe.

\section{LITERATURE.}

Prantl-Untersuchungen zur Morphologie der Gefässkryptogamen, Heft 2, I88I ; also in Engler's Jahrb. I88I, p. 297.

\section{Order 7.-Marattiaceæ.}

The Marattiaceæ differ more widely from the typical ferns than any of the families hitherto described, and are by many authorities separated from them into a distinct class. But the point of divergence most relied on, the endogenous origin of the sporanges, has lost much of its significance since it has been known that the Osmundaceæ and Schizæaceæ present connecting links in this respect. The aërial flat prothallium, the circinate vernation and general structure of the leaf, and the ultimate structure of the sori, present so many points of contact with the other orders of Filices, that it seems most desirable at present to retain them as an aberrant order of the class.

The prothallium, the development of which is very slow, is a dark green elliptical or heart-shaped plate of tissue, lying on the surface of the soil, consisting of one or more layers of cells, and with a projecting hemispherical cushion on the under side. Its development has been followed out in Marattia (Sm.) and Angiopteris (Hoffm.). Chlorophyll is formed in the spore as soon as it begins to germinate. The exospore bursts, and the first cell of the prothallium projects as a papilla between the two lobes. After a considerable time the first division takes place at right angles to the direction of growth, and the first rhizoid is formed. Further divisions follow rapidly, and the prothallium soon becomes a cellular tissue, and is distinguished from that of typical ferns by its deep green colour and by its moderately thick cuticle. One of the cells first formed becomes an apical cell, from which fresh cells are formed until the prothallium has assumed its ultimate cordate form. The antherids make their appearance, after a period of some months, on both sides of the prothallium, but especially on the ventral cushion. Their structure differs in some respects from that of typical ferns. From a single superficial cell are produced a central cell, two upper cells, and a triangular stigmatic cell, which is thrown off, when the antherid is 
mature. Within the central cell are produced from twenty to two hundred antherozoids, each in its own mother-cell. Both antherids and archegones are deeply sunk in the tissue of the prothallium. The archegones, only the uppermost part of the neck of which appears above the surface, are formed on the ventral cushion, very rarely on the upper side of the prothallium. Their development presents no very special features.

The sporophyte generation has, when mature, the habit and appearance of an ordinary fern. The stem is usually erect and short, with tuberous base, never attaining a greater height than from one to two feet ; less often (Kaulfussia, Bl.) a creeping underground rhizome. It resembles the stem of Ophioglossaceæ and Isoëteæ in never branching ; that of true ferns in being densely covered, when erect, with leaves as well as with roots, so that no portion is left exposed. The growing point has a single apical cell, and is concealed in a terminal rosette of large leaves. The fundamental tissue is everywhere traversed by long

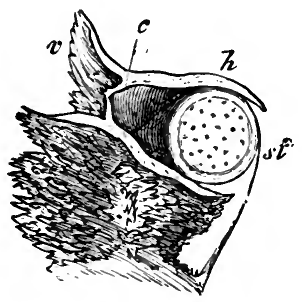

Fig. 70.-Base of leaf-stalk of Marattia cut through. st, stipule ; $c$, commissure ; $v$, anterior, $h$, posterior wing (natural size). (After Sachs.) rows of tannin-cells; and lysigenous mucilage-cells abound in the petioles and in the parenchyme of the pith and cortex of the stem ; they anastomose freely, and are continuous from the stem into the roots. The sclerenchymatous tissue, so characteristic of the parenchyme of the stem of typical ferns, is but feebly developed, or is altogether wanting, in the Marattiaceæ. The 'vascular' bundles are concentric, and resemble those of true ferns. A central xylem, composed of wide scalariform tracheides, is surrounded by the phloem; the bundle-sheath is wanting in the bundles belonging to the stem and leaves, but is present in those of the root. The bundles bend from the stem into the leaves in the ordinary way. The stem and rachis of the leaves are not covered with pales, as in true ferns, nor are they completely glabrous, as in the Ophioglossaceæ.

The leaves are thick, coriaceous, and very large, attaining in some species a length of from five to ten feet. They have a long and very stout petiole, which is channelled on the upper side; the lamina unfolds very slowly, and is either simply or doubly pinnate, less often palmate or digitate. They are furnished at their base with appendages peculiar to the Marattiaceæ among Vascular Cryptogams, the stipules or auricles. While still in the bud the leaves are rolled up in a circinate manner, and are entirely enveloped in the large stipules until the lamina unfolds. The pair of stipules belonging to each petiole form an anterior and a posterior chamber, separated from one another by a longitudinal wall termed the commissure. In the posterior chamber is the rolled-up leaf 
to which the stipules belong, the two posterior wings of the stipule being folded together behind it ; while the chamber formed by the anterior wings encloses all the younger leaves. The stipules remain succulent, not merely as long as the leaves last, but even after the lamina has fallen off; and adventitious buds are not unfrequent upon them. The leaf-stalk is articulated immediately above the stipule; the leaf always becomes detached at this articulation by a smooth scar, leaving behind the base of the leaf-stalk with its succulent stipules. The primary and secondary pinnæ are attached to their respective rachis by similar articulations ; and at each articulation is a pulvinus or cushion, containing collenchymatous tissue. In the mesophyll of the leaf occur, in all the genera, outgrowths of the cell-walls bounding the intercellular spaces and projecting into them. Where the intercellular spaces are sniall these outgrowths have the form of humps and cones; in larger spaces they elongate into long slender filaments which present a super- ficial resemblance to the hyphæ of Fungi, but are quite solid, and consist of cuticularised cellulose. They are found also less abundantly in the leaf-stalk, stem, and root. Layers and bundles of sclerenchyme occur in the mesophyll, but are only feebly developed and of a light colour. The leaves of Kaulfussia are characterised by the presence of remarkably large stomates on the under side, formed in the ordinary way, but distinguished by the great size of the orifice, and by the guard-cells forming a narrow ring, and being surrounded by two or three layers of epidermal cells, which are also arranged in a ring. There are only two semicircular guard-cells, and the structure of these organs is very different from that of the stomates of Marchantia, to which they bear a superficial resemblance. Lenticels occur in the leaf-stalk of many species. Spherocrystals have been found in the mesophyll and leaf-stalk of Marattia cicutæfolia (Kaulf.) and Angiopteris evecta (Hoffm.).

The roots arise endogenously from immediately beneath the growing point of the stem. They strike obliquely downwards through the succulent parenchyme of the stem, penetrating the network of the 'vascular' bundles, with which they may easily be confounded, and generally emerging from a leaf-stalk. They are of a lighter colour, greater thickness, and more delicate texture than those of true ferns, approaching those of Ophioglossaceæ. After entering the soil they branch copiously and apparently monopodially.

The sporanges are produced in large numbers on the under side of ordinary leaves, each being developed, not from a single cell, but from a group of cells. They are situated on the veins, and usually form two rows of sori, which cover the lateral veins either for their whole length or only near the margin of the leaf ; in Kaulfussia they are placed on 
fine anastomosing branches between the lateral veins. The placenta or receptacle on which each sorus is seated is a cushion-like outgrowth of the vein. The sporanges are altogether destitute of an annulus; the wall always consists of several layers of cells. In Angiopteris the sporanges which make up a sorus are quite distinct, ovoid, and sessile, and dehisce by a vertical fissure on the inner side. In all the other genera they are more or less confluent, and the entire boat-shaped sorus is then known as a synange; but each sporange still dehisces separately by a vertical slit on its inner side; or, in Danæa, by an apical pore. The coalescence is most complete in Kaulfussia, where the circular sorus has the appearance of a plurilocular basin. The sorus is usually surrounded by flat lobed hairs of epidermal origin, forming a kind of
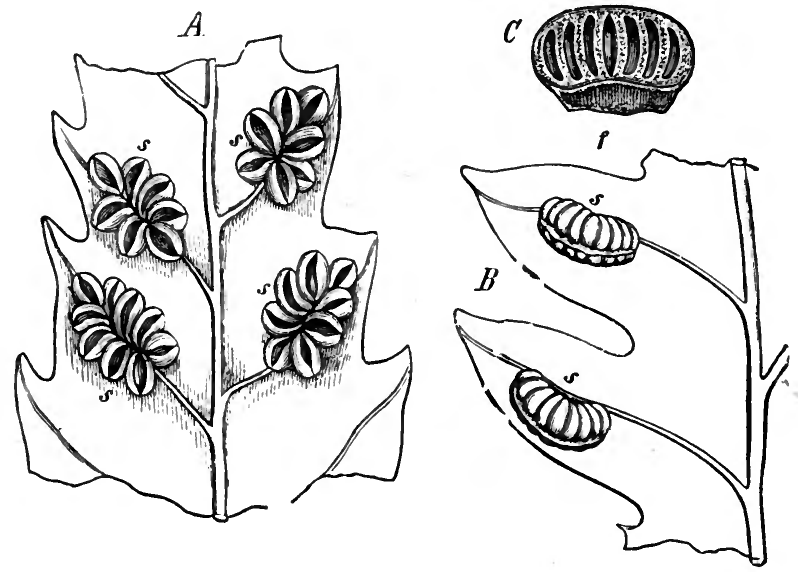

Fig. 71.-A, under side of leaf of Angiopteris caudata; $B$, of Marattia; s, sori ; $C$, sorus of Mlarattia cut through, showing open sporanges. (After Goebel.)

involucre. The true indusium is sometimes altogether wanting. The sporanges originate from the tissue of the leaf itself. The placenta is first formed as a cushion-like outgrowth of the fertile vein, partly from the epiderm, partly from the subjacent tissue. On this originate, in Angiopteris, the separate sporanges as papillæ, each composed of a number of cells. In Marattia, however, while the two rows of sporanges are distinct, those of each row are confluent from the first, but each has its own archespore. The primary mother-cells of the spores are formed at an early period within the archespore.

The spores are formed in fours within their parent-cells, and resemble in general character those of typical ferns. Two different forms of spore sometimes occur in the same species, but they present no difference on 
germination. The wall of the spore is composed of three layers ; the surface is covered by minute wart-like spines.

Vegetative propagation takes place with great facility in some species of this family. In Marattia cicutæfolia the leaves, or even the stipules, have only to be cut into small pieces, and placed in damp soil or in a bottle, when a number of adventitious buds will be developed in connection with the 'vascular' bundles.

The Marattiaceæ comprise only a very small number of species, almost entirely confined to the tropics, and included in the four genera Angiopteris (Hoffm.), Marattia (Sm.), Danæa (Sw.), and Kaulfussia (Bl.). With the exception of the stipules, and the great thickness of the leaves, they have quite the habit of ordinary ferns.

\section{Literature.}

De Vriese and Harting-Monographie des Marattiacées, I853.

Mettenius-Ueber den Bau von Angiopteris, I863.

Luerssen-Mittheil. aus dem 'Gesammtgebiete der Bot., vol. i., Heft 3, I872 ; and

Bot. Zeit., I872, p. 768 ; and I873, pp. 624 and 64 I.

Rüssow-Vergleichende Untersuchungen, I872, p. 185 .

Holle-Bot. Zeit., i 875 , p. 215.

Jonkman-Bot. Zeit., I878, p. I29; and Archives Néerland., I880.

Schenk-Ber. Deutsch. Bot. Gesell., I886, p. 86.

\section{Class V.-Ophioglossaceæ.}

This smail but very well-defined group, although popularly included with the Filices under the common denomination of ferns, differs from them in several important points of structure, in some of which a connecting link is furnished by the Marattiaceæ. The prothallium is underground and destitute of chlorophyll, exhibiting a similarity to that of Lycopodiaceæ rather than to that of true ferns. The stem rarely at-. tains more than a few inches in height, and usually does not branch ; it is remarkable for its slowness in growth. It contains no sclerenchymatous layers. The leaves are not circinate in vernation, and the petiole is furnished at the base with lateral outgrowths, which have been compared to the stipules of Marattiaceæ. The venation is dichotomous or reticulate, and generally inconspicuous. The sporanges are completely endogenous in their origin, and are never borne on the under side of the green leaf, but on a separate branch of the leaf, altogether destitute of green parenchyme, and form a compound 'fructification,' resembling in appearance a spike or panicle: there is no annulus. The 
'vascular' bundles of the stem are collateral; the primitive elements of the xylem are usually scalariform tracheides.

The oophyte generation has been observed in only a few species. In

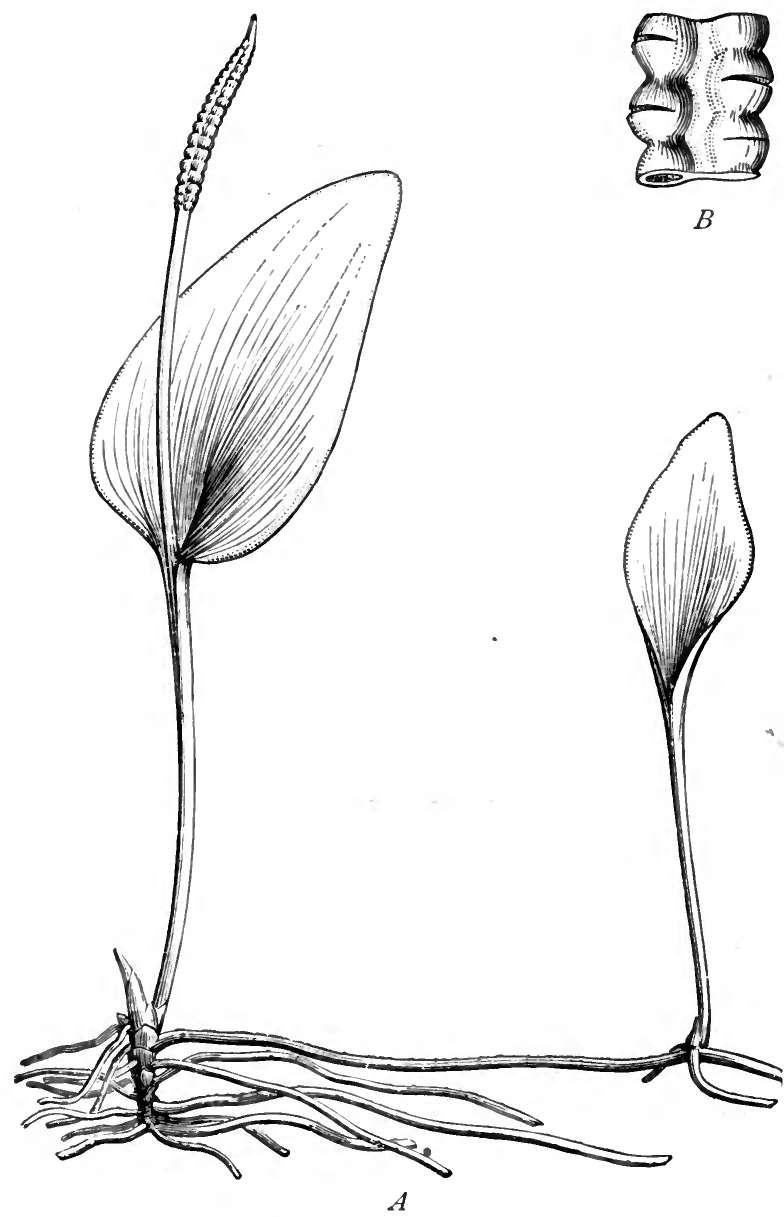

FIG. 72.-Ophioglossum vulyatum L. $A$, p'ant (natural size); $B$, portion of sporophyll (magnified).

Ophioglossum (pedunculosum, Desv.) it has at first the form of a small round parenchymatous tuber, entirely buried in the soil and destitute of chlorophyll, from which is subsequently developed a cylindrical vermiform shoot, which grows erect by means of a single apical cell, 
and very rarely branches, and then but slightly. The apex of this shoot finally appears above ground, develops chlorophyll, becomes lobed, and ceases to grow. When fully developed, the prothallium consists of an

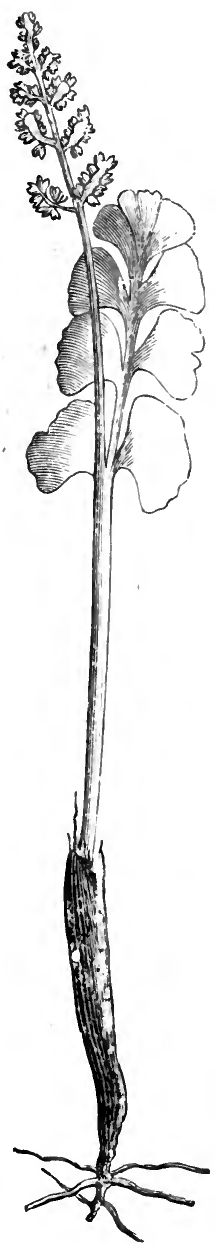

FIG. 73.-Botrychium Lunaria Sw. (nat. size). axial bundle of elongated cells surrounded by shorter parenchymatous cells ; its upper surface is clothed with rhizoids. Its length sometimes amounts to as much as two inches, though generally it is much shorter; its breadth is always very small. In Botrychium (Lunaria, Sw.) the prothallium is a minute light brown or yellowish white ovoid mass of firm cellular tissue, subterranean and destitute of chlorophyll, and producing rhizoids from all sides. In both genera the prothallium is monœcious.

The archegones, antherids, and antherozoids do not differ materially in structure from those of Filices.

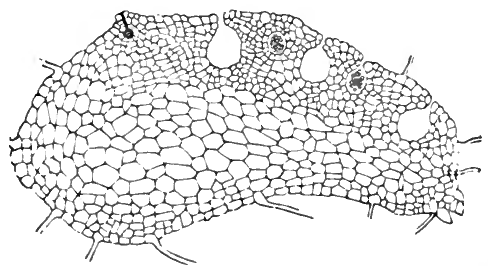

FIG. 74. - Longitudinal section of prothallium of Botrychium Lunaria, showing archegones and antherids ( $\times 5^{\circ}$ ). (After Hofmeister.)

Neither archegones nor antherids are limited in their production to any particular part of the prothallium. In Botrychium (Sw.) the antherids are cavities in the tissue chiefly of the upper side of the prothallium, and the archegones are produced in their immediate vicinity; in Ophioglossum (L.) they project slightly above the surface. Before opening to discharge the antherozoids, they are covered by a few epidermal layers of cells. The mode of formation of the antherozoids resembles that of Marattiaceæ. Their mother-cells originate from repeated divisions of one or two cells of the inner tissue lying beneath these layers. They are comparatively large, and escape through a narrow opening in the layers of cells which originally covered the antherid. The archegone consists of a venter containing the central cell, and a neck composed of four vertical rows, each consisting of two or more cells, and only slightly projecting above the surface. The 
venter is completely imbedded in the prothallium, its wall being developed out of the tissue of the latter.

The course of development of the embryo and rudimentary sporo phyte has not yet been followed out in a sufficient number of instances to warrant a general cescription; in those in which it has at present been observed it appears to present some discrepancies.

The short stem is erect and entirely glabrous, often with a swollen tuberous base; only in Helminthostachys (Kaulf.) is there a creeping anderground rhizome. In only a very few exceptional cases does it branch. The flattened apex of the stem consists of an irregular meristem derived from a single pyramidal apical cell. The fundamental tissue of the stem consists of short nearly cylindrical thin-walled succulent cells, which are longer in the leaf-stalk, interspersed with large intercellular spaces. It exhibits a striking difference from the corresponding tissue of true ferns in the entire absence of sclerenchymatous layers. It is separated by the 'vascular' cylinder into a cortical and a medullary parenchyme. It has an epiderm well provided with stomates, and exhibits sometimes a remarkable development of layers of cork. The 'vascular' bundles form (in Ophioglossum vulgatum, L.) a hollow cylindrical network, from each mesh of which is sent out a leaf-trace. The whole of the tissue which fills up the meshes is frequently transformed into scalariform tracheides, so that considerable lengths of the stem then contain a continuous hollow cylinder of lignified tissue. The bundles of the stem are collateral, the xylem occupying the axial, the phloem the peripheral side; and the structure is the same in Botrychium (Lunaria). Those of the leaf-stalk are four to eight in number, arranged in a circle and separated by fundamental tissue. In Ophioglossum they are collateral, the axial portion consisting of narrow reticulate tracheides, the peripheral portion of a broad band of phloem, containing sieve-tubes; while in Botrychium they are concentric, consisting of a broad band of scalariform or reticulate tracheides surrounded by a thick layer of phloem. There is no bundlesheath in Ophioglossum, and only a rudimentary one in Botrychium.

The roots of Ophioglossaceæ are remarkable from the slight development of the root-cap, and the absence of root-hairs. They spring from the short stem in the midst of the leaf-insertions, and rarely branch, then always monopodially. Like the stem, they originate from a single pyramidal apical cell. The roots of Ophioglossum give rise to adventitious buds.

The leaves are always very few in number, often only one on each stem, and the number is uniform in the same species. They are remarkable for the slowness of their growth, which extends, in Botrychium Lunaria, over five years, the leaf only rising above the surface of the 
soil at the commencement of the fifth year; where there are several leaves, the points of origin of those of successive years have a spiral phyllotaxis. They are quite simple and entire, simply pinnate, or twice or thrice pinnate. There is always a long petiole, which is furnished with a ligular or sheath-like outgrowth on each side; and the coalescence of these appendages forms a hollow chamber within which the leaf is developed, similarly to what takes place in Marattiaceæ. They are never circinate in vernation. They are of coriaceous texture, and are always quite glabrous, and possess a well-defined epiderm furnished with stomates on both surfaces, and in immediate contact with the mesophyll, without any intermediate hypodermal layers. The mesophyll is large-celled and spongy, with large intercellular spaces. 'The 'vascular' bundles are but feebly developed; they anastomose in Ophioglossum, but only dichotomise in Botrychium and Helminthostachys. In most species all the leaves are fertile; but in Rhi-

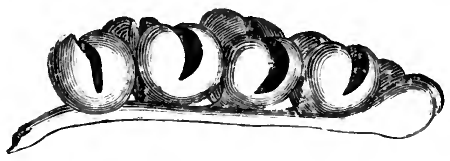

Fig. 75.-Botrychium Lunaria. Portion of sporophyll with open sporanges (magnified). (After Luerssen.)

zoglossum (Presl) (a section of Ophioglossum) there are both barren and fertile leaves. The leaf divides at an early period into two branches-an outer branch which is sterile, and which alone develops chlorophyllous parenchyme; and an inner fertile branch, the sporophyll, which springs either from the base or middle of the lamina or from the leaf-stalk. This branch never has any green parenchyme except in Helminthostachys.

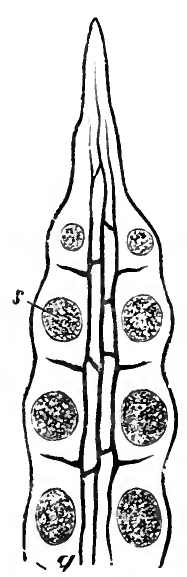

Fig. 76.-Ophioglos. sumvulgatum. Portion of sporophyll with closed sporanges, $s ; g$, 'vascular' bundle ( $x$ I0).

The sporanges resemble in their origin and mode of formation those of Marattiaceæ. They are not formed from a single cell, but from a group of cells in the substance of the sporophyll which are differentiated from the surrounding tissue. The terminal cell of the axial row beneath the epiderm is the archespore from which all the spores are formed; it is surrounded by the layers of mantle-cells constituting the tapete, which are formed out of the epidermal cell immediately above the archespore, and which ultimately disappear. The wall of the sporange, consisting of several layers of cells, is developed from the epiderm, and contains stomates. Strasburger regards each sporange as corresponding homologically to an entire sorus in the Filices-being, in fact, a meta- 
morphosed portion of a leaf. They are buried, in an early stage, in parenchyme, which ultimately becomes entirely absorbed, and which is traversed by 'vascular' bundles anastomosing into long meshes. The sporanges require an entire year for their complete development. They have no annulus, and dehisce vertically from unequal tension of the epidermal and hypodermal layers of cells. In the formation of the spores each mother-cell divides into four 'special mother-cells,' with very thin cell-walls; the protoplasm in each of these becomes invested with a new and firmer cell-wall, and the spores are thus completely formed, and are ultimately set free by the absorption of the walls both of the special mother-cells and of the original spore-mother-cells. The spores are nearly cubical ; the exospore is strongly cuticularised, and is furnished with prominent knobs and ridge.

Vegetative propagation is known to take place only by means of adventitious buds produced on the roots.

The Ophioglossaceæ include only a very small number of species, comprised in the genera Ophioglossum (L.), Botrychium (Sw.), and Helminthostachys (Kaulf.), spread over the whole globe. They are small plants, dying down each year, only a few species attaining the height of more than a foot, with a single or only a very few coriaceous leaves, and a conspicuous 'fructification,' which is simple and spicate in Ophioglossum and Helminthostachys, branched and paniculate in Botrychium. They are of no known economic value. They are represented in our English flora by the 'adder's-tongue' (Ophioglossum vulgatum, L.) and 'moonwort' (Botrychium Lunaria, Sw.).

\section{Literature.}

Mettenius-Filices Hort. Bot. Lipsiensis, I856.

Hofmeister-Abhandl. Sächs. Gesell. Wissenschaften, 1857.

Holle-Bot. Zeit., 1875, pp. 24I et seq.

Prantl-Ber. Deutsch. Bot. Gesell., I 883, pp. 155 and 348 ; and Jahrb. Bot. Gart. Berlin, I 884 .

\section{Class VI.-Equisetaceæ.}

The Equisetaceæ or Horsetails are a very small group of plants, consisting only of a small number of species, arranged in a single genus, of remarkably uniform and peculiar habit. The aërial stems, which are invariably erect or ascending, arise from a creeping underground rhizome, and are characterised by their perfect multilateral symmetry and verticillate branching. The ascending stem is always elongated and slender, fluted with longitudinal furrows and ridges, and is remarkable for the 


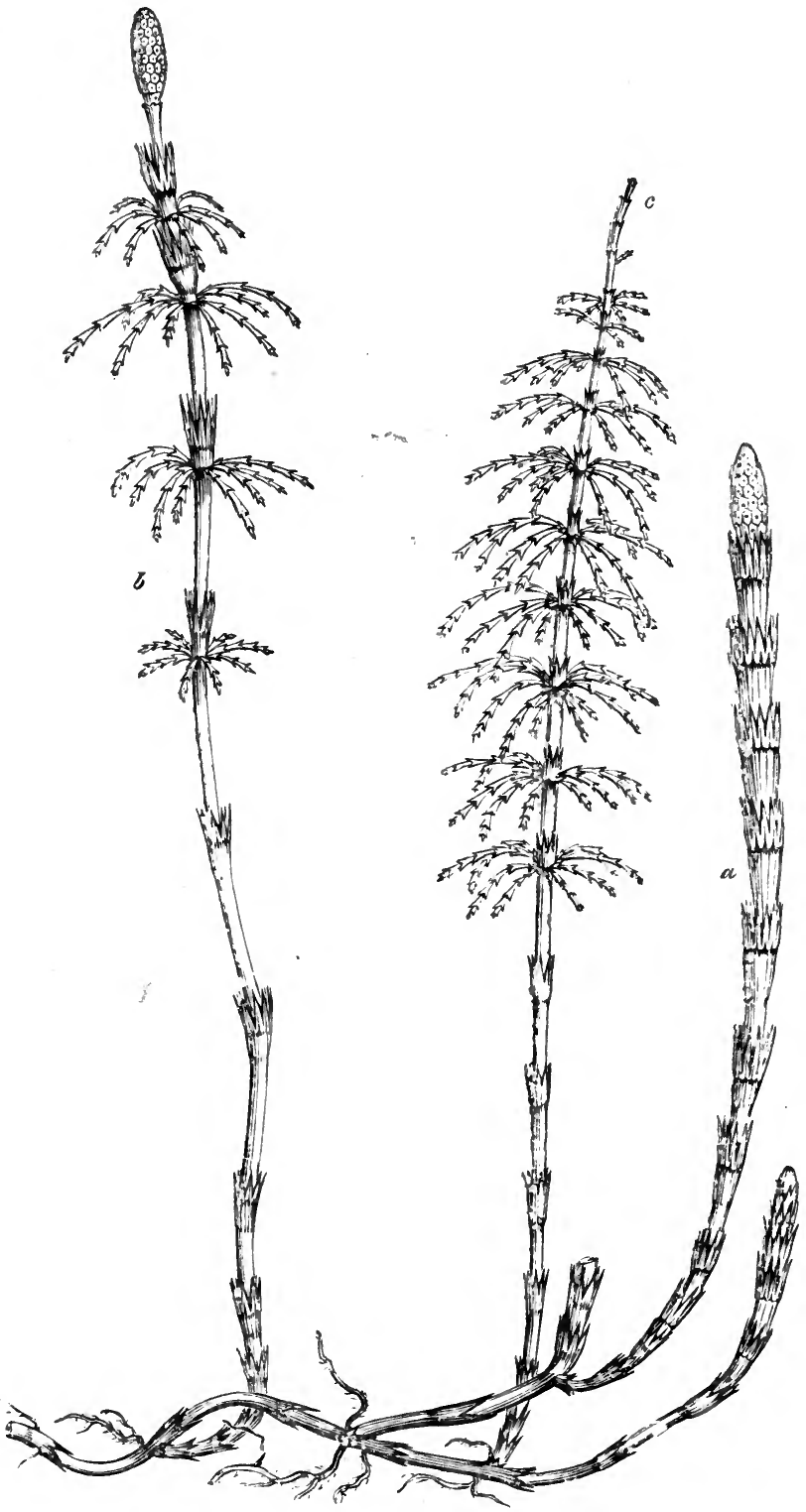

FIG. 77. - Equisctum sylraticum L. a, non-chlorophyllous fertile branch : $b$, chlorophyllous fertile branch; $c$, barren branch (reduced). 
tendency displayed by the epidermal cells to deposit silica in their ccllwalls. It is always divided into very distinct nodes and internodes, and is furnished at the nodes with modified foliar organs of a membranous character, the leaf-sheaths, the margin of which is split into a number of teeth. The tissue of the internodes is permeated by large intercellular aircanals. At the nodes the stem (except in some species the fertile stem) gives out a whorl of symmetrically arranged branches, which almost precisely resemble the main stem except in their smaller size and simpler structure, consisting of internodes and nodes furnished with leaf-sheaths ; but these secondary branches do not usually again branch. The sten and root increase in length by means of a single large pyramidal apical cell, which produces three rows of segments. The 'vascular' bundles of the stem are but feebly developed, and contain but little xylem. Both stem and branches perform the function of leaves, contain chlorophyll, and are provided with stomates. The sporanges are never borne on the branches or leaves, but are collected into spicate or catkin-like 'fructifications,' borne at the extremity either of ordinary vegetative stems, or of special fertile stems which resemble the ordinary stems in structure, but contain no chlorophyll and do not branch. The sporanges spring from the inner side of the peltate scales of which these 'fructifications' are composed ; they dehisce by a longitudinal fissure, but have no annulus like those of ferns. The spores are distinguished from those of all other Vascular Cryptogams by being enclosed in four distinct coats, the outermost of which ultimately breaks up into four ribbon-shaped strips, and detaches itself from the spore except at the point of junction of these strips, which are termed elaters. The elaters are remarkably hygroscopic, absorbing or giving off water with every change in the moisture of the surrounding atmosphere. In consequence of this they are constantly altering their shape, and imparting a somewhat rapid motion to the spores, thus assisting in their dissemination. On germinating the spore gives rise to a strap-shaped prothallium, which has an independent power of growth, and is usually diœecious. The antherids and archegones differ in no essential point from those of other Vascular Cryptogams. Male and female prothallia are generally produced in close proximity to one another, so that impregnation is readily effected through the agency of moisture.

The oophyte generation of Equisetum (L.) springs directly from the spore, which contains chlorophyll. On germinating the spore throws off its outer coats, and changes its form from spherical to pear-shaped. The contents, still clothed in the thin endospore, then divide by a wall, the direction of which is not constant, into two cells of unequal size; according to Stahl the direction of this division depends on the direction of the rays of light. From the smaller of these two cells the chlorophyll 
rapidly disappears entirely ; it undergoes no further division, but elongates rapidly into a long hyaline rhizoid. The larger of the two primary cells, which still contains abundance of chlorophyll, divides further by walls, at first in two directions only, into a multicellular plate which increases rapidly by apical growth, and soon branches in one plane. A difference is now set up between the development of the male and female prothallia. The former remain comparatively small and narrow, and the cell-division continues in the

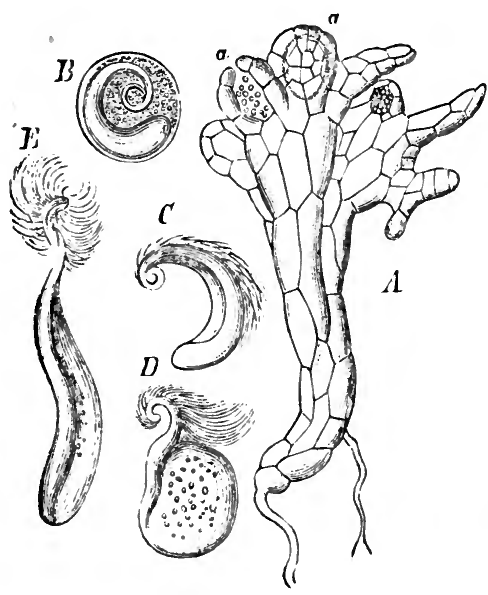

Fig. 78. - $A$, male prothallium of Equisetum arvense L.; $a$, antherids ( $\times 200)$. (After Hofmeister.) $B-E$, antherozo:ds of E. maximum Lam. in different stages of development $(\times 1200)$. (After Schacht.)

two directions only ; they consist, therefore, permanently of only a single layer of cells, and display but little lobing. Their colour is yellowish green. The female prothallia, on the other hand, grow to

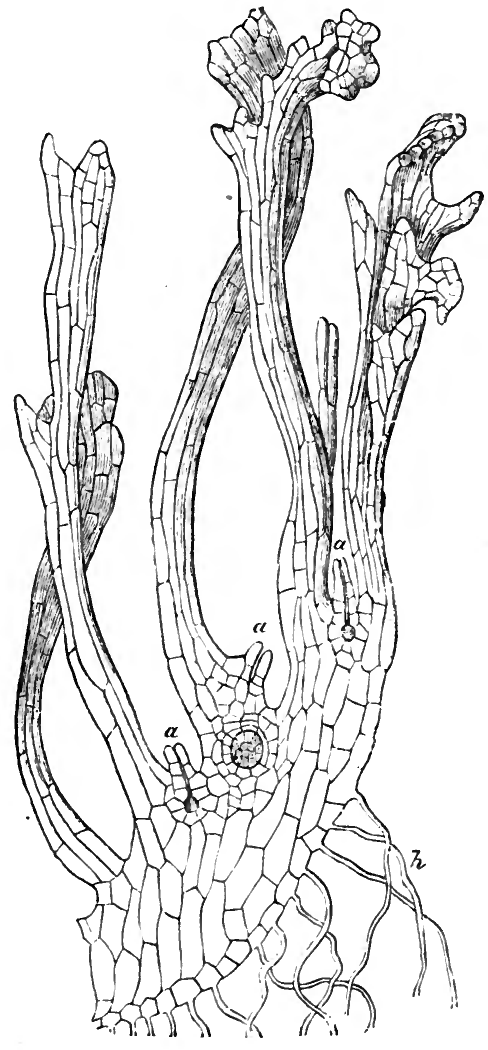

Fig. 79.-Vertical section of lobe of female prothallium of $E$. arvense. $a$, archegones; $h$, rhizoids $(\times 600)$. (After Goebel.)

a considerably larger size, as niuch as half an inch in length, are of a deeper green colour, and at an early period form a number of lobes at their anterior portion, which consist of masses of merismatic tissue, celldivision taking place in the tangential as well as the other two directions; they branch also in the same plane much more abundantly than the male prothallia. The formation of female or male prothallia appears to depend 
on the greater or less supply of nutriment. The antherids make their appearance about five weeks after germination, the archegones not till much later.

The antherids arise at the extremity or margin of the male prothallia. They are first separated off as papillæ by a tangential wall ; further divisions then arise, by which they are divided into a large central cell and a single layer of much smaller peripheral 'mantle-cells.' The contents of the central cell then divide into the mother-cells of the antherozoids. These escape, still enclosed in the delicate wall of the 'special mother-cell,' by the separation from one another, through the action of water, of the apical cells of the mantle-layer ; the expulsion often

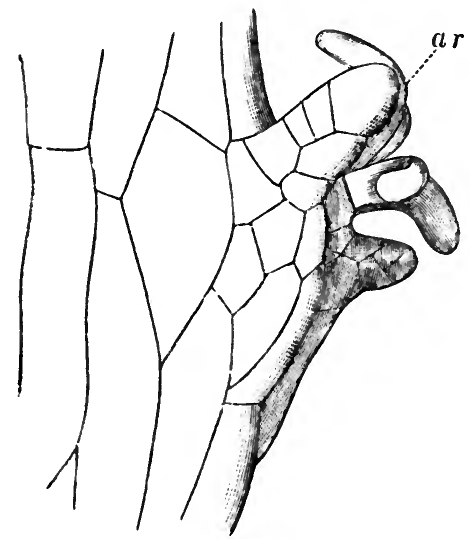

FIG. 80.-Portion of female prothallium of $E$. sylvaticum, with projecting archegone, $a r$. (Atter Buchtien, greatly magnified.) takes place with considerable force, and is due to the swelling up of the walls of the mother-cells ; sometimes they emerge still all united together into a ball. The antherozoids are much more numerous than in ferns ; probably several hundreds are formed in each antherid; they are also much larger, being the largest in any class of Cryptogams. Each antherozoid (see fig. 78 ) is a thread of protoplasm, gradually narrowing from the posterior to the anterior end, where it is coiled spirally, and bears a tuft of very long delicate vibratile cilia. The posterior portion is widened into a thin membranous fin-like expansion, by the undulations of which its motion through the water is greatly assisted, and may continue for many hours. To the posterior portion of the antherozoid is also frequently attached for a time a minute bladder containing starch, which is regarded by some as the wall of the special mother-cell, by others as a vesicle contained in it. The body of the antherozoid appears to be formed from the nucleus of the mother-cell, its cilia from the cell-protoplasm.

The archegones are formed on the under (shaded) side of the thick lobed portions of the female prothallia, a lobe being usually situated immediately beneath an archegone, and assisting in its impregnation by retaining water. By the continued growth of the subjacent tissue they are ultimately pushed on to the upper surface, and hence the direction of growth of the archegone is the opposite of that of ferns. Otherwise 
the mode of development and structure of the archegones of Equisetum differ in no essential respect from those of other Vascular Cryptogams. The basal cell is wanting, and the neck-canal-cell does not extend the whole length of the neck. The lower portion of the neck and the venter remain completely imbedded in the tissue of the prothallium, while the outermost or stigmatic cells of the neck lengthen greatly, and ultimately bend outwards, giving to the archegone, when ready for impregnation, the appearance of a miniature four-armed anchor.

Although the prothallium of Equisetum is normally diœcious, it is not very uncommon to find a few archegones on male, and a few antherids on female prothallia. The abnormal sexual organs then generally make their appearance later than the normal ones.

The mode of formation of the embryo from the impregnated oosperm is essentially the same as in other classes of Vascular Cryptogains. The first division-wall is vertical to the axis of the archegone, and therefore parallel to the surface of the prothallium ; by subsequent walls a division takes place into octants. Of the four quadrants of the upper half, one gives birth to the rudimentary stem, with a triangular pyramidal apical cell, while from the three others proceed two cotyledons, which at a very early period unite in their growth with the first leaf which proceeds from the apex of the stem. From the lower quadrants of the octant are formed the foot and the first root. The first few stems of the sporophyte generation are successively thicker, and with a larger number of teeth in their leaf-sheaths, until ultimately mature stems are produced from perennial underground rhizomes.

The stem of Equisetum always consists of very distinct more or less elongated internodes, which are hollow, but are closed above and below at the nodes by transverse septa or diaphragms. The cortex of each internode is continued upwards above its upper node into a leaf-sheath, which embraces the base of the next internode above, and is split at its margin into teeth, varying from three or four to a considerable number. From each tooth of the leaf-sheath a 'vascular' bundle descends vertically as far as the next node. The teeth at each node always alternate in position with those of the leaf-sheaths belonging to the nodes next above and next below it, and each descending bundle branches at the node into two short diverging arms, each with its own xylem and phloem, by means of which it unites with the two adjacent bundles of the next internode below, where they descend into it from the sheath-teeth in which they originate. In addition to the large central cavity in the axis of each internode, the cortical tissue contains a number of much smaller cavities running vertically through the internode, the lacunce or vallecular canals, which alternate with the 'vascular' bundles, and are there- 
fore intermediate between the sheath-teeth ; these canals are of lysigenous origin - that is, they result from the disappearance of masses of cells. Each bundle also contains a longitudinal air-cavity, or carinal
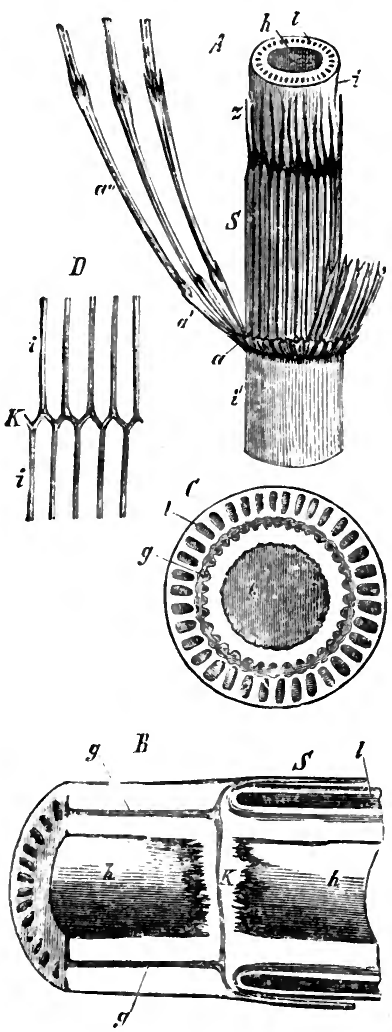

Fig. 81.-E. maximum. A, portion of stem (natural size). $i, i^{\prime}$, internodes ; $h$, central cavity ; $l$, cortical lacunæ ; $S$, leaf-sheath; $\boldsymbol{a}, \boldsymbol{a}^{\prime} \cdot \boldsymbol{a}^{\prime \prime}$, branches. $B$, longitudinal section of rhizome $(\times 2)$. $K$, transverse diaphragm ; $h, h$, cavities ; $g$, 'vascular' bundle ; $l$, cortical lacunæ; $S$, leaf-sheath.' $C$, transverse section of rhizome. $D$, union of 'vascular' bundles of two internodes, $i, i ; K$, node. $(B-D$, diagrammatic.) canal (sometimes called the 'essential air(avity'). The outline of the stem always shows a number of alternate ridges and furrows; the ridges correspond to (or are on the same radii as) the 'vascular' bundles, the furrows to the cortical lacunæ. 'This general description applies equally to the primary vegetative stems, the fertile unbranched stems, and the underground rhizomes; the branches of the barren stems have no axial cavity or cortical lacunæ. In those species where the fertile differ in structure from the barren shoots, this appears to result from an arrest of development of the latter. The difference consists essentially in the absence of chlorophyll, the suppression of branching, and the absence of stomates, as well as in the greater development of the leaf-sheaths. It is possible $^{\circ}$ to induce artificially the fertile shoots of E. arvense (L.) to put out green branches from the lower internodes, chlorophyll being also formed in the main stem.

The branches always spring from within the leaf-sheath at its base, each branch in the space between two teeth; they therefore correspond in number to the 'vascular' bundles of the stem, and are always arranged in a whorl. The same description applies to the roots. The number of leaf-teeth and bundles is always smaller on the secondary than on the primary axes, and these, as a rule, do not again produce branches. In some species even the primary stem never branches. The whorl in which the branches stand is, however, not a true, but a false whorl-that is, the phyllotaxis originally shows a regular spiral one-third divergence ; but by subsequent unequal growth the insertions 
come ultimately to stand on a level. On the rhizomes the ridges and furrows of the outer surface are generally less well marked, and the axial cavity of the internode is sometimes wanting; but the vallecular and carinal canals are always present, and play an important part in the diffusion of air through the tissue. The aërial stems, both barren and fertile, are usually completely formed in miniature during the preceding year within the underground bud, and their rapid growth after they appear above the scil is mainly due to the great elongation of the internodal cells. The ascending stem and all other aërial parts of the plant are always entirely destitute of hairs; while the rhizomes and the underground leaf-sheaths are frequently covered with a felt of roothairs.

The firmness and strength of the slender aërial stem are not due, as in ferns, to the 'vascular' bundles, but mainly to the siliceous epiderm and the firm hypodermal tissue. The epiderm, consisting of a single layer of elongated cells, is provided with stomates in the green, leafy, aërial stem, but not usually in the colourless fertile stem, or in the rhizomes. In most species of Equisetum the stomates lie in one or more longitudinal rows in the furrows of the stem only; but in E. arvense, according to Miss E. A. Southworth ('American Naturalist,' I 884 , p. I04I), also on the ridges. Stomates also occur on the leafsheaths. The stomates either have their orifice on a level with the surface (Equiseta phaneropora) or considerably depressed below it (Equiseta cryptopora); in the latter case they frequently do not open directly into the surrounding air, but are situated in the hypodermal tissue, beneath a 'false stomate,' or pore in the epiderm. The stomates (fig. 82) differ from those of other classes of vascular plants in being formed of two pairs instead of a single pair of guard-cells. Strasburger (Beitr. zur Entwickelungsgesch. der Spaltöffnungen, in Pringsheim's Jahrb., vol. v., p. 297) terms the lower pair 'subsidiary cells' of the true stomate. All the cells of the epiderm, even the guard-cells of the stomates, have their outer walls or cuticle strongly silicified; and these deposits of silica frequently project above the surface in the form of fine granules, bosses, rosettes, rings, transverse bands, teeth, or spines. On the guard-cells they usually have the form of ridges radiating from the orifice. Beneath the epiderm, except on the deciduous fertile stems, bundles or layers of firm thick-walled cells generally constitute a sclerenchymatous hypodermal tissue, which is especially developed in the elevated ridges of the aërial internodes. On the underground stems both epiderm and hypoderm frequently assume a beautiful brown-red colour. In addition to silica, analysis of the ash of Equisetaceæ (Dieulafait, 'Compt. Rend.', vol. c., I885, p. 284) shows the presence 
of a large amount of sulphates, and the total absence of alkaline carbonates.

A large portion of the parenchymatous fundamental tissue is destitute of chlorophyll; it is only in the vegetative aërial shoots that there is any considerable development of chlorophyllous tissue, and then it is usually situated in the furrows beneath the stomates. The 'vascular' bundles of Equisetum are collateral, and are much less strongly lignified than those of ferns. They lie in a circle between the medulla and the cortex, between and somewhat within the cortical canals, and necessarily run parallel to one another. As will be seen from the description given above, each bundle is the result of the coalescence of two branches, one of which originates in the leaf-sheath, while the other develops in the
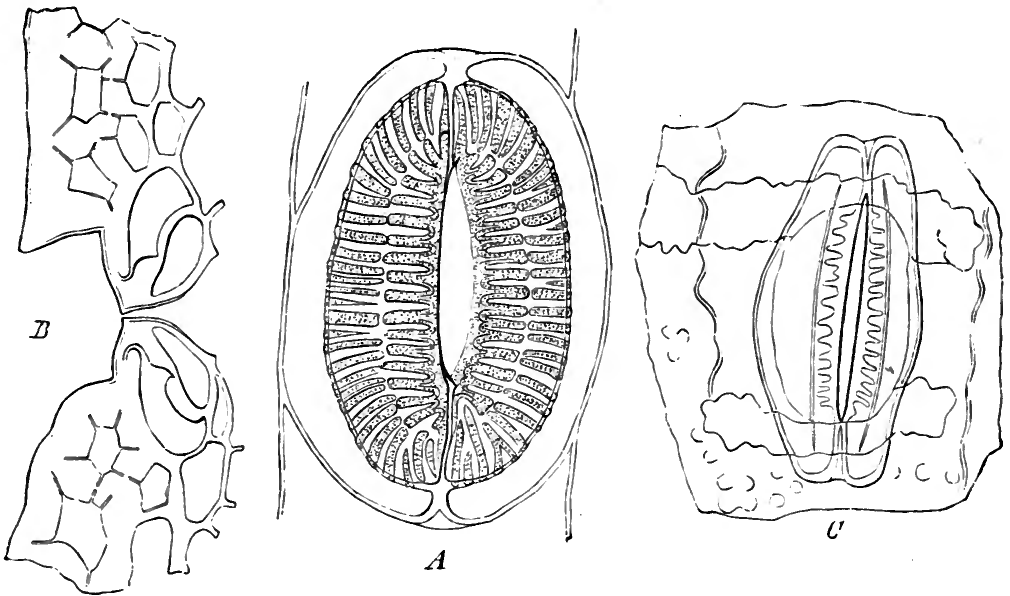

FIG. 82.-Stomate of E. hyemale L. ( $\times 390)$. $A$, front view ; $B$, transverse section of stem, showing side view ; $C$, siliceous residuum after maceration. (After de Bary.)

internode itself, from above downwards. At the angle where the two arms meet, the formation of tracheides begins in each; the lower end of each bundle unites by two lateral branches with the two next bundles, one on each side, of the next lower internode; and the bundles are therefore of the description known as 'common.' Their course resembles more that of the bundles of most Dicotyledons and Conifers than that of ferns. Each bundle is traversed longitudinally on its axial side by a carinal canal, occupying the place of the first tracheides, which have become absorbed; right and left of this, in the mature bundle, are reticulate, annular, and scalariform tracheides; on the outside is the phloem-portion of the bundle, consisting of a few wide 
sieve-tubes and narrow cambiform cells. In most species (e.g. E. arvense) a general bundle-sheath, or plerome-sheath, consisting of a single layer of cells, encloses the entire circle of bundles, as in most Flowering Plants ; while in others (E. limosum, L., and littorale, Kuhlw.) each individual bundle is enclosed in a separate special bundle-sheath, as in ferns. In the colourless fertile shoots they bend out into the pedicels of the peltate scales of the 'fructification,' as they do into the leaf-sheaths.

The growth of the stem takes place through the activity of a single large pyramidal apical cell with an inverted triangular base. There is no other group of plants which exhibits such a well-defined single apical cell or exclusively apical growth. Normally the terminal bud never branches, branching taking place solely by lateral buds produced at the nodes. It was formerly thought that the Equisetaceæ display the only known example of lateral branching being due to the formation of endogenous buds; but recent researches have shown (in E. arvense) that these lateral buds are not of endogenous origin, but originate from a single superficial cell of the growing point of the stem in the ordinary way. The segments resulting from the first divisions of the apical cell lie in three straight rows, and are arranged in a spiral divergence of onethird.

The roots are produced in whorls at the nodes of the underground stem, in direct connection with lateral buds, or, under favourable conditions, at the nodes of the aërial stems. They are furnished with a root-cap, increase by the segmentation of a single apical cell, and are penetrated by an axial 'vascular' bundle surrounded by a large aircavity formed by the coalescence of intercellular spaces owing to the absorption of intermediate cells. The weak bundle, in which the tracheides are but feebly developed, is concentric, with the xylem in the centre. The secondary or lateral roots, which arise in acropetal succession on the primary root, differ in their origin from those of ferns and other Vascular Cryptogams. In these latter it is the innermost layer of cells belonging to the fundamental cortical tissue immediately surrounding the axial 'vascular' bundle that becomes differentiated into the bundle-sheath or endodermal laver, within which lies the pericambium of the bundle itself; and the lateral roots originate from the innermost layer of the cortex separated by the pericambium from the bundle. In the roots of Equisetaceæ the pericambium is wanting, and its place is to a certain extent supplied by the innermost cortical layer, from which the lateral roots spring, and therefore in close contact with the periphery of the axial bundle. The bundle-sheath itself is, in the Equisetaceæ, formed from the row of cortical cells next to the innermost row, and not from the innermost row itself, as in other Vascular Cryptogams. 
'The sporanges of the Equisetaceæ are collected into terminal spicate 'fructifications' of a cone-like or catkin-like character, resembling nothing else among existing. Vascular Cryptogams. These are borne at the extremity either of the ordinary green vegetative stems, whether branched (E. palustre, L.) or unbranched (E. hyemale, L.), or of special fertile stems (E. arvense, pratense, Ehrh., maximum, Lam.), which are

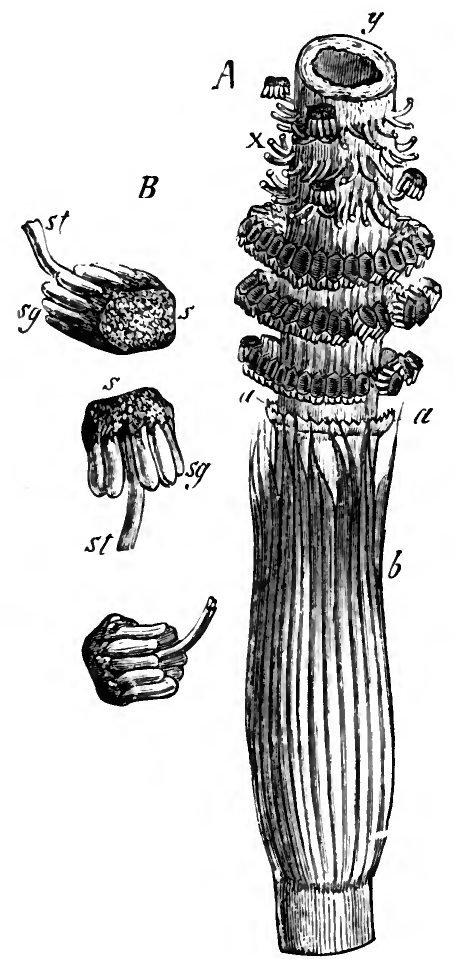

Fig. 83. $-A$, upper part of fertile stem of $E$. maximum (natural size); $b$, leaf-sheath: $a$, annulus; $x$, sporophylls and their stalks. $B$, sporophylls $(\times 6) ; s g$, sporanges. (After Goebel.) then always simple, even when the barren stems are branched, and are usually stouter, nearly or quite destitute of chlorophyll, and with much larger leaf-sheaths and coarser teeth. As already mentioned, these can be artificially converted into vegetative stems; and occasionally deciduous fructifications are borne at the extremity of the ordinary green branched stems, in species which normally produce special fertile stems (E. arvense). The sporanges are not, like those of typical Filices, trichomic or epidermal in their origin; their development closely resembles that in the Marattiaceæ. They are endogenous outgrowths of peculiarly metamorphosed leaves, the peltate scales or sporophylls, arranged, like the branches, in whorls. Intermediate between these and the uppermost whorl of ordinary leafsheaths there is (in E. maximum) a whorl of barren but more or less modified leaf-sheaths, forming a small annular girdle, the involucre or annulus. The whorls of sporangiferous scales, of which a number are formed above this involucre, make their first appearance as similar annular girdles, projecting but slightly from the stem, but gradually forming a hemispherical cushion. This cushion finally breaks up into a number of plates, the surface of which is parallel to that of the stem ; and these, by mutual pressure, become polygonal and usually hexagonal ; each plate or disc is attached to the stem by a slender pedicel at right angles both to its surface and to that of the stem. On the inner surface of these 
discs are developed the sporanges, from five to ten on each disc, arising at first as small multicellular projections. The archespore is the terminal cell of a hypodermal row on the under side of the sporophyll, the sporogenous tissue resulting from its division. The mantle-cells are formed in the same way as in Ophioglossaceæ, but are not so sharply defined. The mother-cells of the spores are connected together in groups of fours or eights, and float freely in the fluid which fills the sporange. The mode of formation of the spores affords an exceedingly good illustration of the production, by free-cell-formation, of new cells within a mother-cell. When division is about to take place, the protoplasm first becomes perfectly clear, the nucleus disappears, and a number of granules arrange themselves in the form of a disc. The protoplasm then again becomes turbid, with the exception of two clear spots, one on each side of the disc, which are the rudiments of the fresh nuclei. These, however, after a time again disappear, and their place is taken by four smaller nuclei, each of which is surrounded by a number of the granules which formed a portion of the original disc. Round these nuclei the cell-protoplasm begins now to collect into four separate masses, which gradually become globular; and these are the special mother-cells of the spores after each has become invested with a very delicate coat of cellulose. This process, which has a remarkable analogy to the formation of the pollen in Flowering Plants, especially in Coniferæ, does not vary in any essential point from that in the other orders of Vascular Cryptogams; but it has been followed out with the greatest minuteness and success in Equisetum (limosum, L.).

The mature sporange dehisces by a longitudinal fissure on its inner side facing the sporophyll. The mechanism of the bursting is similar to that of the anther of Flowering Plants, and results from the unequal contraction of lignified and of non-lignified portions of the wall, which is furnished with annular or spiral thickenings to its cell-walls. The various coats of the spores are formed while still within the mother-cell. The first formed is the outermost, a non-cuticularised coat capable of swelling, which becomes gradually detached, and finally splits into two bands, the elaters, which remain attached to the spore only at one point, in the centre of each, where they meet, while the distal ends of each are dilated into a flattened spathulate form. When the spore escapes from the sporange the four elaters are stretched out nearly straight; when moistened they roll up, owing to their unequal lignification, covering up the spore almost entirely, as they did at first before becoming detached. The second coat is more or less cuticularised, and on germination also raises itself in folds from the innermost coat, which is closely applied to the contents of the spore, and is again differentiated into an outer 
granular cuticularised exospore, and an inner endospore, composed of unchanged cellulose. So strong is the hygroscopic property of the elaters, that, even if lightly breathed on, the spores of Equisetum are seen under the microscope to be in active motion, from constant changes in the humidity of the air. The spores contain chlorophyll, and, in consequence, retain their vitality only for a very few days, and germinate in a few hours after being placed in favourable conditions. In this respect they show a striking contrast to those of ferns.
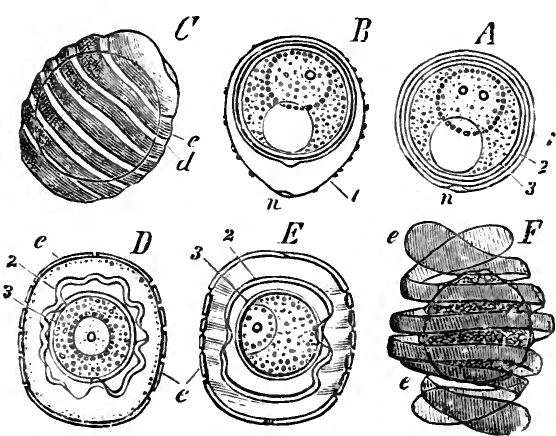

FIG. 84.-Stages in the development of spore of $E$. limosum ( $\times 800)$. I and $\varepsilon$, outer coat from which the elaters are formed ; 2, 3, inner coats. (After Gcebel.)

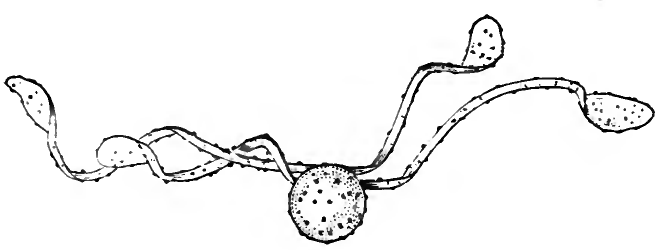

FIG. 85.-Spore with elaters extended (magnified).

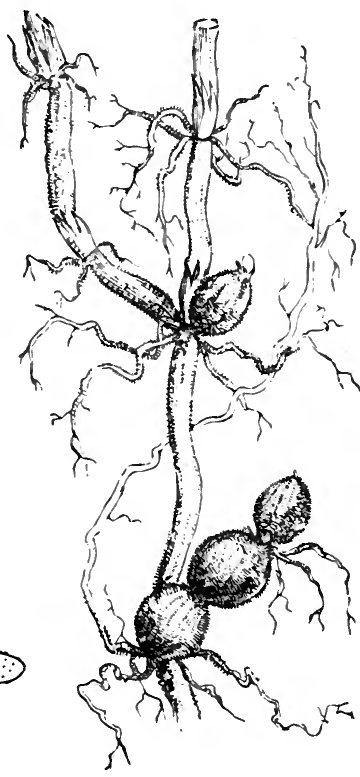

Fig. 86. - E. limosum L. Rhizome and tubers.

The only mode of vegetative propagation known in the Equisetaceæ is by the production of tubers on the rhizomes and on the underground portions of the erect stems ; they are peculiarly modified internodes, filled with starch and other food-materials, and may remain dormant for years. The buds, especially those produced at the lower nodes of the erect stem, also have the power of retaining their vitality for a considerable pericd in a rudimentary condition ; and, when they vegetate, develop into branches of great vigour. Tomaschek ('Oesterr. Bot. Zeitschr.,' I 88 I, p. 245) induced prothallia of Equisetum to hibernate by growing them 
in a warm situation, in which condition they attained a large amount of independence, and propagated freely by budding.

The number of known species of Equisetum, commonly known as ' horsetails,' does not exceed 20 or 25 ; they are most numerous in the temperate regions, decreasing in number both towards the pole and the equator, and are very rare in the Southern Hemisphere. The stem is always very slender, and seldom exceeds two or three feet in height, though E. giganteum (L.) reaches 20 to 40 feet in the tropics, with a climbing habit. Most of the species prefer loose sandy or gravelly soil in damp situations; several grow in marshes or standing water. The erect stems are mostly annual, but in a few species they endure for several years; while the rhizome is always perennial, and frequently attains great size both in depth and in lateral extension. The species are all remarkably similar in habit, differing chiefly in the presence or absence of special fertile stems, the position of the stomates, and the degree of branching; but the classification of the species into two distinct groups of 'homophyadic' and 'heterophyadic' is not a natural one. Each species is also characterised by a special arrangement of the 'vascular' bundles, and of the air-cavities as seen in a transverse section of the stem. In external form, but not in internal structure, they call to mind Ephedra among Gymnosperms, and Casuarina among Angiosperms. The large amount of silex deposited in the epiderm renders several species, especially E. hyemale, useful for scouring purposes, and they are popularly known under the name of 'Dutch rushes.'

\section{LITERATURE.}

Cramer-in Nägeli u. Cramer's Pflanzenphys. Unters., vol. iii., I855.

Sanio-(Epiderm and Stomates) Linnæa, 1857-8, p. 385.

Duval-Jouve--Hist. Nat. des Equisetum, I864.

Rees-(Apex of stem) Pringsheim's Jahrb. wiss. Bot., 1867, p. 209.

Milde-Monographia Equisetorum, I867.

Pfitzer - (Bundle-sheath) Pringsheim's Jahrb. wiss. Bot., I867, p. 297.

Famintzin-(Buds) Bull. Acad. Sc. St. Petersburg, vol. ix., 1876.

Campbell-(Prothallium) Amer. Natural., I883, p. Io.

Leclerc du Sablon-(Sporange) Bull. Soc. Bot. France, I884, p. 292 ; and Ann.

Sc. Nat. (Bot.), vol. ii., 1885, p. 5.

Goebel-(Fertile shoots) Ber. Deutsch. Bot. Gesell., I886, p. I84.

Buchtien-(Oophyte) Uhlworm and Haenlein's Biblioth. Bot., Heft 8, 1887. 


\section{Fossil Vascular Cryptogams.}

Fossil remains or impressions of plants are found in all the stratified geological formations from the Upper Silurian to the latest. Of the Thallophytes that must certainly have existed in the seas from which the oldest fossiliferous strata were deposited, the traces are, as might be expected, few and doubtful ; and it is certain that many markings that have been claimed under this category do not belong to the vegetable kingdom at all. The remains of Vascular Cryptogams make their first appearance in the Upper Silurian, and are remarkably abundant in the Devonian and Carboniferous formations. During these periods the arborescent vegetation of the globe consisted entirely of Vascular Cryptogams and Gymnosperms, no remains that can be referred with certainty to Angiosperms being known earlier than the Permian formation. The structure and mode of reproduction in Vascular Cryptogams seem to have been remarkably uniform from the earliest times to the present. The remains found in the fossil state belong, of course, exclusively to the sporophyte generation; but these indicate not only that nearly every class of Vascular Cryptogams now in existence was represented in the Carboniferous period, but also that none of the primeval forms of vegetable life at present discovered presented characters differing very widely from existing types.

\section{Fossil Rhizocarpee.}

The fossil remains that can be referred, with any degree of certainty, to the Rhizocarpeæ are very scanty. A few leaves found here and there have been described by their discuverers, under the names Marsilidium (Schenk)and Sphenoglossum (Emm.), as representing genera nearly allied to Marsilea; and capsules presenting an external resemblance to the sporocarps of Pilularia and Marsilea have been found in the Eocene.

The Salviniaceæ are represented with much more certainty in the Miocene, impressions of leaves found in various beds belonging to that series being indistinguishable from those of Salvinia. More doubt attends the identification of fructifications referred to this order. Strasburger and Solms-Laubach think it possible that certain minute echinate bodies found in calcareous nodules in the Carboniferous, described under the names Traquairia (Carruth.), Zygosporites(Will.), and Sporocarpon (Will.), the first of which is regarded by its discoverer as a 
Radiolarian Rhizopod, may be massulæ of Azolla. Sir W. Dawson (Bull. Chicago Acad. Sc., I886, p. I05) refers crgans of fructification obtained from the Devonian (=Erian) in Canada and the northern United States-and previously described, under the name Sporangites (Daws.), as sporangia of Lycopodiaceæ - to a genus nearly allied to Salvinia, which he calls Protosalvinia ; but, inasmuch as they are borne on Lepidodendron scales, this explanation is inadmissible. Sir W. Dawson believes the megaspores of Rhizocarpeæ to be the chief cause of the highly bituminous character of the shales in which these bodies are found.

\section{Fossil SelaginellaceÆ.}

Remains of arborescent vegetation more or less nearly allied to the typical Selaginellaceæ of the present day occur in extraordinary abundance in the older fossiliferous strata. Of these the most abundant and best known families are the Lepidodendreæ and the Sigillarieæ.

Of the LEPIDODENDREÆ the stems are known as Lepidodendron, and the fructification occasionally found in organic connection with the

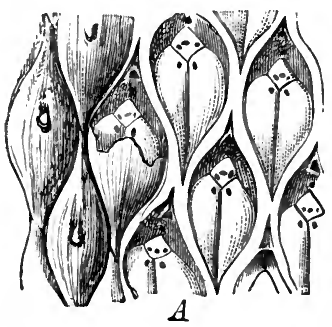

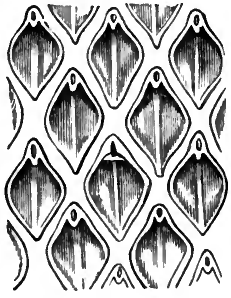

$B$
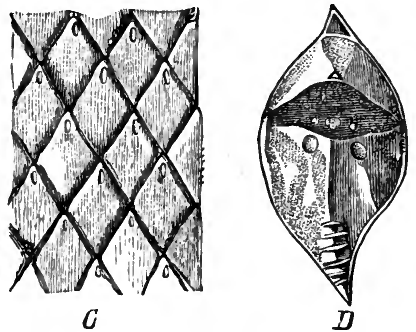

FIG. 87.-A, $B, C$, portions of surface of stem of different species of Lepidodendron (natural size) ; $D$, single cushion (magnified). (After Solms-Laubach.)

branches, as Lepidostrobus. The fructification is distinctly heterosporous ; and although, in a large number of Lepidostrobus cones, microspores only have been detected, this is unquestionably either because the portion containing the megaspores has not been preserved, or possibly because the megasporanges and microsporanges may have been distributed in distinct fructifications - a degree of differentiation unknown in any existing form.

The remains of a large number of species of Lepidodendron occur in the coal measures. They were trees, with stems up to ninety feet in height and two feet in diameter, covered with the diamond-shaped scars of fallen leaves. These scars, together with a portion of the leaf-stalk remaining behind in the form of a cushion, occupied the whole surface of the stem. Wherever the internal structure has been preserved, a 
central 'vascular' cylinder can be detected, consisting of scalariform tracheides. There is distinct evidence of a secondary growth in thickness. The branching was always dichotomous. The leaves were very similar to those of Lycopodium, and were penetrated by a single 'vascular' bundle.

The fructifications known as Lepidostrobus are cone-like structures, not unlike fir-cones in appearance, consisting of densely packed sporophylls. On the upper side of each leaf is a single sporange, often of considerable size. The cones themselves vary in size from that of a hazel-nut to one and a half feet in length. It is seldom that the remains are in a sufficiently perfect condition for the structure of the spores to
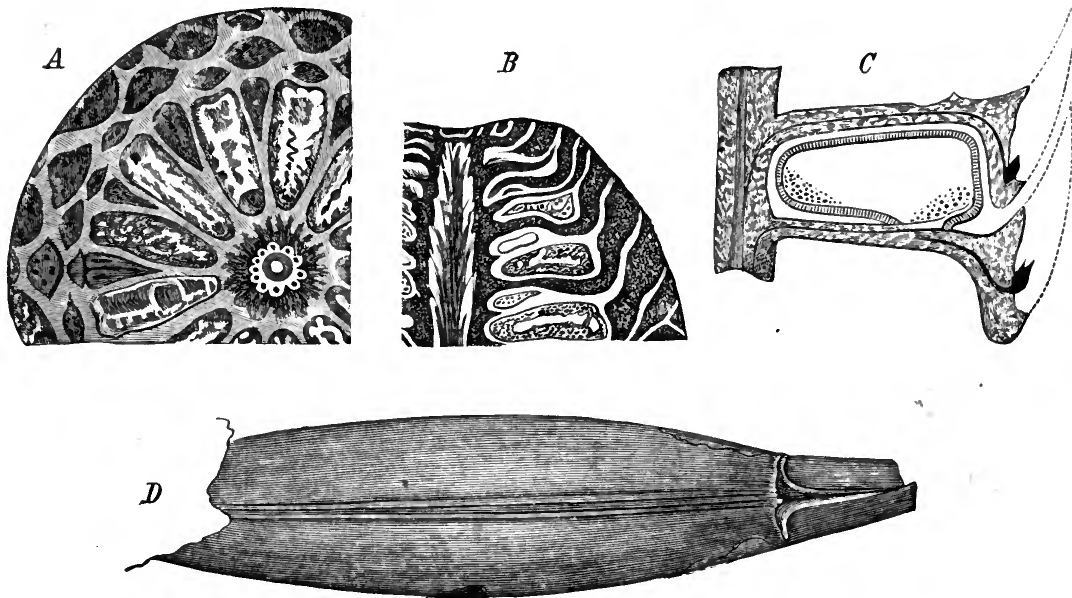

FIG. 88. - A, transverse section of cone of Lepidostrobus Brozenii Schimp. : $B$, longitudinal section (after R. Brown); C. diagrammatic longitudinal section of portion of cone of $L$. ornatus Hook. (after Hooker) ; D, upper surface of sporophyll (Lepidophyllum). (All from Solms-Laubach.)

be made out with certainty ; but in several examples both kinds occur. Where one kind only has at present been detected, it is, in most cases, the microspore, the megaspores being probably in the lower part of the fructification, which has not been preserved or examined. In the megaspores the exospore has three ridges ; there are numerous spores in each sporange. The microspores of L. dabadianus (Schpr.) are connected together in groups of four ; while in L. Brownei (Schpr.) they are in threes.

More or less nearly allied to Lepidodendron are a number of other arborescent genera, among the more striking of which are Ulodendron (Stbg.), Bothrodendron (L. and H.), and Lepidophloios (Stbg.), all from the coal measures. 
Although the genus Sigillaria is still placed by some writers among Gymnosperms, its true place is undoubtedly near to Lepidodendron in the order Selaginellaceæ; the structure of the stem presents no important difference from that of Lepidodendron, while the fructification known as Sigillariostrobus bears a remarkable resemblance to Lepidostrobus.

The remains of various species of Sigillaria occur in enormous
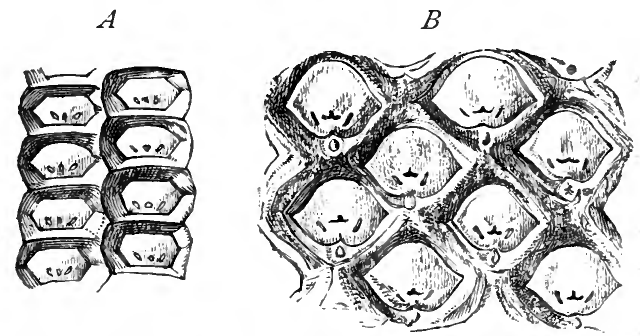
quantities in the coal measures ; and they constituted one of the predominant forms of vegetation of the period. The stems rivalled in height and thickness those of Lepidodendron, and were covered, like them, with the scars of fallen leaves in linear series. They were simple or dichotomously branched. The scars

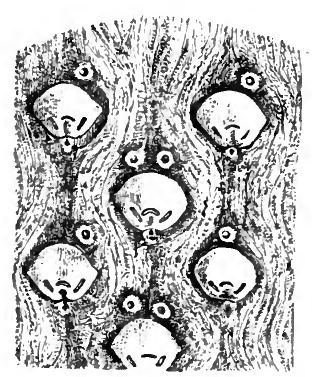

$C$

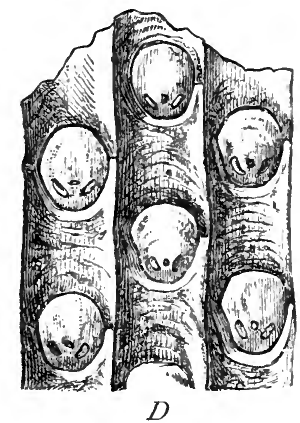

FIG. 89.- $A, B, C$, portions of surface of stem of different species of Sigillaria; D, Leiodermaria. (After Solms-Laubach.)

are circular, ovate, or hexagonal from mutual compression. In the section known as Leiodermaria the cushions which occur in other forms are wanting, and the scars stand out at a considerable distance from one another on the smooth surface of the stem. The leaves, which are occasionally found still attached to the branches, were narrow, linear, and sedge-like, up to as much as one and a half feet in length, with a. projecting midrib. According to Van Tieghem the stem of Sigillaria differs from that of the Lepidodendreæ, and indeed from that of all other Vascular Cryptogams, in the leaf-trace bundles being 'diploxylous'-that is, in the central cylinder having an external secondary and centrifugal as well as an internal primary and centripetal xylem. Renault regards the Rhytidolepida, or Sigillariæ with stem exhibiting raised cushions as well as scars, as Cryptogamic ; the Leiodermariea, or smoothstemmed Sigillariæ, as Gymnospermic; but this view is not supported by a careful examination of the structure. 
Sigillariostrobus, the fructification of Sigillaria, is extremely rare. It was a cone resembling Lepidostrobus, with the sporanges placed singly on the base of the sporophylls. The sporophylls are broadly lanceolate and apiculate. Only one kind of spore has at present been discovered, the megaspores, but it may be regarded as certain that these were associated with a second and smaller kind.

The fossils known as Stigmaria are the roots of Sigillaria, the two having been not unfrequently found in connection with one another. They occur in the Devonian and Carboniferous formations. Fragments have been found from twenty to thirty feet or more in length (S. ficoides, Brongn.), cylindrical and unbranched, or the branching always dichotomous, the two branches running in a nearly parallel direction. The surface is smooth, with numerous shallow saucer-like depressions, the scars of the rootlets, some of which are still very commonly found attached to the primary root. The Stigmariæ obviously lengthened

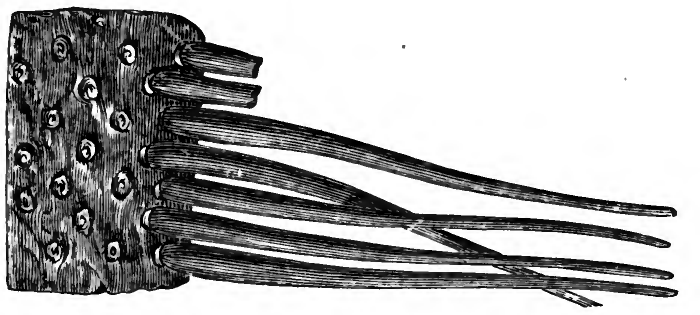

FIG. go.-Stigmaria ficoides Brongn. with rootlets. (After Solms-Laubach.)

exclusively by apical growth. Transverse section shows a hollow 'vascular' cylinder, broken by meshes for the passage of the bundles of the rootlets, and consisting of scalariform tracheides with a central parenchymatous tissue or 'medulla.' In the rootlets the single central bundle consists of a few scalariform tracheides, which leave the cylinder as a triangular bundle, but become circular in the rootlets.

Under the term Lycopodites are included a number of fossil forms, the fructification of which is either entirely unknown, or is not in a sufficiently well-preserved state for definite determination. Some of the leafy stems ought possibly to be referred to Coniferæ; others, with leaves of one kind only, perhaps belong to Lycopodiaceæ; while others, with leaves of two different kinds, are Selaginellaceæ. From beds near the bottom of the Carboniferous series there is a species with thick club-shaped terminal fructification, bearing a striking resemblance to I.ycopodium Phlegmaria (Lycopodites Stockii, Kidst.). Ptilophyton 
(Daws.), from the Devonian and Carboniferous formations of Scotland and North America, should also be included here.

The only fossils that can be referred with any degree of certainty to the Isoëteæ are those comprised in the genus Isoëtites (Schmp.), from the Miocene, which is scarcely distinguishable from existing Isoëtes. More doubt rests on the true place of Solenites (L. and H.), from the Jurassic, which has been referred with equal probability to Gymnosperms.

Of fossil Psiloteæ the remains are few and uncertain. To this family has been referred Psilophyton (Daws.); but the fructification is very
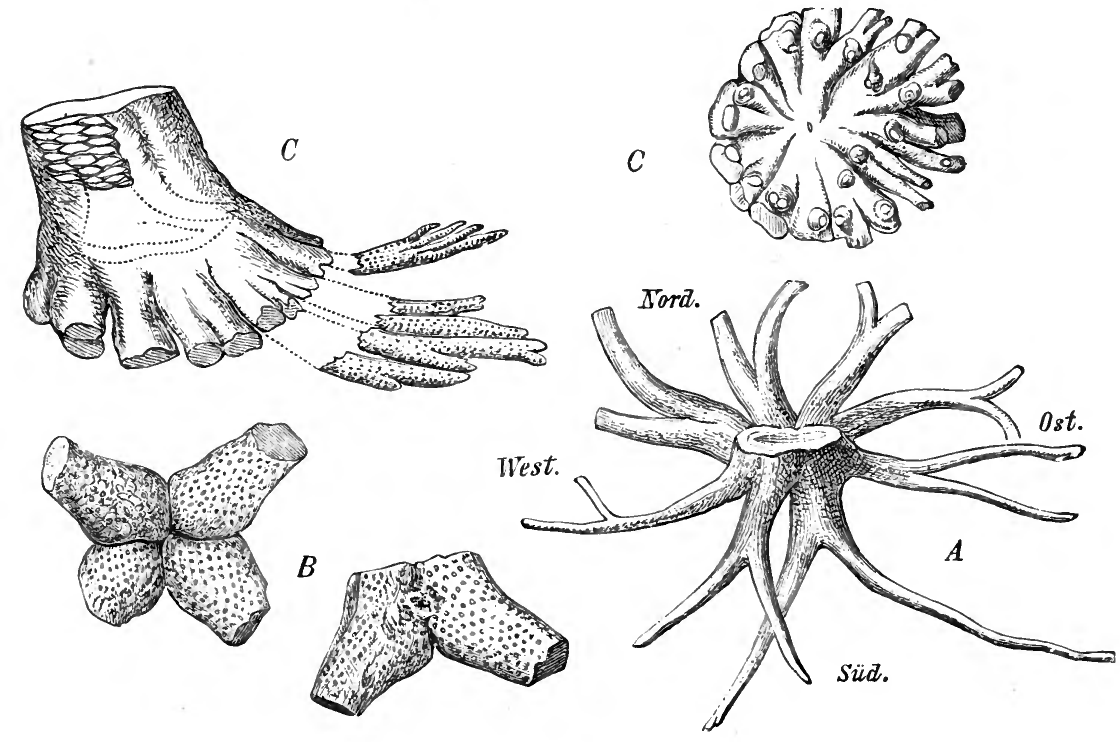

FIG. 91.-Bases of stem of Sigillaria, with Stigmaria roots attached. (After Solms-Laubach.

aberrant from the existing Psiloteæ, consisting of a pair of pod-like capsules at the end of special branches.

\section{Fossil Filices.}

The remains of ferns-or more commonly the impressions of the leaves-are found in all fossiliferous strata from the Devonian onwards. Great difficulty is presented in the classification of fossil ferns by the small fragments in which they are usually found, anything like an entire plant, or even a number of fronds attached to an aërial stem 
or rhizome, being extremely rare. The great majority of species appear to have been herbaceous; or at all events the stems of tree-ferns are

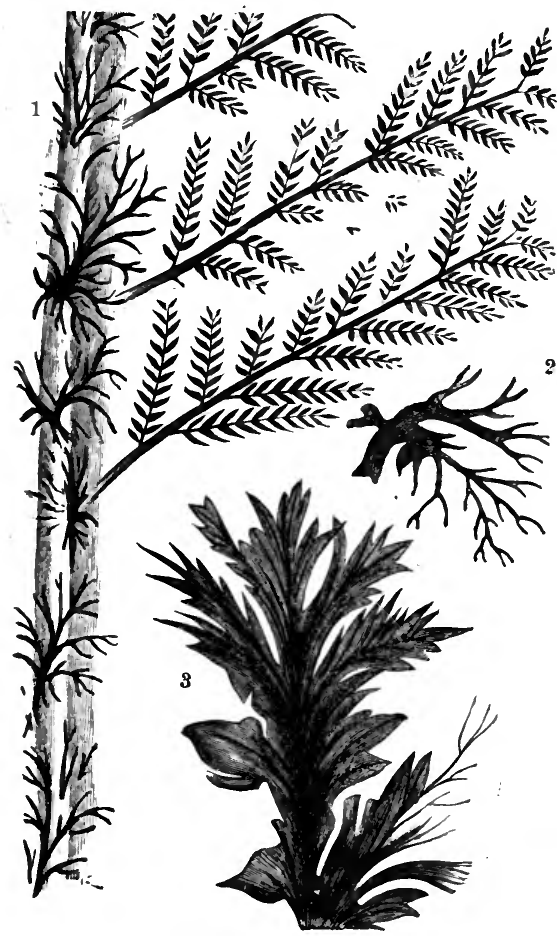

Fig. 92.-Aphlebia, from the Carboniferous formation. I, Sphenopteris crenata L. and $\mathrm{H} . ; 2,3$, Rhaco. shyllum adnascens L. and H. (After Schimper.) not of very common occurrence, even in the coal measures. And although the fructification has frequently been met with, the vast majority of the leaves of which the remains or the impressions have been preserved are barren. The only available system of classification of the greater number of fossil ferns is based on the mode of venation, on which character a number of families have been founded by Brongniart; but it is doubtful whether this has any great value as a natural system of classification. A form of heterophylly different from anything which occurs among existing ferns is found in a few species from the Carboniferous formation, where, in addition to the normal pinnæ of the frond, themselves again pinnate, imperfect pinnæ of much smaller size and simpler structure are intercalated between them.

These imperfect pinnæ, known as aphlebia, were described as distinct species before their true character was known. Thus Rhacophyllum adnascens (L. and H.) is the aphlebia of Sphenopteris crenata (L. and H.) ; while various so-called species of Cyclopteris are abnormal pinnæ springing from the rachis below the normal pinnæ of Neuropteris. On the whole, the leaves of ferns belonging to the Carboniferous period bear a striking resemblance to those of our own day; in many cases they might belong to living genera.

The remains of the fructification of fossil ferns that have come down to us lead us to believe that the existing orders of Filices may have been represented in the earlier geological periods; and none have as yet been 
discovered that cannot be referred to some existing type. The prevalent forms appear to have been the Polypodiaceæ, Hymenophyllaceæ, and Marattiaceæ; this last order having been apparently much more widely distributed and more abundant in the earlier periods than it is now.

The Hymenophyllace may possibly have been one of the earliest differentiated types. In Palæopteris hibernica (Schmp.) (Cyclopteris

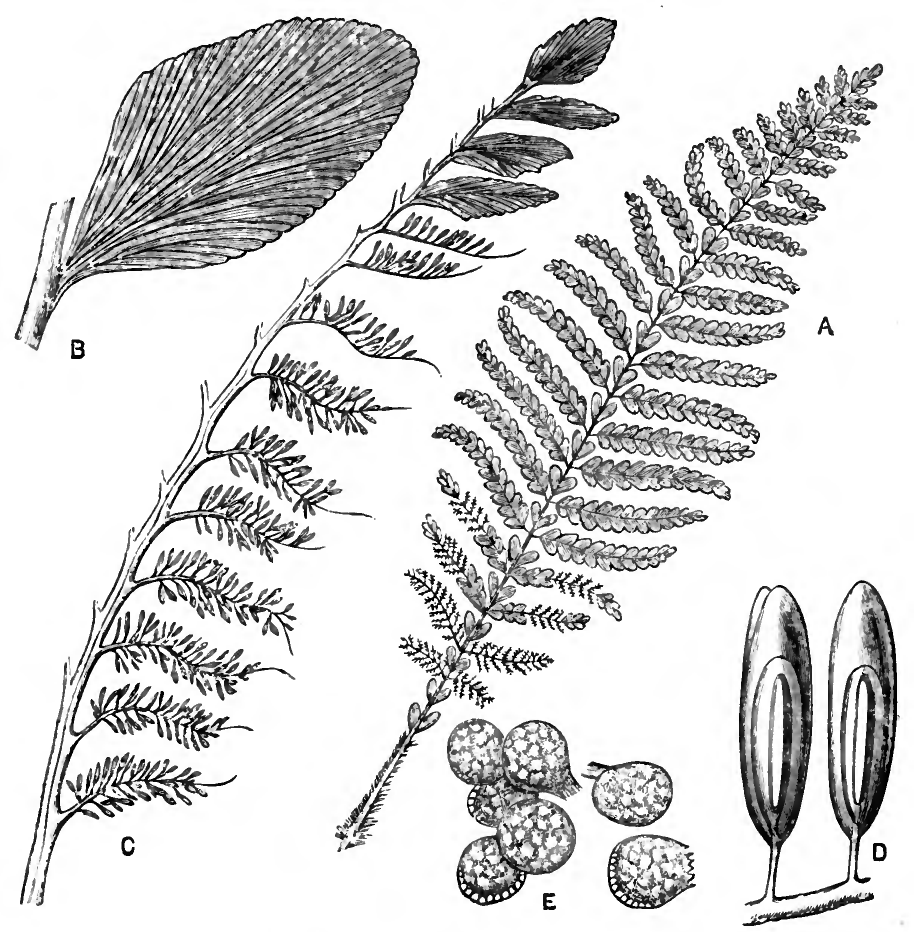

IG. 93.-A, frond of Palcopteris hibernica Schmp. (restored) $(\div 6) ; \mathrm{B}$, pinnule (somewhat mag.): $\therefore$, fertile pinna (nat. size) ; D, two cup-shaped indusia attached to the filiform midrib (mag.); E, sporanges of a hymenophyllaceous fern from the coal measures (mag.). (After Carruthers.)

hibernica, Forbes), specimens have been found in which all the lower pinnæ are fertile. The pinnule was reduced to a midrib supporting the slender stalks of the bilabiate cup-shaped indusia ; and the stalk is continued into the indusium, to which the sessile sporanges are attached. The texture of the frond was not membranaceous, like that of most existing Hymenophyllaceæ, but was more like that of Loxsoma. On the rachis between the pinnæ are seated single large decurrent pinnules. 
The edges of the pinnules are slightly serrate from the numerous dichotomising veins; the lower part of the stipe is clothed with scales. Sporanges with the characteristic oblique annulus of the Hymenophyllaceæ have also been found in the coal measures by Carruthers ('Geol. Mag.,'

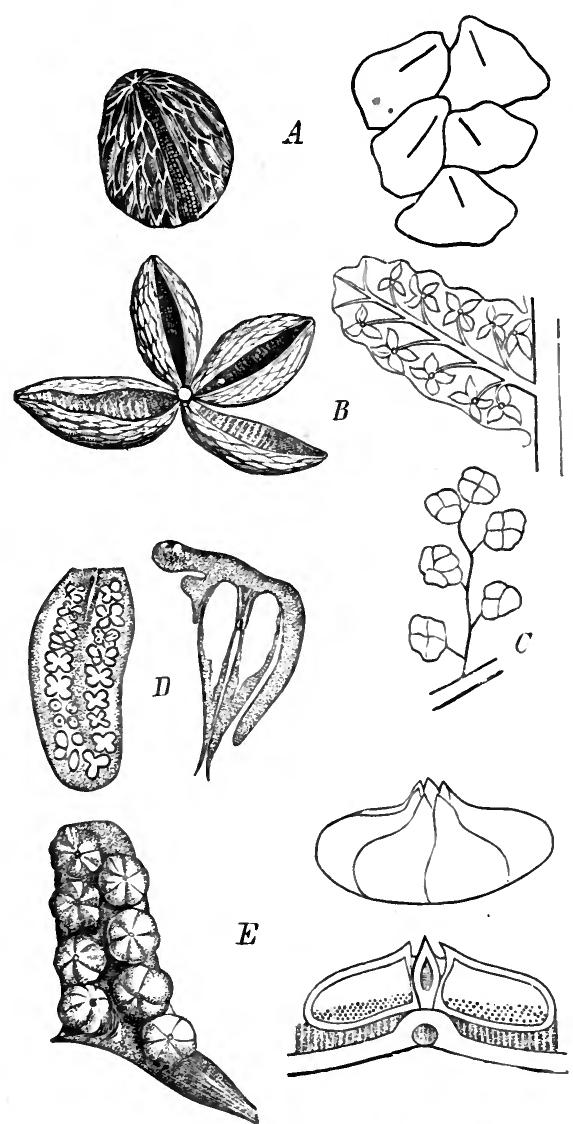

Fig. 94.-Fructifications of fossil Marattiaceæ. $A$, Seftenbergia ophidermatica; $B$, Haulea Miltoni; $C$, Oligocarpia Lindsaoides; $D$, Scolecopteris poly. morpha; E, Asterotheca Sternbergii. (After SolmsLaubach.)
Feb. 1872).

Remains which can be referred with certainty to the Marattiace are not unfrequent. In Scolecopteris (Stur) we have a true synange; the separate sporanges, arranged on a common elevated receptacle, are linear-ovate with a long free apex, and open by a fissure on the inner side without any trace of an annulus. In Asterotheca (Presl) the circular sorus usually consists of six exannulate sporanges closely adnate to one another, the sori are sessile, and are arranged in a single row on each side of the midrib of the pinna. In Renaultia (Stur) a group of cells occurs in the outer wall of the sporange similar to that in Angiopteris, which may be the rudiment of an annulus. Seftenbergia (Cord.) presents important differences. The sporanges are not collected into sori, but are scattered along the veins of the third order; each sporange has at its apex a cap-like annulus. It appears to be a connecting link between the Marattiaceæ

and Schizæaceæ. Other types of Marattiaceæ are presented by Danæites (Göpp.) and Botryopteris (Ren.).

The remaining types of ferns of the Devonian and Carboniferous, and especially those of more recent periods, present the greatest resem- 
blance to Polypodiace fructification resembling that of Osmundaceæ has at present been discovered; but Osmundites (Carruth.), from the Lower Eocene, has been referred to that order by its discoverer from the peculiarities of the structure of the stem. The Ophioglossaceæ are still unrepresented in palæophytology.

The internal structure of the stem and leaf-stalk of most fossil ferns,

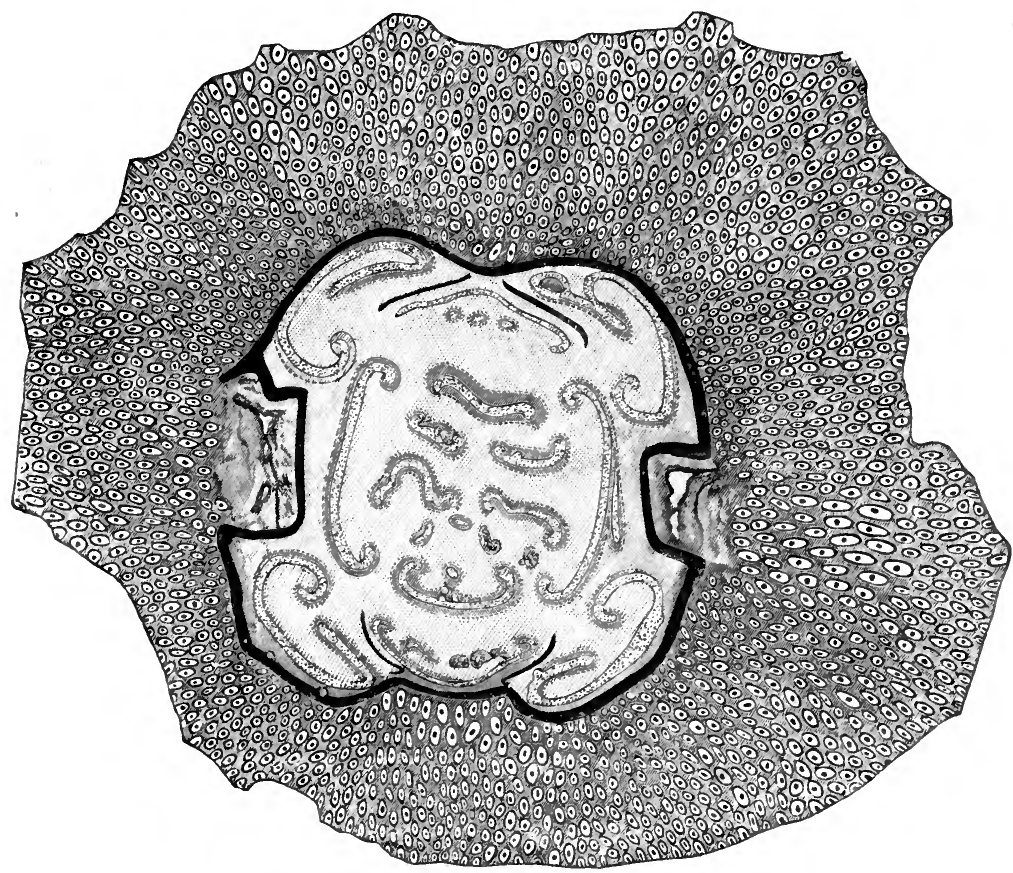

FiG. 95.-Section of Stemmatopteris Cord. invested with roots $=$ Psaronius Cord.

(From a specimen in the British Museum.)

where this can be determined, differs in no important respect from that of living forms. We find the same interrupted ring of 'vascular' bundles, which may be either concentric or collateral, the xylem consisting largely of scalariform tracheides, the same layers of sclerenchyme both in connection with the bundles and beneath the epiderm ; evident indications of gum-passages have even been detected. But though this is by far the most common type of structure, a second is displayed in a few rare examples, in which the arrangement of the 'vascular' elements. 
may be compared to that in the stem of Monocotyledons, as the ordinary arrangement may be to that in the first year in the stem of Dicotyledons. In Stemmatopteris (Cord.) (including Psaronius, Cord., and Zippea, Cord.), from the Bath coal-field, the circumference of the stem is composed of a continuous envelope of sclerenchymatous tissue, within which are perpendicular tracts of 'vascular' tissue not penetrated by meshes. Between these tracts the leaves were given off in perpendicular series, the large single leaf-bundles coming right out from the central parenchyme, in which they existed as well-formed bundles, filling up more or less completely the central cavity (see fig. 95). There is therefore no closed cylinder with central 'medulla' as in ordinary ferns. By some authors it has been proposed to establish the fern-stems which display this character as a separate group under the name Psaronieæ, but there is every reason to identify the stem of Stemmatopteris insignis (Cord.) with the fronds of Pecopteris arborescens (Schl.), which bear fructification indistinguishable from that of Cyathea; and, this character being the more important, the genus must be placed under Cyatheaceæ.

\section{Fossil Equisetacee.}

Remains of the genus Equisetites, evidently very nearly allied to Equisetum, if not identical with it, are found in greater or less abundance in various strata from the Carboniferous to the Tertiary, attaining their maximum development in the Trias. The stems of these fossil horsetails are from one and a half to six inches in diameter, and may have attained a height of from twenty-five to thirty-five feet. They are cylindrical, and are marked with alternate ridges and furrows. At the nodes are tubular leaf-sheaths split at the margin into numerous short teeth, each of which terminates in an elongated bristle; in some species the number of these teeth appears to have amounted to as many as one hundred. The nodal diaphragms are clearly seen in E. arenaceus (Brongn.), the remains of which occur in extraordinary abundance in the Upper Trias ; and, in some species at least, the furrows and ridges of each internode are alternate respectively with those of the internodes next above and next below. Remains of rhizomes have been found closely resembling in structure those of Equisetum. Nearly allied to Equisetites are the genera Schizoneura (Schmp.) and Phyllotheca (Brongn.); the latter differing from the type in its spreading sheath-teeth, and in the ridges and furrows of adjacent internodes not being alternate. The fructification of Equisetites has only been found in a very imperfect condition. That of Phyllotheca bears a close resemblance to the cone- 
like sporangiferous spikes of Equisetum. It contained spores of one kind only.

The group of Calamarieæ-including the stems known as Calamites and Calamodendron, and the fruit known as Calamostachyshave been separated by some authorities from the Equisetaceæ on the ground of their alleged heterospory, but without sufficient warrant from the facts of their structure as actually observed.

The remains of Calamites occur in immense quantities in the Carboniferous strata ; apparently they constituted one of the most important features of the vegetation of that period, disappearing after the Permian. The stems were frequently of gigantic dimensions compared with our existing Equisetums, attaining a height of thirty feet and a diameter of four inches or more. They consist of a hollow central cavity, with a cylinder of tracheides in wedge-shaped bundles, separated at their origin by parenchyme, and alternating at the nodes, where there is a diaphragm or 'phragna.' The leaves, which spring in whorls from each node, do not, as in Equisetites, coalesce laterally into sheaths surrounding the stem. They are narrow and acicular, with a single prominent midrib. At the nodes are occasionally seen saucer-shaped depressions, the scars of the lateral branches, which are sometimes found attached to the primary axis.
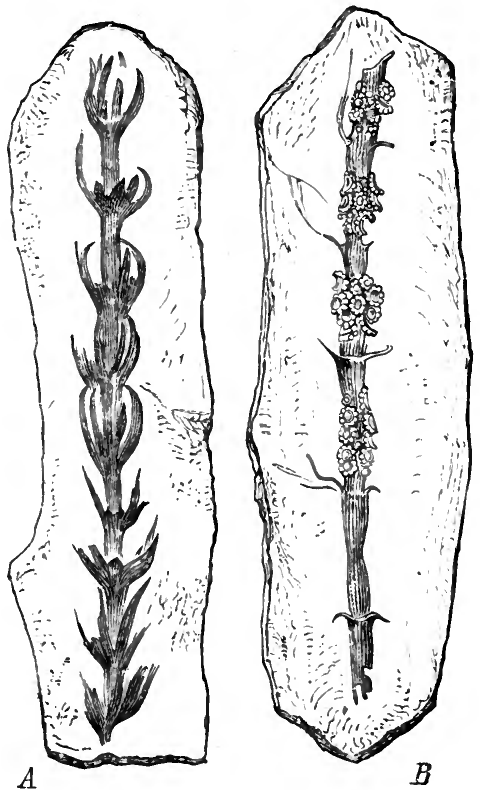

FIG. 96.-A, Phyllotheca equisetiformis; $B$, fructification of Phyllotheca. (After SolmsLaubach.)

The growth of the stem is characterised by a considerable secondary increase in thickness; and, since this phenomenon was formerly unknown among living Vascular Cryptogams, it has induced some authorities to transfer those examples where it occurs, under the name of Calamodendreæ, to Gymnosperms; but this has been rendered unnecessary from the fact that a secondary growth in thickness occurs also in Lepidodendron and Sigillaria, as well as in Isoëtes; and is further contradicted by the fact that fructification of an evidently cryptogamic character has been found in organic connection with stems 
which must be referred to the same group. To the same family as Calamites belong probably Astromyelon (Will.), and at least some species of Arthropitys (Göpp.). The degree of identity in structure of Calamodendron with Calamites is a point on which the best authorities are not yet in agreement.

To the genus Calamitina (Weiss)(Asterophyllites, Ren., Calamocladus, Schmp.) belong a number of calamite stems found with the leaves still in connection with them. These are of very peculiar form, consisting of an ovate-lanceolate basal portion, thickened and marked by a central furrow, and a narrowly-lanceolate acuminate apical portion; the basal
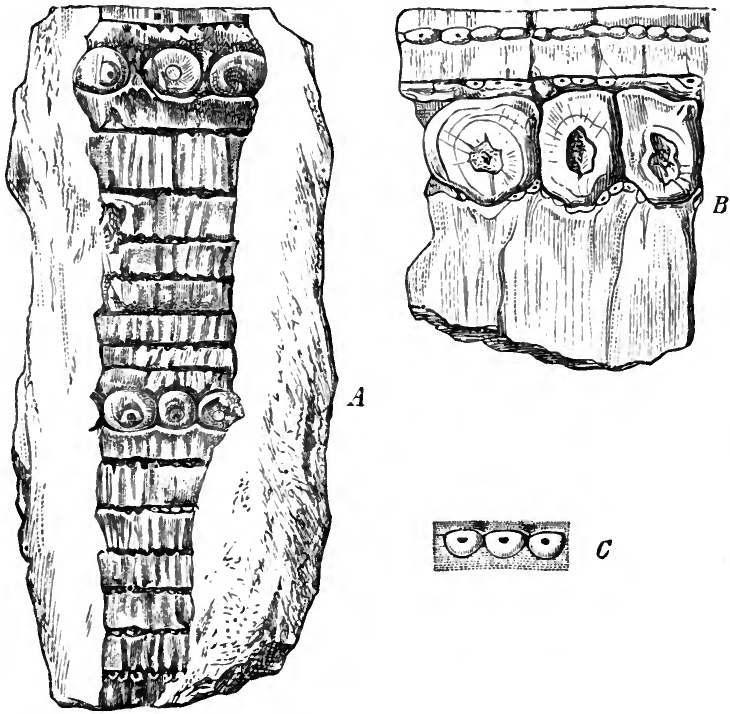

Fig. 97.-Stems of Calamites. (After Weiss.)

portion alone being very frequently preserved. The leaves do not coalesce laterally into sheaths; on falling off they leave behind whorls of round or ovate scars. Bornia (Brongn.) (Archæocalamites, Stur) is an older fossil occurring in the Devonian formation, differing from the more recent forms in the broad flat longitudinal ribs on the stem not alternating in adjacent internodes.

In Annularia (Brongn.), which occurs only in the Carboniferous formation, the leaves are linear-lanceolate, and are penetrated by a single 'vascular' bundle; those of each whorl are united laterally in their basal portion into a shallow saucer-shaped cup, through which the stem 
passes, and from the margin of which spring the linear-lanceolate free portions of the leaves. Annularia has been regarded by some writers as an herbaceous aquatic plant; but there is little doubt that it is the branches and foliage of Calamites.

The fructification of the Calamarieæ, described under the name Calamostachys-with which must be identified Volkmannia (Stbg.) and

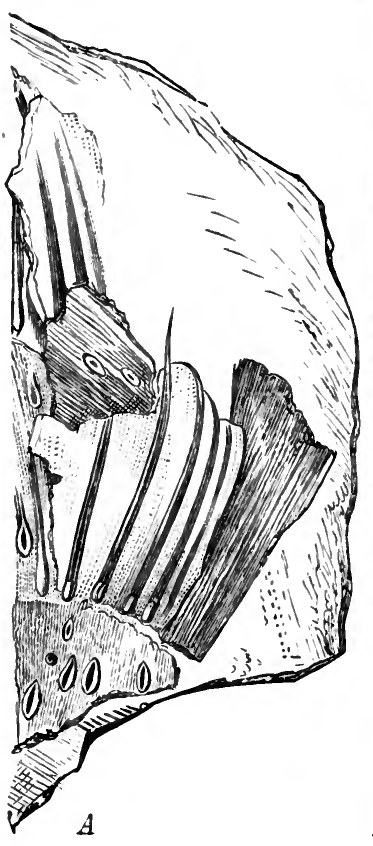

FIG. 98.-Leaves of Calamitina. (After Weiss.)

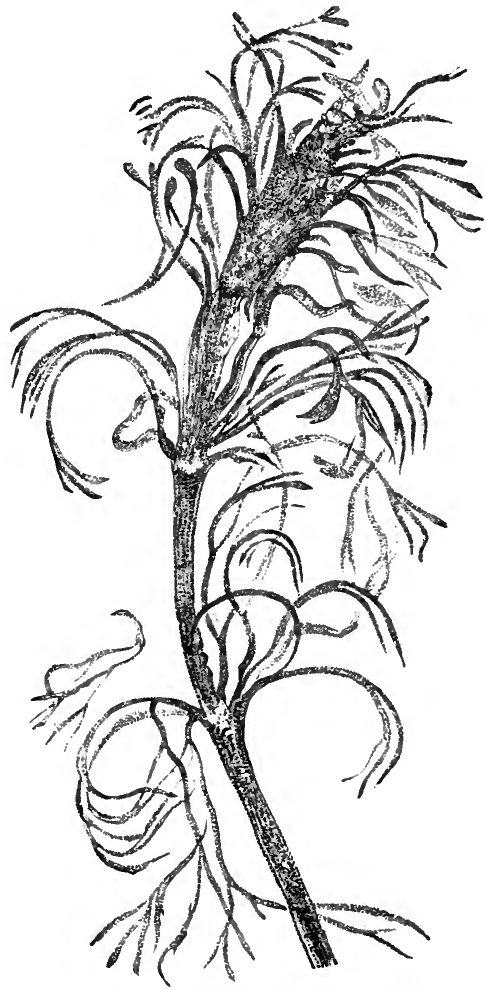

FIG. 99.-Archaocalamites radiatus Stur. (After Stur.)

Bruckmannia (Stbg.) - has not unfrequently been found in organic connection with the stem. Each cylindrical cone-like fructification consists of a number of whorls of sporophylls, but differs from that of Equisetum or of Equisetites in the fertile whorls alternating, in each spike, with barren whorls consisting of a large number of lanceolate acute leaves, free or more or less connate at the base ; the free portions completely cover the next upper fertile whorl and the base of the barren whorl 
above that ; thus giving a remarkable superficial resemblance to a fircone. The sporophylls of each whorl are not united with one another ; they resemble those of Equisetum in their peltate form, and each bears on its under side four sporanges. It is very rarely that the spores are preserved in sufficient perfection for their structure to be made out with certainty. The statement that they are of two kinds, megaspores and microspores, rests on insufficient evidence. Carruthers believes that he has detected in a few cases an outer separable membrane which would

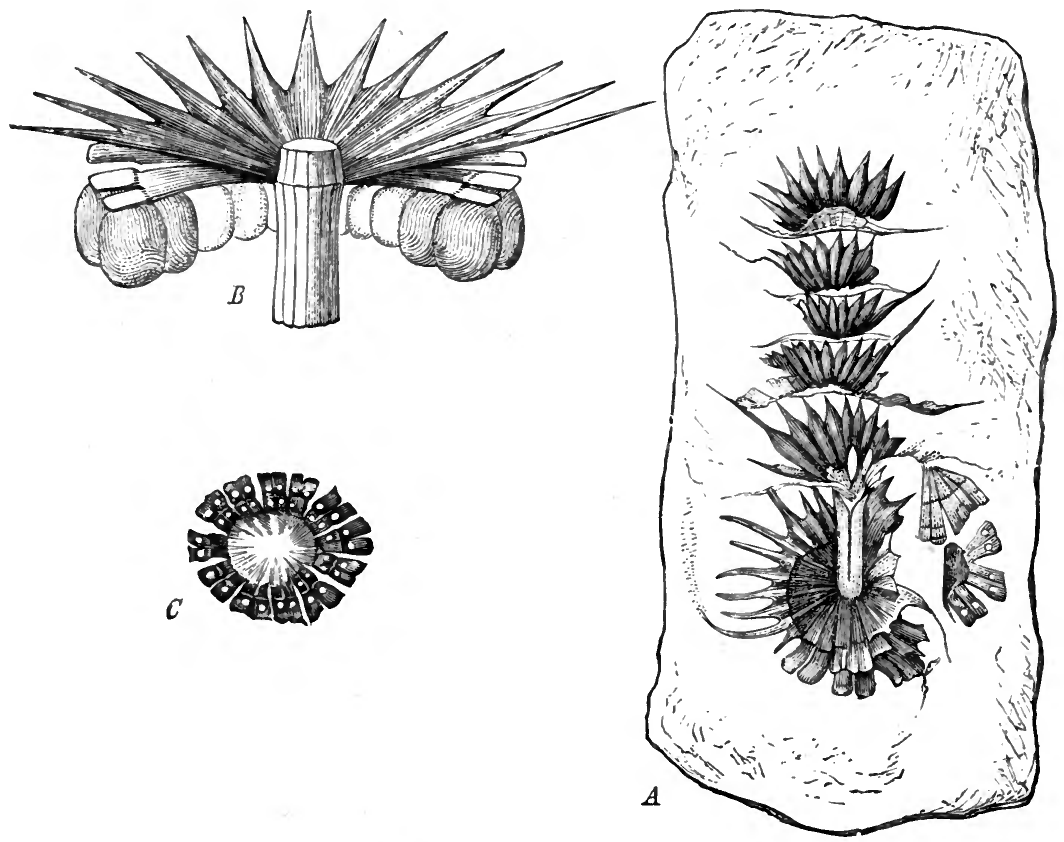

FIG. 100. $-A$, Fructification of Cingularia typica; $B$. portion of a barren and of a fertile whorl $C$, upper surface of tertile whorl. (After Weiss.)

unroll itself in the form of elaters. In Palæostachys (Weiss) the sporophylls stand in the axils of the barren leaves. The fructification of Cingularia (Weiss) has a very remarkable appearance, from the alternate barren and fertile whorls standing out nearly at right angles to the axis ; the leaves of the barren whorls are connate for about half their length; the sporophylls are also united in each whorl into a horizontal plate, divided at the margin into truncate lobes; from the under side of this plate the sporanges hang vertically in radial rows. The remains of Cingularia fructifications are found in large numbers in the coal 
measures. Very little is known of their stem, which appears, however, to have resembled that of the Calamarieæ.

More doubt rests on the affinity with the Equisetaceæ of the group of Sphenophylleæ. The remains of Sphenophyllum (Brongn.) are found in abundance in the Carboniferous formation, but do not come down to more recent times than the Lower Permian. The sten is divided into distinct nodes and internodes, the latter usually marked with conspicuous ridges and furrows, which are not alternate in adjacent internodes, but pass continuously through the nodes. At the swollen nodes are whorls of leaves, with occasional axillary branches. Each whorl appears to consist always of six leaves or of some multiple of six. They are sessile, and obcuneate from a narrow base, sometimes denticulate and bifid at the apex, but are not in any degree connate. Each leaf contains a number of simple or dichotomous 'vascular' bundles. In the centre of the stem is a triangular bundle composed of scalariform tracheides, to which some authorities add spiral tracheides and others with

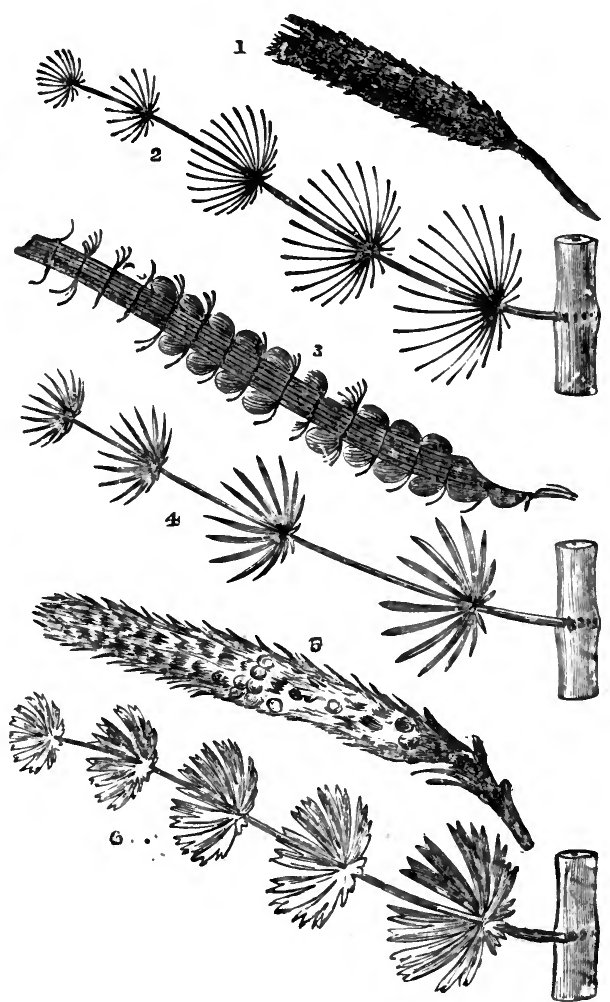

FIG. Ior.-I, 2, Fructification and branch of Asterophyllites; 3, 4, fructification and branch of Annularia; 5, 6, fructification and branch of Sphenophyllum. (After Carruthers.)

bordered pits; the bundle passes through the node without material change. This is often surrounded by some layers of secondary wood; the greater part of the stem, on transverse section, is occupied by a small-celled parenchyme.

The fructification of Sphenophyllum consists of cylindrical conelike spikes resembling those of Calamites. It is composed of whorls 
of sporophylls without any intermediate barren whorls; the separate leaves are often saccate, the narrow apices ascending and covering in an imbricate fashion the bases of the next upper whorl. The position of the sporanges differs materially from that of the other Equisetaceæ. They are comparatively large bodies, lenticular, from $\mathrm{I}$ to $2.5 \mathrm{~mm}$. in diameter, solitary and sessile in the saccate hollow on the upper surface of the base of the sporophyll. The solid remains have not yet been found in a sufficiently perfect condition for the structure of the spores to be determined with any degree of certainty, but no sufficient evidence of heterospory has been presented.

From the form and position of the sporanges the Sphenophylleæ are placed by some writers under Selaginellaceæ; but in the general appearance and structure of the vegetative organs they approach so nearly to the Calamarieæ that it seems best at present to place them here until we are better acquainted with the details of the fructification. Stur has recently described and figured specimens with leaves of Asterophyllites at the base, Sphenophyllum-leaves higher up, and terminating in a fructification.

\section{Literature of Fossil Vascular Cryptogams.}

Sternberg-Flora der Vorwelt, I 821-1838.

Brongniart-Hist. des Végétaux Fossiles, 1820-1840; (Sigillaria, Stigmaria, and Lepidodendron) Arch. Mus. d'Hist. Nat., 1839.

Lindley and Hutton-Fossil Flora of Great Britain, 1833-1837.

Witham-Internal Structure of Fossil Vegetables, 1833 .

Göppert-Systema Filicum Fossilium, 1826; Gattungen der fossilen Pflanzen, I841. Unger-Genera et Species Plantarum Fossilium, 1840.

Corda-Beitr. zur Flora der Vorwelt, 1845.

Hooker-Vegetation of Carboniferous Period, in Mem. Geol. Survey, 1847.

Brown-Triptosporites, in Linn. Soc. Trans., 1851 .

Geinitz-Steinkohlenformation in Sachsen, 1855.

Ludwig-Calamiten-Friichte Palæontographia, I861.

Goldenberg-Flora Saraepontana, 1862.

Binney-Fossil Carboniferous Plants, Palæont. Soc., 1868-1875.

Schimper-Paléontologie végétale, I869-1874.

Weiss-Fossile Flora der Steinkohlenformation, \&c., r869; Beitr. zur fossilen Flora, I $876-1884$.

Carruthers-(Ulodendron and Bothrodendron) Monthly Micr. Journ., I870 ; (Lycopodiaceæ) I869; (Calamites) Seemann's Journ. Bot., I867.

Dawson-Fossil Plants of Upper Silurian and Devonian of Canada, 1871-1882 ; Geological Hist. of Plants, 1888.

De Saporta-Paléontologie Française, 1873.

Grand'Eury - Flora Carbonifère du Dpt. de la Loire, \&c., 1877. 
Renault-Cours de Bot. fossile, vols. i.-iii., I881-1883.

Williamson-Organisation of Plants of the Coal Measures, Phil. Trans. I871-I888 ; (Stigmaria) Palæont. Soc., I887.

Kidston-(Lepidodendron, Sigillaria, \&c.) Ann. and Mag. Nat. Hist., I 885.

Lesquereux-Coal Flora of Carboniferous Formation of Pennsylvania, \&c., I 884.

Stur-Carbonflora der Schatzlarenschichter, I885; Culmflora, I877-1883.

Van Tieghem-Bull. Soc. Bot. France, 1883, p. 169.

Zeiller-Ann. Sc. Nat. (Bot.), I884 ; (Sigillaria) do., I884, p. 256.

Zittel-Handbuch der Palrontologie, 1879-1885.

Solms-Laubach-Einleitung in die Palæophytologie, 1887 (for which see very copious bibliography).

Schenk-Die fossilen Pflanzenreste, in Schenk's Handb. der Botanik, vol. iv., I 888. 


\section{SECOND SUBDIVISION.}

\section{MUSCINEAE.}

The line of demarcation between the Vascular Cryptogams and the plants immediately below them in the scale of organisation, the Muscineæ, is a very sharp one, and their genetic relationship to one another presents considerable difficulties. The lower type of structure is, however, chiefly manifested in the vegetative organs. The mode of sexual reproduction which occurs throughout this group corresponds in its most important features with that in Vascular Cryptogams; and we have here also a division of the life-history of the plants into a sporophyte and an oophyte generation, a true alternation of generations, although the phenomenon differs in one important point from that which we have seen in Vascular Cryptogams, viz. in almost the whole of the vegetative system belonging to the oophyte instead of to the sporophyte generation. To this we have already seen an approach in Gymnogramme (p. 65). The vegetative system is invariably of small size, and almost entirely destitute of vascular bundles and of all other strengthening tissues. Within the group the boundary line is crossed between Cormophytes and Thallophytes; and in the lower orders we entirely lose the differentiation of the vegetative organs into cauline and appendicular organs-in other words, into stem and leaves; the entire vegetative system consisting of an undifferentiated thallus. The mature plant is almost invariably terrestrial in habit, and is attached to the substratum by rhizoids. The appendicular organs, when present, are minute leaves, which never contain true vascular bundles, and usually consist of only a single layer of cells. We find, however, the first stage towards the epidermal and fibrovascular structures characteristic of the leaves of vascular plants, in a distinct midrib and edging of elongated cells with somewhat thicker cell-walls overlapping one another at the extremities, and partially or altogether destitute of chlorophyll. In one group (Sphagnaceæ) the leaves are composed of cells of two different kinds, small cells containing chlorophyll interspersed among much larger empty cells. The leaves, being usually unilamellar, cannot, of course, be pro- 
vided with stomates, though these are frequently present on the organs of propagation; while one group of thalloid forms (Marchantiaceæ) possess stomates of remarkable and complicated structure. The vegetative propagation of the Muscineæ takes place in several ways : Ist, by innovation, i.e. by a process of renewal at the apex, while the oldest parts die off behind ; 2nd, by means of gemmæ, stolons, or detached buds ; and 3 rd, by the non-sexual production of a thallus or protoneme, a process which will be described presently. The facility of these various modes of vegetative multiplication gives rise to the tufted or cæspitose habit of many species.

Notwithstanding the variety in the development of the vegetative structure, the sexual organs of Muscineæ are remarkably uniform in their main features. The male and female organs are termed respectively, as in Vascular Cryptogams, antherids and archegones. The mature antherid is a spherical, ellipsoidal, or club-shaped body, with a longer or shorter stalk, the outer layer of its cells forming an enclosing wall, while each of the small and numerous crowded cells in the interior develops an antherozoid. These bodies are spirally-coiled threads of protoplasm, thicker at the posterior end, and tapering to a fine point at the anterior end, where they are furnished with two long fine cilia, the vibrations of which set them in constant motion; they are set free by the rupture of the wall of the antherid at its apex. The archegones, when in a condition capable of impregnation, are flask-shaped bodies bulging from a narrow base, and produced above into a long neck. The swollen or ventral portion, the venter, encloses one cell much larger than the rest, the central cell, from the larger and lower portion of which is developed, after its separation by a horizontal septum, the germ-cell or oosphere. Above this central cell is an axial row of cells termed the canal-cells, passing through the narrow portion or neck of the archegone, and continued as far as the apical cells, stigmatic cells, or lid-cells, which form what is called the stigma. These canal-cells are transformed before impregnation into mucilage, which finally swells up and forces apart the four stigmatic cells, an open canal being thus formed, through which the antherozoids reach the oosphere. Notwithstanding the general uniformity in structure of the sexual organs of the Muscineæ, their origin varies greatly. They may originate, in the thalloid forms, below the growing apex, from the superficial cells of the thallus, or on special metamorphosed branches; in the foliose forms both antherids and archegones may be formed from the apical cell of the shoot, or from segments of it; and in this case they may take the place of leaves, of lateral shoots, or even of hairs. According to Leitgeb, the order of evolution from the lower to the higher forms of 
Muscineæ is indicated by the position of the sexual organs on the vegetative shoots; as these organs approach nearer and nearer to the apex, the shoot gradually loses its vegetative character, and becomes differentiated into a special fertile branch.

The sexual organs are frequently surrounded by crowded and slightly modified foliar structures, the whole arrangement having then some resemblance to the flower of Phanerogams. Thus, in the thalloid forms, the antherids and archegones are commonly borne on umbrellashaped outgrowths of the thallus which are not inaptiy termed respectively male and female inflorescences. In the foliose forms they are frequently arranged at the extremities or laterally on branches, and closely surrounded by small leaves constituting the perichate or perianth, reminding one of the bracts, or even of the calyx, of Flowering Plants, the whole structure forming an hermaphrodite, monœcious, or dicecious 'flower.' They are often accompanied by barren, hair-like cells, termed paraphyses.

The first result of the impregnation of the oosphere by an antherozoid is the formation of an ovoid embryo by repeated cell-divisions; this continues to grow at its apex, and finally develops into the fructification here known distinctively as the sporogone, the ultimate form of which varies greatly in the different families. In its most perfect form the sporogone is differentiated externally into a slender stalk or seta, which penetrates into the base of the archegone, or even into the underlying tissue, and a spore-capsule, called indifferently the sporange, theca, or urn. Along with the spores the spore-capsule sometimes contains (in the Hepaticæ) elongated cells thickened by a single or double spiral band known as elaters, which assist in the dissemination of the spores. The mature sporange is, in the highest forms, surmounted by a cap or calypter, which becomes completely detached at its base, while the mature lower portion of the archegone encloses the base of the seta in the form of a sheath or vagine; in the lower forms the spore-capsule always remains enclosed in the calypter. The spores of the Muscineæ are always formed in fours within the spore-mothercells, which latter are produced within the cavity of the sporange by free cell-formation, from a special layer or layers of cells known as the archespore. When ripe they have a double cell-wall, the outermost layer or exospore being provided with small excrescences, and the inner layer or endospore bursting through it on germination. The contents consist of protoplasm, chlorophyll-grains, starch, and oil.

The thalloid or leafy plant (as the case may be) does not, as a rule, arise immediately from the germinating spore, but, in all the higher forms, only after the previous formation of a colourless confervoid or 
filamentous structure, the prothallus or protoneme, on which the leafy plant containing chlorophyll arises as a lateral shoot. The Muscineæ present, therefore, an illustration of the phenomenon of alternation of generations; the sexual generation which intervenes between germination and impregnation, or oophyte, consisting of the protoneme (when present), the leafy (or thalloid) plant, together with the sexual organs; the non-sexual generation intervening between impregnation and germination, or sporophyte, consisting of the sporogone only with its spores.

The Muscineæ are divided into two well-marked families, the Musci or Mosses, and Hepatica or Liverworts. In the Musci the immediate result of the germination of the spore is always a protoneme consisting of branched rows of green or colourless cells, and often growing for a considerable time independently, even after it has produced leafy stems by lateral budding. The vegetative structure is always cormophytic, and consists of a filiform stem furnished with two, three, or four rows of leaves, not exhibiting any distinct bilateral structure, and branching monopodially, never dichotomously. The sporogone is only for a time enclosed in the calypter, which is usually eventually ruptured below, the lower portion developing into the vagine, while the upper part is elevated above the apex of the sporogone in the form of a cap. The sporemother-cells are produced from one or more special layers of tissue within the sporange, the archespore, while the axial mass develops into a solid columel. The uppermost portion of the wall of the sporange forms a lid or opercule, which usually becomes detached from the lower portion, to which the term theca or sporange specially belongs, to allow the escape of the spores. The outermost layer of cells of the wall of the sporange is more or less completely differentiated into an epiderm, which is frequently penetrated by stomates. When the opercule is removed, the rim of the sporange is either quite smooth, when it is termed gymnostomous, or the edge is furnished with delicate hair-like appendages, constituting the peristome, arranged in a single row or frequently in two, when they are called respectively teeth and cilia, the former constituting the outer, the latter the inner row. The number of both teeth and cilia is always a multiple of four, or more correctly speaking, a 'power' of two. In the Hepaticæ the protoneme is either scantily developed or is altogether suppressed. The rest of the sexual generation consists either of a flat dichotomously branched thallus or thalloid stem, or of a slender stalk furnished with two or three rows of leaves. In the division into Foliose and Thalloid or Frondose forms, the Hepaticæ therefore present the transition from Cormophytes to Thallophytes. The mode of growth is always distinctly bilateral; the thalloid forms cling 
closely to the ground or to some other substratum; and even in the foliose forms there is a well-marked tendency to the differentiation of an. upper or dorsal and an under or ventral surface. The non-sexual generation or sporogone remains surrounded by the calypter until the spores are ripe ; the calypter is usually at length ruptured at the apex, and remains at the base of the sporogone as an open sheath, while the sporange projects above its apex to allow the escape of the spores. The mother-cells of the spores are either developed from the whole of the archespore, or, in most families, some of the cells develop into elaters ; there is no columel.

\section{LITERATURE.}

Hofmeister-On the Germination, Development, and Fructification of the Higher Cryptogamia, Ray. Soc., 1862.

Leclerc du Sablon., Ann. Sc. Nat., 1885, p. 126; and Bull. Soc. Bot. France, I885, pp. 30 and 187.

Goebel-Die Muscineen, in Schenk's Handbuch der Botanik, vol. ii., I882.

\section{Class VII.-Musci.}

The germinating spore of Mosses gives rise to a prothallium which is always in the typical families of a filamentous conferva-like character, and is hence known as the protoneme. On this is produced the leafy plant with differentiated stem and leaves by lateral budding. These together, therefore, constitute the sexual generation or oophyte, which terminates in the production of the sexual organs. From the fertilised oosphere proceeds the sporogone, which comprises in itself the non-sexual generation or sporophyte.

The protoneme first originates, in typical mosses (Bryaceæ), as a tubular bulging of the endospore or inner coat of the spore, divisions taking place in it in the transverse direction only. It has an unlimited power of apical growth, and often branches copiously, forming a dense felt of considerable size above or below the surface of the soil, in the former case densely filled with chlorophyll. The protoneme usually disappears altogether after the appearance on it of the leafy plant ; but in some cases, especially in the Phascaceæ, it remains vigorous even after the formation of the sporogone. In the Sphagnaceæ the protoneme consists of a flat plate of cells; while in the Andreæaceæ celldivision begins to take place within the spore, the resulting prothallium consisting of a small cellular tissue. The buds which develop into the 
leafy stems appear never or very seldom to arise at the apex of a primary filament of the protoneme, but always as lateral branches.

Mosses display a certain amount of differentiation of tissues. The apical cell of the stem is, except in Fissidens (Hedw.), a three-sided

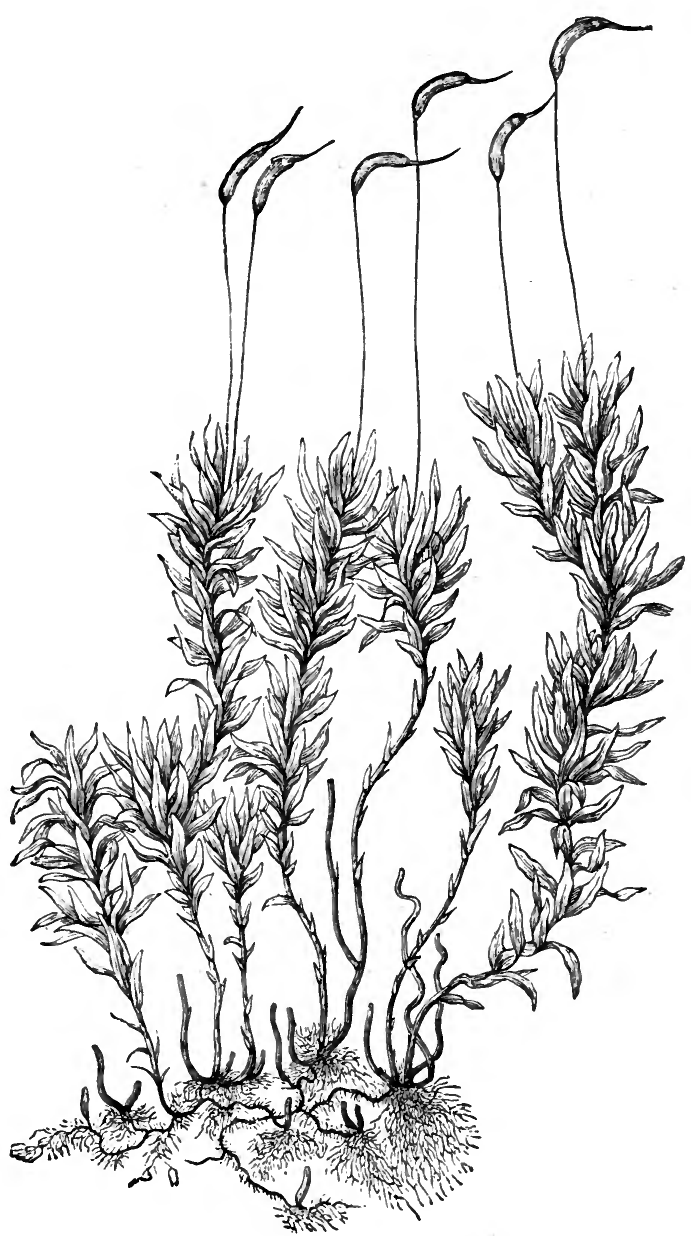

FIG. I02.-Catharinea (Atrichum) undulata W. and M. (magnified). (After Schimper.)

pyramid. The primary meristem of the stem, situated beneath the growing point, which develops into the permanent tissue, usually becomes differentiated into an inner and a peripheral mass; the latter, although 
not strongly defined, partaking of an epidermal character ; the bright red or yellow cell-walls are considerably thicker than those of the central thinwalled large-celled fundamental tissue. In some genera a further differentiation takes place of the axial portion of the central cylinder into a rudimentary 'vascular' bundle with thicker cell-walls ; similar rudimentary bundles being also formed in the pedicel of the sporogone. Both the partially lignified and the thin-walled cells have simple pits in their cell-walls ; these are found in all families of mosses, and are especially abundant in the midrib of the leaves. Some species of Sphagnum (L.) have rudimentary sieve-plates. The central bundle in the stem of Mnium, Polytrichum (L.), and other genera, has been shown by Haberlandt not to possess any of the strengthening functions of a true vascular bundle, but

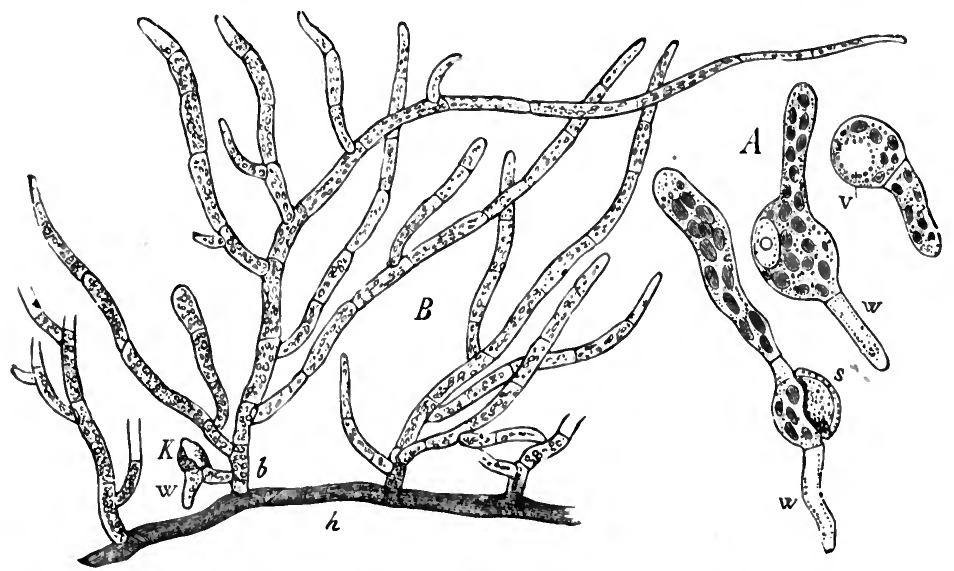

FIG. I03. - A, germinating spore of Funaria hygrometrica L. $(\times 550)$; s, exospore ; $w$, rhizoid ; $z^{\prime}$, vacuole. $B$, portion of protoneme $(\times 90) ; K$, rudiment of leafy axis; $w$, rhizoid. (After Goebel.)

to be constructed for the purpose of the conduction of water. Its cells contain nothing but a watery fluid, without starch-grains, oil, or protoplasm. In genera which have no such central bundle, like Dicranum (Hedw.) and Leucobryum (Hpe.), the epidermal tissue of the stem and branches, with its perforated cells, forms a similar capillary apparatus. In the more highly developed mosses, Haberlandt notes the following distinct tissues:-(I) an epidermal tissue, sometimes developing trichomic structures; (2) a mechanical system, consisting of elongated cells with thickened walls; (3) an absorbing system, most strongly displayed in the rhizoids-also at the base of the sporange ; (4) an assimilating system, often composed of palisade-cells, in the leaves or in the sporange ; (5) a conducting system, consisting of the rudimentary 'vascular' bundles; 
(6) a reserve-system, usually represented by the aquiferous tissue; (7) a secreting system, developed typically in the sporange. No special secretory or excretory organs have been detected in mosses.

The leaves of mosses originate as broad papillose bulgings of a cell of the stem which becomes cut off by a septum. They are always of small size, sessile, and vary in shape from extremely narrow to broadly lanceolate or almost orbicular. The tissue of the greater part of the leaf usually consists of only a single layer of cells, all of which contain chlorophyll, except in the Sphagnaceæ and in Leucobryum, where the cells are of two different kinds, one large and empty, the other very small and chlorophyllous, thus giving the leaf a very light yellow-green colour. In most mosses the marginal cells of the leaf, and a row extending through the middle of the leaf from the base to the apex, are much smaller, and are disposed in several layers, though still thin-walled, thus constituting the rudiments of an epiderm and midrib. The midrib may even extend beyond the apex of the leaf as an awn or bristle. The leaves are usually crowded, especially in the neighbourhood of the sexual reproductive organs. Their phyllotaxis is spiral, or more rarely distichous. The branching of the stem of mosses is apparently neither dichotomous nor axillary; the number of lateral shoots is always much smaller than that of the leaves. When the primary shoot produces a so-called 'flower' at its apex, a lateral shoot situated beneath it not unfrequently displays a more vigorous growth of a monopodial character, and is then termed an innovation. Prolification, or the prolongation of a shoot by the continued growth of the bud within and above the male 'flower,' is a common phenomenon in Polytrichum. Nearly leafless shoots or stolons are sometimes formed beneath or on the surface of

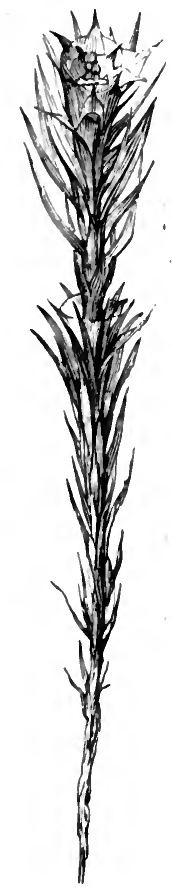

FIG. 104.-Polytrichum commune L. ; proliferous male plant (slightly magnified). the ground, arising finally as erect leafy stems.

In most mosses large numbers of rhizoids are formed on the under side of the stem, often clothing it completely with a reddish brown felt (see fig. 102). They differ from the protoneme in their tendency to grow downwards, and in not usually containing chlorophyll; but there is no sharp distinction between the two, each possessing the power of producing branches indistinguishable from those of the other. 
The non-sexual propagation of mosses takes place in a variety of ways, the first step being, in nearly all cases, the production of a colourless filament of the nature of a protoneme. This protonemal branch, like the true protoneme which springs from a spore, may produce by lateral budding a number of leafy shoots. Protonemal branches of this kind are in some genera (such as Mnium, L., Barbula, Hedw., and Phascum,

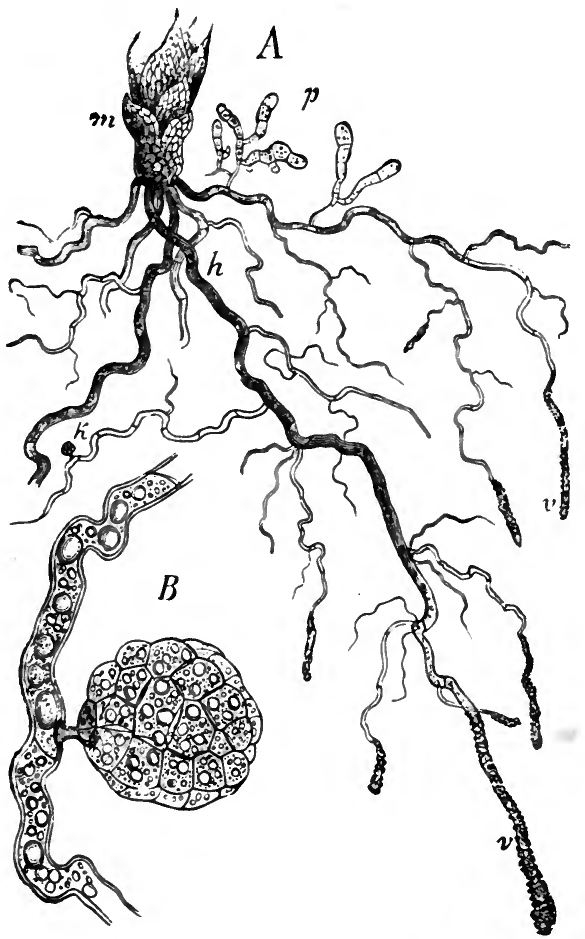

FIG. 105.-A, young plant of Barbula, $m ; h$, rhizoid, producing protonemes $\not$, and underground gemma $k$ $(\times 20)$. $B$, the same gemma $(\times 300)$. (After Goebel.)

L.) produced in large numbers simply by turning over a tuft of moss on the soil. In this state they frequently hibernate, the portion above the soil disappearing entirely. In some mosses the leaves produce a protoneme simply by the growth of particular cells into segmented filaments; and this may even take place with detached leaves if kept moist. The seta or stalk of the sporogone has a special tendency to produce protonemes when in contact with damp soil. Rhizoids also may give rise to gemmæ or leaf-buds, whether above or beneath the surface of the soil. Gemme of a more complicated structure occur in a few species, as Aulacomnion androgynum (Schw.) (Bower, 'Journ. Linn. Soc.,' I 884, xx., p. 465), and Tetraphis pellucida (Hedw.), being stalked fusiform or lenticular multicellular bodies. In the

latter species they are enveloped in an elegant cup or cupule, composed of a number of leaves, out of which they eventually fall, and then put forth protonemal filaments, which give rise first to a flat prothallus resembling that of a fern, and then to a leaf-bud. Gemmæ are produced in a variety of situations, as at the apex of a leaf and on the rhizoids.

The sexual organs of mosses are very commonly enveloped in closely crowded leaves which have undergone a certain amount of modification, 
and the entire structure is sometimes-from analogy with the corresponding structure in Flowering Plants-called the flower. Such a flower may either be hermaphrodite, including both antherids and archegones, or unisexual, and the species may then be monœcious or diøcious. The female and the hermaphrodite flowers are not dissimilar in appearance, while that of the male flowers is altogether different.

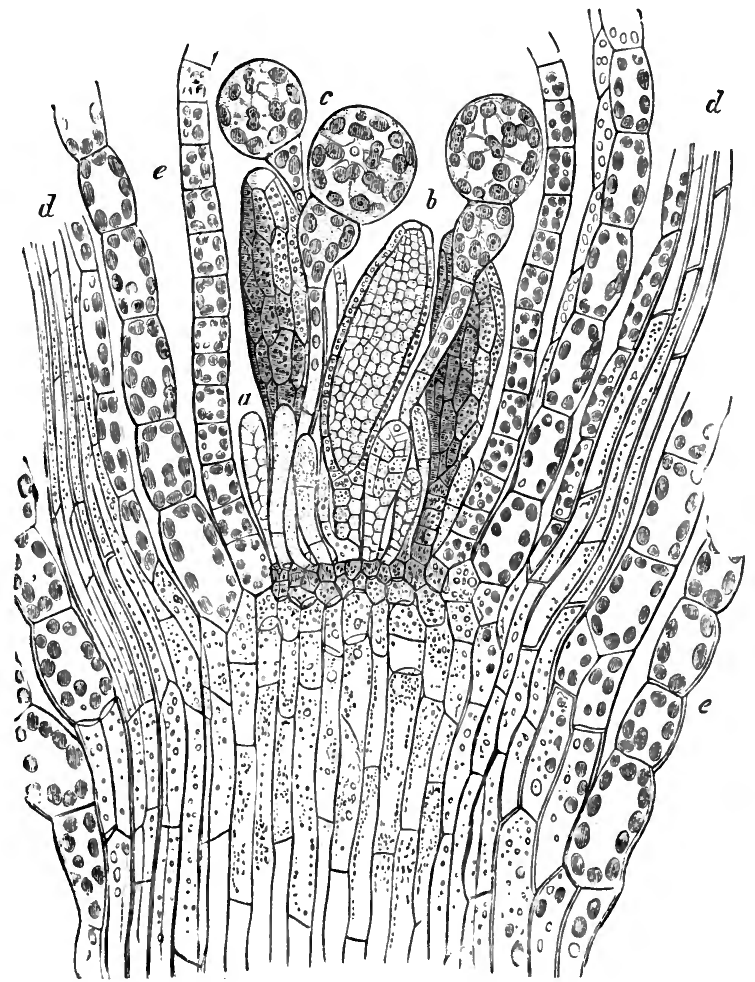

FIG. ro6.-Funaria hygrometrica; longitudinal section through male inflorescence; $a$, young antherid ; $b$, nearly mature antherid ; $c$, paraphyses ; $d, e$, perigonal leaves $(\times 300)$. (After Goebel.)

In the hermaphrodite flowers the archegones usually occupy the central position, corresponding to the pistil in Flowering Plants, the antherids being arranged in an encircling spiral; while the whole is enveloped in a rosette of small leaves termed the perichate or perianth. The entire structure resembles externally an elongated closed bud. Only a single archegone in each flower is usually fertilised or arrives at maturity. The female resemble the hermaphrodite flowers in every respect except 


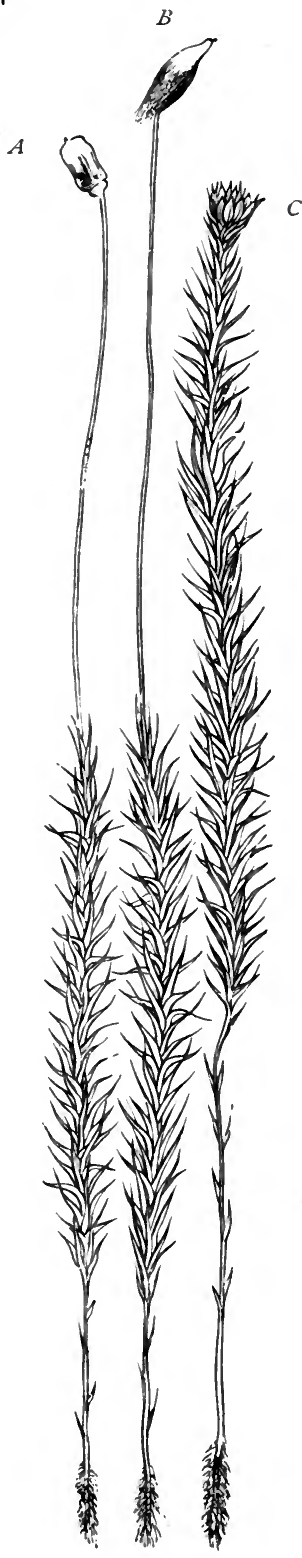

FIG. 107.-Polytrickum commune. $A, B$, mature plants with sporogone; $C$, male plant (nat. size).

that the antherids are suppressed. The male flowers present much greater variety in form and appearance; the male perianth or perigone is usually composed of broader, shorter, and thicker leaves, which sometimes sheath at the base, and are not unfrequently red. The flowers themselves are ovoid, globular, or discoid; the antherids usually stand in the axils of metamorphosed leaves. Both male and female flowers are provided with barren segmented filaments or paraphyses. In the male flowers the paraphyses are filiform, club-shaped, or spathulate, and terminate in several rows of cells; in the female flowers they are simple filiform bodies coinposed of a single row of cells. Their function appears to be to keep the archegones moist until they have been fertilised by the antherozoids.

The first antherid appears to be a terminal structure, being developed out of the apical cell of a branch. An hermaphrodite flower is probably derived from two independent shoots, the female shoot being formed immediately beneath the male organs. The mature antherid is a stalked club-shaped, or less often spherical sac, with a wall composed of only a single layer of cells. In the Sphagnaceæ it opens by longitudinal dehiscence ; in the other orders by an apical slit through which the antherozoids, still enclosed in their mother-cells, are discharged as a thick mucilaginous mass, being imbedded in a jelly which is expelled in jets when the antherid bursts, but which is soluble in water. The antherozoids then escape from their mother-cell walls, and swim about as filiform bodies, furnished at the anterior end with two slender vibratile cilia, and containing a number of starchy granules. The male inflorescence of Polytrichum exhibits a remarkable tendency to prolification (see fig. 
I04). The archegone has somewhat the form of a very long-necked flask. The wall of the venter or ventral portion, which is ovoid and supported on a short stalk, consists of two layers of cells, while the elongated neck, which is often somewhat twisted, is composed of from four to six rows in a single layer. The interior of the venter consists of a single large cell, the central cell, which divides into two by a horizontal septum; the lower segment contains the oosphere, and the upper segment becomes the ventral canal-cell, while the neck is penetrated by a single axial row of

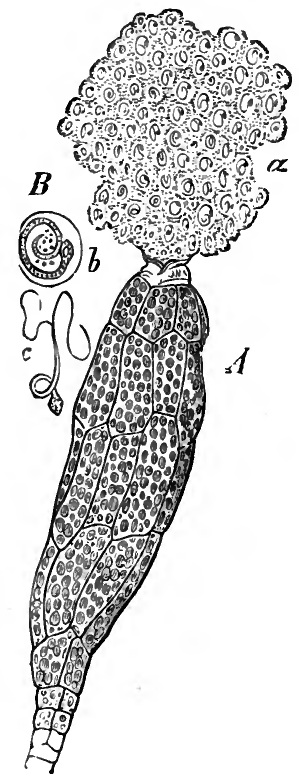

FIG. 108.- $A$, antherid of Funaria hygrometrica, discharging antherozoids, $a(\times 350)$. $B$, antherozoid of Polytrichum; $b$, still enclosed in mother-cell ; $c$, free $(\times 8 \infty)$.

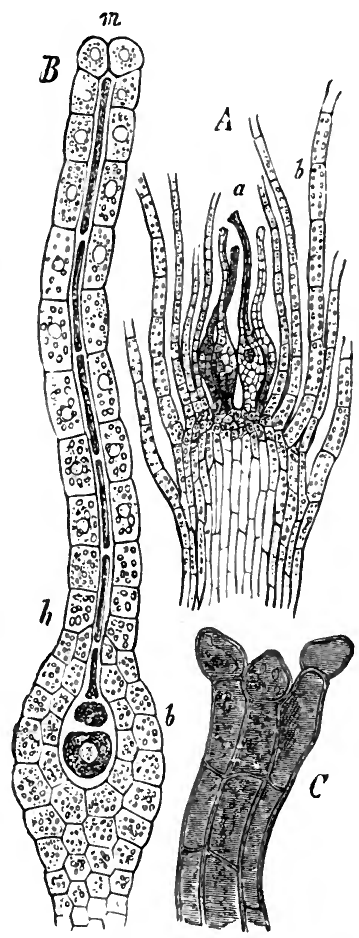

FIG. 109.-Funaria hygrometrica. $A$, longitudinal section through female inflorescence; $a$, archegones; $b$, perichætial leaves ( $\times 100)$. $B$, archegone $(\times 500) ; b$, venter and central cell ; $h$, neck ; $m$, opening of canal. $C$, opening of neck (more highly magnified), with stigmatic cells forced open.

cells which deliquesce into mucilage before impregnation. An open canal is thus left, through which the antherozoids penetrate to the oosphere; the terminal stigmatic or lid-cells of each row of the neck, constituting together the stigma, being forced apart by the exudation of the mucilage. The first archegones are formed from apical cells of shoots. 
The impregnated oosphere, or oosperm, develops into an embryo, from which is derived the sporogone within the ventral portion of the archegone. After investing itself with a cell-wall, it divides by a number of longitudinal, radial, and transverse septa. At an early period in typical mosses the young elongated sporogone ruptures transversely the wall of the venter, the lower part of which forms a sheathing protection to its base, and is termed the vagine, while the upper part becomes elevated in the form of a cap or calypter. In the Sphagnaceæ the sporogone attains almost perfect development before the rupture of the

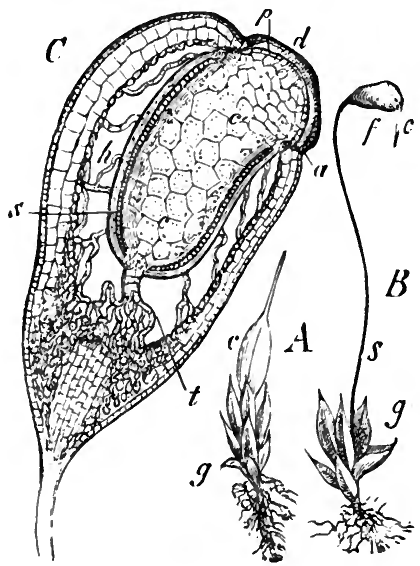

Fig. I10.-Funaria hygrometrica. A, young plant with young sporogone. $B$, mature plant with mature sporogone; $s$, seta; $f$, sporange ; $c$, calypter (natural size). $C$, longitudinal section of sporange (greatly magnified); $d$. opercule; $a$, annulus ; $p$, peristome ; $c$, columel ; $s$, archespore; $h$, air-cavities. (Áfter Goebel.) archegone; in other mosses the various portions of which the sporange is composed are differentiated only at a later date. The sporange is at first filled with fluid contents, the greater part of which is the archespore,

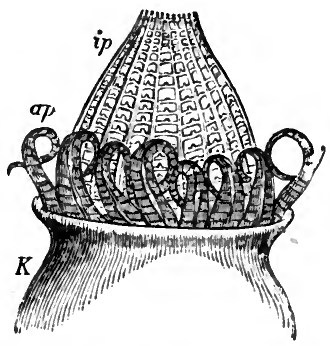

FIG. IIr.-Mouth of sporange of Fontinalis antepyretica L., with peristome : $a p$, teeth; ip, cilia ( $\times 50$ ). (After Schimper.)

developing into the mother-cells of the spores, from each of which are produced four spores by free-cell formation after preliminary indication of bipartition. The withered neck of the archegone, which has assumed a deep reddish brown colour, may often be recognised for some time surmounting the apex of the calypter. The mature sporogone consists of a pedicel or seta - which is usually of considerable length, the lower portion or foot being enclosed within the vagine, but is short in Sphagnum and some other genera-and the sporange or spore-capsule surmounted by the calypter, while the base of the seta is surrounded by the sheath-like vagine. The wall of the sporange is composed of several layers of cells, the outermost of which has a distinctly epidermal character, and is sometimes perforated by stomates with imperfect guard-cells. 
While the greater part of the internal tissue is used up in the formation of the spores, the axial portion always remains unchanged in the form of a solid columel. There are no elaters. Leitgeb regards the sporogone of all mosses (including Sphagnaceæ) as consisting, in its earliest stage of development, of an inner mass of cells, the endothecium, distinctly separated from the peripheral mass, or amphithecium. In Sphagnaceæ the archespore is formed from the latter, in the other orders from the former portion. Among the typical mosses he again distinguishes three types, viz.:-(I) The Archidium-type: the spore-forming and sterile cells are intermingled in the endothecium; the spore-sac is separated from the wall of the capsule by a bell-shaped cavity; (2) the Andreaa-type : the endothecium is differentiated into the archespore and the columel, which does not penetrate the former; the innermost layer of the amphithecium becomes the spore-sac, which is not separated from the wall of the capsule by any cavity; (3) the Bryum-type: the endothecium is differentiated as in the last case, but the columel penetrates the spore-sac, which is separated from the wall of the capsule by a cylindrical cavity. In all true mosses the sporogone is developed by means of a two-edged apical cell. The ripe spores are roundish or cubical, with a thin, finely granulated yellowish, brownish, or purple cuticularised exospore, and an endospore of cellulose, and contain protoplasm, chlorophyll, and oil. The number of spores in a capsule varies from sixteen (Archidium, Brid.) to an immense quantity, and their size also varies inversely. Several cases of hybridism have been recorded in mosses.

Mosses are found in all climates, from the coldest to the hottest; they are most abundant in temperate regions and in damp situations, clothing old walls, the trunks of trees, \&c. A few grow in stagitant, and one genus (Fontinalis, L.) in running water. Some species are saprophytes. They are of scarcely any economical value, but are of great importance in nature in the formation of soil.

\section{LiteratuRE.}

Bruch \& Schimper-Bryologia Europæea, 1836-1 865 .

Schimper-Recherches anatom. et physiol. sur les Mousses, 1848 .

Wilson-Bryologia Britannica, 1855 .

Hofmeister-Pringsheim's Jahrb. wiss. Bot., I 863, p. 259.

Unger-Sitzber. Akad. Wiss. Wien, xliii., I86I, p. 497.

Lorentz-Moosstudien, I 864 ; Pringsheim's Jahrb. wiss. Bot., I867, p. 363 ; Flora, I 867 .

Berkeley-Handbook of British Mosses, I 863.

Leitgeb-Sitzber. Akad. Wiss. Wien, I868, I\$69.

Nägeli-Pflanzenphys. Untersuch., Heft i. p. 75.

Ianczewski-(Archegonium) Bot. Zeit., I872, pp. 377 et seq.

Stahl-Bot. Zeit., I876, p. 689.

Kienitz-Gerloff-(Sporange) Bot. Zeit., 1878, pp. 33 and 49. 
Braithwaite-The British Moss-Flora, I880-1887.

L'Abbé Hy -Bull. Soc. Bot. France, 1880, p. 106 ; Ann. Sc. Nat., xviii., 188 \&, p. 105. Goebel-Flora, 1882, p. 323.

Firtsch-Ber. Deutsch. Bot. Gesell., I883, p. 83 .

Satter-Ber. Deutsch. Bot. Gesell., I884, p. I3.

Haberlandt-Ber. Deutsch. Bot. Gesell., I883, p. 263 ; and Pringcheim's Jahrb. wiss. Bot., I 886, p. 359.

Magdeburg-Die Laubmooskapsel als Assimilations-Organ, I 886.

Vaizey-(Sporogone) Ann. of Bot., i., I 887, p. 73.

Limpricht-Die Laubmoose, in Rabenhorst's Crypt.-Flora Deutschland, r885-I888.

The Musci are classified under four orders, as follows. The Sphagnacex exhibit much more important peculiarities than the other three orders, and are ranked by some writers of authority as a distinct class.

\section{ORDER I.-BRYACEE.}

This order includes the vast majority of the genera of mosses, and all the more familiar forms except the bog-mosses. The sporanges or 'fruits' form objects of great beauty in the autunin and winter, their usual period of maturity, fertilisation taking place in the spring or early summer. In some species the sporogone requires more than a year for its full development. The sporogone consists of a sporange which is always surmounted by a calypter, easily removed by the wind; beneath this is the opercule, which becomes detached, either alone or together with the annulus, a circular layer of hygrometric epidermal cells between the opercule and the edge of the capsule; the whole elevated on a longer or shorter stalk or seta, which is inserted at its lower end in the vagine. The portion of the seta concealed in the vagine is known as the foot, and acts as a kind of root, all the food-material needed for the development of the sporogone being absorbed through it. The central strand of tissue in the seta of the Polytrichaceæ consists, according to Vaizey, of two portions-a leptophloem or rudimentary phloem, in which the storing up and conduction of the food-material takes place; and a leptoxylem or rudimentary xylem, which serves for the conduction of the transpiration-current to the lower portion of the sporange furnished with stomates. In the Polytrichaceæ, in addition to the opercule, a horizontal layer of cells termed the epiphragm remains attached to the points of the teeth of which the peristome is composed, and covers the mouth of the sporange after the removal of the opercule. The sporange is penetrated by a complete axial columel. The spores are formed by free-cell formation in fours within spore-mother-cells, themselves derived from a single primordial layer, the archespore; the walls of the sporemother-cells finally deliquesce, leaving the spores floating in a fluid 
which for a time fills the spore-sac, composed of two or three layers of barren cells immediately enclosing the mass of spores. Between the spore-sac and the wall of the mature sporange is an annular air-cavity, traversed horizontally by rows of chlorophyllous cells, the trabecules. The opercule is simply a piece of the epiderm of the sporange. In most genera a portion of the wall of the sporange, situated near the base of the columel, consists of an assimilating system composed of spongy or palisadeparenchyme, containing chlorophyll, and marked by the presence of stomates. If the detachment of the opercule leaves the mouth of the sporange with a smooth edge, it is said to be gymnostomous, as in Pottia (Ehrh.). More often the mouth of the open sporange is furnished with hair- or tooth-like appendages, arranged in one or two rows, constituting the peristome. The single row of these appendages, or the outer row if there are two, are called teeth, the inner row cilia. In some genera the cilia are furnished with lateral processes uniting them with one another, or they are replaced by a lattice-work of longitudinal or transverse ridges termed the endostome. The inner and outer layers of both teeth and cilia differ from one another in their hygroscopic capacity; hence, as the moisture of the air varies, they bend inwards and outwards, or sometimes coil spirally round one another (Barbula, Hedw.). The peristome has a very beautiful appearance under the microscope, and its structure furnishes useful characters for the discrimination

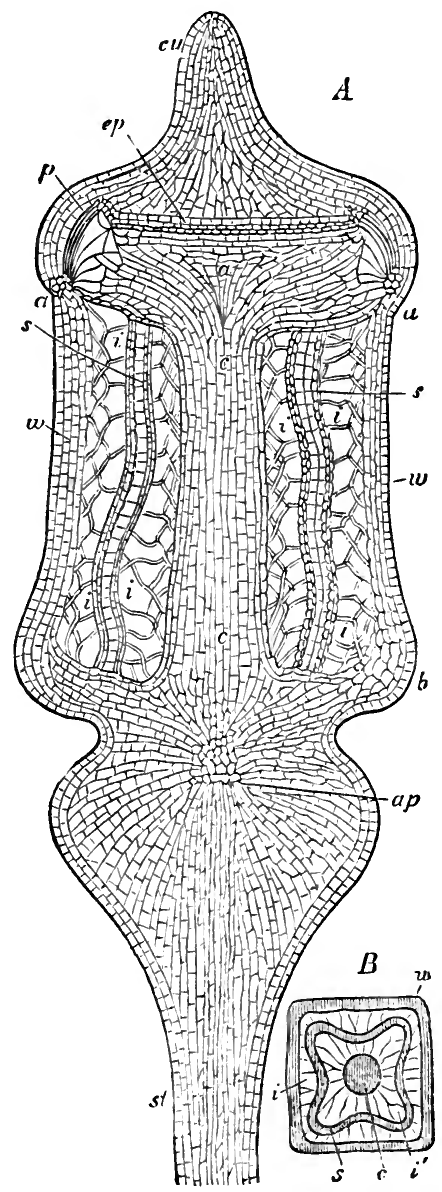

FIG. I12.- $A$, longitudinal section of sporange of Polytrichum piliferum Schreb. $\left(\times I_{5}\right), B$, transverse section $(\times 5 ; . w$, wail of sporange; $c u$, opercule ; $c$, columel ; $p$, peristome ; $e p$, epiphragm ; $a$, annulus; $i$, air-spaces traversed by trabecules; $s$, spore-sac; $a p$, apophyse ; st, seta. (After Lantzius-Beninga.) of the genera. In most genera the teeth and cilia are not composed of cells, but of pieces of thickened cell-wall which become detached from a 
layer of cells beneath the epiderm; but in Polytrichum the teeth are composed of bundles of thickened prosenchymatous cells. The exterior peristome may have two distinct forms. Either the teeth have a double outer and a single inner series of plates (Diplolepida), or the exterior series is simple (Aplolepida), and then the inner series is nearly always double. The Aplolepidæ never have a double peristome; and in the Diplolepidæ the inner peristome is occasionally wanting in particular families or genera. In much the larger number of genera (Arthrodontea) the teeth are septated by transverse walls; in a much smaller number

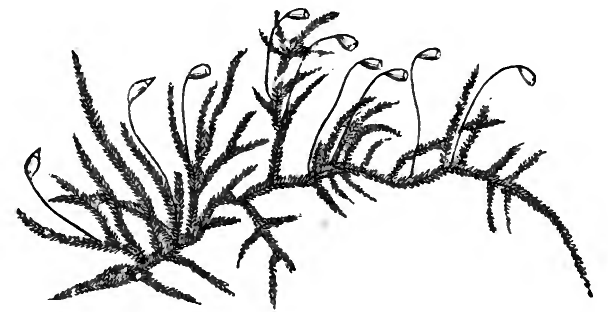

FIG. Ir3.-Hypnum populeum Sw. (natural size).

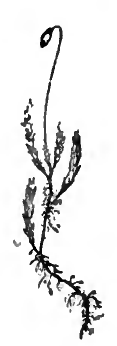
FiG. $115 \cdot-$ Bryum argenteum $\mathrm{L}$.

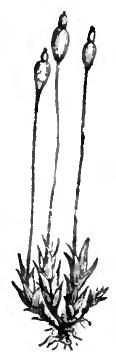

FiG. 116.-Splachnum am. pullaceum L. (natural size).

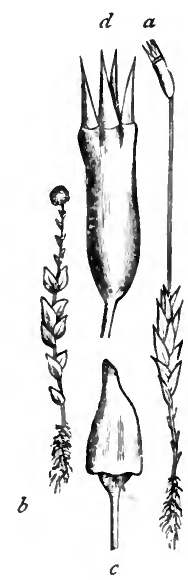

Fic. I14.-Tetraphis pellucida Hedw. $a$ (slightly magnified), with open sporange; $b$, ditto with gemma; $c$, sporange with calypter (greatly magnified); $d$, open sporange, showing peristome.

(Nematodontea) the transverse septa are wanting. The cilia, when present, are usually shorter and less developed than the teeth; they are also composed of two layers of plates, often marked on the surface by a beautiful network; their divisions correspond to those of the teeth. The number of both teeth and cilia is always a multiple of 4 , the most common numbers being $8,16,32$, and 64 . The most perfect type of peristome is seen in the Encalypteæ, from which all the less perfect forms are, according to Philibert, derived by degradation. In addition to the presence of an epiphragm, the genus Polytrichum presents the peculiarity, in most species, of the seta being swollen beneath the sporange, forming an annular cushion known as the apophy'se (see fig. I I2). 
In most Bryaceæ the tissue of the leaf is nearly homogeneous, with the exception of the margin and an elementary midrib composed of elongated prosenchymatous cells; but in Leucobryum (Hpe.) the small chloro$B$
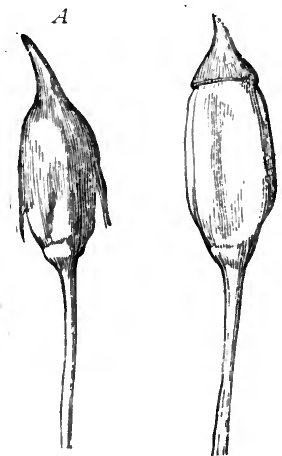

FIG. Ir7.-Sporange of Polytrichum commune, showing epiphragm. $A$, covered by calypter; $B$, with calypter removed ; $C$, with opercule removed (magnified).

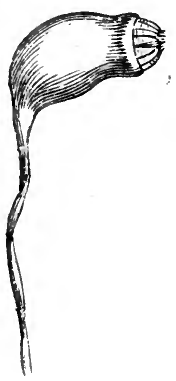

Fig. I18.- Sporange of $H_{y}$ pnum populeum, showing peristome (magnified).

phyllous cells interlace among large empty cells with circular orifices in their walls, as in Sphagnum.

The very numerous genera of Bryaceæ are further classified as under.

Acrocarpi.-Fructification produced at the extremity of the branches. Illustrative genera:-Weissia (Hedw.), Dicranum (Hedw.), Leucobryum (Hpe.), Pottia (Ehrh.), Tortula (Hedw.), Bartramia (Hedw.), Encalypta (Schreb.), Fissidens (Hedw.), Grimmia (Ehrh.), Orthotrichum (Hedw.), Zygodon (H. \& T.), Tetraphis (Hedw.), Buxbaumia (Hall.), Polytrichum (Dill.), Aulacomnion (Schw.), Bryum (H. \& T.), Mnium (B. \& S.), Funaria

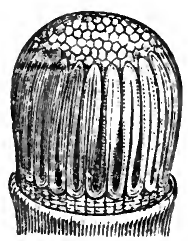

FIg. Irg.- Peristome ot Atrichum undulatum (magnified).

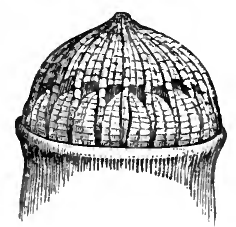

FIG. 120.- Peristome of Cinclidium stygium (magnified).

(Schreb.), Splachnum (B. \& S.), Tayloria (Hook.), Barbula (Hedw.), Ceratodon (Brid.).

Pleurocarpi.-Fructification lateral, not at the extremity of the principal branches. Illustrative genera:-Hedwigia (Ehrh.), Fontinalis (L.), Hookeria (Sm.), Hypnum (Dill.), Leucodon (Schw.), Neckera (Hedw.).

LITERATURE (in addition to the papers already quoted).

Philibert-(Peristome) Rev. Bryol., I 884-I 888.

Vaizey-(Polytrichaceæ) Journ. Linn. Soc., xxiv. (I888), p. I62. 


\section{ORder 2.-Phascacee.}

In the small order of Phascaceæ the roundish sporange dehisces neither by the detachment of an opercule nor by longitudinal slits, but decays to allow of the escape of the spores; the calypter is ruptured laterally without being raised up as a cap; the columel is sometimes wanting. According to Leitgeb, Archidium (Brid.) resembles the Hepaticæ more closely than the Bryaceæ in the processes which lead to the formation of the spores, especially in the differentiation of the archespore into spore-mother-cells which are

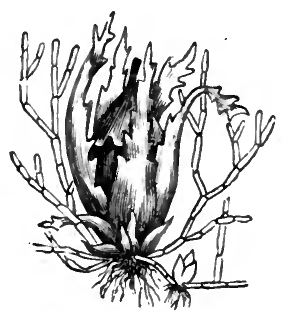

FIG. 121.-Ephemerum serratum Hampe; mature plant with persistent protoneme (magnified). (After Luerssen.)

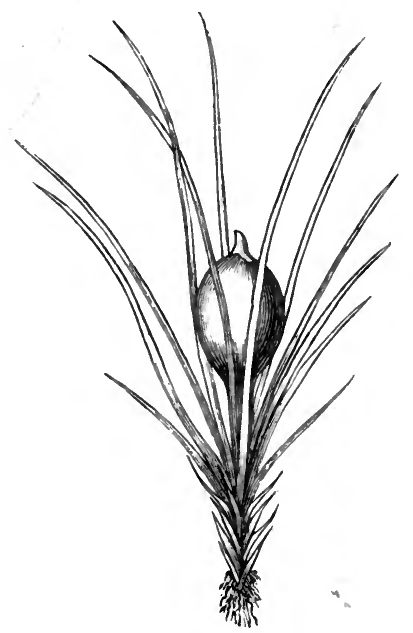

Fig. 122.-Pleuridium subulatum Rabenh. ; sporange (magnified). (After Luerssen.

irregularly interspersed among cells that remain sterile. The sporemother-cells do not number more than from one to seven in each sporange ; in each of them four spores are formed tetrahedrally.

The Phascaceæ are cæspitose in their habit ; the protoneme persists until the maturity of the sporogone. Principal genera:-Phascum (L.), Archidium (Brid.), Ephemerum (Hpe.), Pleuridium (Brid.).

\section{LITERATURE.}

Leitgeb-Sitzber. Akad. Wiss. Wien, 1880, p. 447.

Müller-Pringsheim's Jahrb. wiss. Bot., I867, p. 237.

\section{ORDER 3.-ANDREAACEE.}

The Andreæaceæ constitute a small order of mosses, comprising the single genus Andreæa (Ehrh.), characterised by the absence of an opercule to the sporange, which opens by four, or very rarely eight, longitudinal slits, not reaching either to the base or the apex of the capsule. 
The calypter is elevated, as in the Bryaceæ, on the summit of the ripe sporogone in the form of a cap ; there is a short seta buried in the vagine, and the whole sporogone is elevated on a stalk or pseudopode, as in the Sphagnacer. At the base of the sporange is an enlarged apophyse. The structure of the sporange differs from that of the Bryaceæ in the columel not penetrating the archespore, and in the absence of a cavity between the spore-sac and the wall of the sporange. The contents of the spore divide, while still within the exospore, into four or more cells. As in Sphagnum, the oosphere is always enveloped in a hyaline mass of mucilage in which the antherozoids imbed themselves.

The Andreæaceæ are also cæspitose in their habit, and are natives of cold or mountainous regions.

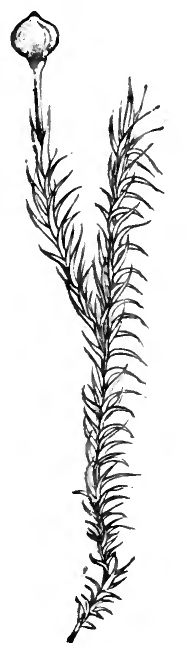

FIG. 123. - Andreaca alpestris Schmp. $(x$ 5).

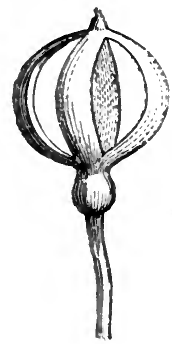

FIG. 124.-A. alpestris Schmp.; dehiscent sporange and apophyse (magnified).

\section{Literature.}

Kühn-Entwickelungsgeschichte der Andreæeaceen, I870.

Waldner-Bot. Zeit., I879, p. 595 ; and Entwick. d. Sporogone v. Andreæa, I887.

\section{ORDER 4.-SPHagnaceÆ.}

The bog-mosses form a large portion of the vegetation of bogs and swamps, and are characterised by the spongy structure of the whole plant, the light yellowish green colour of the leaves, and the bright red globular spore-capsules. The protoneme is much less developed than in typical mosses; and when the spore germinates on dry ground a flat prothallium intervenes between it and the leafy stem. The stem branches abundantly, giving a cæspitose appearance to the whole plant ; and innovations, produced below the apex after the ripening of the fructification, become detached by the decay of the lower part of the stem, and carry on an independent existence. The leaves are lanceolate and apiculate, usually arranged in a $\frac{2}{5}$ phyllotaxis, larger than in other mosses, and of a peculiar structure of their own. As the leaf develops, 
the single layer of cells of which it is composed becomes differentiated into cells of two distinct kinds. A comparatively small number, of a

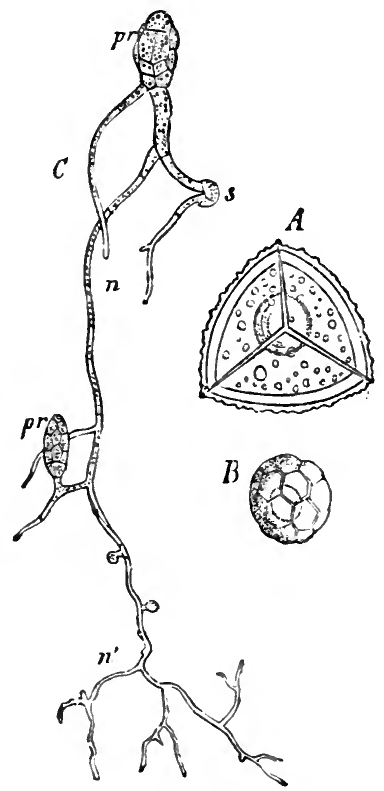

FIG. 12b.-Sphagnum acutifolium Ehrh. $A$, megaspore ; $B$, microspore ; $C$, protoneme, with pr, rudiments of young plants (magninied). (After Schimper.) lozenge-shaped form, grow to a large size and lose the whole of their contents, while their walls are provided with spiral thickening-bands, and frequently display a large circular orifice opening from one cell into the next. A much larger number of cells remain permanently of a very small size, are very narrow in proportion to their length, and, being filled with protoplasm and chlorophyll, constitute the whole of the nutritive tissue of the leaf. These nutritive cells form a kind of network ramifying among the large empty cells ; but, as their total area is small compared with these latter, the entire leaf has, to the naked eye, a semi-transparent very light yellow-green appearance. The tissue of the stem consists of cells of three distinct kinds. In the centre is a cylinder of thin-walled elongated colourless parenchymatous cells; this is enveloped in a layer of dotted prosenchymatous cells, the walls

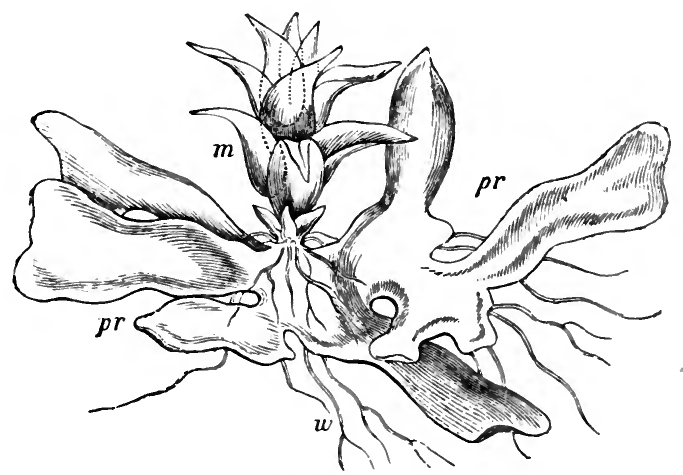

FIG. 126. - Flat prothallium of S. acutifolium, with young leafy stems ( $\times 120)$. (After Schimper.) of which are thicker and of a brown colour; while outside all is an epidermal layer of large thin-walled empty cells, sometimes with spiral 
thickenings and circular orifices, similar to those of the leaves. These serve as capillary tubes, through which the water of the bogs in which these mosses grow is raised, and the whole plant is in consequence always saturated with water like a sponge.

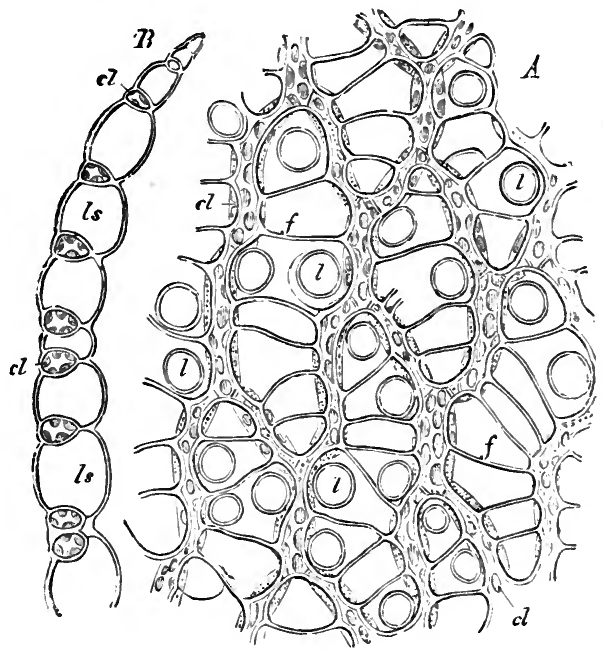

FIG. 127. - A, portion of surface of leaf of $S$. acutifolium. $c l$, small chlorophyllous cells ; $f$, large empty cells; $l$, orifices in these cells. $B$, transverse section (magnified).

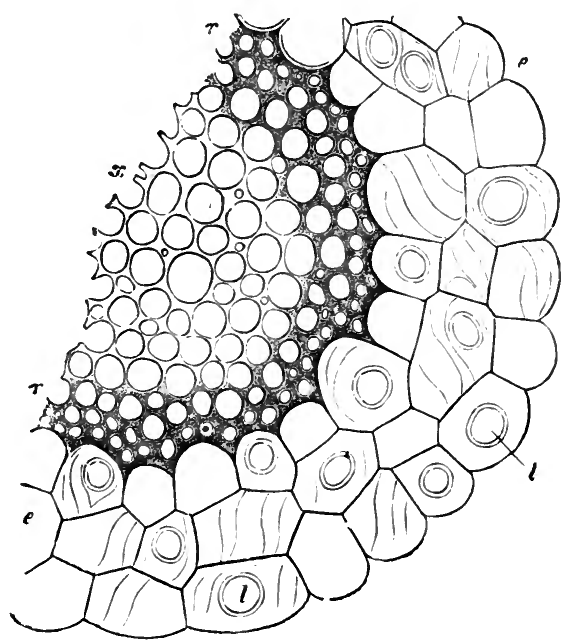

F1G.128.- Transverse section of stem of S. cymbifolium Dill. $x$, inner cells with colourless wall ; $r$, outer layer of cells; $e e$, peripheral layers of cells with orifices, $l(x 9 c 0)$. (Aft $\mathrm{r}$ Luerssen.) 
In their organs of reproduction, and especially in the structure of the sporogone, the Sphagnaceæ exhibit some divergences from the typical mosses. Some species are diœcious, and the 'flowers' of the monœcious species are never hermaphrodite, the male and female organs being always distributed on different branches. The male branches are distinguished by their densely crowded leaves, which are often of a bright red colour, giving a catkin-like appearance to the branch. On removing these the

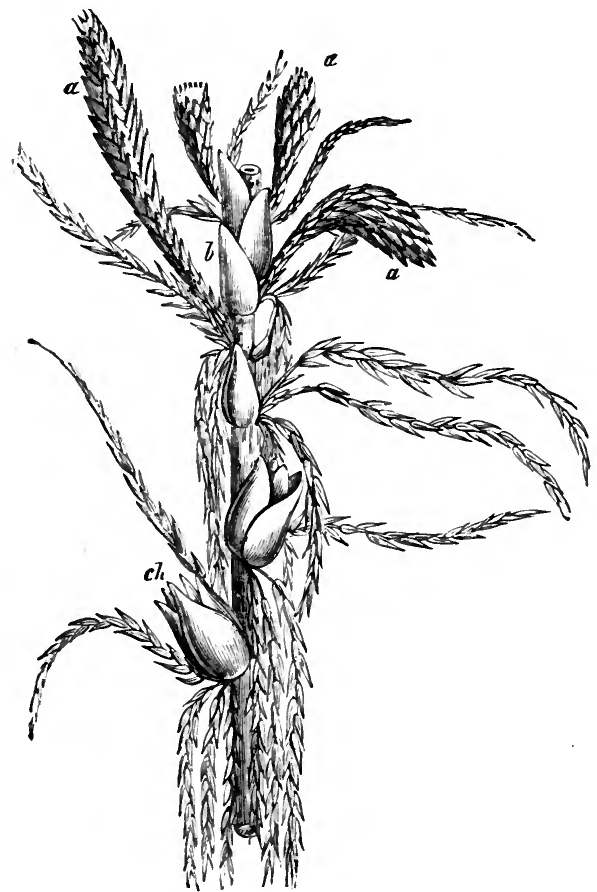

FiG. 129. $-S$, acutifolium. $a$, antheridial branches; $b$, leaves of primary stem; ch, perichætial leaves with sporogones $(x$ 5). (After Schimper.) antherids are found near the middle of the branch. They are minute nearly globular or elliptical bodies, elevated on a slender stalk, and dehiscing by longitudinal fission into valves. The antherozoids are spiral bodies with many coils, and two large flagellate cilia at the posterior end. The archegones are formed towards the extremity of the female branches, are accompanied by paraphyses, and are enveloped by perichætial leaves. They resemble in all essential points those of other mosses. On impregnation the oosperm divides by a horizontal septum into two cells, the sporogone originating from the upper cell only. The nearly spherical usually bright red sporange differs from that of other mosses in being completely enclosed within the venter almost till maturity. It is, in most species, elevated on a long slender pedicel, the pseudopode, which must not be confounded morphologically with the seta of other mosses, being a prolongation of the axis below the vagine. The lower portion of the sporogone is widened out into a broad disc-like foot, resembling in appearance the apophyse of Polytrichaceæ, which is seated on the top of the pseudopode, and enclosed in the vagine. The calypter, when finally ruptured, is not elevated in the form of a cap, but remains attached as a 
frill to the base of the sporange, which dehisces by a transverse slit near the apex, detaching a strongly convex opercule. There is no peristome nor annulus. A portion of the contents of the sporange remains undifferentiated in the form of a low columel not reaching to the apex. The remainder is converted into spores, which differ from those of other mosses in being of two kinds, megaspores and microspores (see fig. 125). According to Warnstorf ('Hedwigia,' 1886, p. 89; and 'Verhandl. Bot.

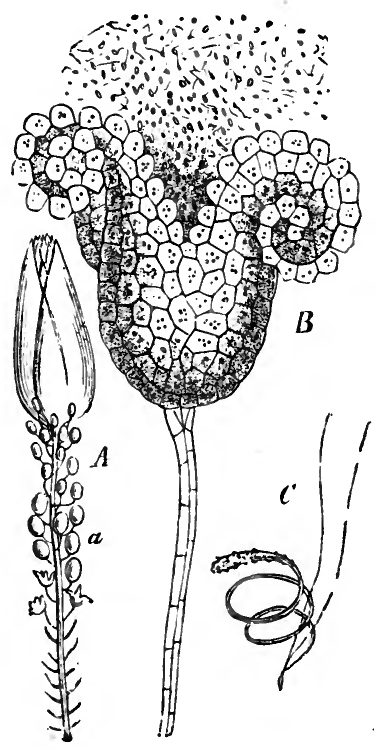

Fig. r30.-S. acutifolium. $A$, male branch, with leaves removed to expose antherids, $a$ (magnified). $B$, antherid (more highly magnified) dehiscing. $C$, antherozoid (still more magnified). (After Schimper.)

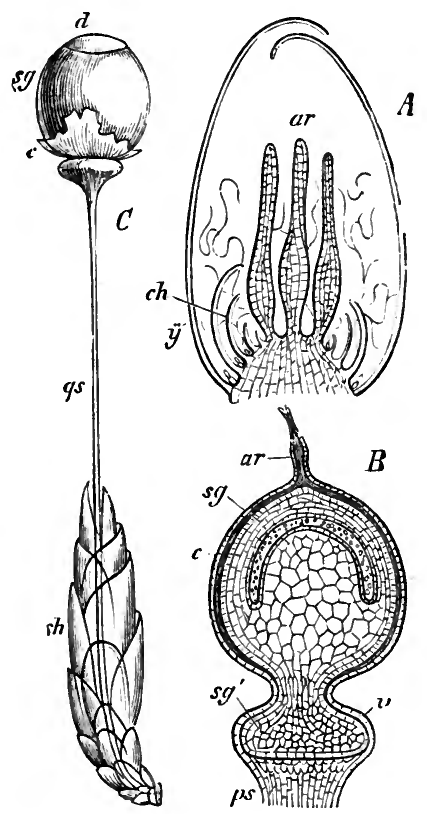

FIG. r31. $-A, S$. acutifolium, section of female inflorescence; $a r$, archegones; $c h$, perichætial leaves. $B$, longitudinal section of sporogone, $\mathrm{sg}$; ar, archegone ; $c$, calypter ; $s g^{\prime}$, foot ; $v$, vagine ; $p s$, pseudopode. $C, S$. squarrosum Pers. ; $s g$, sporogone ; $d$, opercule ; $c$, ruptured calypter; $q s$, pseudopode; $c h$, perichætial leaves (magnified). (After Schimper.)

Verein,' Brandenburg, I886, p. I8I), these two kinds of spore are found either in the same or in different sporanges; the diameter of the former varies between 30 and $33 \mathrm{~mm}$., that of the latter between 12 and $18 \mathrm{~mm}$. The megaspore is by far the most common form, and its germination only has at present been observed. Warnstorf suggests that the two kinds are sexually differentiated, the megaspores giving rise to a female, the microspores to a male prothallium, as in the Heterosporous Vascular Cryptogams. 
All the species of the single genus Sphagnum (L.) grow in bogs and swamps, often covering enormous tracts of ground, and entering largely into the composition of peat. The best authorities differ widely as to the number of species; the most divergent forms are distinguished by well-marked characters, but these merge into one another by a complete series of connecting links.

\section{LITERATURE.}

Schimper-Entwickelungsgeschichte der Torfmoose, 1858 .

Waldner-Bot. Zeit., 1879, p. 595 ; and Entwickelung d. Sporogone v. Andreæa u. Sphagnum, I 887.

Braithwaite-Sphagnaceæ of Europe and North America, I880.

Warnstorf-Die Europ. Torfmoose, I88I ; and Flora, I884.

Limpricht-Bot. Centralbl., x., I882, p. 214.

Röll-Flora, I886.

\section{Class VIII.-Hepaticæ.}

The Hepaticæ or Liverworts are small elegant plants, usually of a bright green colour, which are especially abundant on damp ground or rocks, or by the sides of streams; a few species are aquatic. Some of the genera bear a considerable external resemblance to lichens, others to mosses. Their vegetative structure is either an undifferentiated thallus, or consists of a distinctly differentiated stem and leaves, in both cases attached to the soil by rhizoids. The former are known as the Thalloid or Frondose, the latter as the Foliose Hepatica. The transition marks the passage from the upper of the two great divisions of the vegetable kingdom, the Cormophytes, to the lower division, or Thallophytes ; but intermediate forms occur in the genera Fossombronia (Rad.) and Blasia (Mich.). Even the foliose forms have no true vascular tissue, and no true roots, the functions of which are performed by the rhizoids. Both sections have, except in Riella (Mont.) and Haplomitrium (N. ab E.), a distinct bilateral or dorsiventral structure ; the free side which faces the light is differently organised from that which faces and often clings to the substratum, and which is not exposed to light. The mode of branching in the thalloid forms is dichotomous, and the growing region of the shoot commonly lies in an apical depression formed by the more rapid growth of the cells lying right and left of the apical cell, which has a form allied to wedge-shaped. The filiform stem of the foliose forms, on the other hand, ends in a bud with a more or less prominent cone of growth, and the apical cell is a three-sided pyramid. The leaves of the foliose forms always consist of only a single layer of cells, without even a rudimentary midrib; while the stem sometimes contains the first rudiments 
of vascular bundles in the form of cambium-strings, and is furnished with a slightly differentiated epidermal layer. In the thalloid forms the thallus is composed of a more or less thick plate of tissue, which in one order, the Marchantiaceæ, possesses on the upper side a strongly developed epiderm, provided with stomates of very peculiar form, unlike anything that occurs elsewhere in the vegetable kingdom.

The first result of the germination of the spore is either a filiform protoneme, a flat plate of cells, or a mass of tissue ; but the differentiation of the protoneme from the sexual generation is not so well marked as in the Musci. The non-sexual propagation of the Hepaticæ takes place either by innovation, i.e. by the continual dying away of the stem behind, or by semma, which exhibit a high degree of development. In the thalloid genera Marchantia (L.), Lunularia (Mich.), and Blasia, these gemmæ are found in peculiar outgrowths of the upper surface of the thallus known as cupules, which are cup-shaped in Marchantia (see fig. 150), crescent-shaped in Lunularia, flask-shaped in Blasia. From the base of these cupules there spring hair-like papillæ, the apical cells of which divide repeatedly in both directions, and constitute the gemmæ. In some of the foliose genera, e.g. Madotheca (Dum.), the gemmæ are formed out of cells belonging to the margin of the leaf, and simply detach themselves. Vöchting states that in Lunularia, and Marchantia also, isolated masses of cells possess the power of regeneration or development into new individuals, to whatever part of the thallus they may have belonged. Shoots resembling a normal thallus spring from the pedicel of the inflorescence of Marchantia polymorpha (L.) when lying prostrate on the soil.

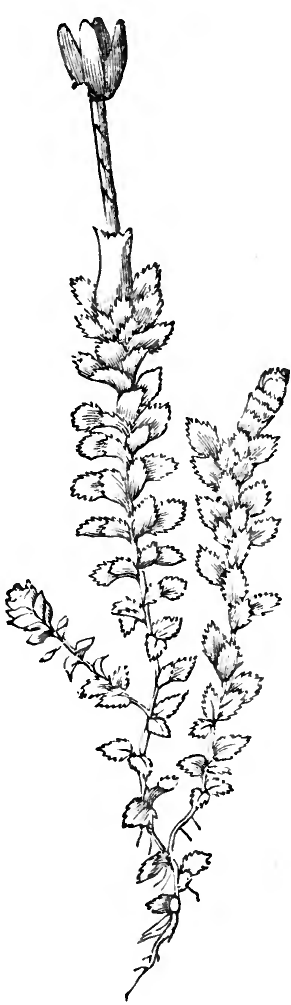

FIG. 132.-Fungermannia nemorosa L. ( $\times$ ro).

The locality of the sexual organs of reproduction, antherids and archegones, varies in the different orders. In one genus, Anthoceros (Mich.), they are endogenous, or originate in the tissue of the thallus itself ; in the remaining thalloid forms they are produced on the upper side of the thallus; and in the Marchantiaceæ on special vertical outgrowths, some of which bear antherids on their upper, others archegones 
on their under side; these male and female inflorescences, as they are termed, may be either monœcious or diœcious. In the foliose orders there is a great variety in their locality and mode of origin.

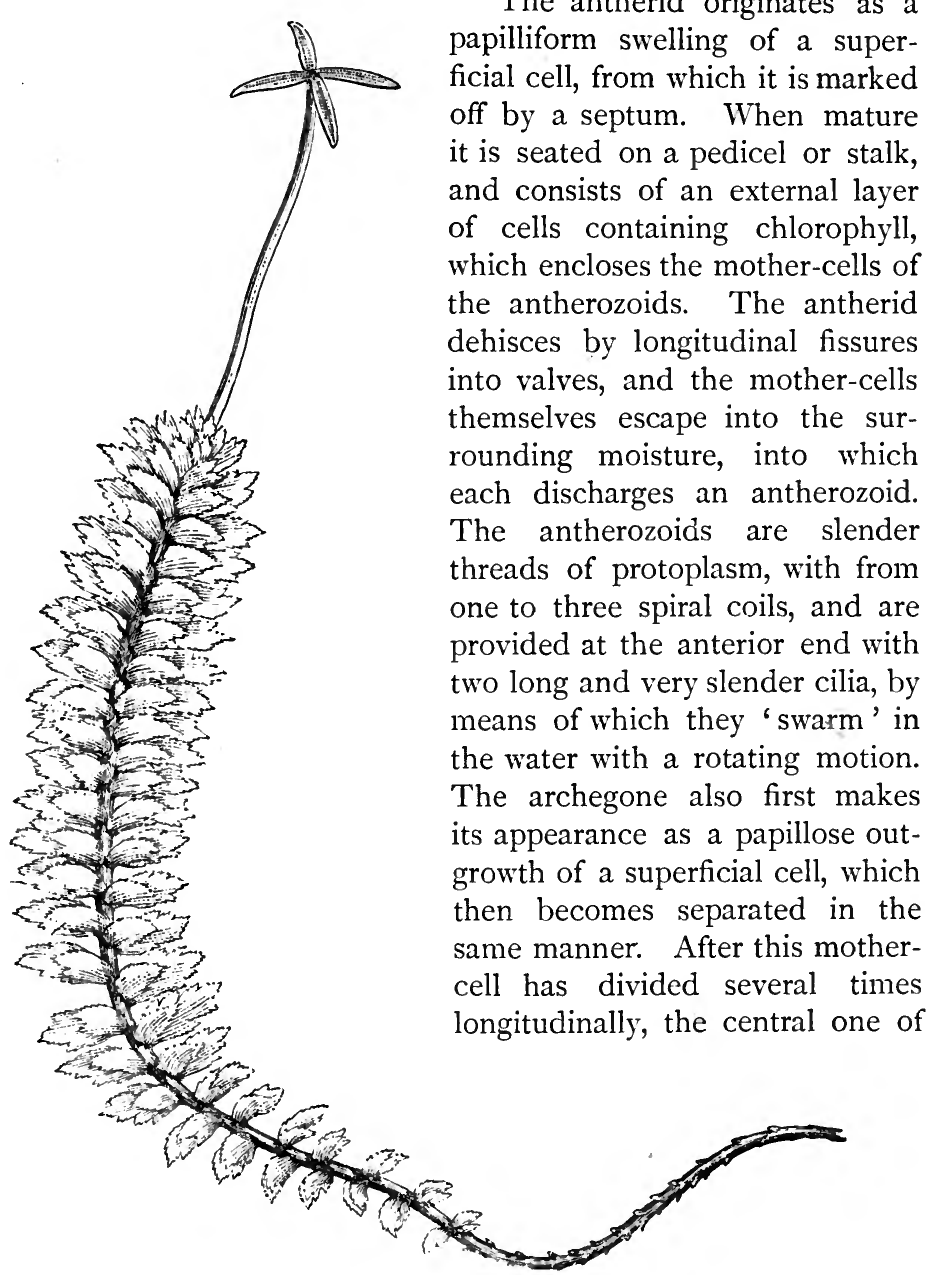

Fig. 133.-Gottschea appendiculata N. ab E. (magnified).

the cells thus formed divides transversely into an upper stigmatic or lid-cell and a lower cell. Two layers are subsequently formed, the upper of which becomes the neck of the archegone, the lower its ventral 
portion, or venter. The lowermost cell of this ventral portion, now known as the central cell, increases considerably in size, and divides by a transverse septum into a lower and larger portion, which encloses the oosphere, and an upper and smaller portion, the ventral canal-cell. In the meantime the upper layer of cells increases in length by the formation of a number of fresh cells, the neck-canal-cells. The ventral portion of the archegone becomes eventually enclosed in a wall, and by the deliquescence of the neck-canal-cells an open channel is formed down to the oosphere. In addition to the perichæte, the archegones are frequently surrounded by a circular wall, originating as an outgrowth of the thallus, and known as the perigyne or involucre.

The result of the impregnation of the oosphere by one or more antherozoids is the production of the embryo, from which is derived the sporogone, which alone constitutes the sporophyte, or non-sexual generation. It is formed entirely from the ventral portion of the archegone. Its external form and internal structure vary greatly in the different groups ; as is also the case with the course of cell-divisions in its formation. Ultimately the wall of the spore-capsule becomes differentiated from the archespore, or layer of tissue which develops into the mothercells of the spores and elaters when these latter organs are present. There is usually no solid axis or columel. The cells which develop into elaters cease early to divide transversely, and thus remain long, while the rest of the cells round themselves off, and become mother-cells of spores. The mature elaters (fig. I 59) have in their wall an elongated single or double spiral band, the twisting and untwisting of which on the absorption and giving off of moisture helps to disseminate the spores. Leclerc du Sablon finds the sporogone of the typical Hepaticæ to be composed, at a very early stage, of sixty-four cells, each of which subsequently divides into four. These cells now elongate in the direction of the axis of the sporogone, and then become differentiated into two kinds. In the one kind the nucleus undergoes repeated bipartitions, and these give rise to the spore-mother-cells; in the other kind the nucleus does not divide, and the protoplasm forms spiral granulations; these become the elaters. Rarely (as in Riella) they are replaced by barren cells filled with food-material for the nutrition of the growing spores. The two kinds of cell are equal in number, each alternating with the other. The degree of complexity of the sporogone in the different orders of Hepaticæ corresponds in the main to the degree of development of the vegetative organs. In the Jungermanniaceæ it bursts longitudinally into four valves, and the walls are composed of two layers of cells furnished with 'ornaments,' or elevated markings of various patterns; in the Anthoceroteæ it splits longitudinally into two valves; 
in the Ricciaceæ and Marchantiaceæ it bursts irregularly, and the wall is composed of a single layer of cells without ornaments, or nearly so. The spores also vary considerably in the different orders. In many Jungermanniaceæ the spore has only a single cuticularised membrane, which is entirely used up in the formation of the germinating filament. In most genera the wall is composed of two distinct separable layers, the exospore and endospore; while in Sphærocarpus (Mich.), Corsinia (Radd.), and some others there is a third outer layer, often beautifully sculptured, which is derived from the membrane of the special mothercells of the spores. This layer is called by Leitgeb the perinium. Warnstorf (Verhandl. Bot. Ver. Brandenburg, I886, p. I8I) finds in Blyttia (Endl.) two kinds of spore, larger and smaller, which he believes to produce female and male plants respectively. In Sphærocarpus the spores are combined into tetrads. When the spore germinates, the endospore breaks through both exospore and perinium, when the latter is present, and protrudes as the first rhizoid.

\section{LITERATURE.}

Bischoff-Nov. Act. Acad. Leop. Car., 1835 .

Gottsche-Ibid., 1838 .

Gottsche, Lindenberg u. Esenbeck-Synopsis Hepaticarum, I844.

Kny-Pringsheim's Jahrb. wiss. Bot., I865, p. 64.

Leitgeb-Bot. Zeit., I87 I, p. 557, and I872, p. 33 ; Mittheil. naturw. Ver. Steiermark, I872; Unters. über die Lebermoose, I874-I 88I ; and Ber. Deutsch. Bot. Gesell., I 883 , p. 246.

Janczewski-(Archegone) Bot. Zeit., 1872, p. 372 et seq.

Carrington-British Hepaticæ, I874.

Kenitz-Gerloff-Bot. Zeit., I875, pp. 777 et seq.

Vöchting-Pringsheim's Jahrb. wiss. Bot., I 885, p. 367.

Satter-Sitzber. Akad. Wiss. Wien, 1882.

Leclerc du Sablon-(Antherozoids) Comptes rendus, cvi., I888, p. 876 .

Liverworts are distributed throughout the entire globe, growing mostly in moist situations. Many tropical species are epiphytic on the leaves of Flowering Plants or ferns. They are of no economic importance. They are classified under five orders, of which the first includes both foliose and thalloid, the remaining four almost entirely thalloid, forms.

\section{Order I.-JUNGERMANNIACEe.}

In this, much the largest order of the class, are included genera with every variety of vegetative development, from an undifferentiated thallus to a slender filiform stem, with sessile leaves seated either in two rows on the upper side, or in three rows, two of them on the upper, and the third, the amphigasters, smaller and adpressed to the under side. The thalloid 
forms have, except in Haplomitrium, a bilateral structure resembling that of the Marchantiaceæ; rhizoids and rudimentary foliar structures are formed on the under, the sexual organs on the upper side. In the foliose forms the leaves, always very small, are frequently bisected or bilobed, the lower lobe or auricle being the smaller one, and amplexicaul or concave. Goebel states that in Java many of the Jungermanniaceæ are epiphytic, and that in these the auricle is frequently hollowed out into the shape of a pouch or pitcher, serving as a receptacle for water (fig. I 40). In some species of Physiotium (N. ab E.) this receptacle is prolonged into the so-called 'tubular organ.' The leaves of the foliose
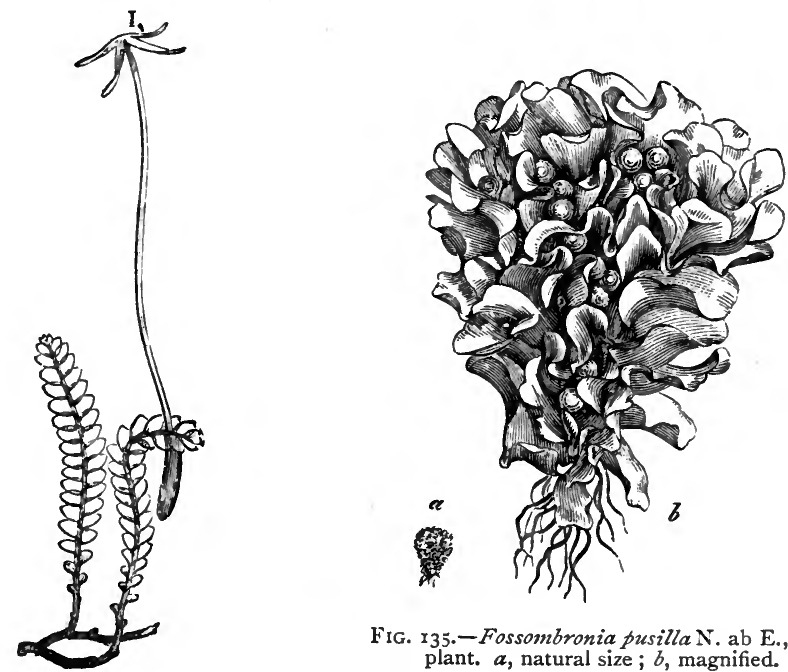

Fıg. 135.-Fossombronia pusilla $\mathrm{N}$. ab E., male plant. $a$, natural size ; $b$, magnified.

FIG. 134.-Calypogeia Trichomanis

Cord. (magnified).

species consist of a single layer of cells without even the rudiments of vascular bundles. There are species which form a connecting link between the foliose and the thalloid Jungermanniaceæ. The mode of branching varies greatly, but growth always takes place by means of a three-sided pyramidal apical cell.

As respects the sexual organs, some species are monœcious, others diœcious. In the foliose genera they are usually formed at the apex of the primary shoots or of special small fertile branches, which have often an endogenous origin on the ventral side. These constitute the acrogynous section of the order, which includes all the foliose genera except Haplomitrium. In the thalloid genera, or anacrogynous section, they 
appear on the dorsal surface of the shoot, at some distance from the apex; while in the acrogynous forms they are formed in close proximity to the apical cell. In Radula (Dum.) the entire female inflorescence, composed of a number of archegones enclosed in

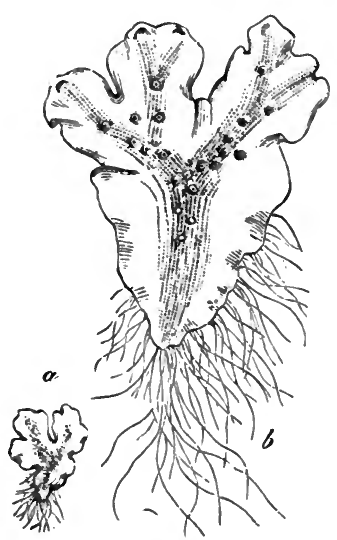

FiG. 136.-Pellia epiphylla Cord., male plant. $a$, natural size; $b$, magnified.

a perigyne, is developed from the apical cell of a shoot, and from its youngest three segments. Neither archegones nor antherids are elevated on receptacles, as in the Marchantiaceæ. The antherids usually occur

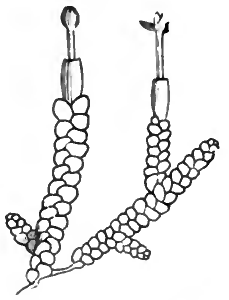

FIG. 137.-Radula compla. nata Dum. Plant with closed and open sporange $(\times 2)$.

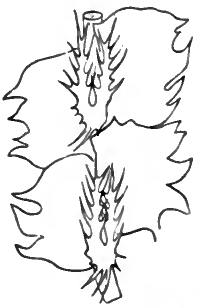

FIG. 138. - Fungermannia barbata Schreb. Under side of leaves with ciliated amphigasters (magnified).

singly or in groups in the axils of the leaves. In Pellia (Radd.) the antherids are imbedded in the thallus, the archegones appearing in large numbers at the apex of the shoot. In the Geocalyceæ (e.g. Calypogeia, Radd.) the female branches are so hollowed out that the archegones are

I.

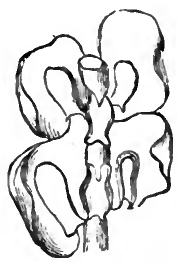

II.

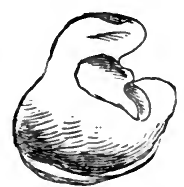

FIG. 139.-I. Under side of stem of Frullania Tamarisci Dum., with true leaves and amphigasters (magnified). II. Leaf of $F$. dilatata (more magnified).

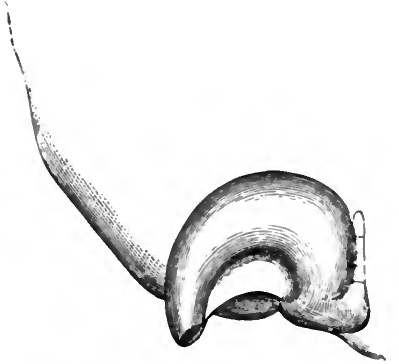

Fig. 140.-Auricle of Frullaria, sp. (magnified). (After Goebel.)

sunk in a deep pitcher-shaped hollow or tube, within which the sporogone is subsequently formed. In other genera they are concealed by the nearest leaves. The modified leaves which thus enclose a group of archegones, or of both archegones and antherids, constitute the perichate, 
each archegone being, in addition, usually surrounded by a distinci membranous envelope, the perianth or perigyne.

In the formation of the sporogone, the fertilised oosphere first divides by a wall at right angles to the axis of the archegone. Only the upper of the two cells thus formed - that is, the one that faces the neck of the archegone-undergoes further divisions; it becomes the apical cell of the sporogone, and sometimes again divides transversely once or twice before a longitudinal wall makes its appearance in it ; the two cells thus formed finaily divide into four apical cells arranged as octants of a hemisphere. The basal portion of the growing archegone swells out and penetrates down into the tissue of the stem, forming the vagine.

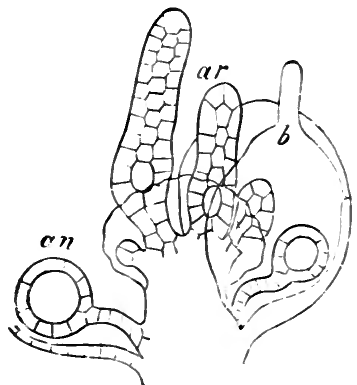

Fig. r4t.-Sexual organs of Radula complanata. ar, archegone ; an, antherid ; $b$, leaf. (After Hofmeister.)

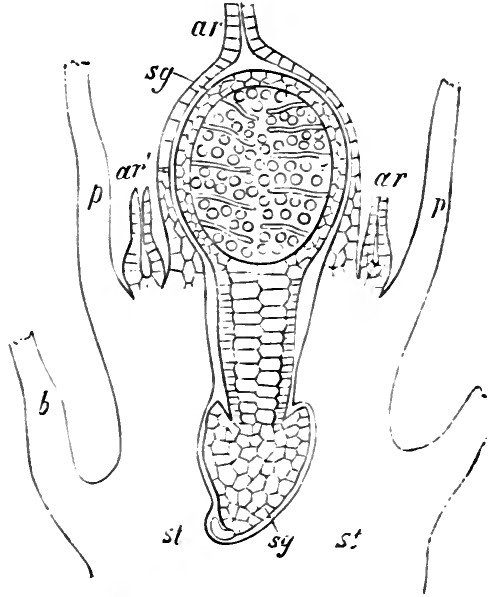

FIG. 142.- Fungermann:a bicuspidata L. Longitudinal section of immature sporogone, $s g$; ar, calypter; $a r^{\prime}$, unfertilised archegones; $p$, base of perigyne; st, stem; $b$, leaf. (After Hofmeister.)

After frequent divisions have taken place, the wall of the spore-capsule becomes differentiated from the inner tissue, out of which are developed the spores and elaters. There is no columel. By rapid extension of the hitherto short pedicel, the calypter is ruptured at the apex, and the globular sporogone, containing the already ripe spores, becomes elevated. The inner of the two layers of which the wall of the sporogone is composed has become absorbed before the ripening of the spores; the single layer of cells which still remains is ruptured at the apex, and splits into four (rarely more) longitudinal valves, which separate suddenly in the form of a star, carrying with them at the same time the elaters, and thus bringing about the dispersion of the spores. The mature elaters are 
long fusiform thin-walled cells, marked internally by from one to three brown spiral bands, but more complicated in structure in the foliose than in the thalloid genera.

Illustrative genera.-Foliose: Radula (Dum.), Jungermannia (L.), I,ejeunia (G. \& L.), Frullania (Radd.), Madotheca (Dum.), Mastigobryum (N. ab E.), Calypogeia (Radd.), Lepidozia (Dum.), Plagiochila (Dum.), Geocalyx (N. ab E.), Chiloscyphos (Cord.), Gymnomitrium (N. ab E.), Lophocolea (Dum.). Thalloid: Metzgeria (Cord.), Aneura (Dum.), Fossombronia (Radd.), Pellia (Radd.), Blasia (Mich.).

\section{LiterATURE.}

Leitgeb-Bot. Zeit., I871, p. 556 ; and Abhandl. Bot. Ver. Brandenburg, 1880, p. 58. Gottsche-Abhandl. Gesell. Naturf. Hamburg, i88o, p. 39.

Goebel-(Epiphytic Species) Ann. Jard. Bot. Buitenzorg, vi., I887, p. 2 r.

\section{Order 2.-MONOCleaceÆ.}

This small order appears to occupy an intermediate position between the Jungermanniaceæ and the Anthoceroteæ. The vegetative structure is either thalloid or foliose. The elongated sporange dehisces longitudinally, and contains elaters, but has no columel.

Principal genus :-Monoclea (Hook.).

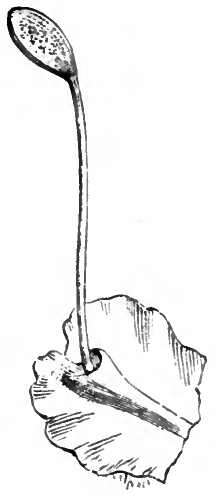

Fig. 143.-Mono:lea Forsteri Hook. (magnified).

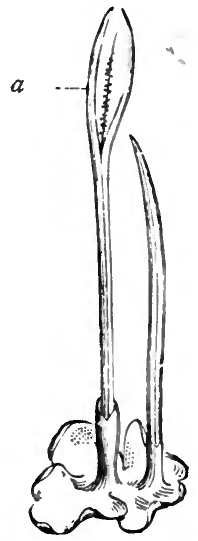

FIG. 145. $-A$. laz'is. a, dehiscent sporange $(\times 2)$.

Order 3.-Anthoceroteæ.

The vegetative structure consists of a flat ribbon-like thallus, the irregular dichotomous ramifications of which form a circular disc composed of one or more layers of cells, each cell containing only a 
single chlorophyll-corpuscle. The antherids and archegones arise endogenously on the upper side of the thallus, apparently without any definite arrangement, and are not protected by a perigyne. The mature sporogone is an elongated dehiscent two-valved pod, provided with stomates, which forces its way through a mass of tissue overarching the archegone, and is known as the involucre. Within the sporange is, in most genera, a solid axial columel; the wall consists of four or five layers of cells ; the rest of the contents, developed from the archespore, becoming the mother-cells of the spores and elaters. Except in some species of Anthoceros (L.) the elaters are of simpler structure than in the other Hepaticæ, having no spiral bands. Anthoceros possesses peculiar cavities on the under side of the thallus, opening by slits or fissures, which are regarded by some authors as stomates, by others as mucilagereceptacles. Filaments of Nostoc, which have found their way into these cavities through the slits, cause peculiar changes in them, and have been mistaken for endogenous gemmæ. The genus Anthoceros is of much interest from the fact that the sporophyte-generation shows a greater vegetative energy than is usually the case with Muscineæ; growth continues at the base of the sporange, and new spores are formed there after those at the apical portion are already mature.

Principal genus:-Anthoceros (L.).

LiteratuRE.

Leitgeb-Die Anthoceroteen, 1879.

\section{ORDER 4.-RICCIACEE.}

The Ricciaceæ are regarded by Leitgeb as forming a connecting link between the Jungermanniaceæ and the Marchantiaceæ; but in some respects they are simpler in their structure than either of these orders. The thallus is usually flat, and branches dichotomously; it floats on water or roots in the soil. In Riella (Mont.) it is submerged and erect, and has the appearance of a ring forming a continuous spiral round an axial stem. It is always destitute of stomates, but is provided with internal aircavities, and with rudimentary foliar organs among the rhizoids. The antherids and archegones are not, as in the Anthoceroteæ, endogenous, but are developed from young superficial cells of the upper surface, which grow into papillæ and become overarched, in the course of their development, by the surrounding tissue. Both antherids and archegones are enclosed in an involucre formed in this way; the antherids are sessile, the involucre sometimes constituting an elevated neck above them. In Riccia (L.) the archegones are ultimately buried in the 
thallus; while in Oxymitra (Bisch.) they are raised above the surface. The sporange is a thin-walled spherical capsule, occasionally produced under water, entirely filled with spores without

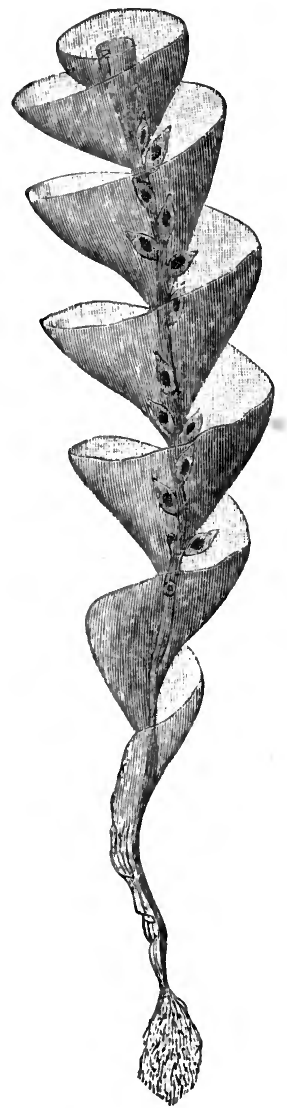

FIs. 146.-Riella helicophyila Mont. (magnified) true elaters or columel, and, with its calypter, depressed in the thallus. It is much less differentiated in its structure than in the other orders. In all the genera except Riccia and Oxymitra the elaters are represented by sterile cells among the spore-mother-cells. The sporange bursts irregularly when ripe, but the spores are only set free by the decay of the

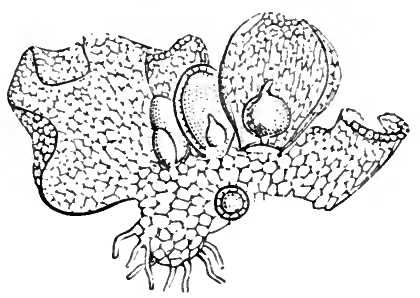

FIG. 147.-Spicerocarpus terrestris Sm. Frond and archegone (magnified).

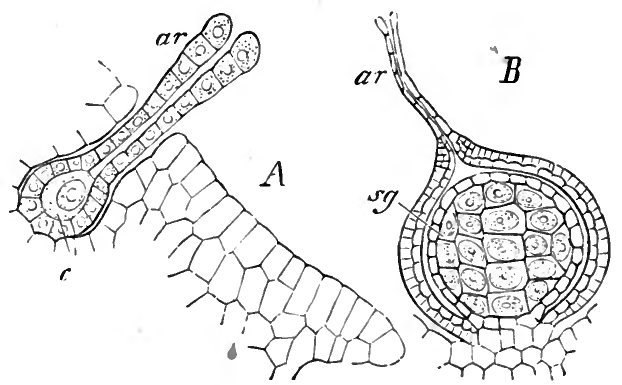

FIG. 148.-Riccia glauca L. $A$, section of apical region of frond. ar, archegone; $c$, oosphere $\left(x_{50}\right)$. $B$, immature sporogone, sg; ar, neck of archegone $\left(x_{300}\right)$. (After Hofmeister.)

surrounding tissue of the thallus. The spores of Sphærocarpus (Mich.) and Corsinia (Radd.) have a beautifully sculptured extine. Riella is altogether diœcious, and perfects its fructification beneath the water.

Principal genera:-Riccia (L.), Duriæa (Bor.), Oxymitra (Bisch.), Riella (Mont.), Sphærocarpus (Mich.), Corsinia (Radd.).

\section{LITERATURE.}

Kny-Pringsheim's Jahrb. wiss. Bot., I866, p. 364. Leitgeb-Die Riccieen, I879. 


\section{ORDER 5.-Marchantiaceש.}

The thallus is flat and ribbon-shaped, and usually branches dichotomously from two apical cells; it is frequently furnished with a well-

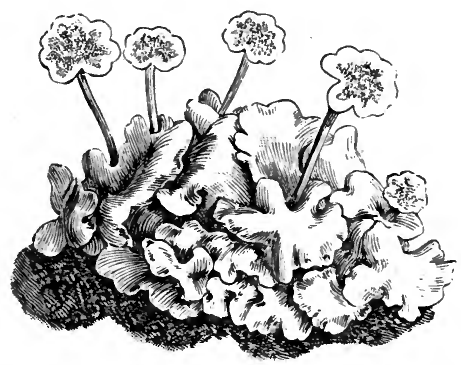

FIG. 149.-Marchantia polymorpha L. Male plant (natural size).

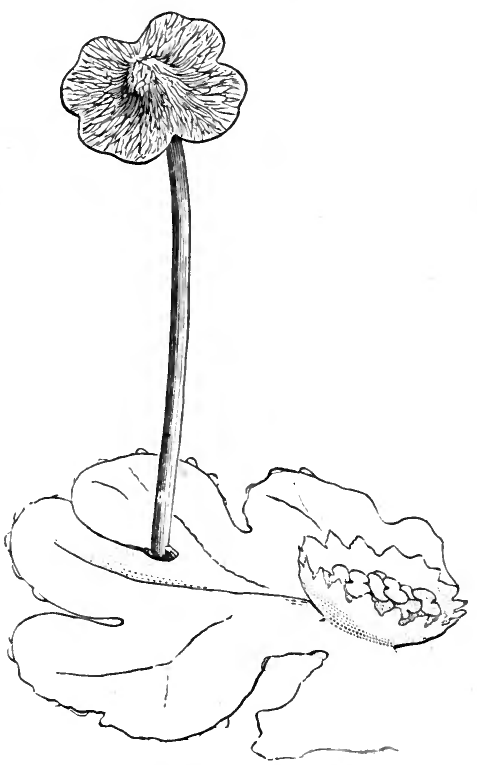

FIG. 150.-M. polymorpha. Male inflorescence and cupule (magnified).

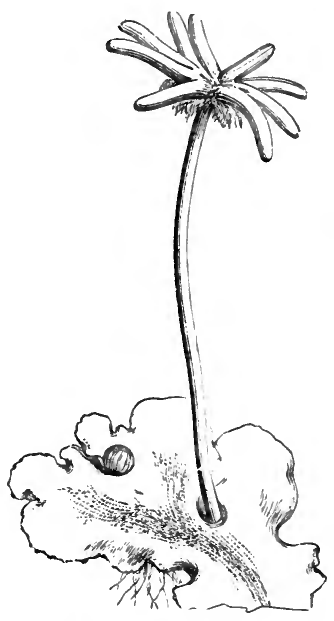

Fig. 15r.-M. polymorpha. Female inflorescence (magnified).

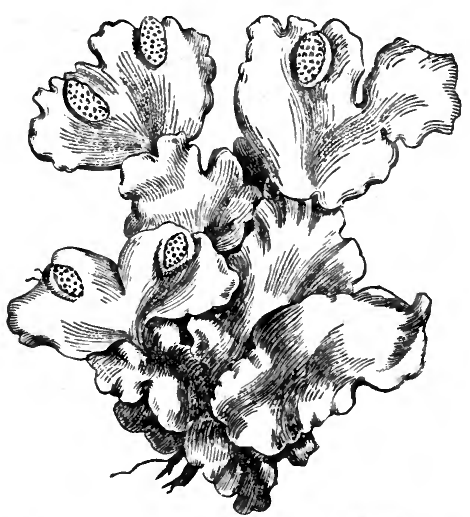

F1G. 152.-Fegatella conica Cord. Male plant (natural size).

marked midrib, and is coriaceous in texture. It is composed of three distinct layers of cells, viz.:-(I) the air-chamber-layer to which the 
stomates belong; (2) a close tissue containing but little chlorophyll, and with the cell-walls pitted or reticulately thickened, without intercellular spaces but sometimes containing mucilage-receptacles; and (3) a ventral
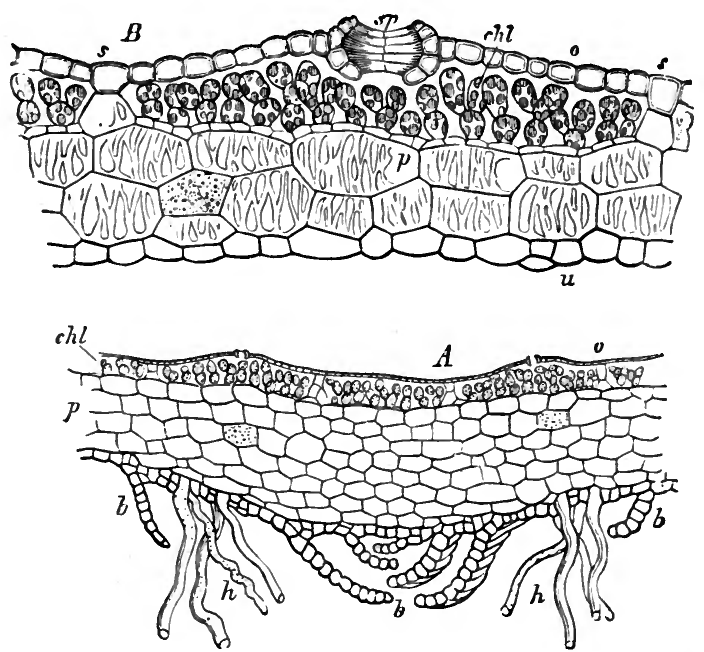

FIG. I53.- $A$, transverse section through middle portion of thallus of $M$. polymorpha $(\times 30) ; B$, through marginal portion (more highly magnified). $p$, colourless layer without intercellular spaces $o$, epiderm of upper side; $c h l$, chlorophyllous layer; $s p$, stomate; $s$, partition-walls between airchambers $;. u$, lower epiderm; $k$, rhizoids, $b$, leaf-like lamellæ. (After Goebel.)

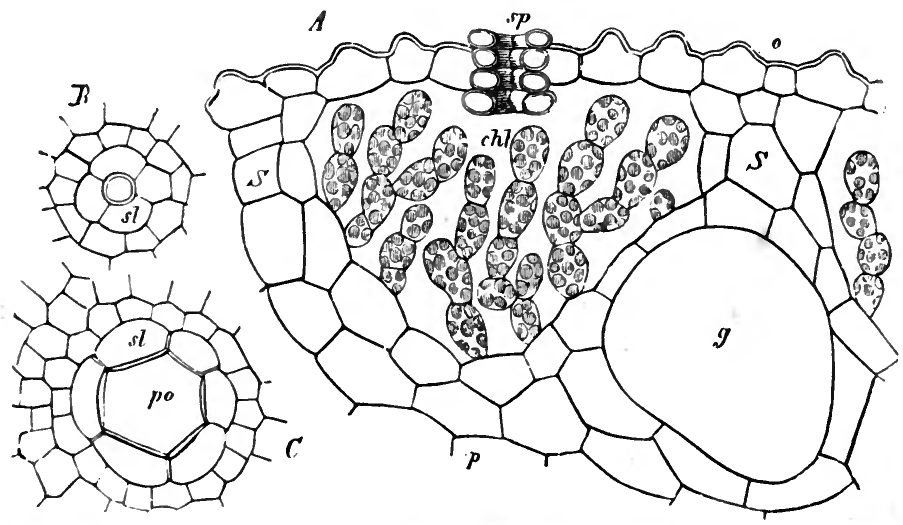

FIG. 154.- Portion of young receptacle of $A T$. polymorpha. A, vertical section; $a$, epiderm; $s p$, stomate; $S$, partition-wall separating air-chamber from chlorophyllous cells; $g$, mucilage-cell.' $B$, $C$, young stomate; po, pore. (After Goebel.)

epidermal layer, from which spring rhizoids and leaf-like lamellæ. The mucilage-passages are especially developed in Fegatella (Radd.) and 
Preissia (Cord.), and the thallus of the latter genus has also rudimentary vascular bundles. The stomates which penetrate the epidermal layer of the upper surface of the thallus into the air-chamber-layer are of a struc-

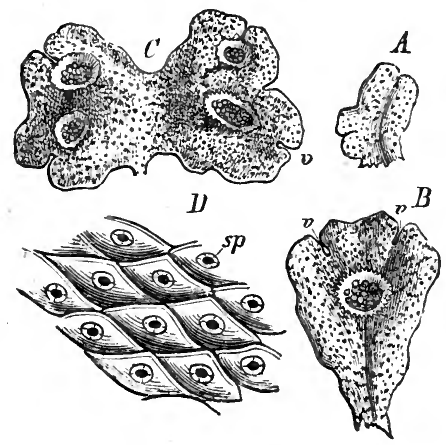

FIG. I55.- $A, B, C$, young shoot of $M$. polymorpha (slightly magnified) with cupules; $v v$, apical region. $D$. portion of epiderm (more highly magnified). $s p$, stomate.

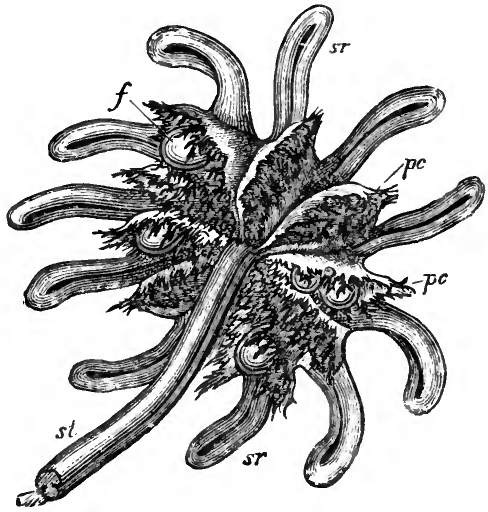

FIG. 156.- Female inflorescence of $M$. poly'morpha seen from the under side. sr, radiating branches; $f$, sporogone. (After Goebel.)

ture quite peculiar to this order. Each stomate is formed, according to Leitgeb, by the simple separation of four or more superficial cells, and the subsequent segmentation of these in a direction parallel to the surface.
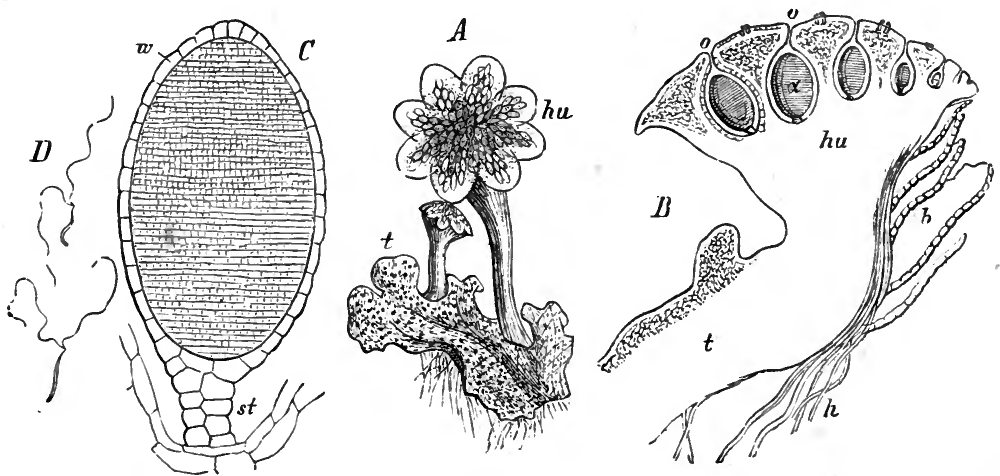

Fig. 157.- $A$, male plant of $M$. polymorpha. $B$, longitudinal section through inflorescence, ha $o, o$, openings to antheridial cavities, $a . C$, nearly ripe antherid. $D$, two antherozoids $(\times 800)$. (After Goebel.)

They are situated in the centre of plates of a rhombic form, consisting of portions of the epidermal layer which overarch large air-cavities. From the base and sides of these air-cavities spring chlorophyllous cells 
in rows directed upwards, but not actually reaching the epidermal layer of cells through which the stomates penetrate; while beneath them is the non-chlorophyllous layer, consisting of cells longest in the horizontal direction without intercellular spaces. Each stomate has a number

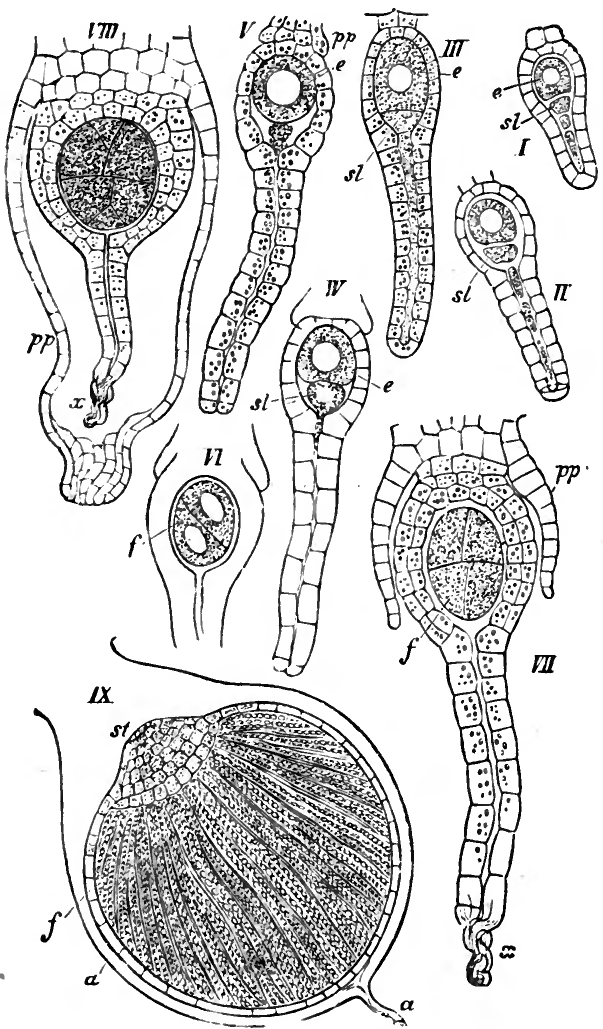

FIG. 158.-Development of archegone of $M$. polymorpha $(\times 300) . \quad I-V$, before, $V I-V I I I$, after fertilisation. $e$, central cell with oosphere; $f$, young embryo ; $s l$, lowest cell of axile row; $p p$, perigyne. $1 X$, immature sporogone in venter of archegone $(\times 30)$; $a$, neck of archegone ; st, stalk of sporange which contains young spores and elaters. (After Goebel.) of guard-cells formed by radial cell-divisions. The details in the structure of the stomates differ in the different genera. Leitgeb describes them as of two kinds, simple and canaliculate. The former are epidermal pores situated immediately above the airchambers; the latter, which occur in Marchantia and Preissia, have the appearance of canals excavated in the surface of the thallus. Some of the rhizoids of Marchantia are characterised by singular internal thickenings to the cell-wall. The peculiar nonsexual organs of propagation of Marchantia, Lunularia (Mich.), and other genera, known as cupules, have already been described (figs. I 50, I55). A peculiar nonsexual mode of propagation by means of gemmæ occurs in Fegatella (Radd.).

The sexual reproductive organs of the Marchantiaceæ are, in most of the genera, borne on erect branches of the thallus of a peculiar umbrella-like form, which have been variously termed receptacles, discs, and inflorescences. They may be male, female, or bisexual ; and, when unisexual, the species may be monœcious or diœcious. In Fegatella the male inflorescences are oval discs sessile upon the thallus (fig. I $^{2}$ ). The inflorescence is generally regarded 
as a transformed thalloid axis. The antherids spring from superficial cells of these branches which are depressed in hollows on the upper surface of the disc, and become overarched by the surrounding tissue. With the exception of one section, the Targionieæ, in which they occur at the apex of ordinary shoots, the archegones are borne on the under surface of the female discs, which are always stalked, while the male discs may be either stalked or sessile. The archegones are variously surrounded by involucres or perigynes. Leitgeb describes the sexual organs as being at first distributed over the surface of the thallus, and becoming subsequently collected into groups or inflorescences, which have at first a dorsal position, but become constantly pushed towards the apex. The mature sporange is usually shortly stalked, and contains elaters, which radiate from the centre towards the circumference. It has no central columel. It either dehisces at the apex with numerous teeth, or is four-lobed, or the upper portion becomes detached by an annular fissure as an opercule. The elaters are well developed, and are furnished with several spiral bands, but do not usually appear to take any part in the expulsion of the spores from the sporange.

The thallus of many Marchantiaceæ displays remarkable hygroscopic properties, which have their seat in the 'mechanical' layer, i.e. the layer of closely packed cells containing but little chlorophyll, which underlies the air-containing assimilating layer. On desiccation this layer contracts

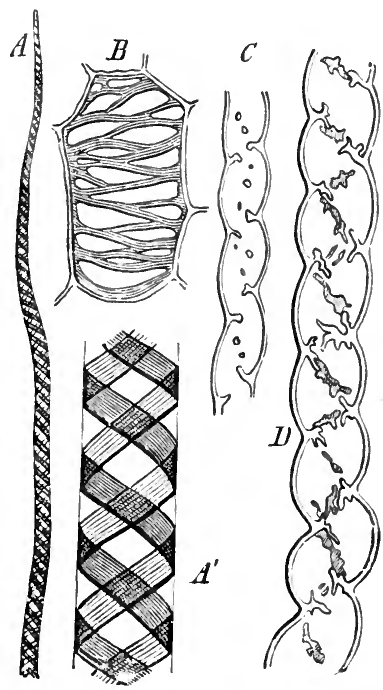

F'IG. I59. $-A$, piece of elater of $M$. polymorpha (magnified). $A^{\prime}$, a portion more highly magnified. $B$, pitted cell of thallus. $C, D$, rhizoids with internal thickenings. greatly, so that the epidermal layer with its stomates is completely protected from further evaporation by the recurved ventral surface covered with brown or violet scales. In this condition the dried-up thallus may retain its vitality for a very long period. The cells of the mechanical layer are frequently occupied by colonies of Nostoc.

Illustrative genera:-Marchantia (L.), Targionia (L.), Fegatella (Radd.), Reboulia (Radd.), Fimbriaria (N. ab E.), Dumortiera (N. ab E.), Plagiochasma (L. \& L.), Preissia (Cord.), Lunularia (Mich.). 


\section{LITERATURE.}

Mirbel--Mém. Acad. Sc., xii., I 835 .

Strasburger-Pringsheim's Jahrb. wiss. Bot., I870, p. 409.

Vogt-Bot. Zeit., 1879, pp. 729 and 745 .

Goebel-Arb. Bot. Inst. Würzburg, I88o, p. 529.

Leitgeb-Sitzber. Akad. Wiss. Wien, I880, pp. 40 and I23; and Die Marchantieen, I $88 \mathrm{I}$.

Prescher-(Mucilage-receptacles) Sitzber. Akad. Wiss. Wien, 1882.

Mattirolo-(Hygroscopic Properties) Malpighia, ii. I888, p. I8I.

\section{FOSSIL MUSCINEÆ.}

No remains have been found earlier than the Tertiary formations which appear to belong to Muscineæ. Here and in the Quaternary beds remains or impressions occur which have been referred to various families of Musci and Hepaticæ, including leaves of a single species of Sphagnum and a single moss-capsule. The leaves of Jungermanniaceæ are not uncommonly found enclosed in amber. 


\section{THIRD SUBDIVISION AND CLASS IX.}

\section{CHARACEAE.}

THE true position of this small group in a natural system of classification has been a subject of much controversy. By some writers of high authority it is regarded as occupying the highest place among green Algæ. On the other hand, although without any lignification of their tissue, the Characeæ display, in the structure of their vegetative organs, a distinctly higher type of structure than the Thallophytes, in the distinct differentiation of the plant into a primary axis or stem, and secondary axes or branches; but the branches are similar in structure to the primary stem. They are, in fact, Cormophytes rather than Thallophytes; and it seems best to retain them as a distinct subdivision intermediate between the Muscineæ and the highest Algæ.

The plant is acrogenous, growing by means of an apical cell contained in an apical bud; the main stem has indefinite apical growth, the branches increasing by definite apical growth. The branches and the organs of sexual reproduction grow in the axils of other lateral organs of more simple structure, which are usually termed leaves; those that subtend the reproductive organs being by some writers described as bracts or bracteoles. In all the Characeæ these appendicular organs spring in whorls from well-defined nodes of the primary stem, imparting the peculiar habit to the plants by which they are distinguished from nearly all other Cryptogams. Each internode consists, in the Nitelleæ, of a single very large cell extending along its whole length, and many times longer than broad. In the majority of the Chareæ this internodal cell is invested by a layer of similar elongated cells of much smaller diameter arranged spirally round it, collectively known as the cortex, and giving the stem the appearance of being spirally striated. Each node consists, in the corticated species, of a single layer or plate of small cells from which the cortex is derived. From the nodes spring the whorls of branches and their subtending leaves. The branches are altogether similar in structure to the primary axis. The leaves have also, in the Charex, a simple cortical layer, with the exception of the apex, where 
the large terminal cell is exposed. In addition to the leaves there spring, from the basal nodes of some species of Chara (L.), other leaflike structures known as stipules, one, two, or three in connection with

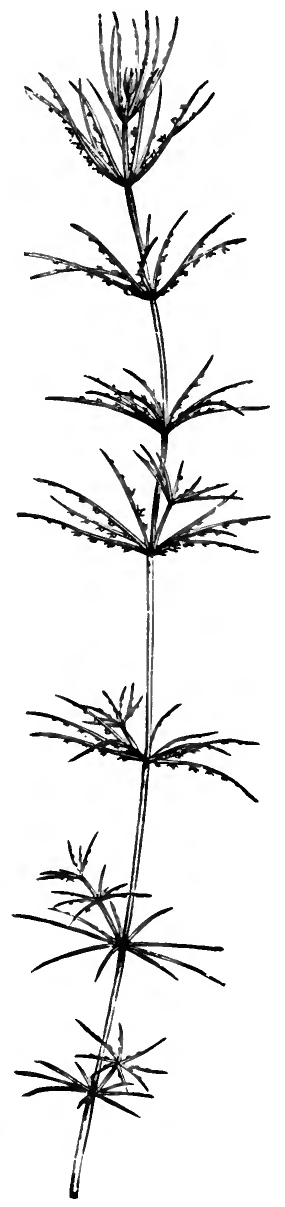

FIG. T60.-Chara fragilis Desv. (natural size). each leaf. The stipular cells are always undivided by septa, and arise as papillæ on the cortical cells.

The cortex of the stem and branches is developed out of the nodal plate of cells; the upward and downward prolongations from the nodes usually meeting about the middle of each internode, where they dovetail into one another. These cortical internodal cells do not, however, like the axial cells, remain entire; they divide, both transversely and longitudinally, into three parallel rows of cells, the central row of each series being somewhat elevated into a ridge. The mode and extent of development of the cortical cells vary according to the species. The number of leaves in a whorl

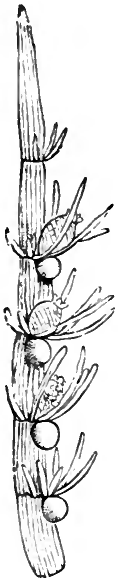

F1G. I6r.-Fertile branch of $C$.his. pida L. (mag. nified). is usually from four to ten. At the lower part of the main stem the internodes are shorter, and from the nodes spring rhizoids or rooting filaments which serve to fix the plant in the soil, consisting of long hyaline nearly undivided tubes, which grow obliquely downwards, and lengthen only at their apex. The rhizoids are always trichomic, springing from superficial cells.

The nearly hemispherical apical cell of the terminal bud of the stem first divides by a transverse wall into a new apical cell and a disc-shaped segment-cell. Each segment then again divides by a wall parallel to the first; the lowest of these does not again divide, but develops into the axial internodal cell, while the upper one undergoes vertical division, and becomes a node. Each successive whorl on the main stem alternates with those immediately above and below it, so that the oldest leaves of a 
whorl, which subtend the branches, are arranged in a spiral line running round the stem; but this is not the case with the branches or secondary axes, where the members of contiguous whorls are superposed.

The Characeæ exhibit in an especially clear and beautiful manner the phenomenon of $c y c l o s i s$, or rotation of the protoplasm (see fig. I6 3 ). The best objects for observation are the large internodal cells of Nitella (Ag.), the apical cells in the leaves of Chara, or some of those belonging to the reproductive organs, especially to the 'manubria.' The cell first of all develops vacuoles in its protoplasm, which coalesce into a single

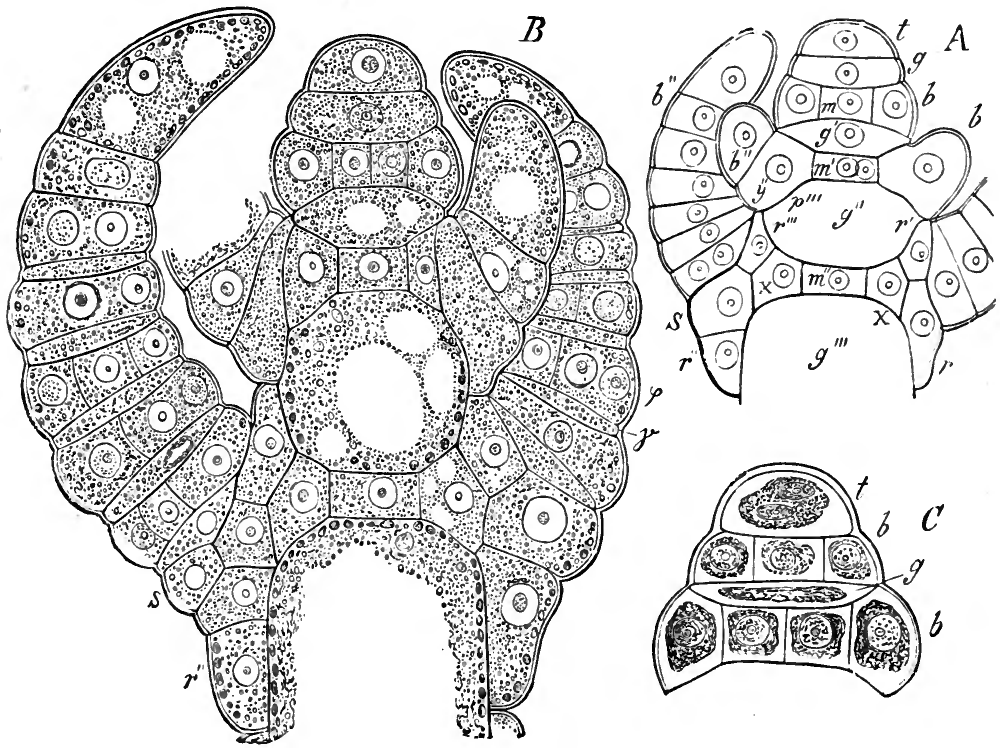

FIG. I62.-Longitudinal section through bud of $C$. fragilis, showing apical cell, $t$, and segments, $g, b$. $A$, cells empty. $B$, with cell-contents, granular protoplasm, chlorophyll-grains, and vacuoles. $C$, with cell-contents contracted by iodine $(\times 500)$. (After Sachs.)

large sap-cavity. The outermost thin parietal layer of protoplasm, in which are imbedded most of the grains of chlorophyll, remains motionless; within this motionless lining is a thick layer of protoplasm, in which a regular current gradually sets up, up one side of the cell and down the other; the boundary between the two currents being marked by hyaline bands entirely destitute of chlorophyll, the neutral zones, in which no movement is visible. The direction of the rotating movement in each cell stands in a definite relation to that of all the other cells of the plant. From time to time the movement ceases, and then begins again in the opposite direction. Before the rotation commences the cell-nucleus has 
usually broken up into a number of fragments. The current is most rapid next to the stationary parietal layer, and becomes gradually slower towards the interior. As the cell grows the rotating protoplasm becomes differentiated into a watery and a less watery denser portion, the former having the appearance of a hyaline cell-sap, in which the latter floats in the form of larger or smaller roundish lumps. Since these denser bodies are passively swept along by the clear rotating protoplasm, the appearance is presented as if the cell-sap caused the rotation. Together with the denser lumps of protoplasm of less regular form, there are also a number of globular masses carried along in the current, which are covered with delicate protoplasmic spines or cilia; their nature and function are involved in obscurity.

Owing to the large size of the cells and the distinct differentiation of the nucleus, the internodal cells of the main axis of Chara and Nitella, as well as the apical cells of the leaves, have been largely used for following the complicated processes connected with cell-division and the division of the nucleus. Schmitz describes the process as one of 'direct division of the nucleus,' Treub and Strasburger as one of 'fragmentation;' Johow differs in some respects from all previous observers; Cagnieul (Bull. Soc. Bot. France, r884, p. 2 I I) finds the process especially easy to follow in the mother-cells of the antherozoids. Schaarschmidt (Bot. Centralblatt, vol. xxii., I 885, p. I) describes peculiar cellwall thickenings and grains of 'cellulin' in Chara hispida (L.).

The Characeæ do not produce spores, i.e. single non-sexual propagative cells; but are multiplied non-sexually in three different ways, the nodes being always the place of origin of the propagative cells. (I) Chiefly in Lychnothamnus stelliger (A.Br.), but also in C. hispida, C. aspera (Willd.), and Lamprothamnus alopecuroides (A.Br.), structures called bulbils or 'amylum-stars' are formed, agglomerations of cells developed round the larger internodal cells at the level of the nodes; they are of beautiful regularity, and are densely filled with starch and other foodmaterials. On germinating they appear to produce at first other bulbils, and from these a new plant. (2) Chara fragilis and other species produce, on old hibernating or on cut nodes, in the axils of the leaves, peculiar branches known as gymnopodal shoots, which differ from the ordinary branches in the partial or entire absence of the cortex in the lowest internode and in the first whorl of leaves. The cortical branches which descend from the first node become detached, bend upwards, and propagate themselves. (3) Also on C. fragilis, Pringsheim describes the occurrence of 'pro-embryonic,' or more properly of prothalloid branches. These also spring from the nodes of the main axis, but differ essentially from the ordinary branches, presenting a similar structure to the pro- 
thallium or 'pro-embryo' which proceeds from the germinating oosperm. No mode of vegetative propagation is known in the other genera.

The sexual reproductive organs of the Characeæ, the male antherids and the female archegones, are visible to the naked eye as minute orangered globes and elliptical green bodies springing from the nodes in the axils of leaves or bracts. The antherids are globular bodies, of a bright red colour when mature, from $\frac{1}{2}$ to $\mathrm{I} \mathrm{mm}$. in diameter, morphologically the terminal cell of a leaf or lateral leaflet. The moderately thick wall of the antherid is made up of eight flat disc-shaped cells called shields, four of which, situated round the distal pole of the ball, are triangular, while the four situated round the base are four-sided. On their inner face there lies a layer of chlorophyllgrains, which eventually turn red, while the outer face is clear and transparent; the walls of these cells are folded inwards at the edge where they meet. From the centre of the inner face of each shield a cylindrical cell, termed a handle or manubrium,

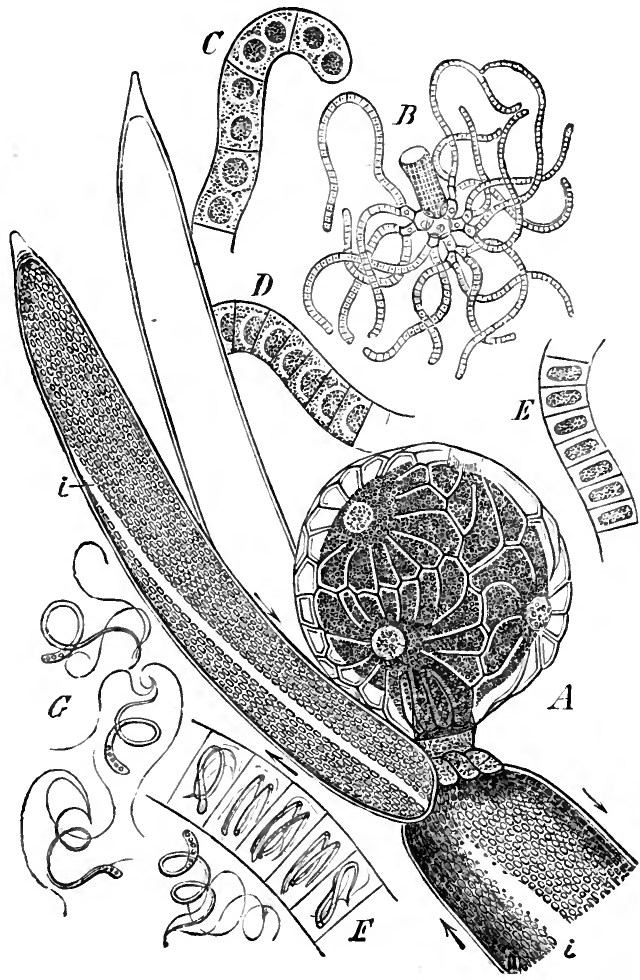

FIG. 163.-Nitella Alexilis Ag. A, nearly ripe antherid sub. tended by two bracts showing direction of protoplasm-cure ents, and neutral zone, $i . \quad B$, manubrium, with capitulum, secondary capitula, and whip-like filaments. $C-F$, antheridial filaments, showing formation of antherozoids. $G$, antherozoids $(C-G \times$ 550). (After Sachs.)

projects inwards nearly to the centre of the globe. The antherid is supported on a short flask-shaped pedicel-cell, which also projects into the interior between the four lower four-sided shields. At the free end of each of the eight manubria is a roundish hyaline cell, the head-cell or capitulum. These twenty-five cells-viz. the eight shields, eight manubria, eight capitula, and the pedicel-cell-constitute the 
framewurk of the antherid. Each capitulum bears six smaller cells, or secondary capitula; and from each of these grow four long whipshaped filaments, bent into a number of coils and filling up the interior of the globe. The manubrium, capitulum, secondary capitula, and whip-shaped filaments, bear a resemblance to a many-thonged whip. The number of these filaments in an antherid amounts to nearly 200 , and each filament is divided by transverse septa into from 100 to 200 small disc-shaped cells. The protoplasm in each of these antheridial cells becomes gradually transformed into an antherozoid strongly resembling the corresponding organ in Muscineæ rather than in Thallo-

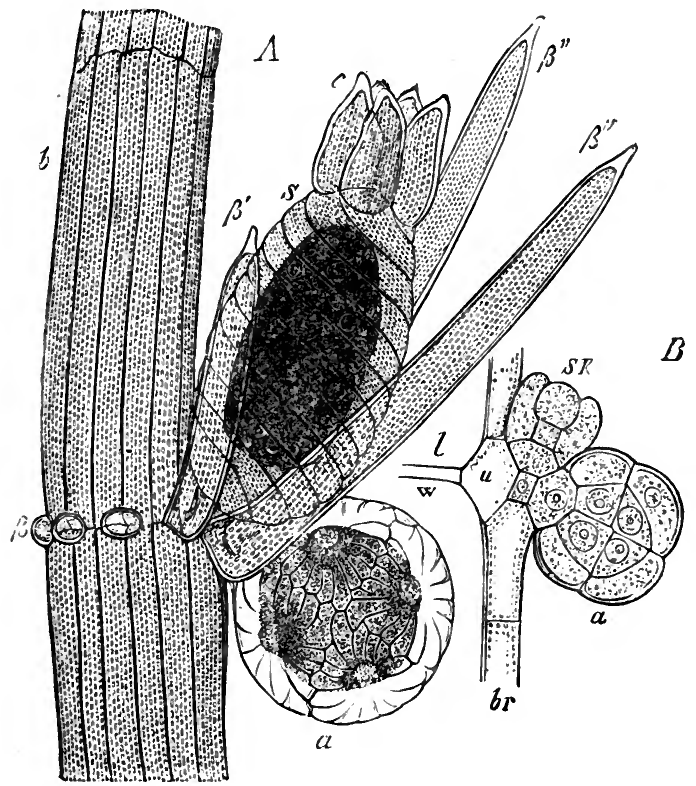

Fig. I6+. $-A$. portion of branch of $C$. fragilis; $a$, antherid ; $S$, archegone; $c$, crown ; $\beta^{\prime}, \beta^{\prime \prime}$, bracts $(\times 50), B$, a young antherid $; S K$, young archegone ( $\times 350)$. 'After Sachs.)

phytes. It is a slender thread of protoplasm coiled spirally like a corkscrew, somewhat thickened at the posterior end, and bearing at its pointed anterior end two long fine cilia. The number of antherozoids in an antherid is, as will be seen, from 20,000 to 40,000 . When ripe, the eight shields fall apart, and the antherozoids escape from their mother-cel's, and move about rapidly in the water by means of their vibratile cilia. This appears generally to take place in the morning, the antherozoids swarming about for some hours till the evening. 
The Characeæ are either monœcious or diœcious. In the former case the male and female organs are formed in close juxtaposition on the same node, the archegone being somewhat below the antherid in Nitella, above it or by its side in Chara. The archegones, like the antherids, are metamorphosed leaves. When ready for fertilisation, the archegone has a longer or shorter ovoid form, and is borne on a short pedicel-cell. In the interior is an axial row of cells enveloped by five tubes, which are at first straight, but are afterwards coiled spirally round the axial row. The lowest portion of each of these tubes is an elongated unsegmented cell; while at the upper part one or two very small cells are segmented off. In Nitella each of the terminal cells again divides into two by a vertical septum. The five terminal cells of Chara and the ten terminal cells of Nitella are not twisted, and form together the crozen. When the archegone is ready for impregnation these crowncells separate from one another, forming the neck, and leaving an open passage down to the axial row. This apical cavity is, however, very nearly closed below by a diaphragm formed by the projecting inwards of the five neck-cells, through which there is only a very narrow opening for the entrance of the antherozoids. The apical cell of the axial row is much larger than the rest, and is the female or germ-cell, corresponding to the

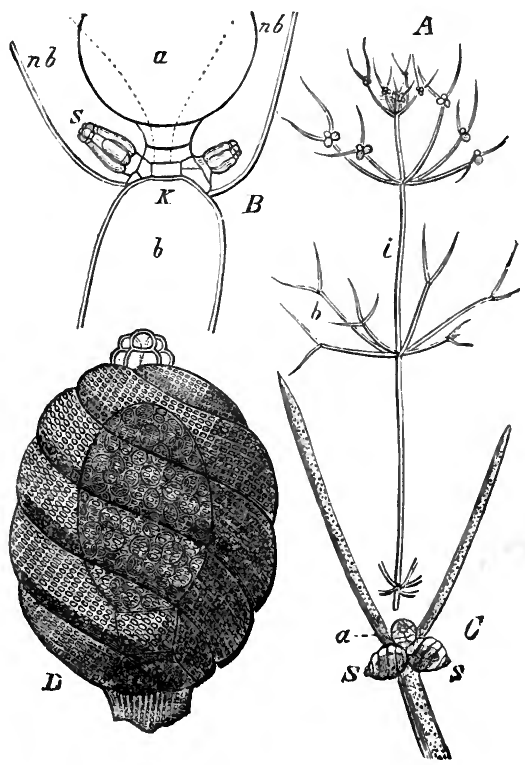

FIG. 165.- $A$, fertile branch of Nitella fexilis (natural size) $;$, internode $: b$, branches. $B$, upper portion of fertile leaf, $b ; \dot{K}$, node $; \boldsymbol{n} b$, bracts $; S$, young archegone. $C$, older leaf with two bracts ; $a$, antherid ; $S$, spermocarp. $D$, half-mature spermocarp (highly magnified). (After Sachs.) central cell in the archegone of the higher Cryptogams. It is filled with protoplasm, oil-drops, and starch-grains; its apical portion, the apical papilla, or receptive spot, containing only hyaline protoplasm. Between the apical cell and the pedicel-cell of the archegone, there is in Chara only a single cell, in Nitella a group of cells, the 'Wendungszellen.' Before fertilisation the crown is a compact structure covering the apical cavity; but when the archegone is ready for impregnation a small aperture is formed in its 
centre, through which the antherozoids force their way, and finally enter the apical cell by the deliquescence of the upper portion of its cell-wall, and coalesce with the apical papilla. The whole contents of the apical cell may be regarded as the oosphere.

Impregnation causes at first very little external change in the structure of the female organ. The protoplasm of the oosphere, now invested with a cell-wall and transformed into an oosperm, gives place to starchy or oily matter; the walls of the enveloping tubes which lie next it increase in thickness and hardness, and the oosperm thus becomes invested in a hard black shell or pericarp. The structure thus formed, the socalled 'fruit' or spermocarp of the Characeæ ultimately becomes detached, falls into the mud at the bottom of the water, and there germinates in the next spring.

When the spermocarp germinates, the oosperm first divides into
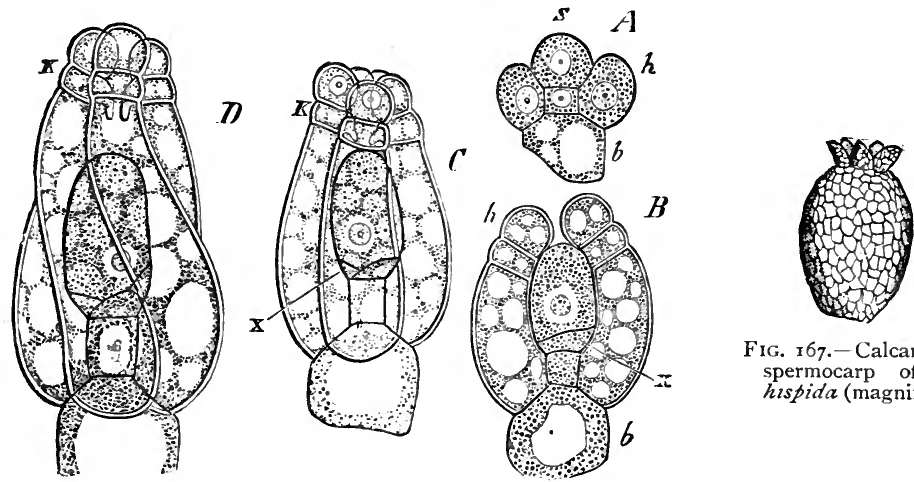

Fig. 167.-Calcareous spermocarp of $C$. hıspida (magnified).

Fig. I66. $-A-D$, stages in development of archegone of $N$. Aexilis. $b$, apex of fertile leaf; $x$, 'Wendungszellen;' $K$, crown $(\times 300)$. (After Sachs.)

three cells, a large basal and two apical cells, the former apparently serving the purpose of supplying with nutriment the young plant which proceeds from the latter; and these three cells may be said together to constitute the embryo. From one of the two apical cells proceeds a long hyaline unseptated filament, coirmonly called the primary root, by means of which the young plant is attached to the soil. The other of the two apical cells develops into a hypha-like filament, consisting at first of a single row of cells with limited apical growth, and called by some writers the 'pro-embryo,' or more correctly the prothallium. In this prothallium are developed two primary nodes at considerable distance from one another, and separated by a very long internode. From the lower of these two primary nodes there springs a whorl of rhizoids, which soon 
usurp the functions of the primary root. The upper of the two nodes is still at some distance from the apex of the prothallium, this apical portion above the upper node consisting of a few much shorter cells. From this upper node is developed the new plant. It is divided by longitudinal septa into two inner and six or eight peripheral cells. The peripheral cells ultimately become rudimentary leaves, which do not, however, form a true whorl. In the midst of them appears a bud, or growing point, developed from one of the inner cells, from which springs the new stem, in a direction nearly at right angles to that of the prothallium. At present the formation of the prothallium has been observed only in the genus Chara.

A remarkable instance of parthenogenesis has been recorded in Chara crinita (Wallr.). The species is dicecious, and male plants are extremely rare. On the female plants the oospheres develop into oosperms without apparently any possibility of their having been impregnated; and the spermocarps thus formed germinate in the ordinary way.

The Characeæ consist of only a comparatively small number of species, but some of them very abundant, growing submerged in deep or in shallow, in stagnant or in running, or occasionally in brackish water. Several species are grown with great facility in fresh-water aquaria, where they multiply very rapidly. The presence of certain species may be detected by the foetid odour of sulphuretted hydrogen given off when decaying. Phipson (Compt. Rend., lxxxiv., 1879, pp. 316, I078) attributes this odour to the presence of a special substance which he calls characin. The typical genus Chara is distinguished by its power of extracting calcium carbonate from the water in which it grows, the whole plant becoming thus covered with a calcareous incrustation, which frequently renders it difficult to make out the

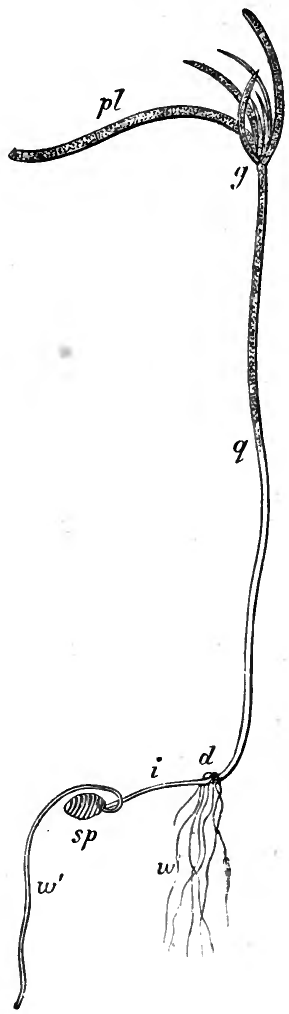

FIG. I68.-Germination of $C$. fragilis. sp, spermocarp; $w$, first root ; $i$, first internode of prothallium; $d$, first node ; $w$ " $w^{\prime \prime}$ rhizoids; $q$, second elongated internode of prothallium; $g$, second'node with first whorl of leaves; pl, apical portion of prothallium $\left(x_{4}\right)$. (After Pringsheim.) structure. Hence the family has acquired the popular names of 'brittleworts' and 'stoneworts.' Nitella translucens (Ag.) sometimes forms enormous mat-like masses at the bottom of ponds.

The systematic position of the Charaçe has been a matter of much 
controversy. In habit and in general appearance they resemble the Algæ, among which they are placed by the majority of writers. But in some important points of structure they differ so widely from all known families of Algæ, that a true estimate of their relationships appears to require their location in a distinct subdivision by themselves. With the exception of the Fucaceæ and the Conjugatæ, the Characeæ stand alone among the larger groups of Cryptogams in the entire absence of true spores. Seeing that the oosperm germinates directly in the soil, the embryo which results from its first divisions developing directly into the new plant, there is no 'alternation of generations' in any accurate sense of the term. From those classes where a true alternation of generations attains its fullest development, the Muscineæ and Vascular Cryptogams, the Characeæ differ in the complete suppression of the sporophytegeneration; while Phanerogams (at all events those Angiosperms which are destitute of endosperm) deviate, on the other hand, in the suppression of the oophyte-generation. In the investment of the oosperm with a lignified pericarp directly without any previous breaking up into carpospores, the Characeæ again differ essentially from all classes of Algæ.

The Characeæ are divided into two orders, viz.-

I. ChareÆ.-Stem and branches usually corticated and calcareous; leaves usually with one or two stipules at their base; antherids usually solitary on each node; crown always five-celled; pericarp often calcareous. Genera : Chara (L.), Lamprothamnus (A. Br.), Lychnothamnus (Leon.).

2. Nitelles.-Stem and branches not corticated nor calcareous; leaves without stipules; archegones often clustered; crown always tencelled; pericarp not calcareous. Genera: Nitella (Ag.), Tolypella (A. Br.).

\section{LiteratuRe.}

Göppert and Cohn--Bot. Zeit., I849, pp. 665 et seq.

Braun-Monber. Berlin Akad. Wiss., I852, p. 220 ; and I853, p. 45 ; and (Parthenogenesis) Abhandl. Berl. Akad. IViss., I 856, p. 337.

Thuret-Ann. Sc. Nat., xvi., I 85 I, p. 18.

Montagne-Ann. Sc. Nat., xviii., 1852, p. 65.

Nägeli-Beiträge zur wiss. Bot., ii., r860, p. 61 .

Pringsheim-Jahrb. wiss. Bot., 1863, p. 294.

Braun-Conspectus systematicus Characearum europæarum, 1867; and Abhandl. Berlin Akad. Wiss., I 882.

De Bary-Monber. Berlin Akad. Wiss., I871, p. 227 ; and Bot. Zeit., I875, pp. 377 et seq.

Bennett-Journ. of Bot., I878, p. 202.

Groves-Journ. of Bot., 1880, p. 97. 
Müller-Bull. Soc. Bot. Genève, I881.

Johow-Bot. Zeit., I88I, pp. 729 et seq.

Nordstedt-Hedwigia, I888, p. I8r.

Allen-Characeæ of America, 1888.

\section{FOSSIL CHARACE $Æ$.}

In various strata, commencing with the Cretaceous, remains known as gyroliths are found, sometimes in great abundance, which appear to be the petrified pericarp of the spermocarp of Characeæ. Upwards of forty species have been described, some of them closely resembling existing forms. 


\section{FOURTH SUBDIVISION.}

\section{$A L G A$.}

THE degree of affinity between the small group of Characeæ and the very large group of Algæ is, as has already been mentioned, a point on which the best authorities are not agreed. But, in passing from one to the other, we finally cross the line which separates the Cormophytes from the Thallophytes. From this point we have to do exclusively with plants whose vegetative organs are in no sense differentiated into axial and appendicular, and which further contain no true vessels and no woody tissue. On their lower limit there is no sharp line of demarcation between the Algæ and the chlorophyllous Protophyta, but the consideration of Algæ as a group by themselves, distinct from Fungi, we regard not only as convenient, but as also most in accordance with their probable affinities.

Within the limits above mentioned, the degree of complexity in the structure of Algæ is very various, and the different types will be best described under the separate families. In their vegetative structure we may recognise three types: the elaboration in the development of a single cell, the loose association of cells into a family or canobe, and the close aggregation of cells into a flament or a thallus. To the latter belong all the higher families, and in some of these we see indications of the various kinds of tissue found in vascular plants. The higher forms, consisting of a well-developed thallus of large size, in which the cells are associated with one another in all three directions, are almost exclusively marine, and include the whole of the organisms popularly known as seaweeds. In the larger forms the plant is attached to the substratum - a rock, stone, or other large alga-by a root-like organ of attachment known as the disc. The attachment is, however, always superficial, and the organ takes no part in the absorption of nourishment for the plant. 'The organ may result from the repeated division of a single cell, or it may be more complicated, being formed out of the termination of the downward growth of cortical rows of cells. In nearly all fresh-water Algæ the single cell, the cœnobe, or the filament is en- 
closed in a more or less strongly developed gelatinous sheath. The greater number of families exhibit both a sexual and a non-sexual mode of reproduction, though in some cases one or the other mode has not yet been detected. In the great majority of families the non-sexual propagating bodies are motile cells or zoospores, minute masses of protoplasm formed singly from the whole contents of a cell by rejuvenescence, or more often in large numbers by free-cell formation, destitute of a true cellulose membrane, but containing protoplasm and a contractile vacuole, and provided with two or sometimes a larger number (rarely only one) of vibratile cilia, by means of which they move about actively for a time, then come to rest, excrete a cellulose membrane, and develop into a new plant. In one class only, the Florideæ, are the zoospores replaced by non-motile tetraspores; in the Conjugatæ and Fucaceæ they are altogether wanting. The simplest form of sexual reproduction is that of conjugation, or the coalescence of two comparatively undifferentiated masses of protoplasm. These masses of protoplasm may be either the contents of stationary cells, which are nearly or quite alike, as in the Conjugatæ, or they may be motile ciliated bodies indistinguishable from zoospores-zoogametes-or they may be distinguished from the true zoospores by their smaller size. From the conjugation of zoogametes there is a gradual transition through intermediate stages to a true sexual process, the impregnation of a stationary oosphere by a motile antherozoid, usually much smaller than the oosphere, the result being the production of an oosperm by the encysting of the oosphere in a coat of cellulose. In the higher families the oospheres and antherozoids are formed in special cells or organs, known as oogones and antherids respectively. In the Florideæ the process displays very great complication; the structure in which the oosphere is formed is known as the carpogone; the fertilised oosphere is the carposperm, which often breaks up into carpospores. In this class also the antherozoids are replaced by motionless protoplasmic bodies known as pollinoids. Multiplication by the simple fission of individuals, by the detachment of gemma, or buds, and by the encysting of special cells or masses of cells into cysts, also occur. In the green Algæ (Confervoideæ heterogamæ and isogamæ and Conjugatæ) single nonmotile cells which become detached for the purpose of propagation are termed by Wille akinetes when they are formed without rejuvenescence, aplanospores when formed by rejuvenescence. The former occur in Trentepohlia (Mart.), Conferva (L.), and Ulothrix (Ktz.), as well as in the Nostocaceæ and Rivulariaceæ, the latter in the Confervaceæ. The two kinds pass into one another, and akinetes into vegetative cells, by insensible gradations. 
Any classification of Algæ which attempts to follow the lines of affinity -in other words, any natural system of classification-must be based on a consideration of both the vegetative and the reproductive organs. All the families of Algæ appear undoubtedly to have sprung from the РRотососсоIDEÆ, and their further development has taken place in three directions-the perfection and differentiation of the individual cell, the association of cells into cœnobes, and cell-division. The production of cœnobes may be supposed to start from such forms as Botryococcus among Protococcacea; the first step in the development of the CENobiæ being the Sorastrea, including Sorastrum, Cœlastrum, and Selenastrum, motile colonies of non-ciliated cells, with no known production of zoospores. The series attains a much higher development in the Pandorinea, including Pandorina, Gonium, and Stephanosphæra, where reproduction is effected by the conjugation of zoogametes. Simple organisms like Chlamydomonas and Chlamydococcus, consisting merely of conjugating zoogametes, are possibly retrogressions from the higher forms, though they may also be stages in a direct ascent from Protococcus. Eudorina, with a rudimentary differentiation of antherozoids and oospheres, unquestionably indicates the line of development of Volvox, in which this differentiation is more strongly developed. In Volvox we have the culmination of the attempt of nature to evolve higher organisms out of conobes. Hydrodictyon is probably an aberrant member of this group, and the Pediastrea are more or less nearly related to them.

From the Eremobice the fuller development of the individual cell has advanced a further stage in the Multinucleate, composed of the Siphonocladacee and Siphonea, and characterised by each individual consisting of an enormously developed cell, often ramifying greatly and. attaining gigantic dimensions, and possessing several, often a very considerable number, of nuclei. In the Siphonocladaceæ the only known mode of reproduction is by the conjugation of zoogametes; and Botrydium displays a distinct affinity with Botrydina among the Eremobiæ. The Siphoneæ or Cœloblastæ, represented by Vaucheria, are a higher development of the same series, in which true sexual organs, oogones and antherids, are formed in addition to non-sexual zoospores ; and in this genus culminates the striving after a higher development in the elaboration of a single cell.

A rudimentary cell-division is exhibited in the Nostochinea among Protophytes, but accompanied by other conditions which prevented its full success there. Where cell-division originated in the Protococcoideæ is not clear, probably in the Eremobiæ; we find it already fully developed in the CONFERvoIDEæ ISOGamæ, the members of which consist of a 
single unbranched or branched filament of cells, the only known modes of multiplication being the conjugation of zoogametes and the direct germination of larger zoospores. In the lowest two classes, the Chroolepidea and Ulotrichacea, embracing a very small number of genera, the filament is usually unbranched; in the two higher, the Confervacea and Pithophoracee, further vegetative activity is displayed in the copious branching : and in the former we have an indication of affinity with the Multinucleatæ in an occasional plurality of nuclei.

The exact course of evolution from the isogamous Confervoideæ is obscure, but it would appear to have taken place in three distinct lines. The first of these, which evidently came to an abrupt conclusion, is the Conjugate, consisting of the Zygnemacee, Mesocarpere, and Desmidiea, a well-marked and sharply differentiated group with no near affinities. 'The first two orders, consisting of unbranched filamentous forms, are probably derived directly from the Confervoideæ, although the change in the mode of reproduction is very abrupt. The production of zoospores is entirely suppressed, and they are reproduced solely by the conjugation of cells belonging to the same or to different individuals. The Desmidieæ must then be regarded as a group adapted, by a certain amount of retrogression in both vegetative and reproductive characters, to life in shallow water; and derived, through such filamentous genera as Desmidium and Hyalotheca, from Zygnemaceæ with lateral conjugation. By some writers the Diatomaceæ are associated with the Desmidieæ; our reasons for placing them among the Protophyta will be given hereafter. The mode of reproduction by conjugation attains its climax in the Mesocarpeæ.

The second line of descent is that of the brown seaweeds. In the PheOSPORE⿸ we have every shade of transition in the mode of reproduction from isogamous to heterogamous. The typical Phæosporeæ, such as Punctaria and Ectocarpus, are characterised by the possession of two kinds of zoosporange, unilocular and multilocular. The zoospores produced in these two kinds of zoosporange present no difference in size or form; but those from the unilocular sporanges appear in all cases to germinate directly, while those produced in the multilocular sporanges are sometimes zoogametes with sexual functions. In some families one or the other kind of zoosporange is suppressed. In the Ectocarpacea and some other genera we have a mode of reproduction closely resembling that in the isogamous Confervoideæ, except in the greater differentiation of the cells which become zoosporanges, a conjugation of zoogametes which are to all appearance exactly alike, though a slight differentiation is exhibited in the fact of one of them coming to rest and partially losing its cilia before conjugation takes place. In the Cutleriacea the differ- 
entiation is more complete ; the male and female swarm-cells are produced either on the same or on different individuals; the female are much larger than the male, and come perfectly to rest, entirely losing their cilia before being impregnated by the former. In the Dictyotacea the differentiation is carried still further, and the female reproductive bodies are from the first motionless oospheres not provided with cilia. Several families of Phæosporeæ exhibit reduction or degradation of the vegetative structure; and among these we are disposed to place the small group of Syngenetica, consisting of but two genera, Hydrurus and Chromophyton, which resemble one another in but few points except the possession of a brown endochrome. In the former genus the propagative bodies are reduced to non-ciliated masses of brown protoplasm, which germinate directly without impregnation; in the latter the vegetative structure is almost entirely suppressed; the propagative bodies are uniciliated masses of protoplasm of two kinds, but without any observed process of conjugation. The step from the Dictyotaceæ to the FUCACEæ is an easy one. In the highest type of brown seaweeds, such as Fucus or Durvillæa, with their typical heterogamous or 'oogamous' reproduction, consisting in the impregnation of a comparatively large oosphere by a number of minute antherozoids, we have the highest attainment of this series of development.

The third line of descent from isogamous Confervoideæ is a much more direct one, to the ConfervoIDEF Heterogane, including the three orders Sphceropleacec, Edogoniacea, and Coleochatacea. In the first of these, which comprises only a single species, we have a distinct differentiation of the male and female reproductive cells, the latter having now become permanently quiescent; but still a strong reminiscence of the Confervaceæ in the multinucleated cells. The CEdogoniaceæ exhibit a distinct advance in vegetative structure, and still more in the cells which contain the male and female reproductive bodies being, for the first time in this series, differentiated into antherids and oogones respectively. Between the Edogoniaceæ and the Coleochætaceæ we have an evident connecting link in Bulbochæte; but the typical genus Coleochæte presents a singular reduction of the non-reproductive portion of the thallus from a filament to a single plate of cells. The mode of sexual reproduction has now attained a much higher degree of complexity. The oogone is surmounted by a tubular appendage, the trichogyne, through which the motile antherozoids find their way to the oosphere in order to impregnate it. "The fertilised carpogone, as it is now called, then becomes invested by a cortical layer of csils, forming the complex body known as the sporocarp.

The Coleuchætaceæ lead up directly to the highest type of structure attained by Algæ, the FLORIDEæ or red seaweeds, a well-defined and 
natural group, though exhibiting remarkable variety in the degree of development of the sexual organs. So striking is the resemblance in the mode of impregnation in the most highly developed genera of Florideæ, such as Callithamnion, Dudresnaya, or Corallina, to that in Coleochæte, that it is scarcely possible to doubt the direct descent of one from the other; the chief difference is in the replacement of motile antherozoids by pollinoids which have no active power of motion. The process of fertilisation is the most intricate which occurs among Thallophytes, and presents a remarkable forecast, so to speak, of the mode afterwards elaborated in Flowering Plants, though only after a very long interval, comprising the entire evolution of the Muscineæ and Vascular Cryptogams. With the loss of motility of the male reproductive cells is also correlated a corresponding loss of motility of the non-sexual reproductive cells or tetraspores. In the higher families of the Florideæ we have also the highest development of the organs of assimilation found among Thallophytes. If the view is correct that the higher Florideæ are derived directly from the Coleochætaceæ, it follows that we must regard all the less highly developed families of this group as retrogressions from the parent type; and this view appears to offer the most probable explanation of the true position of some aberrant forms. In the Helminthocladiacea and Squamariacea the degeneration is exhibited solely in the less perfect development of their thallus or vegetative structure. In the Lemaneacea this is accompanied also by a simpler structure of the sexual organs. But here, as well as in Batrachospermum, we have the first rudimentary appearance of a phenomenon resembling that known as 'alternation of generations,' which plays so important a part in the Vascular Cryptogams, and which may possibly indicate the genesis of the Muscineæ. In the Porphyracea we find a reduction of the thallus to a simple filament or plate of cells, accompanied by only a rudimentary development of both carpogones and trichogynes, and a limited reversion to motility in the tetraspores. Regarding the Porphyraceæ as exhibiting retrogression from the more complicated. Florideæ, rather than as the lowest member of an ascending series, it is difficult to resist the conclusion that the Ulvacea are derived from the Porphyraceæ by further retrogression, displayed in the entire suppression of antherids and oogones, and a reversion to the primitive conjugation of zoogametes. In their vegetative structure the Ulvaceæ differ widely from the isogamous Confervoideæ, with which they are usually associated, while the close resemblance between Ulva and Porphyra is obvious. In the Floridex. the Algæ attain their highest type of development.

By far the larger number of Algæ grow entirely immersed in water, running or stagnant, fresh, brackish, or salt ; some float on the surface without any attachment; others are found on moist soil, among moss, 
\&c. The whole of the marine vegetation of the globe, with the exception of a very small number of species of Flowering Plants, belongs either to the Algæ or to the chlorophyllous Protophytes. They vary in size from the microscopic Desmidieæ and Pediastreæ to that of shrubs or trees in the case especially of some genera of Laminariaceæ and Fucacer ; and in these classes, as well as in the Florideæ, we find a rudimentary differentiation, not only of tissues, but of organs, which leads the way to the much more complete development in the higher classes of the vegetable kingdom. Fresh-water Algæ are, with very few exceptions (species of Bangia, Hildenbrandtia, Lithoderma, Hydrurus, \&c.), green. Among marine Algæ there are many genera of green seaweeds, belonging chiefly to the families Confervaceæ, Siphonocladaceæ, and Ulvaceæ; but these mostly grow in shallow water. As regards all organisms growing in deep seas, it appears to be essential to them that the green colour of the chorophyll should be masked by a coloured pigment, red in the case of the Florideæ, brown in those of the Phæosporeæ and Fucaceæ; the nature of these pigments will be discussed under the separate families. A few of the smaller species, belonging to the Coleochætaceæ, Chordariaceæ, and Squamariaceæ, grow attached to stones, larger Algæ, or other marine objects, as flat discs, gelatinous cushions, or calcareous incrustations, and the deposition of lime takes place to a much larger extent in the corallines. The proportion of ash to the organic constituents is much larger in marine than in land or fresh-water plants, seaweeds having the power of extracting from the salt water large quantities of the soluble salts contained in it. The larger species of Fucaceæ and Laminariaceæ are largely used in the north of Europe for manuring the land and for foddering cattle ; and in former times the manufacture from their ashes of kelp and barilla was an important industry. They are also an important commercial source of iodine. From the quantity of gelatine contained in their thallus, some species of Ulvaceæ, Porphyraceæ, Fucaceæ, and Laminariaceæ are also occasionally used as articles of food or for medicinal purposes.

\section{LITERATURE.}

Greville-Algæ, in Scottish Cryptogamic Flora, 1823-28; Algæ Britannicæ, 1830.

Kützing-Phycologia generalis, I843 ; Tabulæ Phycologicæ, 1845-69; and Species Algarum, 1849 .

Harvey-- Phycologia Britannica, I846-5I ; Nereis Australis, 1847-49 ; British Marine Algæe, I 849; Nereis Boreali-Americana, 1851-58; Phycologia Australica, 1858-63. Hassall-British $\mathrm{F}$ resh-water Algae, 1845 .

Nägeli-Die neuern Algensysteme, 1847 .

Agardh-Species, Genera, et Ordines Algarum, 1848-80 ; Till Algernes Systematik, $1872-87$.

Thuret-Antheridies des Cryptogames, 1851.; Zoospores des Algues, 1851; and E.tudes Phycologiques, 1878 . 
Landsborough - Popular Hist. of British Seaweeds, I85 I.

Pringsheim - Ueber Befruchtung u. Keimung der Algen, 1855 .

Gray-British Seaweeds, 1867.

Woud-Fresh-water Algæ of North America, 1873.

Bornet \& Thuret-Notes Algologiques, I 87680.

Falkenberg-Die Algen, in Schenk's Handbuch der Botanik, vol. ii., I 88I.

Hauck - Die Meeresalgen, in Rabenhorst's Kryptogamen-Flora Deutschland, I 883-85.

Schmitz-Die Chromatophoren der Algen, I882 ; and Journ. Micr. Soc., 1883, p. 405.

Cooke-British Fresh-water Algæ, I 884.

Gay-Bull. Soc. Bot. France, I886, Sess. Extraord., p. 21.

Bennett - Journ. Linn. Soc., xxiv., I887, p. 49.

Wolle-Fresh-water Algæe of the United States, I887.

Wille-(Resting-spores) Pringsheim's Jahrb. wiss. Bot., I887, p. 492.

Stroemfelt-(Attachment-disc) Bot. Centralbl., xxxiii., 1888, pp. 38 I \& 395.

\section{Class X.--Florideæ.}

This large family-known also as Rhodosporeæ and Rhodospermeæ - exhibits the highest type among Algæ in the mode of sexual reproduction, and also possibly in the development of the vegetative organs. It consists almost entirely of seaweeds, including all the red and purple kinds. A few species only, belonging to the genera Hildenbrandtia (Nard.), Batrachospermum (Bory), Lemanea (Bory), Bangia (Lyng.), and a few others, grow in fresh water. Some of these are green, but the great majority of the Florideæ are of a bright red colour, varying with purple, brown, yellowish, or dirty white. The 'fronds' do not attain nearly the size of those of the Fucaceæ and Laminariaceæ, but they are often of delicate texture and finely divided, rendering them the most beautiful of our seaweeds.

The thallus varies within very wide limits in its degree of development. In a few genera, such as Callithamnion (Lyng.), it consists of distinct filaments of cells which are almost always branched; in others, as Porphyra (Ag.), Hildenbrandtia, and Cruoria (Fr.), of a flat plate of cells, composed of only a single or of several layers; in the fresh-water genus Batrachospermum, of an axis with beautifully regular whorls of branches; while in most seaweeds it constitutes a massive parenchyme, or the filaments are held together by a more or less dense gelatinous envelope. Growth takes place, in the majority of cases, by means of a single apical cell, but this is often followed by a strong intercalary growth. The apical cell is not three-sided, as in Vascular Cryptogams, but is either wedge-shaped, dividing by walls which incline alternately to the right and left, or it divides by nearly parallel walls. In some forms, however, especially the prostrate Melobesiaceæ and Squamariaceæ, and 
in the Nemalieæ, the apical cell appears to be replaced by a group of equivalent cells. Wille distinguishes six types of Florideæ as respects their mode of growth; in four of these groups growth takes place from a single apical cell; in two from an apical mass of cells, with peripheral

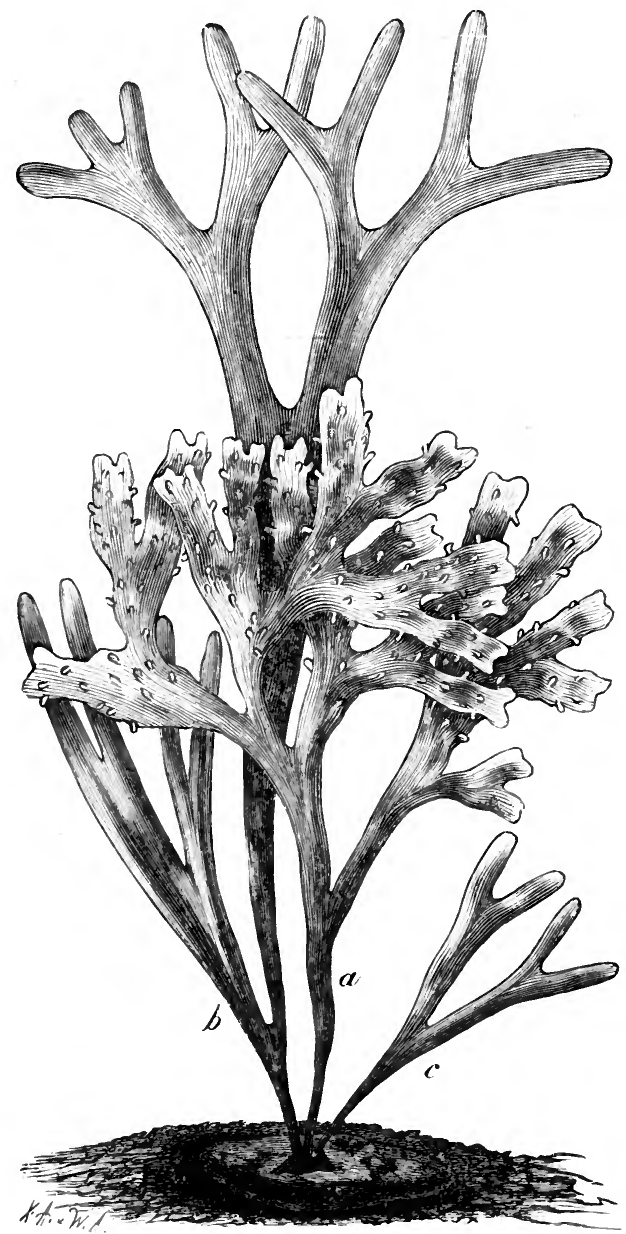

FIG. 169.-Gigartina mamillosa Ag., with cystocarps (natural size). (After Luerssen.)

growth. In the so-called polysiphonous seaweeds, such as Polysiphonia (Grev.), a transverse section of the 'frond' shows a large central elongated cell, surrounded by four or more smaller cells, which are also elon. gated in the longitudinal direction, and which are known as siphons. These pericentral tubes are often connected with one another and with the axial cell by threads of protoplasm. When the pericentral tubes are wanting the frond is monosiphonous. In some genera belonging to the Ceramiaceæ either the single axial tube or both axial and pericentral tubes are surrounded by a pseudo-cortex formed of a dense agglomeration of secondary branches originating at the nodes and closely adpressed to the primary branch. These are always the result of further division of the pericentral tubes, the apical cell remaining

undivided. In other genera a similar cortical tissue is composed of moniliform rows of cells arranged at right angles to the axis.

Although there is in the Florideæ no distinct differentiation of the 
tissue into epidermal, assimilating, and conducting systems, still there are, in the higher forms, cells which are especially concerned with assimilation, and which may be either isodiametrical, or elongated in either direction. Such assimilating tracts are classed by Wille under three heads, viz.:-(I) those which act also for purposes of conducting; (2) those which are altogether distinct from the conducting cells; and (3) those where, in addition to an assimilating, there are also primary and secondary conducting cells. In some species the 'frond' assumes the appearance of a stalked leaf, as in Hydrolapathum (Rupr.) and Delesseria (Grev.), often of the most beautiful form, and presenting even a rudimentary venation. The genera Melobesia (Lmx.), Hildenbrandtia, Cruoria, and some others, consist of small algæ, mostly marine, with crustaceous or gelatinous thallus, growing flat on stones or larger algæ, often of lichen-like appearance. In their mode of growth some Florideæ display bilateral symmetry, and the branching may be either monopodial or sympodial. In Polysiphonia, Spyridia

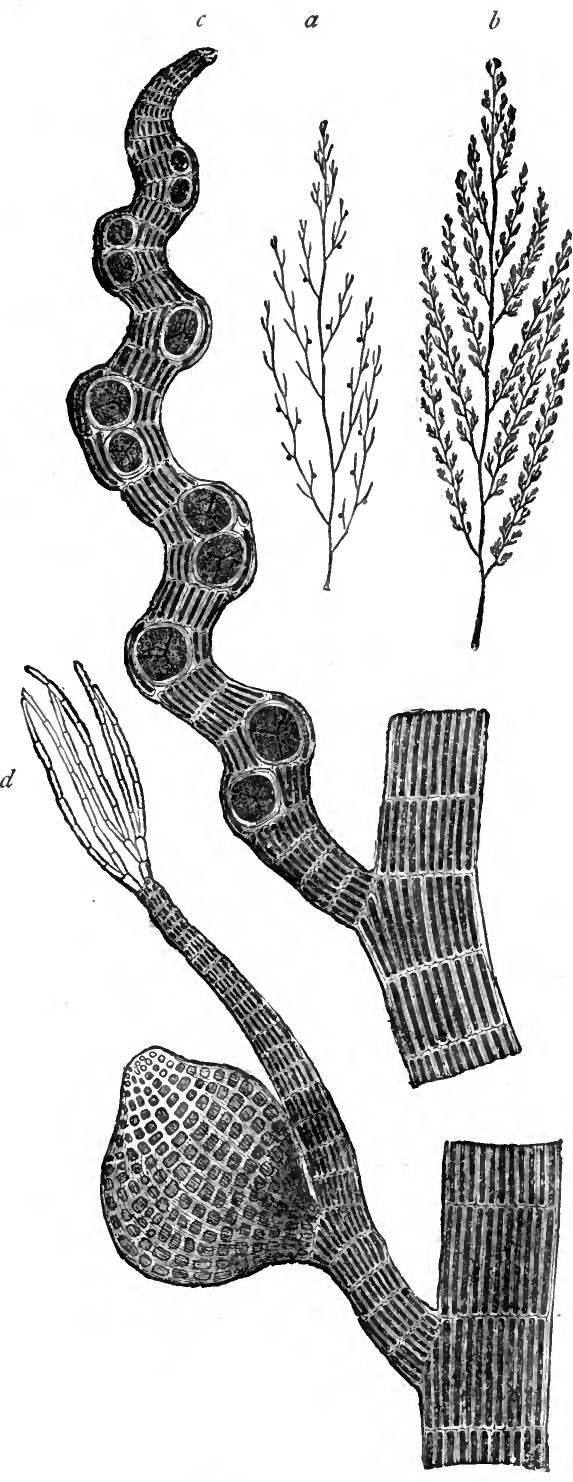

FIG. I7o.-Polysiphonia opaca Zan. a, with cystocarps; $b$, with tetrasporanges (natural size); $c$, branch with tetrasporanges; $d$, branch with cystocarp ( $x$ 100). (After Kützing.) 
(Harv.), and some others, the 'phyllotaxis' is spiral. The genera Rytiphlœa (Ag.), Vidalia (Lmx.), Amansia (Lmx.), and Polyzonia (Suhr) are distinguished by the endogenous formation of the normal lateral shoots. In Pollexfenia (Harv.) and allied genera, Falkenberg records a remarkable congenital union of all the branches of the thallus which lie in the same plane.

The red colouring matter of the Florideæ has been investigated
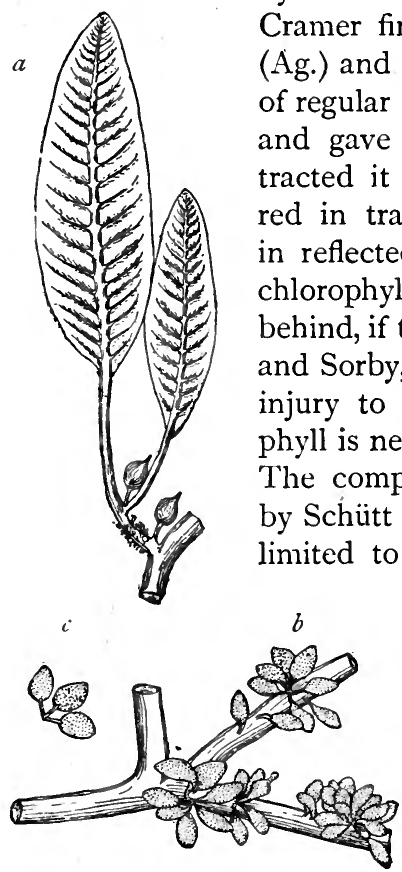

Fig. r7r. - Hydrolapathum sanguineum Stackh. a, two young fronds with two cystocarps; $b, c$, prolifica. tions from the stem (natural size). (After Kützing.)

by Rosanoff, Cramer, Askenasy, Sorby, and others. Cramer first extracted it, from Bornetia secundiflora (Ag.) and Callithamnion caudatum (Ag.), in the form of regular crystals, partly hexagonal, partly octohedral, and gave it the name rhodospermin. Rosanoff extracted it by cold fresh water, and found it carminered in transmitted, reddish yellow, or rarely green, in reflected light. It is insoluble in alcohol. The chlorophyll-grains also exhibit fluorescence when left behind, if the pigment, the phyco-erythrin of Askenasy and Sorby, has escaped from them in consequence of injury to the plant. The spectrum of the chlorophyll is neariy identical with that in Flowering Plants. The compound pigment of the red Algæ is termed by Schüt rhodophyll, the term phyco-erythrin being limited to the portion soluble in water, while the portion soluble in alcohol he calls Floridece-green. Cohn found, in Bornetia (Thur.), colourless crystalloids of an albuminous substance coloured a beautiful red by the same pigment; and Klein has found similar crystalloids in several Florideæ. The chromatophores contain starch-grains, which differ both from the ordinary grains of Flowering Plants and from those of the brown Algæ in being coloured brown or red by iodine. Schmitz (Sitzber. Niederrhein. Gesell., I880) has detected a number of nuclei in the vegetative cells of many Florideæ, but not in the reproductive cells. Hick (Proc. Brit. Ass., I883; ' Nature,' vol. xxix., 1884, p. 581), Massee (l.c.), and Moore (Journ. Linn. Soc. Bot., vol. xxi., 1886 , p. 595) find continuity of protoplasm from cell to cell very beautifully displayed in Callithamnion (Lyng.), Ptilota (Ag.), Polysiphonia, and several other genera, not only in the vegetative cells, but also in the tetrasporanges. In Corallina (L.), Melobesia, Liagora 
(Lmx.), and a few other genera, the 'frond' becomes densely incrusted by a deposit of calcium carbonate, giving to the so-called 'corallines' the external form and appearance of miniature corals.

The ordinary non-sexual propagative organs of the Florideæ are bright red motionless spores, commonly formed in fours in the mothercell, and hence known as tetraspores (the sphærospores of Agardh), and the cell in which they are produced as a tetrasporange. The four spores are sometimes arranged in a row, when they are called zonate; more often as quadrants of a sphere, when they are cruciate : rarely there are only one or two, or occasionally eight. In the Ulvaceæ, Lemaneaceæ,
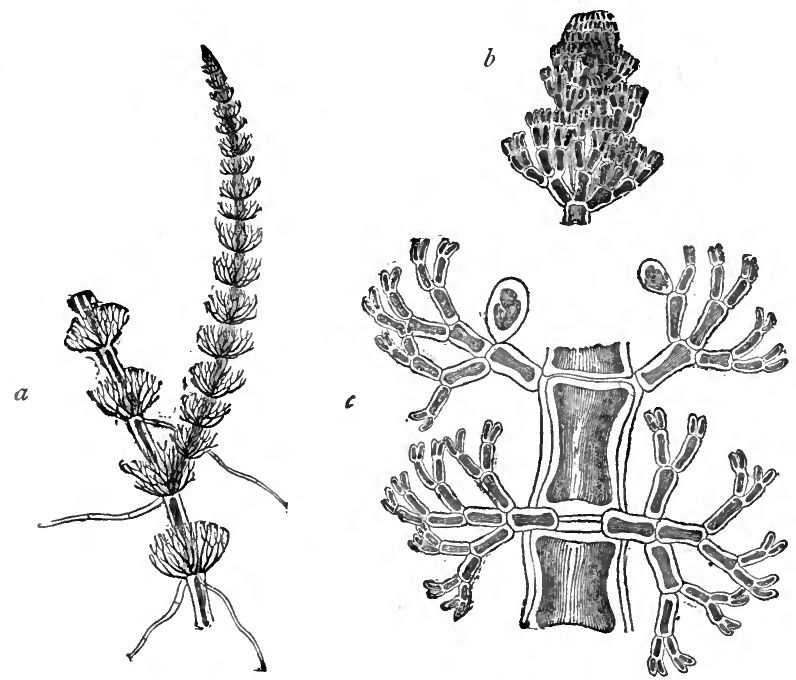

FIG. I72.-Crouania attenuata Ag. $a$, branch $(\times 40) ; b$, apex of branch $(x$ 100); $c$, lower portion of branch with tetrasporanges ( $x$ Ioo). (After Kützing.)

and in some Nemalieæ they are altogether wanting. The tetraspores (see fig. 23I) may be formed in the six following ways:-(I) The whole contents of the sporange become a single spore ; (2) the contents divide into two equal parts by a transverse wall ; (3) they divide into four quadrants by two successive bipartitions ; (4) they divide into four tetrahedra by simultaneous quadripartition; $(5)$ they divide into four by three parallel transverse walls; (6) the contents divide into more than four spores. On germination the tetraspores may give birth either to sexual or to non-sexual individuals. In the monosiphonous Florideæ the tetrasporanges are usually formed at the expense of the ultimate branchlets. In other forms they are most commonly found scattered 
near the margin of the 'frond,' sometimes (Rhodymenia bifida, Ktz.) im bèdded in the thallus, and then often grouped into sori (Nitophyllum, Grev.) ; or, in the Corallinaceæ, enclosed in special conceptacles. In other genera (Phyllophora, Grev., \&c.) they are developed in nematheces, wart-like elevations of the surface, where they are accompanied by barren hyphæ or paraphyses. In others again they are borne on metamorphosed pod-like branches known as stichids, as in Dasya (Ag.), Plocamium (Lmx.), \&c. Only in the Porphyraceæ are the tetraspores endowed with a slow

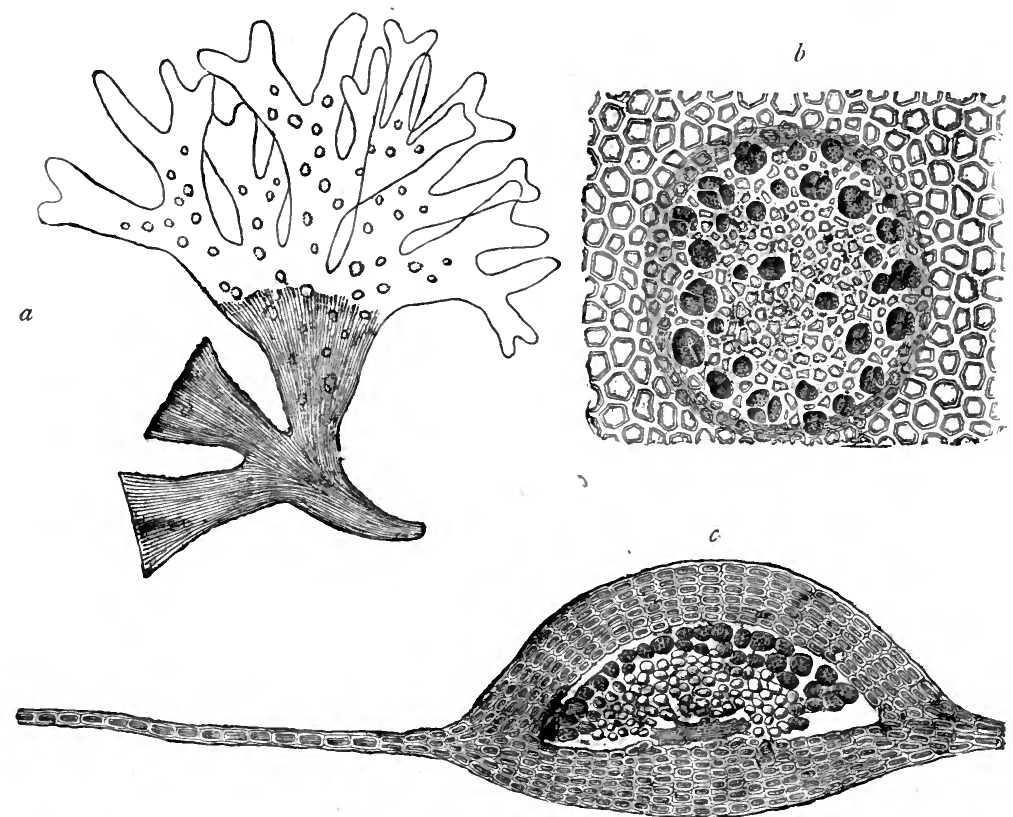

FIG. I73. - Vitophyllum punctatum Harv. $a$, piece of frond with tetrasporanges (natural size); $b$, piece of the thallus with tetrasporanges $(x, 100) ; c$, section through frond showing cystocarp $(x$ 100. (After Kützing.)

amœeboid motion. Zoospores are altogether unknown in the class, except in the Ulvaceæ; but other modes of non-sexual propagation occur in a few cases. In some genera of Ceramiaceæ special organs occur, known as seirospores. Melobesia is characterised by the production of gemma. In Monospora (Sol.) stalked gemmæ or propagules are produced at the forks of the branchlets, and readily become detached, apparently replacing the sexual organs, which are unknown in the genus. Lemanea (Bory) increases by budding. In Hydrolapathum peculiar bud-like prolifications are produced on the stem (see fig. I 7 I). 


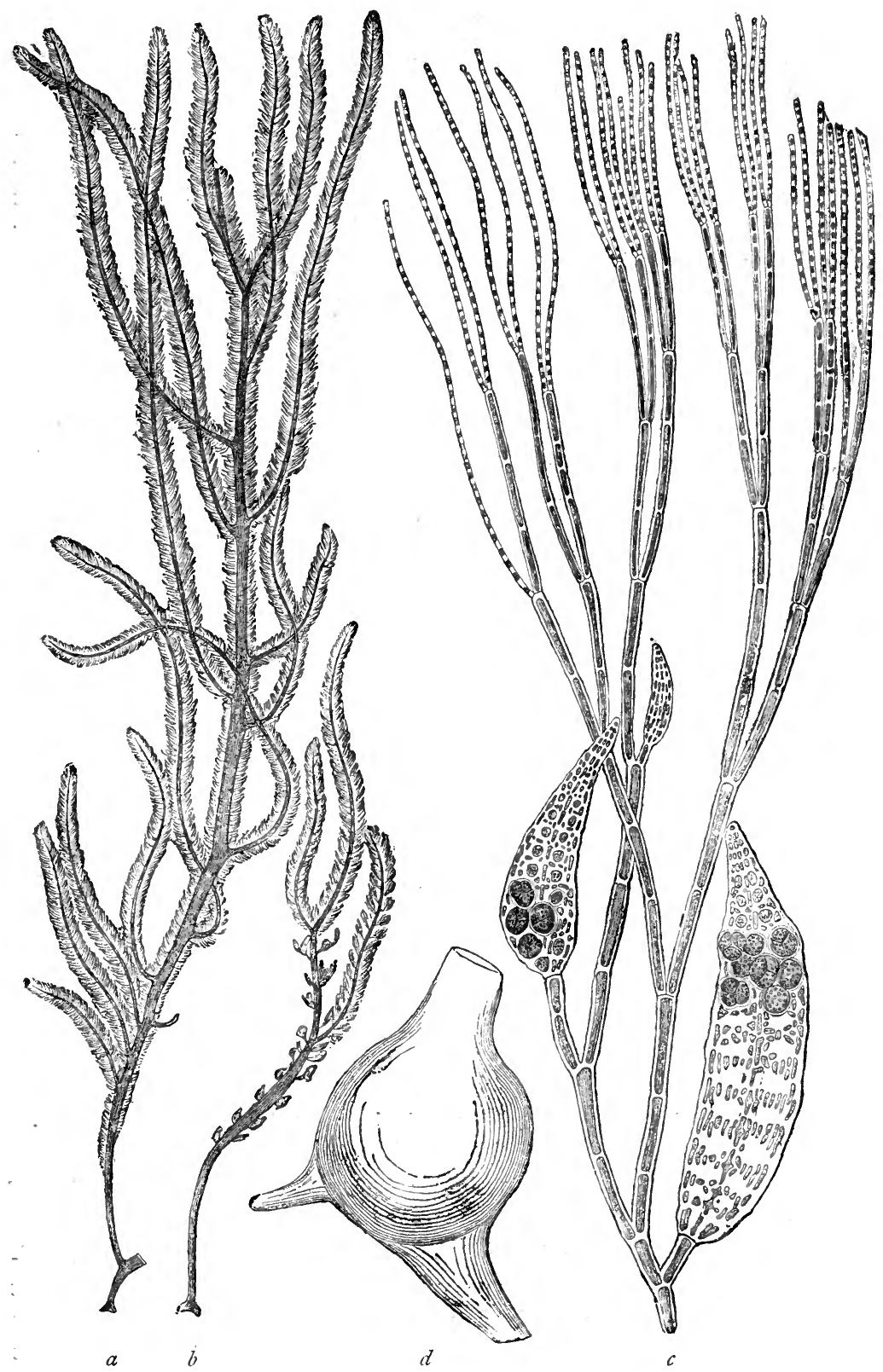

Fig. I74.-Dasya elegans Ag. $a$, piece of frond with tetrasporanges; $b$, piece with cystacarp (natural size); $c$, branch with stichids ( $\times$ roo); $d$, cystocarp ( $\times 25)$. (After Kützing.) 
A true understanding of the sometimes complicated process of sexual reproduction in the Florideæ has been much obscured by the numerous terms employed by the older writers for identical organs, and by incorrect notions as to their functions. The true sexual organs, antherids and procarps, are nearly always formed on individuals which do not produce tetraspores; and the sexual individuals may be monœcious or diœcious; the latter is the most common condition. If the Ulvaceæ are rightly included under Florideæ, we have here a wide departure from
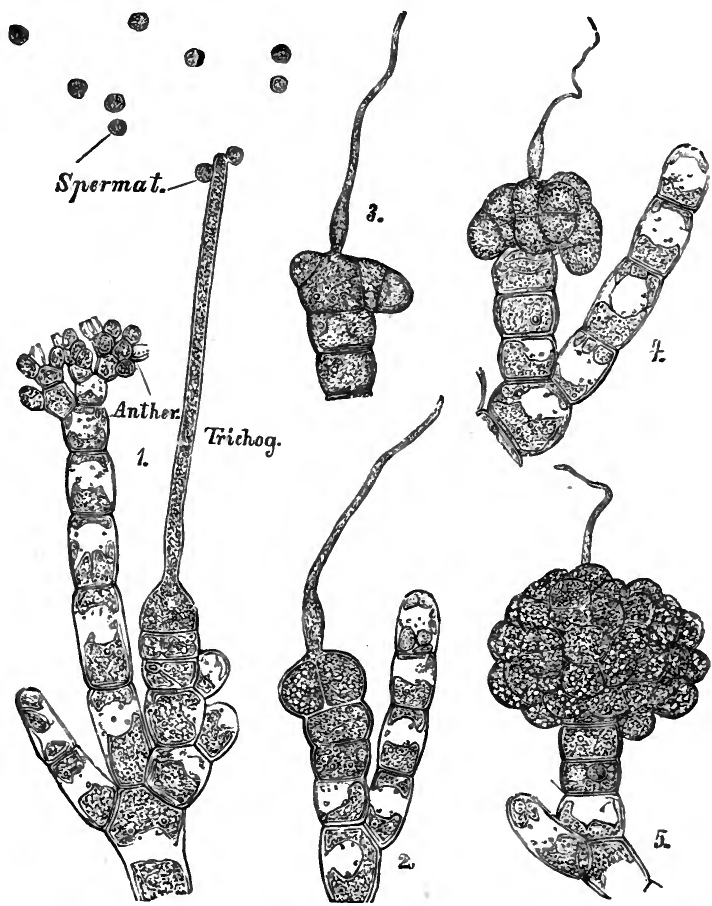

Fig. 175.-Stages in the development of the reproductive organs of Nemalion multifidum Ag. (magnified). (Spermat. $=$ pollinoids.)

the normal type, sexual reproduction taking place by the conjugation of motile swarm-cells.

The antherid consists, in its simplest form (Porphyraceæ), of a solitary cell at the end of a long segmented branch; and in this case it gives birth to a single pollinoid; in other forms the antheridial cells occupy a similar position to the tetraspores, being formed in groups at the expense of the ultimate branchlets. They are also sometimes pro- 
duced, like the tetraspores, in wart-like protuberances or nematheces on the surface of the thallus, and interspersed with paraphyses, sometimes (Gracilaria, Grev.) in depressions which are overarched by the surrounding tissue; or, in the Corallinaceæ, in special conceptacles. When the thallus is otherwise unilamellar, as in Porphyra (Ag.), the spots where the antherids are formed divide by walls parallel to the surface. The fertilising bodies or pollinoids are naked masses of protoplasm, of a spherical or elongated form, sometimes with a beak-like appendage, and are discharged in succession one after another. They are carried along passively by the water, and are distinguished from the antherozoids of other Cryptogams by the absence of cilia, and, in most cases, of any spontaneous power of motion. Wright (Trans. Irish Acad., 1879, p. 27)
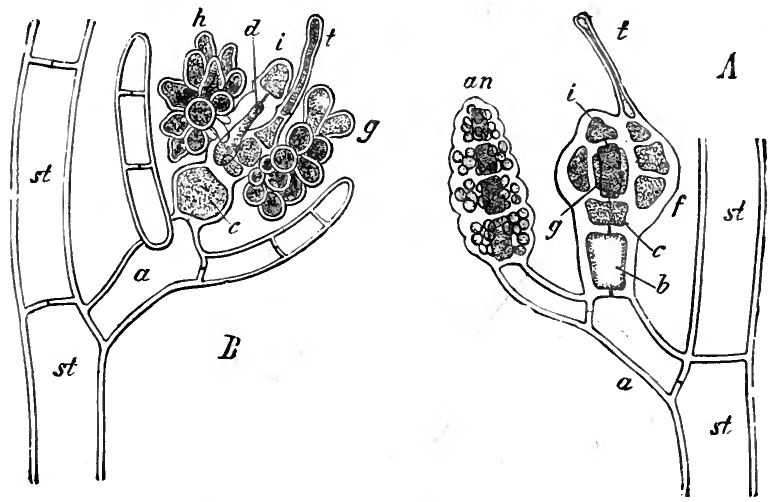

FiG. 176.-Spermothamnion hermaphroditum (magnified). $A$, branch with procarp $(t f g i)$ and antherid $(a n)$ before fertilisation; $B$, after fertilisation, the cystocarp developing; $t$, trichogyne ; $c$, trichophore $; g$, carpogenous cells. (After Nägeli.)

states that in Griffithsia (Ag.) the pollinoids have an obscure amœboid motion, as they have also in the Porphyraceæ ; according to Dodel-Port their access to the trichogyne is greatly facilitated by the currents made in the water by Vorticellæ and other Infusoria ; and there can be little doubt that fishes which feed on seaweeds are an important agent in promoting their fertilisation. The pollinoids and the tetraspores appear to be homologous in their origin.

The female organ before fertilisation-corresponding functionally to the pistil of Flowering Plants-is termed the procarp. In its simplest form (Porphyraceæ and Nemalieæ) it consists of a single cell with a lateral hair-like prolongation, the trichogyne. But in all the higher forms the procarp is composed of one or more fertile cells constituting the carpogone, and one or more infertile cells which make up the tricho- 
phore, the function of which is to convey the fertilising substance from the trichogyne to the carpogone. The procarp is usually formed on the youngest parts of the plant, and often originates from the terminal cell of a lateral branch. Occasionally each carpogone has two trichogynes and two trichophores; or, again, each trichophore may be connected with two carpogones. The trichogyne often becomes eventually coiled

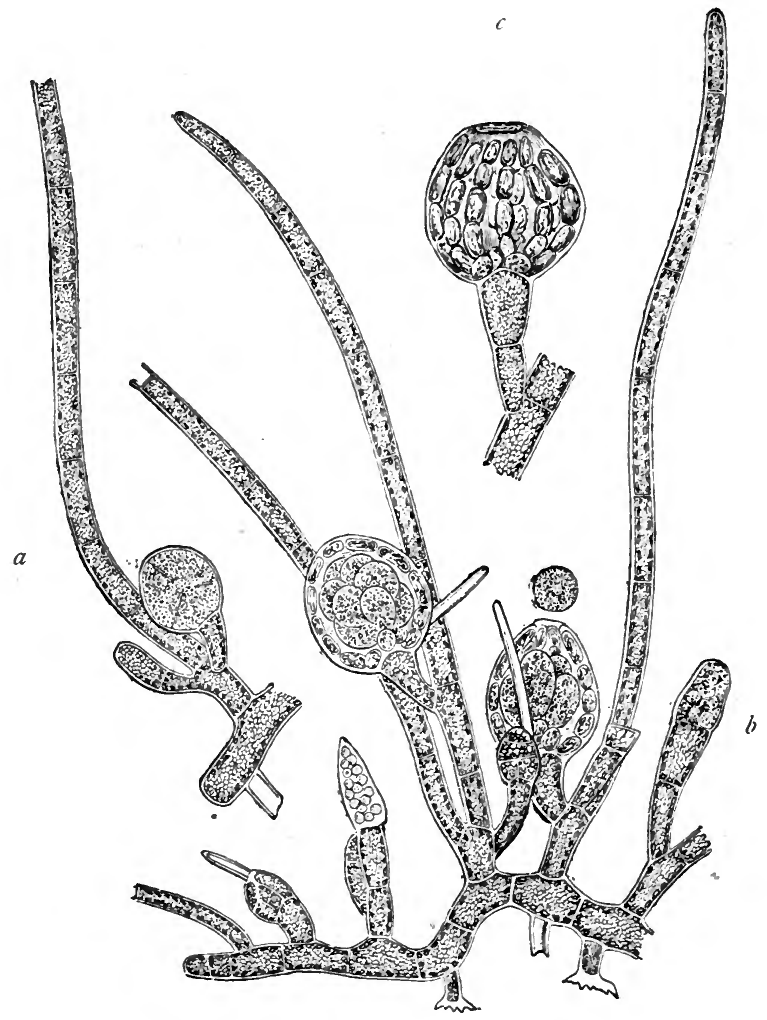

FIG. 177.-Lejolisia mediterranea Born. $a$, flament with tetrasporange ; $b$, plant with cystocarps and antherids ; $c$, empty cystocarp ( $\left.\begin{array}{l}\times \\ 150\end{array}\right)$. (After Bornet.)

spirally at its base. It does not open to admit the entrance of the pollinoids; in the act of impregnation these bodies attach themselves to a spot near the apex of the trichogyne, and at the same time clothe themselves with a cell-wall. At the point of contact the cell-wall of both trichogyne and pollinoid is absorbed; the contents of the latter pass through the trichogyne and the trichophore to the carpogone, impregnat- 
ing its contents, and the trichogyne then disappears. The carpogone now divides by a horizontal wall into two cells ; the upper one of these is functionless, and ultimately disappears ; the lower one contains the impregnated oosphere or carposperm. The carposperm does not, however, in any case possess the power of germinating directly. In the Porphyraceæ it breaks up into eight portions, the carpospores, which germinate after moving about with a slow amœboid motion. In all the other orders the contents of the carpogone undergo, after impregnation, more complicated divisions, and become differentiated into a sterile and a fertile portion, the placenta and the nucleus. The placenta may consist of one or more cells, and frequently occupies the larger portion of the carpogone; or it may be re. duced to very small dimensions. The nucleus is the mass of carpuspores, and may be made up of a number of secondary nuclei. The mass of carpospores is sometines, as in Callithamnion, completely exposed except for a gelatinous membrane by which it is surrounded; but much more often there is gradually formed round the nucleus after impregnation, not only a layer of mucilage, but also a more or less hard solid layer, the pericarp; and the whole structure thus constituted is then known

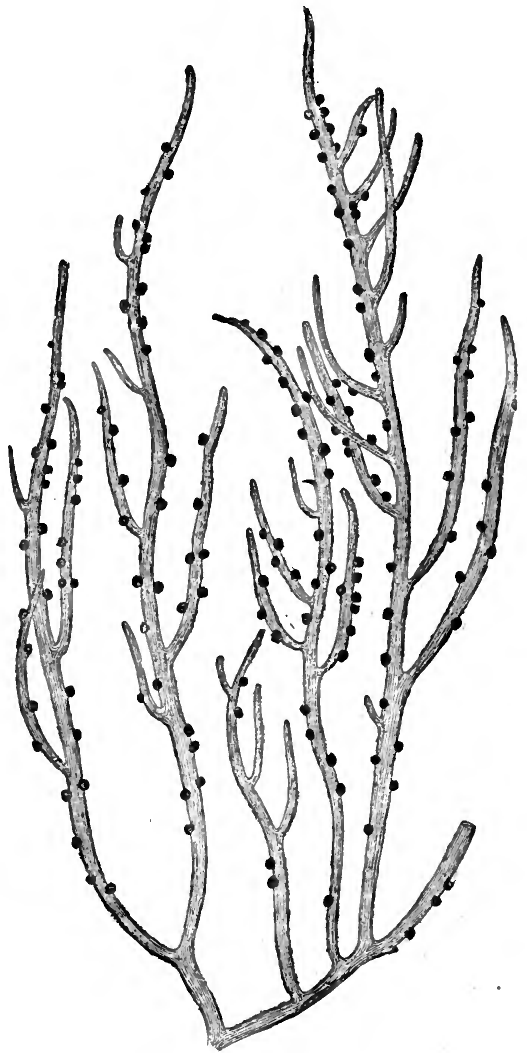

Fig. 178.-Gracilaria compressa Ag. Branch with cystocarps (natural size). (After Hauck.) as the sporocarp or cystocarp. From this cystocarp the carpospores
escape, when ripe, either by the decay of the pericarp ('coccidium' of the older systematists), or through an opening at its apex, the carpostome ('ceramidium' of older writers). In some genera (Polysiphonia, Lejolisia, Born., Bonnemaisonia, Ag.) the cystocarp is completely exposed, conspicuous, and sometimes stalked; but it is usually, as in Gracilaria, 
more or less imbedded in the thallus, often in special fertile branches ; and its situation is then usually indicated by an external wart-like swelling. In Polyides (Ag.); the Squamariaceæ, and other forms with a perfectly flat frond, the cystocarps are enclosed in nematheces.

In a considerable number of Florideæ the formation of the cystocarp is a more complicated process than that already described, the process of impregnation consisting of two distinct stages-(I) the fertilisation of the trichogyne by the pollinoids; and (2) the fertilisation by the impregnated trichophore-cells of the carpospores, which may be at some considerable distance from the trichophore and trichogyne, even on a

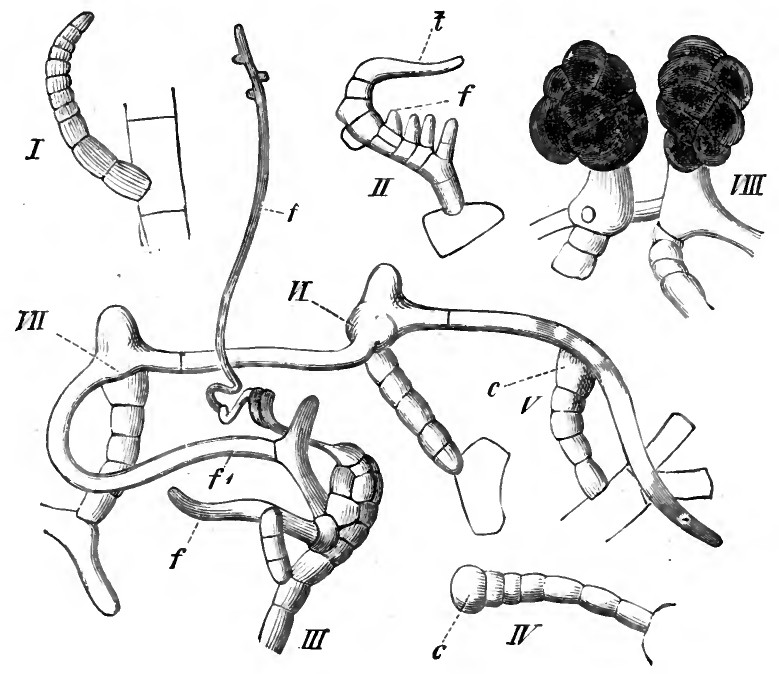

FIG. 179.-Dudresnaya coccinea Crouan. I, young trichophore. $I I$, young trichogyne ; $f$, young fertilising tubes. III, impregnated trichophore with pollinoids on the coiled trichogyne, $f$; the fertilising tube, $f^{\prime}$, impregnating successively the carpogones, $V I I, V I$, and $V$.

$I V$, carpogone before fertilisation; $c$, carpogenous cell. VIII, masses of carpospores.

different branch. This is effected by means of long simple or branched tubes, the fertilising-tubes, or 'ooblastema-filaments' of Schmitz. The following is the process as it takes place in Dudresnaya (Born.). The trichophore consists of a row of cells which, before fertilisation, put out short branches, which subsequently develop into long tubes. No carpogone is found in the immediate neighbourhood of the trichophore; but at some distance are a number of short segmented filaments, the terminal cells of which are considerably larger than all the rest. These cells are carpogones. The fertilising-tubes make their way between the filaments or hyphæ of which the thallus is composed, come into contact 
with the carpogones, and convey to them the fertilising principle from the trichophore. The result is that each carpogone develops into a cystocarp containing carpospores. A single fertilising-tube may in this way impregnate a number of carpogones.

Schmitz describes the process of secondary impregnation in the more highly developed Florideæ as consisting in the fertile cells (carpogones) entering into communication, through orifices in their cell-walls, with certain special sterile cells rich in protoplasm, the auxiliary cells, to which the fertilising material is brought from the trichophore by the ooblastema-filaments. The details of this conjugation between the auxiliary cells and the carpogones are subject to great variation in different genera. In some cases the protoplasmic contents of the two cells coalesce completely, while in others their nuclei still remain distinct after conjugation. The carposperm, or cell resulting from this conjugation, then grows rapidly, and peripheral cells divide off from it, leaving a large central cell which alone remains sterile, all the peripheral cells developing into carpospores. In the Corallinaceæ the ooblastema-filament enters into conjugation successively with several neighbouring auxiliary cells. In a larger number of genera the process is as follows :A short branch of the carpogone, usually consisting of three or four cells, becomes attached laterally to a branch of the thallus, and curves in such a way that the carpogone-cell is closely applied to the nearest auxiliary cell, or reaches it by means of a short protuberance from one or both of the conjugating cells. The entire oosphere, or at all events its nucleus, then passes over into the auxiliary cell. In the Gigartinaceæ the auxiliary cell itself becomes the central cell of the cystocarp.

\section{Literature.}

Nägeli u. Cramer-Pflanzenphysiol. Untersuch., 1855, 1857.

Pringsheim-Monber. Berl. Akad. Wiss., I855, p. I 33 (Quart. Journ. Microsc. Sc., 1856 , p. 124).

Rosanoff-(Rhodospermin) Mém. Soc. Sc. Nat. Cherbourg, 1856 ; Ann. Sc. Nat., iv., 1865, p. 320 ; and Compt. Rend., lxii., 1866, p. 831.

Van Tieghem-Conpt. Rend., lxi., I865, p. 804.

Solms-Laubach-Bot. Zeit., I867, p. I6r.

Askenasy-(Rhodospermin) Ibid., p. 233.

Sorby-(Rhodospermin) Journ. Microsc. Soc., I87I, p. 124.

Klein-Flora, I87I, p. I6I ; and I88o, p. 65.

Agardh-Epicrisis Syst. Florid., I876; and Florid. Morphol. (with atlas), I879.

Bornet and Thuret-Notes Algologiques, fasc. i. and ii., 1876, 1880; and Etudes Phycol., 1878 .

Falkenberg-Nachricht. Gesell. Wiss. Göttingen, I879 and 1880 .

Ambronn-Bot. Zeit., I880, p. 61 ; and Sitzber. Bot. Verein Brandenburg, I880, p. 74 . 
Schwendener-Monber. Preuss. Akad. IViss., I880, p. 327.

Berthold-Pringsheim's Jahrb. wiss. Bot., I882, p. 569.

Schmitz-Sitzber. Akad. Wiss. Berlin, I883, p. 2 I 5.

Ardissone-Phycol. mediterranea, Part i., Florideæ, 1883.

Buff ham-Journ. Quek. Micr. Club, I884, p. 337.

Massee-Journ. Microsc. Soc., I884, pp. I 98 et seq. ; and I886, p. 56 I.

Wille-(Tissue-systems) Bot. Sälsk. Stockholm (see Bot. Centralblatt, xxi., I885,

pp. 282, 315 ; xxiii., I885, p. 330 ; and xxvi., I886, p. 86) ; and Nov. Act.

Leopold-Carol. Akad., lii., I 888, p. 5 I.

Schütt-(Phyco-erythrin) Ber. Deutsch. Rot. Gesell., I888, p. 36.

A complete classification of the very numerous types of structure belonging to the Florideæ would carry us beyond our present limits ; and the principles of such a classification are by no means agreed on by the best authorities, many details connected with the process of fertilisation being still obscure. Agardh, in his 'Epicrisis,' divides the family into six groups, dependent on the structure and mode of development of the cystocarp, and into twenty-two orders. We shall therefore confine ourselves to an account of some groups or special forms, the structure of which has been specially studied, commencing with the most highly differentiated orders.

In the CERAmIACEe, which are exclusively marine, are included a considerable number of the more delicate red seaweeds of our own and other coasts, included in the genera Callithamnion (Lyng.), Griffithsia (Ag.), Ptilota (Ag.), Crouania (Ag.), Ceramium (Lyng.), and others. The thallus is either monosiphonous and uncorticated, or more or less corticated. In Crouania (fig. I 72) the branches are beautifully whorled. The procarp frequently consists of a carpogone and two trichogynes. The cystocarps are formed externally on the branches or at their base, and are frequently closely surrounded by them as by an envelope. With rare exceptions the cystocarp consists of a roundish or lobed nucleus, enclosed in a colourless gelatinous membrane, without any pericarp, and composed of a larger or smaller number of closely packed carpospores. The tetrasporanges are usually external, and the mode of division of their contents varies greatly. The complicated process of fertilisation in Dudresnaya has already been described. In addition to the tetraspores, two other special kinds of non-sexual organs of propagation occur in the order. Some species of Ceramium are characterised by the presence of favelle, dense agglomerations of spores, resembling the cystocarps, but produced at the ends of branches, quite exposed except for a thin colourless membrane. They appear to be homologous to the multipartite tetrasporanges. Callithamnion seirospermum (Griff.) (Seirospora Griffithsiana, Harv.), C. versicolor (Drap.), and some other species, produce seirospores, 


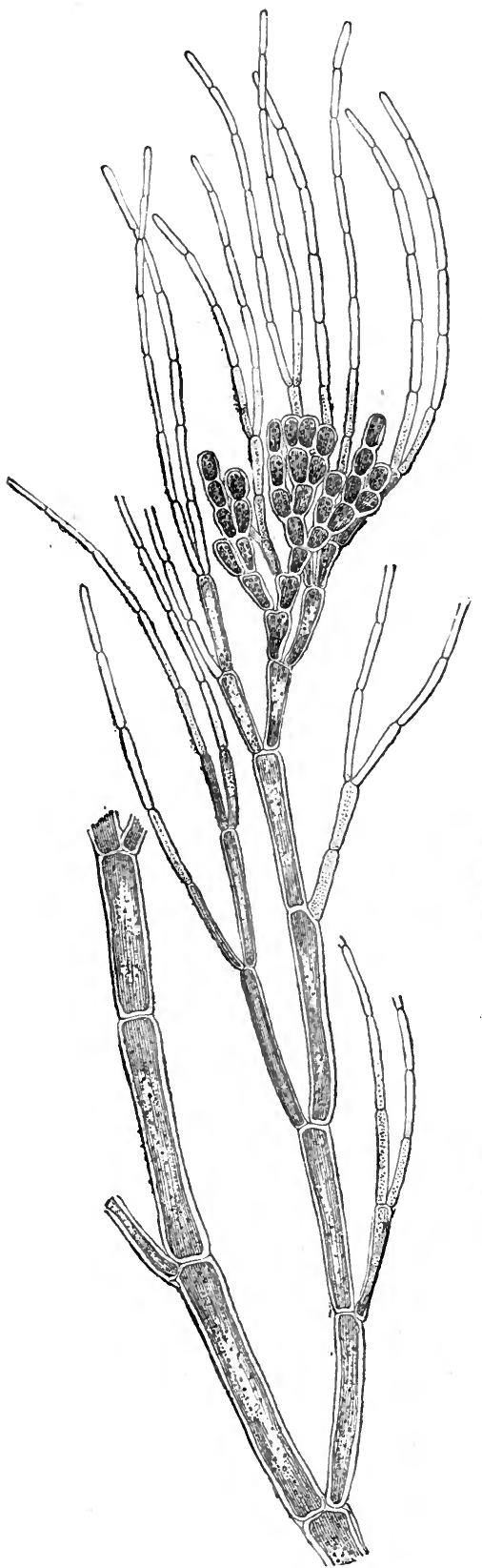

FIG. 180.--Branch of Callithamnio' seirospermum Griff., with se' rospores $(x \geq 0)$. (After Kützing.)

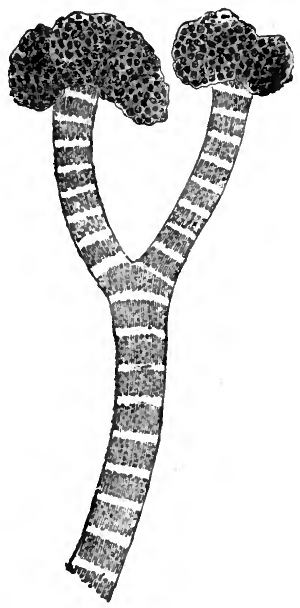

FIG. I8r.-Branch of Ceramium strictum Grev., with favellæ $\left(x_{4}\right.$ o). (After Kützing.)

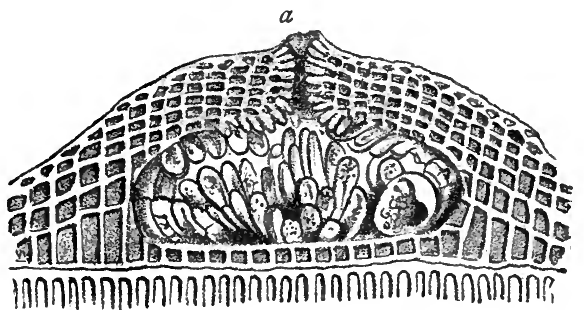

$b$
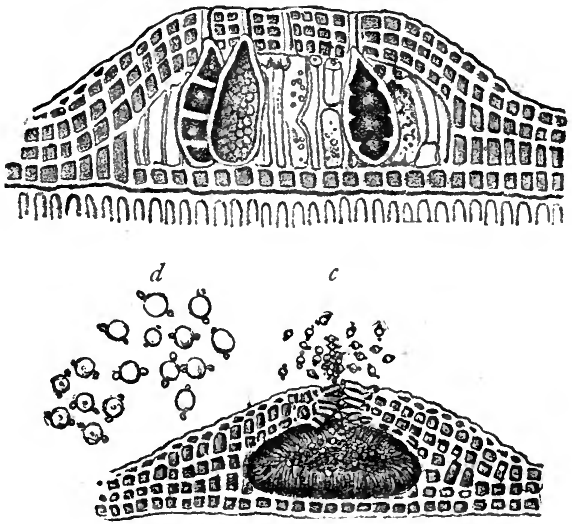

FIG. 182.-Melobesia membranacea Lmx. a, vertical section through female conceptacle ; $b$, vertical section through conceptacie with tetrasporanges ; $c$, vertical section through male conceptacle $(\times 350)$; $d$, follinoids ( $\left.X I_{300}\right)$. ( $A^{\prime}$. er Rosanoff.) 
branched rows of roundish or oval spores resulting from the division of terminal cells of particular branches, or produced on the main branches.

\section{LITERATURE.}

Cramer-Pflanzenphysiol. Untersuch., I857 and 1863.

Nägeli-Sitzber. Münch. Akad. Wiss., I86I, p. 297.

Pringsheim-Abhandl. Berlin. Akad. Wiss., I862, p. I.

The Corallinace (Corallina, L., Melobesia, Lmx., Lithothamnion, Phil., Amphiroa, Linx., \&c.) are distinguished from other marine
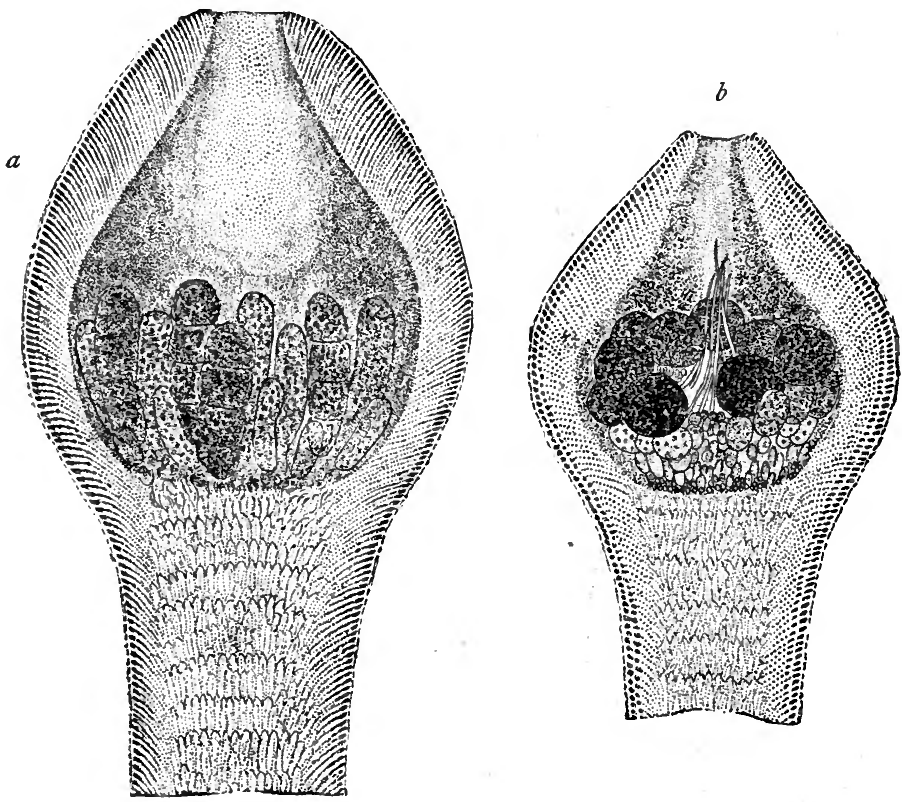

Fig. 183.-Corallina officinalis L. a, longitudinal section through conceptacle with tetrasporanges ; $b$, longitudinal section through cystocarp $(\times 100)$. (After Bornet.)

algæ by their calcareous habit. Most of the species are natives of warmer seas. In Corallina the thallus is at first soft and flexible, but it soon becomes very hard and brittle from the deposition of calcium carbonate. The red colour and branching habit give this genus a remarkable resemblance to small corals, as in C. officinalis (L.), the common 'coralline' or 'nullipore' of our southern coasts. Many species of Melobesia (fig. 182), Lithothamnion, Lithophyllum (Phil.), and other genera, grow as lichen-like incrustations or in the form of small flat 
discs attached to rocks, or on the leaves of Zostera, or on other seaweeds. The sexual reproductive organs and the non-sexual organs of propagation are alike formed in small cavities or conceptacles, which are either entirely imbedded in the thallus, or more often form external wart-like or ovoid swellings. The female conceptacle opens at the apex by an ostiole (fig. I 82,a); the very short sporiferous filaments, the terminal cells of which
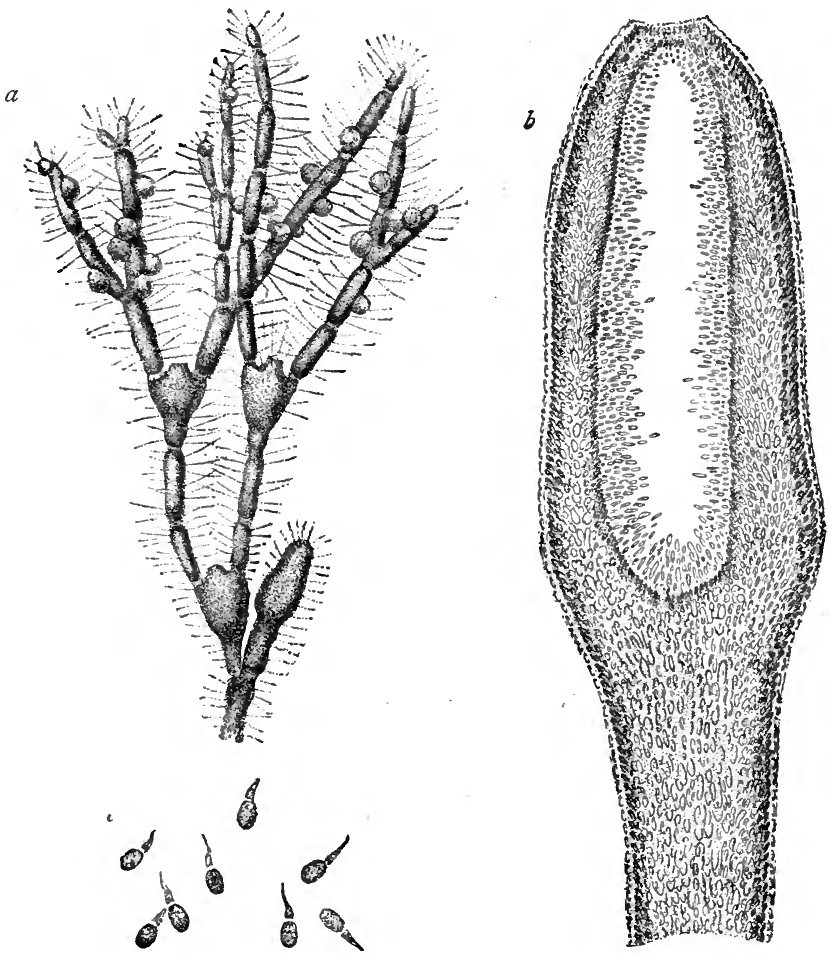

F1G. 184.-Corallina rubens L. $a$, branch with three cystocarps and a male conceptacle; conceptacles of Melobesia Thureti Born. are attached to the upper part of the branch $(\times 20) ; b$, longitudinal section through a male conceptacle deprived of its calcareous incrustation $(x \pm 60)$; $c$, pollinoids $(x$ 400). (After Bornet.)

become the carpospores, spring from the base of the cavity, and are accompanied by paraphyses. The male conceptacles are of similar structure ; the pollinoids (fig. I82, $d$ ) possess one or two short appendages. The non-sexual present a general resemblance to the sexual conceptacles ; the tetrasporanges spring from their base and sides, and are accompanied by paraphyses; the contents of the sporange not un- 
frequently divide into only two tetraspores. The conceptacles are not unfrequently surmounted by singular horn-like processes. Melobesia produces peculiar branching septated gemma.

\section{LiteratuRE.}

Rosanoff-Mém. Soc. Sc. Nat. Cherbourg, 1866.

Areschoug-Observ. Phycol, , iv., I875.

Solnıs-Laubach-Die Corallinenalgen d. Golfes Neapel, I88I.

The greater number of our red seaweeds belong to the following orders, established by Agardh, the boundaries of which are not in all
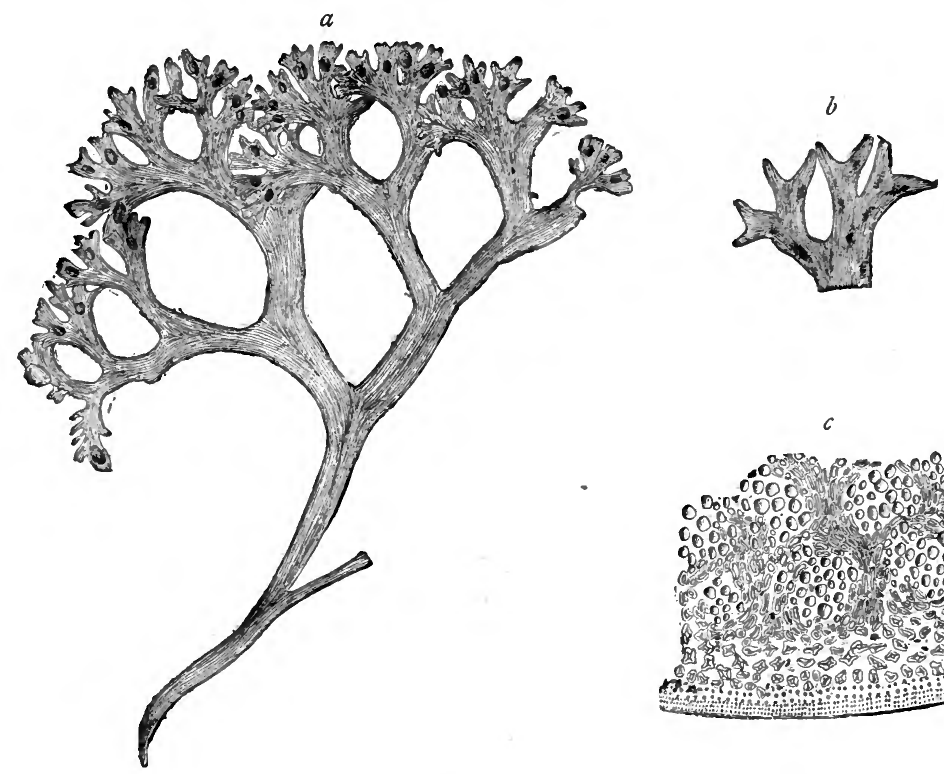

FIG. 185.-Chondrus crispus Stackh. $a$, with cystocarps (natural size); $b$, uppermost portion of frond with tetrasporanges (natural size) ; $c$, section through the frond and a portion of the cystocarp ( $x$ roo). (After Kützing.)

cases well defined, and in regard to many of which much yet remains to be discovered as to their mode of reproduction, viz.:- CRYPTONEMIACEÆ (Nemastoma, Ag., Grateloupia, Ag., Halymenia, Ag., Dumontia, Lmx., Cryptonemia, Ag., \&c.), Gigartinaceæ (Chondrus, Grev., Gigartina, Lmx., Kallymenia, Ag., \&c.), Rhodvmeniace£ (Rhodymenia, Grev., Chylocladia, Grev., Plocamium, Lmx., Hydrolapathum, Rupr., ¿c.), Delesseriaceæ (Nitophyllum, Grev., Delesseria, Lmx.), SphæroCOCCACEÆ (Sphærococcus, Stackh., Gracilaria, Grev., \&c.), HypnÆace 
(Hypnæa, Lmx.), Gei.idiace (Gelidium, Lmx., \&c.), Spongiocarpee (Polyides, Ag.), Lomentariace (Lomentaria, Gaill.), Rhodomelace (Laurencia, Lmx., Chondria, Ag., Rhodomela, Ag., Polysiphonia, Ag., Rytiphlæa, Ag., Amansia, Lmx., Vidalia, Ag., Dasya, Ag., Pollexfenia, Harv., \&c.), Spyridiaceæ (Spyridia, Harv.), and Wrangeliaceæ (Sper. mothamnion, Aresch., Bornetia, Thur., Lejolisia, Born., Wrangelia, Ag., \&c.). A peculiar mode of fertilisation is described in the case of Gracilaria confervoides (Grev.). The procarp is composed of six or seven cells, and its position is indicated by an external swelling on the 'frond;' the pericarp is formed before fertilisation. The cells both of the procarn and of the placenta fuse together by the disappearance of their cellwalls; and the fused cells of the procarp and of the placenta are placed in communication with one another by protoplasmic protrusions or diverticula, proceeding from the fused cells of the procarp and passing through their swollen walls. The cells which form the free surface of the placenta now produce radiating rows of spores formed basipetally, while from the fused procarpial cells other diverticula arise which also form spores at their free ends
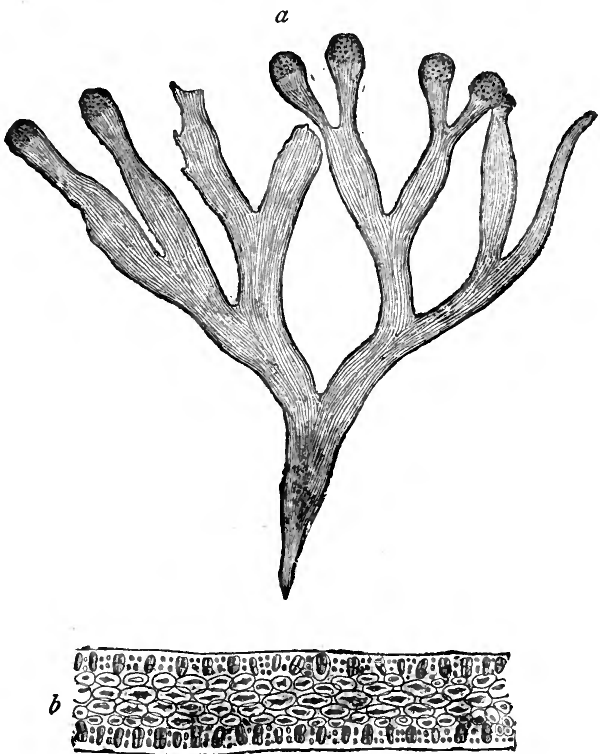

Fig. I86.-Rhodymenia Palmetta Grev. $a$, with tetrasporanges (ratural size); $b$, section through apex of frond with tetrasporanges $(x$ Ioo). (After Kützing.)

independently of the placental cells. It would appear as if by this means a portion of the protoplasm of the pollinoid were conveyed through the trichogyne and the procarpial cells, which play the part of the auxiliary cells of Dudresnaya, to the placental cells. In Polyides the cystocarps are congregated in external amorphous wart-like excrescences formed of vertical confervoid filaments, of which the cartilaginous 'frond' is almost entirely composed, set in firm jelly.

Plocamium coccineum (Huds.) is one of the most abundant of our red seaweeds. Rhodymenia palmata (Grev.), a very common red seaweed, 
is eaten in Scotland under the name of 'dulse.' Chondrus crispus (L.) is known, when dried, as 'carrageen ' or 'Irish moss.' Gracilaria lichenoides (L.), which yields copious gelatine, known as 'Fucus amylaceus,' is largely used as an article of food in Ceylon and on other tropical coasts. Japanese isinglass is a product of species of Gelidium. The

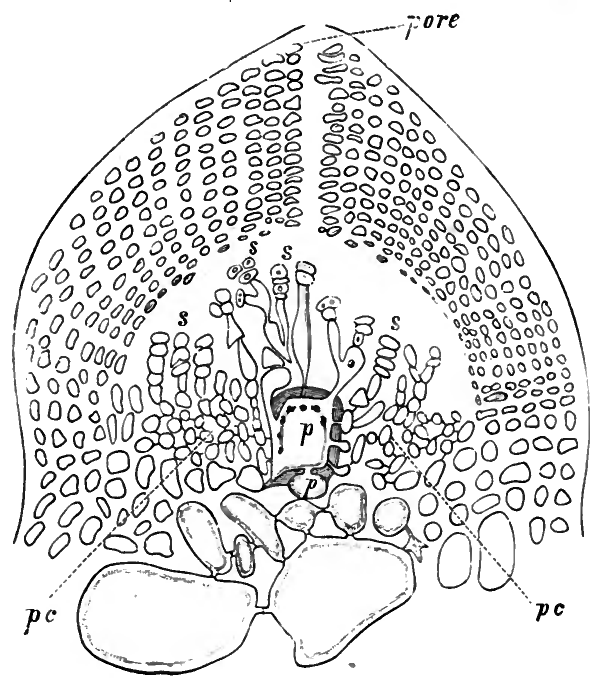

FIG. 187.- Vertical median section of swelling on frond of Gracilaria confervoides Grev. $\not p, \not p$, cells of procarp ; $p c$, placental cells; $s, s, s$, spores $(\times 400)$. (After Johnson.)

substance known to microscopists as 'agar-agar' is yielded also by Gracilaria lichenoides, Eucheuma spinosa (Ag.), and other seaweeds. Several other species are employed in different parts of the world as glues and varnishes. Marchesettia spongioides (Hauck) (Areschougiaceæ), from Singapore, has a remarkable resemblance to a sponge.

\section{LiterATURE.}

Berthold-(Cryptonemiaceæ) Fauna u. Flora Golfes Neapel, I884. Johnson-(Gracilaria) Annals of Botany, i. 1888, p. 213.

The Squamariace (Hildenbrandtia, Nard., Cruoria, Fries, Peyssonnelia, Dcne., \&c.) are a small group of small marine, or rarely fresh-water Algæ, growing on stones or on the shells of molluscs or crustacea, or attached to larger algæ. 'The 'frond' is expanded flat or hemispherical, gelatinous, membranaceous, or crustaceous, with lichen-like habit, composed of a single layer of cells, or more often of short densely 
packed vertical filaments. The species of Hildenbrandtia form rosecoloured incrustations on rocks, stones, and shells in salt or (H. rivularis, Ag.) running fresh water. The tetrasporanges are either terminal cells of special filaments, enclosed in a gelatinous coating and rising vertically from the flat thallus; or they are formed in nematheces, in external wart-like protuberances, or in depressions in the surface of the thallus. The cystocarps are also either formed in nematheces, or are external,

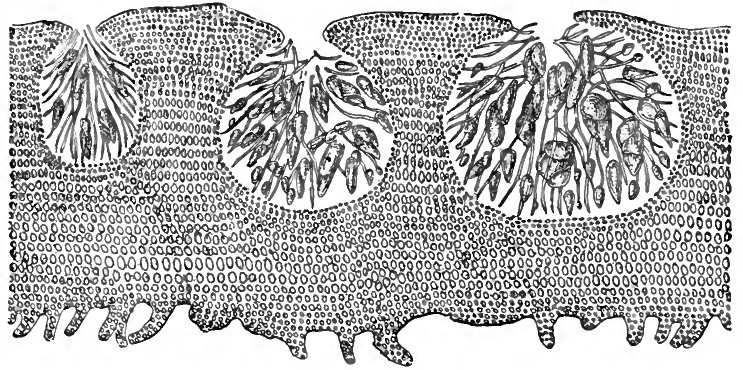

FIG. 188.-Hildenbrandtia prototypus Nardo. Vertical section through thallus, showing three conceptacles with cystocarps ( $\times 300)$. (After Kützing.)

springing from moniliform fertile filaments. It is stated that there are sometimes two kinds of carpogone, one provided with a trichogyne, the other not. After a carpogone of the first kind has been fertilised through its trichogyne, it puts out a fertilising-tube or 'ooblastemafilament,' which impregnates a carpogone of the second kind. In Hildenbrandtia a large number of antherids are developed from a single cell of the thallus.

\section{LITERATURE.}

Schmitz-Sitzber. Niederrhein. Gesell., I879.

Borzl-Rivista Scientifica, I88o.

Petit-Bull. Soc. Bot. France, I88o, p. 194.

Wollny-Hedwigia, I886, pp. I and $\mathbf{2} 25$.

The Helminthocladiaceæ (including Nemalieæ, Batrachospermeæ, and Chætangiaceæ) comprise a number of marine (Helminthocladia, Ag., Nemalion, Ag., Liagora, Lmx., Galaxaura, Lmx., \&c.) and fresh-water (Chantransia, Fries, Batrachospermum, Roth, Thorea, Bory) forms, the relationship of which to one another is uncertain, and the family is not likely to be one that will be ultimately retained. The fresh-water species are mostly of small size, but of great beauty from the elegant symmetry and arrangement of the branches. The 'frond' of Liagora and Galaxaura is calcareously incrusted, like that of a coralline ; that of 
some other genera is very soft and gelatinous; the whole is usually enclosed in a gelatinous envelope. The thallus is of filamentous struc-

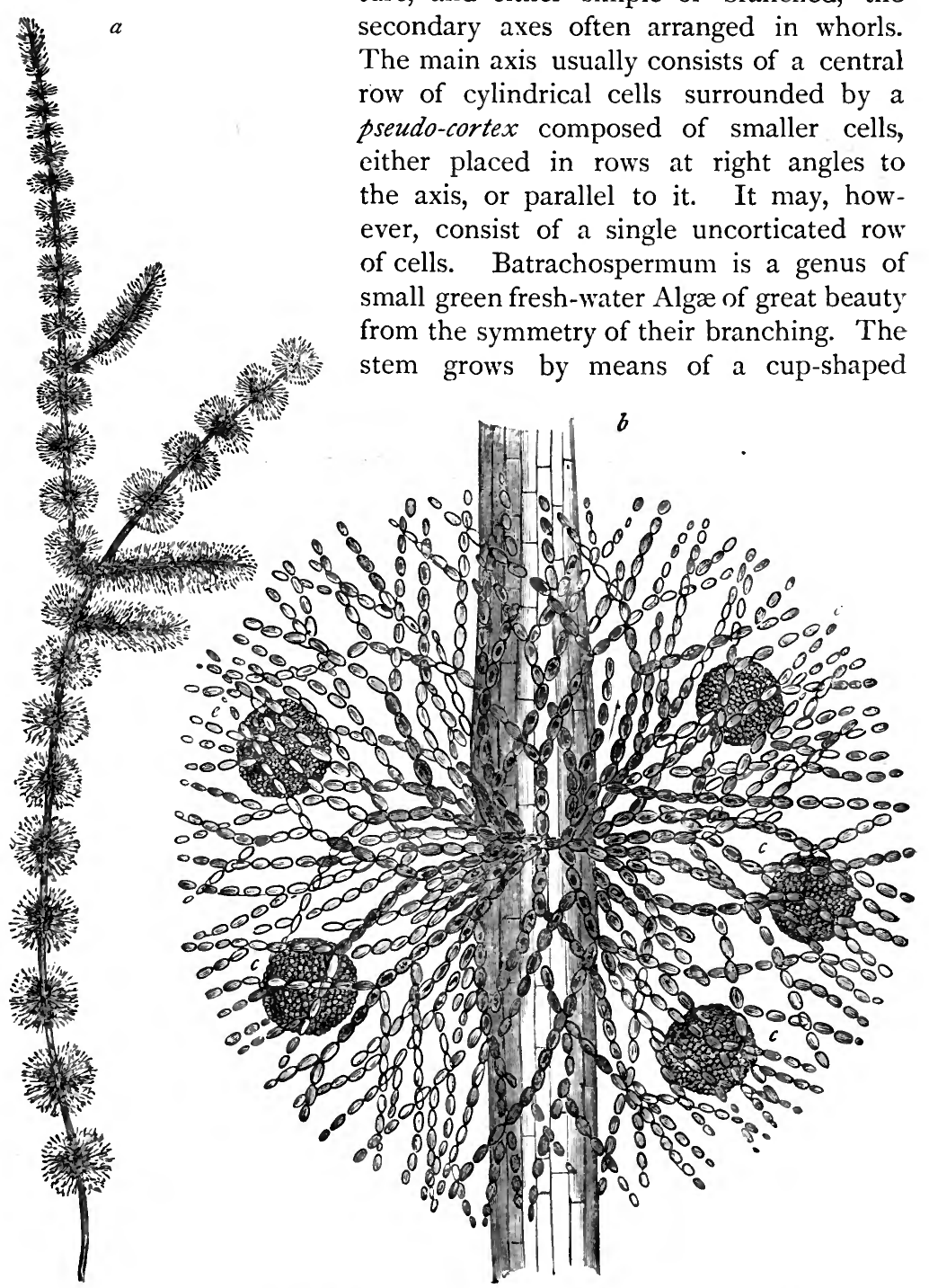

FIG. 189.-Batrachospermum moniliforme Roth. a, portion of plant $(\times 30) ; b$, portion with cystocarps, $\operatorname{cccc}\left(\times x_{150}\right)$. (From nature and after Cooke.) 


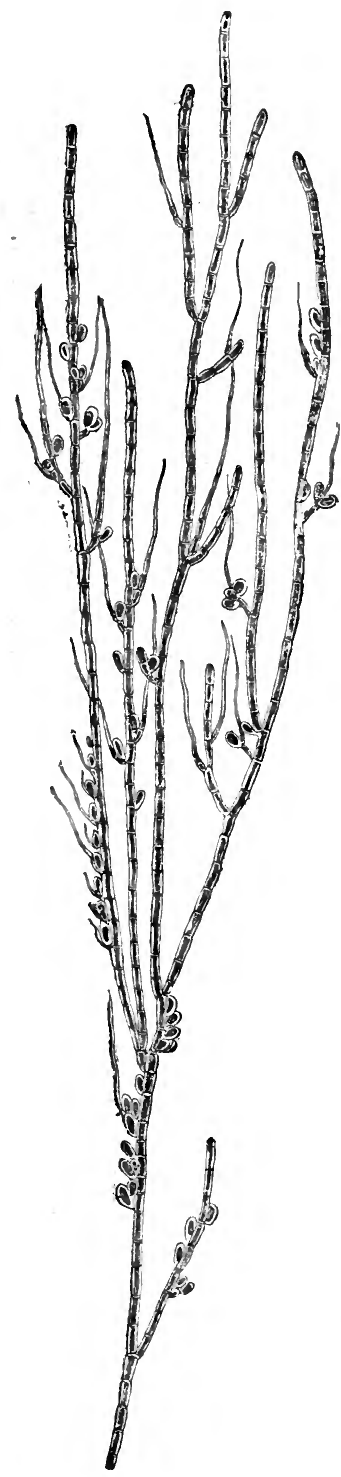

FIG. I9o.-Chantransia virgatula 'lhur. with tetrasporanges ( $x$ I $\infty)$. (After Kützing.) apical cell, which divides by septa; the resulting cells do not divide further, but elongate and swell somewhat at each end into a bone-shaped form, producing the whorled branches. From the basal cells of these branches secondary branches grow vertically downwards over the main axis, producing the pseudo-cortex. According to Sirodot, absorption takes place only in special thin-walled cells; the resting-cells, with thicker walls, often display continuity of protoplasm. In Nemalion and Batrachospermum the procarp is unicellular, and bears at its apex the long thin-walled trichogyne. The antherids are scattered in groups at the end of peculiar ovoid cells. After fertilisation the carpogone divides by longitudinal walls into a multicellular glomerule enclosed in a gelatinous envelope; the terminal cells of the branches of the glomerule produce the spores. The cystocarps are external in the axils of the branches in Chantransia and

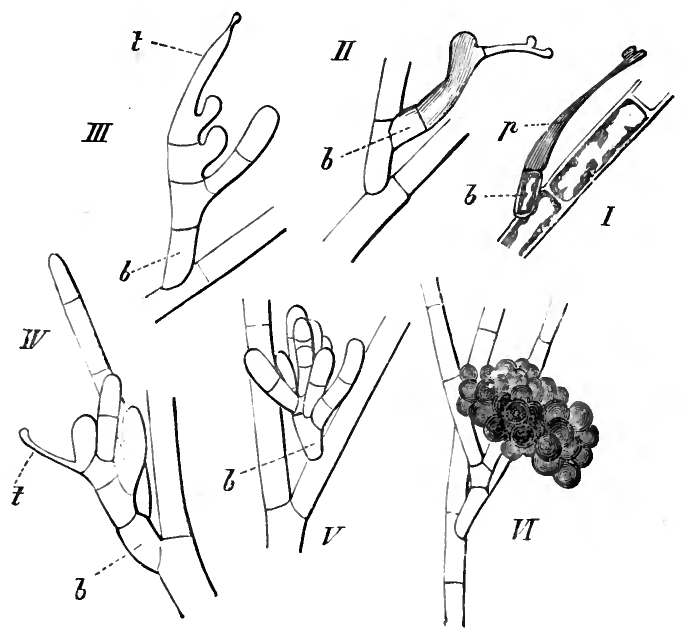

FIG. I9I. $-C$. corymbosa Thur. $I$, unicellular procarp, $b$, with pollinoid attached. $I 1-V$, stages in the branching of the procarp after impregnation $(\times 40)$. VI, cystocarp ( $\times$ 250). (After Thuret.) 
Batrachospermum, more or less imbedded in the thallus in the other genera of the order. In several of the genera tetraspores are unknown.

A very singular genetic connection exists between the genera Chantransia and Batrachospermum, it being possible to transform the former into the latter by changing its conditions of life. The germinating carpospores of Batrachospermum put out a kind of protoneme, which is the Chantransia of Fries, the non-sexual generation of Batrachospermum ; this can propagate itself by simple budding from generation to generation, producing, as a rule, as its organs of propagation, only non-sexual tetraspores. Chantransia grows especially in dark situations under water, and, when transferred to the light, undergoes a metamorphosis. There springs up from the Chantransia protoneme a branch which is in every respect a Batrachospermum, and which bears sexual organs only, and no tetraspores. On one species only of Chantransia, C. corymbifera (Thur.), are sexual organs known. Although this phenomenon is sometimes spoken of as an example of 'alternation of generations,' it is not identical with the process known under that name in the higher Cryptogams, being rather a difference in the mode of development dependent on a change in the vital conditions.

\section{LiterATURE.}

Solms-Laubach - Bot. Zeit., I867, p. I6r.

Sirodot-Compt. Rend., lxxvi., I873, pp. I216, I335 ; lxxix., I874, p. I366 ; xci., I880, p. 862 ; xcii., I881, p. 993 ; Bull. Soc. Bot. France, I875, p. I28 ; and Les Batrachospermées, I 884 .

Arcangeli-Nuov. Giorn. Bot. Ital., I882, p. 155 .

Massee-Journ. R. Microsc. Soc., I886, p. 56I.

The LEMANEACEÆ are a small group of fresh-water Algæ, comprising the genera Lemanea (Bory) and Sacheria (Sir.), growing in rapidly running water, as beneath mill-wheels. The thallus is filiform and cartilaginous, of a dull grey or greenish colour, and consists of a single row of tubular cells, or of an axial row surrounded by rows of smaller cortical cells ; it displays swellings or projections at regular intervals. It grows by means of an apical cell, from which segments are cut off at right angles to the direction of growth. By transverse septation each segment divides into a central cell surrounded by peripheral cells ; the central cell becomes a member of the central axis, the peripheral celis members of the cortical tubes. The 'frond' increases by budding at the free surface of the rooting system, finally producing cæspitose tufts. No non-sexual spores are known. The only other mode of reproduction is sexual. The antherids are short cylindrical cells produced externally in the neigh- 
bourhood of the swellings, with a more or less regular annular arrangement. The trichogyne is a long transparent cylindrical tube, simple or branched, produced within the tubular thallus. The procarp is unicellular, and of a very simple structure. The carpogone puts out before impregnation a number of segmented filaments resembling paraphyses, and enclosed in a transparent jelly. After the oosphere has been im-

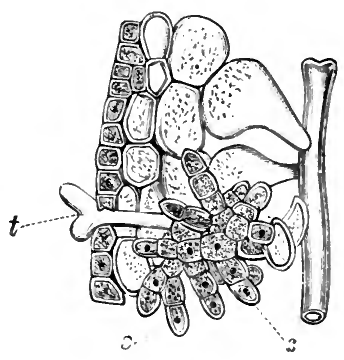

B

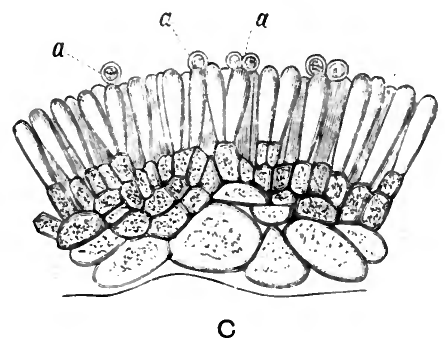

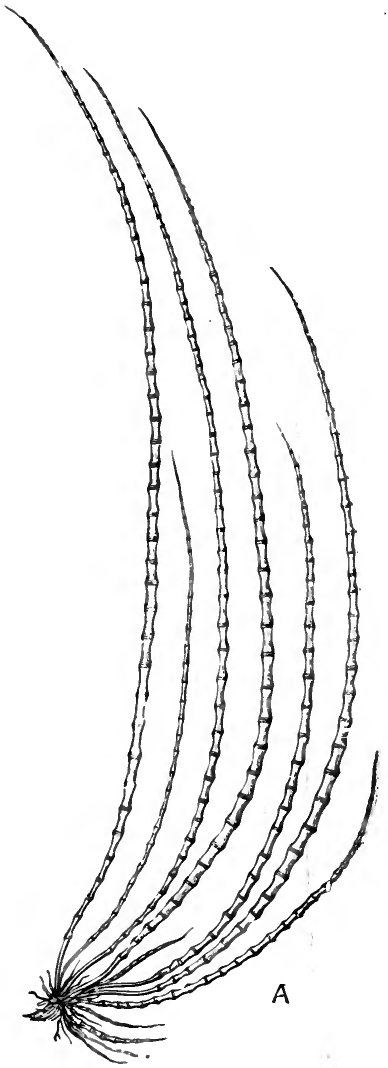

Fig. r92.- $A$, Lemanea nodosa $\mathrm{Ktz}$. (natural size). $B$, section of tube with ferrale organs; $t$, trichogyne, at the base of which sporiferous filaments $(s)$ are beginning to be formed $(\times 200)$. $C$, transverse section of male organs; $a$, antherids $(\times 400)$. (After Sirodot.)

pregnated, it puts out an 'ooblastema-filament,' and the trichogyne disappears ; at the extremity of this filament are produced the carpospores. On germinating the carpospore puts out a protonemal filament somewhat resembling that of mosses, on which the fertile axes are produced as lateral branches. This is regarded by some as a rudi- 
mentary alternation of generations; and Peter asserts (Bot. Verein München, Feb. 28, I887) that the sexual form of Lemanea fluviatilis (Ag.) may develop out of heteromorphic branches of a Chantransia.

\section{Literature.}

Wartmann-- Beitr. zur Anat. und Entwick. der Lemanea, 1854.

Sirodot-Ann. Sc. Nat., xvi., I872, p. 5 ; 1873 , p. 241 ; and Compt. Rend., lxxix., I874, p. 1366.

Ketel--Anat. Untersuch. über Lemanea, I887.

The PoRPhyraceæ or Bangiaceæ are marine or fresh-water Algæ belonging to the two genera Porphyra (Ag.) and Bangia (Lyngb.). They are regarded by some authors as much lower in structure than the red

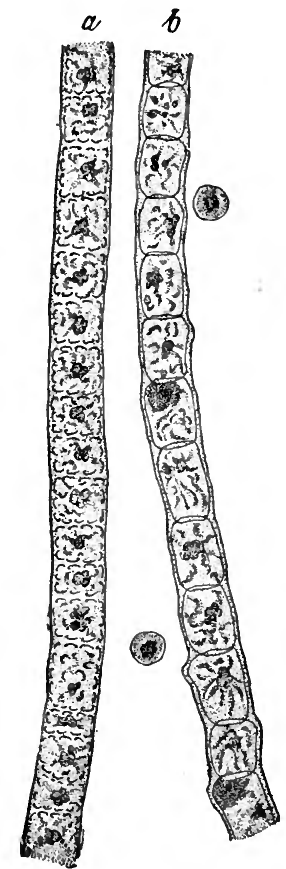

Fig. 193.- $-a, b$, Bangia ceramicola Chauv. Portions of barren and fertile filaments $(\times 330)$. (After Thuret.)

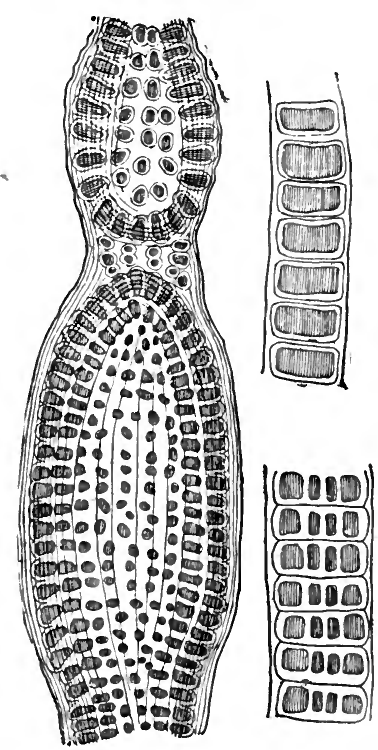

FIG. 194.-B. fusco-purpurea Lyngb. Filament in different stages of development $(\times 200)$. (After Küitzing.)

seaweeds, but are best placed at present, from their mode of sexual reproduction, as one of the lowest families of Florideæ. The thallus is either filiform (Bangia), or is a thin transparent plate (Porphyra) com- 
posed, in its vegetative portion, of a single layer of cells ; in both cases coloured by phycoerythrin. The tetrasporanges and the male and female organs appear to be homologous to one another, and not to be sharply differentiated. The tetraspores are motile for about forty-eight hours after their escape from the tetrasporange ; by some writers they are described as being endowed with an amœboid change of form. The trichogyne is quite rudimentary; the pollinoids attach themselves singly or. in numbers to the fertile portion of the thallus where the oogones or rudimentary carpogones occur. While in this position they are invested by a thin cell-wall of cellulose, and then put out a slender thread of protoplasm which pierces the cell-wall of the oogone, nearly the whole of the protoplasm of the pollinoid passing into this organ. According to Berthold, the contents
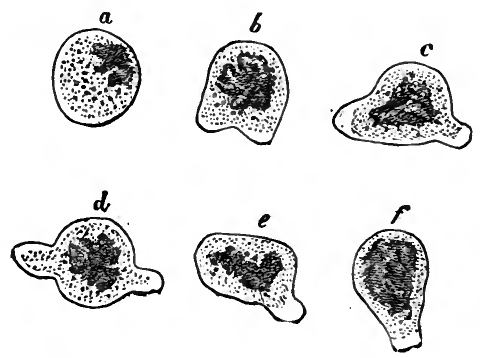

FIG. 195.-Tetraspores of Bangia fusco-purpurea Lyng., showing amoboid changes of form (magnified). (After Reinke.)

of the oogone break up, after impregnation, into eight carpospores, the 'octospores' of Janczewski, which move about, on escaping, in an amœboid manner, putting out and withdrawing protoplasmic protrusions, then come to rest and germinate. Porphyra vulgaris (L.), not uncommon on the coasts of Western Europe, is eaten under the name 'purple laver.'

\section{LiteratuRE.}

Janczewski-Ann. Sc. Nat., 1873, p. 241.

Reinke-Pringsheim's Jahrb. wiss. Bot., I878, p. 274.

Goebel-Bot. Zeit., I878, p. 199.

Berthold--Mittheil. Zool. Stat. Neapel, I880 and I882.

The position of the UlvacEæ is still uncertain. The group includes a small number of genera-Ulva (L.), Enteromorpha (Lk.), Phycoseris (Ktz.), Prasiola (Ag.), and Monostroma (Thur.) — of fresh-water or more often of marine or brackish Algæ, of a bright green colour, consisting of a flat usually ribbon-shaped plate, composed of either one (Monostroma) or two (Ulva) layers of cells; less often (Enteromorpha) having the form of a tube. The cells are sometimes arranged symmetrically in groups of four (Prasiola). The male and female reproductive organs, which are rudimentary in the Porphyraceæ, are entirely suppressed in the Ulvaceæ, and we find a reversion to a much simpler mode of repro- 
duction in the conjugation of equivalent swarm-cells. Ulva produces two kinds of swarm-spore-megazoospores with four cilia, and micro-
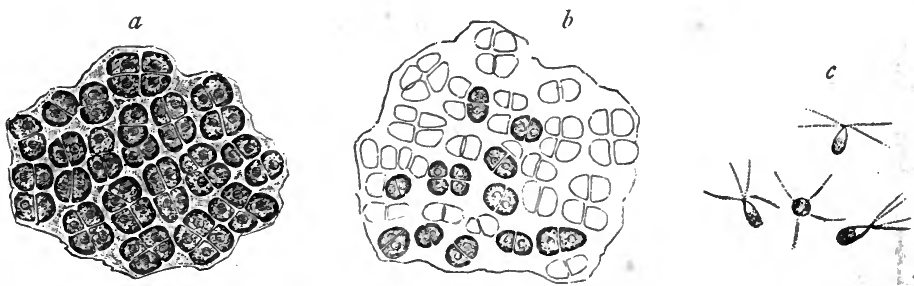

F1G. 196.-Ulva. $a$, portion of frond showing cells which produce the swarm-spores; $b$, portion of frond with empty cells; $c$, megazoospores (magnified).

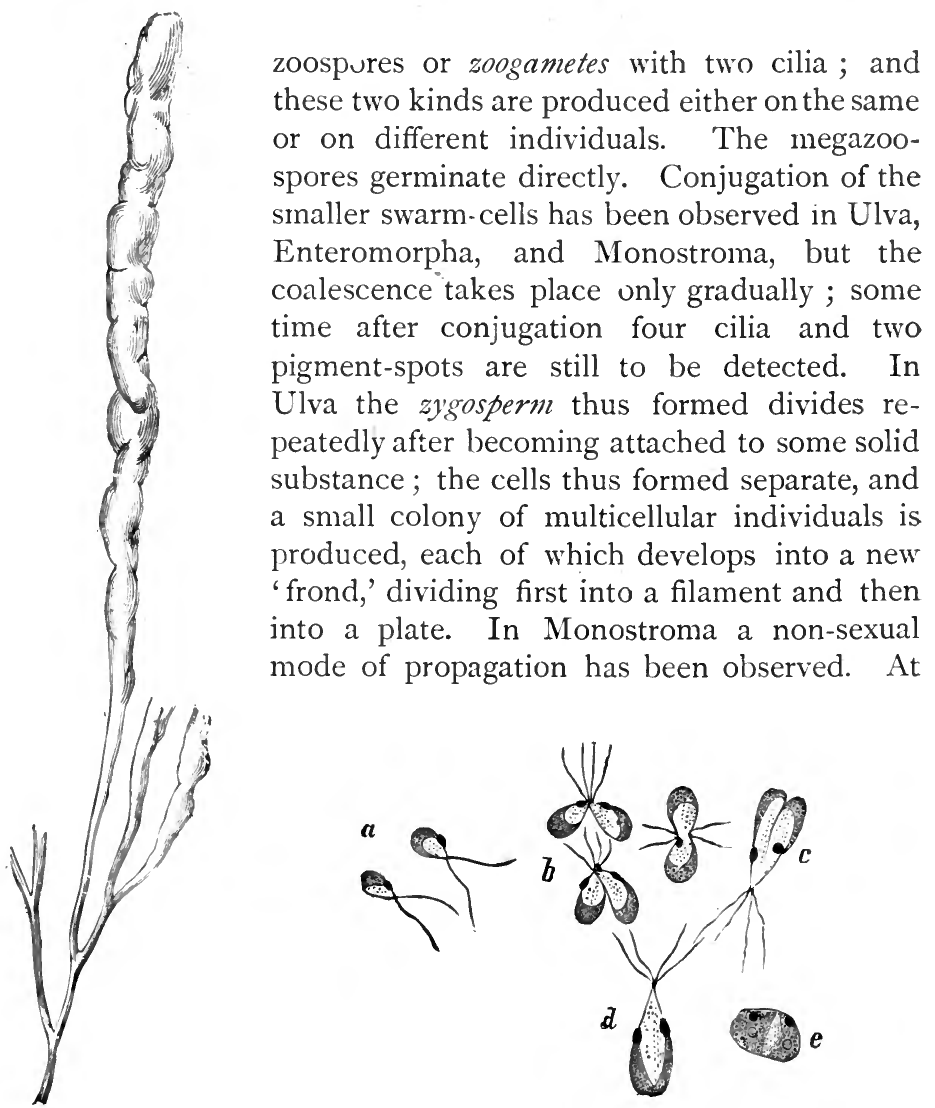

FIs. 197. - Enteromorpiza intestinalis Lk. (natural size). (After Hauck.)
Fig. 198. - Stages in the conjugation of the zoogametes of Monostroma bullosum Thur. (magnified). 
certain spots the cells divide in a direction parallel to the plane of the thallus, and a small projection is thus formed which becomes detached and develops into a new 'frond.' Geddes (Trans. R. Soc. Edinburgh, I 88I, p. 555) describes also a process of gemmation in Enteromorpha. The ordinary mode of reproduction in the Ulvaceæ so closely resembles that in the Confervaceæ that the two families are generally considered as nearly allied; but the difference in the structure of the thallus is so great that it is difficult to believe in any near affinity between them. On the other hand, the structure of the thallus in Ulva and Porphyra is almost identical; and it is at least as probable that the Ulvaceæ are derived from the Porphytaceæ by further retrogressive metamorphosis displayed in the complete suppression of the antherids and carpogones, and the reversion of the tetraspores into motile swarm-spores of two kinds, the smaller of which are zoogametes. On the other hand, Monostroma may be allied to Tetraspora among the Protococcaceæ. Several species of Enteromorpha form a large portion of the green vegetation in salt ditches or on muddy sea-shores, or on rocks between high and low water mark; Prasiola grows on bare rocks or stones, or on salt soil ; the substance known as 'green laver' consists of several species of Ulva.

\section{Literature.}

Jessen-Prasiolæ Monographia, I848.

Thuret-Mém. Acad. Sc. Nat. Cherbourg, I854, p. 9.

Wittrock-Monogr. Monostroma, I866.

Janczewski et Rostafinski-Mém. Acad. Sc. Nat. Cherbourg, I874, p. 369.

Areschoug - Bot. Notiser, 1876.

Thuret et Bornet-Etud. Phycol., I878.

Reinke-Pringsheim's Jahrb. wiss. Bot., I878, p. 531.

-Borzl-Studi Algologici, 1883 .

\section{Class XI.-Confervoideæ Heterogamæ.}

The small group of green fresh-water Algæ comprised in this class form a connecting link between the lower Florideæ and the Isogamous Confervoideæ, from which latter they are distinguished by the sharp differentiation of their male and female organs of reproduction. In the highest order, the ColeochæтасеÆ, the mode of reproduction bears a striking analogy to that in the Nemalieæ, being effected through the agency of a tubular trichogyne; but the male elements are no longer immotile pollinoids, but motile swarming antherozoids, naked biciliated or multiciliated protoplasmic bodies, but much more closely resembling the corresponding structures in the lower Algæ than the coiled anthero- 
zoids of the Muscineæ and Vascular Cryptogams. The vegetative thallus is here either composed of branching filaments, or is reduced to a flat plate of cells. In the two lower orders, the CEDOGONIACEÆ and the SPHÆROPLEACEÆ, it consists of an unbranched filament of uninucleated or multinucleated cells; and in them the impregnation of the oosphere by the motile antherozoids is brought about directly, without the intervention of a trichogyne. Non-sexual propagation by means of swarming biciliated zoospores, formed within zoosporanges, and bearing a close resemblance to the antherozoids, occurs in the Coleochætaceæ and Sphæropleacæ; in the CEdogoniaceæ the zoospores are much larger bodies, bearing a tuft of cilia. The class displays a rudimentary alternation of generations.

\section{Order I.-Colenchetaceæ.}

The typical genus of this small order, Coleochate (Bréb.), comprises several species of small fresh-water Algæ forming minute discs or cushions attached to submerged plants, from $\frac{1}{10}$ to $\frac{1}{4}$ inch in diameter, consisting, in the simpler forms, of a single layer of cells, often arranged in rays proceeding from a common centre. Some of these cells are furnished with colourless bristle-like protuberances fixed into narrow sheaths. All the cells of which the thallus is composed usually lie in one plane, but their degree of union with one another varies. In C. scutata (Bréb.) they are closely united into a compact disc, which continues to grow by peripheral increase, the marginal cells dividing by radiating and tangential walls. In C. soluta (Pringsh.) the thallus consists of a number of branches, which ramify dichotomously, and lie side by side, more or less closely crowded, in one plane. In other species, as C. pulvinata (A. Br.) and divergens (Pringsh.), the branches do not ramify in one plane only, but develop also segmented ascending branches, which form, in the latter species, together with the original disc, a nearly hemispherical cushion. The entire thallus is always enveloped in mucilage.

Non-sexual propagation takes place in Coleochæte by means of biciliated zoospores, produced either in all the cells of the thallus or only in the terminal cells of the branches. The entire protoplasmic contents of the mother-cell or zoosporange are used up in the production of the zoospores, which escape from them either at the side or at the back. Sexual reproduction is effected by the impregnation of an oosphere formed within an oogone by motile antherozoids, through the agency of a trichosyne. The oogone is, in C. pulvinata, always constituted out of the terminal cell of a branch, which swells up and at the same time elongates at its extremity into a narrow hair-like trichogyne, which then 
opens at its apex and exudes a drop of colourless mucilage. The oogone still contains chlorophyll, and its protoplasmic contents contract into a green oosphere. At the same time flask-shaped protuberances grow out from adjoining cells, and these, becoming cut off from the parentcells by septa, are the antherids. The entire contents of each antherid escape as a single ovoid antherozoid furnished with two very long and slender cilia. Other species are diœcious, the antherids being produced on different individuals from the oogones. The antherozoids probably pass into the trichogyne through its open apex, and thence into the oogone; but the act of impregnation has not actually been observed hitherto.

The first result of the impregnation of the oosphere is its investment

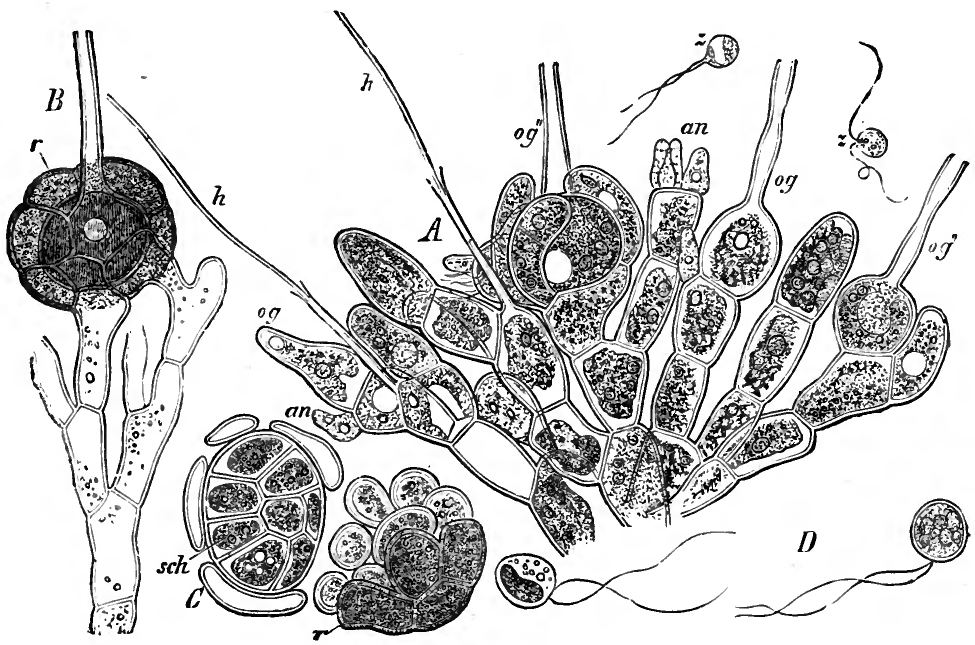

FIG. 199.-Coleochate pulvinata A. Br. A, portion of fertile thallus $(\times 350)$; an, antherid ; og, oogone ; $h$, hyaline hair ; $z$, antherozoid. $B$, ripe oogone with its pericarp, $r(\times 280)$. C, formation of carpospores within the spermocarp $(\times 280)$. D, zoospores ( $\times 280)$. (After Pringsheim.)

by a cell-wall of cellulose, and a considerable increase in its size. The fertilised oogone, with the exception of the trichogyne, then becomes. surrounded by a pericarp, or cortical layer of cells; the oogone and pericarp together constitute the spermocarp enclosing the fertilised oosphere or oosperm. The spermocarp subsequently becomes further invested by a cortex of closely applied branches resulting from the continued development of cells at the base of the spermocarp. After the complete development of this organ, which takes place between May and July, the vegetative cells of the thallus disappear, and its walls assume a darkbrown colour. The spermocarp remains dormant through the winter; 
the cortical layer is then thrown off, and the oosperm divides into several cells or carpospores. The germinating carpospore does not give rise to a new thallus, but to a zoospore, which gives birth to several successive nonsexual generations propagated by zoospores, until the cycle of generations is completed by the production of $\mathfrak{a}$ sexual individual.

Mycoidea parasitica Cunn. (Trans. Linn. Soc., vol. i., r879, p. 301) is probably nearly allied to Coleochæte, which it resembles in the nature of its thallus and in its mode of reproduction. It is endophytic in the cells of the leaves of Camellia in tropical India, inflicting great injury on the trees. Ward (Trans. Linn. Soc., ii., I884, p. 87) contends that Mycoidea is in reality an epiphyllous lichen. Möbius (Ber. Deutsch. Bot. Gesell., I888, p. 242) regards Mycoidea, and the nearly allied Chætopeltis (Berth.), as more probably belonging to Chætophoraceæ.

\section{Literature.}

Brébisson-Ann. Sc. Nat., i., 1844 , p. 25.

Pringsheim-Jahrb. wiss. Bot., I860, p. I.

Kny-Ber. Deutsch. Bot. Gesell., I884, p. 93.

\section{ORder 2.-CEDOGONIACEE.}

This small order, as at present constituted, cornprises only two genera-- Edogonium (Lk.) and Bulbochæte (Ag.).

Edogonium includes several species, abundant in streams, ponds, and tanks. They are readily distinguished by the fact that they never branch, by the cells being of small diameter and considerable length, filled with a homogeneous dark-green protoplasm with a parietal nucleus, and by the peculiar appearance of annular striæ near one end of some of the cells. These striæ result from the appearance known as 'intercalary surface-growth.' Below the septum is formed an annular deposit or cushion of cellulose; at this place the cell-wall splits, as if by a circular cut, into two pieces, which separate from one another, but remain united by a zone of the cell-wall formed by an extension of the cushion. This process is constantly repeated over a short space of the cell-wall immediately beneath a septum, each slit being a little further from the septum than those that preceded it ; so that these pieces, forming small projections, give to the upper end of the cell the appearance of consisting of caps placed one over the other; while its lower end appears as if enclosed in a long sheath consisting of the portion of the cell-wall below the caps. This lower portion of the cell is always cut off by a septum from the upper cap-bearing portion. The filaments are fixed at their base by a rhizoid to solid bodies or submerged plants.

Non-sexual propagation takes place in CEdogonium by means of zoospores, the formation of which affords a typical example of the process 
first described by A. Braun as the 'rejuvenescence' of a cell, i.e. the transformation of the entire protoplasm of a vegetative cell into a ' primordial cell,' which subsequently invests itself with a new cell-wall, and forms the starting-point of the life of a new individual. In some one cell of a filament, either the terminal or some other, sometimes even in the single cell of which a young filament is composed, the protoplasm contracts into a globular body which ultimately becomes free by the rupture of the cell-wall, by a transverse slit, into two very unequal halves. When this takes place in the terminal cell of a filament or the single cell of a young individual, the upper smaller portion of the cell-wall is lifted up like a lid, or even completely thrown off like a cap. The zoospore thus formed, which in some species is one of the largest and most striking known, has a nucleus, a red 'pigment-spot,' and an anterior hyaline region, to which is attached a tuft of cilia, visible even before its escape from its mother-cell. At the period of escape it is still enveloped in a transparent membrane, which, however, it soon breaks through, and then moves about in the water with great velocity for perhaps half an hour, displaying at this period a number of vacuoles. On coming to rest, the zoospore becomes attached by its anterior hyaline end, loses its cilia, invests itself with a cell-wall, puts out a rhizoid from the point of attachment, and develops into a filament with transverse septa. From the position occupied by the zoospore in the mother-cell, the direction of growth of the new individual must be at right angles to that of the parent-filament. Many of the plants which spring from zoospores are non-sexual, producing nothing but zoospores.

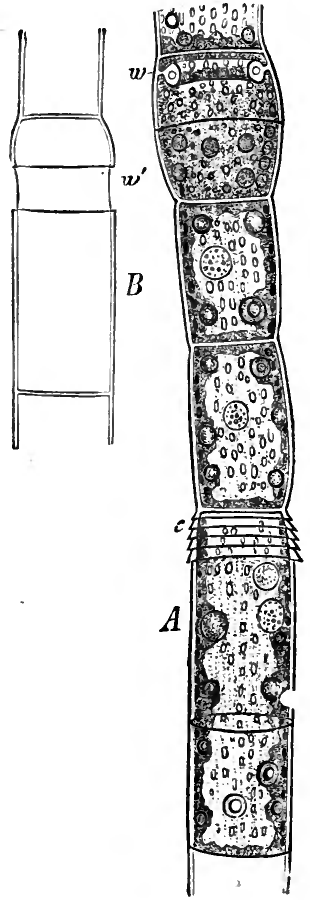

F1G. 200. - Portion of filament of CEdogonium. $w$ in $A$, the cushion of cellulose which has lengthened to the piece of cell-wall, $z t^{\prime}$ in $b^{\prime} ; c$, cellcaps (magnified).

Edogonium is also reproduced by resting-spores (IVille, Bot. Gesell. Stockholm, Sept. 26, I 883 ; see Bot. Centralbl., xvi., I 883, p. 21 5).

The sexual reproduction of CEdogonium still shows a high degree of differentiation of the male and female elements. The antherozoids are very similar in form to the zoospores, but much smaller, and they are provided with a similar tuft of cilia. The antherids are cells belonging to ordinary filaments, but shorter and not containing so much chlorophyll 
as the rest, lying either singly among the ordinary vegetative cells, or sometimes in groups of as many as twelve. In most species each antheridial cell divides either horizontally or vertically into two 'special mother-cells,' each of which gives birth to an antherozoid. The oogones are developed either in the same filament as the antherids or not, some species being monœcious, others diœcious. They are also frequently in groups of from three to six. Their development always takes place out of
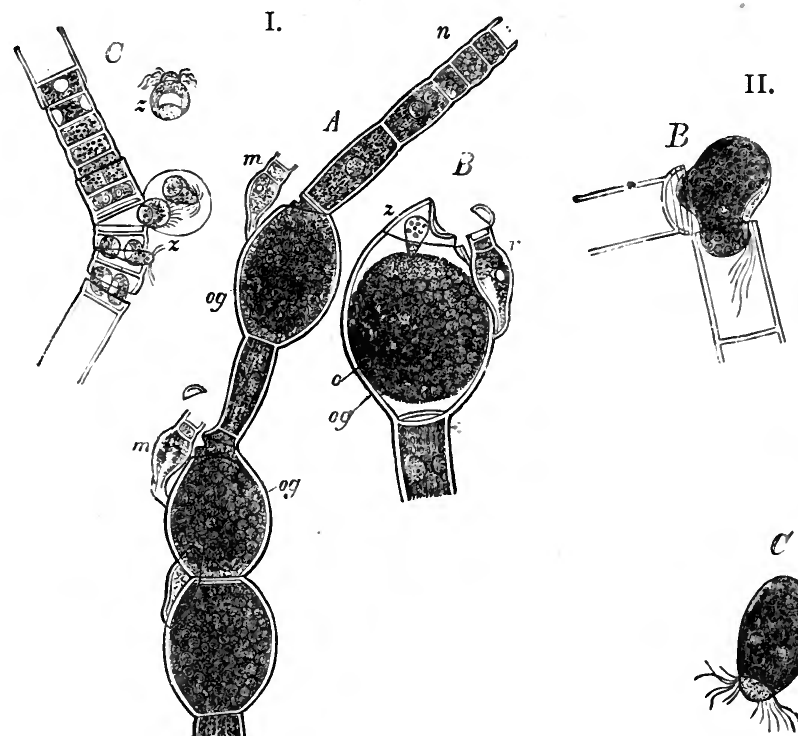

II.

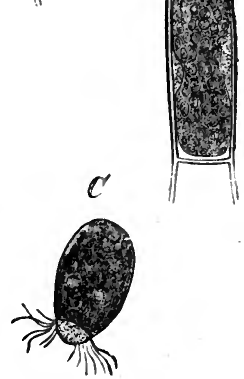

FIG. 201.-I. A, filament of Edogonium ciliatum Hass.; $n$, zoosporange; og, oogone with 'dwarf male,' $m$. $B$, oogone at the moment of impregnation; $o$, oosphere ; $z$, antherozoid ; m, 'dwarf male.' C, E. gemelliparum Hass.; piece of filament in which zoospores, $z$, are being formed, from which the 'd warf males' are produced $(x 250)$. II. Zoospores; $A$, still within the zoosporange ; $B$, in the act of escaping ; $C$, free zoospore. (After Pringsheim.)

the upper half of the lower portion of a cell provided with cell-caps at its upper end, which has just divided, and which, directly after the division, swells up into a spherical or ovoid form. Immediately before impregnation the protoplasm contracts into an oosphere, containing in one portion densely crowded chlorophyll-grains, and, at the spot opposite to the part of the wall of the oogone which is to open, a hyaline 'receptive spot.' The oogone opens in several ways. Sometimes an oval orifice is 
formed at the side, through which the colourless portion of the protoplasm protrudes in the form of a papilla which takes up the antherozoids. In other cases the oogone splits in the same way as the zoosporanges, throwing back a kind of lid; through the lateral crevice exudes some colourless mucilage in the form of a beak-like canal, through which the antherozoids enter, and coalesce with the hyaline portion of the oosphere. Immediately after impregnation the oosperm invests itself with a cell-wall, and assumes a brown colour, still remaining within the oogone, which separates from the other cells of the filament, and falls to the ground, where the oosperm passes a period of rest before germination as a hypnosperm.
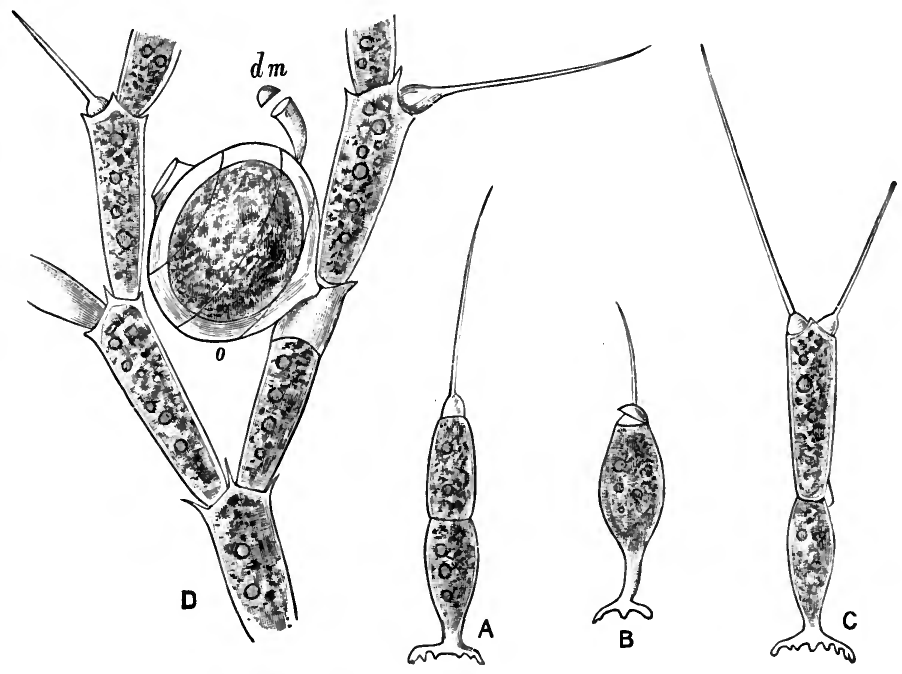

Fig. 202.-Bulbochate setigera Ag. $B$, unicellular antheridial plant. $A, C$, young bicellular plants. $D$, mature plant with oogone, $o$, and 'dwarf male,' $d m$ ( $\times 400$. ' (After Cooke.)

In some species the mode of fertilisation is more complicated. Peculiar zoospores known as androspores are produced non-sexually in special cells of the parent-plant, similar to those which give birth to the antherozoids, only that there is in their case no preliminary formation of 'special mother-cells.' These androspores, which closely resemble the antherozoids in form and size, fix themselves after swarming to a definite spot on the female plant, on or near an oogone, producing very small male plants, which are known as 'dwarf males' or micrandres. Each of these consists of two or three cells, the uppermost of which is an antherid. This gives birth to one or more antherozoids, which escape 
by the lifting up of a lid, and which impregnate the oospheres in the usual way.

When the hypnosperm germinates after a lengthened period of rest, it does not immediately develop into a new plant, but breaks up into several zoospores, usually four ; these give birth to several generations of non-sexual plants, until the cycle is completed by the production of antherids and uogones. The sexual plants, however, especially the female ones, produce zoospores as well.

The species of Bulbochate (classed by some writers with Coleochæte) are minute plants growing in fresh water, and differing from Edogonium in having branched filaments; the terminal cells of the branches ending in long hyaline bristles, which are swollen at the base. The modes of reproduction correspond closely to those in Edogonium. Wittrock includes also Coleochæte and Sphæroplea among the CEdogoniaceæ.

\section{LiteratuRE.}

Braun-Verj. in der Natur, I85I (Ray Soc. Bot. and Phys. Mem., I853).

De Bary-Ueber CEdogonium u: Bulbochæte, 1854.

Pringsheim-Jahrb. wiss. Bot., I858, p. I.

Carter-Ann. and Mag. Nat. Hist., I858, p. 29.

Juranyi-Pringshein's Jahrb. wiss. Bot., I873, p. I.

Wittrock-Prodr. Monogr. Edogoniearum, 1874.

Wille-Pringsheim's Jahrb. wiss. Bot., I 887, pp. 443 and 454.

\section{ORDER 3.-SPHÆROPLEACEÆ.}

This order comprises at present the single species Spharoplea annulina Ag., the simplest of the class, found occasionally on flooded fields. The filaments are cylindrical and unbranched, and are composed of cells which vary in their comparative length and breadth to an extraordinary degree; sometimes the length will hardly exceed the breadth, while in other cases it may be as much as ninety times as great. The transverse cell-walls are of great thickness, their surface is irregularly wavy, and they swell out here and there into great 'beams' and excrescences of cellulose from both the lateral and longitudinal walls. During the development of these septa, orifices are formed in them for the passage of the antherozoids. The cells contain a large number of chromatophores and starch-grains, as well as, when mature, a considerable number of small nuclei.

The sexual reproductive elements are oospheres and antherozoids, formed in different cells of the same filament, which may therefore be regarded as rudimentary oogones and antherids. A filament may consist of 
only two cells, and then one becomes an oogone, the other an antherid. When the number of cells is greater, the oogones and antherids sometimes alternate with one another, but this is not always the case. The contents of an oogone break up into several spherical oospheres, each of which is characterised by a hyaline speck or 'receptive spot.' The antherozoids are produced in extraordinarily large numbers by the breaking up of the contents of an antherid which had previously assumed a brownish red colour. They are furnished with two long slender vibratile cilia, and enter the oogones through the orifices in the transverse walls already mentioned; in their passage they go through remarkable

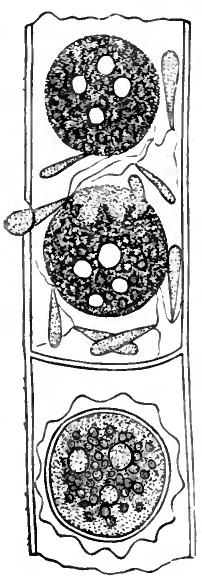

Fig. 203.-Portion of filament of Spheroplea annulina Ag.; upper cell containing oospheres and antherids, lower cell an impregnated oosperm $(\times 500)$. (After Cohn.)

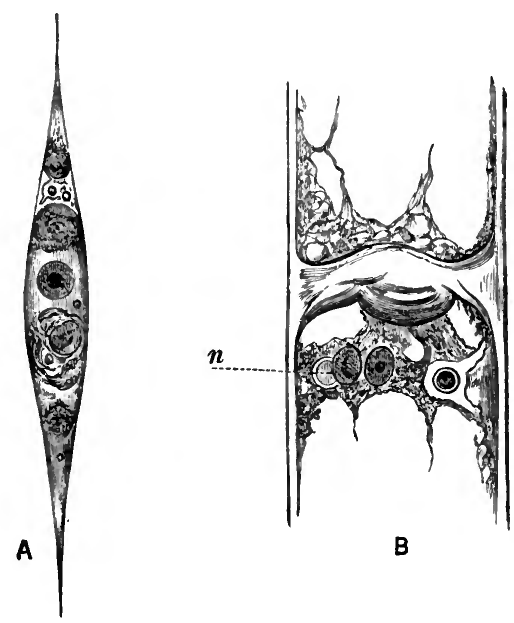

F1G. 204. $-S$. annulina. $A$, young unicellular plant $(\times 900) ; B$, portion of mature filament, showing thick transverse wall and two nuclei, $n(\times 800)$. (After Rauwenhoff.)

changes of form. The fertilised oospore, or oosperm, clothes itself with a thick cuticularised warty membrane, and its contents turn a brickred colour. It usually hibernates within the oogone in the form of a hypnosperm; in the spring its contents break up into three or four zoospores, each of which develops into a slender thread consisting at first of a single fusiform cell which displays no distinction of base and apex, each extremity being elongated into a flagelliform point. The oosphere may also break up into zoospores without previous impregnation.

Probably nearly allied to Sphæroplea, but of somewhat uncertain position, is Cylindrocapsa (Reinsch) (Cienkowski, Mél. Biol. Acad. St. Pétersbourg, I 876 , p. 534), the mode of reproduction of which is 
heterogamous. In other respects it indicates affinity with Ulothrix, and is surrounded by a remarkably thick lamellated gelatinous envelope. It is made by some writers the type of a distinct family, the CyLindroCAPSACEE.

\section{Literature.}

Cohn-Ann. Sc. Nat., v., 1856, p. 187 .

Heinricher-Ber. Deutsch. Bot. Gesell., I883, p. 433.

Rauwenhoff-Rev. Internat. Sc. Biol., 1883, p. 176; and Arch. Néerl. Sc. Exact. et Nat., I887, p. 9 I.

\section{Class XII.-Fucaceæ.}

This family-adopting the limits first proposed by Thuret-consists of a small number of genera of large olive-brown seaweeds distinguished by their mode of sexual reproduction, and by the entire absence, throughout the class, of zoospores, or indeed of any kind of non-sexual spore.

The thallus or 'frond' is often several feet in length, cylindrical or flattened, or, in Himanthalia (Lyng.), cup-shaped, of a cartilaginous texture, and is attached to the sea bottom by a branched rhizoid or attachment-disc. This organ is altogether superficial, and has no function in the absorption of food-material, like the root of higher plants. It is formed entirely of filaments originating from the stipe or stem. In some species detached branches have the power of maintaining their existence, and even multiplying for an indefinite period, floating on the surface. Nearly all the species are perennial. Although the thallus does not display the same amount of external differentiation into 'stipe' and 'frond' as some of the Laminariaceæ, the differentiation of internal tissues is quite as great. In the centre of the thallus is a medullary system composed of elongated cells, and surrounded by a cortical system of shorter nearly isodiametrical cells ; there is only a very rudimentary development of epiderm. The thallus increases in thickness by the radial division of the outermost rows of cells or hyphe of which the cortex is composed. Growth in length is entirely apical, taking place, according to the most recent observations, by the segmentation of a single well-marked four-sided apical cell, which may be seated, as in Fucus furcatus (Ag.), at the base of a depression at the apex of the frond. Grabendörfer states (Bot. Zeit., I885, pp. 609 et seq.) that in Durvillæa (Bory) there is no apical growing point. The thallus of the Fucaceæ always branches dichotomously and monopodially, the branches lying, when not disturbed, in a single plane. In the more highly 


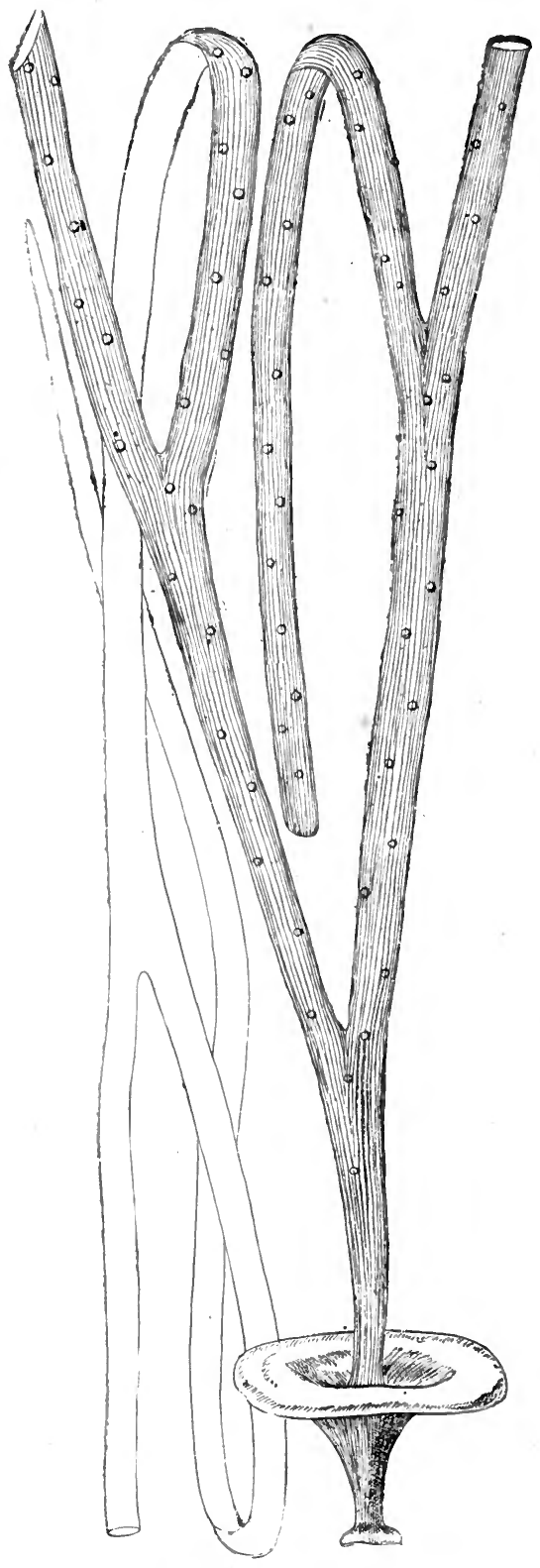

FIG. 2050-Himanthalia lorea Lyng. (natural size). (After Hauck.)

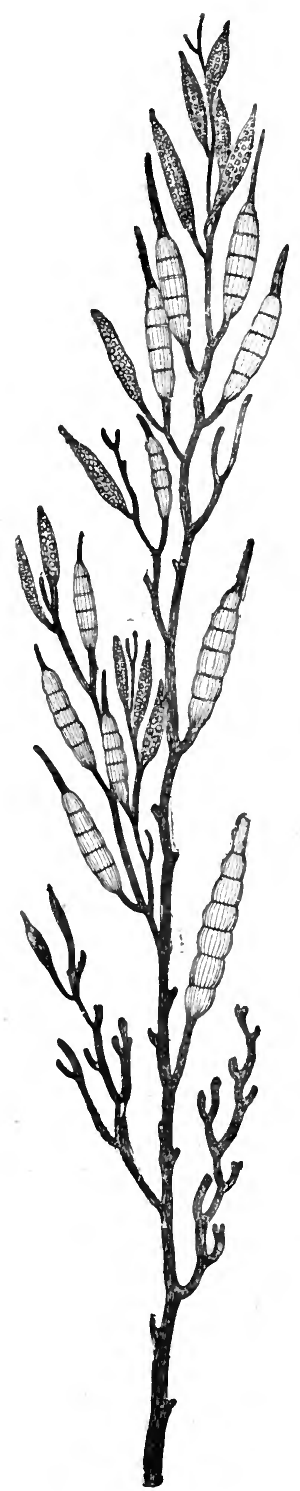

F1G. 206.-Halidrys siliquosa Lyng. (natural size). (After Hauck.) 
developed genera, such as Sargassum (Ag.) and Durvillæa, there is a more or less advanced differentiation of lamina or leaf from stipe or stem ; and the 'leaves' are even arranged spirally and furnished with a rudimentary midrib.

The cell-wall often consists of two distinct layers, an inner firm compact but thin layer, and an outer gelatinous one which swells greatly in fresh water, filling up the intercellular spaces, and causing the slimy character which the Fucaceæ commonly assume after they have lain for some time in fresh water. The cells contain chlorophyll; but the green colour is in all cases entirely masked by a pigment of a brown or olive colour, which can be extracted from the dead plant by cold fresh water. The nature of this pigment has been investigated by Millardet, Rosanoff, Sorby, Schütt, and others. According to Millardet, an olivegreen alcoholic extract may be obtained from quickly dried and powdered specimens. If this is then shaken up with double its volume of benzine and allowed to settle, the upper layer of benzine is coloured green by having taken up the chlorophyll, while the lower alcoholic layer is yellow, and contains phycoxanthin in solution. Thin sections of the thallus, after complete extraction by alcohol, still yield a reddish brown substance which in fresh cells adheres to the chlorophyll-grains, but can be dissolved out with cold waier, especially if the frond be first reduced to powder. To this reddish brown substance, the spectrum of which has one absorption band between $\mathrm{E}$ and F, Millardet gives the name phycophain. Schütt states that the spectrum of phycophæin has no characteristic absorption bands, but a regular increase of absorption from the red towards the blue end. He proposes to limit the term phycophæin to the portion soluble in water, and phycoxanthin to that soluble in alcohol, while the entire compound pigment of the Fucaceæ and Phæosporeæ he would call phaophyll. Sorby applies the term fucoxanthin to the principal colouring matter of the olive-green seaweeds (Fucaceæ and Laminariaceæ). It is soluble in bisulphide of carbon, imparting to it a beautiful amber colour; its spectrum shows two obscure absorptionbands in the yellow. Hick (Journ. of Bot., I885, pp. 97 and 354) has detected continuity of protoplasm in several species of Fucus, both in the cortical layers and in the central medullary tissue. The intercommunication of the protoplasmic contents of contiguous cells is also effected, as in the Laminariaceæ (see p. 244), through structures of the nature of sieve-plates.

In many of the Fucaceæ air-bladders are formed in the frond by the hollowing out of large cavities in the interior of the tissue, which serve to float the frond in the water, and to aid in the process of fertilisation. These are especially noticeable in the common 'bladder-wrack' 


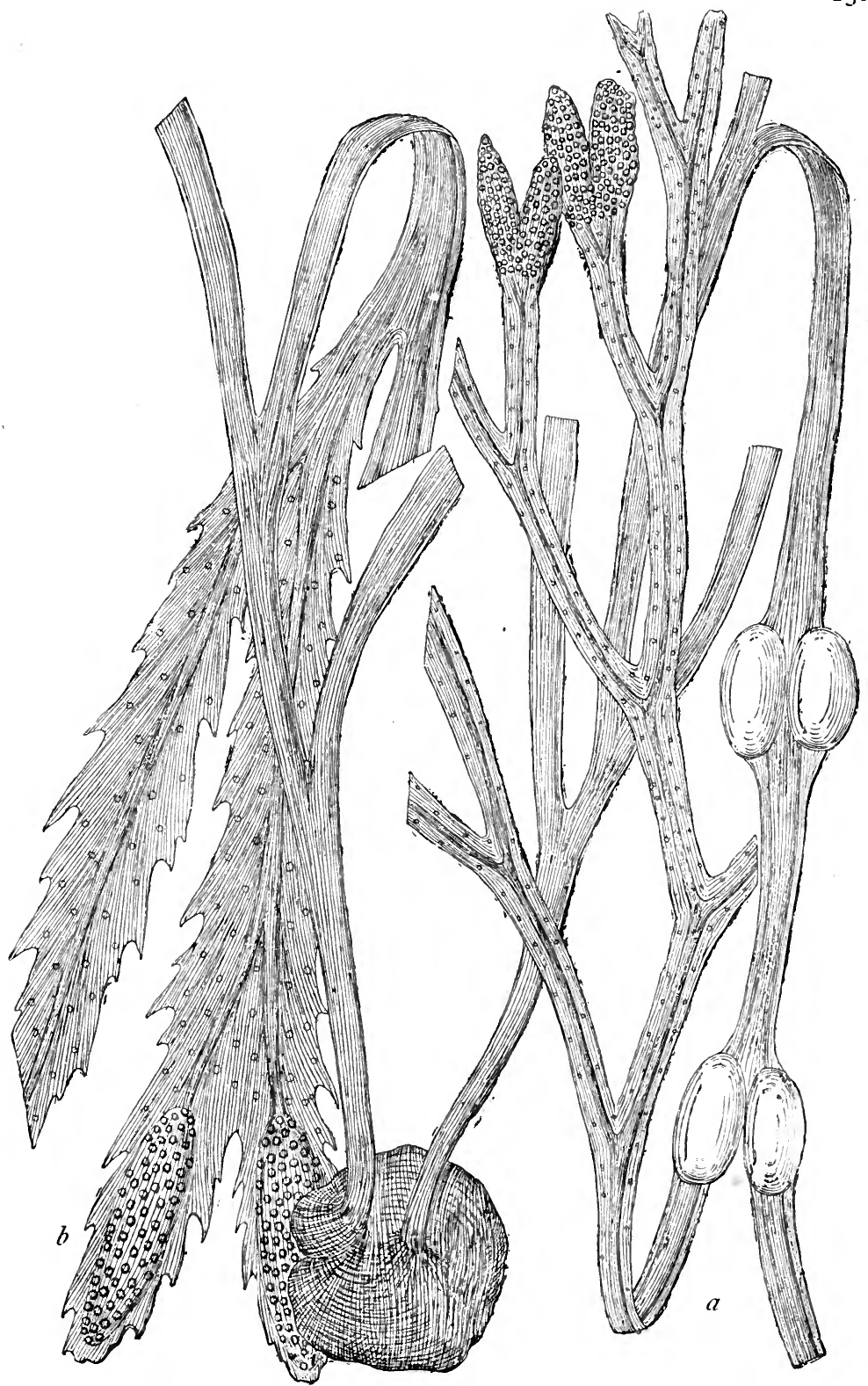

F1G. 207.- $a$, Fucus vesiculosus L. ; $b, F$. serratus L., with their attachment-discs united in growth (natural size). (After Kützing.) 
of our coasts, Fucus vesiculosus (L.), and in other species of the genus. In the 'gulfweed' of the 'Sargasso Sea' (Sargassum bacciferum, Ag.) these bladders are spherical, and are elevated on pedicels above the surface of the frond, giving them the appearance of berries (fig. 2 I I ). In Halidrys (Grev.) they are ovoid, segmented, and pod-like in appearance (fig. 206).

The only reproductive organs of the Fucaceæ are sexual, antherids and oogones. Both kinds are formed in globular cavities known as conceptacles, which are either distributed uniformly over the thallus, or are congregated in particular portions of it, which are then known as receptacles. These are always either the terminal portions of branches, or are in the parts provided with air-bladders, so as to be elevated above.

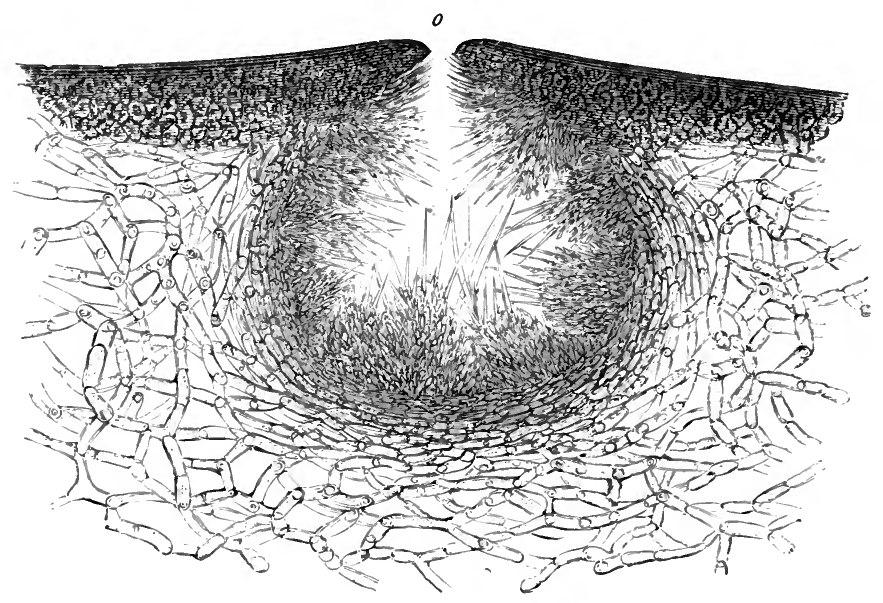

FIG. 208.- Section of male conceptacle of $F$. vesiculosus, clothed with branched hyphæ bearing the antherids; $o$, ostiole (magnified).

the surface of the water for the purpose of fertilisation. In Fucus (L.) the receptacles constitute the warty extremities of the branches; in Himanthalia (Lyng.) the whole of the long whip-shaped stem which proceeds from the cup-shaped thallus is a receptacle (fig. 205) ; in Sargassum (Ag.) they occupy distinct fertile branches. In some species there are separate male and female conceptacles, and then they are always diœcious ; in other species antherids and oogones are contained in the same conceptacle, the female organs occupying the lower, the male organs the upper part of the cavity. There are also sometimes cavities of precisely similar structure, but producing no sexual organs, which may be degraded or aborted conceptacles. Both the fertile and barren conceptacles are clothed internally by a dense weft of loose hyphæ, which 
are a prolongation of those of which the thallus is composed, and frequently project, through the mouth or ostiole of the conceptacle, into the surrounding water. When infertile these hyphæ are known as paranemes or paraphyses. In the male conceptacles they are usually branched, unbranched in the female. Both the barren and fertile conceptacles are always first formed in the neighbourhood of the growing point, the cavity originating from the absorption of a row of cells at right angles to the surface.

The antherids are produced on lateral branches of the hyphæ in the male or in the upper part of bisexual conceptacles. Each consists of an ovoid thin-walled or sometimes double-walled cell, the abundant protoplasm of which breaks up into a number (usually sixty-four) of

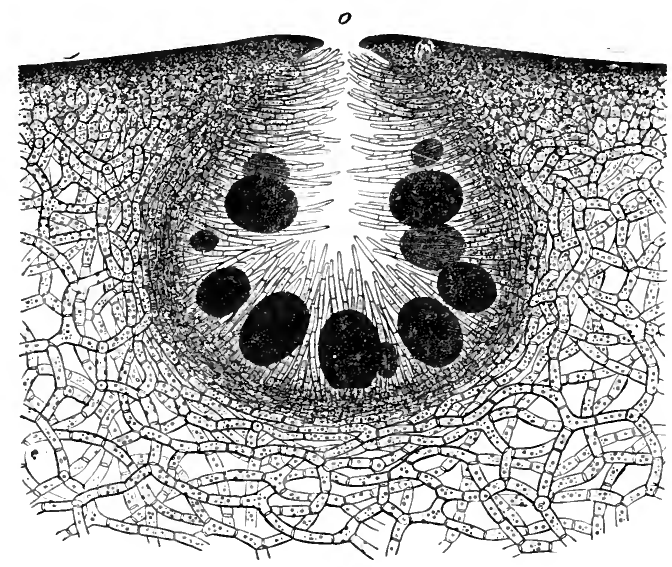

Fig. 209. - Section of female conceptacle of $F$. vesiculosis, clothed with unbranched hyphæ bearing the oogones; $o$, ostiole (magnified).

minute antherozoids, pointed at one end, with a pair of cilia of unequal length placed laterally below the beak-like apex, and contains an orangered pigment spot and a nucleus. The olive-brown oogones are developed from unbranched hyphæ in the female, or in the lower part of bisexual conceptacles. These fertile hyphæ are at first unicellular, and are bounded at the base by a septum ; the single cell subsequently divides into a basal pedicel-cell, and an upper portion, which swells into a spherical or ellipsoidal form, the oogone, filled with protoplasm coloured brown by phycophæin, and always provided with a wall composed of two layers. Either the whole of the contents of the oogone contract into a single oosphere, or it divides into two, four, or eight oospheres, each with its own nucleus. Impregnation always takes place outside 
the conceptacle. The outer layer of the double wall of the oogone bursts, the inner layer still continuing to enclose the oospheres in a thin bladder-like membrane. In this form they escape from the conceptacle through the ostiole into the surrounding water, where the remaining membrane is also absorbed. In the meantime the antherids have become detached, the inner layer of the double cell-wall having burst through the outer layer, and collect in large numbers before the ostiole of the female or of the bisexual conceptacles, forming orange-red masses which are often caught by the paraphyses which hang out from the ostiole, or are left on the shore at low tide. On the return of the tide, or after they have remained for a time entangled in the paraphyses, the inner membrane of the antherid also becomes absorbed, and the antherozoids escape at the same time that the oospheres become released from their
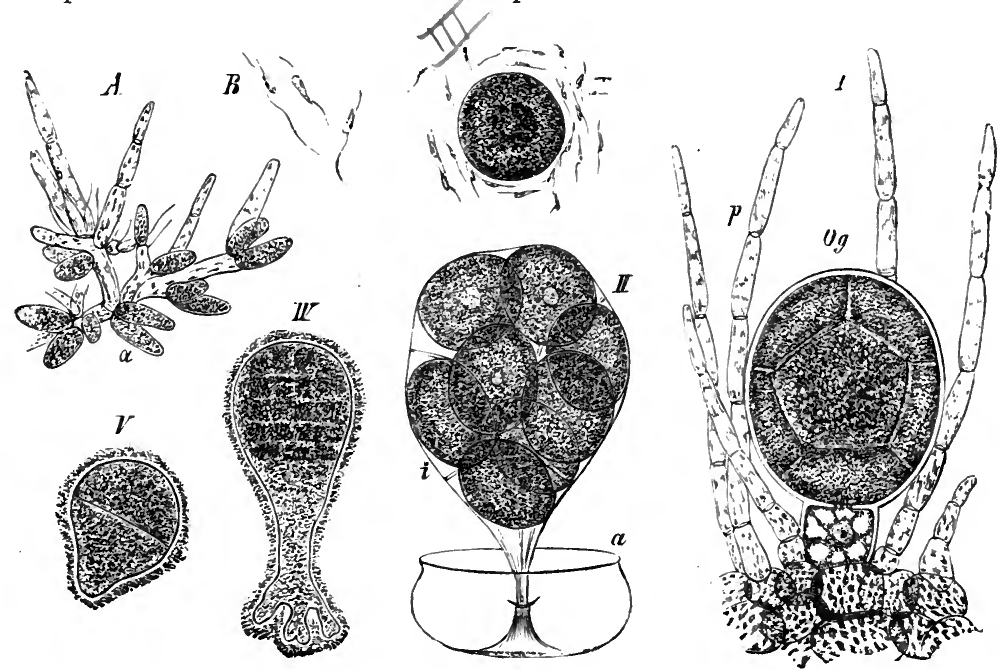

FIG. 210. $-F$. vesiculosus. $A$, branched hypha bearing antherids $(\times 160) . \quad B$, antherozoids $(\times 330)$. $I$, oogone, $O g$, containing eight oospheres; $p$, unbranched hyphæ. II, oospheres preparing to escape ; $a$, outer, $i$, inner layer of cell-wall of oogone. III, oosphere surrounded by antherozoids. $I V, V$, stages in germination of oosperm $(\times 160)$. (After Thuret.)

enveloping membrane. The antherozoids frequently collect round the oospheres in such numbers that the motion of their cilia imparts to the comparatively very large passive oosphere a rolling movement which lasts for about half an hour, when they become absorbed into it and impregnate it. The oospheres are receptive over their whole surface; and, although it has been calculated that the bulk of an oosphere is equal to that of from 30,000 to 60,000 antherozoids, an oosphere can apparently be fertilised by a single antherozoid. In this family the mode of repro- 
duction consisting in the impregnation of a passive oosphere by motile antherozoids attains its highest development among Algæ. The antherozoids retain their motility and vitality for from one to three days. The oospheres will show signs of a rudimentary germination even when unfertilised, but in that case the germ soon perishes. Thuret succeeded in obtaining a hybrid Fucus by impregnating the oospheres of F. vesiculosus (L.) by the antherozoids of F. serratus (L.).

A short time after impregnation the oosperm invests itself with a cell-wall, fixes itself to some other body, and begins to germinate without any intervening period of rest. 'The first transverse division of the young germinating filament is followed by others in various directions, so that a solid mass of pseudoparenchyme is at length formed, fixed to the bottom by a root-like rhizoid.

The Fucaceæ constitute a small and well-marked family of seaweeds, united by some systematists with the Phæosporeæ, or at least with the Laminariaceæ, to make up the Fucoideæ of Agardh, or the Melanospermeæ of Harvey. They are, however, well distinguished by their mode of reproduction. The family is represented in Britain by the genera Halidrys (Grev.),

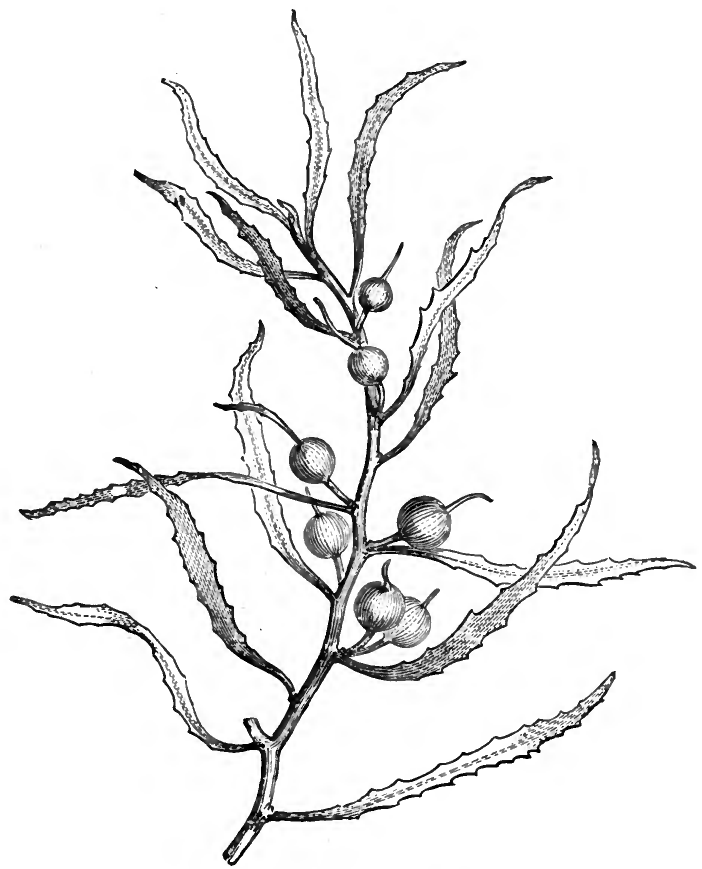

FIG. 2Ir.-The gulfweed, Sargassum bacciferum Ag. (natural size).

Cystosira (Ag.), Pycnophycus (Ktz.), Fucus (L.), Ascophylla (Stackh.), and Himanthalia (Lyng.), and includes also the exotic genera Sargassum (Ag.), Pelvetia (Dcne.), Durvillæa (Bory), Splachnidium(Grev.), and a few others. Although the number of native British species described by Harvey is only thirteen, some of these occur in such vast quantities that the Fucaceæ 
cover a larger amount of surface of tidal rocks than all the other seaweeds together. Among these may be especially mentioned the familiar bladder-wrack, Fucus vesiculosus, so abundant on all our coasts. The well-known gulfweed, Sargassum bacciferum, distinguished by its berrylike air-bladders, a native of warmer seas, is sometimes thrown up on our shores, where it is carried by the gulf-stream. It very rarely fructifies ; detached pieces, buoyed up by the air-bladders, being able to retain their vitality for an indefinite length of time. An enormous floating mass of this seaweed, consisting entirely of detached pieces, is said to cover an area of 200,000 square miles in the Atlantic, about lat. $20-25^{\circ} \mathrm{N}$. and long. $40^{\circ} \mathrm{W}$, where it has maintained itself with but little shifting since the time of Columbus, affording a home and breeding-place for countless numbers of marine animals. The family is, however, chiefly European; a large proportion of the species live only in shallow water, being exposed at every ebb-tide, or only at neap-tides, when fertilisation takes place. The distinctions between the different genera are made to rest on the disposition of the air-bladders and conceptacles, and on the more or less distinct differentiation of the leaf-like organs. The frond of Splachnidium is partially gelatinous. The structure of that of Durvillæa, one of the largest of seaweeds, is very beautiful, being permeated by very large and regular cavities resembling a honeycomb. Together with the Laminariaceæ, our native Fucaceæ are largely used in the manufacture of kelp, though not to the same extent as formerly, and as a source of iodine; they are also employed by farmers as a manure for their fields. On the coast of Chili the poorer classes use a species of Durvillæa for food, and a soup is made from it which is mucilaginous and sweet.

\section{Literature.}

Agardh-Species, Genera, et Ordines Fucoidearum, I 848 .

Thuret-Ann. Sc. Nat., I854, p. 195.

Pringsheim-Monber. Berlin. Akad. Wiss., 1855, p. 133.

Rosanoff-(Pigment) Mém. Soc. Sc. Nat. Cherbourg, I867, p. 145.

Millardet-(Pigment) Comptes Rendus, lxviii., I 869, p. 462.

Kraus et Millardet-(Pigment) Mém. Soc. Sc. Nat. Cherbourg, 1870, p. 23.

Kny-Bot. Zeit., 1872, p. 699 ; and 1875, p. 450.

Sorby-(Pigment) Proc. Roy. Soc., 1873, pp. 455 et seq.

Reinke-Jahrb. wiss. Bot., I876, p. 399 ; and Bot. Zeit., I877, p. 651.

Rostafinski-Beitr. z. Kenntniss d. Tange, 1876.

Thuret \& Bornet-Etudes phycologiques, 1878.

Kuntze-(Sargassum) Engler's Bot. Jahrbuch, 1880, p. I 91.

Bower-(Conceptacle) Quart. Journ. Microsc. Sc., I88o, p. 36.

Die Cystoseiren (Fauna u. Flora Golfes Neapel), I883.

Hanstein-Sitzber. Phys. -Med. Gesell. Würzburg, 1884, p. I04; and Arbeit. Bot. Inst. Wuirzburg, 1885, p. 289. 
Dodel-Port_'Cystosira) Biolog. Fragmente, pt. i., I885.

Behrens-(Fertilisation) Ber. Deutsch. Bot. Gesell., I886, p. 92.

Schiitt-(Phycophæin) ibid., r887, p. 259.

Woodworth-(Apical Cell) Ann. of Bot., i., 1888, p. 203.

\section{Class XIII.-Phæosporeæ.}

The Phæosporeæ or Phæozoosporeæ form, together with the Fucaceæ, the whole of the olive and brown seaweeds of the globe, formerly grouped together under the names Fucoideæ, Melanosporeæ, or Melanospermeæ; but of many the history of development is at present but imperfectly known ; and when this is ascertained more fully, they may possibly be separated into groups having but little affinity with one another. A number of the Phæosporeæ are epiphytic, and a few parasitic on other seaweeds; a very few grow in fresh water.

The ordinary mode of multiplication of the Phæosporeæ is, so far as is known at present, non-sexually by means of zoospores, which occur in all the orders except the most aberrant groups-the Dictyotaceæ, where they are replaced by motionless spores, and the Syngeneticæ. In the Sphacelariaceæ there is another mode of non-sexual propagation by means of gemmæ or propagules. Each zoospore has a large red pigmentspot and two cilia, a longer one pointing forwards and a shorter one directed backwards. They differ from those of the green Algæ, such as the Confervoidex, in the lateral insertion of the cilia at the base of the colourless apex. They are produced in zoosporanges, which are either external, when they are usually the terminal cells of short branches, or are imbedded in the thallus, in which case they are frequently collected into definite groups or sori, and are interspersed with barren filaments or hyphæ, known as paranemes or paraphyses. These are often swollen and club-shaped at their apex ; the zoosporanges sometimes spring as lateral branches from similar filaments. The zoosporanges are of two kinds, unilocular and multilocular (the 'oosporanges' and 'trichosporanges' respectively of Thuret). The former are comparatively large, nearly spherical, ovoid, or pear-shaped, and their contents break updirectly into a large number of zoospores which escape through a terminal or lateral opening. The latter kind have somewhat the appearance of jointed hairs, and are segmented in the transverse direction only ; or less often are more like the unilocular zoosporanges in form, but are divided internally by both transverse and longitudinal septa. Each cell gives birth to a single zoospore; and these either escape each separately 
from its own mother-cell, or an opening is formed at the apex of the sporange through which all the zoospores escape after dissolution of the septa. The zoospores are in all cases imbedded in mucilage ; no differ-

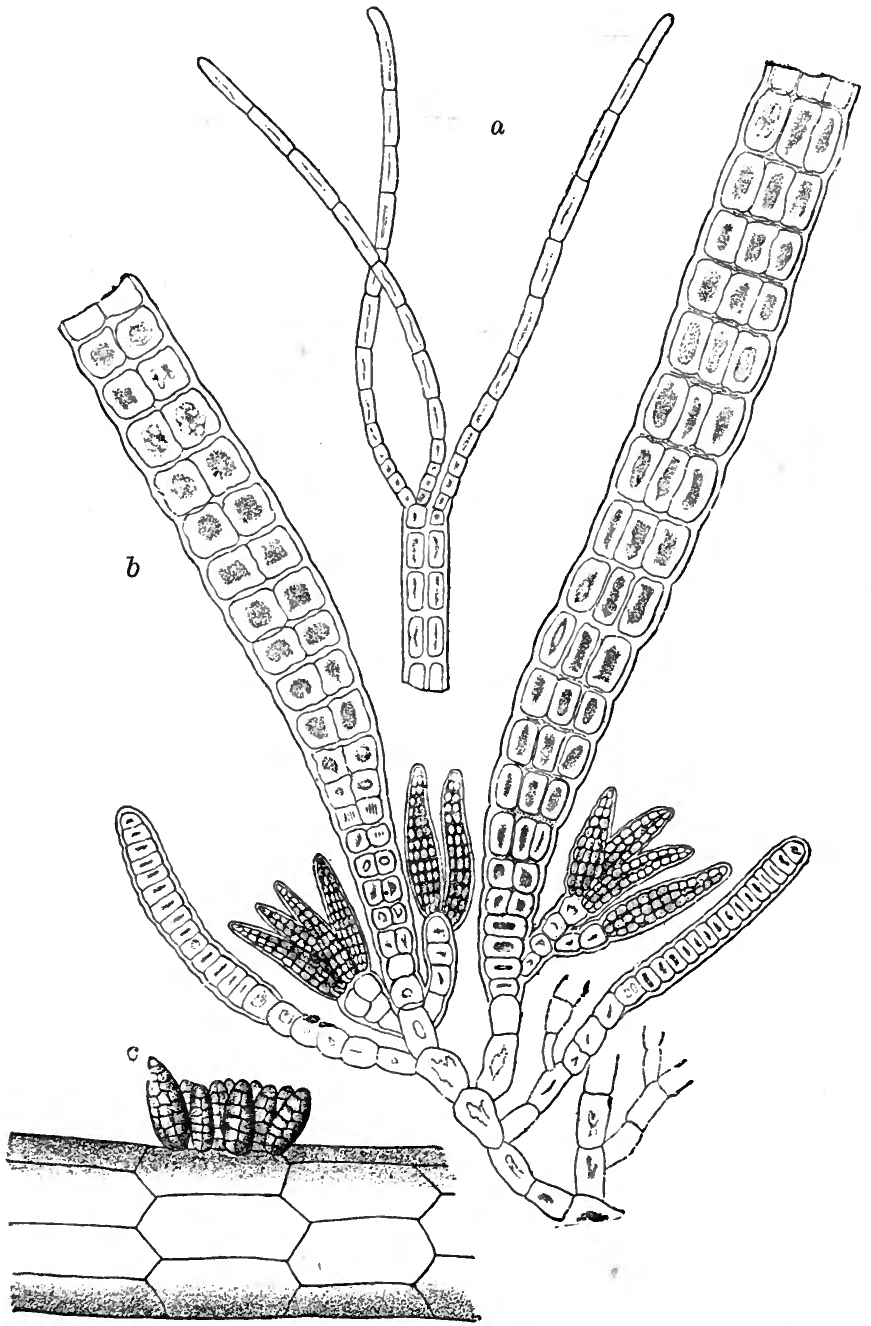

FIG. 212.-Giraudia sphacelarioides D. and S. $a$, upper portion of thallus $(\times 250) ; b$, lower purtion with multilocular sporanges $(\times 250)$. (After Areschoug.) $c$, portion of filament with unilocular sporanges $(x 602)$. (After Hauck.) 
ence is observable in size or form between those produced in the two kinds of sporange, but those from the unilocular sporanges appear in all cases to germinate directly, while those from the multilocular sporanges are sometimes zoogametes with sexual functions. The two kinds of sporange may be borne on the same or on different individuals ; in the former case they are occasionally developed at different times. In certain orders or groups one or the other kind is altogether wanting.

The various modes of sexual reproduction known in the Phæosporeæ present a most interesting gradual transition from the conjugation of equivalent motile zoogametes to the impregnation of a quiescent oosphere by motile antherozoids. In Ectocarpus (Lyng.), Giraudia (D. and S.), and Scytosiphon (Ag.) conjugation takes place between swarmcells from the multilocular sporanges, which are to all appearance exactly alike ; but a slight sexual differentiation is exhibited in the fact of one of them coming to rest and partially losing its cilia before conjugation takes place. In Cutleria (Grev.) and Zanardinia (Nard.) the differentiation is more complete. The male and female swarm-cells are produced either on the same or on different individuals; the latter are much larger than the former, and come perfectly to rest, entirely losing their cilia before being impregnated by the former. In Dictyota (Lmx.) the differentiation is carried still further, and the female reproductive bodies are from the first motionless masses of protoplasm not provided with cilia. In Dictyosiphon (Grev.) (Punctariaceæ) a different kind of conjugation has been observed.

The degree and mode of development of the thallus differ very widely within the class. A few species of Ectocarpaceæ, belonging to the genera Streblonema (Derb.) and Ectocarpus (Lyng.), are microscopic. Some of the Mesoglœaceæ and Ralfsiaceæ are small seaweeds epiphytic on those of larger growth, with a flat radiating thallus reminding one of Coleochæte. In some of the Ectocarpaceæ the thallus consists of simple branched or unbranched filaments resembling those of the Confervaceæ. In the Sphacelariaceæ each branch is composed of a row of larger central surrounded by a layer of smaller cortical cells, all originating from a large uncorticated apical cell. In the Cutleriaceæ filaments of cells become separated from the margin of the thallus, the basal portions of which are coalescent into a solid tissue, the increase in breadth of which is due to the branching of the filaments. The Laminariaceæ include, in the genera Alaria (Grev.), Laminaria (Lmx.), Macrocystis (Ag.), and others, the most gigantic of marine organisms, in which the thallus or 'frond' is to a certain extent differentiated externally into rhizoid or organ of attachment, stipe or stem, and 


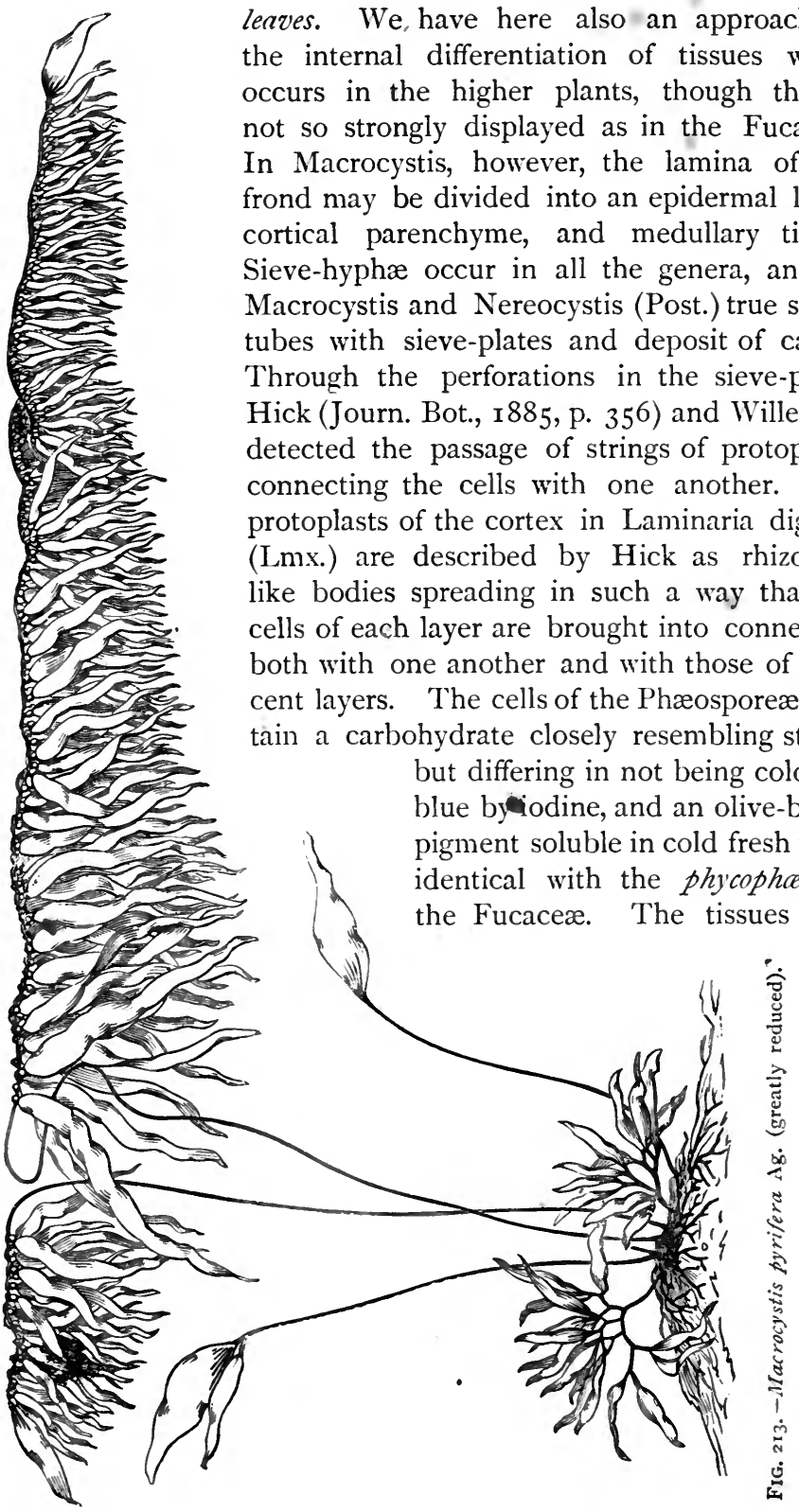


of the Laminariaceæ and of other large marine Algæ belonging to other groups display remarkable elasticity or other properties to enable them to resist the traction of the waves. In the larger species the frond is buoyed up by air-bladders.

Janczewski describes the occurrence in the class of three distinct modes of growth, viz.- (r) The thallus and all its ramifications terminate in a generative apical cell which divides in a direction parallel to its base, and thus gives birth to a series of segments. 'This occurs in the Sphacelariaceæ and in Dictyosiphon, but is the least common mode. (2) By peripheral growth, i.e. the marginal cells of the thallus are the youngest, and are more or less united into a generative peripheral zone (Myrionema, Grev., Leathesia, Gray, Ralfsia, Berk.). (3) By intercalary growth. This is much the most common mode, and there are, again, three modifications of it, viz. - I. The thallus terminates, when young, in one or more hairs, the common growing point of the thallus and of the hairs being situated at their point of junction (Ectocarpus, Desmarestia, Lmx., Carpomitra, Ktz., Cutleria, Sporochnus, Ag.). 2. The thallus is differentiated into three 'organs'-frond,

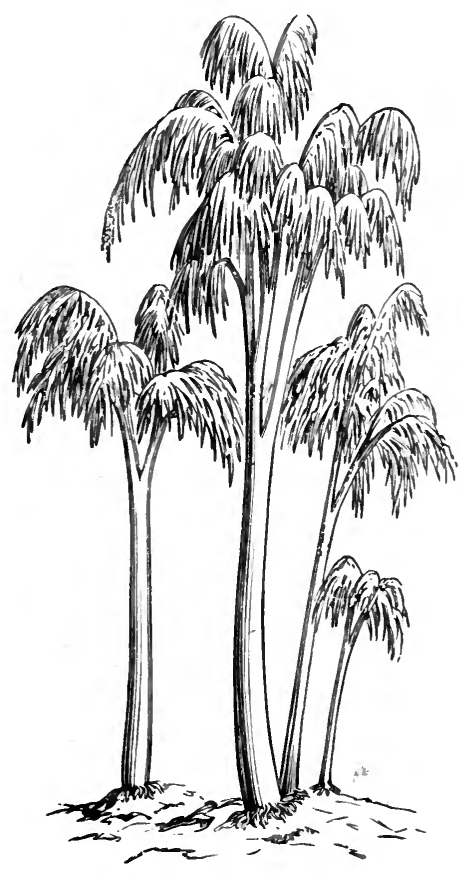

FIG. 214.- Lessonia fuscescens Bory stipe, and rhizoids ; the growing point from which the stipe and frond originate is common to these two organs, while the rhizoids increase by apical growth (Laminariaceæ). 3. The absolutely undivided thallus is regenerated from the growing point situated at the base of the frond (Scytosiphon, Chorda, Punctaria, Grev., Asperococcus, Lmx.).

\section{LiterATURE.}

Magnus--Festschr. Gesell. naturf. Freunde, Berlin, I873.

Areschoug - Bot. Notis., 1873 .

Gobi- Bot. Zeit., I877, p. 425 .

Reinke-Ibid., p. 44I.

Thuret \& Bornet-Etudes Phycologiques, 1878. 


\section{Falkenberg-Mittheil. Zool. Stat. Neapel, I878, p. 53 I. \\ Wille-Bot. Sällsk. Stockholm, Nov. 19, 1884 'see Bot. Centralbl., xxi., 1885, pp. 282 et seq.). :}

In so many of the Phæosporeæ the lifehistory is at present but imperfectly known, and different authors differ so widely as to the best characters to be employed in classification, that no attempt is here made to arrange into orders all the known forms. A description is given only of the best-marked groups.

The LAMINARIACEæ include many of the largest of the brown seaweeds of both warmer and colder seas; in the southern hemisphere they form dense submarine forests of gigantic size, frequently making even deep water impassable for boats, and forming a home for myriads of marine animals; the individual 'fronds' sometimes attaining a length of several hundred feet. The thallus is coriaceous, is not articulated, and is usually attached to the sea-bottom by rhizoids or root-like organs of attachment, or less often by a discoid expansion, from which springs a tough cylindrical stipe or stem, the tissue of which is more or less differentiated into a medullary portion, an internal and an external cortical portion, and an epidermal portion, the cells of which are coloured brown by phycophæin. It increases in length by intercalary growth at the junction of the stipe and lamina. Although most of the larger species are perennial, Areschoug states that even the largest species of Nereocystis (Post.) are annual. In others the stem increases in girth from year to year, attaining sometimes the thickness of a man's thigh. In Chorda filum (Stackh.), one of the commonest of our

FIg. 215. - Laminaria saccharina Lmx., with rhizoids. $s$, portion of frond which produces zoospores (reduced $\frac{1}{6}$ ). (After Reinke.) seaweeds, the entire thallus is cylindrical and whip-like, as much as forty feet in length, 

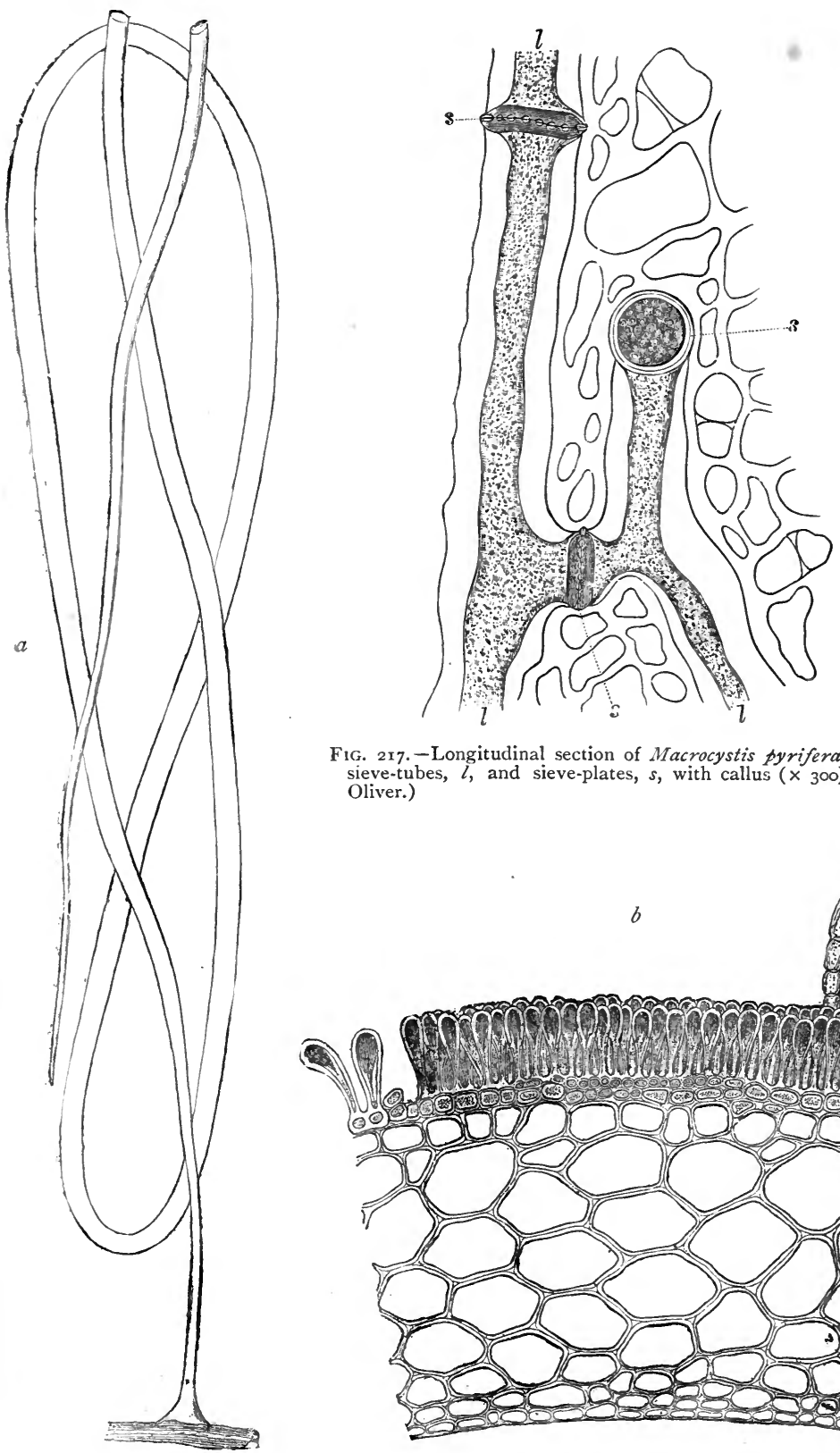

F1G. 217. - Longitudinal section of Macrocystis pyrifera, showing sieve-tubes, $l$, and sieve-plates, $s$, with callus $(\times 300)$. (After Oliver.)

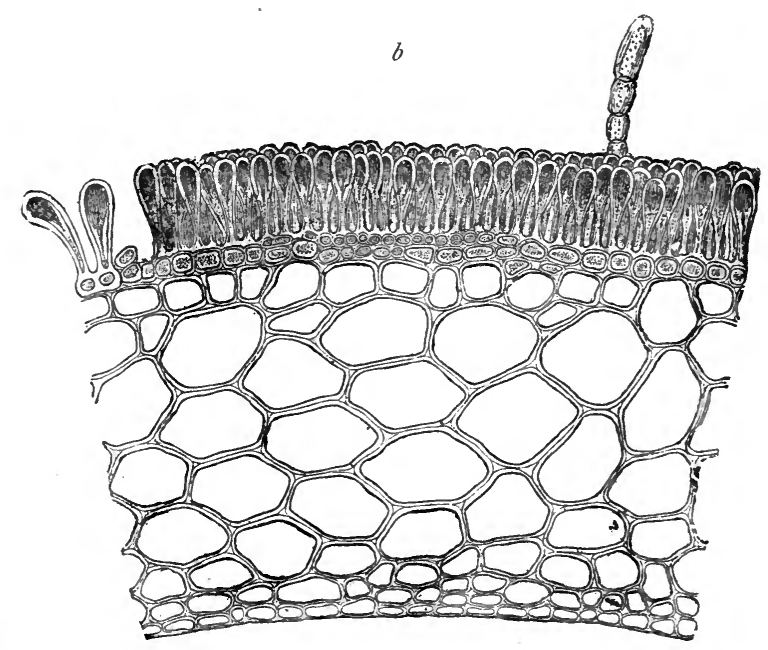

Fig. 216.-Chorda flum Stackh. a, uppermost and lowermost portion of frond (natural size); $b$, transverse section, showing differentiation into cortical and epidermal layers $(x$ 200). (After Hauck.) 
and is septated by transverse divisions; it is constantly dying off at the apex, the growing point lying at its base immediately above the rhizoids. More often the upper part of the thallus is differentiated into branched annual 'leaves' of cartilaginous texture, usually flat, but sometimes tubular, and often ribbed. Lessonia (Bory) grows erect to a great height, and resembles a branching tree with pendent leaves two or three feet long (fig. 2 I4). In Thalassiophyllum (Post.), Agarum (Grev.), and other genera, the frond is beautifully perforated; these perforations are formed from hollow conical papillæ by which the frond is first covered; the tissue diminishes at the apex of the cones, then bursts, and the opening enlarges as the frond grows. In Macrocystis (Ag.) the stalk-like base of each branch of the frond is swollen out into a large pear-shaped air-bladder. In Nereocystis the air-bladder is barrel-shaped, six or seven feet in length, and crowned with a tuft of fronds. Sieve-hyphæ or trumpet-hyphæ with imperfect sieve-plates occur in all the genera; and Oliver has discovered in the comparatively weak stems of Nereocystis and Macrocystis a structure almost identical with that which occurs in the weak climbing stems of many Flowering Plants, true sieze-tubes with perfectly formed sieve-plates both in the septa and in the longitudinal cell-walls, provided with a true callus-formation (fig. 2 I 7 ).

Zoosporanges of one kind only - the unilocular-are at present known in the Laminariaceæ; these are distributed uniformly over the surface of the thallus or are collected into sori, and are interspersed with simple unsegmented club-shaped sterile hairs or paraphyses. Of the mode in which the zoospores act as propagative organs very little is known. Areschoug has observed the germination of the zoospores of Chorda tomentosa (Lyng.) after the coherence of two of them by their beaks ; but he does not regard this as a true process of conjugation. Gardiner be lieves that he has detected the conjugation of zoospores in Alaria (Grev.).

Along with the Fucaceæ, the Laminariaceæ are one of the most important commercial sources of iodine. The species of our own shores are employed in the manufacture of kelp. Alaria esculenta (L.) is used by the inhabitants of Scandinavia and Iceland as an article of food, as also are Laminaria digitata (Lmx.) and other species under the name of 'tangle.' The stems of the last-named species are employed for surgical purposes; those of Ecklonia (Hornem.) and others of the larger genera are used as siphons and for making fishing-nets.

\section{LITERATURE.}

Reinke-Pringsheim's Jahrb. wiss. Bot., I876, p. 317.

Areschoug-Observ. Phycol., iii., I 875, iv., I883, v., I884 ; and Acta Soc. Sc. Upsaliensis, $1875, \mathbf{1} 883$, and $\mathbf{1} 884$.

Will-(Macrocystis) Bot. Zeit., I884, pp. 801 et seq. 
Wille-(Sieve-tubes) Ber. Deutsch. Bot. Gesell., I885, p. 29.

Gardiner-(Conjugation of Zoospores) Proc. Cambr. Phil. Soc., I 886.

Humphrey -(Agarum) Proc. Amer. Acad. Sc., I 886, p. 195.

Oliver-(Sieve-tubes) Ann. of Bot., i., I887, p. 95.

In the Punctariacee, Sporochnace£, and Scytosiphonace£the limits of which orders are not settled by systematists - the structure of the thallus varies greatly. In Punctaria (Grev.) and Phyllitis (Ktz.) it is flat and leaf-like, from one to six layers of cells in thickness; in other genera it is slender, cylindrical, erect, and more or less branched, the main axis being either solid or hollow, and consisting of a pseudo-parenchymatous tissue, in which the outermost or the two or three outer rows of cells are much smaller than the inner ones. In
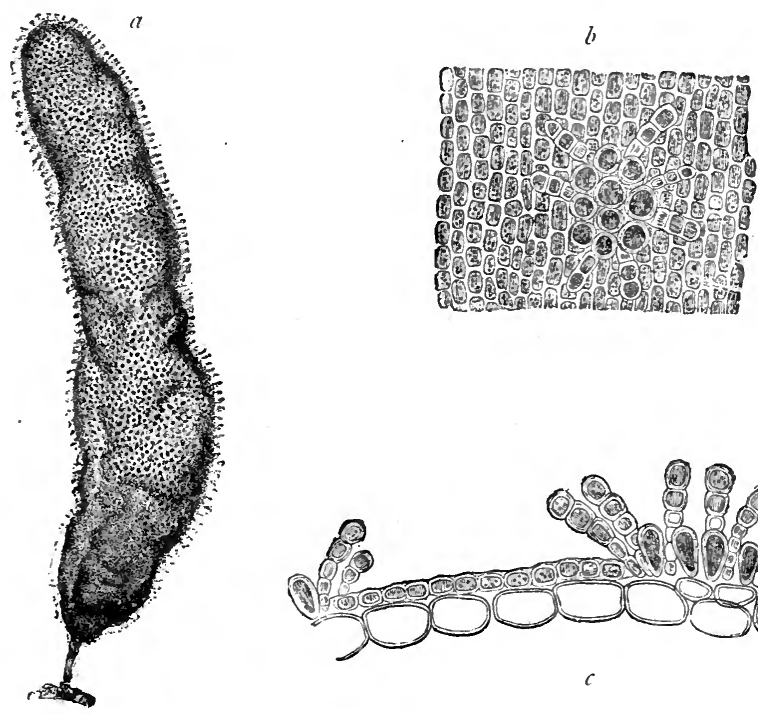

FIG. 218. - Asperococcus bullosus Lmx. a, natural size (after Bornet); $b$, portion of surface with sorus $(\times 100) ; c$, transverse section through thallus and sorus ( $\times$ IOO). (After Kützing.)

Dictyosiphon (Grev.) the 'frond' branches into delicate hairs. In Arthrocladia (Duby) the branches are arranged in delicate whorls. In Scytosiphon (Ag.) the thallus is elongated, cylindrical, and unbranched, but constricted at intervals, and resembles that of Chorda in habit. In other genera, as Asperococcus (Lmx.) and Hydroclathrus (Bory), it is hollow and bladdery. In most of the genera both kinds of zoosporange are known, while in others one or the other has not yet been detected. 
Their arrangement, on which the delimitation of the orders is largely made to rest, varies greatly. They may be collected into wart-like sori on the surface of the thallus, appearing sometimes like dark dots uniformly distributed, or they may spring from the branches. In Sporochnus (Ag.) the unilocular sporanges are collected into a peculiar receptacle

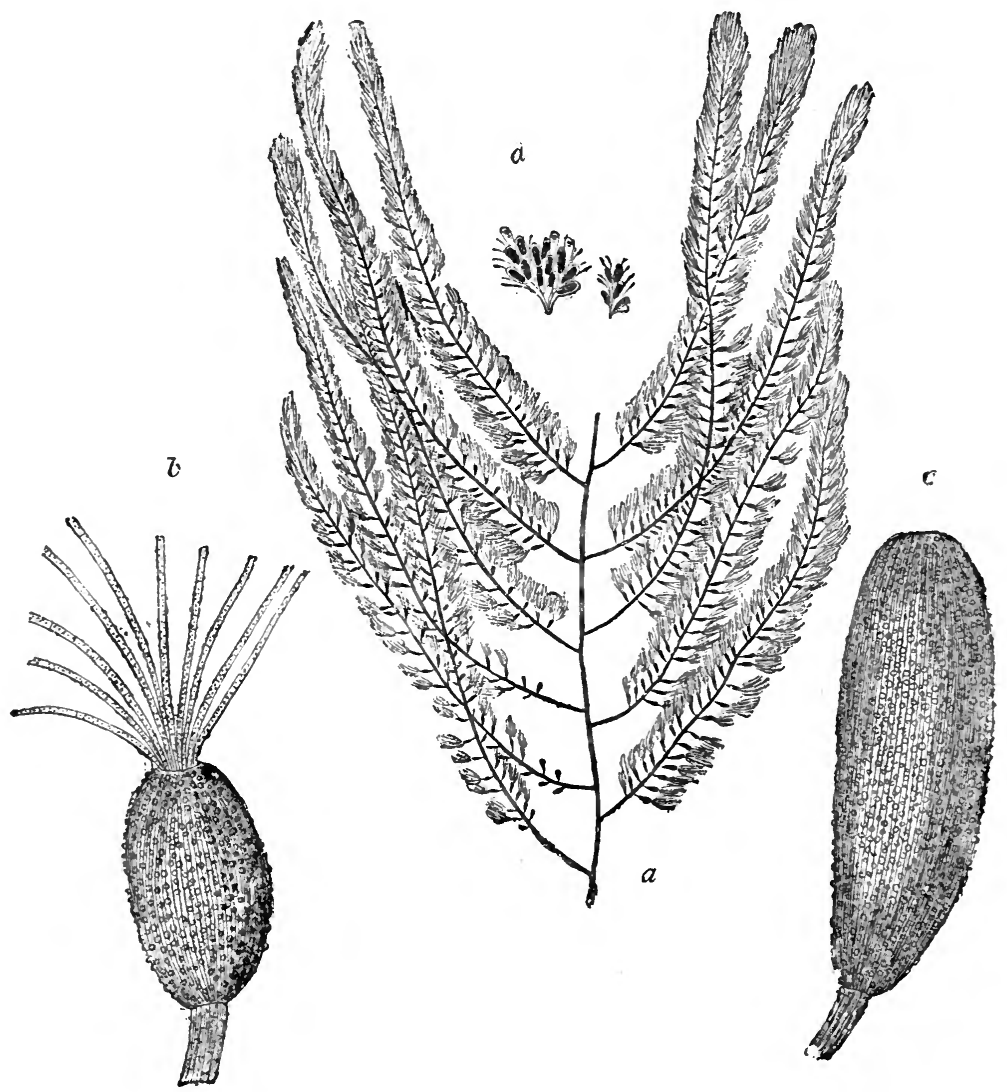

FIG. 219.-Sporochnus pedunculatus Ag. $a$, natural size ; $b$, receptacle containing zoosporanges; $d$, unilocular zoosporange ( $x$ Ioo). (After Kützing.)

consisting of pear-shaped swellings near the extremity of the branches, composed of a dense mass of filaments on which the sporanges appear as lateral branches. Very little is known of the further history of the zoospores. In Scytosiphon lomentarium (Ag.) Berthold ('Mittheilungem Zool. Stat. Neapel,' ii., I88I) has observed conjugation of the swarm- 
spores contained in the multilocular sporanges, which must therefore be regarded as zoogametes, and the phenomena are the same as in the Ectocarpaceæ. Areschoug ('Observ. Phycol., iii., 1875) describes a remarkable kind of conjugation-altogether peculiar as far as the brown seaweeds are concerned-in the swarm-spores of Dictyosiphon hippuroides (Lyng.), somewhat resembling that in the Conjugatæ. Two, or sometimes three, of the zoogametes cohere by their apices, and the contents slowly pass entirely into one of them, but only after they have come to rest. Both then become invested with a thin coat of cellulose, and the one into which the endochrome has passed, which may be called the female element, subsequently germinates. In other cases the conjugating zoogametes put out conjugating tubes not unlike those of the Zygnemaceæ. Some of the zoospores also germinate without conjugating.

\section{LiTERATURE.}

Reinke-Pringsheim's Jahrb. wiss. Bot., I878, p. 362.

The Mesogleace£ or Chordariaceæ (Myrionema, Grev., Leathesia, Gray, Chordaria, Ag., Mesoglœa, Ag., \&c.) are seaweeds with a gelatinous or cartilaginous thallus of hemispherical or cylindrical outline, variable in size, and forming small gelatinous or slimy cushions or branching tufts on larger seaweeds. Each filament is composed of a vertical central row of cells, surrounded by a 'cortex' of radial rows at right angles to the central row. On these cortical rows are placed the zoosporanges, which are both unilocular and multilocular, concealed within the periphery of the 'frond.' Nothing is known of the conjugation of the swarm-spores; they appear to germinate directly, giving rise to a creep-

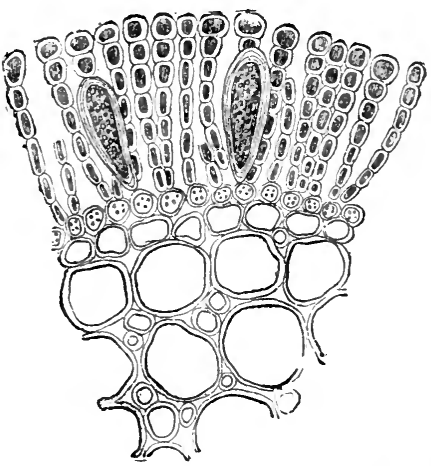

FIG. 220.-Chordaria Aagelliformis Ag. Transverse section through thallus, with unilocular zoosporanges $(x$ 200). (After Kützing.) ing branched filament, from which the ascending axes subsequently rise.

The EctocarPaceæ constitute an ill-defined group of small, occasionally microscopic, marine (Elachista, Duby, Ectocarpus, Lyng., Giraudia, Derb.) or rarely fresh-water (Pleurocladia, Br.) Algæ, usually 
attached in tufts to larger algæ, and resembling in habit the fresh-water Confervaceæ. The thallus consists of segmented more or less branched filaments, either composed of a single row of cells or corticated. The growing point of the filament does not lie at its apex, but at the extremity of a basal portion, the true thallus, the terminal hair-like portion being

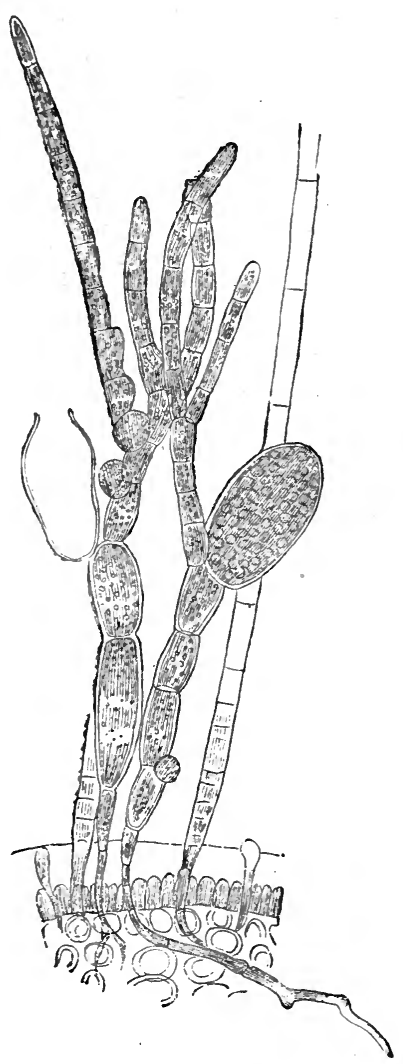

FIG. 221.-Ectocarpus investiens Hauck, epiphytic on Gracilaria compressa $(\times 250)$. (After Burnet.) deciduous. The zoosporanges are of both kinds, and are either external and stalked, or are ordinary cells of a filament, whether terminal or intercalary. Multilocular sporanges are sometimes produced on the

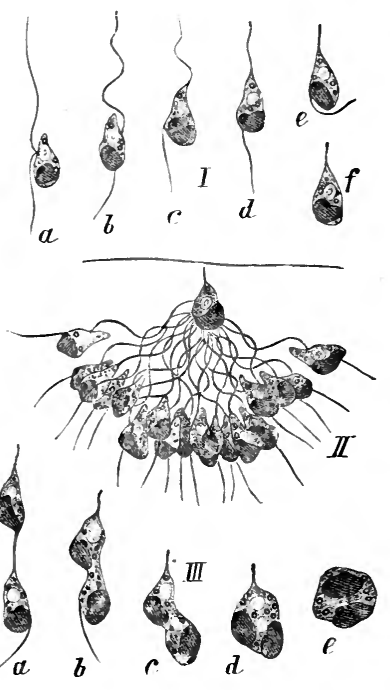

Fil. 22:2. - Corijugation of zoogametes of Ectocarpus siliculosus $\mathrm{Ktz}$. $I, a-f$, female zoogamete, gradually losing its cilia. $I I$, male zoogametes swarming round female zoogamete $I I I, a-\ell$, stages in the coalescence of the male and female zoogametes $(x 790)$. (After Berthold.)

same individual as the unilocular, but at a later period. The swarmcells which escape from the unilocular sporanges are non-sexual zoospores, germinating directly after coming to rest, and investing themselves with a cell-wall. Those contained in the multilocular sporanges all escape through a single terminal opening, and partake to a certain extent of sexual properties, or become under certain conditions zoogametes. 
Goebel has observed their conjugation in Giraudia sphacelarioides (Derb.) and Ectocarpus pusillus (Griff.), Berthold in E. siliculosus (Ktz.). 'The process is thus described by Berthold. There is no apparent difference between the male and female gametes. The female swarm-spores lose their cilia and come to rest first. They appear to be in a receptive condition only for a few minutes, during which time they seem to exercise an attractive force on the male gametes, which swarm round them until coalescence takes place. The impregnated gamete immediately clothes itself with a cell-wall, and proceeds to germinate. If unimpregnated it will still germinate, though not so rapidly; as also do the male swarm-spores which fail to conjugate; but in this case the resulting new individuals are weakly, and soon perish. This process in the Ectocarpaceæ may be regarded as the first stage between the conjugation of equivalent zoogametes and the impregnation of a passive oosphere by an antherozoid. Wright (Trans. Roy. Irish Acad., 1877, p. I5) has detected on an Ectocarpus a parasitic Chytridium, the zoospores of which he believes to have been mistaken for sexual organs of the host.

\section{LiteraTURE.}

Askenasy-Bot. Zeit., I869, p. 785 .

Janczewski-Mem. Soc. Sc. Nat. Cherbourg, 1875, p. 97.

Goebel-Bot. Zeit., I878, pp. I77, 193.

Berthold - Mittheil. Zool. Stat. Neapel, ii., I88r.

The Tilopterideæ ('Tilopteris, Ktz., Haplospora, Kjellm.) are a small and ill-defined family, probably nearly related to the Ectocarpaceæ.

The Sphacelariaceæ (Sphacelaria, Lyng., Stypocaulon, Ktz., Chætopteris, Ktz., Cladostephus, Ag.) are all small marine Algæ, mostly parasitic ; Chætopteris plumosa (Ktz.) grows on rocks at a considerable depth below the surface. The thallus usually consists of a number of rows of cells united into a pseudo-parenchyme, and often differentiated into an appearance of a ' medullary' row surrounded by 'cortical' tissue. In Cladostephus and Stypocaulon these corticating rows of cells descend to the base of the stem, and form rhizoids or organs of attachment. The zoosporanges are of both kinds, and are usually placed at the ends of special branches, while in Stypocaulon they are axillary ; but very little is certainly known about the germination or possible conjugation of the swarm-spores. The apical cell of each branch is uncorticated, and frequently develops into a hollow chamber of considerable size termed a sphacele, filled, when young, with dark mucilaginous contents, which at a later stage become watery. Geyler has described two kinds of sexual 


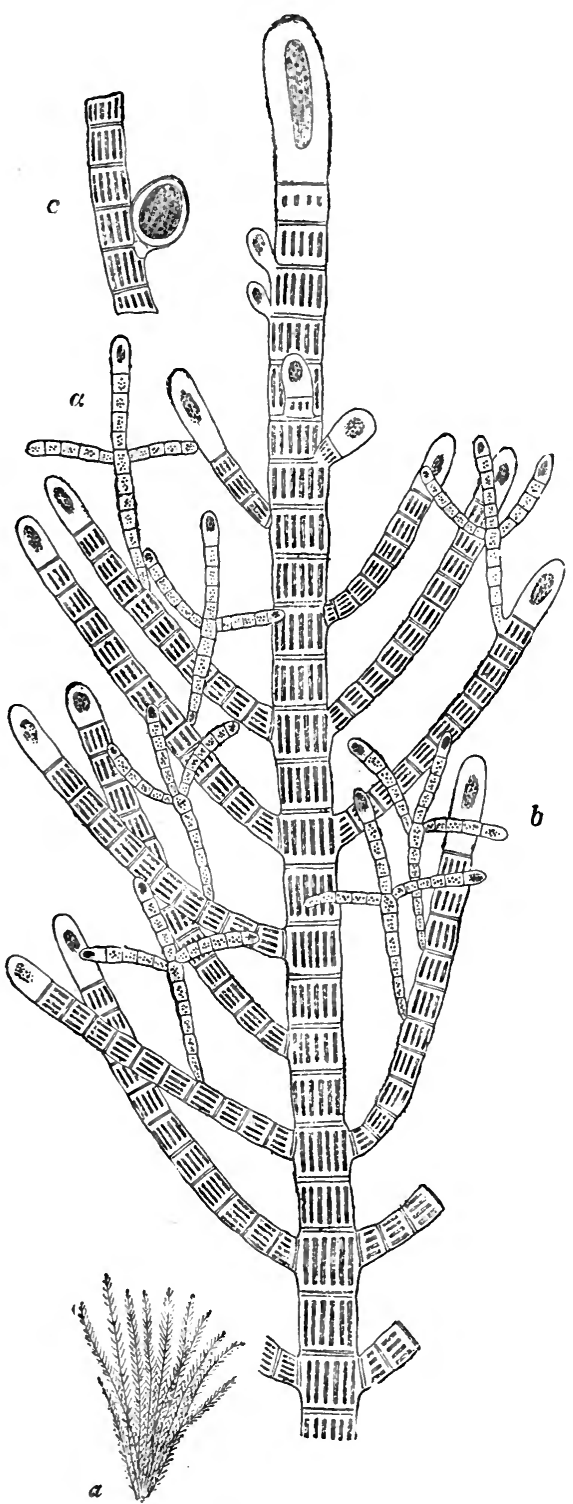

FIG. 223. - Sphacelaria cirrhosa Ag. a, natural size : $b$, hranch with propagules, $a(x$ IOO); $c$, filament with unilocular zoosporange ( $x$ I 0 ). (After Hauck.) organ, antherids and 'sexual spores' (oospheres), formed within the sphaceles; but Janczewski believes that the supposed antherozoids are in reality the zoospores of parasitic Fungi (Chytridiaceæ), to whose attacks these seaweeds are especially liable. Pringsheim describes two kinds of fructification produced by Cladostephus, one in the autumn, the other in the winter; but Wollny suggests that both the autumnal fructification and the socalled unilocular sporanges may be due to the attacks of parasitic Chytridiaceæ. The Sphacelariaceæ have a strong tendency to multiply by means of buds, gemmæ, or propagules. Janczewski describes the mature gemmæ as consisting of a pedicel and

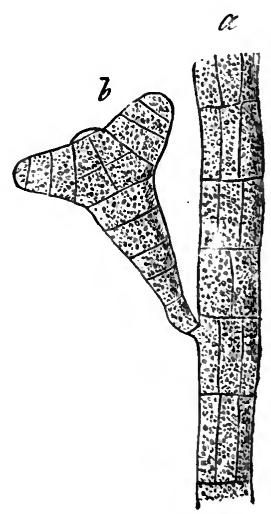

FIG. 224.-S. cirrhosa. a, filament with propagule, $b\left(\begin{array}{ll}x & 140) \text {. (After }\end{array}\right.$ Reinke.) 
three rays diverging above, with a hair springing from the centre of the rays. They become detached like the basidiospores of Fungi, and are constantly being formed afresh.

\section{LITERATURE.}

Geyler-Pringsheim's Jahrb. wiss. Bot., I866, p. 479.

Janczewski-Mem. Soc. Sc. Nat. Cherbourg, xvi., I872, p. 337 ; and Ann. Sc. Nat., I873, p. 253 .

Magnus-Zur Morphologie der Sphacelarieen, I873.

Pringsheim-Abhandl. Berlin Akad., I873, p. 137.

Rischawi-Algol. Untersuch., i., I874 (Just's Jahrb., I874, p. I3).

Wollny-Hedwigia, I88o, p. 65.

The Ralfsiaceæ (Ralfsia, Berk., Lithoderma, Aresch., \&c.) are small seaweeds (with the exception of two species of Lithoderma which grow in fresh running water) with crustaceous thallus, attached to stones, rocks, or the shells of molluscs and crustacea, composed of a pseudo-

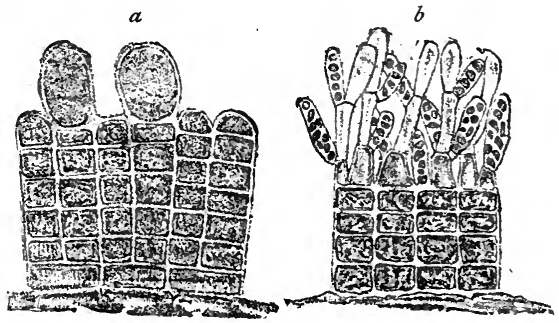

FIG 225.-Lithoderma fatiscens Aresch. a, vertical secticn of portion of thallus with unilocular zoosporanges; $b$, with multilocular zoosporanges ( $\times 320$ ). (After Hauck.)

parenchymatous tissue of vertical rows of cells. They have both kinds of sporange, collected into wart-like groups or sori on the surface of the thallus, but nothing is known with regard to the function of the swarmspores.

The small order of CuTLERIACEÆ, comprising the genera Cutleria (Grev.), Zanardinia (Nard.), and Aglaozonia (Zan.), consists of a small number of seaweeds, nearly all natives of warmer seas, although others from colder climates have been erroneously included in it. The thallus is coriaceous or membranaceous, flat, and either erect (Cutleria), or prostrate (Zanardinia), with the peculiarity that the marginal filaments are dissociated in their growth from the rest of the 'frond.' A true sexual mode of reproduction has been observed by Reinke in Zanardinia, and by Falkenberg and Janczewski in Cutleria. The former genus is monœcious, the latter diœcious. The oogones and antherids are both collected into sori, the former very dark brown, the latter orange-coloured. 
The oogones are divided into thirty-two or sixty-four cells, each of which produces an oosphere. The oospheres are at first biciliated swarm-cells or zoospheres endowed with active motion, closely resembling the zoospores of other Phæosporeæ, but are-larger and variable in form-one of the very few instances known in the vegetable kingdom of the occurrence

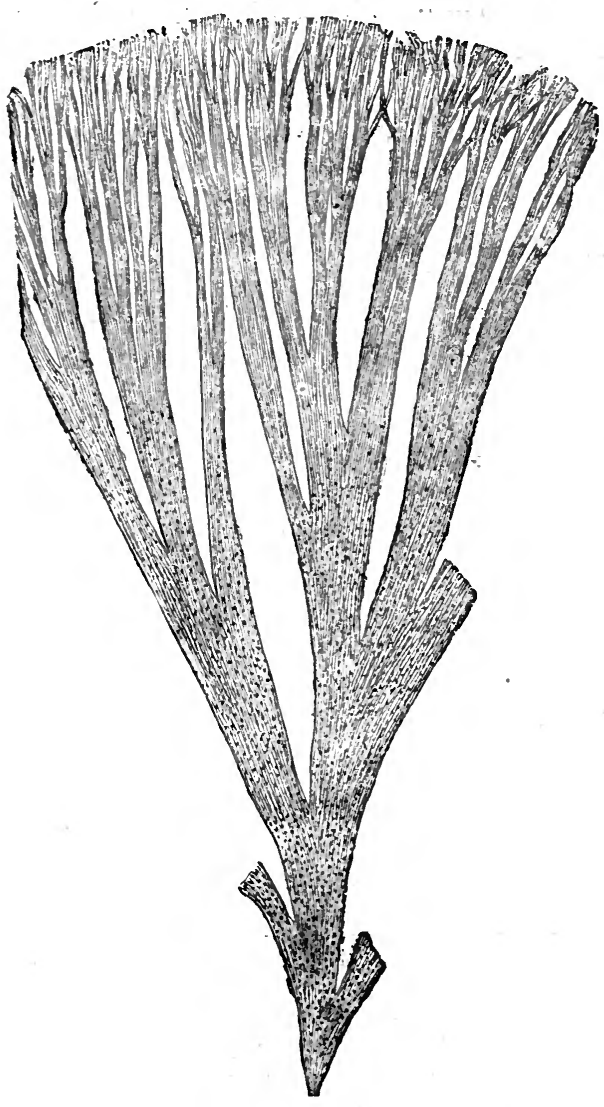

FIG. 226. - Cutleria multifida Grev. (natural size). (After Hauck.) of such organs: They are said to be destitute of a nucleus. The antherids are also divided into a number of cells, each of which produces two antherozoids, the normal number in an antherid (in Cutleria adspersa, De Not.) being I 28. The antherozoids are also biciliated swarm-cells, but smaller than the oospheres ; they have each an orange pigment-spot, and are identical in structure with those of the Fucaceæ. The antherozoids do not approach the oospheres until the latter have come to rest and lost their cilia; the absorption of a single antherozoid into the oosphere is then sufficient to impregnate it ; it becomes invested with a cell-wall of cellulose, and begins to germinate at once. Thuret states that in C. multifida (Grev.) the oospheres germinate without having been fertilised. The thallus resulting from the germination of the impregnated oospheres is said to be dorsiventral, producing rhizoids on the ventral side only. Zanardinia produces also non-sexual zoospores in unilocular sporanges; and has another non-sexual mode of propagation, by budding. In Aglaozonia reptans (Ktz.) the non-sexual zoospores are the only reproductive organ known; and Falkenberg 


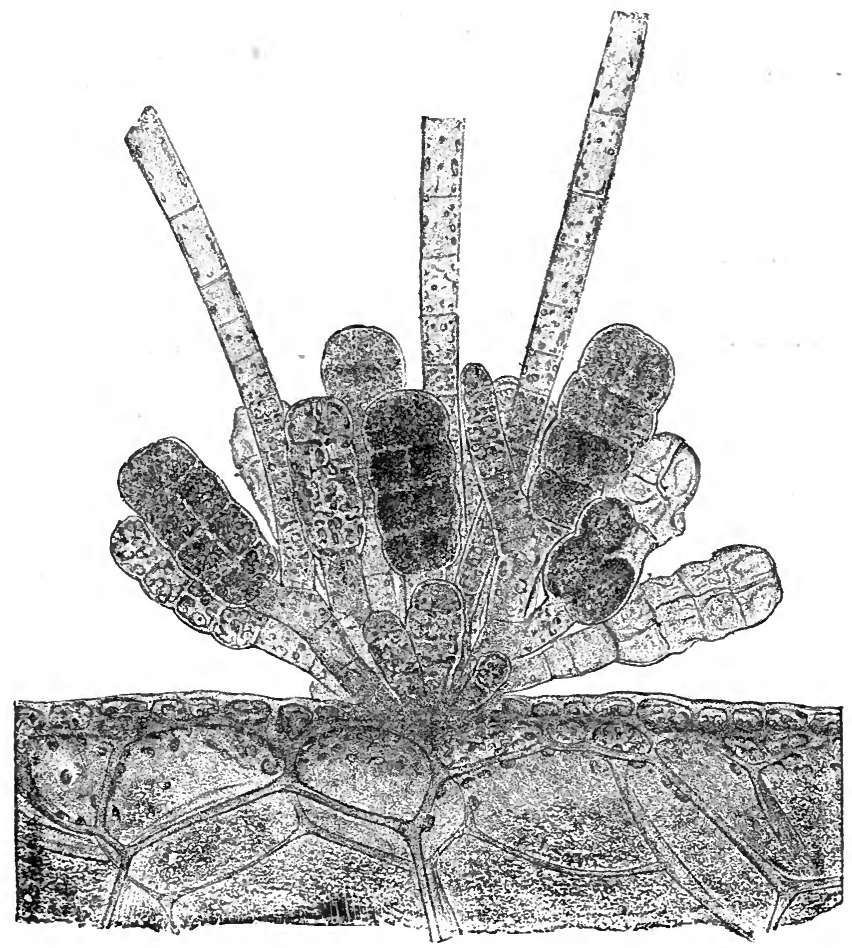

F1G. 227. - C. multifida; transverse section of portion of thallus $w$ ith a sorus of multiloculan zoosporanges in different stages of development $(x, 330)$. (Atter Bornet.)

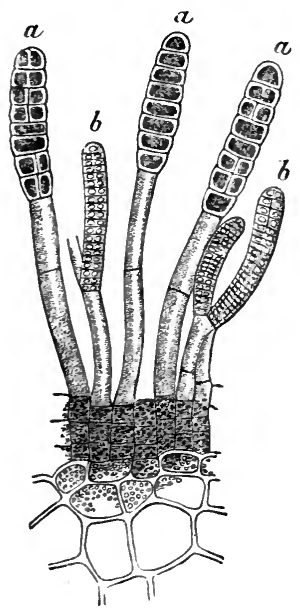

F1G. 228.-Zanardinia collaris Crouan. $a$, oogones; $b$, antherids (magnified). (A'ter Reinke.) 
regards this species as probably a non-sexual generation in the cycle of development of Cutleria multifida. The chief argument for placing the Cutleriaceæ among the Phæosporeæ is the occurrence of non-sexual zoospores, but the mode of sexual reproduction indicates a distinct approach to the Fucaceæ; in this latter class, however, the structure of the antherids is quite different.

\section{LiteratuRE.}

Janczewski-Mém. Soc. Sc. Nat. Cherbourg, I872, p. 345, and Ann. Sc. Nat., xvi., I883, p. 210.

Reinke-Monber. Berlin. Akad. Wiss., I876, p. 565 ; and Nova Acta Acad. Leop.Carol., I878, p. 67.

Falkenberg-Mittheil. Zool. Stat. Neapel, i., I879, p. 420.

The order Dictyotaceæ, comprising, according to Bornet, the eight genera Dictyota (Lmx.), Zonaria (Harv.), Stœchospermum (Ktz.), Lobospira (Thur.), Spatoglossum (Ktz.), Padina (Adans.), Taonia (Ag.), and Dictyopteris (Lmx.), has been united by some writers with the Cutleriaceæ, while by others it has, with much more reason, been erected into a distinct class, of equal rank with the Phæosporeæ. It differs, in fact, from the other orders of Phæosporeæ in several important points. The thallus of the Dictyotaceæ is membranaceous, usually erect flat and leaf-like, seldom ribbed, often beautifully variegated in zones from the presence of prismatic hairs or from incrustation of calcium carbonate. Growth takes place either by means of a single apical cell (Dictyota), or from a group of equivalent cells. Non-sexual organs of propagation are known, and other organs which are probably sexual. The Dictyotaceæ differ, in the first place, from all other Phæosporeæ in the absence of motile ciliated zoospores. The non-sexual tetraspores are produced in tetrasporanges developed on the margin of the thallus, or in sori on its surface, on special non-sexual individuals. Although the contents of each sporange usually break up into four spores, when they resemble in all respects the tetraspores of the Florideæ, this is not always the case ; occasionally they divide into only two spores, and still less often the entire contents of the sporange escape as a single naked spore. The spores germinate directly, after investing themselves with a cellulose membrane. The presumed sexual organs, oogones and antherids, are collected into sori in similar situations, but not on the same individuals as the tetrasporanges. Some species are monœcious, others diœcious. The contents of each oogone consist of a single undivided motionless oosphere. The contents of the antherids, on the other hand, divide into a large number of motionless pollinoids. Up to the present time, however, actual impregnation of the oospheres by the pollinoids has not been 
observed. As the Cutleriaceæ present an approach towards the Fucaceæ, so the Dictyotaceæ may possibly indicate the point of departure of the

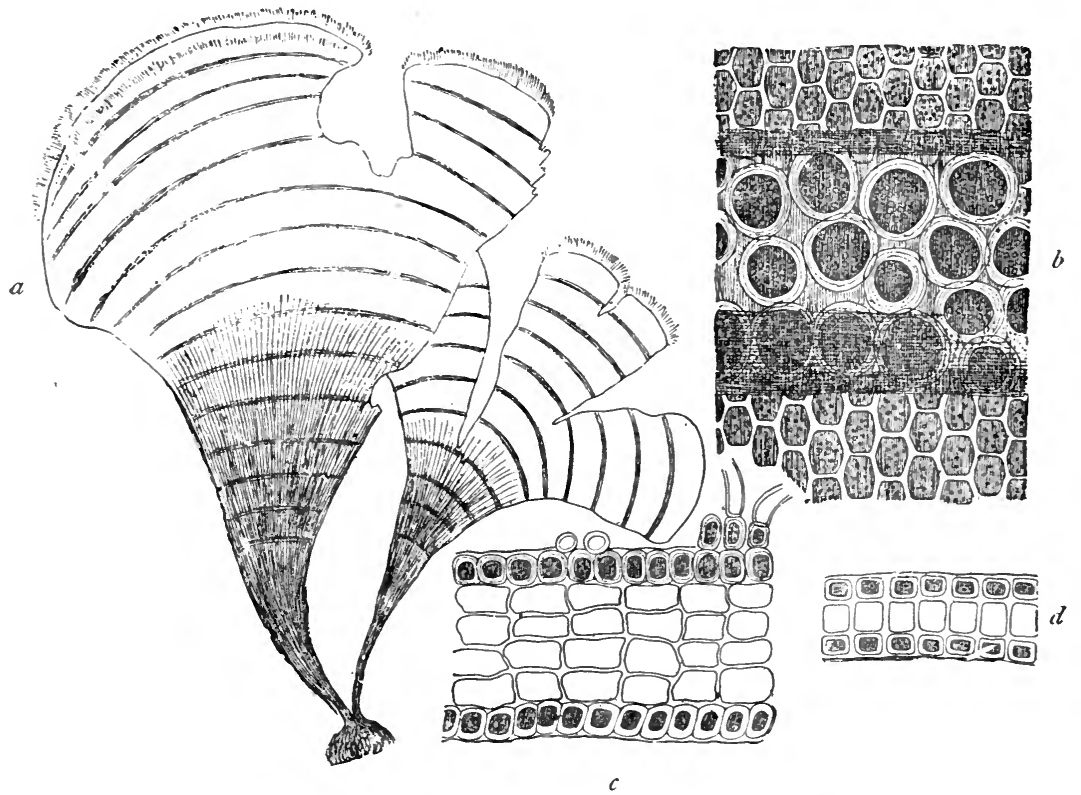

FIG. 230.-Padina Pavonia Gaill. a, natural size; $b$, portion of surface of thallus with tetrasporanges ; $c$, iransverse section of upper portion of thallus; $d$, of lower portion ( $x, 10)$. (After Kützing.)

Florideæ, agreeing with that order in the presence of tetraspores and of non-motile pollinoids; but as the oogone presents no indication of even a rudimentary trichogyne, and there is no process analogous to the forma-
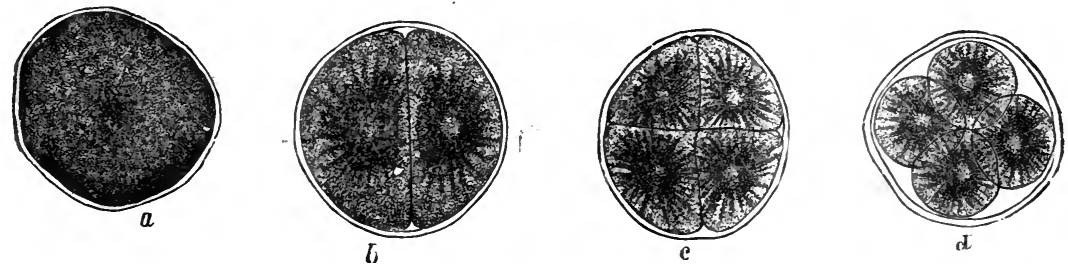

FIG. 23r.--Stages in the formation of the tetraspores in Padina Pavonia (magnified). (After Reinke.)

tion of a cystocarp, it seems best, until more is known of the process of fertilisation, to retain the Dictyotaceæ as an aberrant order of Phæosporeæ, with which they also agree best in the nature of their pigment. 


\section{LiteratuRE.}

Reinke-Nova Acta Acad. Leop.-Carol., I878.

Thuret \& Bornet-Etudes Phycologiques, 1878 .

Hauck-(Padina) Hedwigia, I887, p. $4 \mathbf{1}$.

The position of the small family of SyngeneTicÆ, as constituted by Rostafinski, is one of great uncertainty. The two genera of which it is composed have generally been regarded as of a very low type of structure,

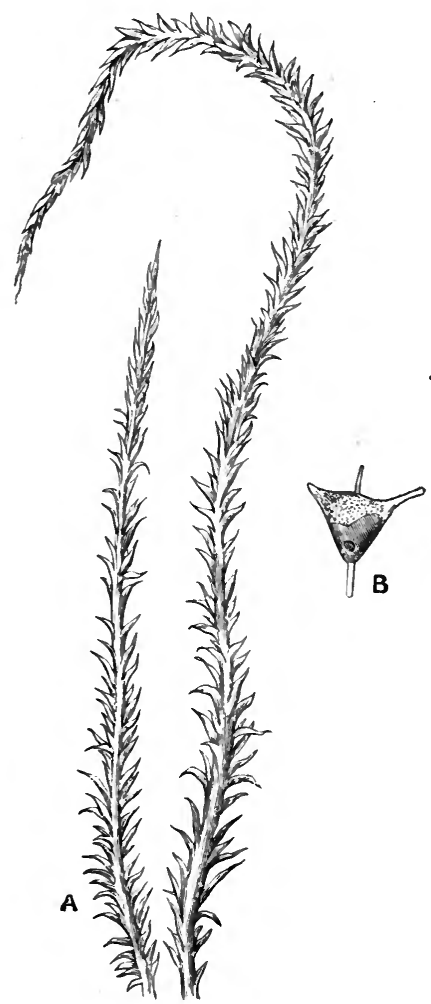

Fig. 232.-A, Hydrurus penicillatus Ag. (natural size). (After Cooke.) $B$, zoo.

spore (greatly magnified). (After Lagerheim.)

pulsating vacuoles. Propagation takes place by means of zoospores of very peculiar form, produced in the branches only, two or four from each cell. When mature the zoospores are tetrahedral, each angle being nearly related to one another. The probability seems to be in favour of both genera having been derived from the Phæosporeæ by retrogressive metamorphosis in different directions. Heckel and Chareyre (Journal de Micrographie, I885) regard Hydrurus and Chromophyton as presenting a connecting link between the Diatomaceæ and the Phæosporeæ.

Hydrurus Ag. consists of a filamentous thallus, attaining sometimes a foot in length, slimy and affixed to a conical disc, and growing in cold fresh running water. The filaments are simple below but branched above, often with exceedingly fine penicillate divisions, filled with a brown or olive endochrome identical with phycophæin. The surface is naked or densely covered with delicate hair-like appendages, which are occasionally fasciculate. The thallus is composed of cells dispersed through the gelatinous matrix ; towards the apex of the branches the cells are in close contact with one another, but in the older parts of the thallus they are some distance apart. Each is surrounded by a very delicate membrane, and Lagerheim states that some of them contain
n takes place by means of zoospores of

and it is very doubtful whether they are 
prolonged into a slender colourless beak; in one of the angles is a brown chromatophore; and attached to the centre of the opposite side a single short cilium, and near it two pulsating vacuoles, but no pigment-spot. The zoospores appear to germinate directly without conjugation. Lagerheim has also detected, on different individuals from the zoospores, peculiar resting-spores, through the vitality of which Hydrurus remains dormant through the summer and autumn, its active life extending only through the cold season. Hydrurus is placed by Rabenhorst and Cooke a mong the Palmellaceæ.

Chromophyton Wor. is an epiphytic organism which vegetates and hibernates within the hyaline cells of the leaves of Sphagnum and other aquatic mosses. In this state it consists of unciliated naked masses of protoplasm with pulsating vacuoles, and endowed with an amœboid motion. While still within the cells of the host, these bodies become invested with a delicate cell-wall, multiply by repeated bipartition, and assume the condition of resting-spores, the endochrome being now of a brownish red colour. From these resting-spores are developed zoospores, minute ellipsoidal or nearly spherical bodies, $8-9 \mu$. long and $4-6 \mu$. broad, with a single cilium, a contractile vacuole, and a bright yellow or yellowish brown pigment-disc, consisting of a substance apparently identical with the diatomin of the Diatomaceæ. These zoospores are imbedded in a colourless mucilaginous matrix, in which condition they float in large numbers on the surface of the water of bogs in the form of a fine yellow dust. When completely immersed in water, the zoospores are set free from their investing mucilage, and at once begin to swarm. After a time each zoospore develops a second colourless gelatinous envelope, with a tubular opening below, through which it absorbs water. In this encysted condition, having now lost its cilium, it multiplies by bipartition. Although two forms of zoospore have been observed, one much smaller than the other, no process of conjugation has been detected. Cornu describes a second species of Chromophyton with stalked bodies which may be sporanges, and a siliceous coat like that of diatoms. Although in some respects presenting a resemblance to a degraded form of Phæosporeæ, it is possible that Chromophyton may be a stage in the development of some organism belonging to a totally different class. In some respects it may be compared to the Chytridiaceæ among Fungi.

\section{LITERATURE.}

Woronin-(Chromophyton) Bot. Zeit., I880, pp. 625, 64I.

Rostafinski - Hydrurus u. seine Verwandtschaft, Krakow, I 882 (Ann. Sc. Nat., xiv,, I 882 , p. 5). 
Cornu-(Chromophyton) Bull. Soc. Bot. France, I883, p. xciii.

Hansgirg-Oesterr. Bot. Zeitschr., I 884, p. 31 .

Lagerheim-Ber. Deutsch. Bot. Gesell., 1888, p. 73.

Phaothamnion Lagerh. (Bot. Zeit., I885, p. 604) is a fresh-water alga forming brownish yellow tufts on Vaucheria, Cladophora, \&c. Certain cells develop into zoosporanges, each of which produces two biciliated zoospores, and the alga has also a palmella condition. Notwithstanding the brown endochrome, and the fact that the zoospores germinate directly and have not been observed to conjugate, Lagerheim places this genus near to Chroolepideæ and Chætophoraceæ, making it the type of a new family; PhæothamnieÆ. It may possibly, however, be more nearly related to the Syngeneticæ.

\section{Class XIV.-Conjugatæ.}

The Conjugatæ, as defined by de Bary, constitute an extremely wellmarked and natural group, composed of the three families Mesocarpacee, Zygnemacee, and Desmidiacea, with no near affinities (except possibly with the Diatomaceæ). The individual is unicellular in most of the Desmidiaceæ ; but in some genera of desmids, and in all belonging to the other two orders, it consists of a filament of cells, which is almost invariably unbranched. The arrangement of the bright green endochrome, in spiral bands, plates, discs, or stars of beautiful symmetry, is altogether peculiar to this group of plants, and renders them among the most interesting and beautiful of microscopic objects. No formation of zoospores occurs throughout the class, and the ordinary mode of vegetative increase is by simple cell-division, and the breaking up of old individuals in the filiform genera into fragments. They retain their power of life through the winter, when under conditions unfavourable to the formation of zygosperms, by the production of resting-spores, or single cells which retain for a long period their vitality. These may be either akinetes or aplanospores in Wille's sense of the terms. Gay states (Bull. Soc. Bot. France, I886, p. 4I) that the filaments of Zygnema (Ktz.), especially when growing in dry situations, have a tendency to break up into cysts, i.e. fragments which become enclosed in a mucilaginous sheath, resulting from the gelification of the outer layers of the cell-wall. These cysts may preserve their vitality for months, and then, when moisture again penetrates the sheath, they divide by transverse septa, and develop into new individuals. The single cell of the Desmidiaceæ and the filament of the filiform genera is enveloped in a 
thin transparent mucilaginous sheath. According to Klebs (Untersuch. Bot. Inst. Tübingen, I886, p. 333) this sheath is composed of two distinct portions, a homogeneous substance which is but slightly refringent, and a portion which consists of minute rods placed at right angles to the cell-wall. He regards this mucilaginous sheath as entirely independent of the substance of the cell-wall, and derived from the protoplasmic contents of the cell by diffusion through the cell-wall. The same structure probably prevails also in the Confervaceæ and other filiform algæ growing in fresh water. The Desmidiaceæ possess a remarkable power of apparently spontaneous motion, which will be spoken of in detail under that order.

The only sexual mode of reproduction in the Conjugatæ is the conjugation of stationary cells, found nowhere else except in some of the Zygomycetes. This consists, in the unicellular genera, of the complete union or fusion of the protoplasmic contents of two individuals; in the multicellular genera, of the isogamous union of the whole or a part of the contents of gametes or non-motile unciliated cells into a zygosperm; conjugation may take place between cells belonging to the same or to different filaments. Whether the two conjugating cells are physiologically equivalent or not will be discussed under the separate orders, and the process described more in detail. Klebahn finds the union of the two nuclei in the zygosperm to take place only slowly in Zygnema (Ktz.) (Zygnemaceæ); while in Closterium (Nitzsch) (Desmidiaceæ) they remain distinct even in the mature zygosperm.

The Zygnemaceæ must be regarded as the typical family of Conjugatæ, from which the Desmidiaceæ have probably been derived by tetrogression, exhibited, in most cases, by the reduction of the filament to a single cell. The Mesocarpaceæ display an approach to a higher type of sexual reproduction in the more complicated processes connected with the formation of the zygosperm. The reasons for excluding the Diatomaceæ from the Conjugatæ, contrary to the opinion of some writers, and placing them in a totally different group, will be given hereafter.

Many of the Conjugatæ are extremely abundant in fresh water, whether running or stagnant, to which they are almost entirely confined ; some of the filiform species grow also on moist ground and among moss.

\section{LITERATURE.}

De Bary-Untersuchungen über die Conjugaten, 1858 .

Gay-Essai d'un Monographe des Conjuguées, 1884 .

Bennett--Journ. Linn. Soc., xx., r884, p. 430.

Klebahn-(Zygosperm) Ber. Deutsch. Bot. Gesell., I888, p. I60. 


\section{ORder I. - MESOCARPACEe.}

The species belonging to this family consist of cylindrical unbranched or very rarely branched filaments of elongated cells, in which the chlorophyll is not arranged, as in the Zygnemaceæ, in stars or spiral bands, but in a thin axile plate occupying one diameter in each cell, and containing a number of conspicuous starch-grains ; those of adjacent cells lying usually or invariably in the same plane. Vegetative propagation takes place by the breaking up of a filament into its constituent cells ; sexual reproduction by a process of conjugation, which may take place either between cells of the same or of different filaments.

The ordinary mode of conjugation in the Mesocarpaceæ is that termed scalariform, viz. between the several cells of two different filaments. In most species of Mesocarpus (Hass.) this takes place in the following way. When two filaments lie very near one another side by side; each cell of each filament puts out a short protuberance on the side facing the other filament. While these are forming, the greater part, but not the whole, of the endochrome in each cell passes into the protuberance thus formed, a portion being apparently always left behind As soon as the two protuberances meet, the cell-wall becomes absorbed at the extremity of each, and an open tube is thus formed in which the protoplasm of the two conjugating cells coalesces, with expulsion of cellsap and consequent contraction into a globular zygosperm. The zygosperm is not formed in the centre of the short tube, but at one extremity of it, in contact with what may possibly be regarded as the female filament, although the differentiation is doubtful, and in any case exceedingly slight. The zygosperm may be the result of the coalescence of three cells instead of two. The zygosperm is at once separated from the rest of the conjugating tubes, or from the mother-cells, by a septum on either side. In Staurospermum (Ktz.), where the cells are very long and narrow, four cells take part in the formation of each zygosperm. Two of the slender filaments, lying side by side, bend towards one another convexly so as to bring a part of each filament where there is a septum in contact. Both the septa and the longitudinal bounding-walls become absorbed at this spot, and the greater part of the contents of the four cells coalesce into a zygosperm, which is often of a more or less quadrate form, and is again sharply marked off from the four mother-cells by septa at the truncated corners. Lateral conjugation also takes place in some species of Mesocarpus between two adjacent cells in the same filament. In this process each of the two cells puts out a horn-like protuberance at the end adjacent to the other cell ; these protuberances bend towards one 
another and meet; the septum between them disappears; the endochromes of the two cells draw towards one another and coalesce, with condensation of the protoplasm, in the connecting tube thus formed (fig. 235). In M. neaumensis (Bennett, Journ. Micr. Soc., i 886, p. I 5 ) the

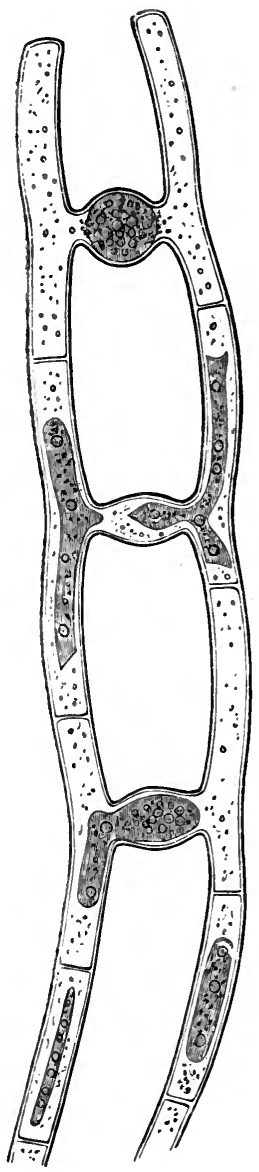

Fig. 233.-Mesocarpus parnulus Hass.; stages in the formation of zygosperm ( $\times 750)$. (After de Bary.)

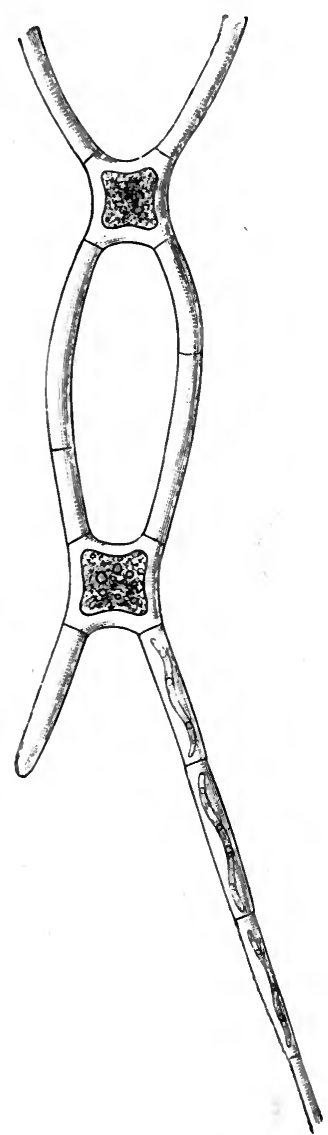

FIG. 234. - Staurospermum gracillinum Hass., with quadrate zygosperms, showing axile plate of chlorophyll in the cells which have not conjugated $\left(x_{400}\right)$. (From) nature.)

zygosperm is not formed in the connecting tube, but in one of the conjugating cells. In Gonatonema (Wittr.) parthenosperms are said to be formed closely resembling zygosperms, but not resulting from the 
coalescence of the contents of two cells. Several species of Mesocarpus frequently put out long connecting tubes between two filaments, which assume a barrel-shaped form, but without any formation of zygosperms. In this condition they closely resemble Mougeotia (de By.).

The most important point in which the Mesocarpaceæ differ from the Zygnemaceæ is in the processes which take place after the formation of the true zygosperm. Immediately after its formation, it divides into two, three, or more cells, the central one only of which is fertile, germinating after a period of rest ; the other sterile cells, which are separated from the fertile cell by septa, taking no part in the germination. The germinating cell is therefore here a resting-spore or hypnospore, produced non-sexually, and the whole structure is, as Pringsheim points out, a rudimentary sporocarp, indicating an approach to the higher classes of Algæ; while the family is, on the other hand, con-

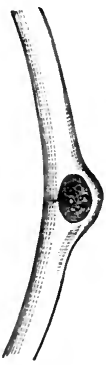

FIG. 235.-Mesocarpus pleurocarpus de By.; lateral conjugation $(\times 200)$. (From nature.) nected with the Zygnemacex through the species of Zygnema in which the zygosperm is formed in the connecting tube; and the best writers are by no means agreed as to the limits of the two orders.

Wittrock has described the formation of the 'sporocarp' as taking place in three different ways in the Mesocarpaceæ, viz.:-(I) By the tripartition of the zygosperm into a hypnospore and two sterile cells; when the conjugation is lateral, the sterile cells are not separated from one another by the hypnospore, but are permanently united with one another. (2) By quadripartition of the zygosperm; this has been observed only in the case of scalariform conjugation, the sterile cells being arranged two on one side and one on the other side of the hypnospore.

(3) The zygosperm is cruciform or $\mathrm{H}$-shaped, and the sporocarp is formed from it by quinquepartition, two sterile cells bounding the hypnospore on each side; this mode also only takes place in scalariform conjugation. Although these characters have been used by Braun and others for the separation of the genera of Mesocarpaceæ, Wittrock regards them as of very little systematic value, since in one species, Mougeotia calcarea (Wittr.), he observed all three modes of reproduction on one and the same filament. In this same species Wittrock also records the formation of parthenosperms, precisely resembling the normal zygosperms, but not resulting from any act of conjugation. An outgrowth springs from a filament, but is not met by any corresponding outgrowth from another filament. It is, however, cut off by a septum, and divides intö sterile cells and a hypnospore, just as if fecundation had taken place. 
In Gonatonema notabile (Wittr.) parthenogenetic hypnospores are formed by tripartition of the contents of an ordinary cell which swells up into the form of a cask.

The phenomenon of reproduction in the Mesocarpaceæ is regarded by some as a rudimentary appearance of an 'alternation of generations.' The sexual generation or oophyte is completed by the production of the zygosperm as the immediate product of fecundation. This does not germinate directly, but its formation is immediately followed by celldivision, or the development of the non-sexual generation or sporophyte ; the sporocarp consists of the germinating hypnospore-in the immediate formation of which no process of impregnation took part-and the investing sterile cells or 'pericarp.' Pringsheim, regarding the process of conjugation in the Mesocarpaceæ as representing a distinctly higher type than that in the Zygnemaceæ, divides the process in the former family into two stages. The first stage, to which he applies the term 'copulation,' consists in the simple union of two cells by the absorption of the dividing cell-wall; the second stage is an intimate coalescence of the protoplasmic contents of the conjugating cells, effected by the motility of the chlorophyll-bodies; and this stage he terms 'connubium.' The hypnospore might, indeed, be correctly termed a 'carpospore,' and we have here a point of departure in the direction of a much more highly specialised type of structure. But the complete similarity of the two conjugating cells before conjugation necessitates the retention of the Mesocarpaceæ among the Conjugatæ.

Limiting the order in accordance with the above-named characters, the genera which the Mesocarpaceæ comprise are Mesocarpus (Hass.), Staurospermum (Ktz.), Craterospermum (Br.), and Gonatonema (Wittr.). Several species of Mesocarpus and Staurospermum are not infrequent in stagnant water, especially in moor pools and among Sphagnum. The filaments are not so copiously invested with mucilage and not of so bright green a hue as those of the Zygnemaceæ; Staurospermum capucinum (Ktz.) has a beautiful violet tinge.

\section{LiteratuRe.}

Wittròck-Algologiska Studier, Upsala, I867; On Gotlands och Oelands Sötwasseralger, 1872 (Quart. Journ. Micr. Sc., 1873, p. 123); On the Spore-formation of the Mesocarpere, 1878 . 


\section{ORDER 2.-ZYGNeMACEÆ.}

The individual consists, as in the Mesocarpacex, of a filament of cells placed end to end, which is almost always simple and unbranched. The filaments are cylindrical, and the cells of which it is composed often of comparatively large size ; those of Spirogyra crassa (Ktz.) as much as $\frac{1}{40}$ of an inch $(125 \mu)$ in diameter, and twice as long as broad. The chlorophyll is arranged in one or more straight (Siro-

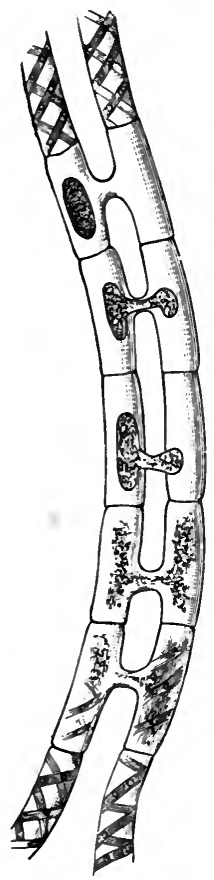

FIG. 236.-Spirogyra porticalis Vauch.; stages in the formation of zygosperm $(\times \quad 100)$ (From nature.) gonium, Ktz.) or more commonly spiral (Spirogyra, Lk.) bands, or in stars placed in pairs in each cell (Zygnema, $\mathrm{Ktz}$.), or occasionally in an axile plate (Mougeotia, de By.), and encloses large starch-grains and a nucleus, often very large and easily discernible even without the use of staining reagents, connected with the parietal protoplasm by radiating threads. In some species of Zygnema the characteristic appearance of the endochrome is assumed only when the cells are about to conjugate. The ease with which some members of this family, especially species of Spirogyra and Zygnema, are cultivated in fresh-water aquaria, and the beautiful arrangement of the endochrome, not only make these algæ extremely striking objects under the microscope, but afford especially good opportunities for observing, in their details, the processes of division of the nuclcus and of the cell. ${ }^{1}$ It is also in this family that the interesting process of conjugation is most easily followed.

The filaments increase in length by ordinary celldivision; and single cells, which become very easily detached, are able to develop in this way into new individuals, corresponding, therefore, functionally to the non-sexual spores of fungi. Like the Desmidiaceæ and other floating algæ, they can obtain their nourishment entirely from the water, and increase without any attachment to the substratum. The formation of resting-cells and of cysts has already been mentioned. The only other known mode of reproduction is by conjugation; but the reproductive organs of other algæ or fungi, which are sometimes parasitic upon or

${ }^{1}$ See Strasburger, Ueber Zellbildung und Zelltheilung; also Sachs, Text-book of Botany, 2nd English ed. 1882, p. 16. 
endophytic in species of Spirogyra and Zygnema, have been mistaken for zoospores.

The usual mode of conjugation is the scalariform, between the cells of two filaments lying side by side. The first stage is the putting out of lateral protuberances at right angles to the axis of growth, from the cells in each filament towards the corresponding cells in the other filament. The protuberances put out by opposite cells at length meet ; the protoplasm-mass of each of the two cells has by this time begun to contract, withdrawing itself from the cell-wall, and rounding itself off into an ellipsoidal form, with expulsion of some of its cell-sap, the chlorophyllbodies at the same time losing their characteristic arrangement. The cell-wall then opens between the two protuberances, and the whole of the protoplasmic contents of one of the two cells passes through the connecting tube thus formed, and glides slowly through it into the other cell-cavity, coalescing with its protoplasm-mass. After complete union the combined protoplast is again ellipsoidal or spherical, and scarcely larger than each of the two before coalescence, further expulsion of water and consequent contraction having taken place. In some species of Zygnema the zygosperm is formed, not in either of the conjugating cells, but in the connecting tube,

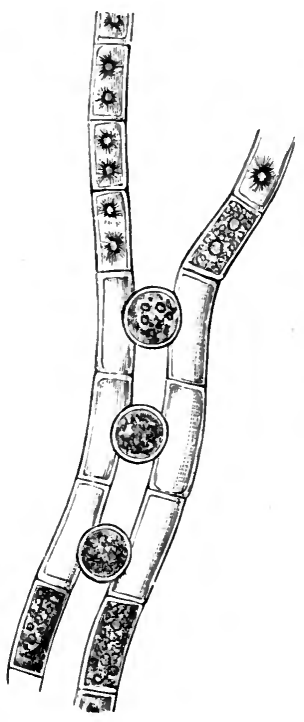

FIG. 237. - Zygnema pectinatum Ag., in conjugation $(x$ IOO). (After Cooke.)

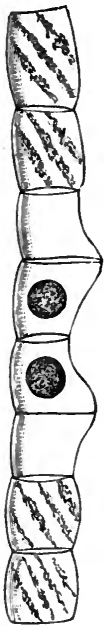

FIG. 238. - Spirogyra bellis Hass.; lateral conjugation ( $x$ 100). (From nature.) as in the Mesocarpaceæ. In Sirogonium no connecting tube is formed, but conjugation takes place by genuflexion; the two filaments are brought into contact by a knee-like bend in each ; at the point of contact the adjacent cells of the two filaments are placed in communication by the disappearance of the cell-walls, and a zygosperm is formed in one of the two cells by the coalescence of the two protoplasts.

A second mode of conjugation, not nearly so frequent, is the lateral, between two contiguous cells of the same filament. Protuberances formed near the adjacent ends of contiguous cells bend towards one another till they meet; the cell-wall between them then disappears; 
and conjugation is effected though the curved tube thus formed by the coalescence of the protoplasts of the two cells. The zygosperm is never formed, as in the Mesocarpaceæ, in the connecting tube, but in one of the two cells. Lateral conjugation frequently takes place with groups of four cells, the zygosperms being formed in the two central ones.

The protoplast formed by either mode of conjugation finally secretes a cell-wall of cellulose, and becomes a zygosperm. Germination sometimes takes place while still within the mother-cell ; but most commonly both filaments perish after conjugation, with the exception of the numerous zygosperms, which fall to the bottom, the green endochrome having in the meantime turned to a brick-red colour. It then remains dormant through the winter as a resting-cell or hypnosperm, germinating in the spring. Whether the axis of growth of the new individual is parallel or at right angles to that of the old individual is differently stated by different observers. On the commencement of germination, one end of the zygosperm of Spirogyra attaches itself like a root to a stone or to some other alga, so that in the earliest stage of the new individual there is a differentiation between base and apex; but this soon disappears. The innermost of the three layers of which the cellwall of the hypnosperm is composed bursts through the other two, and protrudes like a bag. The chlorophyll then arranges itself in spiral bands, with starch-grains within them, and the cell divides by transverse septa into a filament, all the cells being from this time precisely alike. Instances are recorded of filaments persisting through the winter. Hofmeister states that the growth of Spirogyra is intermittent, and that the filaments exhibit a nutation, due probably to differences in the rapidity of growth of different sides of the same cell. Where branching takes place, it appears to be confined to the barren portion of a filament in which zygosperms have been formed.

Although the view is contested by some writers, the process of conjugation is regarded by most as a sexual process, but one of the most rudimentary character, the differentiation of the two conjugating elements being exceedingly slight. As de Bary has pointed out-and his statement is confirmed by nearly all more recent observers-the direction of conjugation is clearly governed by some physiological law, the movement of the protoplasm between the two filaments almost invariably taking place in one direction only, so that one of the two conjugating filaments is entirely emptied, while the other is filled with zygosperms. ${ }^{1}$ Designating the former as the male and the latter as the female filament, it is frequently the case that the cells of the

1 Hassall, however, asserts and figures the contrary (British Fresh-ivater Alga, i., p. 130). 
female are both longer and broader than those of the male filament; and the contraction of the protoplasm has been observed to begin earlier in the male than in the female filament. It is also stated that the protuberance from the female cell is shorter but broader than that of the male cell, the latter fitting into the former as into a socket. The chief argument against the sexuality of the filaments is the occurrence of lateral conjugation; and when this takes place a sexual differentiation can be assumed only of the individual cells and not of the filaments; but that there is some differentiation of this kind would appear from the fact that when lateral conjugation takes place in a group of four cells the zygosperms are formed in the two centre cells, which may be regarded as female. The phenomena may then be compared to those in Sphæroplea. Bessey states (in lit.) that scalariform and lateral conjugation may sometimes be seen in different parts of the same filament. The female filaments are, as a rule, very much more abundant than the male; and it is not uncommon for conjugation to take place between one male and several female filaments, while the reverse is at all events much more rare. Occasionally one cell will conjugate with two others, the zygosperm being then the product of one female and two male cells. Several instances are recorded of hybridism between two different species of Spirogyra. Parthenogenesis, or the formation of parthenosperits capable of germination, and in all respects resembling zygosperms, but formed out of the contents of a single cell without any previous process of conjugation, is also stated to occur.

The genera included in the Zygnemaceæ with the above characters are Zygnema (Ktz.), Spirogyra (Lk.), Mougeotia (de By.), Sirogonium (Ktz.), and Zygogonium (Ktz.). Several species of Spirogyra and Zygnema are among the commonest of fresh-water Algæ in both stagnant and running water, forming dense bright green masses, often with a slimy feel, owing to the well-developed mucilaginous sheath in which each filament is enveloped. While conjugation is in active progress, which is mostly in the early summer, the filaments of Spirogyra assume a dull green or even brown colour, easily recognised by the naked eye. The other genera are more frequent in moor pools.

\section{LiteratuRE.}

Pringsheim-Flora, 1852, pp. 465 et seq.

Cleve-Monografi Zygnemaceæ, I 868.

Hofmeister-Würtemb. naturw. Jahresheft, i874, p. 2 I I.

Overton-Ber. Deutsch. Bot. Gesell., i 888, p. 68.

(For fuller bibliography see Bennett, Journ. Linn. Soc., xx., I884, p. 430). 


\section{Order 3.-DesmidiaceE.}

The Desmids are unicellular organisms, for the most part solitary, and inhabiting almost exclusively fresh water, especially stagnant, where they occur in very large numbers; a very few spẹcies are brackish. They always float free without any attachment to the bottom or to other algæ, and many species possess a power of apparently spontaneous motion through the water similar to that of diatoms, though not so strongly marked. In several genera, as Desmidium (Ag.) and Hyalotheca (Ehrb.), the individuals are united into long filaments; and either the separate individuals or the filaments are invested by a more or less dense mucilaginous envelope, species of Desmidium and Hyalotheca frequently forming a green slime on the surface of moor pools. The origin and structure of the mucilaginous sheath appear to be the same as in the Zygnemaceæ. According to Hauptfleisch, the cell-wall of desmids always consists of two distinct layers, sometimes of more, which are then provided with a girdle-band similar to that of diatoms. He also states that in nearly all species the cell-membrane is perforated, and that through these pores proceed threads of protoplasm, connecting the protoplasm in the interior of the cell with the gelatinous envelope which is excreted through the pores from the cell-contents. In the filamentous species the protoplasm is probably in connection throughout the filament.

The cells vary greatly in size and form in different species, the largest (Cosmarium, Cord., Micrasterias, Ag.) being just visible to the naked eye. The individual is usually divided by a deep constriction into two symmetrical halves; and even where this is not the case, the cellcontents - chlorophyll-bodies and starch-grains-are symmetrically arranged in the two halves of the cell. The cell-wall is smooth, or punctated, warty, or even elevated into spines, but has no (or very little) deposit of silica. The cells contain a large quantity of chlorophyll of a bright green colour, never concealed by any pigment, often arranged in bands or stars, and containing much starch. Each genus has its own general form of cell, often of very great beauty. In Docidium (Bréb.), Penium (Bréb.), and Tetmemorus (Ralfs) the individual or 'frustule' is elongated, cylindrical, and usually divided by a constriction into two halves placed end to end; in Closterium (Nitzsch) it is crescent-shaped; in Micrasterias it is very thin and flat, usually with a more or less orbicular or elliptical outline, deeply divided into two symmetrical halves, and each half more or less deeply lobed; in Euastrum (Ehrb.) the individual is usually smaller than in Micrasterias, often very minute, and 
the half-cells have a smooth, sinuate, or beaked margin, with circular inflated protuberances; in Cosmarium the half-cells are quite undivided, and the whole outline often nearly orbicular; in Xanthidium (Ehrb.) and in most species of Staurastrum (Mey.) the surface is elevated into prominent tubercles or spines.

The transparency of the cell-wall in desmids enables the rotation of the protoplasm to be distinctly seen; and at the colourless spaces at the extremities of some species of Closterium and Docidium the dancing 'brownian' movement of particles suspended in the cell-sap is very

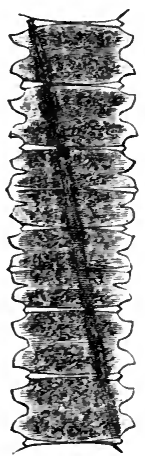

A
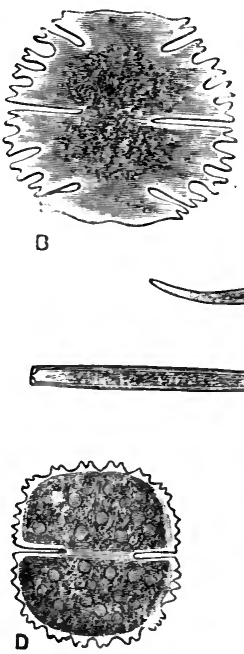
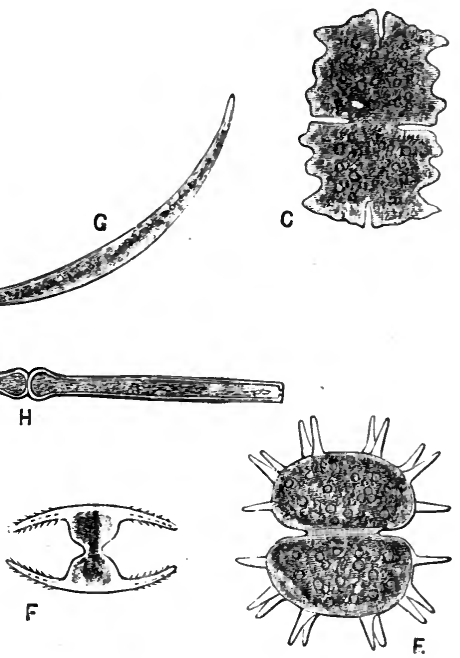

F1G. 239.-A, Desmidium Swartzii Ralfs; B, Micrasterias rotata Grev. ; C, Euastrum rostratum Ralfs ; D, Cosmarium colatum Ralfs ;, , Xanthidium cristatum Bréb.; F, Staurastrum Arachne Ralfs; G. Closterium DianceEhrb.; H, Docidium baculum Bréb. (All afier Ralfs and variously magnified.)

evident. Klebs describes four kinds of movement in desmids, viz. :(I) A forward motion on the surface, one end of each cell touching the bottom, while the other end is more or less elevated and oscillates backwards and forwards; (2) an elevation in a vertical direction from the substratum, the free end making wide circular movements; (3) a similar motion, followed by an alternate sinking of the free end and elevation of the other end ; and (4) an oblique elevation, so that both ends touch the bottom-lateral movements in this position; then an elevation and circular motion of one end, and a sinking again to an oblique or horizontal position. These movements are, according to this observer, all due to an exudation of mucilage, and the first two to the: 
formation, during the motion, of a filament of mucilage by which the desmid is temporarily attached to the bottom, and which gradually lengthens. The movements of desmids are especially vigorous when they are in the act of dividing. Stahl found that, like the movements of zoospores, they are affected by light.

Vegetative propagation takes place by division or fission, a process which can be easily followed out in species of Cosmarium or Staurastrum, the whole being completed in the course of a few hours. When celldivision is about to commence, the endochrome retreats slightly from the band or 'isthmus' which connects the two half-cells with one another; and the two halves then separate from one another, retaining their connection only by a transverse band formed by the gradual broadening of the isthmus; this is after a time divided into two by

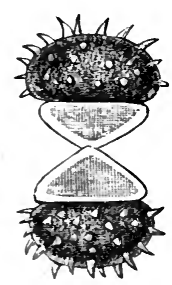

A

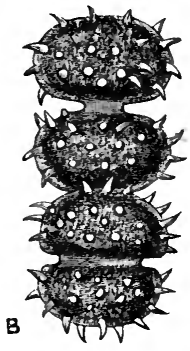

FIG. 240.-Staurastrum teliferum Ralfs, dividing $(\times 400)$. (From nature.)

a septum along the length of the isthmus, midway between the two half-cells and parallel to the constriction between them. The endochrome now passes out of each original half-cell into the half of the band in connection with it, and at the same time the half-band bulges, and, growing rapidly, assumes the form and appearance of an original halfcell. Fresh formation of chlorophyll is at the same time taking place in it, and the half-band becomes a complete half-cell, but sometimes slightly larger. We have now two individuals attached to one another by their larger halves; these frequently remain in contact for a considerable period, but at length separate. In the spiny species of Staurastrum the spines are developed very rapidly on the half-bands while their development into half-cells is progressing.

A sexual process of conjugation takes place in the following way in the genera where the individuals are quite distinct. Two individualswhich cannot in any way be differentiated as male and female-lay themselves either parallel to or across one another, and the pair become enveloped in a common mucilaginous coating. In each individual the outer of the two layers of which the cell-wall is composed gives way, and a circular opening is formed at the constricted part; the inner layer of the cell-wall of each individual protrudes through the opening in the form of a bladder, and these two protrusions come into contact. The outer cell-wall is then thrown off, and the wall separating the two con- 
jugating protrusions disappears. The two protoplasmic bodies then unite in the conjugating tube thus formed into a nearly spherical zygosperm, enclosed in a cell-wall which ultimately becomes differentiated into three layers, the innermost and outermost of which are colourless, while the middle one is firmer and brown. The outer surface remains in some species smooth, while in many it becomes, when mature, covered with warts or spines, which are not unfrequently barbed. In those genera where the individuals are associated into filaments, conju-
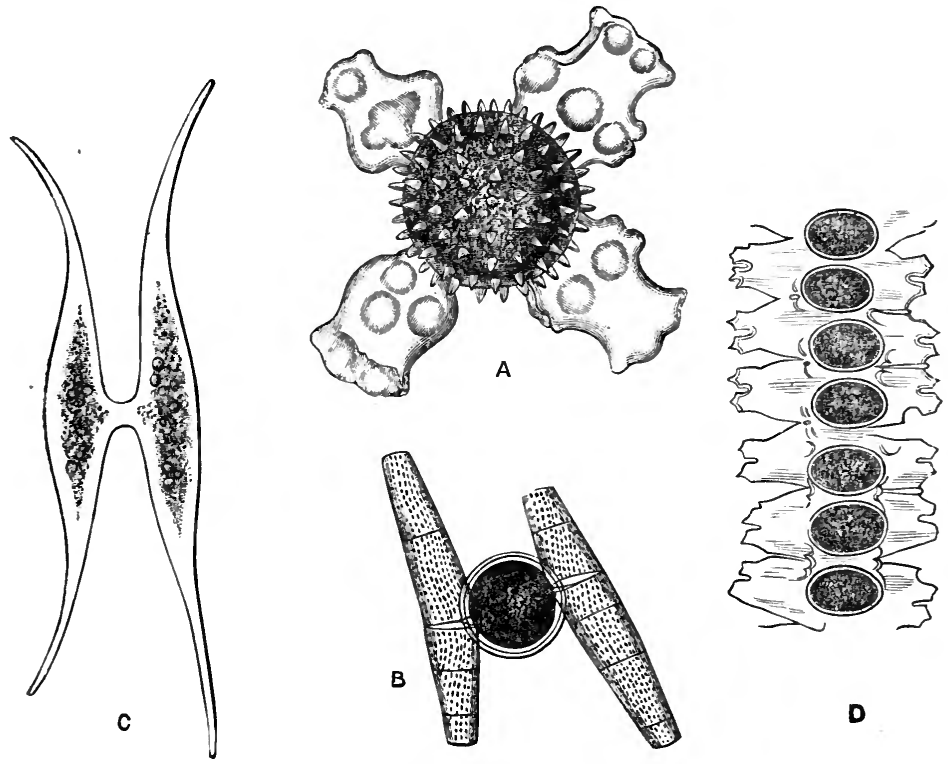

B

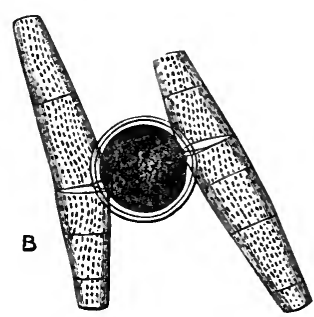

D

FIG. 24I.-Zygosperms of desmids. A, Euastrum pectinatum Bréb. $(\times 400)$. B, Penium margaritaceum Bréb. $(\times 300)$. C. Closterium rostratum Ehrb. early stage $(\times 200)$. D, Desmidium Swartzii Ralfs ( $\times 600$ ). (All after Ralfs.)

gation takes place between the cells of different filaments, and a large number of zygosperms may frequently be seen in the same filament. In Gonatozygon (de By.), where the cells are very long and slender, the process is very similar to that in Zygnema. The statement of the occurrence of zoospores in the Desmidiaceæ is founded on erroneous observation, the antherozoids of parasitic fungi having possibly been mistaken for zoospores.

After remaining for a considerable time at rest, the zygosperm germinates by the bursting of its two outer coats, the protoplasmic contents escaping still enveloped in the very thin innermost coat. In this embryo, 
as it may be termed, the protoplasm and chlorophyll-corpuscles are already distributed symmetrically into two half-cells, which contract somewhat, and the whole becomes invested by a new cell-wall. A constriction has in the meantime made its appearance between the two halves, and the new individual rapidly assumes its mature form, but is at first of small size. It soon divides repeatedly, and each generation gradually increases in size until the full size is attained.

The number of known species of desmids is not large compared with that of diatoms; they are found in great abundance in the midst of larger algæ in fresh water, especially in moor-pools, sometimes forming a green scum on the surface.

\section{LiteratuRE.}

Ehrenberg-Die Infusionsthierchen, 1838 .

Ralfs-British Desmidiex, I 848 .

Nägeli-Gattungen einzelliger Algen, 1849.

Stahl-Verhandl. Phys.-med. Gesell. Wüirzburg, I88o, p. 24.

Fischer-Bot. Zeit., I883, pp. 225 et seq.

Wolle-Desmids of the United States, I 884.

Klebs-Biolog. Centralblatt, I885, p. 353.

Cooke-British Desmids, I 887 (which see for further bibliography).

Hauptfleisch-Zellmembran u. Huillgallerte der Desmidiaceen, I888.

\section{Class XV.-Confervoideæ Isogamæ.}

In this class the individual still consists of a filament of cylindrical cells, placed end to end, which may be branched or unbranched. As in the Conjugatæ, the only known sexual mode of reproduction is an isogamous one between two masses of protoplasm, which are not clearly differentiated beforehand into a male and a female element; but the conjugating bodies are not the contents of stationary cells, but are motile ciliated swarm-spores or zoogametes, produced by free-cell formation in ordinary or in slightly differentiated cells of the filament, hence. termed gametanges, their conjugation resulting in the production of a zygosperm. The filament increases in length by the repeated transverse septation of successive apical cells, or less often of intercalary cells. The ordinary mode of multiplication is a non-sexual one, by means of naked ciliated zoospores, closely-resembling the zoogametes, but often larger, and formed singly or in pairs in a cell. Vegetative propagation also takes place by the formation and detachment of cysts or restingcells, which may be either akinetes or aplanospores. The cells very frequently display a plurality of nuclei, but this is not nearly so strongly 
marked as in the unicellular Multinucleatæ. The class includes one large order, the Confervacea, and three smaller ones, the Ulotrichacee, Pithophoracee, and Chroolepidea, though the boundaries between them are not in all cases well defined. In the Confervaceæ and Ulotrichaceæ the filament which springs from the germination either of a zoospore or of a zygosperm resulting from the conjugation of zoogametes, attaches itself to the substratum-a stone, another alga, or some other aquatic plant-by a rhizoid, which may consist of a single cell, or may branch into a number of cells. As in the higher algæ, the rhizoid is not a nutritive organ, but simply an organ of attachment. These algæ may, however, continue to grow and retain their vitality for a long period in water without any attachment to the substratum.

\section{Order r.-Confervacee (including Chetophoracee).}

The term Confervaceæ has been very vaguely applied to a variety of green freshwater organisms, but is now limited to a comparatively small number of genera of fresh-water, and a few brackish and saltwater algæ, in which each individual consists of a segmented branched or unbranched filament of cylindrical or discshaped cells, invested by a mucilaginous sheath, and in which multiplication takes place non-sexually by megazoospores, or sexually by the conjugation of smaller zoogametes. Both kinds of swarm-cell have two cilia, or the former in some cases four ; Lagerheim describes, in Conferva bombycina (Ktz.), megazoospores with a single cilium. From each parent-cell are produced either one or two megazoospores.

In only a few species has the process of conjugation of zoogametes been actually observed, and the systematic position of a large number of the species is therefore at present only conjectural. Areschoug has followed both the conjugation of the zoogametes and the direct germination of the megazoospores in Urospora (Aresch.). In

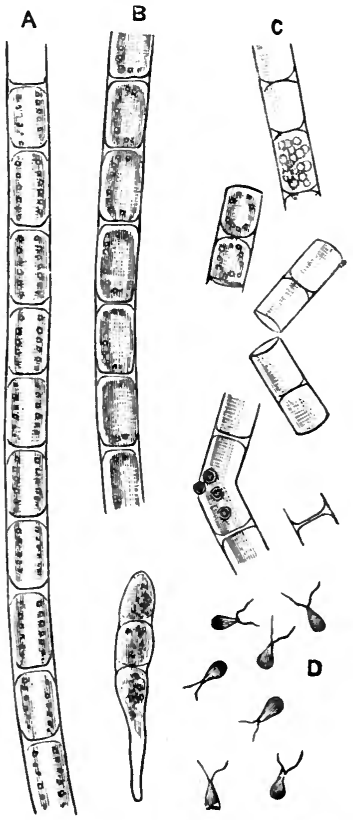

Fig. 242. - Microspora floccosa Ther. $A, B$, portions of filament. $C$, filament dividing for the escape of zoospores. $D$, zoospores $(\times 300)$. (After Cooke.) Conferva (L.), Chætophora (Schr.), Draparnaldia (Ag.), and some other 


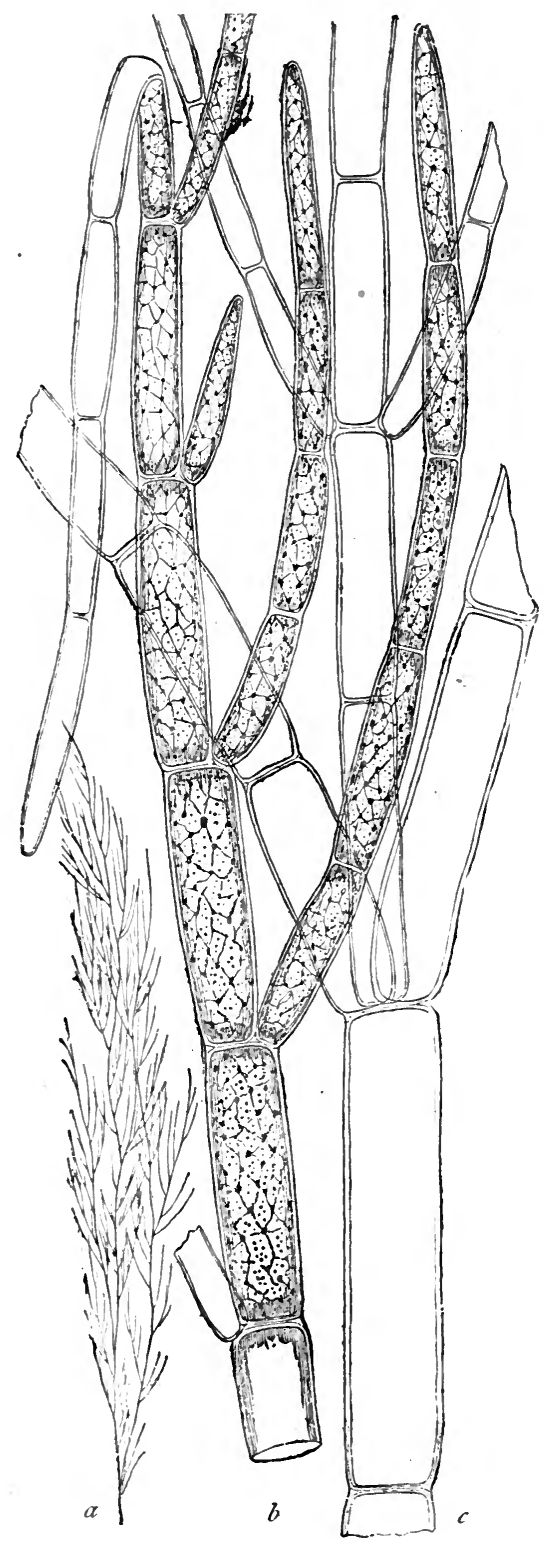

FIG. 243.-Cladophora gracilis $\mathrm{Ktz}$. a natural size ; $b$, upper, $c$, lower portion ( $\mathbf{x} \cdot \mathbf{2 c o})$. (After Hauck.) genera, vegetative propagation takes place by means of restingspores or cysts, usually found in swollen barrel-shaped cells. In Conferva the resting-cells may be either akinetes or aplanospores; and Wille believes that they are produced especially under circumstances unfavourable for the formation of zoospores. The resting-spores of Confervaceæ are formed in three different ways: either (I) by rejuvenescence, and the formation of a new cell-wall round the contracting contents; or (2) by separation of a portion of the cell-substance so as to form a swollen part of the mother-cell, and the thickening of the cellwall at this portion; or (3) by the simple thickening of the wall of the mother-cell. In the formation of aplanospores, one, two, or four proceed from a single cell by the cell-contents rounding off and enclosing themselves in a cell-wall while still within the parent-cell. They hibernate within the parent-cell, and germinate in the spring. Resting swarm-cells, naked masses of protoplasm endowed with an amœboid power of motion, are formed in the same way.

The mucilaginous sheath of the Confervaceæ appears to have the same construction as in the classes of algæ already described, but is often but feebly developed. Wille states that the 
spores put out an organ of attachment even before they germinate. In Chætophora and other genera which make up the Chætophoraceæ of Hassall, the terminal cell of the main axis or of its branches is prolonged into a colourless hyaline bristle. These are especially well developed in Draparnaldia, an exceedingly beautiful organism not uncommon in

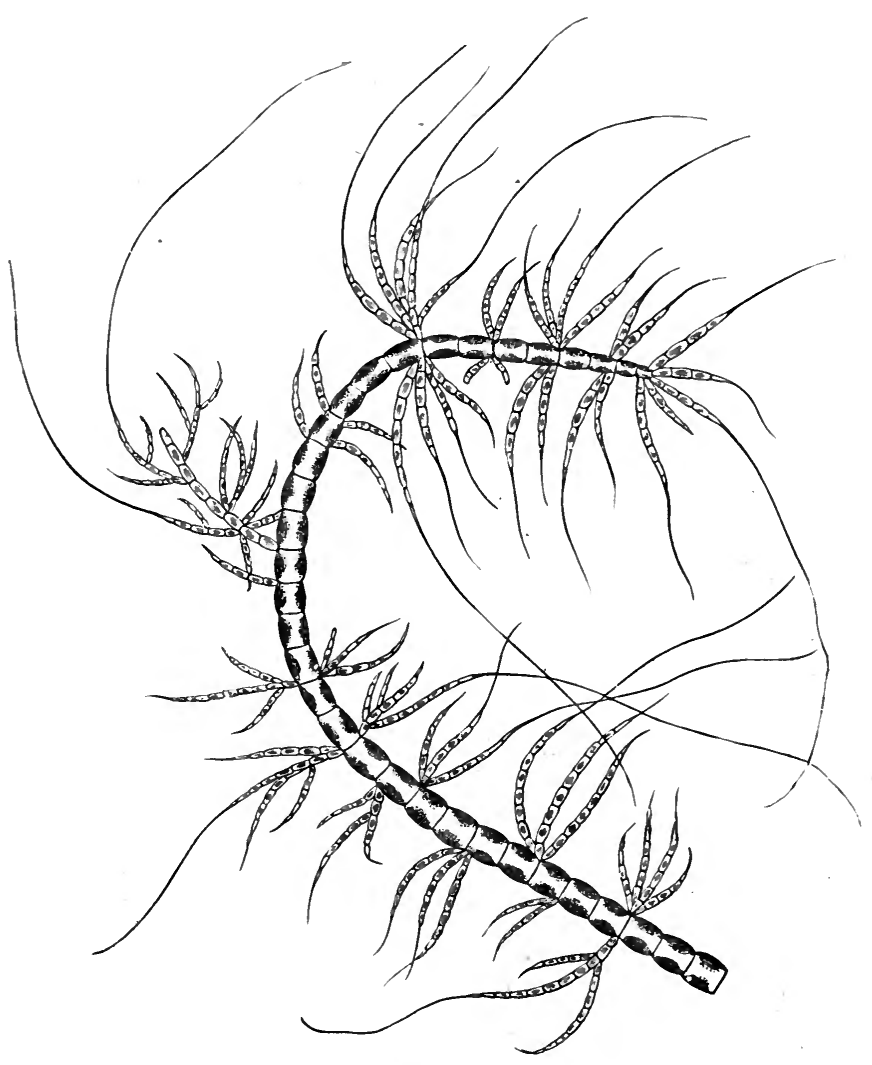

FIG. 244. - Draparnaldia glomerata Ag. ( $\times$ Ioo). (From nature.)

fresh water, which exhibits a somewhat higher type of development than the other genera, being differentiated into an axis or central tube, and smaller secondary branches arranged in regular whorls; the zoospores being produced in the latter only. Maupas states (Compt. Rend., lxxxix., I 879, p. 250) that the cells of Cladophora contain a large number of nuclei ; and Schmitz (Sitzber. Niederrhein. Gesell., 1879) finds four nuclei in a 
cell in certain conditions of Conferva. In this, and in the possession of proteinaceous crystalloids (Klein, Bot. Zeit., I 880, p. 782), these genera show an affinity to Siphonocladaceæ. Binuclearia (Wittr.) (Bot. Centralbl., xxix., I887, p. 60) appears to have always two nuclei in each cell.

There are still many points to be cleared up in the life-history of the Confervaceæ, although some of the genera are among the most abundant of fresh-water organisms; and the bounds and systematic position of the family are still uncertain. According to some observers, many of the species are connected genetically with forms at present placed under the Protophyta; to this view further reference will be made hereafter. Andersson (Bot. Centralbl., xxxv., I 888, p. 35 I) believes Palmella uvæformis (Ktz.) to be a resting condition of Draparnaldia. Among the genera now included in the order are Conferva (L.), Microspora (Thur.), Cladophora (Ktz.), Rhizoclonium (Ktz.), Stigeoclonium (Ktz.), Chætomorpha (Ktz.), Draparnaldia (Ag.), Chætophora (Schr.), Urospora (Aresch.), and Binuclearia (Wittr.). Phæothamnion (Lagerh.) (see under Syngeneticæ) ought possibly to be included here; as also Spongocladia (Aresch.) (see p. 290). Several species of Cladophora, Chætomorpha, and Rhizoclonium grow in brackish or even in salt water.

\section{Literature.}

Vaucher-Hist. des Conferves d'eau couce, 1803 .

Areschoug - Nova Act. Reg. Soc. Upsala, vi., I868, and ix., I874.

Reinhardt-Arb. Naturf. Gesell. Charkoff, 1876.

Wille-Bot. Centralbl., xi., I882, p. I1 3 ; and Pringsheim's Jahrb. wiss. Bot., I887,

pp. 437,459 , and 492 .

Lagerheim - Ber. Deutsch. Bot. Gesell., I887, p. 409.

Murray and Boodle-(Spongccladia) Ann. of Bot., ii., I888, p. I69.

\section{Order 2 (?).-PithophoraceÆ.}

The Pithophoraceæ must be admitted as a distinct order only with very great doubt, both because the mode of sexual reproduction is at present unknown, and because of their strong resemblance to the Confervaceæ. The family, consisting of a single genus, was founded on Pithophora Kewensis Wittr., an inhabitant of warm tanks in the Botanic Gardens at Kew, Oxford, and elsewhere ; other species have since been found in tropical America. The thallus is composed of branching filaments of cells resembling Cladophora, but increasing only by bipartition of the terminal cell, and presenting here and there barrelshaped cells very rich in chlorophyll, in which are formed resting-spores of non-sexual origin. These germinate directly, and in opposite directions, from the two apices. There is another mode of non-sexual propagation by 'prolific cells' ; but no zoospores nor any sexual mode of 
reproduction have as yet been detected. They are distinguished by the remarkable development of their rhizoids or organs of attachment.

\section{LiterATURE.}

Wittrock-On the Development and Systematic Arrangement of the Pithophoraceæ, 1877.

\section{ORDER 3.-UlotrichacEÆ.}

This small order includes the genera Ulothrix (Ktz.), Hormiscia (Aresch.), and perhaps one or two others, not uncommon in fresh and occasionally in brackish water. The life-history of U. zonata (Ktz.) and other species has been investigated by several observers. They exhibit considerable affinity both to the Confervaceæ and to the Hydrodictyeæ. Each individual is composed of an unbranched filament of short cells, broader than long, and nearly uniform in length. Some of the cells are megasporanges, giving birth to 2, 4, or 8 megazoospores with 4 cilia; others are microsporanges or gametanges, producing 16 or $3^{2}$ biciliated microzoospores or zoogametes. From the non-sexual megazoospores to the zoogametes there is, however, a gradual transition, the only constant difference between them being the number of cilia. Those microzoospores which do not conjugate, as well as the megazoospores, germinate directly, germination sometimes taking place even within the mother-cell. Their escape is, however, sometimes arrested, when they lose their cilia, invest themselves with a thick cellwall, and assume a palmelloid condition. The plants which spring from the germination of the megazoospores are larger than those which spring directiy from the micro-

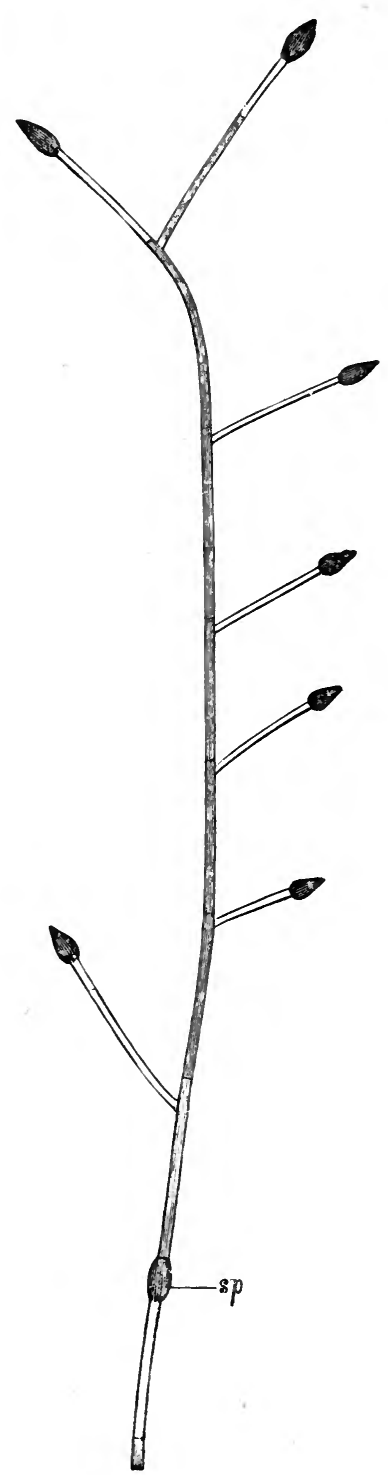

FIG. 245.-Pithophora Kewensis Wittr., branching plant; sp, spore ( $\times 20)$. (After Wittrock.) 
zoospores, as also than those which spring from the zygosperms resulting from the conjugation of the zoogametes. The escape of the swarm-spores was observed by Cramer to take place, usually in the morning, even in water which froze on the surface every night, conjugation following quickly afterwards. The two kinds of swarm-spore are never produced in the same cell, but in different cells of the same filament, and Cramer believes that conjugation takes place between zoogametes from the same filament. The megazoospores use up in their formation the whole protoplasmic contents of the mother-cell, while in the production of the
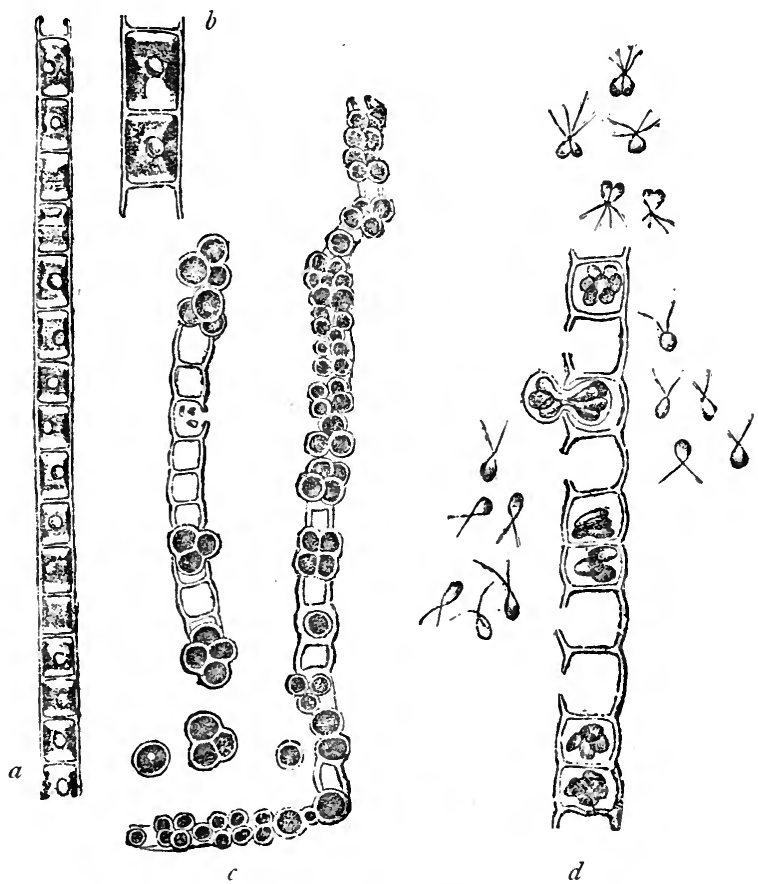

FIG. 246. - Ulothrix implexa Ktz. $a$, vegetative filament $(\times 480) ; b$, portion of the same $(\times 800) ; c$, palmella-condition $(\times 480) ; d$, es sape and conjugation of zoogametes $(\times 800)$. (After Dodel-Port.)

microzoospores or zoogametes a portion of the contents forms a bladder which escapes with them, but soon perishes. According to IVille (Bot. Centralblatt, vol. xi., I882, p. I I3) Ulothrix also produces cysts or resting-spores, which may be either aplanospores or akinetes. In some other members of the order the filament is branched. Schaarschmidt points out that a state closely resembling the microsporiferous filaments of Ulothrix occurs in the development of the Confervaceæ; and 
Hansgirg (Bot. Centralblatt, I885) believes that the filamentous genera placed in this genus are connected genetically with forms classed under the Chætophoraceæ, Siphonocladaceæ, and Ulvaceæ. To this order belong also Hormidium (Ktz.) and Schizogonium (Ktz.).. Wildeman (Bull. Soc. Bot. Belg., I886, p. 7) traces a genetic connection between Ulothrix and Pleurococcus.

\section{LiteratuRE.}

Cramer-Vierteljahrschrift Nat. Gesell. Zïrich, 1870.

Cienkowski-Mél. biol. Bull. Acad. St. Pétersbourg, I876, p. 53 I.

Dodel-Port-Pringsheim's Jahrb. wiss. Bot., I876, p. 417 ; Bot. Zeit., I876, p. 177. Gay-Bull. Soc. Bot. France, I888, p. 65.

Hansgirg-Flora, 1888, p. 259.

\section{Order 4.-Chroolepidee.}

This order, as constituted by Borzi, comprises a small group of algæ found on damp walls, the trunks of trees, and similar situations, not unfrequently imbedded in the thallus of lichens, or constituting their gonidial element. The thallus consists of a branched or unbranched filament of cells, usually somewhat rounded or moniliform in outline, and is distinguished by the masking of the colour of the chlorophyll by a golden yellow, orange, or red oily pigment, soluble in alcohol and imparting a strong odour of violets. This pigment, which occasionally occurs also in other lowly organised algæ and protophytes, has been examined by Rostafinski, and found to be a derivative of chlorophyll to which he gives the name chlororufin. Microzoospores or zoogametes and megazoospores are produced in gametanges
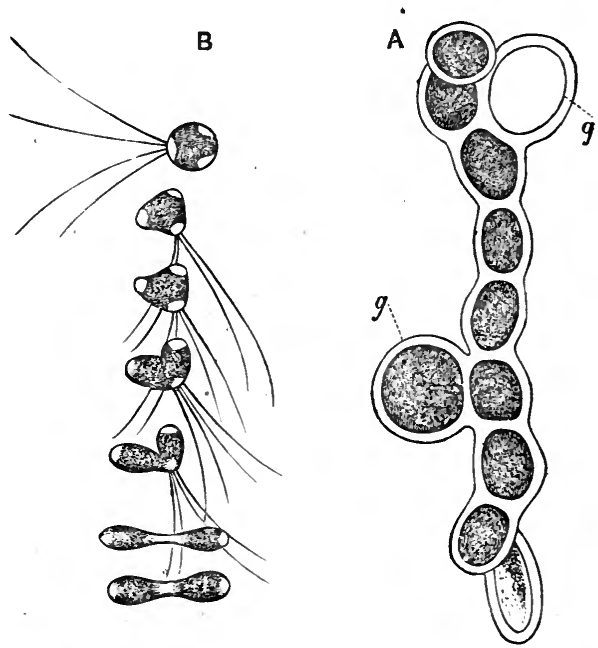

FIG. 247.-Trentepohlia Bleischii Rbh. A, filament with swollen cells in which the zoogametes are formed (gametanges), $g ; B$, stages in the conjugation of the zoogametes $(\times 330)$. (After Wille.) or zoosporanges, which are indistinguishable from the vegetative cells except by their somewhat larger size, and which are either terminal or intercalary. Conjugation of the 
smaller swarm-spores has been observed in Chroolepus (Ag.), but they can also germinate without conjugation. Chroolepus also produces restingspores. Of this genus one species, C. aureum (Ktz.), is common on walls and rocks, and another, C. umbrinum (Ktz.), occurs on the bark of trees. C. Iolithus (Ag.) is one of the few algæ that grow in perfectly dry situations on gneiss \& c., and on a siliceous rock in the Hartz Mountains known as 'violet-stone.' The genus Trentepohlia (Mart.) is now merged by many writers in Chroolepus. Wille has pointed out that the organism described as Gongrosira de Baryana (Rbh.), which grows attached to the shell of fresh-water molluscs as a green velvety coating, is a form of Chroolepus or Trentepohlia.

The genera included under the Chroolepideæ by Borzi in addition to Chroolepus and Trentepohlia are Microthamnion (Näg.), Acroblaste (Reinsch), Leptosira (Borz.), Chlorotylium (Ktz.), and Pilinia (Ktz.). Acroblaste grows in salt water attached to mussel-shells, but its position here is doubtful. Leptosira produces zoospores, some of which germinate directly, while others are said to conjugate, but in a manner different from other zoogametes, by the end which does not bear the cilia. To this family probably belongs also Trichophilus (Weber), a remarkable alga parasitic on the hairs of a sloth, which produces two kinds of zoospore (Bot. Centralblatt, vol. xxxiv., I888, p. I6r).

Caspary-Flora, I858, p. 579.

\section{LiteratuRE.}

Hildebrand-Bot. Zeit., r86r, p. 81.

Gobi-Bull. Acad. Sc. St. Pétersbourg, 1872.

Schnetzler-Bull. Soc. Vaud. Sc. Nat., 1879, p. 267 ; 1880, p. 13 ; and 1883, p. 53. Borzl-Studi Algologici, I883.

Wille-Pringsheim's Jahrb. wiss. Bot., I887, pp. 426 and 484 .

Wildeman-C. R. Soc. Roy. Bot. Belgique, I888, p. 140.

De Toni-Notarisia, 1888, p. 581 .

\section{Class XVI.-Multinucleatæ.}

In this newly-constituted group are inclyded the four orders of Siphoneæ, Botrydiaceæ, Dasycladæcea, and Siphonocladaceæ, the near relationship of which to one another is scarcely doubtful, although the first displays sexual reproduction of a high type, with strongly differentiated antherids and oogones, which are not found in the other orders. All the orders are also propagated non-sexually by zoospores. Their common characteristic is the extraordinary development in size 
of the single cell, which nowhere else in the vegetable kingdom attains anything like so great dimensions. Under ordinary conditions the individual is entirely unseptate, except where it is about to form reproductive bodies, whether sexual or non-sexual. The very large number of nuclei is universal in the Siphonocladaceæ; and, although their occurrence in the Siphoneæ rests chiefly on the evidence of Schmitz, there can be little doubt that this order also shares in the peculiarity, which does not lead on to cell-division, as in the groups of algæ already described; and this must clearly be regarded as indicative of a lower or more ancestral type of structure. Whether the Siphonocladaceæ and Dasycladaceæ are an earlier form leading up to the Siphoneæ, or whether they have been derived from the latter by retrogression, indicated by the suppression of the sexual organs, is uncertain, though the probability appears to be in favour of the latter hypothesis.

\section{Order I.-Siphonee (Creloblaste).}

The thallus is in this family ordinarily unicellular, although often copiously branched, until the commencement of the formation of the organs of vegetative propagation or of sexual reproduction.

In the genus Vaucheria DC., which alone represents this order, the plant consists, when in a non-reproductive state, of a single elongated cell of a pale green colour, branching in various ways, sometimes as much as a foot in length, increasing by apical growth. Maupas (Comptes Rendus, l.c.) and Schmitz (Sitzber. Niederrhein. Gesell., I879) state that each tube contains a large number of nuclei. The non-sexual organs of propagation are of two kinds, motionless resting-spores and motile zoospores. The former are produced simply by the abstriction of ends of particular branches, which swell up to an oval form, become cut off from the rest of the tube by a septum, contract, and finally develop a new cell-wall within the old one, thus affording an illustration of the formation of a new cell by rejuvenescence. This process takes place especially as a result of injury to the thallus. In some cases the newly-formed spore is set free simply by the absorption of the original cell-wall, and falls off with the remains of the mother-cell still attached to it, germinating after a few days; or it is thrown out with a jerk, and goes through a period of rest as a hypnospore before germinating. Another method is the swelling up to a considerable size of certain branches, which separate at the base, and put out at once one or more germinating tubes. The zoospores are among the most beautiful of those of any class of Algæ, being of considerable size, and entirely surrounded by a fringe of fine cilia. In their formation the extremity 
of a branch is cut off by a septum as a zoosporange; the dark green endochrome in it gradually contracts into an ellipsoidal form, finally forcing its way out by the rupture of the cell-wall at the apex of the branch. The rotatory motion imparted to the zoospore by its fringe of cilia begins even within the mother-cell. During its escape it sometimes gets nipped in two by the pressure of the cell-wall, and each half then becomes a zoospore, one inside, the other outside, the wall of the mother-cell. The zoospores are formed in the night and escape in the morning; their spontaneous motion lasts for a period varying from less than a minute to several hours. As soon as they have come to rest they
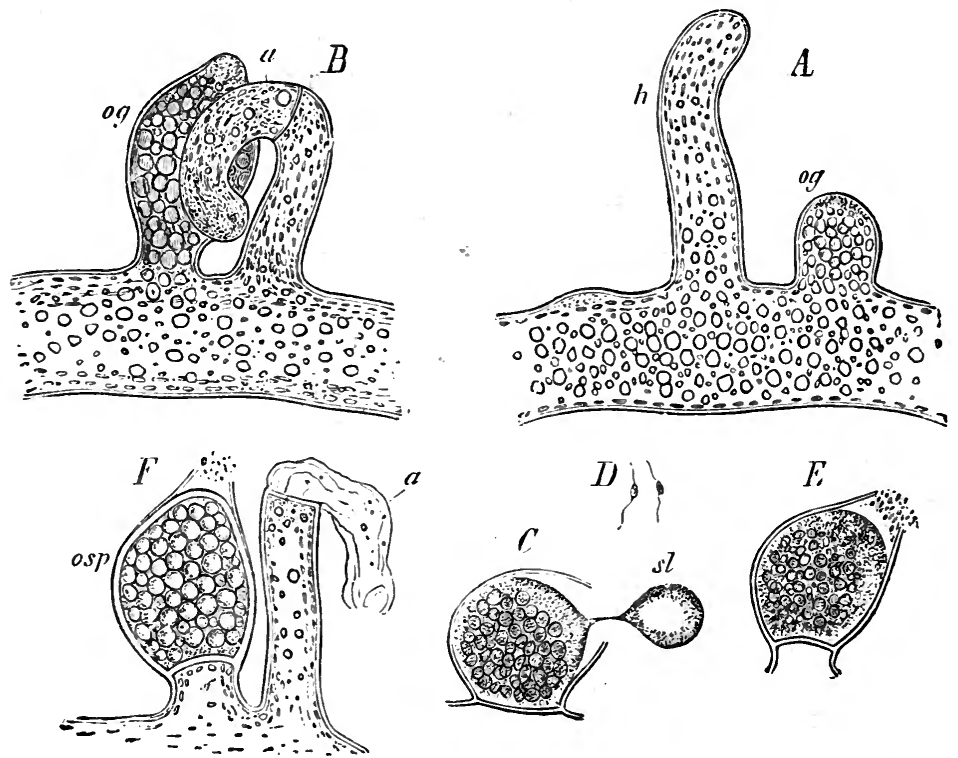

FIG. 248.-Vaucheria sessilis Vauch. $A, B$, formation of antherids and oogones; $h$, male branch; $a$, antherid; og, oogune. $C$, oogone opening and ejecting drop of mucilage, $s l$. $D$, antherozoids. $E$, antherozoids entering oogone. $F: a$, empty antherid; osp, oogone with fertilised oosperm (magnified). (After Pringsheim and Goebel.)

lose their cilia, and become invested by a cell-wall of cellulose; their germination begins during the same day or the following night. The spore puts out either one or two germinating tubes, formed by its inner coat or endospore bursting through the outer coat or exospore; and the new plant usually fixes itself by a rhizoid - or root-like organ of attachment.

The sexual reproductive organs of Vaucheria, oogones and antherids, originate as lateral protuberances on a filament, sometimes even on 
the germinating tube which springs directly from a zoospore. Most of the species are monœcious, and the oogones and antherids are usually found very near together. The antherids are the terminal portions of slender branches, in some species straight, in others curved and more or less resembling horns or hooks. They contain but little chlorophyll, and the protoplasm breaks up into a large number of biciliated antherozoids, which escape through the ruptured apex. The two cilia are of unequal length, and point, one backwards, the other forwards. The oogones arise as thick swellings, often somewhat resembling a bird's head in shape, and are densely filled with chlorophyll; they are finally cut off from the rest of the tube by a septum. The coarsely-granular green protoplasm collects in the centre of the oogone, leaving a colourless portion at the apex which corresponds to the beak of the bird. Here the oogone opens, and a colourless drop of mucilage is sometimes expelled. When the greater part of the contents has contracted into an oosphere, a number of antherozoids force their way in through the open mouth of the oogone, and impregnate the oosphere by coalescing with it. The oosperm, resulting when the impregnated oosphere has become invested by a cell-wall of cellulose, assumes a red or brown colour, and passes through a period of rest as a hypnosperm. On germination several nonsexual generations are produced, ending in the formation

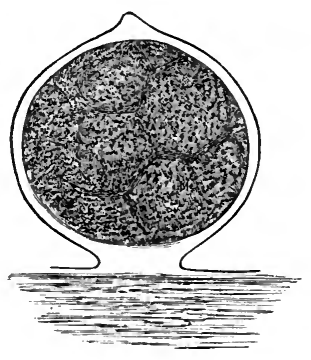

A

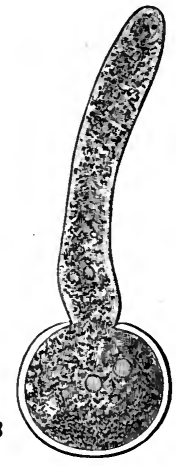

FIG. 219. - Vauchcria dichotoma Lyng. $A$, oogone: $B$, germinating spore ( $\times 200)$. (After Woronin.)

of sexual organs. The formation of antherids and oogones begins in the evening and is completed the next morning; fertilisation being usually accomplished between Io A.M. and 4 P.M. It is most usual for zoospores to be formed on parts of the thallus which are completely submerged in water; while the sexual organs are more commonly found when the plant grows on moist ground or on the margin of a ditch.

Several species of Vaucheria are frequent in fresh, while some occur also in brackish or salt water ; others abound on moist or shady ground, being especially common in flower-pots or on neglected gravel-paths, where they form light green tufts or thick mats. The normally unicellular thallus is liable to segmentation as the result of injury; and, even when uninjured, has a tendency to become septated by thick 
gelatinous walls. In this condition it was formerly described as a distinct organism under the name Gongrosira. These gongrosira-cells, when isolated, develop into ordinary plants ; or sometimes their protoplasm breaks up into fragments which escape from the cell-wall and move about with an amoboid motion. These invest themselves after a time with a cell-wall and remain in this condition as spherical resting. cells or hypnospores, finally developing into ordinary filaments. Wille has, however, shown (Bot. Centralblatt, vol. xvi., I883, p. I62) that the organisms formerly grouped under Gongrosira are states of algæ belonging to a number of widely separated genera, such as Trentepohlia

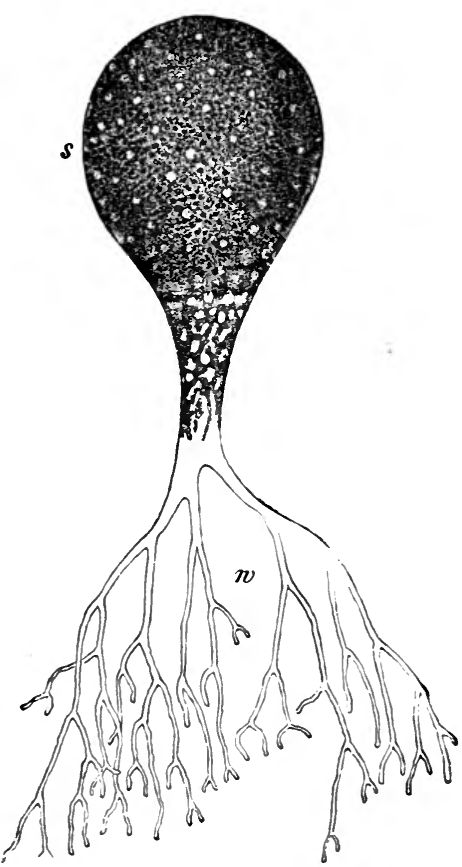

FiG. 25c.-Botrydium granulatum Wallr. $s$, vesicular portion; 2 , rhizoids $(\times 30)$. (After Woronin.)

(Chroolepus), Botrydium, Stigeoclonium, \&c. In some species of Vaucheria the filaments have a tendency to branch copiously at the extremity, the branches interweaving into $a$. ball. Several species are liable to. the formation of singular galls caused by the attacks of a rotifer belonging. to the genus Notommata (Benkö, Bot. Centralbl., vol. xiv., I883, p. I).

Phyllosiphon (Kühn) is a truly parasitic chlorophyllous alga occurring in the south of Europe within the leaves of Arisarum vulgare, the position of which appears to be near this family. The single cell contains a large number of nuclei ; the mode of reproduction is unknown (Kühn, Sitzber. Naturf. Gesell. Halle, 1878 ; Just, Bot. Zeit., I882, p. 2 et seq.; Schmitz, id., I882, p. 523 et seq. ; Franke, Jahrber. Schles. Gesell., I883, p. I95).

Endoclonium (Franke) (Cohn's Beiträge, I883, p. $3^{65}$ ), Chlorochytrium (Cohn), Endosphera (Klebs), and Phyllobium (Klebs) (Bot. Zeit., I881, p. 249 et seq.) are green parasitic algæ found within the cells of the leaves of various land and aquatic plants; and, in the case of Chlorochytrium, also on animals (Bot. Zeit., I 885, p. 605). They are stated to. produce megazoospores, which germinate directly, and microzoospores or zoogametes, which germinate only after conjugation; but their exact position is altogether uncertain. 


\section{LITERATURE.}

Thuret-Ann. Sc. Nat. (Bot.), xiv., I850, p. 214.

Pringsheim-Monber. Akad. Berlin, I856, p. 225 (Quart. Journ. Micros. Sc., 1856, p. 63).

Schenk-Würzburg Verhandl., viii., I858, p. 235.

Walz-Pringsheim's Jahrb. wiss. Bot., I866, p. I 27.

Solms-Laubach-Bot. Zeit., I867, p. 361 .

Woronin - Bot. Zeit., I869, p. I37 et seq.

Nordstedt-Bot. Notiser, 1878, p. 176; and 1879, p. 177 ; and Scottish Naturalist, 1886.

Stahl-Bot. Zeit., 1879, p. 129.

\section{ORder 2.-BOTRYDiaceE.}

This order consists at present of only a single genus, Botrydium Wallr., represented by the single species B. granulatum (Wallr.), differing widely from Vaucheria in its mode of reproduction. This remarkable organism forms minute green blobs on wet clayey ground or in dried-up pools, and is attached to the soil by branching root-like rhizoids. The young plant consists of a single nearly spherical cell, branched hyaline prolongations of which constitute the rhizoids, while in the upper swollen part the protoplasm forms a hyaline parietal layer containing chlorophyll. From this protoplasm are ultimately produced a number of zoospores, each provided with only a single cilium, which germinate directly on the damp soil after becoming invested with a double cell-wall of cellulose. If the zoosporange is exposed to drought, the vesicular portion shrivels up and the chlorophyll is driven into the underground portion, which then divides into a number of green cells. These may germinate in three different ways :-(I) Each cell becomes an underground zoosporange, producing zoospores of the ordinary kind; or (2) each cell may develop into an ordinary vegetative plant; or (3) each cell becomes a hypnosporange, closely resembling the ordinary vegetative plant, with a vesicular portion above the surface, and hyaline rhizoids, but of an olive-green colour; these may retain their vitality for a whole year and then produce zoospores. The ordinary vegetative plant may also, under certain conditions, break up into a number of resting-spores, of a brownish red colour, which have been described as species of Protococcus. These may either give birth to zoospores of the ordinary kind or to biciliated zoogametes which conjugate in pairs, or sometimes in larger numbers. The resulting zygosperm ('isospore' of Rostafinski) soon rounds itself off and germinates.

\section{LITERATURE.}

Janczewski et Rostafinski-Mém. Soc. Sc. Nat. Cherbourg, I874, p. 273. Janczewski u. Woronin-Bot. Zeit., I877, p. 649 et seq. 
Order 3.-Dasycladacee.

The Dasycladaceæare clearly distinguished from the other orders of the class by their verticillate branches and their external sporanges. In Acetabularia Lmx. the thallus has the form of a small hymenomycetous fungus with a hemispherical or funnel-shaped cap or 'pileus' at the summit of a cylindrical 'stipe' or stalk. From the lower end of the stalk proceed a number of root-like branches which fix the plant to the substratum. The whole plant consists of a single ramifying cell,

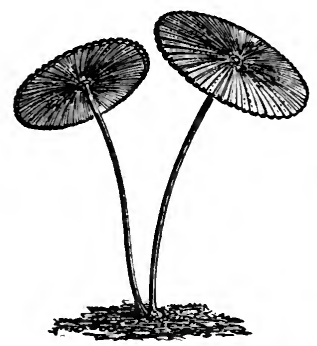

FIG. 251.-Acetabularia mediterranea Lmx. (natural size).

the walls of which are, when mature, permeated by calcium carbonate. The cap is divided by regular radial projections into a large number of chambers of nearly equal size, which are in communication with one another above the insertion of the stalk. The upper part of

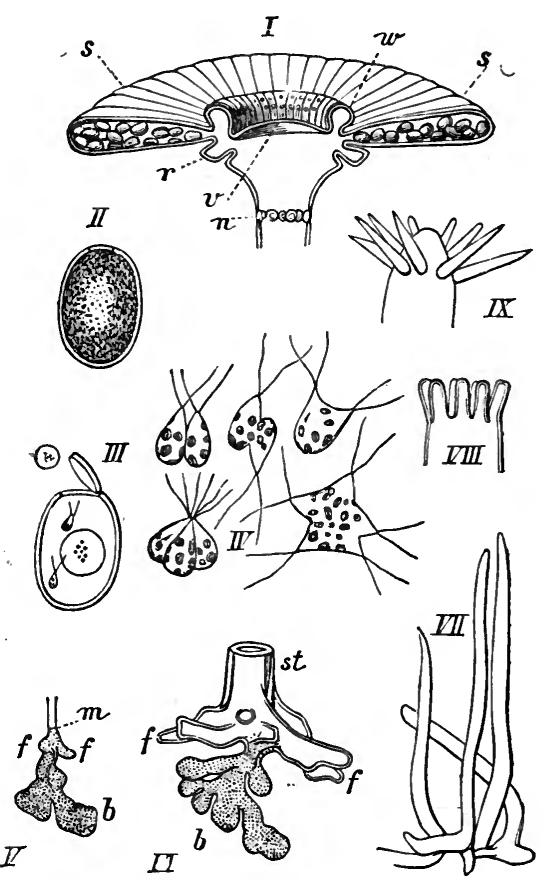

FIG. 252.- $A$. mediterranea. $I$, cap (magnified); $n$, scars of branches ; $r$, rudimentary whorl of branches; $w$, ring above the cap; $v$, depressed apex $\left(x_{4}\right)$. $I I$, sporange with lid ( $x^{\prime}$ 1 20). III, the same, showing the escape of the swarm-spores $(x+120)$. I $V$, conjugation of zoogametes. $V, V I$, lower part of stem, showing rhizoids, $b$. VII, plant germinating from a zygosperm. $V I I I$, origin of branches at summit of the stem ( $x \mathrm{r}_{20}$ ). IX, at a later stage (x 90$)$. (After de Bary and Strasburger.)

the thallus perishes at the end of the season, while the lower portion is perennial. After a number of sterile thalli have been produced, a fertile thallus appears, similar in structure to the sterile ones. In the chambers of the cap of this thallus are produced the zoosporanges, a large number in each chamber, of an ellipsoidal form, and furnished at one end with a lid, which subsequently becomes detached. When mature the protoplasm of the sporange breaks up into a number of swarm-spores, 
which escape into the surrounding water by the removal of the lid. It would appear from de Bary and Strasburger's observations that some of these swarm-spores germinate directly, while others conjugate to form a zygosperm; but that conjugation never takes place between zoogametes from the same sporange. One species of Acetabularia is a native of the Mediterranean; the rest are tropical. In Dasycladus Ag. the spherical zoosporanges stand singly at the apex of verticillate branches, and are surrounded by branchlets of the second order. The biciliated zoospores or zoogametes are of one kind only, and are flattened and heart-shaped.
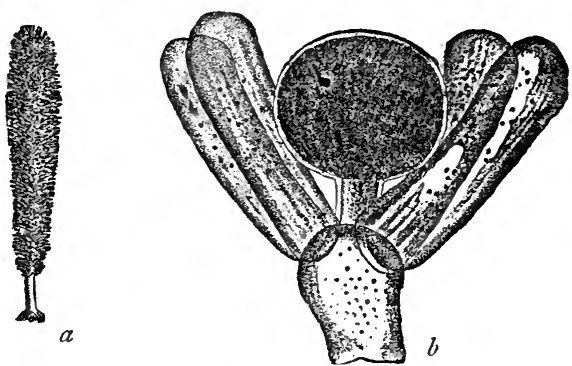

FIG. 253.-Dasycladus clava formis Ag. a. natural size ; $b$, piece of branch of a whorl with a zoosporange $(\times 50)$. (After Hauck and Derbès and Solier)

Those from the same plant show no disposition to conjugate; but as soon as those from different plants are brought together, true zygosperms are formed. In Neomeris Lmx. the surface consists of a large number of usually hexagonal facets, and is covered with deciduous hairs. The

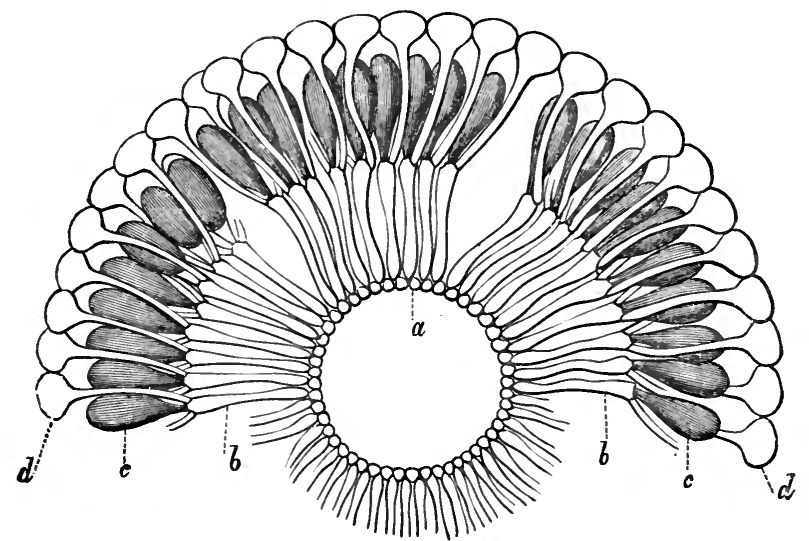

Fig. 254. -Neomeris Kelleri Cram. ; transverse section through tube. $a$, insertion of the branches; $b, b$, primary branches; $c$, central secondary branch or zoosporange; $d$, elongated lateral secondary branches ( $\times$ 40). (After Cramer.)

very large axial cell is always simple; the lateral branches again divide into three branchlets, of which the central one is ovoid and fertile, the two lateral ones greatly elongated and sterile. The fertile branch is a 
zoosporange, no conjugation of swarm-spores having been observed. Klein (Bot. Zeit., $\mathbf{1 8 8 0 , ~ p . ~ 7 8 2 ) ~ h a s ~ d e t e c t e d ~ f i n e ~ p r o t e i n a c e o u s ~ c r y s t a l - ~}$ loids in Dasycladus (Ag.) and other allied forms. To this family belong also Polyphysa (Lmx.), Cymopolia (Lmx.), and some other genera.

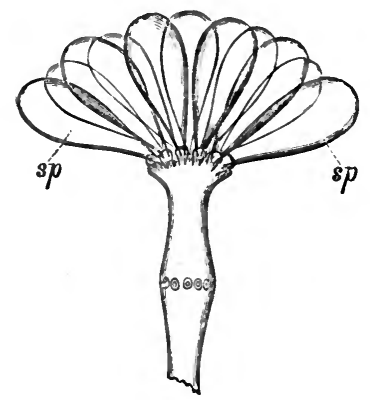

FIG. 255.--Polyphysa peniculus R. Br., with whorl of zoosporanges, $s p$ (magnified). (After Agarth.)

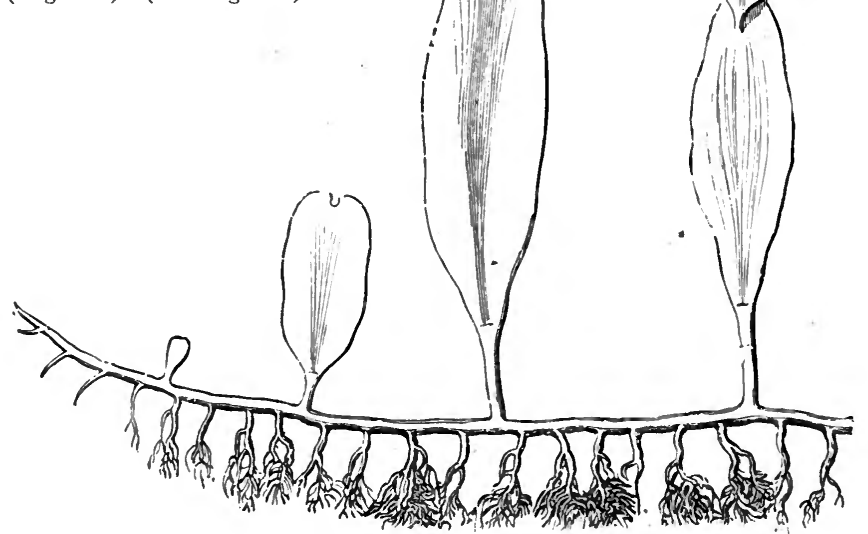

FIG. 256.-Caulerpa prolifera Lmx. (natural size). (After Reinke.)

\section{ORDER 4.--SiphoNocladaceÆ.}

This order comprises a number of very remarkable green algæ, mostly inhabitants of warm and shallow seas, characterised by the thallus consisting of a single cell which is often of very great size and much branched, differentiated into a root-like and stem-like portion. The undivided cell very commonly contains a large number of nuclei; and the cell-wall is 
often strongly encrusted with calcium carbonate. In several of the genera of Siphonocladaceæ, but little is at present known as to the mode of reproduction; and until this has been more fully ascertained, their true affinities are uncertain; and it is possible that the order, as at present constituted, includes forms which are not nearly allied to one another. In none of the genera is a fertilisation of oogones by antherozoids known, similar to that of Vaucheria. The ordinary mode of reproduction appears to be by zoospores which germinate directly without conjugation. Other modes of non-sexual propagation occur in some of the genera, by 'propagules' or by 'prolification.' The following are some of the more remarkable forms included in the group.

The Caulerpee include the single genus Caulerpa Lmx., characterised by its greatly-branched thallus of remarkably leaf-like appearance. Very little is known about the mode of reproduction. The ordinary process of propagation appears to be by 'prolification' from all parts, the so-called 'roots,' 'stem,' and 'leaves.' Within the tube are solid branched layers of cellulose stretching from wall to wall, and forming a closed net. It often covers enormous tracts of the shore between high and low water marks with a green coating.

The Valoniace. (Valonia, Gin., Siphonocladus, Schr., Struvea, Sond., Anadyomene, Lmx., \&c.) are an ill-defined family, in which the cell is frequently swollen up into a bladderlike structure; the mode of propagation is apparently by non-sexual zoospores. To these are closely allied the UDOTEAcEe (Avrainvillea,

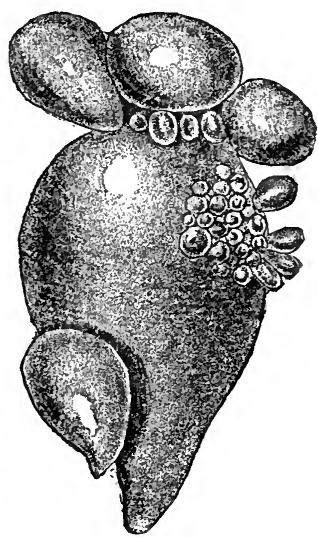

FIG. 257.-Valonia mairophysa Ktz. (natural size). (After Hauck.) Dcne., Penicillus, Ktz., Udotea, Lmx., Halimeda, Lmx., \&c.). Halimeda has a remarkable Opuntia-like appearance, from the single cell consisting of a large number of pear-shaped branches, each connected with the one below it by a narrow base, and the whole encrusted by calcium carbonate.

In the Bryopsidee (Bryopsis, Lmx., Derbesia, Sol.) and SponGODIEÆ (Codium, Stackh.) the thallus is not encrusted with calcium carbonate. Codium forms a spongy spherical or cylindrical floating mass, of considerable size, consisting of branched tubes. It is apparently propagated by zoospores. In Bryopsis Lmx. the thallus has a branched root-like colourless portion, and an erect cylindrical stem, the upper half of which branches into pinnate leaf-like ramifications with limited apical 
growth ; in these branches zoospores are formed; conjugation between them has not actually been observed. External organs of reproduction known as 'conceptacles' have also been described on several species of Bryopsis, which have been conjectured to be true sexual organs, whether male or female, but their true structure and functions are altogether obscure. If, as is probable, some of the swarm-spores of Codium

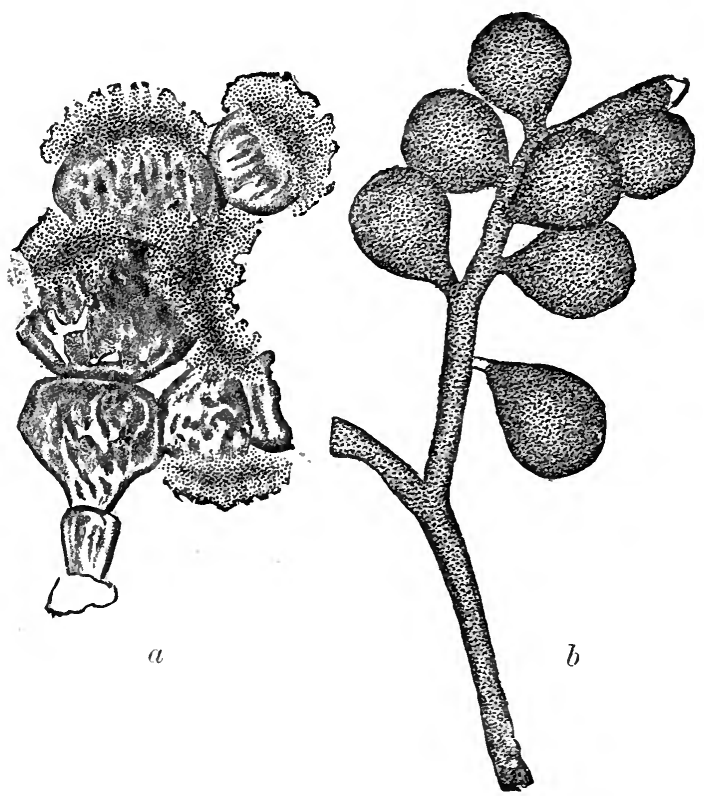

Fig. 253. Halimeta Tuna Lmx. $a$, natural size; $b$, portion with zoosporanges $\left(\times 5_{50}\right)$. (After Derbès et Solier.)

and Bryopsis are in reality conjugating zoogametes, this would bring these two families into close relationship to the Botrydiaceæ; and this is probably the nearest affinity of the latter group. Spongocladia (Aresch.), described by Zanardini as belonging to the Siphoneæ, appears to be a genus more nearly allied to Cladophora, in which the filaments are remarkably infested with sponge-spicules.

\section{LITERATURE.}

(Dasycladacee and Siphonociadacece.)

Nägeli-In Zeitschr. wiss. Bot., I 844 .

Derbès \& Solier-Ann. Sc. Nat. (Bot.), I850, p. 240. 
Braun-Verjüngung in der Natur, I851, p. 136 (Ray Soc., Bot. and Phys. Mem., 1853).

Woronin-Ann. Sc. Nat. (Bot.), xvi., I862, p. 200.

Pringsheim-Monber. Berlin Akad., I87 I, p. 240.

Arcangeli-Nuov. Giorn. Bot. Ital., 1874, p. 174.

De Bary u. Strasburger-(Acetabularia) Bot. Zeit., p. 7 I 3 et seq.

Cornu-Compt. Rend., lxxxix., I879, p. 1049.

Schmitz-Sitzber. Niederrhein. Gesell., I879 and I88I.

Berthold-Bot. Zeit., I88o, p. 648 ; and Mittheil. Zool. Stat. Neapel, I88o, p. 72.

Murray-(Rhipilia Ktz. = Avrainvillea Dcne.) Trans. Linn. Soc., ii., I886, p. 225

Wakker-(Caulerpa), Versl. Akad. Weten. Amsterdanı, I886, p. 251 ; and I887,

p. 251 .

Agardh-Till Algernes Systematik, Siphoneæ, I887.

Cramer-Ueber die verticillirten Siphoneen (Neomeris und Cymopolia), IS87.

Noll-Bot. Zeit., I887, p. 473.

Murray and Boodle-(Struvea) Ann. of Bot., ii., I888.

\section{Class XVII.-Cœnobieæ.}

In this class are included a small number of minute (mostly microscopic) fresh-water organisms, characterised by the cells being associated together into a canobe, i.e. into a colony of more or less equivalent cells resulting from the division of a common mother-cell. As this division always takes the form of repeated bipartition, the number of cells constituting a colony is necessarily, when perfect, a power of 2 , viz. $4,8,16,32$, 64 , \&c. The cells constituting the cœnobe are more or less imbedded in a gelatinous envelope, which is sometimes enclosed in a membrane common to the whole colony ; in the higher forms the cells, or some of them, are ciliated, the cilia protruding through the enveloping membrane, and the colony moves about in the water with very great activity ; the lower forms are not ciliated, but the colony is nevertheless endowed with a very considerable power of motion. The cœenobe is always of an exceedingly beautiful regular form, spherical, or less often discoid or cubical, or, in the Hydrodictyeæ, in the form of a net. The five orders of which it is composed, the Sorastreæ, Pandorineæ, Pediastreæ, Hydrodictyeæ, and Volvocineæ, form a series of ascending development. Very little is known about the reproduction of the first ; the Pandorineæ, Pediastreæ, and Hydrodictyeæ multiply by the conjugation of zoogametes; while in the Volvocineæ, which represent the highest type attained by organisms of the cœnobe type, the mode of sexual reproduction is much more complicated, the male and female reproductive cells being separately formed in distinct antherids and oogones. 


\section{ORDER I.-VOLVOCINEE.}

The well-known Volvox globator L. may be taken as a type of this interesting family. This organism is not uncommon in clear pools, and is visible to the naked eye as a minute pale-green globule, about $\frac{1}{50}$ inch in diameter, rolling through the water, the motion being due to numerous colourless cilia projecting from its surface. It is one of the most beautiful objects that can be observed under the microscope.

Under a sufficiently high power of the microscope, Volvox is seen to be a membranous transparent hollow sac studded with green points; in the interior are darker green globules, the original number of which is apparently always eight. The green peripheral corpuscles or swarmcells are each provided with a pair of vibratile cilia, which protrude through the enveloping sac ; they vary in form, but are usually somewhat pear-shaped, and contain a starch-granule, a reddish-brown pigment-spot, and one or two contractile vacuoles, the cilia being borne at the narrow anterior hyaline end. The internal green globules are young individuals formed within the parent, which thus constitutes a colony or canobe; but all the cells which make up the colony are not equivalent as respects their reproductive power. The larger number of the cells are sterile or purely vegetative, while a much smaller number, developed at particular spots in the colony, are generative, these again being differentiated into non-sexual propagative and male and female reproductive cells. The sterile cells are the peripheral or swarm-cells, 2-3 $\mathrm{mm}$. in diameter, which precisely resemble in structure Chlamydococcus, the motile stage of Pleurococcus, or the zoospores of many algæ. The gelatinous membrane which envelopes each of these swarmcells is pierced by a number of canals, which lie nearly in one plane, and which are filled by green or colourless extensions of the protoplasmic interior. Since the canals of adjoining swarm-cells correspond in position, they appear as if they were all connected together by a network of fine reticulations. The membrane is also perforated by two pores, through which the vibratile cilia protrude into the surrounding water. These bodies present the unusual phenomenon of cells endowed with spontaneous power of motion, which have, nevertheless, as far as is known, no reproductive function, and are therefore not properly called zoospores. The non-sexual propagative cells, zoospores or parthenospores, are similar in structure to the sterile swarm-cells, but from two to three times their diameter. Very early in the development of the young colony the contents of the mother-cells of the zoospores begin to divide by repeated bipartition, all in the same colony being usually . at the same stage of development at one time ; the daughter-colonies, 
or zoosporanges thus formed have the form and appearance of the parent-colony, each segment possessing a single chlorophyll-body, which contains starch. Ultimately, while still within the parent-colony, vibratile cilia are developed in its peripheral segments, which cause it to rotate, clothed at first by a transparent mucilaginous envelope, which it at length breaks through. The number of colonies of zoospores thus produced within the parent-colony is normally eight, resulting apparently from the eight cells into which the parent-colony breaks up on its third segmentation. The young colonies complete their growth in a few days, attaining a diameter of from 100 to $150 \mathrm{~mm}$., and have by this time absorbed the greater part of the chlorophyll and starch of the parent-colony, from which they finally escape.

Volvox may multiply by this non-sexual mode of propagation for several successive generations, and these are succeeded by a sexual mode of reproduction. The male and female reproductive cells are formed either in the same or in different colonies; or, according to other observers, the so-called 'diœcious' species are in reality proterandrous, producing antherids at an earlier, oogones at a later stage. While the non-sexual propagation by zoospores goes on through the whole year, the sexual cells appear to be produced only in the autumn. The oogones are at first quite indistinguishable from the non-sexual cells except in size, but are much more numerous, and soon manifest a distinction from the fact that they do not divide. On their first appearance they are about three times the size of the sterile cells; their protoplasm increases rapidly, and becomes of a dark-green colour, from copious production of chlorophyll. They have at first a frothy appearance from the formation of vacuoles, but afterwards appear to be densely filled with the dark-green endochrome. They soon become flask-shaped, the narrow end touching the periphery of the colony, and the larger end hanging free inside; but, when ready for impregnation, round themselves off into a spherical form, their contents being an oosphere enveloped by a gelatinous membrane. The antherids present at first sight a still closer resemblance to zoospore-colonies at an early stage, but are lighter in colour from containing a smaller quantity of chlorophyll. Their contents soon begin to divide, but in two directions only, the young colony thus developing into a plate instead of a sphere of segments enveloped in a gelatinous coating. The colony ultimately resolves itself into a bundle of antherozoids, naked fusiform masses of protoplasm, each consisting of a thicker but elongated body, in which the chlorophyll has been transformed into a yellow-brown pigment, and a slender colourless beak, with a pigment-spot at its base, where also are attached on one side two very long cilia. About the time when the oogones, with their 


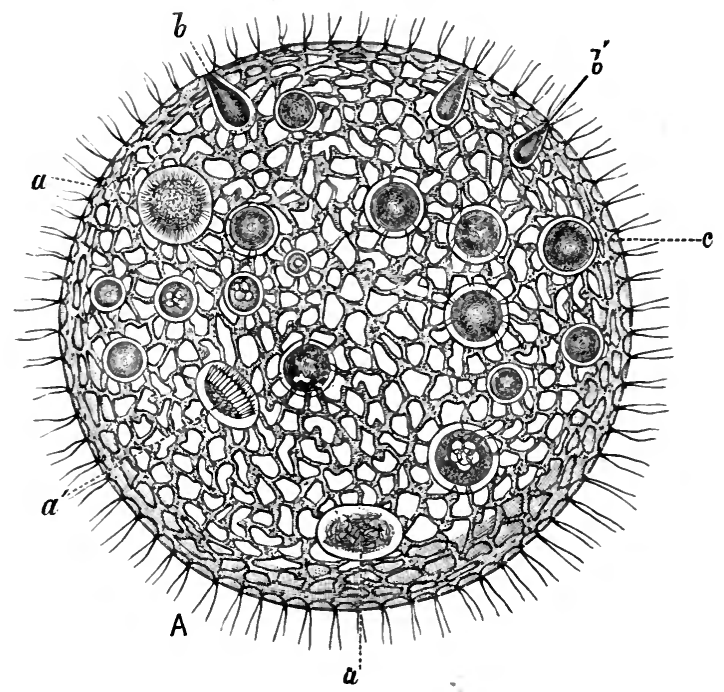

\section{(-)}

(2)
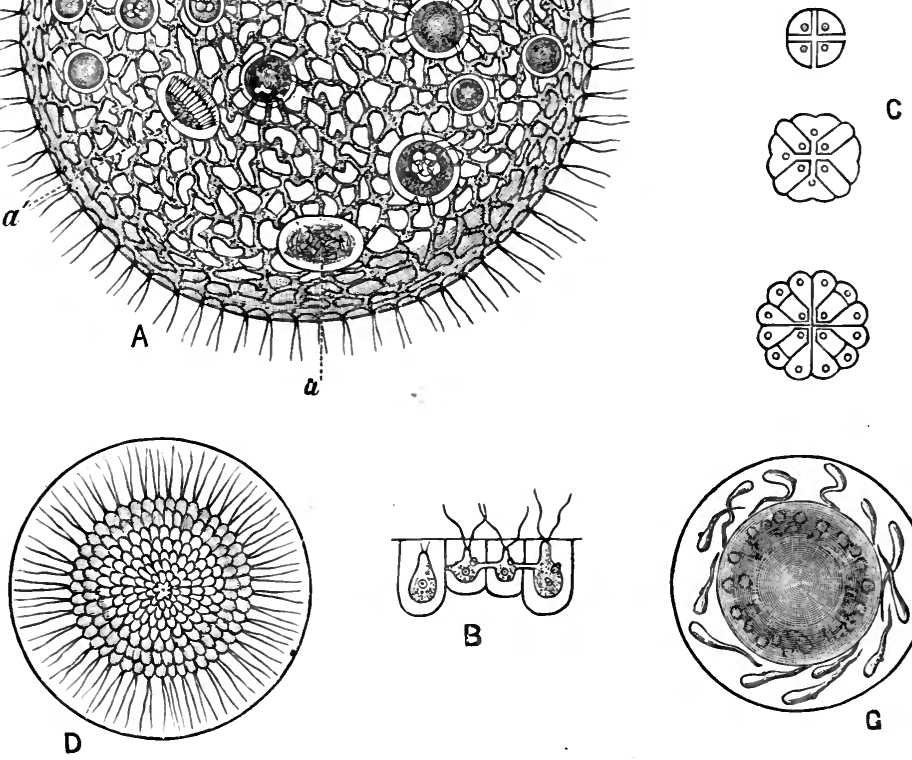

B
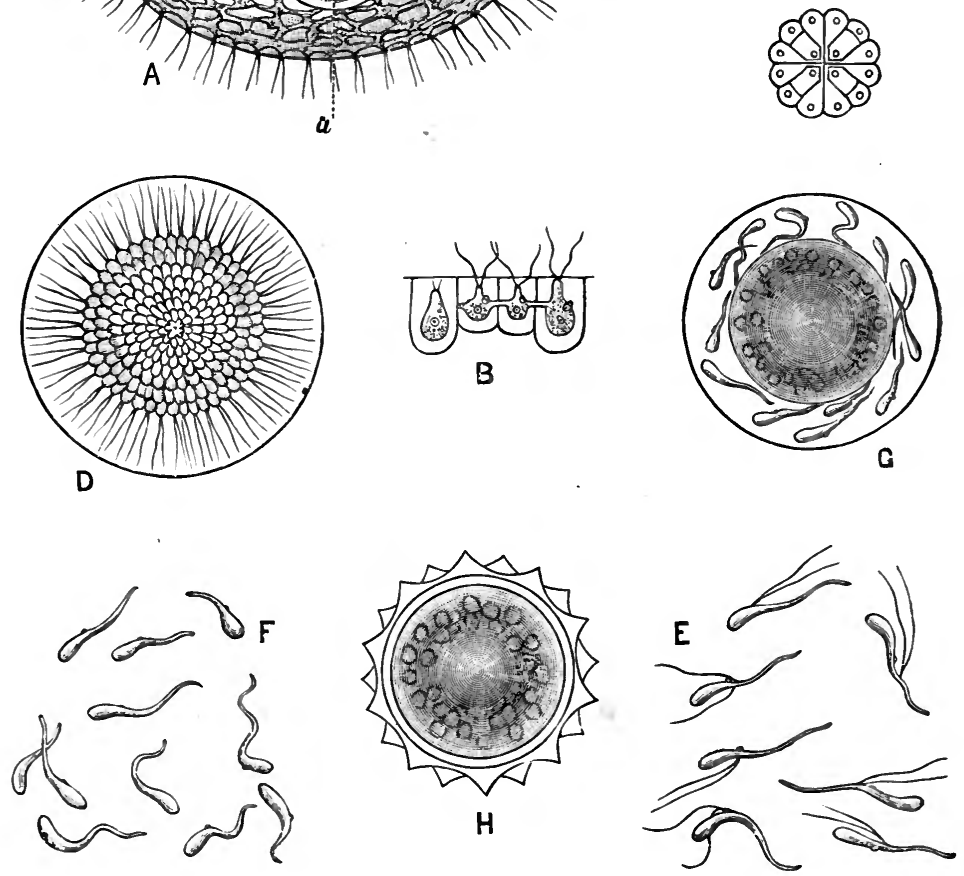

Fig. 259.-Voliox globator L. $A$, colony, sexual generation; $a$, antherids; $b$, oogones; $c$, oospheres. $B$, ciliated peripheral cells. $D$, antherid. $E, F$, antherozoids. $G$, oogone containing mature oosphere and antherozoids. $H$, mature oosperm. $C$, mode of division of parent-cell of a zoosporange (all highly magnified). (After Cohn.) 
oospheres, are mature, the movement of the cilia begins to set the entire antherid in motion; but it shortly breaks up, and the separate antherozoids are seen in rapid motion within their gelatinous envelope, which they ultimately break through, and then move about rapidly in all directions within the cavity of the parent-colony. They assemble in large numbers round the oogones, and some of them finally penetrate through the gelatinous membranes of these organs, and coalesce with the oospheres. The number of sexual reproductive colonies within a parent-colony varies greatly ; Cohn has observed five or six male and about forty female. The impregnated oosphere now becomes an oosperm by the development of a cell-wall of cellulose, which is at first single and smooth, but becomes subsequently differentiated into three distinct layers, of which the two inner ones are smooth, while the outermost becomes ultimately covered with conical or warty elevations, giving it on section a stellate appearance. The chlorophyll of the oosperms gradually disappears, and is replaced by an orange-red pigment dissolved in oil, giving a red tinge to the entire organism as seen by the naked eye. Soon after the maturity of the oosperms, the parent-colony breaks up, and the peripheral swarm-cells escape from the combination and swim about freely in the water ; their further history has not been traced. The orange-yellow oosperms sink to the bottom, and there hibernate as hypnosperms. Their contents are said to break up into eight Volvoxcolonies, which ultimately escape by the rupture of the outer and absorption of the inner coats of the oosperm, and swarm about in the water.

In Eudorina Ehrb. the cœnobe is a hollow ellipsoid body, consisting of usually 16 or 32 cells enclosed in a gelatinous envelope, each provided with two long cilia which protrude through canals in the envelope, and a red pigment-spot. Daughter-colonies are formed non-sexually within the parent-colony by repeated bipartition of its cells, the cells of the daughter-colony being arranged in a disc. The male and female reproductive bodies are formed in special daughter-colonies which may be termed antherids and oogones respectively; the oospheres contained in the oogones are each provided with two cilia, and are therefore true zoospheres; the antherozoids, which closely resemble those of Volvox, swarm round the oogones until their cilia become entangled in those of the zoospheres ; they then force their way into the gelatinous envelope of the oospheres, and finally coalesce with them.

Volvox and Eudorina are regarded by Ehrenberg and Stein as belonging to the Flagellate Infusoria.

Under the name of Scyamina, Van Tieghem (Bull. Soc. Bot. France, r 880, p. 200) describes a singular blackish organism found on the surface of ponds, which he regards as a genus of Volvocineæ destitute of chlorophyll. 


\section{LiteratuRE.}

Ehrenberg-Die Infusionsthierchen, 1838 .

Busk-Trans. Micros. Soc., I853, p. 31 .

Cohn-Jahrber. Schles. Gesell., I856, p. 237 ; and Beiträge, i., I875, Heft 3, p. 93

(Pop. Sc. Rev., 1878, p. 225).

Carter-(Eudorina) Ann. Nat. Hist., I858, p. 237 ; and 1859 , p. I.

Braun-Bot. Zeit., I875, p. I89.

Stein-Der Organismus der Infusionsthiere, fart iii., 1878 .

Henneguy-Journ. d. Micrographie, I 878 , p. 485 .

Maupas-Compt. Rend., lxxxix., 1879, p. 129.

Kirchner in Cohn's Beiträge, iii., 1879.

\section{OrdER 2.-HYDRÖDICTYEÆ.}

The relationship of the Hydrodictyeæ to the other families of Cœnobieæ is somewhat obscure. They differ from them in the form of the conobe, which, instead of being minute and globular, ellipsoidal or tabular, is of considerable size, and presents the appearance of a net. The only known mode of reproduction is by the conjugation of zoogametes.

As here constituted the order is limited to the single genus Hydrodictyon Roth, one species of which is moderately common in ponds and ditches, and is known under the name of 'water-net.' When the plant is mature, the cœenobe consists of a sac-like net several centimetres in length, composed of a great number of cylindrical cells united at their ends so as to form a 4- or 6-cornered mesh. The ordinary mode of propagation consists in the protoplasm of one of the cells breaking up into from 7,000 to 20,000 megazoospores, each furnished with four cilia, which move about with a trembling motion within the zoosporange, come to rest in the course of half an hour, and then arrange themselves in such a way that, by their elongation, they again form a net of the original kind, which is set free by the absorption of the wall of the mother-cell, and attains, in the course of three or four weeks, the size of the mothercolony. In other cells of the mature net the protoplasm breaks up into from 30,000 to 40,000 smaller swarm-cells or zoogametes, furnished with only two cilia, which at once leave the gametange and swarm about for some hours. Conjugation between these has been observed to take place even within the gametange, more than two sometimes uniting together. The resulting zygosperm retains its green colour, and invests itself with a firm cell-wall. After remaining for several months at rest as a hypnosperm, it begins to grow slowly, and, when it has attained a considerable size, its contents break up into two or four megazoospores, which come to rest after a few minutes, and assume a peculiar angular form when they have attained a considerable size, putting out horn-like appendages. In each of these polyhedra the green parietal 
protoplasm again breaks up into zoospores, which swarm about for twenty or forty minutes within a sac which protrudes out of the protoplasm. When they come to rest, they arrange themselves within the sac into a small net consisting of from 200 to 300 cells, which gradually grows to
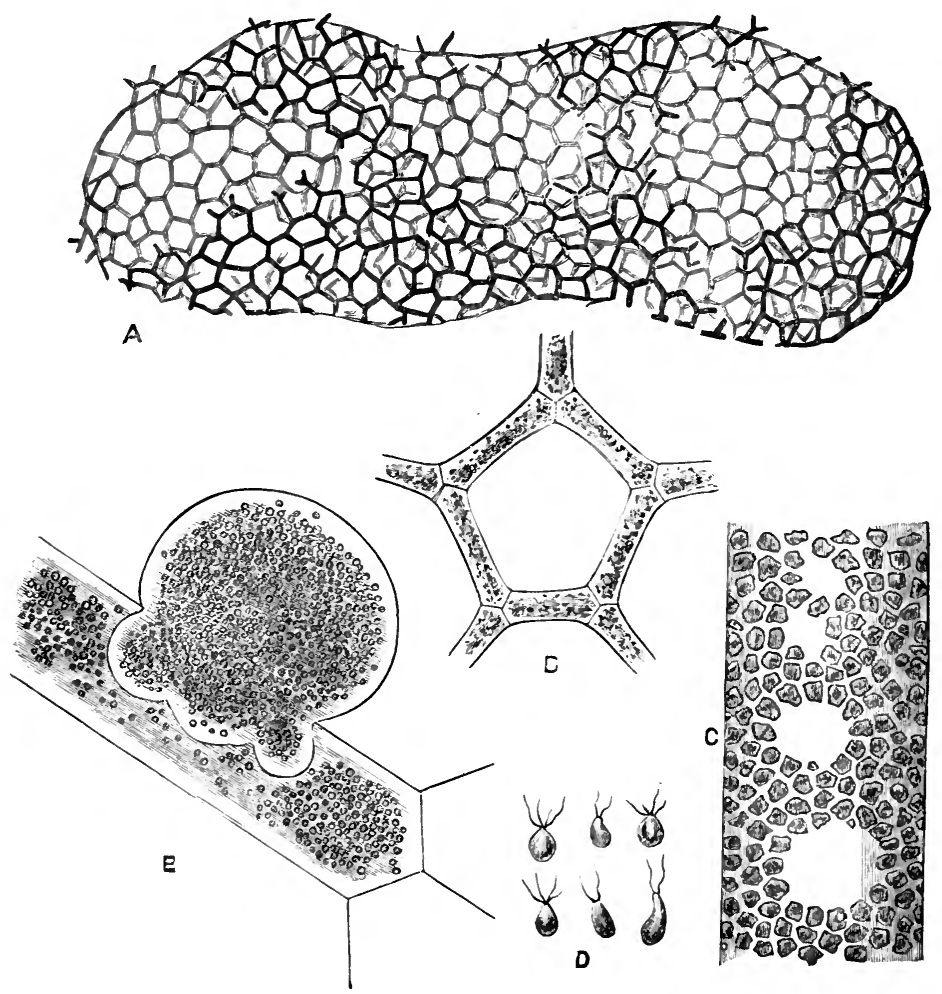

FIG. 26o.-Hidrodictyon utriculatum Roth. $A$, net (natural size). $B$, mesh ( $\times$ ro), $C$, megazoo sporange $(\times 300)$. D, megazoospores $(\times 600)$. $E$, gametange with zocgametes $(\times 300)$. (After Cohn.)

one of the ordinary size. In some of the polyhedra smaller and more numerous microzoospores are formed; but they also appear to unite again into a net without displaying sexual functions.

\section{LiteratuRE.}

Nägeli-Gattungen einzelliger Algen, 1849, p. 92.

Braun-Verjiingung in der Natur, I85I (Ray Soc., Bot. and Phys. Mem., I853); and Algæ unicellulares, 1855 .

Pringsheim-Monber. Berl. Akad., I860, p. 775 (Quart. Journ. Micr.Sc., I862, pp. 54 and 104). 


\section{Order 3.-PediastreÆ.}

The Pediastreæ are most nearly allied to the Hydrodictyeæ in their mode of reproduction. Of the typical genus Pediastrum Mey., several species are very common in fresh water, whether stagnant or running, attached in the form of minute (usually microscopic) discs to other algæ or water-plants, or swimming free. Each disc is of a regular symmetrical

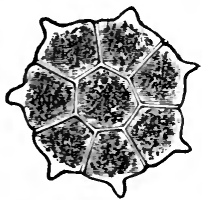

A

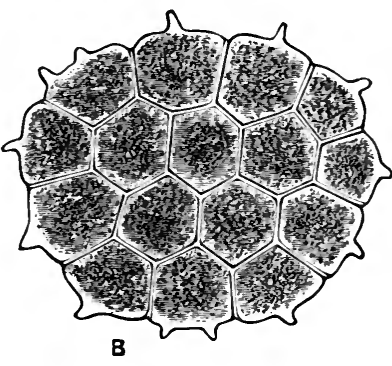

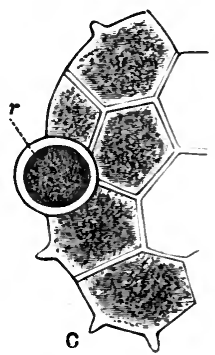

FIG. 261.-Pediastrum integmum Näg. "A, younger, $B$, older cœnobe $(\times 300)$. $C$, portion of older cœnobe showing resting-cell, $r(\times 600)$. (From nature.)

form, usually elliptical, and consists most often of 8 , 16 , or 32 cells, or some larger number which is probably always, when perfect, a power of two. The conobe is invested in a very thin gelatinous envelope, and the peripheral cells have commonly horn-like or crescent-shaped appendages. Pediastrum is multiplied either by non-sexual propagation or by sexual reproduction. In the former

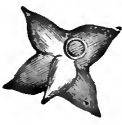

A

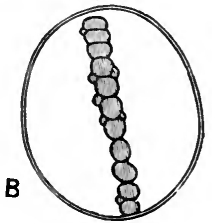

Fig. 262.- $A$, polyhedra of Pediastrum ( $\times 550)$. B, formation of Pediastrum. disc within polyhedra $(\times 550)$. (After Askenasy.) case one of the ordinary vegetative cells becomes a zoosporange, its protoplasm breaking up into a number of nearly globular megazoospores each furnished with two very fine and inconspicuous cilia, which, after swarming about for a time, lose their cilia and arrange themselves in the form of a plate, which then escapes from the zoosporange invested in mucilage, and develops into a new Pediastrum-disc. Others of the cells become gametanges, the contents dividing in the same way into zoogametes of an ovoid or pear-shaped form, which conjugate after escaping separately from the mother-cell, but apparently only with those from other gametanges. The peripheral cells of the conobe appear to have a tendency to develop into resting-spores. 
Askenasy has observed the development of the Pediastrum-conobe by another method from the polyhedra form, previously regarded as. a distinct genus under the name Polyedrium (Näg.). In this form each individual consists of a minute flat angular cell often provided with spines or hook-like processes. From this a Pediastrum-disc is developed in precisely the same way as from a Pediastrum-cell. The cell-contents break up into a number of megazoospores, which escape in the form of a plate after swarming about for a time; then, losing their cilia, and placing themselves in a plane side by side, develop into an ordinary Pediastrum. Reinsch, on the other hand (Notarisia, I888, p. 493), regards Polyedrium as the type of a separate family of Palmellaceæ.

\section{LITERATURE.}

Nägeli-Gattungen einzelliger Algen, I 849 .

Braun-Verjüngung in der Natur, I851 (Ray Soc., Bot. and Phys. Mem., I853); and Algæe unicellulares, I855.

Lagerheim-Bot. Centralbl., xii., I 882, p. 33 .

Askenasy-Ber. Deutsch. Bot. Gesell., I888, p. I27.

\section{ORDER 4.-PANDORINEÆ.}

In the higher genera of this order, Pandorina (Ehrb.), Gonium (Müll.), and Stephanosphæra (Cohn), the individual is a spherical or tabular cœnobe, the cells of which are united together by a gelatinous matrix with a definite bounding-wall. With them are associated also some unicellular organisms, Chlamydococcus (A. Br.) and Chlamydomonas (Ehrb.), which may possibly be connected with them by a process of degeneration. Whether isolated or associated, each cell possesses a pair of whip-like vibratile cilia attached to the anterior pointed end, by means of which it is rapidly propelled through the water; in the case of the social genera these cilia project through the common gelatinous envelope of the colony. Multiplication takes place either non-sexually by simple subdivision of the cells of a colony, or sexually by the union of two (or occasionally more than two) zoogametes into a resting zygosperm. A characteristic feature of the family is the formation of a colony of cells within each cell in the mother-colony. The organisms here included were described by Ehrenberg as constituting a family of Infusorial Animalcules. They live, associated with larger algæ, in fresh water, running or stagnant, often in such quantities as to impart to it a green colour. The family closely approaches Volvocineæ through Eudorina.

Of the unicellular Pandorineæ Chlamydomonas Ehrb. may be taken as a type. In the form in which it is known under this name, it 
consists simply of a single motile primordial cell, in other words, of a zoospore or swarm-cell. These are megazoospores, half as long again as broad, each with two contractile vacuoles, a lateral red pigment-spot, and two long cilia ; in the posterior half is a nucleus. After the conclusion of the period of swarming, these zoospores become invested with cellulose, and, after a long period of rest as hypnospores, multiply non-sexually by division into four-less often into two. According to Rostafinski sexual reproduction takes place by one of these megazoospores dividing, by successive bipartitions, into eight daughter-cells, which are then microzoospores-or, more correctly, zoogametes. These have a longish almost elliptical form, and a light green colour, one nucleus, a red pigment-spot, and four cilia. They are distinguished from the true zoospores, not only by their smaller size, but also by the large colourless extremity in place of the two contractile vacuoles. They swarm out, and soon begin to conjugate in pairs, coming into contact by their colourless extremities, and coalescing into a single cell, the ends which bear the cilia at the same time rounding off and approximating. This body has now eight cilia and two lateral pigment-spots ; ultimately the eight cilia disappear, and a zygosperm is formed, which multiplies by simple division without swarming. Dangeard finds in Chlamydomonas pulvisculus (Müll.) a differentiation of male and female gametes, the latter being considerably larger than the former. In $\mathrm{C}$. Morieri (Dang.) he describes a peculiar mode of conjugation of zoogametes, which he compares to that of Spirogyra.

Chlamydococcus A. Br. presents a similar life-history; and, according to some observers, the organisms known as Pleurococcus, Glœocystis, and others usually included under Protococcaceæ, are identical with the resting conditions of Chlamydomonas ; and, under suitable conditions, can be made to produce biciliated zoospores with two contractile vacuoles and a nucleus.

Under the Volvocineæ, and near to Chlamydomonas, Dangeard (Ann. Sc. Nat., vii., I 888, p. I०5) and Stein include also Chlorogonium (Ehrb.).

Among the most interesting of the social Pandorineæ is Pandorina Ehrb.. Each family or cœnobe consists of sixteen cells closely crowded together, and surrounded by a thin gelatinous envelope through which the cilia protrude. Non-sexual multiplication is preceded, after the colony has come to rest, by the absorption of the cilia in the sixteen cells, each of which then breaks up into sixteen smaller cells; and these sixteen daughter-families are set free by the absorption of the gelatinous envelope of the parent-colony; each becomes itself invested by a gelatinous envelope, and grows to the size of the original parent-colony, 
having in the meantime developed two cilia from each of its cells. Sexual reproduction takes place in the following way. Sixteen daughterfamilies are first of all formed in the same manner, but the gelatinous envelopes of the young colonies deliquesce, and the separate $25^{6}(=\mathrm{I} 6$ $\times$ r6) swarm-cells are set free as zoogametes. These vary in size, but. are always rounded and green at the posterior end, pointed hyaline and with a red pigment-spot in front, where they bear two cilia. Among the crowd of these swarm-cells-now swimming about freely-some, irrespective of their relative size, approach one another in pairs, their pointed anterior apices coming into contact, and they finally coalesce into a body which has at first somewhat the shape of an hour-glass, but gradually contracts into a sphere, in which the two pigment-spots and the four cilia are still to be seen for a time, but soon disappear. This whole process occupies about five minutes. The resulting zygosperm is then a spherical cell enclosed in a cell-wall, which remains at rest for some time as a hypnosperm, its green colour becoming changed to brick-red. If the dried-up hypnosperms are placed in water, they begin to germinate after about twenty-four hours. The outer layer of the cell-wall is ruptured, an inner layer becomes gelatinous and swells up, and the protoplasmic contents escape in the form of one, two, or three large zoospores. Each of these, after a short period of swarming, loses its cilia, surrounds itself with a gelatinous envelope, and breaks up, by successive bipartitions, into sixteen portions, which develop cilia, and form themselves into a new cœnobe.

A still more remarkable succession of phenomena is exhibited by Stephanosphara Cohn, a rare organism occurring occasionally in the rainwater which collects in the hollows of large stones in mountainous countries. In addition to the process of vegetative or non-sexual pro-

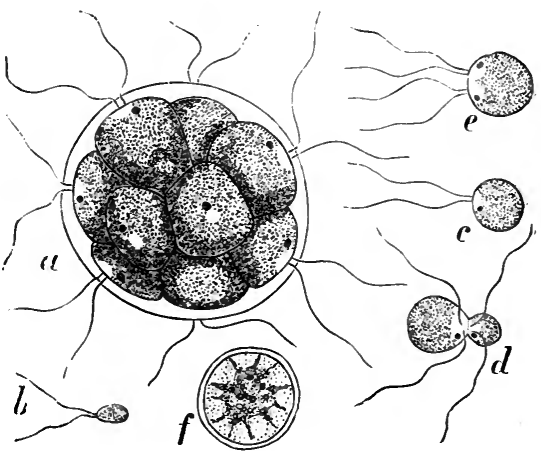

FIG. 263. - Pandorina morum Fhrb. a, swarming cœnobe ; $b, c$, swarm-cells; $d, e$, coniugation of zoogametes; $f$, zygosperm ( $\times$ 500). (After Pringsheim.) pagation, the cells belonging to a family, each of which possesses a red pigment-spot, divide repeatedly into zoogametes, which ultimately become free, and coalesce into resting zygosperms or hypnosperms. Motionless balls, which are probably the result of this conjugation, accumulate at the bottom of the water, and assume a red colour. After- 
these resting-cells have lain for some time dry, and then again been flooded, the contents break up into four or eight zoospores, which invest themselves with a cell-wall, and, in the course of a single day, divide, by successive bipartitions, into an eight-celled cœnobe, which again, during the next night, gives birth to eight motile families. The enclosed primordial cells of Stephanosphæra are of a bright green colour, fusiform, and are attached to an equator of the investing membrane at both ends by branched strings of protoplasm. The whole family rotates on an axis at right angles to the plane which passes through them all.

In Gonium Müll. the cœenobe is a tabular aggregation of cells moving rapidly through the water by the aid of vibratile cilia. Its life-history has not been fully followed out, and very little is known of its mode of reproduction.

\section{LiteratuRE.}

Henfrey-Trans. Micros. Soc., 1856, p. 49.

Cohn \& Wichura - (Stephanosphera) Nova Acta Acad. Nat. Cur., xxvi., Suppl. I857,

p. I (Quart. Journ. Micros. Sc., 1858, p. 131).

Archer-Quart. Journ. Micros. Sc., I865, pp. 166, I85.

Cienkowski-Bot. Zeit., I865, p. 2 I.

Pringsheim-Monber. Berlin Akad., I869, p. 721 ; and Bot. Zeit., 1870, p. 265.

Volten-Bot. Zeit., I871, p. 383 .

Rostafinski - Bot. Zeit., p. 785 ; and Mém. Soc. Sc. Nat. Cherbourg, I875.

Goroshankin-Nachr. Gesell. Naturf. Moskau, I 875.

Hieronymus - Oesterr. Bot. Zeitschr., I874, p. 313 et seq.

Reinhard - Arbeit. Naturf. Gesell. Charkoff, 1876.

Bréal-Bull. Soc. Bot. France, I S86, p. 238.

Dangeard-(Chlamydomonas) Ann. Sc. Nat., vii., I888, p. 105.

\section{ORDER 5.-SORASTREe.}

In this order are included a few genera distinguished by the cœnobe being unciliated. In Sorastrum Ktz. the colony consists of a more or

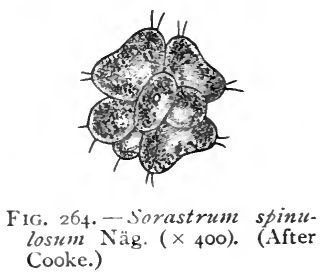

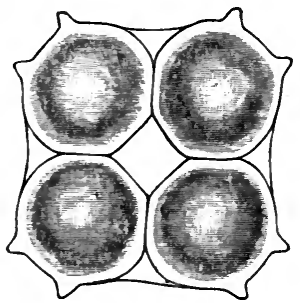

FIG. 265.-Calastrum cubicum Näg.

$(\times 600)$. (From nature.)

less spherical aggregation of closely-packed, horned or bifid, somewhat 
wedge-shaped cells; in Selenastrum Reinsch the cells are crescentshaped ; in Calastrum Näg. the cœnobe is spherical or cubical, composed of a single layer of cells, and hollow in the centre. The species are found occasionally in bog-pools ; although unciliated, the cœnobe swims freely in the water with a kind of rolling motion. Very little is known with regard to the mode of reproduction; no formation of zoospores has been detected. Lagerheim describes the mode of formation of a cœnobe of Selenastrum by cell-division within the mother-cœenobe. The affinities of this very beautiful family are clearly with Botryococcus among the Protococcaceæ, and upwards with the Pandorineæ. Scenedesmus Mey. is very probably a primordial or a retrogressive member of this family.

\section{Literature.}

Nägeli-Gattungen einzelliger Algen, I849, p. 97.

Reinsch-Algen-Flora Mittel-Franken, 1867.

Lagerheim-Bot. Centralbl., xii., I882, p. 33.

Bennett-Journ. Micr. Soc., I887, p. I3.

\section{FOSSIL ALG.E.}

All that we know of the relationships between the animal and vegetable kingdoms leads us to the conclusion that the appearance of animal life, both in fresh and in salt water, must have been preceded by that of aquatic vegetation; and it is almost certain that these primeval vegetable organisms must have had a structure and mode of life which would classify them under the head of Algæ or of Schizophyceæ. But, since even the largest of these organisms would probably consist entirely of cellular tissue, it is not to be anticipated that their remains could be handed down to us in the fossil state except in those cases where the cell-walls were either silicified or impregnated or coated with lime.

As far back as the Laurentian period, beds of graphite occur which must undoubtedly have been the result of the decomposition of vegetable matter, but all traces of the structure of the organisms from which it has been derived are lost. 'The structures from the Russian coal-fields described by Reinsch as the remains of algæ allied to the Scytonemaceæ, are either the spores of Vascular Cryptogams, or, in many cases, are inorganic crystallisations. Even the very earliest argillaceous deposits, whether from fresh or from salt water, display long rounded trailing impressions, which are believed by some writers to be the remains of algæ; but it is exceedingly difficult to distinguish between these and 
the trails of aquatic animals, or even ripple-marks. Carruthers is disposed to regard the structure which he has called Nematophycus, from the Lower Erian or Upper Silurian beds of Canada, as the earliest algoid remains or impressions which have come down to us. The true nature of the tracings in the still earlier Laurentian rocks known as Eozoon canadense is still a subject of controversy with palæontologists and petrologists.

Coming down to more recent periods, the organisms described as Chondrites and Confervites, found in the Cretaceous beds, were possibly algæ allied to the Confervacex, and are thought by some to have had a large effect in the precipitation of chalk from sea water, from the great quantity of carbonic acid which they removed. From nodules in the Pleistocene of Canada, Dawson obtains remains which he places under genera allied to Ulva or Fucus, and possibly also to Laminaria. Various other remains, sometimes of gigantic size, found in strata extending over a very wide geological range, are referred by Saporta and others to algæ allied to the Laminariaceæ and Fucaceæ; but the evidence is generally too imperfect to justify a settled conclusion on the subject.

Of the calcareous remains of algæ which have come down to us, the most remarkable are those described by Munier-Chalmas, including more than fifty genera, which he refers to the Siphonocladaceæ, mostly found in the Triassic, Jurassic, Cretaceous, and Tertiary strata. The calcareous skeleton contains hollow chambers and canals where the rays and the organs of reproduction were seated in life, rendering them very liable to be mistaken for the remains of Foraminifera, under which class of animals many of them have been placed by palæontologists. Among these is the genus Ovulites from the Eocene.

\section{LITERATURE.}

Balfour-Introduction to Palæontological Botany, I872.

Carruthers -- (Nematophycus) Monthly Microscopical Journal, I872, p. 208.

Munier-Chalmas-Comptes Rendus, I877, p. 814 ; Bull. Soc. Géol. France, I881, p. $66 \mathrm{I}$.

Saporta-Les organismes problématiques des anciennes mers, I884.

Reinsch-Micro-palæophytologia, 1884 .

Nathorst-Nouvelles observations sur des traces d'animaux et autres phénomènes d'origine purement mécanique décrits comme Algues fossiles, I 886.

Delgado-Etudes sur les Bilobites, I886, 1888.

Dawson-Geological History of Plants, 1888.

(See also under Fossil Vascular Cryptogams.) 


\section{FIFTH SUBDIVISION.}

\section{FUNGI.}

UNTIL recent years Fungi were looked upon as a great group embracing all Thallophytes which do not vegetate by means of intrinsic chlorophyll. With the advance of research and the widening of knowledge, a new classification of Thallophytes was established, mainly by Sachs, which was based on the characters of the sexual organs, and under it groups were constituted composed of Algæ and Fungi alike, in recognition of the principle that a mere physiological attribute, such as the presence or the absence of chlorophyll, should be no bar to the bringing together of organisms associated with each other by morphological characters. With the analogy before their eyes of the relationship of flowering parasites devoid of chlorophyll with green Flowering Plants, morphologists readily accepted the proposed grouping, and until a few years ago it was generally adopted. It then became apparent that this step, though in the right direction, exceeded due bounds; and, with the first publication by de Bary of the classification of Fungi used in this treatise, a new movement, which cannot, however, be justly called a reaction, took place. This classification recognises a main group of Fungi branching off from the Algæ (Chlorophyceæ), and definitely marked by morphological relationship. This main group differs from the old group of Fungi not only in its internal disposition, but in the exclusion from it of Mycetozoa and Bacteria, though it resembles the old group in its latter days in the inclusion of lichen-forming fungi. As clearly characterising and delimiting the group, the words of de Bary ('Lectures on Bacteria,' p. 2) may here be quoted :-

'The term Fungi denotes a group of lower plant-forms, distinguished by definite characteristics of structure and development, and recognised at once when we see a mushroom or a mould. The members of this group are all, as a matter of fact, devoid of chlorophyll, but they might contain chlorophyll and yet belong to this group, just as a bird may have no apparatus for flight, and yet be allowed to be a bird. To these Fungi, as defined by natural history, and not by physiological characters 
only, Bacteria are as little related in structure and development as bats are to birds; the relationship is even less, because there are a few, though only a few, true Bacteria which contain chlorophyll and decompose carbon dioxide, and which are therefore not Fungi in the physiological sense.'

\section{Histolugical Characteristics.}

The thallus of fungi consists of one or more cylindrical hyphe branching in monopodial fashion, rarely dichotomously, and increasing by apical growth. In numerous instances the hypha remains, for a period at least, unsegmented, but most frequently transverse septa are formed either in the apical cell or in segment-cells of the first order. The thallus of the simple filamentous fungi consists of one hypha with its ramifications. The so-called compound thallus of larger fungi is formed of hyphæ of which the branches meet and remain in close contact. While all fungi have the filamentous habit to begin with,

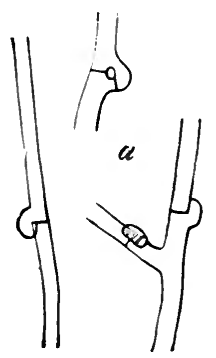

Fig. 266.-Clamp-conne:tions: mycele of $H_{1}$. pochuus centrifugus Tul. ( $\times$ 390). (After de Bary.)

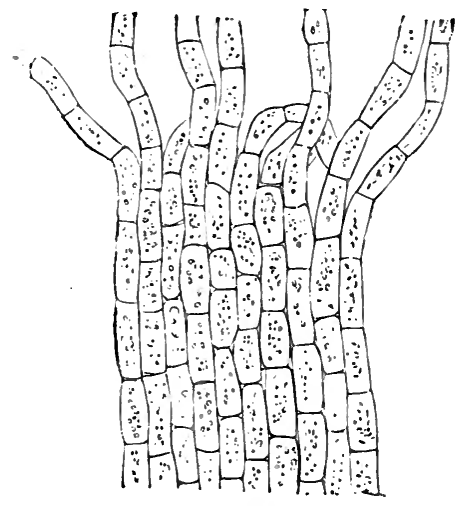

FIG. ${ }_{2}-7$. - Pseudo-parenchyme breaking up at end into separate hyphæ: lectria cinnabarina $\mathrm{Fr}$. (highly magnified). (After Reinke)

some remain so throughout their whole development, and others are characterised by both habits in different periods of their life-history. It should also be mentioned that the whole thallus of a fungus may be reduced to a single globular cell. Clamp-connections take place, especially in the Basidiomycetes, between adjoining segment-cells of the same hypha by means of a protuberance emitted from the one nearer the growing-point. This protuberance issues immediately above the transverse wall, and effects a junction with the cell beneath. By this means open communication is maintained between the cells for a time, but it is 
eventually closed by the formation of a transverse wall in the protuberance. Cross-links, loops, \&c., are frequently formed between branches of the same hypha, or between originally distinct hyphæ, by the resorption of the membranes at the point of contact. The coherence of the compound thallus is most commonly effected by the more or less dense interweaving of the hyphæ, and by the cementing of them together in many cases by an intercellular substance. The union of the component hyphæ may proceed so far, and the conditions of pressure, \&c., be so favourable, that a tissue is formed resembling the parenchyme of higher plants. Being thus different from it in mode of formation, the tissue in question is termed pseudoparenchy'me.

The form of hypha described is not universal among fungi. Sprouting, as it is called, is characteristic of the thallus of the yeast-fungus Saccharomyces, and it occurs in certain stages of other fungi, such as Mucor. This process consists in the production of ovoid or globular cells, by means of excrescences which remain connected by a narrow base with the parent cell, and are eventually cut off at or before maturity by a cross-parti-
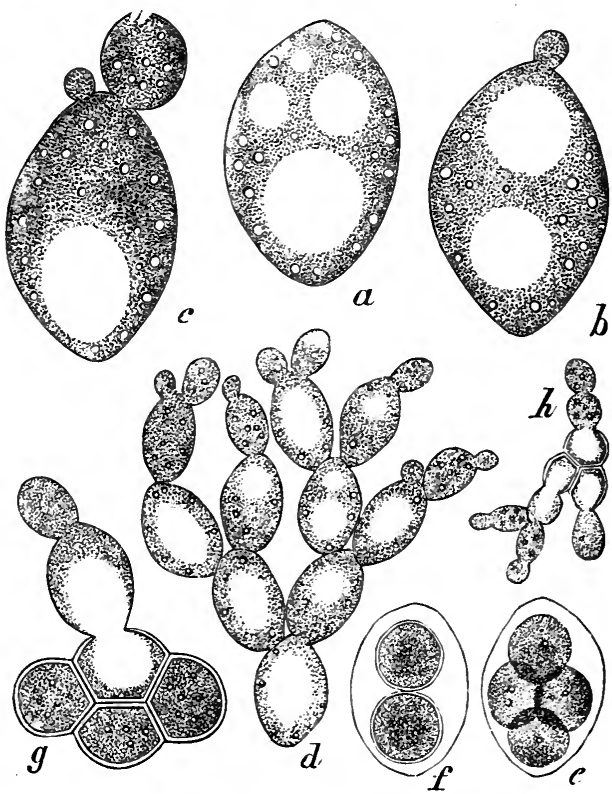

FIG. 268.-Saccharomyces cerezisiae Meyen. a, single cell of beer-yeast ; $b, c$, stages of sprouting; $d$, colony of sproutcells; $e$, cell with four ascospores; $f$, one with two; $g$, group of ascospores with one sprouting; $h$, further developnient of a similar group $(h \times 750$, the others much more $)$. ( $(e-h$ after Reess.)

tion. This process, on being repeated again and again undisturbed, exhibits in the result the appearance of a copiously-branching hypha formed of bead-like cells. This connection, however, is very easily broken, and the usual appearance presented is that of small aggregates of sprouting cells.

Cell-contents.-The cells of fungi are characterised rather by the absence of certain cell-contents than by the presence of peculiar substances. The absence of chlorophyll and of starch-grains is most note- 
worthy, and the physiological substitution for the latter of fatty matters Glycogen is found in the asci of Discomycetes and Tuberaceæ, and in the vegetative cells of these and other fungi. Crystalloids of albuminoid substance occur in the sporophores of Mucorini. Nuclei are of frequent occurrence in the cells of the reproductive system of many fungi, and in the vegetative cells of the Saprolegnieæ and other groups, though absolutely satisfactory evidence has not been produced with regard to their common presence in the thallus of fungi, apart from the reproductive system. Unsegmented hyphæ resemble the Siphoneous Algæ in their multinucleate condition, though single cells of segmented hyphæ also sometimes contain several.

Cell-membrane.-The typical cell-membranes of fungi consist of a substance differing from cellulose in its behaviour to the usual reagents, which is therefore known by the special name of Fungus-cellulose. Richter contends that this difference is more apparent than real, since he found that after prolonged maceration in a 7-8 per cent. potash solution, membranes exhibited the ordinary cellulose reaction which had refused the reaction after treatment of the usual kind with boiling potash solution, \&c. De Bary, who originally gave the name of Fungus-cellulose to the membranes of fungi, welcomes these observations as confirming the undoubted near affinity of such membranes to ordinary cellulose, but points out that it merely proves that the membranes of the fungi operated on by Richter are altered by maceration with potash in the way described. "Whether this alteration consists in the removal of some substance which was present from the first must remain uncertain; such an explanation has not been proved, and others are at least possible' ('Comp. Morph.', p. I3). It is specially noteworthy that the membranes of certain filamentous fungi (Saprolegnieæ, \&c.) exhibit the ordinary blue reaction with iodine.

The membranes of fungi undergo thickening and stratification, but are rarely pitted. The capillitium-threads of Lycoperdon are pitted, for example, and spiral and annular thickening occurs in the corresponding structure in Batarrea. Membranes very frequently become coloured with age, and undergo sclerosis; while in contrast to that condition other membranes often occur, which, though hard and horny in a dry state, swell up enormously by absorption of water, and acquire a gelatinous consistency.

Calcium oxalate, though of common occurrence in various forms in fungi, is of extreme rarity within their cells; Russula adusta (Fr.) and Mutinus caninus (Fr.) are the only recorded instances known to us. 


\section{Differentiation of the Thallus.}

It is usually possible to draw a fairly sharp distinction between the vegetative part of the thallus, the mycele, and that portion specialised for the bearing of propagative bodies, the sporophore. In reduced forms, however, such distinction will be seen to be arbitrary, since propagative cells are formed in such cases from otherwise undifferentiated hyphal cells. The mycele, which serves the same physiological purposes as roots in point of the absorption of nutriment and of attachment, occurs in a variety of forms. The simplest and the typical form is a loose filamentous condition, spreading on or in the substratum, and sometimes provided with special branches termed haustoria, which penetrate cells of living plants and act as special organs of nutrition and of attachment. Such are the haustoria of Peronosporeæ and Erysipheæ, sc. A denser condition of mycele is represented by a membranous state to be found in forms vegetating on the surface of fluids and in fungi which attack wood, such as dry-rot (Merulius lacrymans, Fr.) and very many others. Strands
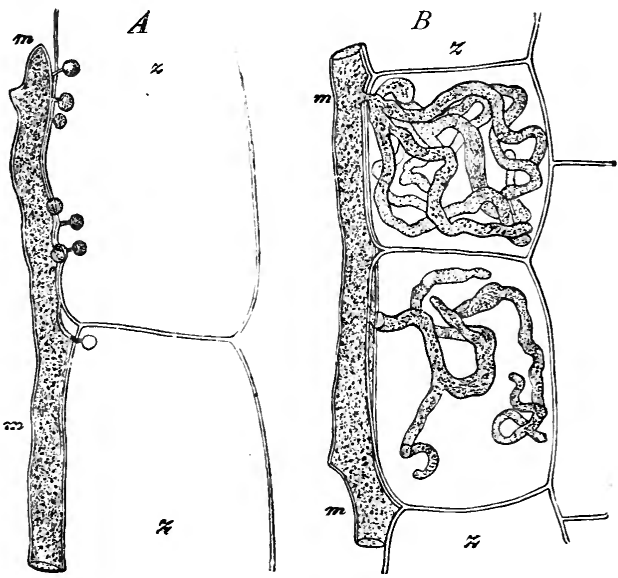

FIG. 269. - Intercellular mycelial hyphæ $(m)$, with haustoria penetrating into cells (z), $A$, of Cystopus candidus Lév.; $B$, of Peronospora calotheca de By. ( $\times 390)$. (After de Bary.)

of mycele are formed frequently in the Gasteromycetes and other fungi possessing compound sporophores. The strand-mycele of Agaricus melleus (L.), formerly known as Rhizomorpha, possesses a highly-developed structure, in which a cortical and a medullary region may be distinguished. Most compact of all forms of mycele are those known as sclerotes-densely compacted tuberous bodies. These consist of a central medullary tissue composed of very compact uniform hyphæ, sometimes pseudo-parenchymatous, enclosed by one or more layers of cortical cells with sclerosed walls. They are resting states of mycele, and act as stores of reserve material. With sclerotes may be classed such sclerotioid bodies as Pachyma and Mylitta, the develop- 
ment of which is quite unknown. Sclerotes were formerly classed together under the generic name of Sclerotium before it was recognised that such bodies are mere growth forms, or rather resting forms, of myceles of different fungi. Such a strand-mycele as that of Agaricus melleus (L.), formerly considered an independent fungus (Rhizomorpha), noticed above, has been aptly called a sclerote with a growing-point. B. Frank (Ber. Deutsch. Bot. Gesellsch., I 885) has described masses of fungal hyphæ having a dense sclerotioid structure investing the roots of trees (Cupuliferæ, Salicaceæ, Coniferæ) and intimately associated with the superficial cells of the root. To these bodies, termed mycorhiza, a symbiotic relationship with the trees in question is attributed, viz., the

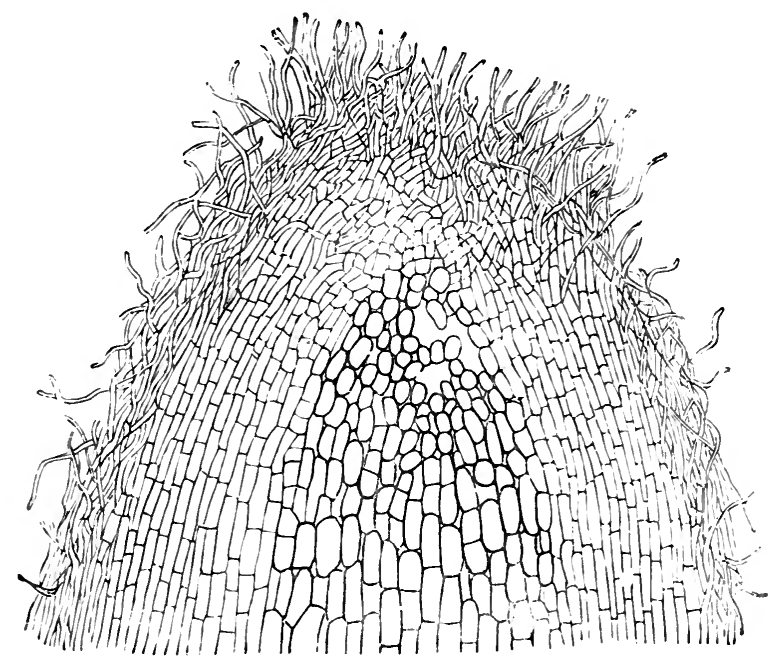

Fig. 270.-Agaricus melleus L. Longitudinal section through apex of rhizomorph-strand ( $x$ 250). (After de Bary.)

absorbing function of root-hairs, the formation of which mycorhiza suppresses.

The sporophores of fungi are either simple or compound. They arise from the mycele, and produce the spores or definite organs of propagation. Simple sporophores are commonly erect branches of the mycele which either remain unbranched or branch again. The spores are borne at the extremities, and with the production of these bodies the growth of the sporophore either ceases altogether, or it may be renewed with farther production of spores. The modes of branching and the forms of sporophore are characteristic of species of fungi. Compound sporophores are structures often of considerable size, of 
varying external appearance, and of a certain degree of differentiation of tissue. This differentiation is exhibited in the formation of layers, sometimes pseudo-parenchymatous, adapted for special functions. They are

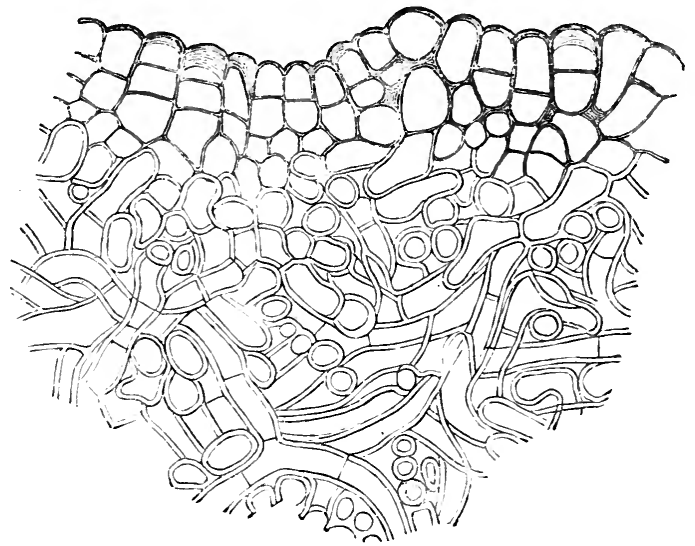

Fig. 271.-Section through sclerote of Sclerotinza Sclerotiorum Lib., showing its cortical medullary tissue $(\times 375)$. (After de Bary.)

commonly characterised by the bearing of spores, or special sporemother-cells, on definite regions and in more or less definite arrangement. They form, as a rule, that portion of the whole organism which

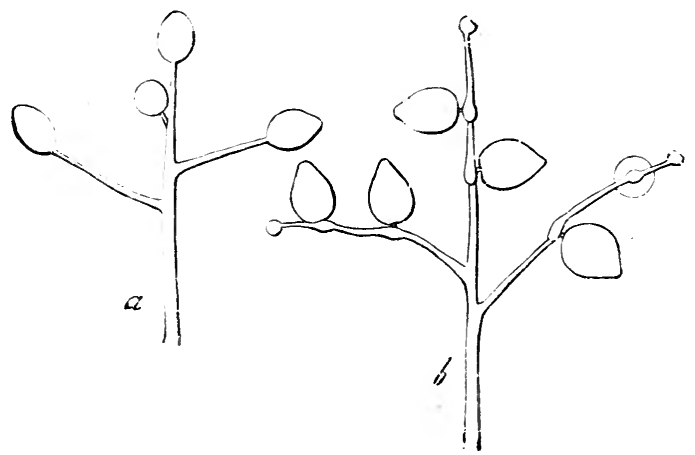

FIG. 272.- Simple sporophores of Phytophthora infestans de By. $a$, formation of first spores (zoosporanges) at ends of branches; $b$, two ripe spores on cach branch and a third being formed ( $x$ about 200 ). (After de Bary.)

is popularly termed a fungus, such as the stalk and cap of mushrooms, the peridium of puff-balls, and the like. The structure of these is, as has been said, very diverse, and it will be found described in more or 
less detail under the different groups of fungi. It may be well to note that transition-forms occur between the simple and compound types of
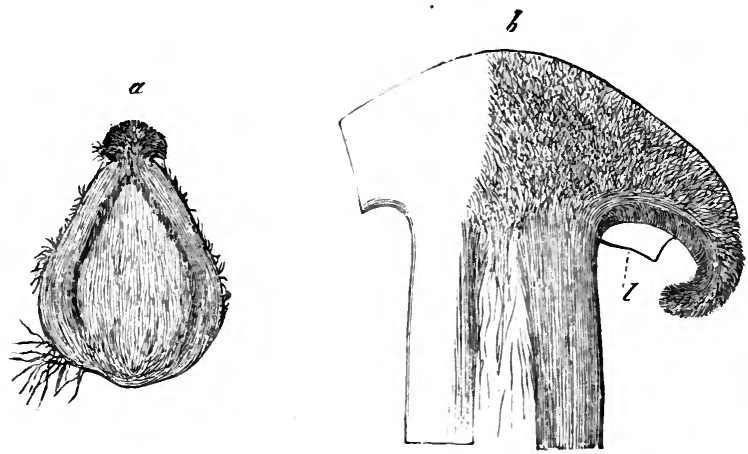

Fig. 273.-Agaricus dryoplitus Bull. a, compound sporophore, longitudinal section showing the course of the hyphæ, a very young complete specimen $x_{3} 3 \mathrm{~mm}$. in height, first leginnings of pileus; $b$, older specimen with pileus $2.5 \mathrm{~mm}$. in breadth : $l$, piece of a lamella (slightly magnified). (After de Bary.)

sporophore : for example, Penicillium, though commonly simple, sometimes produces tufts of sporophores formerly supposed to belong to a different fungus under the generic name of Coremium.

\section{SPORES.}

The prevailing mode of spore-formation is by acrogenous abjunction. The terminal portion of the mother-cell or a special protuberance formed on it is cut off by a transverse wall, and this daughter-cell then drops off as a spore. The basidiospores of Basidiomycetes may be taken as an example. Finely pointed processes are formed on the summit of the basid, and these swell into ball-like form at the apex. The globular body is then abjointed and set free as a spore. Series or chains of spores are successively formed in like fashion in Cystopus, Penicillium, Uredineæ, \&c. Spores are also endogenously formed within mothercells-sporanges-and these are of two kinds, motile and non-motile. Examples of non-motile spores thus formed are to be found in Mucor, and in the ascospores of Ascomycetes. Such spores are either set free by the disappearance of the sporangial wall or by internal causes effecting their ejection. Motile spores or zoospores (swarm-spores) possess the power of moving freely in water by means of fine whip-lashes or cilia, and examples of these are to be found in the Saprolegnieæ and Peronosporeæ, the groups presumably most nearly related to Algæ. That the phenomenon of the production of swarm-spores is one nearly akin to that 


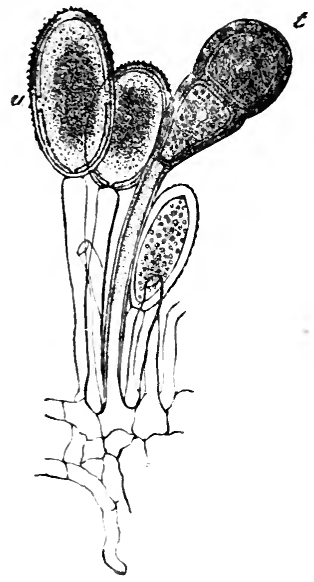

- Fr. 274. Pucinia graminis Pers. $t$, teleutospores; $z$, uredospores ( $\times$ 39\%). (After Sachs.)

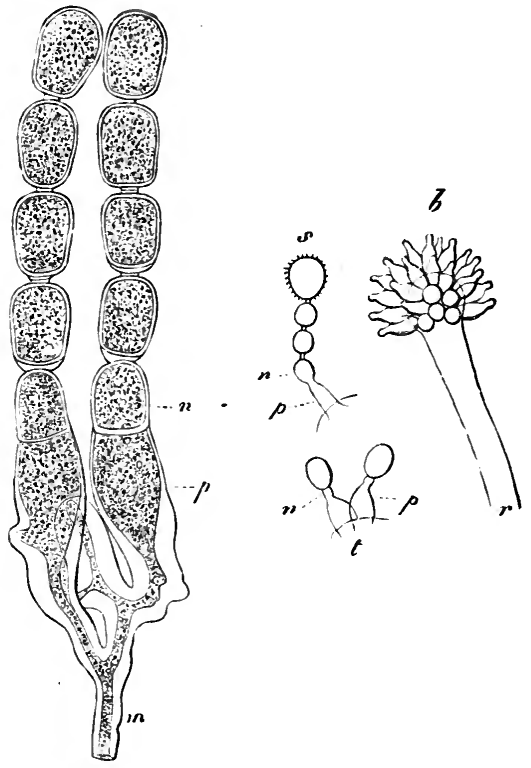

Fig. 275. $M$, mycelial branch of Cystopus Portulacie. Lév, producing two basids abjointing spores, in series; b, sporophore of Eurotium herlariorum Lk. with sterigmala; $s$ and $t$, portions showing sterigmata, $p, p$, with their spores, $n$ being the youngest $(\alpha \times 390$, the rest $\times 3 \mathrm{co}$ ). (After de Bary.)
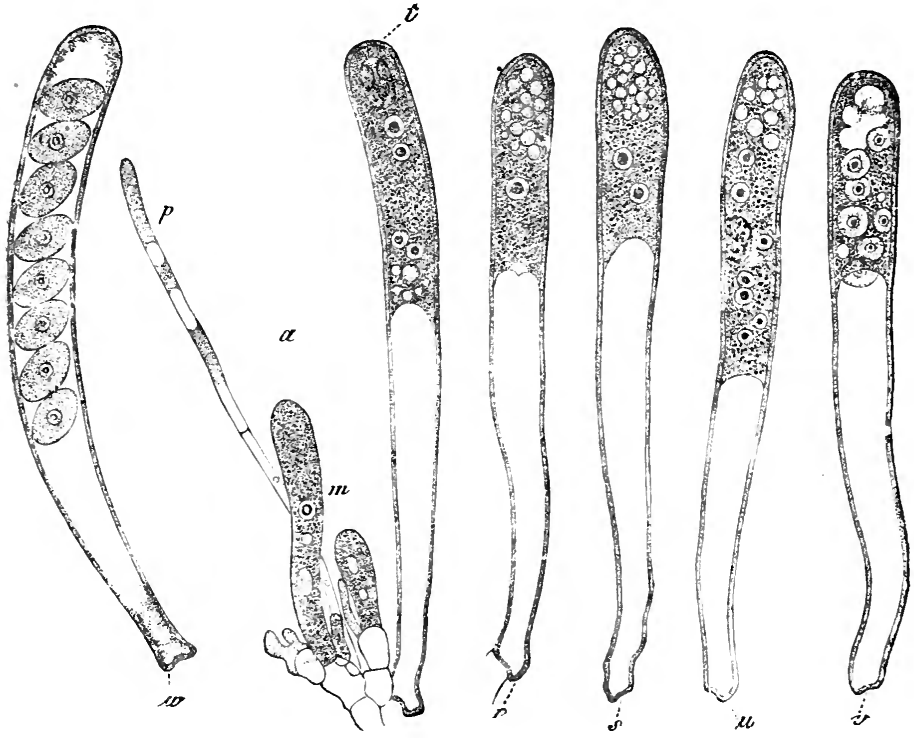

Fig. 276.-Peziza (Pyronema) confuens Pers, a, small portion of hymenium ; $p$, paraphyse attached to, not originating in, hyphal branches from which the three asci spring: $m$, young asci; $r-z v$, successive stages, according to letters, in the development of ascospores within asci ( $\times 390)$. (After de Bary.) 
of simple germination by the emission of a germ-tube is manifest. The example of Phytophthora infestans (de By.) illustrates this. The acro-

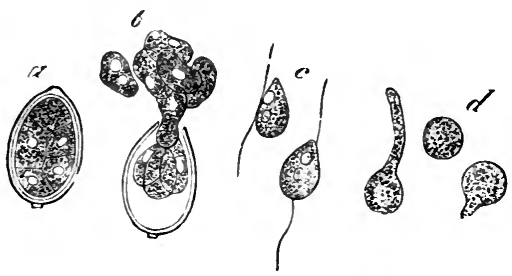

FiG. 277.-Zoosporanges of Phytophthora infestans de By: $a$, division completed ; $b$, escape of zoospores $; c$. free zoospores; $d$, spores come to rest and germinating $(\times 390)$. (After de Bary.) genously-formed zoosporange produces zoospores in pure water containing free oxygen in fair amount. In nutrient solutions, on the other hand, no zoospores are formed, and the potential zoosporange simply emits germ-tubes. Germination of spores, however, takes place characteristically in fungi by the emission of germtulies under conditions of temperature, moisture, and the like presently to be discussed. Germination by the formation of sprout-cells, however, occurs in a number of forms.

\section{Sexual Reproduction.}

This subject is incidentally so fully discussed under the different groups, that nothing need be said here beyond calling attention to the fact that it falls under the same types as in Algæ. Such a form as Polyphagus may, however, be mentioned since it exhibits a type apart from ordinary isogamous or oogamous reproduction.

\section{Conditions of Germination.}
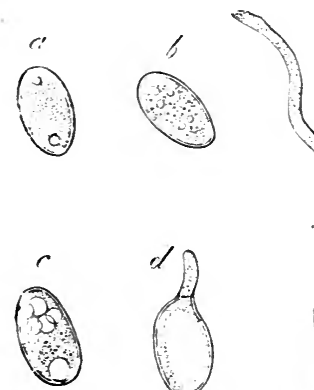

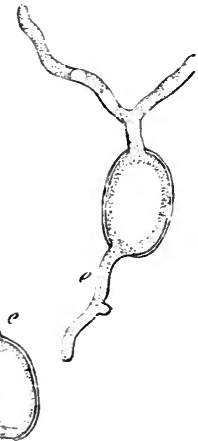

FIG. 278.-Ascospores of Heliella cscultnta Pers. Stages of germination in order of letters ( $x$ 390). (After de Bary.)
Spores may be divided into two categories with reference to their power of germination, viz. those, by far the majority, which are capable of germination from the time of maturity, and those which must undergo a period of rest. Of the first kind a considerable number, generally speaking thin-walled watery spores, sporids, or zoospores, do not retain this power for more than a period measured by hours or days. The conditions under which they are kept are, as will be expected, of importance in this respect. Many spores retain the power of germination for a long period if kept in an air-dry 
state. This time extends in numerous instances to one or two years, and, in the case of spores of Ustilagineæ especially, to longer periods. The spores of Tilletia caries (Tul.) germinated after eight and a half years, and those of other species after shorter intervals varying from seven an'd a half downwards. Resting-spores, or those of the second category, generally undergo more or less definite periods of rest corresponding to periods of vegetation. While germination cannot be procured before the lapse of this time, they frequently exhibit inability to survive the occasion presumed to be favourable. Such are hibernating spores like the teleutospores of Uredineæ, and the oosperms of Peronosporeæ. Resting-cells belonging to saprophytes again, e.g. the zygosperms of Mucorini, while they undergo a necessary period of rest of varying duration, yet display no partiality for seasons of the year, and this also is intelligible in view of their mode of life.

The power of resistance of spores to external agencies operating against their vitality is in maily instances very great. The spores and zygosperms of several Mucorini withstand mechanical injury and repair slight wounds while preserving the power of germination. Shortlived spores and those of aquatic fungi do not bear desiccation; but a great number of spores retain the power of germinating, as has been stated, for considerable periods in an air-dry state. Spores adapted for hibernation in temperate climates, and, it may be assumed, long-lived spores, withstand very low degrees of temperature, ranging below zero C. ; while such long-lived spores, on the other hand, are very sensitive to high temperatures. The capacity for germination after exposure to high temperatures is maintained or not within certain degrees, according to the dryness or humidity of the environment. Thus it has been shown that while no spores are known to withstand a temperature of $100^{\circ} \mathrm{C}$. in water or watery vapour, and many perish under these circumstances at much lower temperatures, the same spores can endure a considerably higher temperature in a dry state. Dry spores of some fung: have been found to withstand temperatures up to $120^{\circ} \mathrm{C}$. and beyord, but it is probable that $130^{\circ} \mathrm{C}$. marks the death-point of all. Others, again, perish at degrees considerably below $100^{\circ} \mathrm{C}$. It must, of course, be borne in mind that the duration of the exposure is an important factor in such experiments, and that sjores which support a high temperature for a few minutes or an hour are killed by longer exposure. It is probable that much individual variation exists in regard to this matter and to the duration of life under ordinary circumstances, and that in this lies the explanation of conflicting results obtained by different experimenters.

There is not much known as to the maximum, minimum, and 
optimum temperatures at which the actual germination of spores takes place. According to Wiesner the minimum for the spores of Penicillium glaucum (Lk.) is from $\mathrm{I}^{\circ} 5^{\circ} \mathrm{C}$. to $2^{\circ}$, the optimum about $22^{\circ} \mathrm{C}$., and the maximum $40^{\circ} \mathrm{C}$. to $43^{\circ}$. This may be taken as fairly illustrative of other fungi in temperate countries in the open. Those which germinate, like many Mucorini and fungi inhabiting excrement, in the digestive tract of warm-blooded animals, have a much higher minimum, and an optimum agreeing with the body temperature. A supply of water and of oxygen must accompany the favourable temperature in all cases, and of nutrient substances in some. Speaking generally, parasites germinate freely in pure water or vapour, and saprophytes in nutrient substances, but the spores of many fungi germinate in both.

\section{Conditions of Vegetation.}

Under this head it will be necessary to consider little else than the nutritive adaptation of fungi, since they resemble other plants in the general conditions of vegetation, in their dependence on temperature, light, \&c. The optimum temperature varies, as might be expected, in the cases of fungi which flourish at different seasons of the year, and in different climates. The optimum temperature for the growth of mycele in Penicillium glaucum is about $26^{\circ} \mathrm{C}$., while that of spore-formation is the same as that of germination, about $22^{\circ} \mathrm{C}$. These figures may be taken as fairly illustrative.

Luminosity ${ }^{1}$ is exhibited by a considerable number of fungi-Agaricus olearius (DC.) and the rhizomorph form of A. melleus, Polyporus annosus (Fr.), and P. sulphureus (Fr.) (Europe), Agaricus igneus (Tul.) (Amboyna), A. noctilucens (Lév.) (Manilla), A. Gardneri (Berk.) (Brazil), A. lampas (Berk.) (Australia), A. Emerici (Berk.) (Andaman Islands), a species of I)idymium (Jamaica), and probably by a number of other forms, the evidence as to which is doubtful. It is a phenomenon dependent upon the life of the organism, and the progress in it of destructive metabolism.

As regards nutrition, the absence of chlorophyll and the consequent inability to decompose carbon dioxide drive fungi to seek for organic carbon-compounds. In taking up food, fungi cause chemical changes in the organic bodies which furnish the food, e.g. fermentation. The well-known ferment-fungi need only be mentioned. It is in the highest degree probable that the solvents secreted by such fungi as penetrate dense woody and other structures are ferments. All fungi may be

1 Vines, Lectures on the Physiology of Plants, p. 317; see also Phillips, Proc. Woolhope Clul, I 888 . 
divided primarily into such as feed on the decaying bodies of plants and animals and dead organic substances-saprophytes - and those which attack living bodies---parasites. Between the two extremes of strict saprophytes and strict parasites there are intermediate forms. Some saprophytes, which ordinarily live throughout their course of development as such, have the power of living as parasites either wholly or during a part of their course of development. Such are called facultative parasites. Similarly some parasites which ordinarily live as such have the power of passing at all events a part of their lives as saprophytes. Such are facultative saprophytes. The lichen-forming fungi which live socially with algæ may be placed in another category. Most fungi are saprcphytes, and it is obvious, from the fact that so many are confined to specific substrata, that there is much variation in the nutritive adaptations of such forms. These adaptations are, however, more clearly marked in the case of the smaller number which lead parasitic lives. Some are confined to single species of host-plants ; many range over allied species, some of them attacking plants outside the group mostly affected, or exempting from attack certain species within the group. Others, again, may be said to be omnivorous parasites, attacking plants or animals of diverse groups. With regard to the predisposition of the host to the attack of the parasite, it is impossible for the most part to say exactly wherein it lies. Reference may be made to the case of species of Pythium which as facultative parasites attack Phanerogams, \&c. The amount of water present in the host determines there the degree of predisposition to attack. While a sickly condition may constitute a predisposing cause to the attack of a parasite in some cases, it is by no means so in the majority of instances. It has been asserted that certain cultivated plants, such as cereals and the potatoplant, have by cultivation acquired an 'inherent tendency' to certain parasitic diseases, whereas it is obvious that the growing together of vast numbers of these plants furnishes opportunity for the spread of diseases which, in the absence of other evidence, may be taken to account for extensive outbreaks. Parasites commonly attack their hosts by the penetration of the membranes of the uninjured host, though cases are numerous where the entry is made by means of the stomates, or of wounded surfaces only. Most are endophytes, but a small number -e.g. Erysiphe-are epiphytes, which send haustorial branches into the body of the host. The result of attack is either the destruction of the host, or the production of deformities by anomalous processes of growth in the parts affected. 


\section{LICHEN-FORMING FUNGI.}

These are strictly parasitic fungi which, without the aid of algal hosts, do not develop beyond the earliest stage of germination. Their nutritive inter-relations with their hosts, however, mark them off from other parasites. The hyphæ of the lichen-fungus embrace the algal cells, and the two elements together compose a thallus of definite form. The algal cells form by means of their chlorophyll-contents organic carbon-compounds by which the fungal cells benefit; but here the

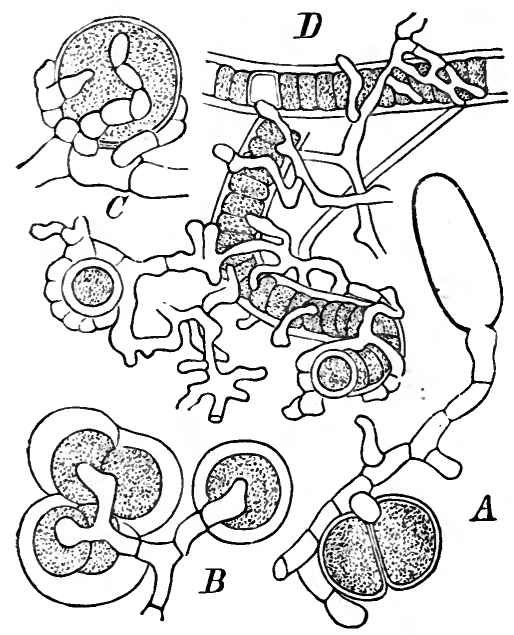

FIG. 279. Algal cells of Lichens. $A$, spore of Physcia parietina Nyl. germinating on Protococcus :'iridis Ag. B, Synalissa symphorea Nyl. with Glococapsa. C, Cladonia furcata Hoffm. with Protococcus. D, Stereocaulon ramulosum Ach. with Scytonema. (A, B, and $C, \times 950$, $D \times 650$.) (After Bornet.) resemblance to true parasitism ceases. The host exhibits no sign of exhaustion, since a reciprocal accommodation exists between the two elements. The rhizoid filaments of the fungus draw from the substratum mineral substances, the raw material of food. The hyphal cells are fed by the exosmose of starch and the like from the algal cells, and the inference is justifiable that the algal cells receive in exchange by endosmose thc waste products of the fungal protoplasm. There thus exists a lasting consortism or symbiosis between the elements, and the result is a thallus which may be treated from the point of view of the systematist as an autonomous organism. It must never be forgotten, howevér, that it is fundamentally two organisms, one of which, the fungal, cannot live without the other, while the latter can and does exist separately and independently in nature. It is a question not definitely decided whether certain algal forms thus living in consortism can or cannot live separately, and it is also doubtful whether the fungal portion of such lichens as live on the bark of trees or substrata rich in humus, does not live partially as a saprophyte. Evidence certainly points in this direction. The symbiotic relations existing in lichens are comparable with those described by Geddes, Brandt, and others, as in operation in Radiolarians and other animals, the 'yellow-cells' of which are actively' vegetating algæ. 
By far the greater number of lichen-forming fungi are Discomycetes or Pyrenomycetes. A few small tropical genera, Cora (Fr.), Rhipidonema (Mattir.), Dictyonema (Mont.), and Laudatea (Johow.), are Basidiomycetous, and two other tropical forms, Emericella (Berk.) and Trichocoma (Jungh.), have recently been declared by Massee (Phil. Trans. Roy. Soc. Lond., vol. 1 78, p. 305) to be Gasteromycetous Lichens. The two last-named cases are by no means satisfactorily established, and much more and better evidence must be forthcoming before

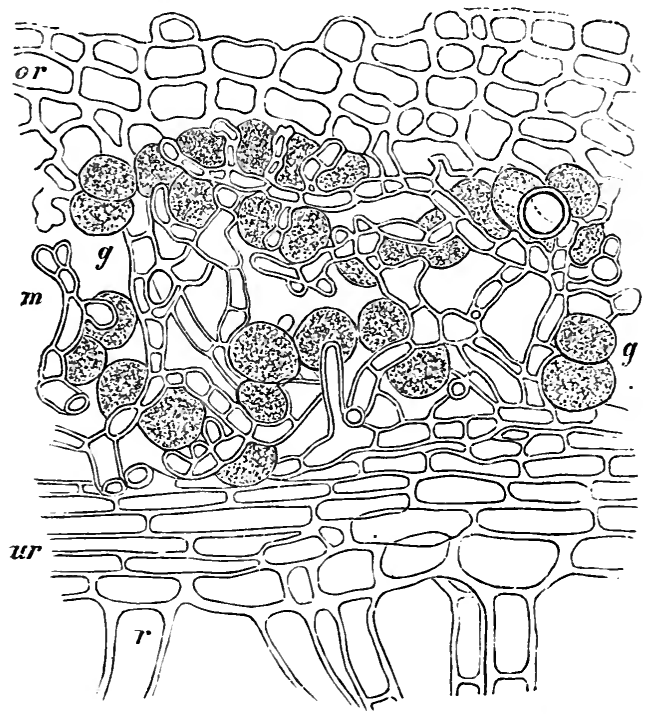

Fig. 280. - Coccocarpia molybdia Pers. Transverse section of thallus. or, upper, and $u r$, under cortical layer. $m$, so-called medulla; $g$, algal cells; $r$, rhizoids $(\times 6,0)$. (After Bornet.)

they can be adopted as lichen-forming fungi. Propagation is effected by the spores of the fungal thallus, and an adaptation exists in certain lichens examined by Stahl for the supply of algæ to the new lichen. Algal cells, the offspring of

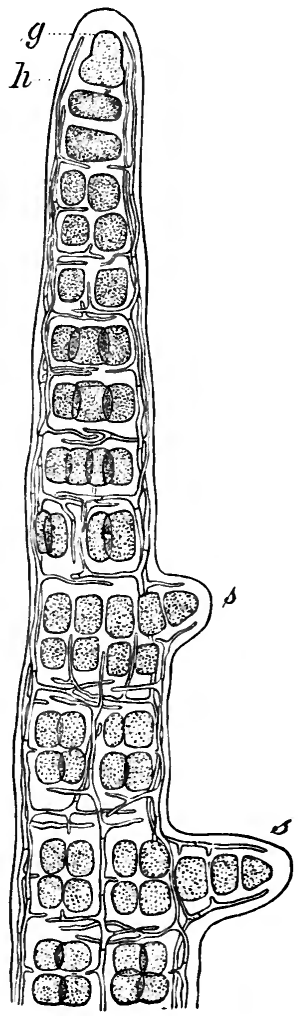

FIg. 281.-Ephebe pubescens Fr. Branch of thallus with two young lateral branches $(s) ; g$, algal cells ; $h$, hyphæ $(\times 500)$. (After Luerssen.) the thallus algæ, which have been carried up into the hymenium, are cast out along with the spores, so that, both falling in the same neighbourhood, the germ-tubes of the spores find suitable hosts at once. This primary synthesis, however, probably takes place comparatively rarely in lichens as a whole. Propagation is very abundant by means of soredes or brood-buds 
consisting of one or more algal cells surrounded by hyphæe which separate from the parent-thallus. As a rule one species of alga furnishes all the algal cells of a lichen; more rarely two, and then one prevails in abundance

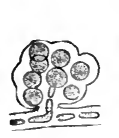

a

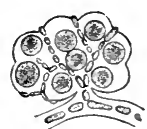

$b$

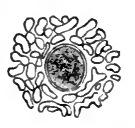

C

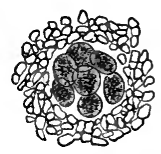

d

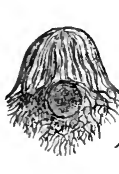

e

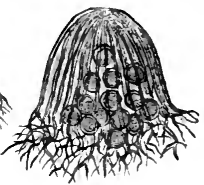

$f$

FIC. 282. - Lsne'a barbata Fr. Development of soredes. a, group of eight algal cells attached to hypha; $b$, similar group with branching hypha ; $c$, sorede with algal cell in optical section; $d$, sorede with algal cells divided; $e, f$, germinating soredes $(\times 500-700)$. (After Schwendener.)

over the other. The same species of alga, however, may be found in consortism with different species of fungus, and taking part in the composition, therefore, of differently formed thalli-different lichens in short.

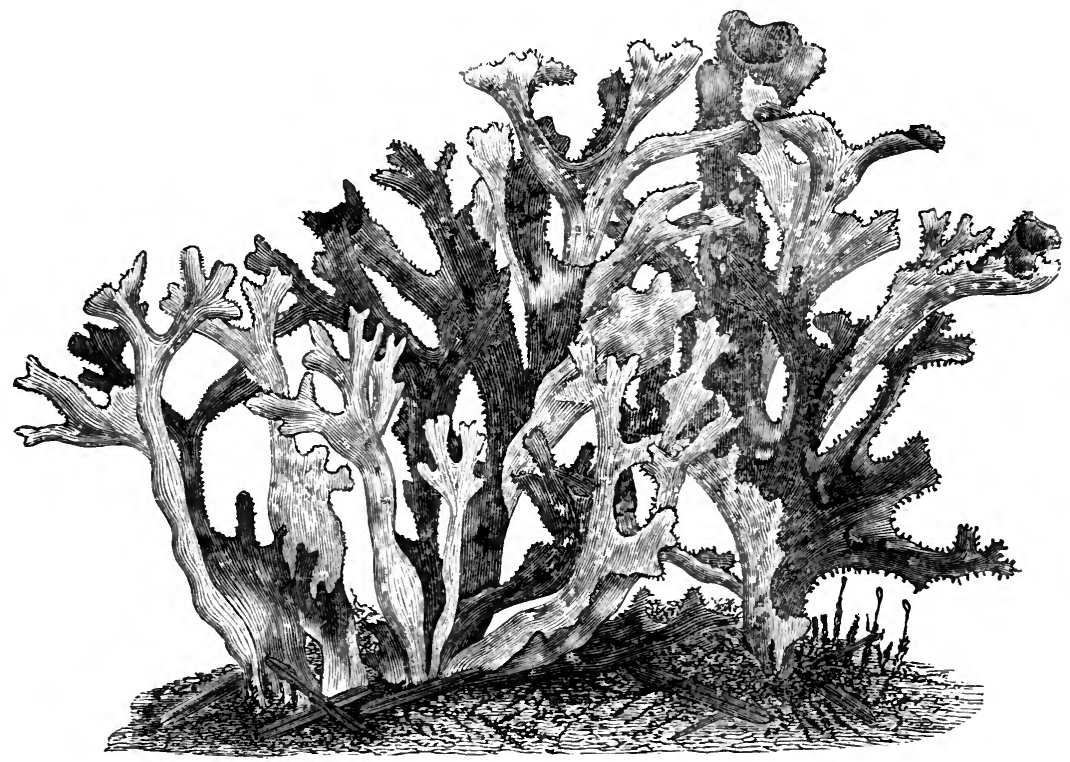

FIG. 283.--Cetraria islandica Ach., a fruticose lichen (natural size).

Stahl experimentally proved this in his successful attempts at lichen synthesis. The algæ which furnish the hosts belong to different groups, and both unicellular and filamentous forms occur.

The thallus of lichens is of two sorts, the heteromerous and the 
homoiomerous. The heteromerous thallus mainly consists of the fungus body of the lichen differentiated into a cortical layer and a medullary layer, the algæ occurring either as a definite layer where the cortical and the medullary hyphæ join, or they are scattered throughout the medulla, or form a dense mass in it. Such thalli exhibit considerable variety in forms of growth, and are called foliaceous, fruticose, crustaceous,

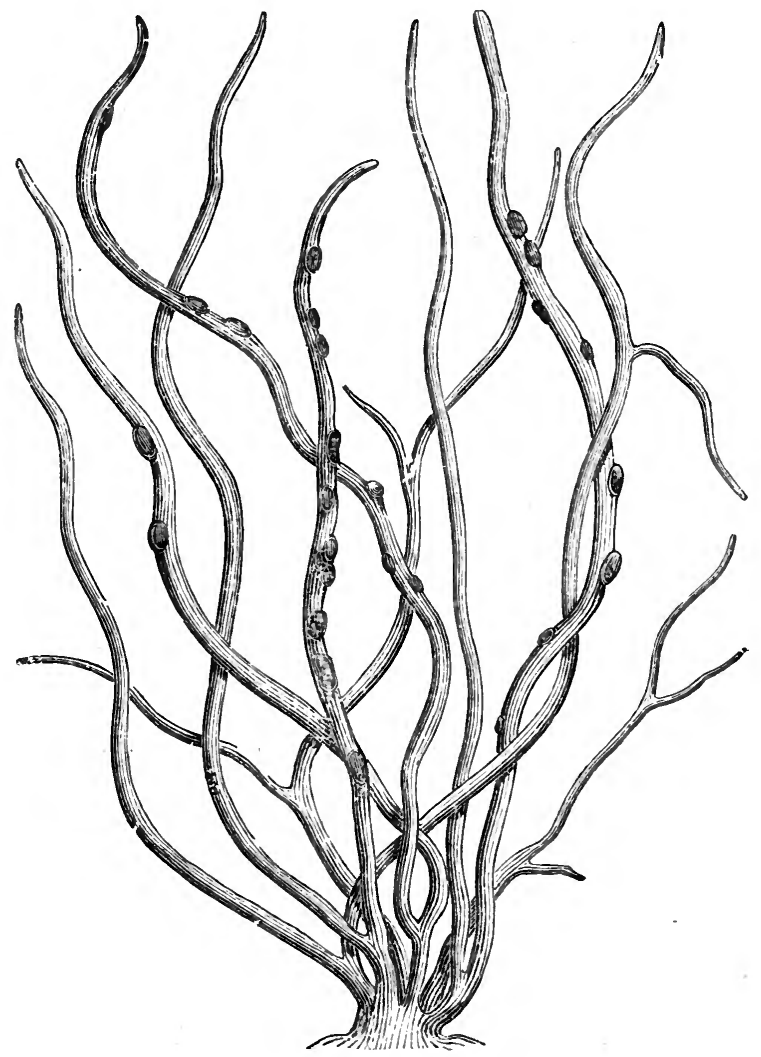

FIG. 284.-Roccella tinctoria DC. A filamentous lichen. Small plant (natural size).

\&c., in descriptive works. The homoiomerous thallus consists of algal cells and hyphæ more or less equally distributed and alike in bulk. Collema, referred to below, is a gelatinous lichen, exemplifying this structure. Though the fungus does not actually prevail in bulk, it modifies the form of the thallus.

Until comparatively recent times, lichens were considered to be 
independent organisms, the algal portion, the so-called 'gonidia,' being regarded as only specially developed cells arising from the colourless cells of the thallus. In 1868 Schwendener first accurately determined their dual nature, though de Bary had two years before indicated the possibility of this state of things in the case of the Collemaceæ, \&c. The discovery so far, though sufficiently convincing, was based on anatomical considerations only, but the matter was finally proved, as well as a thing can be proved, by the experiments of Bornet, Treub, Reess, and Stahl. Reess succeeded in producing the thallus of Collema by synthesis, and Stahl went a step farther, and effected the formation of no less than three species of lichen. His observations on the relations of the algal and fungal elements of the lichen-thallus crowned the work of demonstration of its dual nature. Many systematic lichenologists who have been unable to shake off the traditions of their study still cling to the old view of the independent nature of lichens. It is hardly necessary to point out that the judgment of morphologists on such matters is the one to be trusted, especially as the matter has once and for all passed beyond the state of trust in authoritative opinion into the perfect state of complete proof.

\section{Literature (Books of General Reference).}

$D_{\mathrm{e}}$ Bary-Vergleichende Morphologie u. Biologie der Pilze, Mycetozoen u. Bacterien (Leipzig, 1884). [Translation by Garnsey and Balfour, Oxford, Clarendon Press, 1887, referred to in text as de Bary, Comp. Morph., \&c.]

(In the above book a complete guide to the detailed morphological literature will be found.)

\section{Systematic.}

Saccardo-Sylloge Fungorum (1882, in progress). This work is intended to include all known Fungi.

The student should also consult the numerous works of Fries, dealing chiefly with Basidiomycetes; Corda's Icones Fungorum (Prag, 1837-54); and for British Fungi, Berkeley's Outlines of British Fungology (1860) ; Cooke's Handbook of British Fungi (1871); the same author's Illustrations of British Fungi (I88I, in progress) ; Stevenson's Hymenomycetes Britannici (Edinburgh, I886) ; and Phillips' Handbook of British Discomycetes (London, I 887).

\section{Diseases of Plants caused by Fungi.}

Frank-Krankheiten der Pflanzen (Breslau, 1880-81).

Sorauer-Handbuch der Pflanzenkrankheiten (Berlin, I886).

Snith, W. G. - Diseases of Field and Garden Crops (London, 1884).

\section{Literature of Lichen-thallus.}

This literature is too vast to be quoted here in detail, but the reader is referred to the following essential papers.

Bornet-Recherches sur les gonidies d. Lichens (Ann. Sc. Nat., sér. 5, xvii. and xix.). Johow-Ueber Westind. Hymenolichenen (Sitzber. Berl. Acad., I884). 
Reess-Ueber d. Entstehung d. Flechte Collema glaucescens (Monber. Berl. Acad., I871).

Reess-Ueber d. Natur d. Flechten (Samml. wiss. Vorträge von Virchow u. v. Holtzendorff, 1879).

Schwendener-Die Algentypen d. Flechtengonidien (Basel, r869).

Schwendener-Erörterungen z. Gonidienfrage (Flora, 1872).

Schwendener-Die Flechten als Parasiten d. Algen (Verh. d. Basel. naturf. Ges., I873).

Stahl-Beitr. z. Entwickel. d. Flechten, ii. (Leipzig, I877).

Treub-Lichenencultur (Bot. Zeit., I873).

Treub--Onderzoek. over d. Natuur d. Lichenen (Diss.) (Leiden, 1873).

SPECIAL literature is quoted under each group.

\section{GROUP I.-PHYCOMYCETES.}

\section{Class XVIII.-Oomycetes.}

\section{Order i.-PERONOSPOREe.}

The thallus of the Peronosporeæ consists of irregularly and copiously branched hyphæ inhabiting for the most part the living, and especially the chlorophyll-bearing, tissues of terrestrial flowering plants of different natural orders. The mode of life in this case is parasitic, and the hyphæ usually follow the intercellular spaces, and in many cases send short processes termed haustoria into the adjoining cells. These haustoria are variously formed according to the species. They are generally branched in Peronospora (Corda) and globular in Cystopus (Lév.). The hyphæ of other species (Phytophthora, de By.) traverse the cells of the host-plant. Trans-
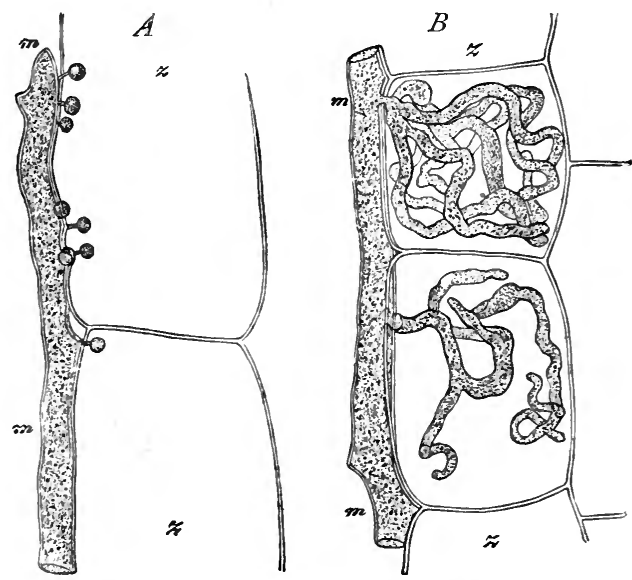

FIG. 285. - Intercellular mycelial hyphæ $(m)$, with haustoria penetrating into cells $(z), A$, of Cystopus candidus Lév.; $B$, of Peronospora calotheca de By. ( $\times 390)$. (After de Bary.) verse walls do not commonly appear in the hyphæ until the period of the formation of reproductive organs. The effect of this parasitic mode 
of life on the host is extensive destruction of the tissues, usually ending in death. Hypertrophy is produced in other cases, especially at the time of the formation of oosperms, leading to swellings and distortions of the parts affected.

Of the species of Pythium (Pringsh.) transferred to this order by de Bary (Bot. Zeit., I88I) from the Saprolegnieæ, some are saprophytes inhabiting the dead bodies of both plants and animals, while others are both parasites and saprophytes.

The oogones are globular cells with either a smooth or a granulated wall of some thickness, situated, as a rule, terminally, or more rarely interstitially. Soon after separation by a transverse wall from the hypha which bears it, the protoplasm of the oogone, which is rich in drops
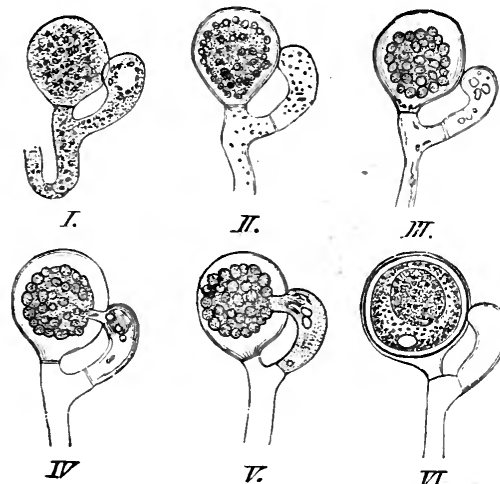

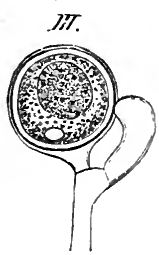

n.

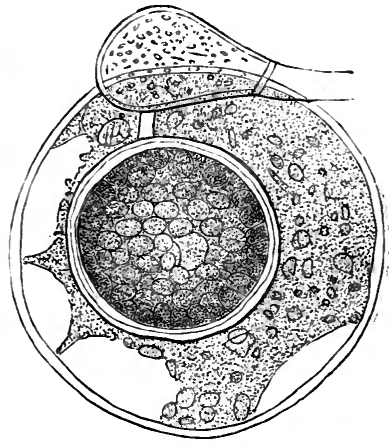

VII

FIG. 286.-Fertilisation of Peronosporeæ. I.-VI., Pythium gracile Schenk. Successive stages accord: ing to numbers ( $x$ about 800 ). VII., Peronospora arborescens de By. Oosphere is invested with a thick membrane, outside of which is the periplasm contracting to form outer coat of oosperm ( $x 600)$. (After de Bary.)

of fatty matter, begins to collect into a central mass containing the drops and bounded by a hyaline layer. Outside this central body (osphere) there is left over a clear mass of protoplasm (periplasm), which fills up the space between it and the wall. While the oogone is thus developing, the antherid arises, either from the pedicel-cell of the oogone itself, or as the terminal cell of a neighbouring branch. It has commonly the form of an irregularly bent tube with an unthickened cell-wall, and at first ordinarily granular protoplasm. It applies itself closely to the wall of the oogone, and sends through it a delicate straight impregnating tube, which penetrates to the surface of the oosphere. The protoplasm of the antherid also undergoes about this period a differentiation into two masses ; one, threadlike but irregular, and occupying the middle, 
contains the more granular particles, and is termed the gonoplasm, while the other (periplasm) surrounds it. The gonoplasm enters the oosphere through the impregnating tube of the antherid, and thus accomplishes the act of impregnation. Sometimes two, rarely more, antherids arise and apply themselves to the oogone, and this varies both with species and individuals. After impregnation the oosperm assumes a cellulose membrane, and gradually ripens. The fatty contents collect into one body occupying the middle, and the membrane becomes thicker and differentiated into two cellulose layers, the extine and the intine. The periplasm develops into a brown, often granulated and warty membrane, the extine, enclosing the oosperm, while the original wall of the oogone generally breaks up, but may in some cases persist.

The oosperms germinate in water after a period of rest generally lasting throughout the winter ; and this takes place either by the emission of a germ-tube which gives rise directly to a new thallus like the parent one, or the protoplasm divides into a number of zoospores, which, extruded together within a globular sac and escaping from it, swim for a short time, and, after settling down, push out each a germ-tube which produces a new thallus. In other species, again, both methods of germination occur, some of the oosperms directly emitting germ-tubes, while in the others the production of zoospores intervenes. In certain species, the oosperms of which produce a germ-tube directly, a short mycele (promycele) is formed, which, after bearing a few conidiospores, dies, and these conidiospores in turn propagate new thalli.

The non-sexual organs of propagation (conidiospores) are borne upon special branches of the thallus (sporophores) in a variety of ways characteristic of the genera and in a minor degree of the species. These germinate either by means of a germ-tube directly produced, or the contents break up into zoospores, which, after swarming, settling down, and becoming invested with a membrane, also produce germ-tubes.

The usual course of life is the production upon the thallus of vast numbers of conidiospores, which propagate the species extensively throughout spring and summer, followed in autumn by the bearing of sexual organs, with which the generation terminates. De Bary points out ('Comp. Morph., ' $\&$ c., r 884) that only in the instances above mentioned of the production from the oosperm of a promycele bearing a few conidiospores, can a distinct alternation of generations be recognised. There is indeed merely the succession of one oosperm-bearing generation to another, the propagating spores being only accessory products of the thallus. In such cases as Pythium vexans (de By.) and Artotrogus (Mont.), for example, there are no such organs of propagation at all, or at least long-continued research, has failed to discover them. Other 
species appear again to have lost the power of producing sexual organs, and this is notably the case in Phytophthora infestans (de By.), the potato-disease fungus, which succeeds in hibernating by means of a perennial mycele. In such a case the species is entirely dependent upon the propagating spores for distribution.

Cystopus (Lév.).-The thallus consists of hyphæ inhabiting the intercellular spaces of the tissue of flowering plants, and provided with

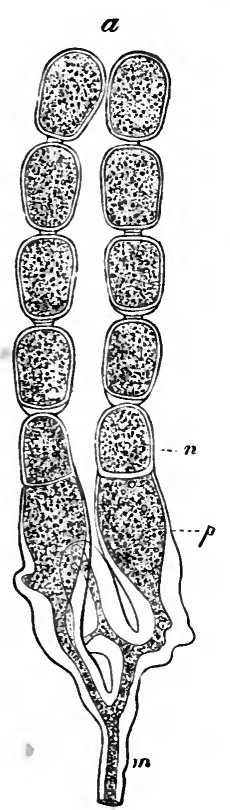

FIG. 287. - $m$, mycelial branch of Cystopucs Portulacea Lév., producing two sporangiophores, $p$, bearing zoosporanges, $\boldsymbol{n}$, in series $(\times 390)$. (After de Bary.) haustoria. The oosperms are resting-cells which germinate in spring by means of the production of zoospores in the usual way. The propagating zoospores are borne in zoosporanges at the end of cylindrical or club-shaped zoosporangiophores in vertical series. A small broad swelling first appears at the apex, and then a transverse wall cuts off the upper portion, which rounds off and thus becomes the first and oldest zoosporange of the series. Then another is cut off in the same fashion, while the sporangiophore elongates. A series or chain is thus produced, each zoosporange joined to its neighbour by a very short and slender connecting stalk. The first cell at the top of the series has a thicker wall than the others, is yellowish in colour, and is, at least in the vast majority of cases, incapable of germination. If germination does take place, a germ-tube is said to be produced, while all the other members of the series give rise to zoospores. 'These chains of zoosporanges arise in dense masses side by side below the epiderm of the host, which is gradually ruptured, permitting their escape, the thick wall of the top member of the series serving as a shield in bursting the epiderm. When the zoospores germinate, their germ-tubes enter the host by way of the stomates, by this means attaining directly the intercellular spaces. The disease thus set up in the host is not so active as in the case of species of Peronospora, and the parts affected do not perish so rapidly. During the formation of oosperms in Cystopus candidus (Lév.), regions of the host undergo acute hypertrophy. The commonest species of the genus is C. candidus ('white rust'), which attacks a large number of Cruciferæ. Cabbages and the Shepherd's Purse (Capsella bursa-pastoris) suffer conspicuously from it, while the latter is often affected by Peronospora parasitica (de By.) in company with it: Other well-known species are C. Portulaceæ (Lév.) and C. cubicus (Lév.). 
Peronospora (Corda).-The thallus and the sexual organs closely resemble those of Cystopus. In both genera the passage of protoplasm from the antherid into the oogone is not directly visible, and the oogonial periplasm is more abundant than in the other genera. In germinating, the oosperm produces a germ-tube, but the process of germination has not been observed in a number of species, and, as de Bary says (Journ. Roy. Agric. Soc., I 876), it is quite possible that the species of Peronospora which, like Cystopus, produce zoospores from their 'conidia' (zoosporanges) present also the same phenomenon in connection with the oosperms. The sporophores of Peronospora commonly issue from the host-plant through the stomates, and are, for the most part, regularly and copiously branched. At the fine points of the branches the non-sexual propagating bodies are produced singly. These are in some species conidiospores germinating by the emission of a germ-tube, and in others zoosporanges producing zoospores. Conidiospores and zoosporanges are borne in precisely similar fashion, and present the same appearance up to the production of the germ-tube or zoospores, as the case may be. The zoospores are formed within, and escape from the original zoosporangial membrane and not from an extruded sac. Intermediate between these forms are the plasmatoparous species (P. densa, Rab., and P. pygmæa, Ung.), in which the whole protoplasm escapes from the spore in a mass through the opening of a papilla-like point in the wall, and, at once becoming globular, secretes a cellulose membrane, and subsequently germinates by the emission of a short thick germ-tube. The germ-tubes both of zoospores and of conidiospores penetrate directly the epiderm of the host and the cells underlying it, until an intercellular space is reached. This genus contains a large number of well-known parasites, such as P. viticola (de By.) on the vine, P. nivea (de By.) on Umbelliferæ, P. parasitica (de By.) on Cruciferæ, P. Schleideniana (Ung.) on onions ; P. Viciæ (de By.), P. Trifoliorum (de By), \&c. Hypertrophy is frequently produced in the host at the time of oosperm-formation, but not so acutely as by Cystopus. The oosperms of several species are unknown, and of these P. Rumicis (Corda) and P. Schachtii (Fückel) hibernate by means of their perennial mycele, while P. Ficariæ (Tul.), the oosperms of which are known, passes the winter in the same way.

Phytophthora (de By.).- This genus was founded for the reception of $\mathrm{P}$. infestans (de By.), which was formerly placed in Peronospora. Industrious research has failed to discover the sexual organs and oosperms of this species. Mr. Worthington Smith claims to have found them, but the balance of evidence is distinctly against this. The sexual organs of Phytophthora omnivora (de By.) have been 
observed, however, and fertilisation takes place in the usual way. A very small quantity of gonoplasm (not visibly differentiated) passes over into the oosphere. The antherids and oogones arise together in this species, and develop in close connection. The oosperms form each a promycele, as described above. The sporangiophores of

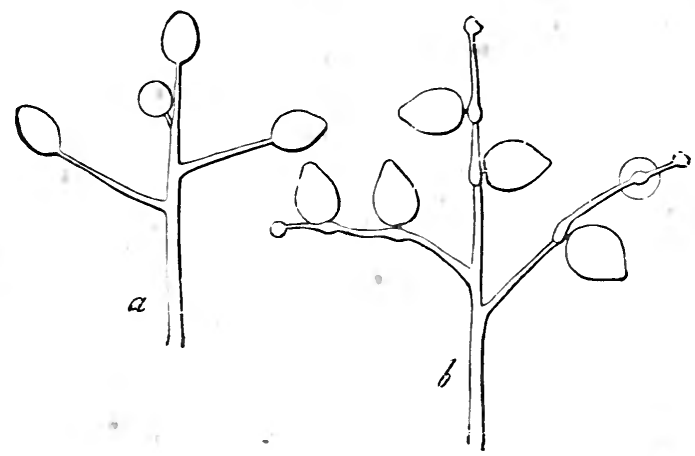

FIG. 288.-Simple sporophores of Phytophthora infestans de By. a, formation of first spores (zoosporanges) at ends of branches : $b$, two ripe spores on cach branch and a third being formed ( $x$ about 200 ). (After de Bary.)

Phytophthora, which resemble those of Peronospora in general habit, differ from them in the fact that each branch bears more than one propagating body-not in chains, like Cystopus, but at intervals on the branch. In P. infestans a propagating cell is produced at the apex of each branch ; and as it ripens a papilla-like swelling arises beneath it ;

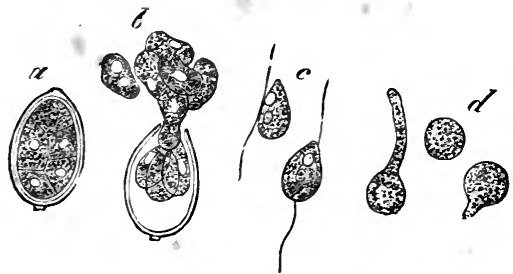

Fig. 289.-Zoosporanges of Phytophthora infestans de By. $a$, division completed; $b$, escape of zoospores ; $c$. free zoospores ; $d$, spores come to rest and germinating ( $x$ 390). (After de Bary.) the branch grows on and turns the cell aside. These propagating cells are usually zoosporanges, but not unfrequently they are conidiospores, differing from them in no other respect than the production of a germ-tube directly instead of zoospores. The zoospores are formed within and escape directly from the zoosporange itself, as in Peronospora.

Phytophthora infestans has a special economic interest, as the cause of the well-known potato-disease. The disease first appears, as a rule, on the green leaves of the potato plant in July or August, the sporangiophores emerging through the stomates. Sporanges are formed, under favourable conditions of temperature, moisture, \&c., in a few hours, are 
wafted away, and, falling on ather potato leaves, there produce zoospores, or germ-tubes directly, in drops of water formed by dew or rain. The germ-tubes penetrate the epiderm, setting up fresh growths of mycele in new plants, and thus the disease is propagated. Countless numbers of such propagating cells, each potentially the mother of a number of zoospores, may thus be set free from a few diseased plants, and the spread of infection and destruction of tissue in warm moist weather is almost inconceivably rapid. The disease extends to all parts of the plant, including the tubers, in which the mycele often remains in a resting condition throughout the winter (as in certain species of Peronospora mentioned above), and from which a fresh start is made in the following year. The interest attaching to the subject is mainly economic, and an extensive literature bearing upon it has grown up-by far the greater part of it utterly worthless.

Pythium. (Pringsh.).-Several species of this genus are saprophytes, inhabiting the dead bodies of plants and animals, while others are true parasites on fresh-water algæ, on prothallia, and on flowering plants. The thallus and sexual organs are of the type described. The oosperms of P. proliferum (de By.), like those of Phytophthora omnivora, form a promycele; while of $\mathrm{P}$. vexans (de By.) the oosperms only are known. The formation of propagating spores occurs at the end of simple thallushyphæ. A terminal cell is cut off by a transverse wall, and usually becomes a zoosporange. This body expands at the apex into a thin globular sac, into which the whole of its protoplasm empties itself. There zoospores are differentiated, and, bursting the sac, escape and germinate. There is some variation according to species in the forms of the zoosporanges; sometimes they are round or oval and sometimes elongated. They have not the definite arrangement which characterises the other genera. P. intermedium (de By.) and P. de Baryanum (Hesse) sometimes form spores which emit a germ-tube instead of the usual zoosporanges. P. gracile (Schenk), P. entophytum (Pringsh.), and P. Chlorococci (Lohde) inhabit fresh-water algæ, P. Equiseti (Sad.) and P. circumdans (Lohde) attack prothallia; while P. de Baryanum infests seedlings of different phanerogams and fern-prothallia. The last-named is capable of attaining full development as a saprophyte on both dead plants and animals. P. intermedium, also saprophytic, becomes a parasite on fern-prothallia. It is worthy of note that these fungi are parasitic only on seedlings, prothallia, \&c., which contain abundance of water ; and though P. de Baryanum causes local injury to grown plants, this power may be raised to one of destruction under water. Pythium vexans is found in diseased potato tubers. 


\section{Fossil Form.}

Peronosporites (W.G.S.).-This genus was founded by Mr. Worthington Smith for the reception of a fossil fungus Peronosporites antiquarius (W.G.S.), first detected by Mr. Carruthers in the axis of a Lepidodendron from the coal measures. Mycele and bodies which may well be oogones are visible in the preparations. The fungus is probably nearly related to Pythium.

\section{LiteratuRe.}

De Bary-Recherches sur le développement de quelques Champignons parasites

(Ann. Sc. Nat., 4 sér., Tom. xx.). (Contains reference to older literature.)

De Bary-Zur Kenntniss der Peronosporeen (Beitr. zur Morph. u. Physiol. d. Pilze, ii.).

De Bary-Untersuch. uiber die Peronosp. u. Saprolegn. (ibid., iv.).

De Bary-Research into the Nature of the Potato-fungus (Phytophthora infestans de

By.) (Journ. Roy. Agric. Soc., I876, xii.).

De Bary-Zur Kenntniss der Perozosporeen (Bot. Zeit., I88I).

Cornu-Monogr. d. Saproleg. (Pythium) (Ann. Sc. Nat., 5 sér., Tom. xv.).

Hesse-Pythium de Baryanum, Halle, 1874.

Millardet-Le Mildiou (Paris, G. Masson, I882 ; and Journ. d'Agric. pratique, I 88 I, T. i., No. 6, and I882, T. ii., No. 27).

Pringsheim-Die Saprolegnieen (Pythium) (Jahrb. wiss. Bot., i.).

Schröter-Peronospora obducens (Hedwigia, I877, p. I29).

Schröter-Protomyces graminicola (ibid., 1879, p. 83).

W. G. Smith-Resting-spores (so called) of Potato Disease (Gard. Chron., I875, iv., N.S. ; and 1876 , vi., N.S.).

W. G. Smith-Peronosporites antiquarius, W. G. S. (Gard. Chron., I877). [See also G. Murray, Academy, I7 Nov. 1877 and following numbers; and Williamson, Phil. Trans. Roy. Soc. Lond., I88I.]

A. Zalewski-Zur Kenntniss der Gattung Cystopus (Bot. Centralb., 1883, No. 33).

\section{Order 2.-ANCYlisteæ.}

This order embraces a few genera which, so far as what is known of them indicates, are related most nearly to Pythium. All the members of the group) are parasitic in fresh-water algæ (Cladophora, Mougeotia, Spirogyra, Mesocarpus, Closterium, \&c.), and they are all farther characterised by simplicity of structure. The thallus is represented by hyphæ at first undivided, which often extend from one end of the host-cell to the other. Ancylistes Closterii (Pfitz.) displaces the chorophyll-plates of its host, and ultimately causes the death of the cell. Lagenidium (Schenk), found in filamentous algæ, causes the separation of cell-contents from cell-wall, and discolours the chlorophyll, which gathers together into a mass.

The sexual organs are formed by the division into cells of the thallushyphæ by transverse walls. Of these cells, some swell and become oogones, while others remain small and act as antherids (Myzocytium, 
Schenk); or different individuals produce the oogones and the antherids (Lagenidium, Ancylistes). A perforation having been made in the oogonial wall, the whole of the protoplasm of the antherid empties itself into the oogone (there being no periplasm), and the united mass rounds itself off and becomes the oosperm. The germination of the oosperm has not been observed.

Propagation takes place by means of zoospores (Lagenidium), and to this end either the whole thallus-hypha becomes transformed into a zoosporange, or it is divided into a series of such. Each zoosporange sends out through the membrane of the host-cell to the surrounding water a protuberance, through which the contents escape after the fashion of Pythium, forming uniciliated zoospores, which ultimately attack the fresh cells of other algæ. In Ancylistes the only propagation known is a process of extension of its hyphæ from one host to another.

\section{LITERATURE.}

Cornu-Monogr. des Saprolegn. (loc. cit.).

Cornu-Note sur l'oospore du Myzocytium proliferum, Schenk (Bull. Soc. Bot.

France, xvi., 1869, p. 222).

Pfitzer-Ein neuer Algen Parasit (Monatsber. Berl. Acad., 1872).

Schenk-Ueberdas Vorkommen contractiler Zellen im Pflanzenreich (Würzburg, i 858). Zopf-Ueber einen neuen parasitischen Phycomyceten, \&c. (Lagenidium) (Bot. Zeit., I879, p. 35I).

\section{Order 3.-Monoblepharidee.}

The single genus Monoblepharis(Corn.), like the preceding group, is closely related to Peronosporeæ and especially to $\mathrm{Py}$ thium. The thallushyphæ bear both terminal and interstitial oogones, in which there is no preliminary differentiation of periplasm, but the whole protoplasm contracts and forms the oosphere, while the apex
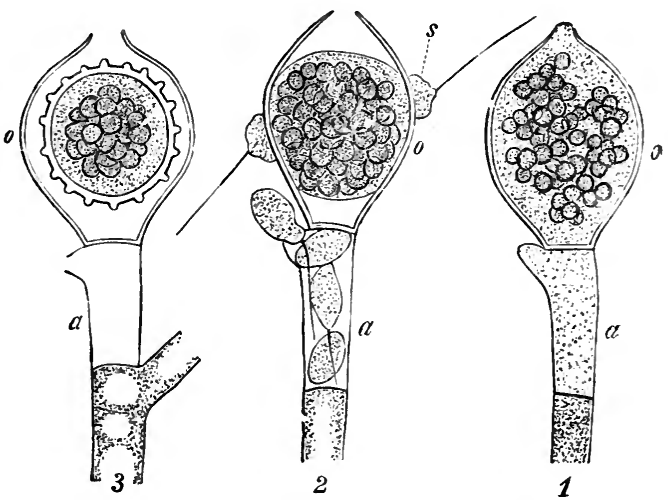

FiG. 290.-Monoblepharis spharica Cornu. Filament bearing an oogone, $o$, and antherid, $a$, antherozoid, $s$. The numbers indicate successive stages $(\times 800)$. (After Cornu.)

of the oogonial wall opens. The antherid (usually a cell adjoining an oogone) produces several swarming antherozoids, which escape, one of 
them attaining and entering by the apical opening of the oogone, and uniting with the oosphere. The resulting oosperm has not yet been observed to germinate.

Propagation takes place by the formation of uniciliated zoospores in zoosporanges, from which they escape in the same way as those of Phytophthora.

\section{LiteratuRE.}

Cornu-Monogr. des Saprolegn. (loc. cit.).

\section{Order 4.- SAPROLEgNiEe.}

The Saprolegniex, as their name indicates, are saprophytes on the dead bodies of both plants and animals in water ; with at all events the exception of the Saprolegnia of the salmon disease, which is both saprophyte and facultative parasite. The cause of the predisposition to this disease has not yet been exactly determined, as for example has been the case with those species of Pythium which possess a similar mode of life. Prof. de Bary points out with regard to them that susceptibility to disease in the host is in relation to the amount of water present. The problem in the case of the salmon disease has every appearance of being a more complex one. The Saprolegnieæ bear in other respects much resemblance to the Peronosporeæ, and especially to Pythium, which until recently was included among the former. Pythium indeed presents points of relationship with the types of Oomycetes in general; and the relationship is rendered the more striking by the union in some of its species of both parasitic and saprophytic modes of life. The thallushyphæ of the Saprolegnieæ are usually of relatively large size, springing from slender rhizoids buried in the substratum.

The oogones arise, as in Peronosporeæ, on branches of the thallushyphæ. In most cases, however, several oospheres are formed in each oogone (sometimes as many as thirty or forty), and, no periplasm having been differentiated, the whole of the oogonial protoplasm is included in them. It happens in some cases that only one oosphere is formed, but the number is variable according to species, and also partly according to individuals. Pits arise, but by no means always, in the oogonial wall.

The antherids, which are commonly club-shaped, are produced on slender branches of the thallus; and each antherid is borne either on the same hypha of the thallus as the oogone to which it is attached, or on a hypha which bears no oogones. The remarkable point about these antherids is their impotency, since no actual observation of the transference of protoplasm from them to the oospheres has ever been made, though they perforate the oogonial wall, and processes, like impregnating tubes sent through, come in contact with the oospheres. These processes grow from one oosphere to another, and may even 
emerge again outside the oogonial wall, but they remain closed at all points, and after a day or two perish. In the case of certain species, the antherids never produce these processes, or the oogones may be without antherids. In other cases antherids are never produced at all, or only by way of rare exception. In the meantime the oospheres ripen into oosperms, while the antherids, if present, perish. Pringsheim has recently endeavoured to show that impregnation takes place in certain species by the transference into the oospheres of minute portions of antheridial protoplasm moving in amœeboid fashion. De Bary points out that, while Pringsheim has not actually seen this, the sole evidence trusted to is that of stained preparations, which appear to exhibit open communication between antherid and oosphere, \&c. In any case the observation does not affect those cases where antherids are either wanting, or do not produce the penetrating tubular processes.

The ripe oosperms thus parthenogenetically produced germinate after a period of rest varying from a few days to several months. Germination takes place, as in the Peronosporeæ, either by means of a germ-tube, or zoospores are produced.

Propagation is effected by the agency of zoospores produced in special zoosporanges, and also exceptionally by means of certain restingcells formed by the mycele after transverse division of the hyphæ (Saprolegnia). These swell out into globular form, with thick membranes and plentiful protoplasm, and germinate by the emission of a germ-tube, or zoospores are formed in them ('resting sporanges' of 
Pringsheim). These resting cells or sporanges are formed only on old myceles, and by no means regularly.

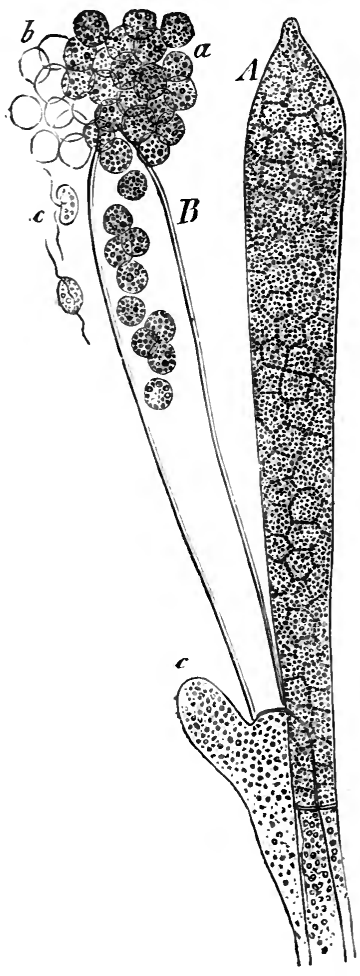

FIG. 292.-Zoosporanges of Achlya N. ab E. $A$, with zoospores formed but still enclosed. $B$, with zoospores escaping. At $a$ they are invested with a cell-membrane, at $c$ they are free, empty membranes at $b$ ( $x$ about 300$)$. (After de Bary.)

The zoosporanges vary in form with the genus, and in a minor degree with the species. The usual form is a large clubshaped zoosporange containing a great number of biciliated zoospores, which escape from it through an opening at the apex; though in poorly developed individuals (and normally in Aphanomyces, de By.), the zoosporange is more cylindrical, and only one row of zoospores is formed. In Saprolegnia (Nees ab Esenb.) the zoospores are actively motile when they escape. Their activity ceases for the most part after a few minutes; they settle down, assume a thin cellulose-membrane, rest for a short time, only to escape from this membrane, and resume active movement before final settling down and germination. The spores of individuals may on the other hand omit the second period of movement, and germinate directly on first settling down. In Achlya (Nees ab Esenb.) and Aphanomyces the spores escape from the sporange without cilia and active movement. They arrange themselves in globular fashion outside the apex of the sporange, assume each a thin cellulosemembrane, within which they rest for a few hours, and, escaping from it, swim about, and, settling down, ultimately germinate. In the sporanges of Dictyuchus (Leitg.) the spores are each enclosed in net-like cellulose walls, from which they escape, not by any special orifice of the sporange, but by taking as it were the shortest cut through the sporangial wall and empty spore-cases if they come in the way.

In Aplanes Braunii (de By.) the formation of propagating spores is as a rule omitted. When produced they give rise to germ-tubes directly without swarming.

The zoospores produced by oosperms behave, so far as is known like those from the corresponding zoosporanges. 
The modes of zoospore-formation in Phytophthora and Cystopus, Pythium Achlya, and Aphanomyces, Dictyuchus, and lastly Saprolegnia, express in an interesting way the relationships of these genera.

\section{LITERATURE.}

De Bary - Beitr. zur Kenntniss der Achlya prolifera (Bot. Zeit., I 852).

De Bary_Einige neue Saprolegnieen (Pringshein's Jahrb. wiss. Bot., ii.).

De Bary-Untersuch. über die Peronosp. u. Saprolegn. (Beitr. zur Morph. u. Physiol. der Pilze, iv.).

De Bary $-Z u$ Pringsheim's Neue Beob. ïber d. Befruchtungsact der Gattungen Achlya und Saprolegnia (Bot. Zeit., I883).

Cornu-Monograph. der Saprolegn. (Ann. Sc. Nat., I872).

Hildebrandt-Mycolog. Beiträge, i. (Pringsheim's Jahrb. wiss. Bot., vi.).

Hartog-On the Formation and Liberation of Zoospores in the Saprolegniex (Quart. Journ. Micr. Sc., I887).

Hartog-Recent Researches on Saprolegnieæ (Annals of Botany, 1888).

Huxley and Murray-Salmon Disease (Reports of Inspector of Fisheries, I882, I883,

I884, I885. See also Quart. Journ. Micr. Sc., I882, and Journ. Bot., I885).

Leitgeb-Neue Saprolegnieen (ibid., vii.).

Lindstedt-Synopsis der Saprolegn., Berl., I872.

Pringsheim-Entwickelungsgeschichte der Achlya prolifera (N. Acta Acad. Leop.Carol., xxiii., p. I \%.

Pringsheim-Beitr. zur Morph. u. Systematik d. Algen, ii. Die Saprolegn. (Jahrb. wiss. Bot., i., ii., and ix.).

Pringsheim-Neue Besbacht. über d. Befruchtungsact von Achlya u. Saprolegnia (Sitzber. Berl. Acad., 8 Juni, 1882). Nachträgliche Bemerk. zu dem Befruchtungsact von Achlya (Pringsheim's Jahrb. wiss. Bot., xiv.).

Reinsch-Beobacht. ïber einige neue Saprolegn. (ibid., xi.).

Thuret-Rech. sur les zoospores des Algues, I85I.

Ward-On Saprolegnieæ, and also on Pythium (Quart. Journ. Micr. Sc., I883). Contain histological details.

\section{Class XIX.-Zygomycetes.}

\section{ORDER I.-MUCORINI.}

The Mucorini are for the most part terrestrial saprophytes, the remainder being parasites on other Mucorini. The thallus consists of a copiously branching hypha undivided up to the time of the production of spores or sporanges, when transverse walls first appear. Sexual reproduction is effected by the formation of a zygosperm, while spores and propagating cells (like some of the resting-cells produced by the mycele of Saprolegnia) are also borne, the former regularly and in characteristic forms, the latter only in special cases and under certain conditions. 'The production of a zygosperm is effected by the conjugation of two specially differentiated cells, gametes, not to be distinguished from each other by any mark or power of movement. The two cells thus contributing to 
its formation either, by their simple fusion, themselves constitute the zygosperm, or this body is the direct offspring (daughter-cell) of the union. The spores are produced either in terminal sporanges or singly at the apex of a sporophore, or again serially in like fashion to the last. In a considerable number of cases the zygosperms are unknown, and it

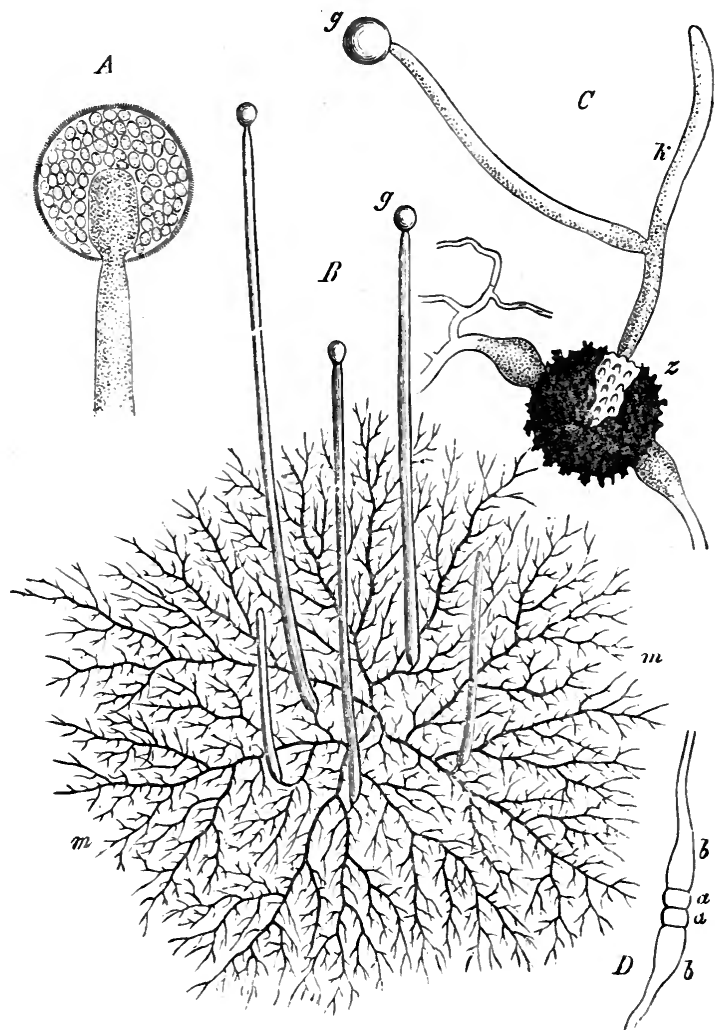

FIG. 293.-B, Phycomyces nitens Kze. Plant grown on decoction of plums ; mycele, $m$, sporophore, $g$. $A, C$, and $D, M$ ucor Mucedo L. $A$, sporange in optical longitudinal section. $C$, zygosperm $(z)$ borne on suspensors. $k$, germ-tube; $g$, sporange. $D$, conjugation. $a$, $a$, gametes; $b, b$, suspensors. ( $B$ slightly, $A, C$, and $D$ more highly magnified.) (After Brefeld.)

may be assumed, on the weighty authority of de Bary, that in certain of these they do not occur, since industrious observation has failed to discover them. They are known, in fact, only in nineteen species, though future research may bring a fair number more to light. Where they have been observed the life-history proceeds as follows. The germinating 
zygosperm gives rise directly to a promycele bearing the characteristic spores, and these in turn produce on germination a mycele which bears spores again, and ultimately a zygosperm. It has been observed in an artificially nourished individual, that the germinating zygosperm at once produced a mycele which subsequently bore spores without the intervention of the promycele stage. In another instance (Sporodinia grandis, Link) zygosperms have been observed on a mycele which arose from a spore, before the production of sporophores upon it ; while it sometimes happens in this species that a zygosperm is produced on a mycele arising directly from a zygosperm without the intervention of spores at all. But in the great majority of cases the production of spores precedes the formation of a zygosperm on the same mycele. In many species the zygosperms are of rare occurrence, and an indefinite number of successive spore-bearing generations come between zygosperm and zygosperm. Throughout the whole order spores are produced in vastly greater numbers than zygosperms. Syzygites (Ehrenb.) is the generic name given to certain forms of doubtful affinity which produce, so far as is known, zygosperms alone.

Sub-order I : MUCOREÆ.-The members of this group are for the most part saprophytes on the excrement of animals, fruits, bread, saccharine fluids, \&c. The thallus-hyphæ are relatively large and much ramified. The conjugating hyphæ arise either as branches of the mycele or on special hyphæ somewhat resembling sporangiophores, their place of origin being, in different instances, in either morphological or merely local approximation to each other. At an early stage of development they come into contact by their apices, and a firm connection between the two is established. Thus joined the development of each goes on, and soon a transverse wall cuts off the apical portion of each. This portion is a gamete, and the rest of the hypha, generally club-shaped, its suspensor. A pore next appears in the centre of the original wall separating the two gametes, and gradually the whole wall disappears and the contents conjugate. The zygosperm thus formed increases in size, drawing upon the contents of the suspensors. The protoplasm becomes dense, and the fatty contents gather into a large drop. The wall commonly becomes covered externally with warts or spines at all points except where the suspensors are attached. The form of the whole is roundish or drum-shaped, the smooth walls adjoining the suspensors corresponding with the sides of the drum. The wall is divided into two coats, the outer one (extine) brown or black, and the inner one (intine) stratified, and either entering the corrugations of the extine or remaining smooth along the surface of contact with it. The suspensors usually remain in statu quo, but in Rhizopus nigricans (Ehrenb.), where 
one gamete is about half the height, though of the same breadth, as the other, the suspensor of the smaller one becomes greatly enlarged after conjugation, while the other remains as it was. In most cases the suspensors eventually decay, but in others (Phycomyces, Kze., and Absidia, Van Tiegh.) an outgrowth of darkly coloured hyphæe takes place from each suspensor and invests the zygosperm. In Mortierella (Coemans), which has a smooth extine, this outgrowth arises from the hyphæ bearing the suspensors (as well as from the suspensors in one case), and forms a compact integument of the zygosperm. In M. nigrescens (Van Tiegh.) this outgrowth begins after conjugation, first from the suspensors, then from the adjoining hyphr; while in M. Rostafinskii (Bref.) the outgrowth
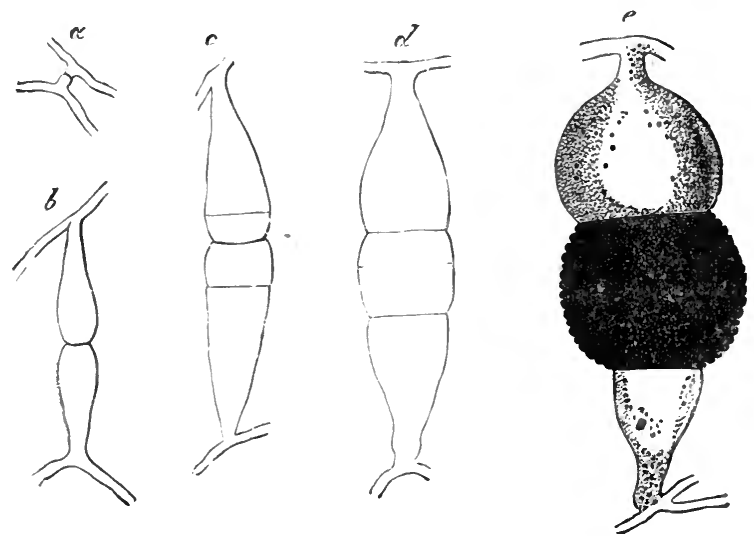

FIG. 294. - Rhizopus nigricans Ehr. Formation of a zygosperm. Stages according to 1 tters ( $x$ about 9o). (After de Bary.)

takes place solely from the adjoining hyphæ, and begins so early that an investment is formed before actual conjugation takes place.

A phenomenon resembling that of the parthenogenesis of the Saprolegnieæ is exhibited by a number of the Mucoreæ in the formation of azygosperms. This occurs in Absidia, Sporodinia (Link), and Spinellus fusiger (Van Tiegh.), and the formation of these bodies ensues when gametes have failed to conjugate, and even when single gametes only are produced. They possess the structure and power of germination of normal zygosperms, just as the parthenogenetic oosperms of Saprolegnia do. Bainier states that Mucor tenuis (Link) forms only azygosperms, and de Bary suggests that the (as yet little known) Azygites of Fries may be found to exhibit this phenomenon.

On the germination of the zygosperm, as has been said, a promycele bearing sporanges is produced directly, and these sporanges have the 
same structure as those that follow them. They are globular sacs borne at the end of sporangiophores, and the spores produced within them are never endowed with the power of active movement. The different forms of sporange and sporangiophore afford characters for the genera of the group. Mucor (Michel.), Pilobolus (Tode), Sporodinia (Link), Phycomyces, Rhizopus (Ehrenb.), Circinella (Van Tiegh.), and Absidia. possess a peculiar conformation of the basal wall of the sporange. It bulges inwards in a conical or more or less oval form (see fig. $293 \mathrm{~A}$ ), and presents an appearance which has suggested the name of columel for this peculiarity. Of the genera possessing a columel some are distinguished by a fugacious sporangial wall, others by a firm persistent one, while the mode of branching of the sporangiophore (or the absence of branching) and its general form, afford other generic characters. Mortierella has a fugacious sporangial wall but no columel. Tham nidium (Link), Chætostylum (Van Tiegh.), and Helicostylum (Cord.) have two kinds of sporange, the one kind like those of Mucor, and the other smaller (sporangioles) with a persistent wall, no columel, and containing but a few spores, which however resemble the others in function.

On old and on badly nourished myceles of some species, accessory propagating bodies are formed (chlamydospores, stylospores, \&c.). All such accessory spores are capable of giving rise to normal characteristic myceles either at once or after a period of rest. In Mortierella single acrospores are borne on slender mycelial hyphæ. The old myceles and even the sporangiophores of Mucor break up into resting-cells like those of Saprolegnia with thick walls. The chlamydospores (Van Tieghem) of Mortierella are such bodies, and where they occur terminally, de Bary regards them as transitional forms to the acrospores of the same genus just mentioned. Brefeld and Van Tieghem have described (Mucor racemosus, Fres., \&c.) another form of accessory propagating spores, which are produced in series or chains through transverse division of the mycelial hyphæ. These either remain joined together in conferva fashion, as Berkeley says, or they part company, and each such cell exhibits a yeast-like vegetation.

Sub-order 2: ChæтосLAdiEÆ.-The mycelial hyphæ of Chætocladium (Fres.) become attached to the hyphæ of the Mucor-host, and, by the resorption of the cell-wall at the place of contact, effect a direct communication. At such places of attachment a large number of globular protuberances are produced close together, forming a body of considerable size, which may be regarded as a food-reservoir. The act of conjugation and the formation of the zygosperm agree in all essential particulars with the corresponding processes in the Mucorex. The intine 
of the zygosperm has a smooth surface, not entering the external warts of the extine. Azygosperms have not been observed. The sporophores terminate in a fine hair-point, but below this give rise to a whorl of branches nearly at right angles to each other, terminating again each in a hair-point. These again branch more or less in like fashion. The ultimate branches become swollen, and on these swellings fine short sterigmata arise, each sterigma bearing a spore. The mass of spores thus produced has a bunch-like aspect.

Cunningham's Choanephora, found by him on the flowers of Hibiscus, appears to approach most nearly to Chætocladium.

Sub-order 3 : Piptocephalideæ.-This very small group (Piptocephalis, de By., Syncephalis, Van Tiegh.) is, like the last, composed of parasites on the Mucoreæ, and to this end the mycelial hyphæ bear

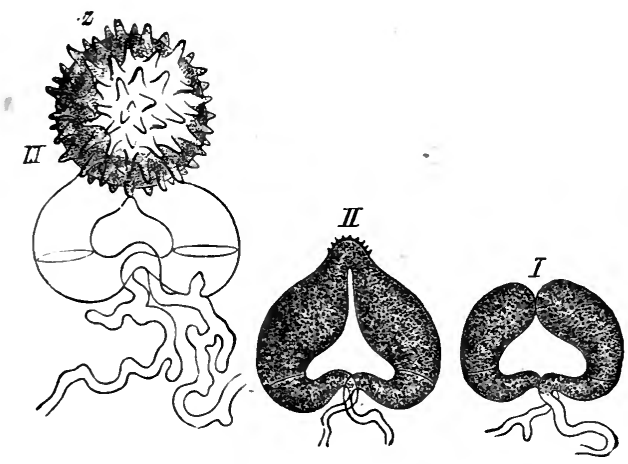

FIG. 295.-Piptocephalis Freseniana de By. and Wor. Conjugation and formation of a zygosperm, $z$. Stages in the order of the numbers ( $\times$ 650). (After Brefeld.) haustoria, each of which emits from its slightly swollen base a small crop of short delicate rhizoids traversing the Mucor-hypha affected. The conjugating hyphæ of Piptocephalis are arched somewhat like an inverted $\cap$, the point of contact being the summit. Actual conjugation occurs, as in the Mucoreæ; but when this stage is reached, the product of the conjugation begins to swell at the point of union, and generally on the convex side, into a globular body, which becomes echinulate as it swells. When it has attained its full size and development at the expense of the protoplasm of the united ganietes, it becomes separated from them by transverse partition, and remains seated, as it were, on the summit of the arch. Though not the morphological equivalent of the zygosperm of the Mucoreæ, but rather the offspring of the original zygosperm produced by the conjugation of the gametes, it will be most convenient to regard it as the zygosperm. The sporophores bear at their apices series or chains of spores produced by transverse partition. In Piptocephalis the sporophore is dichotomously branched at the summit, and each bifurcation bears a capitulum of chains of spores. Accessory acrospores are sometimes prcduced by Syncephalis. 
De Bary ('Comp. Morph.,' p. I 56) treats the incompletely known Dimargaris and Dispira, both of Van Tieghem, as at present doubtful Mucorini, probably near Piptocephalideæ. Another small group of genera of doubtful position is formed by Kickxella (Coem.), Martensella

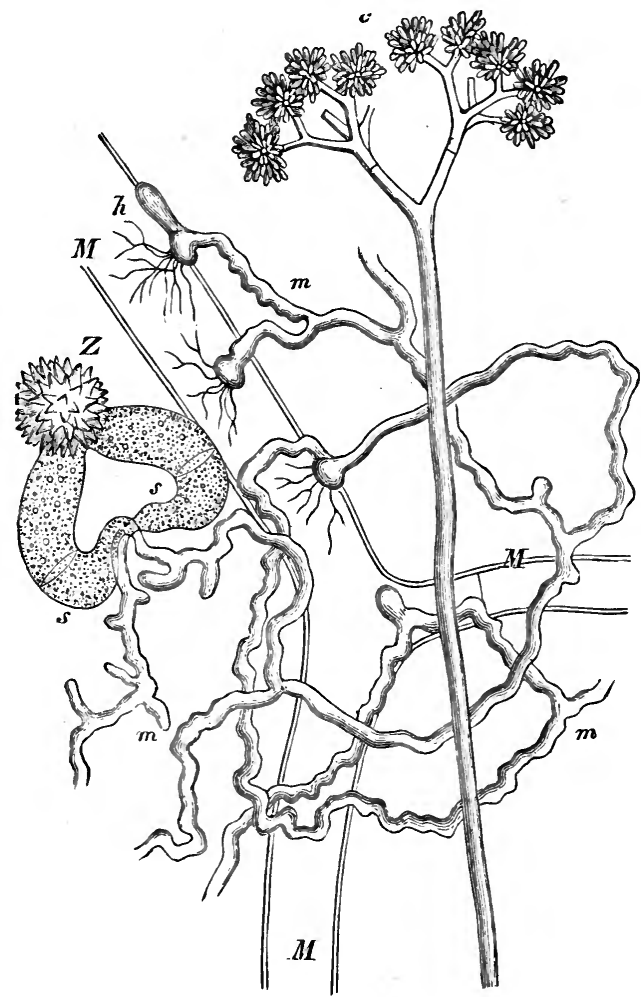

Fig. 296. $-P$. Freseniana. $M$, a mycelial tube of Mucor Mucedo, the host of Piptocephalis. The mycele of the latter, $m$, penetrates $M$ by haustoria, $h$. $Z$, zygosperm. $c$, sporophore $\left(\times 300\right.$, the rest $\left.\times 6_{30}\right)$. (After Brefeld.)

(Coem.), Coemansia (Van Tiegh. and Le Mon.); while Sorokin's Zygochytrium, an aquatic saprophyte on dead insects, the account of which needs confirmation, stands in a like uncertain position.

\section{LiteratuRE.}

Bainier-Observ. sur les Mucorinées et sur les zygospores des Mucorinées (Ann. Sc.

Nat., 6 sér., Tom. xv., I883).

De Bary und Woronin-Beitr. zur Morph. u. Physiol. der Pilze, i. and ii.

Brefeld-Bot. Unters. iiber Schimmelpilze, i. and iv. 
Brefeld - Ueber Gährung, iii. (Landw. Jahrb., Thiel, v., I876).

Coemans-Spicilège mycologique (Bull. Soc. Bot. Belg., i.).

Coemans-Quelques Hyphomycetes nouveaux (Bull. Acad. Roy. de Belgique, 2 sér.,

Tom. xv.).

Coemans-Recherches sur le polymorphisme et les différents appareils de réproduction

chez les Mucorinées (ibid., Torn. xvi.).

Coemans-Monographie du genre Pilobolus (Mém. Couronn. de l'Acad. Roy. d.

Belgique, Tom. xxx.).

Cunningham - On the Occurrence of Conidial Fructification in the Mucorini, illustrated

by Choanephora (Trans. Linn. Soc. Lond., 2 ser., i., I 878 ).

Fresenius-Beitr. zur Mycologie, i. and iii.

Gilkinet-Mém. sur le polymorphisme des Champignons (Mém. Couronn. Acad.

Belg., Tom. xxvi., I875).

Hildebrand-Ueber zwei neue Syzygites Formen (Pringsh. Jahrb., vi.).

Klein-Zur Kenntniss des Pilobolus (Pringsh. Jahrb., viii.).

Tulasne-Note sur les phénomènes de copulation, \&c. (Ann. Sc. Nat., 5 sér., Tom. vi., I 866).

Van Tieghem et Le Monnier-Rech. sur les Mucorinées (Ann. Sc. Nat., 5 sér., Tom. xxvii., I873).

Van Tieghem-Nouv. Rech. sur les Mucorinées (ibid., 6 sér., Tom. i., 1875).

Van Tieghem-Troisième Mém. sur les Mucorinées (ibid., 6 sér., Tom. iv., I876).

Zimmermann-Das Genus Mucor (Ćhemnitz, 1871).

\section{ORDER 2.-ENTOMOPHTHOREÆ.}

This small group of parasites inhabiting the bodies of insects agrees with the Mucorini only in the formation of zygosperms. The mycele vegetates within the body of the insect attacked, and consists either of septate branching hyphæ (Entomophthora, Fres.), or of a yeast-like mass of cells (Empusa, Cohn). Zygosperms are formed, as described by Nowakowski (Entomophthora ovispora, Nowak., and E. curvispora, Nowak.), by the conjugation of adjacent hyphæ which emit corresponding lateral protuberances. These meet, become united in an $\mathrm{H}$ fashion (somewhat as in Spirogyra), and enter thus into open communication. As a result of this conjugation, there arises, either on the conjugating branches or near them, a globular body, which develops at the expense of the protoplasm of the united hyphæ, and finally becomes cut off by a wall. This must be regarded as a zygosperm, morphologically the equivalent of that of Piptocephalis. Azygosperms occur in E. radicans (Bref.) and certain species of Empusa, arising either as lateral outgrowths, or sometimes as terminal bodies. The cell-membrane of both zygosperms and azygosperms becomes much thickened and differentiated into a thick extine, generally of regular outline, and a thin intine, while. in the contents a large fatty drop appears. Zygosperms and azygosperms both rest for a considerable period within the dead body 
of the host, the surrounding mycele disappearing. On germination, which Nowakowski describes in Empusa Grylli (Fres.), a short promycele is emitted which bears a single spore.

Commonly, however, neither zygosperms nor azygosperms are formed, and after the death of the insect, spores are produced on its outer surface. In the case of Empusa-for example, E. Muscæ (Cohn), which attacks the common house-fly in large numbers in autumn-tine yeast-like mycelial cells, at the time of the death of the insect, send forth each a tube, which hursts through the skin, and outside becomes a short club-shaped sporophore bearing a single acrospore. Each sporophore bears but one spore, and then perishes. The spores are capable of germination at once, but the power lasts only for a few days. Affected flies in this condition are common enough objects attached to windows, \&c., and surrounded by a whitish mass of spores. The mycele of Entomophthora, which is septate, much branched, and often anastomosing, sends branches through the skin to the outer surface, where farther ramification takes place, investing the body of the insect. These branches range themselves at right angles to the insect's body, and terminate together at nearly the same elevation. Each such branch is a sporophore, which, as in Empusa, forms a single acrospore. The spores are capable of germination at once like those of Empusa; and in both genera either a very short tube is formed, bearing a secondary spore, as in the promycele of the zygosperm, which, on germination, may attack a fresh insect, or the germ-tubc of the primary spore may do so without the intervention of secondary spores.

Completoria complens (Lohde), found by Leitgeb in fern prothallia, and Conidiobolus utriculosus (Bref.), described by Brefeld as a parasite on Tremellini, are two forms placed here which, unlike the rest of the group, do not attack inșects. Brefeld, who has investigated the group minutely, does not accept the conjugation as a real one, and brings forward arguments against it based on the anastomosing of hyphæ and the situation of the zygosperms. His opinion, if accepted, would lead to placing the group elsewhere; but de Bary states ('Comparative Morph.,' p. I 59) that Nowakowski's and Brefeld's different observations may be explained by the different behaviour of different species.

\section{LITERATURE.}

Brefeld-Untersuch. über die Entwickel. der Empusa Muscæe und Empusa radicans und die durch sie verursachten Epidemien der Stubenfliegen und Raupen (Abhandl. d. Naturfórsch. Gesellsch. zu Halle, xii.).

Brefeld-Ueber Entomophthoreen und ihre Verwandten (Sitzungsber. d. Gesellsch, Naturforsc'.1. Freunde zu Berlin, 1877). See also Bot. Zeit., r877, p. 345.

Brefeld-Bot. Unters. über Schimmelpilze (Ent. radicans), iv., 1881, p. 97. 
Cohn-Empusa Muscæ und die Krankheit der Stubenfliege (Nova Acta, xxv., p. 1).

Cohn-Ueber eine neue Pilzkrankheit der Erdraupen (Tarichium megaspermum)

(Beiträge zur Biologie der Pflanzen, Bd. i., Heft I, p. 58).

Eidam-Eine auf Excrementen von Fröschen gefundene Entomophthoree (Bot.

Centralblatt, xxiv., 1885 ).

Fresenius-Ueber die Pilzgattung Entomophthora (Abhandl. d. Senkenberg. Ges., Bd. ii.).

Giard--Deux espèces d'Entomophthora, \&c. (Bull. Sc. du Départ. du Nord, 2 sér., 2 Ann., No. 11 ).

Frey und Lebert-Die Pilzkrankheit der Fliegen (Verhandl. d. Naturf. Ges. zu Zïrich, I856).

Leitgeb-Completoria complens, ein in Farnprothallien schmarotzende Pilz (Sitzungsber. d. Wien. Acad., Bd. 84, Abth. I).

Nowakowski-Die Copulation bei einigen Entomophthoreen (Bot. Zeit., I877).

Nowakowski-Entomophthoreæ (Abhandl. d. Acad. d. Wiss. zu Krakau, I883). Polish, see Bot. Zeit., I 882.

Sorokin--Zwei neue Entomophthora Arten (Cohn's Beiträge zur Biol. d. Pflanzen, Bd. ii., Heft 3 , p. 387 ).

\section{Order 3.-Chytridiaceæ.}

The Chytridiaceæ are a group of minute, more or less aquatic, parasitic fungi, embracing forms which may, in the present state of our knowledge of them, be thus classed together ; but whether it will eventually appear that these are naturally related to each other, or are merely organisms of different affinities presenting a similar appearance owing to similar environment and ways of life, is but a subject for speculation. However, there are points in which all agree, and their life-history may be briefly sumnıarised thus :-Zoospores - mostly uniciliated (the rest with two cilia), and containing generally a drop of fatty substance, and, in the larger forms at least, a nucleus - are produced in zoosporanges of various forms and sizes. These escape from the apex of the zoosporange, which is provided in some cases with a lid, either successively or in a mass held together by a viscous substance, from which they are gradually set free. An undulating alteration of outline, accompanied by amœboid movement, takes place in the zoospores of certain species towards the end of the period of their activity. The zoospores give rise again to zoosporanges. Resting-spores are known in certain cases, which likewise give rise to zoosporanges ; while in the Rhizidieæ a process probably intermediate between oogamous reproduction and isogamous conjugation takes place. Of the four sub-orders, the first (Rhizidiea) is manifestly nearly related to the Mucorini and the Ancylisteæ; the second (Cladochytriece) may be regarded as allied to the Rhizidieæ; the third (Olpidiea) and the fourth (Synchytriea) in all probability following the second. De Bary suggests ('Comp. Morph.', p. 169) that in 
this order the whole group may be looked upon as a lateral branch of the Mucorini or Ancylisteæ successively modified (degraded) by aquatic parasitism, with its extremity represented by the Synchytrieæ, Woronina (Cornu), and Rozella (Cornu). De Bary also discusses (loc. cit.) the suggested relationship to such algæ as Protococcaceæ, Characium, Chlorochytrium, \&c. Apart from the possession of chlorophyll, the conjugation of zoospores in these algæ separates them from the Chytridiaceæ, in which group such a process has not (at least as yet) been discovered. Granting a relationship of the simpler Chytridiaceæ with Protococcaceæ, \&c., these might be regarded as leading up to Rhizidieæ, Ancylisteæ, and Mucorini ; unless one regards the Chytridiaceæ as composed of two distinct sub-groups, Rhizidieæ and Cladochytrieæ, related to Mucorini and Ancylisteæ; and the Olpidieæ and Synchytrieæ to Protococcaceæ, \&c. Only further research may determine these questions of affinity.

Sub-order i : RHIZIDIEÆ.-The life-history of Polyphagus Euglenæ
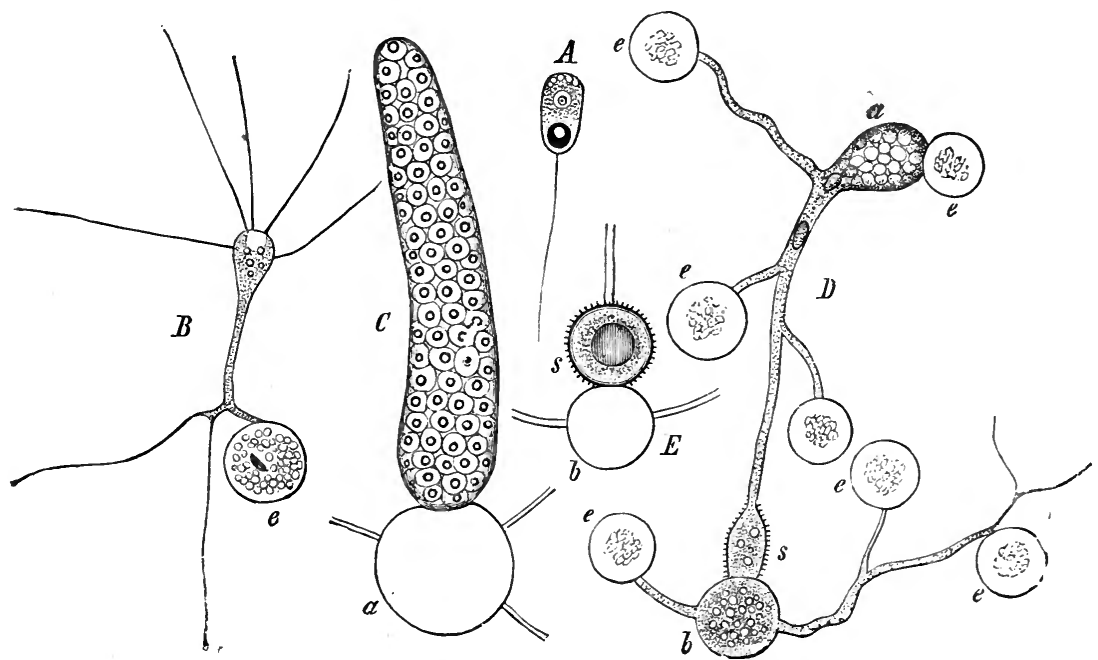

FIG. 297.-Polyphagns Euglence Now. A, zoospore with drop of fatty matter and nucleus. $B$, young plant attached to resting Euglena, $e$. $C$, zoosporange containing spores resting on empty prozoosporange, $a$. $D$, conjugation: $a$, the receptive individual ; $b$, the supplying individual ; $s$, the swollen end of conjugation tube (rudiment of resting-spore); $e, e, e$, the Euglenæ. $E$, portion of $D$ five and a half hours later: $b$, empty, $s$, mature; represent the same parts as in $D$. $(A \times 550$, $B, D, E, \times 350, C \times$ about 400 .) (After Nowakowski.)

(Nowak.), described by Nowakowski, furnishes us with the most highly developed type of the whole group. The mycele consists of very slender branching rhizoids, tapering each to a very thin point, and attaching themselves to the Euglena-hosts. The original germinating zoospore 
from which these arose remains, as it were, the centre of the system of rhizoids, and, nourished by them, grows considerably in size. At length, when it has attained full development, it becomes a prozoosporange, since from it there grows out a thick, cylindrical, thin-walled process, into which all the protoplasm passes, and within which it breaks up into zoospores. These, escaping, repeat the life-history. Zygosperms (or oosperms) are produced by the conjugation of gametes, which play unequal parts in the process. The one (supplying) individual is round and larger than the other (the receptive) individual. A rhizoid from the receptive individual places its apex in contact with the supplying individual itself, and begins to grow in girth. The cell-wall at the place of contact disappears, the protoplasm of both unites and passes into a swelling which has arisen on the conjugating tube of the receiving individual close behind the place of contact. This swelling then becomes the zygosperm, which is provided with a thick wall, sometimes covered with fine spines, appearing as early as the outset of the swelling process. It happens-though rarely - that the tubes of two or three receptive individuals attach themselves to one supplying plant, and a corresponding number of zygosperms is thus formed. After a period of rest, the zygosperm germinates by producing a zoosporange. Generation after generation of zoosporanges intelvene between zygosperm and zygosperm. "Which of the two should be called the male and which the female, is not easy to determine. . . . It is evident that we have before us an intermediate case between the ordinary forms of oogamous and isogamous conjugation.' (De Bary, loc. cit., p. I63.)

A series of incompletely-known forms may be placed beside Polyphagus (Nowak.), viz.:-Physoderma (Wallr.) (pro parte), Rhizidium (A. Br.), Rhizophydium (Schenk), Obelidium (Nowak.), Chytridium (A. Br.), Phlyctidium (A. Br.). Resting-cells of some of these have been found, but their genesis is unknown.

Sub-order 2: CladochytrieÆ.-This is a small sub-order, the members of which mostly inhabit the tissues of marsh plants, and possess copiously branching mycelial rhizoids, bearing terminal and interstitial zoosporanges. The zoospores give rise on germination to a mycele like the parent one. Resting zoosporanges occur. No process of conjugation is known either between filaments or zoospores. Cladochytrium (Nowak.) and Physoderma (pro parte) compose the sub-order.

Sub-order 3: OLPIDIEÆ.-The Olpidieæ are wholly destitute of a mycele, and the life-history, as described by Fischer for Olpidiopsis Saprolegniæ (Fisch.), and O. fusiformis (Cornu), which inhabits species. of Achlya, is a very simple one. The zoospores of O. Saprolegniæ perforate the young mycelial hyphæ of Saprolegnia, and, after a few days of 
growth in amœboid fashion, a cell-wall is secreted, and each becomes a zoosporange. Swellings arise on the mycele of the host as the result of this parasitism. The zoosporange then sends forth a cylindrical process, which perforates the wall of the Saprolegnia, and through it the zoospores are discharged. The zoosporanges are either smooth and capable of emission of zoospores at once, or are covered with fine spines and capable either of emission at once or of resting. While the latter are generally formed under adverse circumstances, it seems to occur with some regularity that the zoospores of the smooth zoosporanges give rise to spiny zoosporanges, and vice versâ. The life-history of these two species may be taken as typical, and the incompletely-known species of Olpidium (A. Br.) doubtless conform to it.

Sub-order 4 : Synchytrieæ.-The Synchytrieæ inhabit the epiderm of terrestrial Flowering Plants, in which they excite the production of small yellow or dark-red galls, owing to the abnormal swelling of the epidermal cells affected. Like the Olpidieæ, they have no mycele, but they are distinguished from that sub-order by the formation of a sorus of zoosporanges. From the germinating zoospore an initial cell is formed, the contents of which break up into a sorus of zoosporanges. In Pycnochytrium (de By.) (= Chrysochytrium, Schroet., and Leucochytrium, Schroet.) the initial cell is a resting-cell, which eventually germinates by the gradual protrusion of its contents into a globular sac seated upon the extine. Within this sac the sorus of zoosporanges is formed by the division of the protoplasm. Each zoosporange produces a considerable number of zoospores, which again give rise to resting-cells. In Eusynchytrium (Schroet.) an indefinite number of sorus-forming generations, which at once produce zoospores, intervene between resting-cell and resting-cell; while in Synchytrium Taraxaci (de By.) the resting-cell produces a zoosporange without the intervention of a sorus, a process suggestive of the Olpidieæ. No conjugation of zoospores nor any sexual process has been observed in any member of the group.

Woronina and Rozella, which inhabit Saprolegnieæ, may be placed with Synchytrieæ.

De Bary (loc. cit., p. I 70) treats as doubtful Chytridiaceæ (I) Tetrachy trium triceps (Sorok.), the zoospores of which are said to conjugate; and (2) Hapalocystis mirabilis (Sorok.), the zoospores of which are described as conjugating within the mother-cell. The observations, however, require confirmation.

Beyond the general reference to Professor de Bary's 'Comparative Morphology,' \&c., the student is specially referred to that source with regard to this incompletely-known group. 


\section{LiteratuRE.}

De Bary-Beitr. zur Morph. u. Physiol. der Pilze, i. (Physoderma [Cladochytrium]).

De Bary und Woronin -Beitr. zur Kenntniss der Chytridieen (Ber. Naturf. Ges. Freiburg, Bd. iii. ; and Ann. Sc. Nat., 5 sér., Tom. iii.).

Woronin-Neuer Beitr. zur Kenntniss der Chytridieen (Synchytrium Mercurialis)

(Bot. Zeit., I868, p. 81).

Woronin-Chytridium Brassicæ (in his paper on Plasmodiophora, Pringsheim's Jahrb. wiss. Bot., Bd. xi.).

Braun-- Ueber Chytridium, \&c. (Monber. und Abhandl. Berl. Acad., I855).

Braun-Ueber einige neue Arten der Gattung Chytridium und die damit verwandte

Gattung Rhizidium (Monber. Berl. Acad., I856).

Cienkowski-Rhizidium Confervæ glomeratæ (Bot. Zeit., 1857).

Cohn-Ueber Chytridium, \&c. (Nova Acta Leop.-Carol., xxiv., Pt. i., p. 142).

Cornu-Chytridinées parasites des Saprolegniées (in Monogr. d. Saproleg., Ann. Sc.

Nat., 5 sér., Tom. xv., p. II2).

Fisch-Ueber zwei neue Chytridiaceen (Sitzber. d. phys. med. Soc. zu Erlangen, I 884).

Fischer-Ueber d. Stachelkugeln in Saprolegniaschlauchen (Olpidiopsis) (Bot. Zeit., I 880).

Fischer-Untersuch. über die Parasiten der Saprolegnieen (Pringsh. Jahrb., Bd. xiii.).

(Berlin Habilitationschrift, I882).

Fischer-Zur Kenntniss d. Chytridiaceen (Erlangen, 1884).

Kny-Ueber Entwickelung des Chytridium Olla (Sitzber. d. Berl. Naturf. Freunde.

See also Bot. Zeit., 1871, p. 870).

Nowakowski-Beiträge zur Kenntniss d. Chytridiaceen (Cohn's Beitr. zur Biol. d. P'flanzen, ii.).

Nowakowski-Polyphagus Euglenæ (ilid., ii.).

Schenk-Algol. Mittheilungen (Verhandl. d. Phys. Med. Ges. zu Würzburg, Bd. viii.). Schenk-Ueber d. Vorkommen contractiler Zellen im Palanzenreiche (Würzburg, 1858 ).

Schroeter-Die Pflanzenparasiten aus der Gattung Synchytrium (Cohn's Beitr. zur Biol. d. Pflanzen, i.).

Schroeter-Untersuch. iiber die Pilzgattung Physoderma (Ber. d. Schlesischen Ges., I882).

Sorolin-Einige neue Wasserpilze (Tetrachytrium triceps) (Bot. Zeit., I874).

Sorokin-Uebersicht d. Gruppe Syphomycetes (Hapalocystis mirabilis) (Arbeiten d. Naturf. Ges. an der Univ. Kazan, 1874, Bd. iv.). (See Just's Jahresbericht, I875.)

Thomas-Synchytrium cupulatum (Bot. Centralblatt, xxix.).

\section{Order 4.-PRotomycetacee.}

Protomyces macrosporus, Ung., to which there have recently been added a considerable number of species, many of them on insufficient grounds, is a parasite on Umbellifers, especially Ægopodium Podagraria, Meum athamanticum, and more rarely Heracleum sphondylium, inhabiting the intercellular spaces of the leaf, petiole, stem, flower-stalk, and pericarp. It possesses a branching septate mycele, at irregular intervals on which there are formed interstitially large somewhat oval 
resting progametanges, with a stratified membrane and dense contents. These persist when the mycele dies, and hibernate. After this period of rest, and on liberation from the decaying tissues of the host (in water), the intine, with the contents, bursts the extine, and, becoming free, constitutes the gametange. Within it a large number of minute short rod-shaped gametes are formed, while a portion of the protoplasm remains unused in the process. These gametes are ejected, and, being without the power of spontaneous movement, they remain
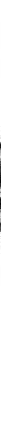

FIG. 298.-Protonyces macrosporus Unger, $a$, a mature resting progametange; $b$, gametange ; $c, d$, and $\ell$, further stages of the same in the development of gametes. $c$ shows the parietal protoplasm, $d$ the same divided into gametes, $e$ the gametes rounded off and separated from the rest of the parietal protoplasmic layer ( $\times$ 390). (After de Bary.)

in more or less proximity to each other. Where pairs of gametes come together, they emit fine processes which conjugate, the whole having the appearance of a dumb-bell or of the letter $H$. The germination of these has been observed on the epiderm of Egopodium ; it takes place by the emission from one of the original gametes of a germ-tube, to the nourishment of which the protoplasm of the united gametes contributes. This germ-tube, on entering the tissues of the host, repeats the life-history.

\section{LiTERATURE.}

De Bary--Beitr. zur Morph. und Phys. der Pilze, i.

Von Thiimen-Eine neue Protomyces Species (Hedwigia, 1874).

Wolff--See footnote to de Bary's paper 'Protomyces microsporus und seine Verwandten' (Bot. Zeit., I874, p. 82).

Other literature of systematic interest in Saccardo's Sylloge.

\section{Order 5.-Ustilaginez.}

The parasites which are grouped together under this name affect Flowering Plants of different natural orders, but are especially conspi- 
cuous as causing diseases of grasses. As a rule the attack of the parasite is limited to one special region of the host, e.g. the ovary, or the whole flower, or the leaf, or the stem, or even, in a few cases, the root; and when the fungus has attained its maturity, the result commonly is that the part affected has been destroyed with the exception of the epiderm or integument and the remains of vascular tissue, and is replaced by a powdery mass of brown or black resting-spores. The mycele sends its long thin hyphæ mostly along the intercellular spaces, in many cases emitting branched haustoria into the adjoining cells, and the resting-

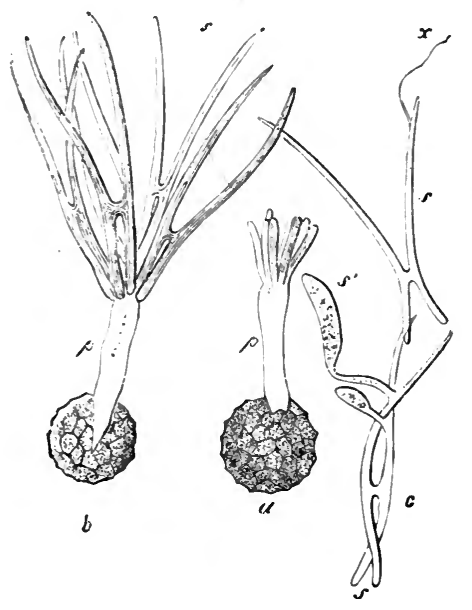

Fir. 299.-Tilletia caries Tul., germinating. In $a$, gametes on promycele, $p$. In $b$, gametes, $s$, coniugate in pairs. In $c$, a germtube proceeding from pair of gametes, $s$. $s^{\prime}$, a sporid $\left(x_{460}\right)$. (After Tulasne.) spores are formed either on all parts of the hyphæ or on particular branches.

The life-history, briefly stated, begins with the production from the resting-spore of a promycele which bears sporid-like gametes; these gametes conjugate in pairs, and the united pair either directly produce a new mycele, or sporids which do so. This mycele then bears restingspores again in another host. Variations on this course of life-history will be mentioned later on. Though these conjugating gametes differ from those of Protomyces in their acrogenous origin on a promycele, they may yet be considered homologues of those, just as the acrogenous spores of Chætocladium are undoubtedly homologous with the endogenuus spores of Mucor.

In Entyloma (de By.) the resting-spores are borne interstitially at indefinite intervals on the mycele, as in Protomyces ; in Tilletia (Tul.) they occur singly, and only terminally on the spore-bearing hyphæ; while in Geminella (Schroet.) they are borne, two together, in series throughout the length of the special hyphæ. In Urocystis (Rabenh.), Sorosporium (Rudolphi), and Tuburcinia (Berk.) they are united, several together, into a kind of coil, which is invested with a transitory or a persistent integument. With the exception, perhaps, of Graphiola (Port.), the exact relationship of which to the Ustilaginer has yet to be determined, Sphacelotheca Hydropiperis (de By.), formerly Ustilago Hydropiperis, according to de Bary's description, affords the best example of a well-developed stroma. This fungus attacks the ovule of 
Polygonum Hydropiper, and replaces it by a dense plexus of hyphæ, which exhibits a differentiation of a thick outer wall enclosing the whole, a cylindrical columel, both colourless, and a dark-violet mass of resting-spores filling up the space between. An undifferentiated basal portion discharges the function, as it were, of a meristem, and adds new elements to wall, columel, and spore-mass. The fungus attacks only the ovule; and as it grows thus in bulk, the unaffected wall of the ovary is burst, and exposes the brittle wall of the sporal mass, which breaks at the slightest touch, and sets the resting-spores free.

The germination of the resting-spores, which are usually round or many-sided, and possessed of both intine and extine, the latter often covered with characteristic fine granulations, varies according as it takes place in water merely or in a nutritive fluid. In water only the restingspores of Entyloma, Tilletia, Tuburcinia, and Urocystis produce a short promycele-tube, which bears simultaneously on its blunt apex a whorl, or 'crown' of elongated gametes, varying in number. Many species of Ustilago (Pers.) and Tolyposporium (Woron.) produce a promycele-tube which divides into a number of cells, from each of which bud off laterally rod-shaped sporids or gametes, somewhat as a yeast-cell buds off. The resting-spores of Thecaphora Lathyri (Kuhn) and Ustilago longissima (Tul.) give rise to a short slender promyceletube, which bears an acrogenous sporid, or several serially; while in Thecaphora hyalina (Fingerh.), Ustilago carbo (Tul.), and U. destruens (Tul.) it divides into several cells, each of which produces, if any, only one sporid.

The conjugation of gametes in pairs takes place either before or after separation from the promycele, by means of short or long cross hyphæ, according to the distance between them. The product of this union is the outgrowth from the connected gametes of a mycelial germtube, or, as occurs in Tilletia, Entyloma, Tuburcinia, and Urocystis, sporids are produced on the outgrowth from the connected pair, and these then emit mycelial germ-tubes. In a number of forms gametes are constantly produced which do not conjugate, but give rise to mycelial germ-tubes, as sporids do, while in Sorosporium Saponariæ (Rudolph.) the resting-spore itself emits the mycelial germ-tube directly, without the intervention of promycele, gametes, and sporids. What occurs regularly in these species may occur exceptionally in the case of individuals the gametes of which ordinarily conjugate; that is, they may fail to produce gametes or sporids at all, or their gametes may fail to conjugate, either all of them, or, where the number of gametes is.an uneven one, the odd gamete. In such exceptional instances the 
resting-spore or the single gamete, as the case may be, produces a mycelial germ-tube, as a sporid does.

When the resting-spores germinate in nutritive fluids, as the experiments of Brefeld show, the product is, according to the species, either directly a mycele which bears spores, or an abundant yeast-like outgrowth from the promycele. In cases where the resting-spores failed to germinate, they were permitted to do so in water, and the sporids so formed, on being introduced into a nutritive fluid, gave rise to myceles bearing acrospores, resembling, as the case might be, either the gametes or the sporids.

Accessory acrospores resembling the sporids are borne on branches of the mycele of certain species of Entyloma before the production of resting-spores. The branches of the mycele which bear them protrude through the stomates and epiderm of the host. They probably giverise to new myceles, as the sporids do. The same thing occurs in Tuburcinia Trientalis (Berk.), only here the accessory spores differ in form from the promycelial sporids. They produce in this case undoubtedly each a mycele which bears resting-spores.

Brefeld regards the conjugation of the gametes as a merely vegetative process, and in no way analogous to any sexual act. De Bary ('Comp. Morph.,' p. I 82) subjects Brefeld's arguments to destructive criticism, while stating Brefeld's case in the fairest terms. While the student is referred to the source quoted for the details, it may be shortly stated that de Bary's arguments are broadly based on the regularity with which conjugation occurs, and on the fact that it takes place equally regularly in pairs, under the normal conditions of germination in water. He shows, besides, conclusively how the process differs from the well-known vegetative anastomosing of hyphæ, \&c.

De Bary regards the higher forms of Ustilagineæ, such as the coilforming. Urocystis, Sorosporium, and Tuburcinia, and Sphacelotheca with its well-developed stroma, as connected through the simpler forms (e.g. Entyloma) with Protomyces. Both produce (in the one case acrogenous, in the other endogenous) conjugating cells of equal value. The next indicated ally is Cladochytrium, the spores of which are zoospores (a matter not affecting the homology), but these fail to conjugate so far as is known. At all events the nearest ally appears to be, in the present state of our knowledge, that group of Chytridiaceæ to which Cladochytrium belongs, through Entyloma and Protomyces.

The peculiarity is to be noted that in Protomyces and the Ustilagineæ the act of conjugation takes place at a stage of the life-history which bears no homology with the sexual states of other Phycomycetes. 


\section{Literature.}

De Bary-Untersuch. iiber die Brandpilze (Berlin, 1853).

De Bary - Protomyces microsporus und seine Verwandten (Bot. Zeit., 1874) (Enty. loma).

Brefeld-Botanische Untersuchungen, v. (Leipzig, I883).

Cornu-Sur quelques Ustilaginées nouvelles (Ann. Sc. Nat., 6 sér., Tom. xv.).

Fischer von Waldheim-Beitr. zur Biologie und Entwickelungsgesch. der Ustilagineen (Pringsh. Jahrb., Bd. vii.).

Fischer von Waldheim-Les Ustilaginées et leurs plantes nourricières (Ann. Sc. Nat., 6 sér., Tom. iv.),

Ed. Fischer-Beitr. zur Kenntniss der Gattung Graphiola (Bot. Zeit., 1883).

Kuhn -Die Krankheiten der Culturgewächse (Berlin, I858).

Prillieux-Quelques observ. sur la formation et la germination des spores des Urocystis (Ann. Sc. Nat., 6 sér., Tonı. x.).

Schroeter-Bemerk. u. Beobacht. ïber einige Ustilagineen (Cohn's Beiträge zur Biologie der Pflanzen, Bd. ii.).

Tulasne-Mém. sur les Ustilaginées comparées aux Uredinées (Ann. Sc. Nat., 3 sér., Tom. vii.).

Tulasne-Second Mém. sur les Uredinées et les Ustilaginées (ibid., 4 sér., Tom. ii.).

Ward-Entyloma Ranunculi, Proc. Roy. Soc., xli. (I886).

Winter-Einige Notizen uiber d. Fam. d. Ustilagineen (Flora, I876).

Wolff-Beitr. zur Kenntniss der Ustilagineen (Bot. Zeit., 1873).

Wolff-Der Brand des Getreides (Halle, I874).

Woronin-Beitr. zur Kenntniss der Ustilagineen (Tuburcinia). (De Bary und Woronin's Beitr. zur Morph. u. Phys. d. Pilze, v.).

The older literature will be found quoted in Tulasne, Fischer von Waldheim, and in de Bary's 'Brandpilze.'

\section{GROUP II.-SPOROCARPE E.}

\section{Class XX-Ascomycetes.}

The Sporocarp.

This large class is distinguished by the universal formation of spores in asci, for the most part tubular in shape, but sometimes broadly ovate or roundish, and borne terminally on special hyphæ termed ascogenous hypha. When an ascus has reached its full size, and only then, the formation takes place within it of ascospores by free-cell formation. The young ascus is at first filled with finely granular protoplasm, which contains a nucleus, and within it a smaller body, probably a nucleole. The protoplasm next gathers itself together at the upper part of the ascus, while a watery fluid occupies the remainder of the cavity except a thin 
layer of protoplasm coating the wall. At this stage the full growth of the ascus is commonly reached, and the formation of ascospores begins with the division of the nucleus into two; then by the same process four appear, then eight, which in the majority of cases represents the number of ascospores. In many Ascomycetes, however, other numbers typically prevail, e.g. one, or two, or four, or sixteen, forty, fifty, and so on to over a hundred. Dothidea (Fr.), for example, has two to four, Sordaria (Ces. and De Not.) four, sixteen, sixty-four, and one hundred and twenty-eight. Whatever the number, the nuclei always possess the same
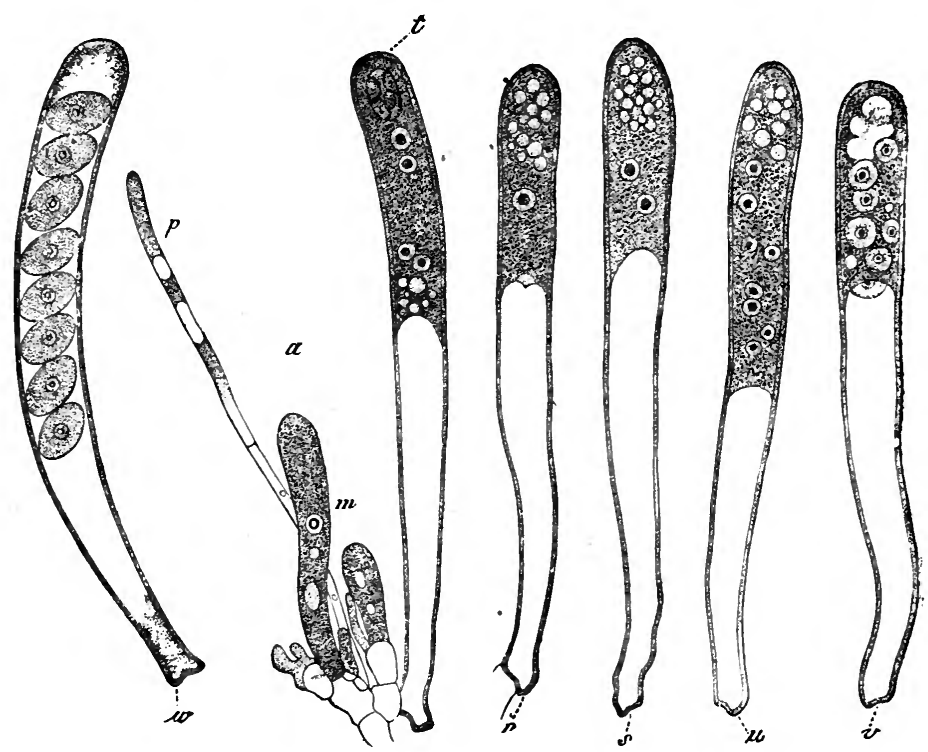

Fig. 300. Peziza (Pyronema) confluens $\mathrm{P}$. a, small portion of hymenium ; $p$, paraphyse attached to, not originating in, hyphal branches from which the three asci spring; $m$, young asci ; $r w$, successive stages, according to letters, in the development of ascospores within asci ( $\times$ 390). (After de Bary.)

structure in all stages of multiplication, but they become smaller in size as the number advances. Round each nucleus there gathers a clear mass of protoplasm, and ultimately this becomes enclosed by a membrane, and, growing in size, thus develops into a spore. The ascospores are arranged in a series, one over the other within the ascus. The protoplasm left over within the ascus and outside the spores differs from that within the spores in exhibiting a reddish or violet-brown colour after treatment with iodine solution. De Bary originally proposed the term 'epiplasm' for this portion of the contents ; but, Errera having. 
shown that it contains a relatively large proportion of glycogen, he has more lately ('Comp. Morph.,' p. 77) adopted for it the term glycogen-mass or simply the glycogen. In certain cases the separation of the glycogen from the protoplasm takes place before the formation of spores, the former occupying the lower part of the ascus, and in some instances both the apical and the basal portions on either side of the protoplasm in which the nucleus is situated and the ascospores are formed.

Such are the asci which characterise the great class of Ascomycetes. They are borne as a rule in considerable numbers mostly between hairlike bodies, the paraphyses, and united into hymenia within special sporocarps. The sporocarps are either seated on a fine mycele or they are borne on a large stroma (thallus), which assumes in different genera diverse characteristic forms. The whole body of the Ascomycetous type is always built up of septate hyphæ.

The sporocarps are composed of two main elements-of the asci with the ascogenous hyphæ, and of the envelope including paraphyses. These two elements, though much interwoven with each other, are of distinct origin. The paraphyses, for example, are never borne by the ascogenous hyphæ, and the asci never by the cells of the envelope; at all events the one thing certain about so-called exceptions is their doubtful character. According to the structure of the mature sporocarp, the Ascomycetes may be classed in three divisions : the Discomycetes, with discocarps or apotheces (hymenia exposed); the Pyrenomycetes, with pyrenocarps or peritheces (hymenia within flask-shaped bodies open at the neck); and a third assemblage of forms with cleistocarps (enclosed hymenia).

The hymenial disc of the apothece, consisting of asci and paraphyses placed perpendicularly to the surface, is when ripe fully exposed. The asci are imbedded, so to speak, in the paraphyses, and the whole mass terminates in a regular surface. The paraphyses originate beneath from a dense plexus of hyphæ called the subhymenial layer or hypothece, directly continuous with the outer envelope termed the exciple or with the tissue of the stroma as the case may be. The paraphyses thus form a part of the envelope-tissue as distinguished from the ascus-apparatus. The ascogenous hyphæ are interwoven with those hyphæ of the hypothece which bear the paraphyses. Terminating upwards in the asci they are barely otherwise distinguishable in the mature apothece, unless in certain cases by their greater size and the blue colour they assume after treatment with potash. The asci grow up between the paraphyses, and reach the surface, as has already been indicated, about the period of ripening. As a rule the apothece exhibits a regular progressive marginal growth, with, in a considerable number of cases, an intercalary 
growth in addition, giving rise to irregularities of shape. The basinshaped apotheces of Peziza (Discomycetes) and of the gymnocarpous lichens are the characteristic forms, while with them may be placed the large stromata of Morchella (Dill.) and allied genera, which are club-shaped and in the form of stalked caps. The Hysterineæ and the Phacidiaceæ, Ascobolus (Pers.), Pyronema (Fckl.), \&c., which show no marginal extension, approach the Pyrenomycetes in this respect.

The perithece does not differ essentially from the apothece. As a rule it is much smaller, rarely more than one millim. in diameter, and it consists of an outer wall enclosing an ascogenous hymenium at all points but one narrow opening, the ostiole. The whole perithece is round or flask-shaped, and the ostiole is simply a pore in the wall or a channel through the neck of the flask. In other words, while an apothece is generally larger, it does not differ in any marked way from a perithece, except that its hymenium has an open surface, while the margin of the perithece is arched over, leaving only a narrow opening for the escape of the spores. The asci arise from ascogenous hyphæ, either exclusively at the base of the perithecial cavity or at all points of the inner surface, and in successive crops, producing in all a considerable number of ascospores. The envelope consists of a wall which, when a stroma is absent and the peritheces appear singly on the mycele, is composed of a dense pseudo-parenchyme clothed sometimes externally with hairs. Where the peritheces are borne on a stroma there is no sharp differentiation of wall-structure. The neck, when present, is bùt a prolongation of the wall, and the ostiole arises (for at first the cavity is fully closed) as an intercellular passage either schizogenously by the separation of tissue through unequal growth, or lysigenously by the absorption of the tract of tissue originally occupying its place. In many cases it is hard to say by which process it arises, and it is likely enough that both sometimes have a share in it. One distinguishes here between paraphyses which arise and stand in relation to the asci as in the apothece, and periphyses, by which is meant other hairs of like origin arising from the hymenium at places where there are no asci-for example, in the region of the neck. Sometimes the periphyses protrude through the ostiole. They are always present in greater or less numbers, except, according to Füisting, in Massaria (De Not.) ; while paraphyses are absent from a number of genera, both of fungi and of lichens. In Chætomium fimeti (Fckl.) the perithece remains closed, and this transition form leads us to the division which possesses cleistocarps.

Just as the peritheces are essentially folded over apotheces, so the cleistocarps may be described in general terms as peritheces which 
with wart-like excrescences, or quite smooth. This peridium consists of a pseudo-parenchyme of densely compacted hyphæ, showing, in the case of Stephensia (Tul.), separate layers. The external cells are denser and thicker-walled than those within, but a gradual transition takes place from one to the other, and again from the latter to the cells composing the veins or seams of tissue which traverse the interior and divide the spore-bearing tissue into chambers. The walls of such chambers in (Genabea (Tul.) possess a pseudo-parenchymatous structure like the peridium, but in general such walls consist of a logser tissue. Only by the perishing of this peridium or its rupture by external agencies do the spores escape.

Certain authors divide the Tuberaceæ into two families, the Tuberea, containing 'Tuber, with an assemblage of allied genera mentioned below; and the Elaphomyceee, containing Elaphomyces, Onygena (Pers.), and Penicillium (Link). Though the sporocarps of Elaphomyces and Penicillium undoubtedly resemble each other, there is at all events as yet hardly sufficient ground for going so far as to assume for Elaphomyces (or Onygena) the life-history of Penicillium. Onygena again, though it may be placed beside Elaphomyces, is hardly near enough morphologically to deserve other than a provisional juxtaposition.

Of the Tuberea, Hydnobolites is the simplest, with asci distributed through the internal tissue, and the peridium represented only by the outer layer of sterile hyphæ. Genabea, with a regularly corrugated peridium and asci arranged in groups imbedded in tracts of sterile hyphæ, forms another type with Terfezia ('Tul.), in which the large masses of fertile hyphæ are separated by branching white seams of sterile tissue. These sterile tracts or seams proceed inwards from the thick peridium. 'There is a third type, characterised by a stout peridium enclosing an internal mass consisting of thick plates of tissue, which proceed from the peridium, and are separated by many narrow channels or chambers. The wall of these chambers bears the hymenium. This type includes the remaining genera Tuber (truffles), Balsamia (Vitt.), Choiromyces (Vitt.), Pachyphlœus ('Tul.), Stephensia, Hydnocystis (Tul.), Hydnotria (B. and Br.), and Genea (Vitt.).

Elaphomyces has a thick, hard, corky peridium consisting of two distinct but united layers. The external one is thin, and either smooth or warty ; the inner thicker, and composed of a dense plexus of thickwalled hyphæ. When ripe the internal substance consists of a dark mass of spores traversed by a delicate cobweb-like capillitium which arises from the inner surface of the peridium. Before maturity the ascogenous hyphæ may be recognised by their greater diameter than the capillitium-hyphæ, but they vanish with the ripening of the spores. 
According to Boudier (Bull. Soc. Bot. France, xxiii., I876), Elaphomyces is probably parasitic on roots; but this is not certainly established.

In Onygena, which inhabits animal remains, the peridium is stalked, and the ascospores (eight in each ascus) become free through the disappearance of the ascus when ripe, and ultimately escape on the rupture of the peridium.

\section{ORIGIN OF THE SPOROCARP.}

The following types, selected by de Bary ('Comp. Morph.,' p. I97) as illustrating the origin of the sporocarp of the Ascomycetes, show an amount of variation in this process which, it may be anticipated, will be extended with farther research into the subject, while certain gaps between these types may be filled up. Taking the most simple instance of the origin of such a sporocarp, that of Eremascus albus Eid. described by Eidam, the sexual act preceding the formation of the sporocarp is manifestly the conjugation of two sexual elements of identical structure. Two cells of the septate mycele send forth, close by the septum which parts them. each a short lateral tube,

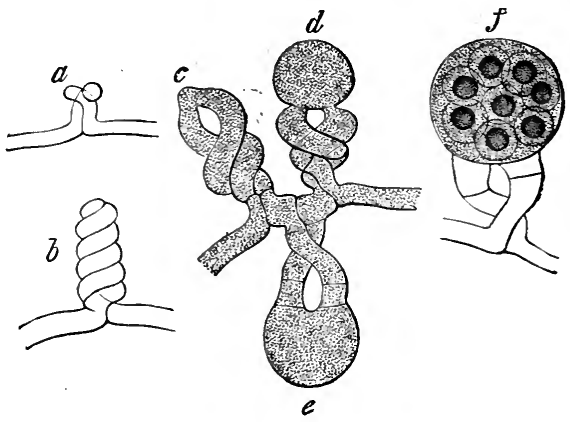

FIG. 302.-Eremascus albus Eidam. Fertilisation and formation of sporocarp. Stages in order of letters. In $f$ the ascospores are formed ( $\times 900)$. (After Eidan.) the two tubes being not only exactly alike but in close contact from the outset. They continue to grow outward, winding round each other in a spiral course, performing three or four revolutions apiece. At this stage a septum grows across the base of each tube, and the apices conjugate. As a result of this act, a globular swelling arises at the apex, the protoplasm of the tubes is withdrawn into it and enclosed by transverse walls growing across the tops of the tubes. Within this body (an ascus), which so strikingly resembles a simple zygosperm, there are subsequently formed eight ascospores. [The carpogone itself becomes an ascus here.]

The next type embraces such forms as the Erysipheæ, Eurotium, Penicillium, Sordaria, Melanospora from among cleistocarpous and pyrenocarpous forms; and Gymnoascus, Pyronema, Ascobolus from gymnocarpous and discocarpous fungi, and the Collemaceæ (discocarpous) 
from the lichens. It is characterised by the production on the mycele or the thallus-hyphæ of a hody consisting sometimes of a cell, sometimes of a chain of cells, called the carpogone, or with reference to its function the ascogone, since from it there arise the ascogenous hypha. (In Podosphæra, a genus of Erysipheæ, a single stalked ascus only is formed.) In this type the sexual act which precedes the farther development of the carpogone is distinctly of a higher character. In such forms as Pyronema and Eurotium an antheridial filament is produced which fertilises the trichosyne, as the special conjugating portion of the carpogone is called; and in the Collemaceæ detached male cells, pollinoids, formed in special antherids, often described as 'spermatia' and 'spermogones,'are conveyed passively to the trichogyne, and there, becoming attached, fuse their contents into those of the trichogyne. There is a distinct difference here between the sexual organs in the parts they play and in their structure; though in the Erysipheæ, Penicillium, Sordaria, and Gymnoascus, the actual process of fertilisation has not been observed, yet the constant presence of the organs of sexuality justifies our regarding the function as extremely probable. The case is not so strong with regard to Melanospora and Ascobolus, where the antherid is either not constant in its appearance, or with difficulty to be distinguished from the hyphæ of the envelope. A third type is that of Polystigma, which closely resembles the Collemaceæ in the origin of the sporocarp. The carpogone, trichogyne, and antherid with pollinoids are here very much the same as in that group, only the sexual union has not been observed, and there is present in the early development of the carpogone and surrounding it, a special coil of pseudo-parenchymatous hyphæ which is ultimately concerned in the formation of the envelope-tissue of the sporocarp. Conforming also to the type represented by the Collemaceæ, and more especially allied to Polystigma in this respect, is the process as described for Xylaria. Here too there is a special coil of hyphæ, and in the interior of it a chain of large cells (like the carpogone of Polystigma) called by Füisting 'Woronin's hypha.' This hypha vanishes, and no connection has been discovered between it and the ultimate ascogenous hyphæ in the hypothece. Again no trichogyne has been observed to arise from 'Woronin's hypha,' and therefore no union with it of pollinoids, though bodies are recorded for Xylaria which resemble these male organs. The difference in the origin of the sporocarp between this type and Polystigma is essentially this : that here no distinct carpogone gives rise to the ascogenous hyphæ which have their origin in the special coil mentioned, since 'Woronin's hypha' disappears before this stage in the development of the sporocarp. Sclerotinia sclerotiorum (de By.) affords another type, since the ascogenous hyphæ and those of the 
envelope, which are unconnected with each other though interwoven in the hypothece, may be traced down to the apparently uniform tissue of the stalk. De Bary thinks, however, that these may have a distinct origin-the ascogenous hyphæ in those proceeding from the original coil formed in the sclerote, and the envelope-hyphæ in others springing with them from the sterile tissue of the sclerote-that the coil in fact may be (or may contain) a carpogone, though there is no sign of antherid or pollinoids. The tracing of the continuity of these hyphæ is impossible throughout the long stalk with its uniform tissue. With this type are to be classed the lichen-fungi investigated by Krabbe (Sphyridium, Flot., Bæomyces, Pers., and Cladonia, Hill) the sporocarps of which exhibit a clear distinction between ascogenous and envelope hyphæ from an early stage. The former, however, have not been traced to a carpogone or other special initial organ, and neither antherid nor pollinoid has been discovered. Such genera as Claviceps, Epichloe, Pleospora, \&c., in which all that has been observed is a gradual specialisation of uniform hyphæ to the functions of ascogenous and envelope hyphæ follow this last type as the farthest removed from those forms described under the second type.

\section{Course of Development.}

Within this large class several more or less distinct types of the course of development may be recognised. Just as in the case of the origin of the sporocarp, Eremascus albus is among the simplest of all. This remarkable type (the sporocarp of which is destitute of envelopetissue) possesses no other reproductive bodies than the ascospores produced in the single ascus which represents the sporocarp. That is to say, the germinating ascospore gives rise to a thallus which directly bears the sporocarp again. In the same case are also the Collemaceæ with probably all lichen-fungi, and Pyronema, Ascobolus, Gymnoascus, Hypocopra, and Sclerotinia sclerotiorum, which last, however, possesses other propagating bodies in the shape of mycelial resting-cells comparable with the soredes of lichens. Another type (to which Sclerotinia Fuckeliana, de By. and Wor., belongs) is but one remove beyond this, since the life-history may go directly from sporocarp to sporocarp, though in the typical state acrospores intervene. Here the germinating ascospore gives rise to a thallus which bears acrospores, or, as has been said, the sporocarp again ; though never both together or successively on the same thallus. The germinating acrospore in turn produces a thallus with precisely the same properties and capabilities as that arising from the ascospore, except that in some cases there appears to be a tendency to 
go on producing other acrospore-bearing thalli. In a third type acrospores are always formed (so far as experience goes) on the primary thallus produced by the germinating ascospore. This type de Bary subdivides into two as follows : $(a)$ the primary thallus arising from the ascospore is only a promycele bearing sporids, which in turn produce a definite thallus, which either bears a sporocarp at once, or develops as sub-type $(b)$. There is here then a necessary intervention of acrospores (sporids) before the sporocarp is again formed. (b) The primary thallus arising from the ascospore is a definite one, which ultimately bears the sporocarp, it is true, in all cases of complete development, but not until acrospores have, been formed on it. The sub-type to some extent suggests the first type, since the acrospores are not morphologically a necessary intervention, though their appearance is invariable. The thallus produced by the germinating acrospore resembles the primary one in all respects. The development in this type may stop short with the formation of acrospores, and this is often repeated in succeeding generations.

The spores of such intervening states are invariably acrospores, and they appear either singly or on hymenia on the free surface of the thallus; or they are produced in pycnids, bodies resembling peritheces. The spores so produced are termed stylospores, or better, pycnospores, as de Bary proposes. A species may produce only one of these kinds of acrospore, e.g. Erysiphe ; or under favourable circumstances more than one kind, e.g. Pleospora.

I. ERysipheÆ.-The mycele of the Erysipheæ infests the surface of green living plants, through the epiderm of which it sends down haustoria into the tissues beneath. The mycele is delicate and cob-web like in appearance and consists of branching septate hyphæ, and is secured, so to speak, to the host-plant by means of the haustoria. In the course of the branching of these hyphæ they frequently cross each other, and at such points of contact the sporocarp is formed. If Podosphæra (Kze.), which has only a single ascus, be taken for the sake of simplicity, its development may be described as taking place in this fashion. From one of these crossing hyphæ, at the point of contact there springs an oval cell, the carpogone, which is separated by a transverse wall from the hypha. From the other hypha, likewise at the point of contact, there springs also a cell, longer and thinner than the other, which is similarly cut off by a septum. It overtops the carpogone to which it adheres, and the upper portion, which is slightly bent over the carpogone, is farther cut off from the lower by a transverse wall. The upper portion is the antherid and the lower its stalk. From the hyphæ at the base there now grow up a number of tubes, which envelop 
the carpogone and form the single-layered outer perithecial wall. From the inner surface of the cells composing this wall there subsequently arise a number of other cells forming an inner wall several cells thick. The growth of these separates the antherid from the carpogone, and it takes part in the formation of the outer wall. From the outer wall, the cells of which have become larger and brown in colour, fine rhizoids are produced near the base, and in some species a few fine hairs at the apex termed appendiculce. Meanwhile the carpogone has divided into two cells, one the ultimate ascus, and the other its pedicel-cell. Within the ascus finally eight ascospores are formed.

In Erysiphe (Hedw.) the chief points of difference from Podosphæra
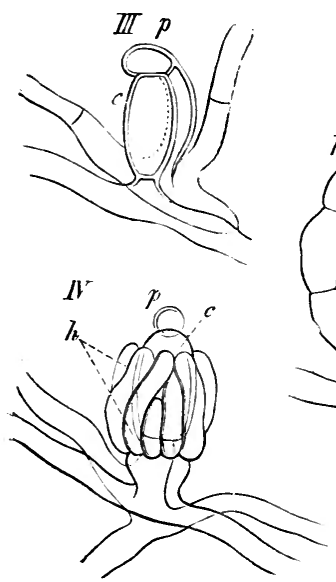

FIG. 303.-I, II, Podosphara pannosa de By. and Wor. I, chain of spores on sporophore and mycele. $I J$, ripe sporocarp with ascus, $a$, emerging through wall of sporocarp, $h$. $I I I-l, l$. Castagnei de By. and Wor., fertilisation. III, c, carpozone: $p$, antherid. IV; older state; $h$, hyphal branches of envelope. $V$, still older state in optical longitudinal section; $a$, ascus $(\times, \infty)$. (I, $I I$, after Tulasne, $I I I-l$, , after de Bary.)

to be noted are these. The antherid winds spirally round the clubshaped carpogone, which divides into a series of cells-produces a number of asci-and the inner wall of the perithece is more developed.

The germinating ascospore gives rise to a mycele provided with haustoria, on a suitable host, and from this thallus there spring short sporophores which produce successively a series of acrospores. The acrospores in turn produce a mycele exactly like the primary one from the ascospore-which like it, if completely developed, ends by bearing the sporocarp again. But owing to external conditions such as varying weather, nutrition, and the like, this consummation is frequently not reached, and acrospores only are then formed generation after generation. 
For example, the acrospore form called Oidium Tuckeri (Berk.), which occurs abundantly, and is well known as vine-mildew, never produces in Europe, so far as is known, peritheces. These it is believed have been found on native vines in North America, which is supposed to be the home of the disease, the perithecial form being the fungus described as Erysiphe (Uncinula) spiralis (Berk. et Curt.).

The Erysipheæ are parasites infesting living flowering plants of many natural orders. Among the best known and most destructive are the above-mentioned vine-mildew ; E. lamprocarpa (Lk.) on Compositæ, Plantago, Verbascum, Labiatæ; E. graminis (Lev.) on grasses ; E. Martii (Lév.) on Umbelliferæ, clover, lucern, lupins, \&c.; E. communis (Lk.) on Polygonum, Rumex, Convolvulus, Dipsacus, Lathyrus, Delphinium, Aquilegia, Ranunculus, \&c. Podosphæra Kunzei (Lév.) attacks species of Prunus, and Podosphæra Castagnei (de By.) is a wellknown mildew of hops, though it also attacks many other plants of different natural orders.

2. Eurotium (Link). - The carpogone is formed by the rolling up in corkscrew fashion of the tip of a mycelial hypha, the turns of which, four or five in number, gradually come into closer contact till they present the appearance of a hollow screw. It is then divided by transverse walls into as many cells as there are turns in the screw. From the bottom turn of the screw there grow up two or three branches of irregular diameter, which take an irregular course towards the apex, but remain in close contact with the outside of the carpogone. Sometimes one ascends by way of the inside of the screw. One, however, climbs faster than the others and reaches the apex first; this is the antherid. Impregnation by it having taken place at the apex of the carpogone after the absorption of a minute portion of the wall, both the antherid and the other branches of the basal turn of the carpogone which follow it proceed to branch copiously, the hyphæ being septate, until the carpogone is completely enveloped. In this way the outer perithecial wall is formed as in the Erysipheæ. From it, as in the last type too, the inner wall grows inward, filling up the space between the outer wall and the carpogone with several layers, and pressing apart the turns of the screw. The wall-cells are of a pseudo-parenchymatous appearance, and the membrane of the outer wall becomes covered externally by a golden-coloured substance. The whole of these envelope-cells, it should be mentioned, increase in volume considerably. From the carpogone there now proceed numerous ascogenous hyphæ, which press among and suppress the inner wall-cells, and, branching plentifully, bear at the ends of the branches oval asci. These contain each eight ascospores. So copiously does this take place that, of the ascogenous hyphæ soon only 
the traces may be seen, and by the time of maturity even the ascus-walls disappear and the perithece contains little but ripe ascospores.

When the ascospore germinates it produces a mycele, on which there shortly arise upright sporophores with round swollen apices bearing numerous short sterigmatı over the surface. On the sterigmata chains of acrospores are formed successively, which, proceeding radially from the
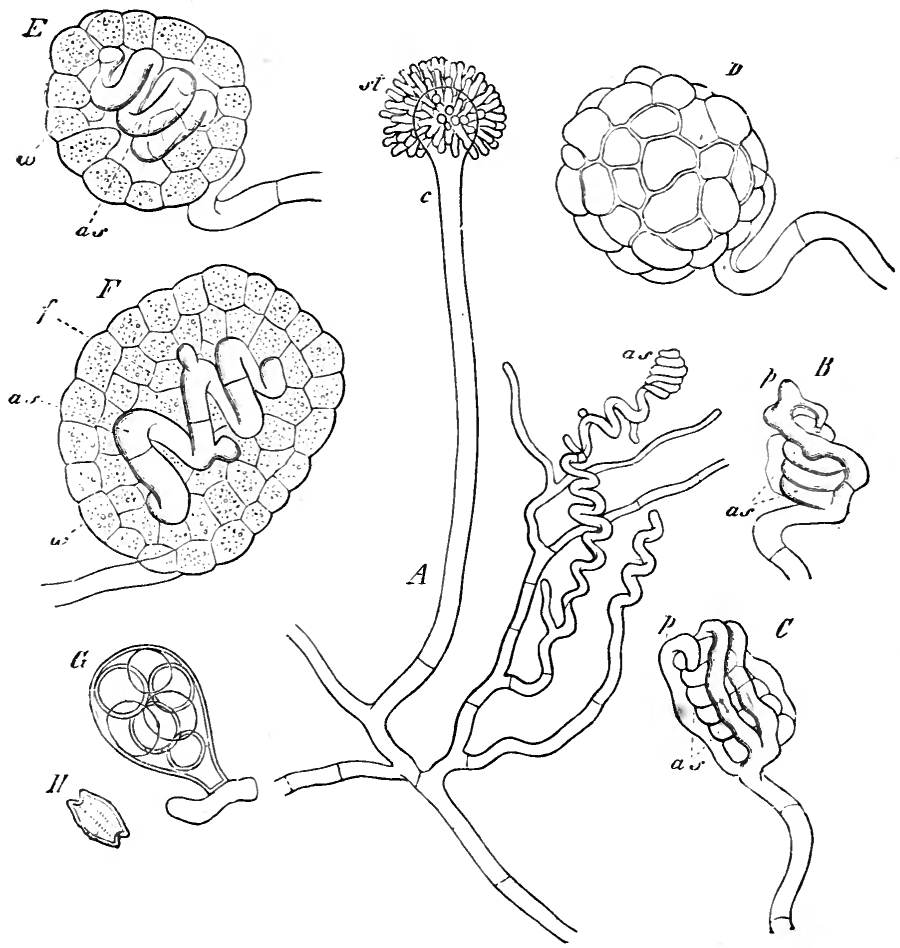

FiG. 304.-Eurstium repens de By. $A$, branch of mycele with sporophore, $c$, and sterigmata, st; early stage of carpogone at as. $B$ : spirally twisted carpogone, as, antherid, $\not p$, and an envelopehypha. $C$, older state with more envelope-hyphæ. $D$, young sporocarp. $E$ and $F$, young sporocarps in optical longitudinal section. In $E$ the inner wall is beginning to be formed; $w$, the outer wall; $f$, the nner wall and other cells filling space between it and carpogone. $G$, ascus with spores. $H$, ascospore of $E$. herbariorum Lk. $(A \times 190$, the others $\times 600$.) (After de Bary.)

apex of the sporophore, surround it with a globular mass of acrospores. The course of development is the same here as in the Erysipheæ, and generation after generation of acrospores is usually formed in succession without the myceles attaining to the formation again of the sporocarpthis being the result. of the external conditions of life of the fungus. 
The species of Eurotium are saprophytes, and are found inhabiting decaying plants, fruits, \&c., and forming in such situations a loose mycele of delicate thin-walled cells. The common mould formerly called Aspergillus glaucus (Link) is the acrospore stage of Eurotium herbariorum (Link), and was believed to be an independent form before de Bary discovered the pleomorphism of this fungus and identified it with the sporocarp stage (Eurotium).

3. Penicillium (Link). - The sporocarp of Penicillium takes its origin in the winding round each other once or twice of two lateral branches of mycelial hyphæ. These are so like each other that it is impossible, from the observations made on them, to say which is male and which female-a question on which the ultimate development throws no light, since it is uncertain whether the ascogenous hyphæ proceed from either or from both, and moreover, besides being alike in formation, they are equal in activity. Neither has any observation been made of the conjugation of these presumptive sexual elements - though their position towards each other signifies a sexual union. Together with the outgrowths from these of numerous short ascogenous hyphæ, there arises: from the neighbouring hyphæ of the mycele a dense growth which completely envelops the presumptive carpogone and becomes interlaced with the ascogenous hyphæ proceeding from it-these being at first thicker hyphæ than those of the envelope-tissue. However, with the growth of the whole body, the cells of the envelope increase considerably in volume, especially the central mass, and acquire thickened pitted cellwalls, while the layers nearer the circumference form themselves into an outer wall the cells of which have yellowish-brown nembranes. The whole has a pseudo-parenchymatous appearance. The originally outermost cells are cast off, owing to their taking no part in the growth. While this development of the envelope has been going forward, the ascogenous hyphæ have been pushing in between the interstices of the cells, and sharing in the process of thickening of the cell-membranes. At this stage of the history of the sporocarp a period of rest intervenes lasting about six or seven weeks. This past, the ascogenous hyphæ begin anew their growth in vigorous fashion, and, branching copiously at the expense of the cells of the envelope, ultimately produce at the ends of the branches short thick twisted terminal branches, which bear serially strings of asci containing each eight ascospores. So far is this process carried that finally not only is the whole interior envelope-tissue used up, but the asci themselves disappear, leaving enclosed by the outer wall only a dense mass of ascospores. De Bary compares the existence here of two forms of ascogenous hyphæ-viz. the relatively slender form which traverses and uses up the envelope-tissue, and the short 
twisted thicker form which bears the asci-with the occurrence of the two forms of hyphæ in the ripening sporocarp of Elaphomyces. Some authors, it may be remembered, place Penicillium and Elaphomyces side by side.

The germinating ascospore produces a mycele in all respects like that which bore the sporocarp, a much-branching anastomosing septate flocculent mycele, which bears acrospores serially in succession at the end of their characteristic sporophores. The sporophore arises from the mycele in the form of an upright septate stalk, which bears at its summit cymose branches ending in sterigmata of equal height. On the sterigmata are the chains of acrospores. Such a sporophore has a brush-like appearance, the stalk being the handle, and the branches, sterigmata, \&c., the hairs. The sporophores arise in dense masses, and in all produce enormous numbers of spores. So densely do they occur in exceptionally favourable situations-in the case of Penicillium glaucum (Lk.)that they are sometimes bound together in bundles, fasciated as it were, and bear at the summit a dense crown of chains of spores. This form was originally described as a distinct genus by the name of Coremium glaucum (Lk.). As in Erysiphe and Eurotium, so in Penicillium, the course of development, after the production of acrospores, may omit the formation of the sporocarp on the same thallus through external conditions being unfavourable to its development. This, in fact, is the usual case in Penicillium, and generation after generation of thalli bearing acrospores only, and there stopping short, intervene as a rule between sporocarp and sporocarp. Perhaps the commonest of all moulds is Penicillium glaucum (Lk.), occurring on decaying fruits, on bread, \&c., \&c., in the acrospore-bearing condition. The sporocarp occurs, very rarely, in dark places where there is a poor supply of oxygen, and mostly on bread.

4. Gyminoascus (Baranetsk.) and Ctenomyces (Eidam) do not differ in any very striking peculiarity from types already discussed. The origin of the sporocarp is characterised by the fact that while one sexual hypha entwines the other, it is the entwining one which is the carpogone - which subsequently produces the ascogenous hyphæ-and the other, round which the carpogone winds, is the antherid. 'The relative positions of these certainly recall the case of Eurotium, where the antherid occasionally ascends by way of the inside of the screw ; but here, on the other hand, the carpogone takes, as it were, the active step, and winds round the antherid. These have their origin as lateral shoots either of the same hypha or of different hyphæ ; or it may be that only the entwining one (carpogone) is a lateral shoot, and the other merely the intercalary portion of a hypha. The ascogenous hyphæ branch. 
copiously, and ultimately bear at the ends asci containing each eight ascospores, and the envelope-tissue is contributed by shoots from the neighbouring nycele and from the base of the carpogone.

As already mentioned above, no acrospore stage intervenes here between sporocarp and sporocarp, i.e. the ascospore, on germinating, produces a thallus, which again bears the sporocarp directly. Gymnoascus is a saprophyte growing on dung.

5. Ascobolus (Pers.).- The carpogone arises on the mycele in the form of a thick curved sausage-shaped lateral hypha, which becomes divided by transverse walls into six or seven cells, about as long as they

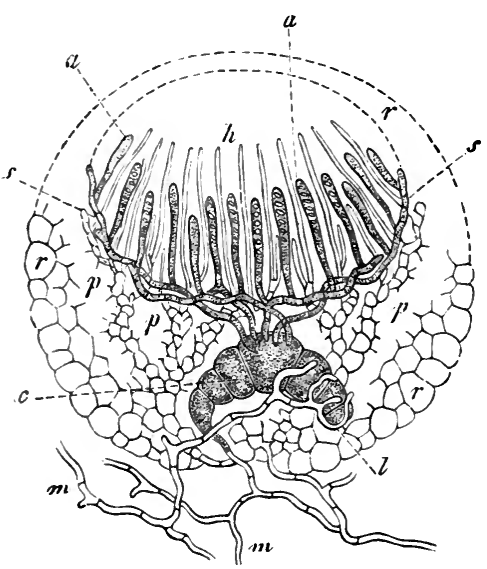

Fig. 305.-A scobolus furfuraccus Pers. Young sporocarp in longitudinal section (diagrammatic). $m$. mycele; $h$, hymenium ; $c$, carpogone with ascogenous hyphx, $s$, in the subhymenial layer, and $a$, asci (shaded); $l$, antherid; $p-r$, tissue of envelope giving rise to paraphyses. (After Janczewski.)

are broad. While in this stage the farther end of it is clasped by the branching end of a much thinner hypha-like one of the ordinary mycelial hyphæ-which, it may be assumed, is the antherid, from analogy with those types already discussed. At all events, it soon loses its identity in the dense growth of envelopehyphæ which; immediately after this stage has been reached, are produced both from the ordinary mycele and from the hyphæ which bear the carpogone and presumptive antherid. These envelopehyphæ, which soon enclose the carpogone in a round mass with a differentiated rind, next proceed to develop in the upper region over the carpogone (which is situated in the basal portion) the subhymenial layer of a discocarp. From this subhymenial layer there rise upward the straight perpendicular paraphyses. By the time the development has gone so far, the carpogone gives rise to a dozen or more ascogenous hyphæ from a cell near the middle of the row, which has manifestly obtained from its neighbours contributions from their contents. The ascogenous hyphæ grow upward to the subhymenial layer, where they branch and spread about among the roots, so to speak, of the paraphyses, and here bear asci. The asci grow straight upward among the paraphyses to the hymenial surface. The portion of the rind (envelope-tissue) immediately over the hymenial surface is ruptured, in consequence of the expansion of this surface 
during growth, to permit the escape of the ascospores, and as new asci are produced (mostly taking the place of older ones), the expansion often continues till the hymenial surface becomes convex.

Ascobolus, like Gymnoascus, has no intervening acrospores, and the germinating ascospore gives rise to a thallus which bears the sporocarp directly. It is a saprophyte, and the species abound on dung.

6. Pyronema (Fckl.).-Pyronema confluens (Tul.) (or Peziza confluens, Pers., as it was formerly called), which, when mature, forms a discocarp like Ascobolus, differs considerably from that genus in the structure of the carpogone and antherid, though both, doubtless, belong to

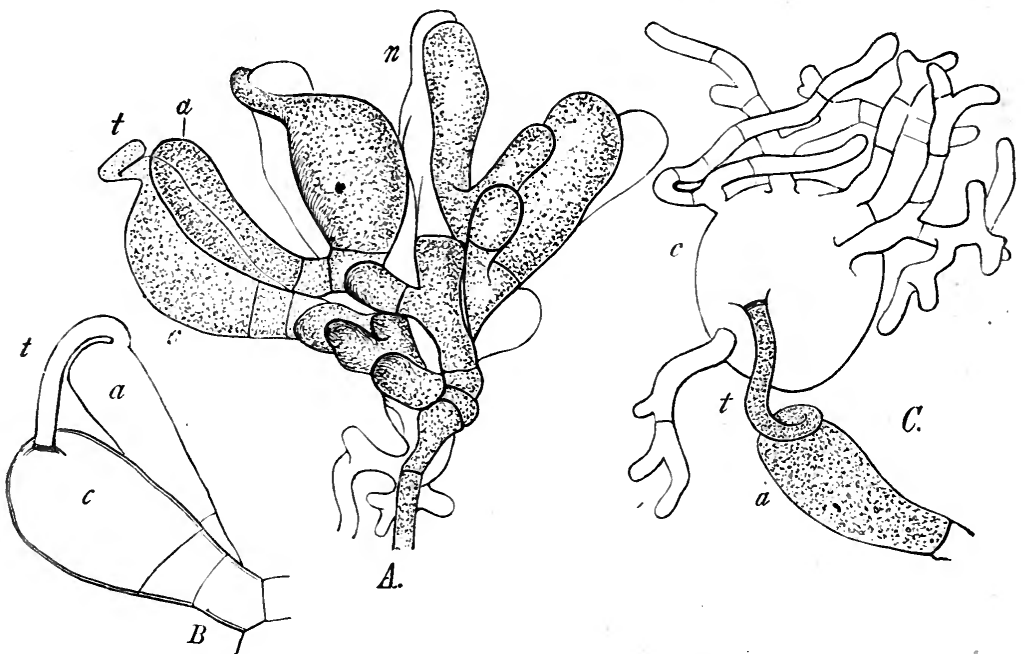

FIG. 306.-Pyronema confuens Tul. A:c, carpogones; $a$, antherids; $t$, trichogynes. The trichogyne marked $t$ has not yet become united with $a ., B$, older state. The trichogyne $t$, proceeding from carpogone $c$, and cut off by a transverse wall, is in open union with $a$. $C$ : the antherid, $a$, is in communication through $t$ with carpogone, $c$, which is swollen and emitting ascogenous hyphæ ( $\times$ about 300 ). (From de Bary, after Kihlman.)

the same main type in this respect. On the mycele of Pyronema confluens there arise clusters or rosettes of more or less club-shaped cells by forked branching at the summits of erect hyphæ, occurring generally in pairs ; these pairs in turn having their origin in densely branched groups of hyphæ. The rosettes consist each of : three kinds of cell : the broad club-shaped, slightly curved cells are carpogones, and are usually borne on two pedicel-cells ; the antherids are also club-shaped, of the same height, but of about half the breadth ; and the third kind are sterile cells of cylindrical form. Two or three pairs of carpogones and antherids are included in each rosette. From the top of the carpogone there grows forth a slender curved trichogyne, with plentiful supply of 
protoplasm ; and this organ, instead of behaving passively in the operation, bends over till it touches the top of an adjoining antherid, to which it adheres. When this has taken place, the trichogyne becomes separated by a transverse septum at the base from the carpogone, and then, through the dissolution of the intervening membrane, the contents of trichogyne and antherid are mingled. After impregnation the carpogone increases in volume, and from numerous points of its surface there are emitted ascogenous hyphæ. From the sterile cells and the whole basal region of the rosette, the envelope-hyphæ now grow forth and form a large stroma enclosing the carpogones and antherids-the latter remaining almost unaltered, full of protoplasm, and taking no part in the formation of the envelope-and upon the stroma a free hypothece bearing the paraphyses. In the production of asci and the farther development of the apothece, Pyronema agrees with Ascobolus.

Pyronema, like Ascobolus and Gymnoascus, produces no acrospores; and sporocarp follows sporocarp without intervention on successive thalli.

7. Sordaria (Ces. and de Not.) and Melanospora (Corda), both Pyrenomycetous forms, are placed next Ascobolus by de Bary with respect to the morphology of their sporocarps--of course excluding such differences of form as ar€ peculiar to their being Pyrenomycetes, while Ascobolus is, as has been shown, a Discomycete. Fundamentally there is little real difference in the mode of origin of the sporocarp; and Chætomium and Ascotricha may eventually prove to belong to the same series.

8. COllemaceÆ.-In the Collemaceæ, a group of discocarpous lichens, the structure, development, and mode of behaviour of the male sexual element is wholly different from any hitherto described, while the carpogone remains of similar structure, though, of course, modified to meet the requirements of the changed conditions. The male cells are pollinoids formed in a flask-shaped antherid, somewhat resembling a perithece. It is sunk beneath the surface of the thallus, and opens by means of a narrow neck. The flask consists of a wall of denselycompacted hyphæ, giving off towards the interior a layer of numerous delicate hyphæ (sterigmata), which converge towards the central portion of the flask. These form at their apices successively in series numerous pollinoids, which soon fill the central space. The pollinoids are thinwalled rod-shaped cells, with an outer membrane of a gelatinous kind, readily swelling and dissolving in water. In damp rainy weather water gets access to the pollinoids, and through the swelling action mentioned they are forced out through the neck of the antherid and dispersed over the surface of the thallus. The development of the antherid 
generally somewhat precedes the origin of the carpogone. Under the surface of the thallus a hypha not distinguishable from its neighbours gives off a broader lateral branch, which coils itself up two or three times, and then sends forth the tip of the coil, which, growing upward, emerges through the surface of the thallus into the open. The tube is commonly somewhat swollen as it passes through the superficial tissue, and for some short distance above it, and attains a height above the surface of four or five times its breadth. This is the trichogyne. The coil as it grows is divided by transverse walls into about a dozen thin-walled cells, and the trichogyne likewise into a similar number. Its development having taken place, and the suitable conditions of moisture having dispersed the pollinoids over the surface, these, wher-

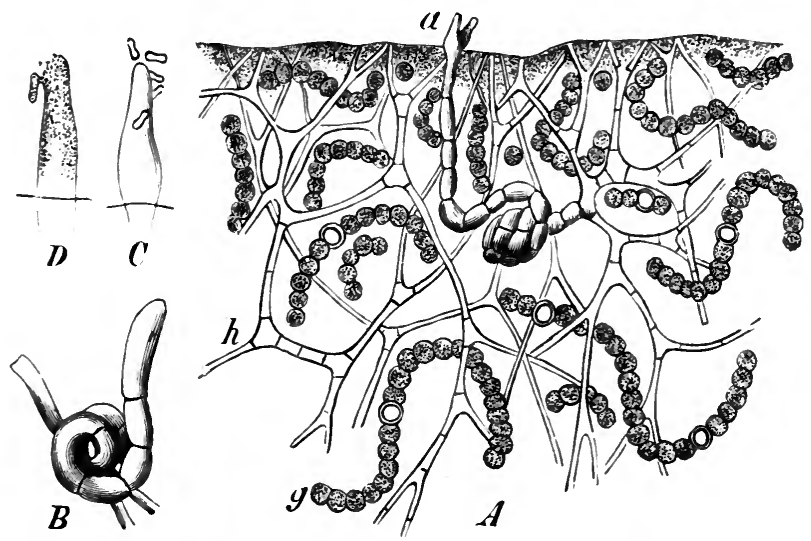

FIG. 307. $-A$, Leptoginum microphyllum Ach., section of thallus. a, point of trichogyne; $g$, algal cells; $h$, hyphæ. $B$, Collema pulposum Bernh., young carpogone. $C$, tricho: gyne with pollinoids of $L$. microphyllum. $D$, a similar one showing union with pollinoid. $(A \times 350, B, C, D \times 750$. $)$ (After Stahl.)

ever they come into contact with a trichogyne, stick to it, sometimes in considerable numbers, and an open communication between pollinoid and trichogyne is established by means of a short minute process from the pollinoid. When this has been accomplished the cells of the trichogyne collapse, remaining distended only where a transverse septum occurs in its course, while the cells of the coil increase in volume and in number through the growth of fresh transverse walls. The neighbouring thallus-hyphæ then give out numerous shoots, which not only grow round the coils, but press them asunder. The hyphæ on the side next the surface then give off branches in that direction, the end shoots of which form the first paraphyses, after displacing the intervening tissue in their course. The enveloping hyphæ extend laterally until a basin- 
shaped pseudo-parenchymatous exciple is formed, the margin of which reaches the surface. The interior of this basin is then soon filled with upright paraphyses like those which originally attained the surface. The turns of the original coil become unloosed, and eventually there are given off from it ascogenous hyphæ which, after branching in the subhymenial zone like those of Ascobolus, finally produce successive asci in the mature apothece.

In Physma Massal. the carpogone is produced from the hyphæ which form the wall of the antherid, and the trichogyne rises to the surface outside the wall. Eventually the paraphyses and asci are produced in the place formerly occupied by the sterigmata of the antherid,



Fig. 308.--Leptogium microphyllum Ach., young apothece in section. $h$, hyphæ; $g$, algal cells ; $a$, thalloidal exciple; $b$, exciple proper; $c$, hypothece. The apothece is filled with paraphyses, among which may be seen bladder-shaped ascogenous hyphæ with three young asci $\left(\times 53^{\circ}\right)$. (After Stahl.)

and the antherid is thus transformed into the sporocarp. The species of Collema (Ach.) have no acrospores, and resemble in the course of their life-history Ascobolus, Pyronema, \&c. For structure of lichenthallus, see p. $3^{18}$.

9. Polystigma (Pers.) is a genus of parasitic fungi bearing a striking resemblance to the Collemaceæ in its sexual reproductive apparatus. Antherids and pollinoids are formed differing in no material respect from those of the Collemaceæ-the pollinoids being in this case more thread-like and bent. The genesis of the sporocarp is characterised here, however, by the formation of a fundamental coil of hyphæ smaller than the thallus-hyphæ. The carpogone appears among these, consisting of a spirally-wound hypha of two or three turns, with broad short cells. 
It traverses the fundamental coil, and its apex grows out as a trichogyne, which protrudes through a stomate of the leaf of the host-plant. Pollinoids have been observed attached to it, but so far no actual communication has been detected. Accompanying the trichogyne are a few fine hyphæ, which, after the collapse of the trichogyne, protrude through the stomate like the tip of a small brush. The farther development of the sporocarp (the envelope-tissue arising from the fundamental coil) is like that of the last type, with this difference, that, instead of an apothece, it is a perithece which is here produced.

The ascospore produces on germinating a short promycelial tube, the end of which bears a sporid. The sporid, on germinating in turn on the leaf of a suitable host (Prunus), sends its germ-tube through the outer wall of the epiderm, and branches within the epidermal cell, these branches again penetrating into the parenchyme of the leaf. Here a thallus is formed, which remains covered by the epiderm of the leaf of the host until the sporocarp is again produced.

ıo. XylarieÆ, \&c.-In Xylaria (Hill), Hypoxylon (Bull.), Ustulina (Tul.), Diatrype (Fr.), Stictosphæria (Tul.), Eutypa (Tul.), Nummularia (Tul.), and Quaternaria (Tul.), we have the occurrence of a fundamental coil preceding the formation of the peritheces, followed by the gradual disappearance, as mentioned above for Xylaria, of 'Woronin's hypha,' which is formed in it, without its taking part in the formation of the ascogenous hyphæ. These arise, together with the paraphyses, from the perithecial wall. No trichogyne is formed from 'Woronin's hypha,' and there are no antherids. Before the formation of the peritheces in Xylaria there are borne on the same stroma in dense hymenia bodies which resemble acrospores, or it may be pollinoids. In this genus they have not been observed to germinate, though similar bodies germinate freely in Ustulina, e.g., and other genera. In Xylaria at all events they may be functionless pollinoids persisting in an organism in which indications of a carpogone (in the form of 'Woronin's hypha') also still remain.

i I. Sclerotinia (Fckl.).- The sporocarp of Sclerotinia sclerotiorum (de By.) is in the form of a disc at first cup-shaped, borne at the summit of a stalk arising from a sclerote. It takes its origin from an entangled primordial coil of hyphæ with gelatinous membranes situated just beneath the dark peripheral cells of the sclerote. There are many such coils in each sclerote, but they do not all attain this farther development. The bundle of hyphæconstituting the stalk of the sporocarp breaks forth, as has been said, from this region of the sclerote, the central portion of the hyphæ arising from the coil, and the external hyphæ from the ordinary tissue of the sclerote. In the growth of the stalk it has 
been found impossible to trace any anatomical distinction between these elements, and therefore it amounts to no more than a probability that the hyphæ from the coil are the ultimate ascogenous hyphæ; while those from the tissue of the sclerote may furnish the envelope-tissue of the sporocarp. The main difference between the development of S. sclerotiorum and S. Fuckeliana in this respect consists in the primordial coil of the latter originating not within the sclerote, but in the central portion of the bundle of stalk-hyphæ after it has reached the external surface.

S. sclerotiorum possesses, so far as is known, no intervening acrospores. The germinating ascospore produces a mycele on which sclerotes are formed, and on these only the sporocarps again. S. Fuckelíana sometimes does the same, and de Bary has observed a single instance of the sporocarp being produced on the mycele without even the formation of a sclerote. The sclerotes of this species, however, frequently produce filamentous sporophores bearing acrospores, this stage being that formerly known as Botrytis cinerea (Pers.). It never happens that a sclerote bears both acrospores and sporocarps, either together or after each other. The primary mycele may bear acrospores directly without interfering with the subsequent production of sclerotes, but this does not happen often. The mycele produced by the germinating acrospores is similar in all respects to the primary one arising from the ascospore, with the reservation that it has a greater tendency than the other to the production of sporophores. In this species there are also often formed certain abortive acrospores, or it may be pollinoids.

12. Pleospora (Rabenh.).- In the origin of the perithece of Pleospora herbarum (Rabenh.), the traces of sexuality disappear from view, and indeed it is stated that the asci arise among the paraphyses as branches of the basal cells of the latter. In the life-history of this fungus a considerable number of forms are embraced. Besides the ascospores, which are compound multicellular bodies, there are in the second category acrospores of three sorts, viz. (a) Double or multicellular acrospores of rounded short cylindrical form, previously taken to be an independent species (Macrosporium Sarcinula, Berk.). Each such compound spore appears as a rule singly on its sporophore. (b) Conical pearshaped likevise compound spores appearing in series, often in branching series. This was also formerly described as an independent species of Alternaria (Nees ab Esenb.). (c) A small form of acrospore recorded by Bauke, but not, according to de Bary, Cladosporium herbarum (Link), which, though placed in genetic connection with Pleospora herbarum by Tulasne, does not belong here. In the third category there are pycnospores formed in pycnids interstitially arising on mycelial hyphæ. The pycnids consist of a wall of several layers, from the inner surface of 
which there converge series of cells producing successively (terminally and laterally) pycnospores. These are about twice as long as broad, and very thin-walled, but surrounded by a hyaline gummy substance. Not only are all these forms on record, but the mycele shows a tendency to pass into a resting state, and single cells or groups of cells becoming detached add to the means of propagation. There is some contradiction involved in the accounts of the occurrence of some of

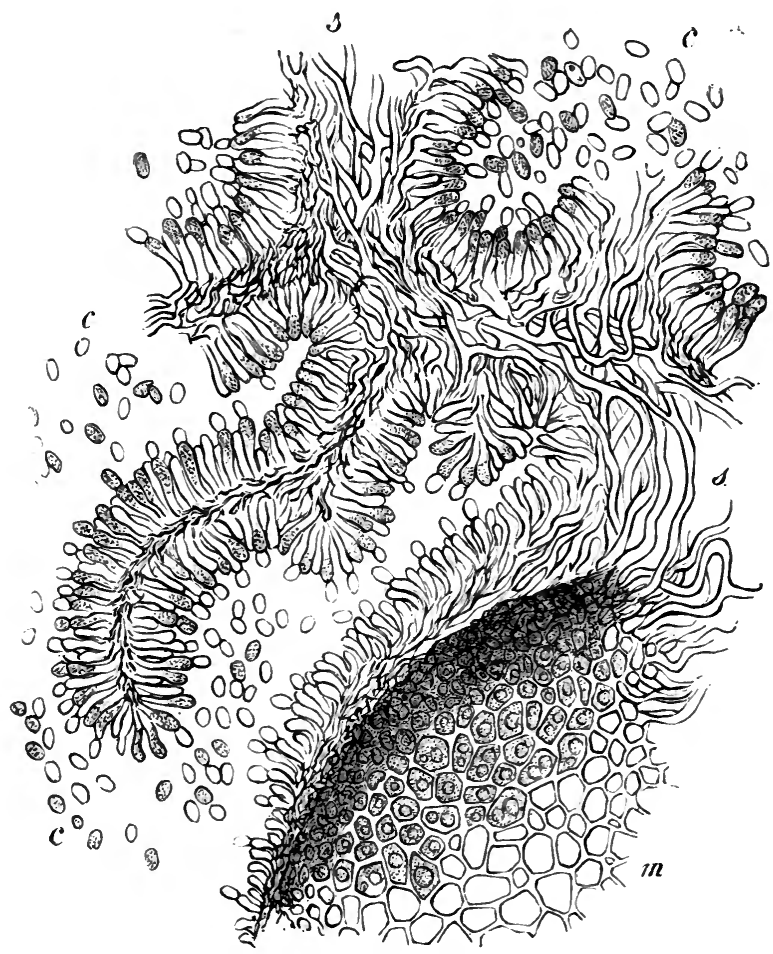

Fig. 309.-Claviceps purpurea Tul. Longitudinal section of portion of sclerote, $m$, in Sphacelia stage, producing conidiospores, $c$ (much magnified). (After Tulasne.)

these forms and the order of their succession given by Bauke and by Gibelli and Griffini, and further research may be expected to throw light on the matters in dispute, as alsn on the question whether or not we have here one species very rich in spore-forms or two species resembling each other, but each less rich in forms.

I3. Claviceps (Tul.).- - The peritheces of Claviceps purpurea (Tul.) appear as it were in a kind of capitulum (immersed in the same stroma), 


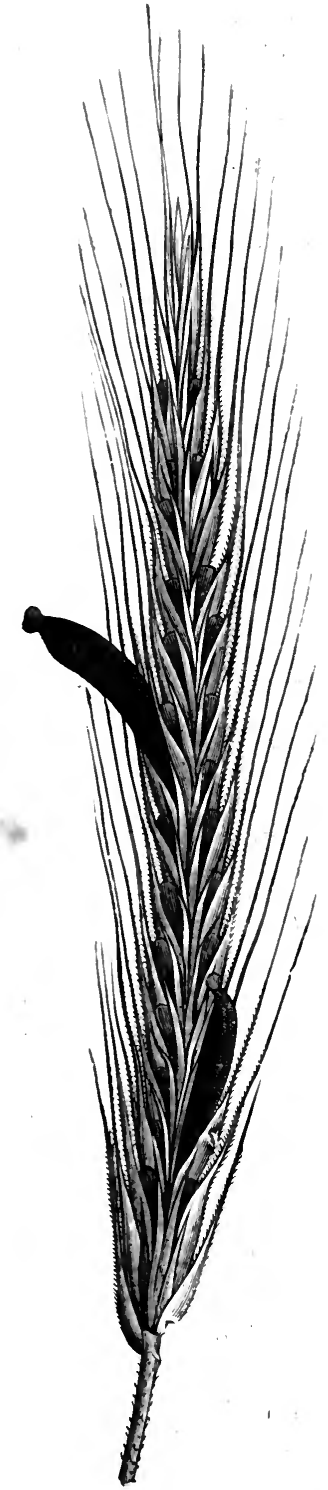

Fig. 310.-Ear of rye with two mature sclerotes (ergot) of Claviceps purpurea (natural size). (After Luerssen.) borne on the summit of a stalk arising from a sclerote (the well-known ergot of grasses); the ascospores are filamentous in form, and on germinating produce hyphæ at several points. When this takes place under suitable circumstances on the pistil of grasses, the tubes enter, and, besides penetrating the tissue, form at length a white hymenium on the surface. This hymenium consists of numerous cylindrical sterigmata, which bear acrospores at their apices. ('This stage was described by Léveillé by the name of Sphacelia.) These are given off in drops of a sugary juice which oozes out between the flower-leaves in which the pistil lies. This juice, 'honey-dew,' is eaten greedily by insects, which doubtless eat the acrospores with it. These propagate the Sphacelia state. At the base of this acrospore-forming body the formation of the sclerote proceeds, and it ultimately replaces the ovary, emerging from the flower of the grass with its base seated on the floral receptacle. It gives rise in turn to the sporocarp again.

The allied genera Cordyceps (Fr.) and Epichloe (Fr.) agree with Claviceps in the development of the sporocarp.

Besides the above distinctly marked types, the origin of the sporocarp and the life-history of a considerable number of other forms have been more or less completely investigated. It would be entirely beyond the proportions of the present book to enter into a description of these, and a discussion of the controversies that are bound up with the accounts of the multitude of incompletely known forms. The citation of the literature at the end of this section will guide the student to original papers, but he may also be referred here, as in so many other cases of difficulty, to de Bary's 'Comparative Morphology and Biology of Fungi,' \&c., I 887 , as containing an exhaustive and critical. treatment of these more or less obscure forms. 
He will find there also more information on the development of the sporocarps (both discocarpous and pyrenocarpous) of the types

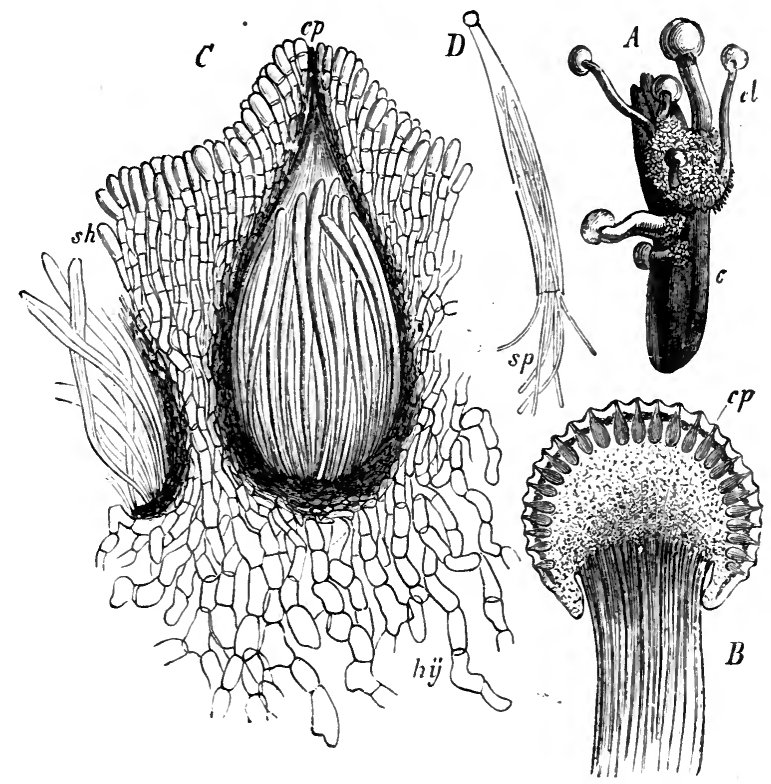

FIG. 3Ir.-Clarice'ps purpurea Tul. $A$, sclerote which has produced seven stromata. ' $B$, upper portion of a stroma in longitudinal section. $c p$, peritheces. $C$, longitudinal section of perithece. $c p$, ostiole ; $s h$, cortical tissue; $h y$, inner tissue of stroma. $D$, ascus isolated. $s p$, ascospores issuing. ( $A$, natural size, $B$ slightly, $C$ and $D$ highly magnified.) (After Tulasne.)

quoted than it is possible to give in this place without burdening the section beyond proportion with matter of no striking morphological significance.

\section{Homologies of THE ORgans.}

De Bary, the founder of the system of classification of fungi adopted in the present book, calls attention to the striking parallelism between Ascomycetous forms on the one hand and the Mucorini, Peronosporeæ, and Saprolegnieæ on the other. From the oosperms and the spores of the sporocarps there arises a thallus which closes its development with the formation of sexual organs and the oosperm and sporocarp resulting from their union. In many cases the life-history is confined to this; for example, from the Phycomycetes, Pythium vexans, \&c. ; from the 
Ascomycetes, Eremascus, Pyronema, and Ascobolus. In most cases, however, there intervenes the formation of non-sexual spores which may be in a species all of one sort, e.g., Erysiphe, Peronospora ; or of several sorts ; and such spores are, moreover, in many cases exceedingly alike.

Eremascus might almost belong to the Mucorini (Piptocephalideæ), while on the other hand it is not wanting in the essential attributes of an Ascomycete. In the form of its sexual organs it completely resembles Penicillium, Gymnoascus, Eurotium, \&c. Again, great agreement is to be recognised between the thallus, spores, and sexual organs of the Erysipheæ (Podosphæra especially) and those of the Peronosporeæ. The resemblance ceases with the farther development of the results of sexual union, and at this point the groups diverge from the point of contact of Eremascus and Podosphæra with the Mucorini and Peronosporeæ. Of course the envelope-apparatus of the asci is not included in any comparison, as being of purely secondary importance ; and since such envelope is actually wanting in Eremascus, the case is made the clearer. It is also pointed out that though the oogones of the Peronosporeæ have no envelope, it is by no means impossible that such may be found, while the zygosperms of Mucorini, as has been shown, are sometimes provided with an envelope. On such evident grounds as these, cited from de Bary ('Comp. Morph. and Biol. of Fungi,' p. 232), who enters minutely into the matter (as well as the subject of the sexuality of the Ascomycetes), the relationship of these groups with each other is abundantly established.

\section{Doubtful Ascomycetes.}

I. LaboulbenieÆ.-The Laboulbenieæ are a small assemblage of remarkable parasites on insects, attacking mostly water-beetles, but also other insects, including the house-fly. They possess no mycele, and occur fixed on the chitin of the insect attacked by means of a short process which serves as a haustorium, if that name may be applied to it. Above this rises a stalk consisting usually of two cells, one above the other, bearing at the summit a simple perithece and a few lateral hairs (the appendage) composed of seriated cells sometimes having minute round swellings at their apices. Before the complete development of the perithece has been reached, there is emitted from its summit a short fine process, which may be a trichogyne ; and according to Karsten (Stigmatomyces, Karst.) the minute round swellings on the hairs become free and attach themselves to the trichogyne. Doubt, however, has been cast upon the accuracy of this observation by the investigation of Peyritsch, who also attaches no great value to the suggestion that the so-called 
trichogyne is fertilised by the contact with it of one of the young hairs. The perithece contains a number of asci, and these eight or twelve double ascospores. The ripe double ascospore attaches itself to a fresh host by one of its ends, and develops into the new plant.

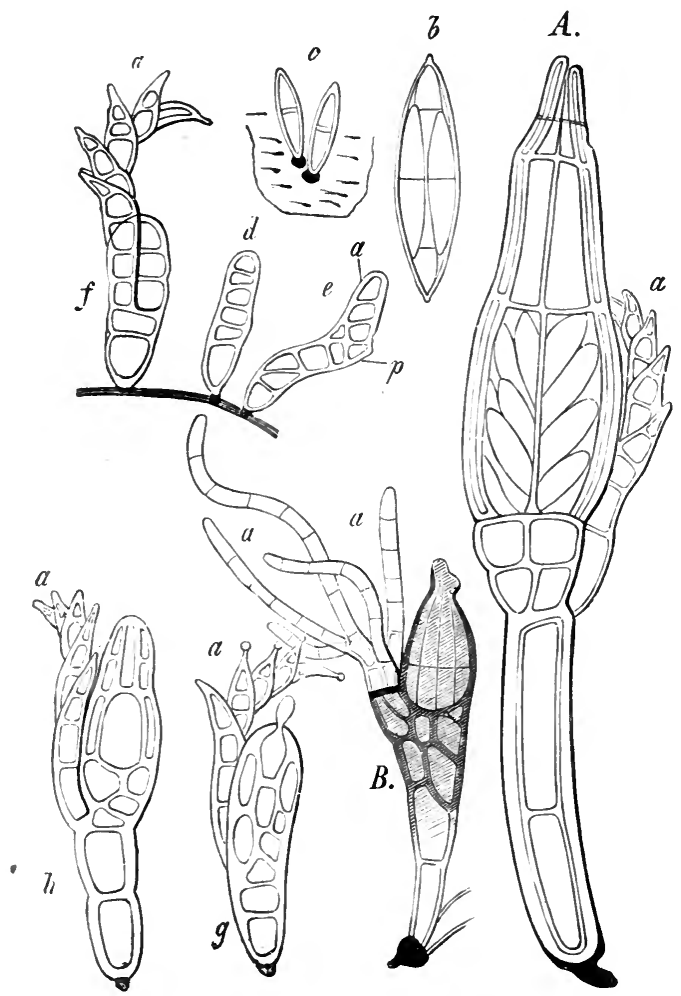

Fig. 312.-A: $b-h$, Stigmatomyces Baeri Peyr. (St. Musce Karsten). A, optical longitudinal section of ripe specimen with organ of attachment at base; the asci are seen through wall of perithece. $a$, everywhere the appendage; $b$, an isolated ascus with spores; $c-h$, stages of development of perithece and appendage in order of letters. $B$, Laboulbenia fagellata Peyr. $a$, the appendage. $(A, c, g, h \times 350 ; b, d, e, f \times 450 ; B \times 125$. (After Peyritsch.)

2. Exoascus (Fückel).-The species of Exoascus mostly attack fruits, and set up in them sometimes conspicuous deformities. While some of them possess a mycele which penetrates the parenchyme of the fruit, \&c. (e.g. E. Pruni, Fckl., E. deformans, Fckl.), others extend no farther than between the cuticle and the epiderm-cells. In the former case the terminal cells of the hyphæ which emerge from the surface 
become asci. In the latter case either certain cells become asci while others remain sterile or the whole body of hyphæ form asci. In E. alnitorquus (Sadeb.) these asci have a pedicel-cell ; in E. aureus (Sadeb.) there is nothing but asci left at maturity. When the ascospores germinate they give rise to a yeast-like sprouting.

3. Saccharonyces (Meyen).-The species of Saccharomyces occur in fermenting substances, and are well known from their power of converting sugar into alcohol and carbonic acid. Among the familiar species
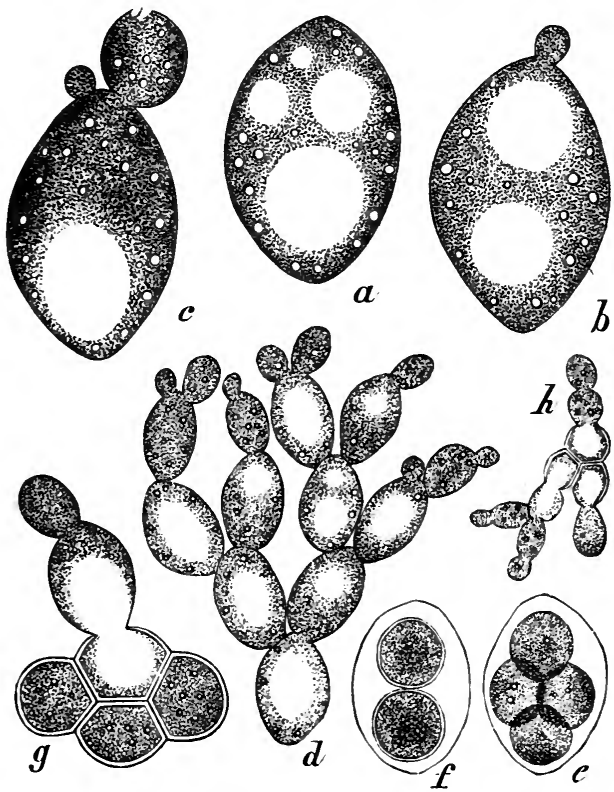

Fici. 313.-Saccharonyces corevisia Meyen. a, single cell of beer-yeast ; $b, c$, stages of sprouting ; $d$, colony of sproutcells ; $e$, cell with four ascospores; $f$, one with two; $g$, group of ascospores with one sprouting; $h$, further development of a similar group $(h \times 750$, the others much more). (e-h after Reess.) are S. cerevisiæ (Meyen) (ordinary yeast), S. ellipsoideus (Reess), S. Pastorianus (Reess), alcoholic ferments which are apparently mere formspecies. With these should be placed S. Mycoderma of Reess, and Chalara Mycoderma of Cienkowski ; and the 'thrush' fungus S. albicans (Reess), which lives parasitically on the mucous membrane of the human digestive organs, but is also capable of exciting a feeble alcoholic fermentation in sugar solutions. With the exception of the last-mentioned forms in which hyphæ occur, the species of Saccharomyces are unicellular fungi which increase by sprouting.

The cells, in which a nucleus has not been demonstrated, are round or oval in form, and the sprouting takes place in the form of a protuberance, which gradually swells and becomes constricted and finally cut off by a wall at the point of origin. These new cells either separate at once, or chains or groups remain united as they have been formed: When such cells are cultivated, on the cut surface of a potato for example, certain cells may form asci, each containing two to four ascospores. These are at once capable of germination, which takes 
place by the sprouting process described, though they may retain the power of germinating for a longer period.

This cell-increase by sprouting is, as has been seen, by no means confined to Saccharomyces, but occurs in other groups of fungi (e.g. Mucor), and the special character which entitles them to this place in the classification of fungi is the production of asci, which they share only with the Ascomycetes. They may therefore be regarded as much degraded Ascomycetous forms-the other alternative, that they are early forms from which typical Ascomycetes have developed, being disposed of by the establishment of the connection of this great group with the Phycomycetes as already described.

\section{LITERATURE.}

Barenetski-Entwickel. d. Gymnoascus Reessii (Bot. Zeit., 1872).

De Bary-Ueber d. Fruchtentwickel. d. Ascomyceten (Leipzig, I863).

De Bary-Beitr. zur Morph. u. Physiol. d. Pilze, iii., I87o.

De Bary-Exoascus Pruni (Beitr., i.).

De Bary-Ueber einige Sclerotinien, \&c. (Bot. Zeit., I886).

Bauke-Zur Entwickelungsgesch. d. Asconyceten (Bot. Zeit., I877).

Bauke-Beitr. zur Kenntniss d. Pycniden (Nova Acta Leop., xxxviii., 1876).

Borzl-Studii sulla sessualità degli Ascomicete (N. Giorn. Bot. Ital., x., 1878).

Brefeld-Botan. Untersuch., ii. and iv. ; compare also v.

Brefeld-Mucor racemosus und Hefe (Flora, I873).

Brefeld-Ueber Gährung (Thiel's Landwirthsch. Jahrb., 1875, 1876).

Cienkowski-Die Pilze der Kahmhaut (Mélanges Biol. Acad. St. Pétersb., viii.).

Cornu-Reproduction des Ascomycètes (Ann. Sc. Nat., 6 sér., Tom. I I).

Currey-On the Fructification of certain Sphæriaceous Fungi (Phil. Trans. Roy. Soc., 1858 ).

Eidam-Beitr. zur Kenntniss d. Gymnoasceen (Cohn's Beitr., iii.).

Eidam-Zur Kenntniss d. Entwickel. d. Ascomyceten (ibid.).

Eidam-Ueber Pycniden (Bot. Zeit., 1877).

Engel-Les ferments alcooliques, 1872.

Fisch-Zur Entwickelungsgesch. einiger Ascomyceten (Bot. Zeit., 1872).

Füisting-De nonnullis Apothecii Lichenum evolvendi rationibus (Diss. inaug. Berol., I 865).

Fiiisting-Zur Entwickelungsgesch. d. Pyrenomyceten (Bot. Zeit., 1867, i868).

Füisting-Zur Entwickelungsgesch. Lichenen (ibid., 1868).

Gibelli-Sugli org. reprod. del gen. Verrucaria (Mem. Soc. Ital. di Scienc. Nat., i.). Gibelli e Griffini-Sul polimorfismo della Pleospora herbarum (Arch. d. Laborat. di

Bot. Crittog. Pavia, i., I875).

Gilkinet-Recherches sur les Pyrénomycètes (Bull. Acad. Belg., I874).

Hansen--Oidium lactis, \&c. (Medd. fra Carlsberg Laborat., Bd. i.).

Hansen-Untersuch. über d. Physiol. u. Morph. d. Alkoholfermente (ibid.).

Hansen-Untersuch. iúber d. Organismen welche sich zu verschiedenen Jahreszeiten in d. Luft finden, \&c. (ibid.).

Hansen-Untersuch. tiber d. Physiol. u. Morph. d. Alkoholgährungspilze (ibid., Bd. ii.). 
Hansen-Bemerk. iiber Hefepilze (Allg. Zeitsch. f. Bierbrauerei, \&c., I883; Bot. Centralbl., xvii.).

Hartig-Wichtige Krankheiten d. Walabäume, p. IoI.

Hartig-Untersuch. aus d. Forstbot. Institut zu Muinchen, i.

Janczewski-Morphol. d. Ascobolus furfuraceus (Bot. Zeit., 1871).

Karsten-Stigmatomyces (Laboulbeniaceen) in Chemismus der Pflanzenzelle, 1869.

Kihlman-Zur Entwickelungsgesch. d. Ascomyceten (Acta Soc. Sc. Fennicæ, xiii., I883).

Krabbe-Entwickel., Sprossung und Theilung einiger Flechtenapothecien (Bot. Zeit., I882).

Krabbe-Morphol. u. Entwickelungsgesch. d. Cladoniaceen (Ber. d. D. Botan. Gesellsch., I883).

Kühn-Mittheil. d. Landw. Instituts Halle, i.

Lauder Lindsay-Spermogones and Pycnides of Lichens (Trans. Roy. Soc. Edinb., xxii.).

Low-Ueber Dematium pullulans (Pringsh. Jahrb., Bd. vi.).

Mattirolo-Sullo sviluppo e sullo sclerozio della Peziza Sclerotiorum Lib. (N. Giorn. Bot. Ital., xiv.).

Millardet_Mém. Soc. d'Hist. Nat. Strasbourg, vi., I868 (Myriangium, \&c.).

Pasteur-Mém. sur la fermentation alcoolique (Ann. Chim. et Phys., Tom. Iviii., 1860).

Pasteur-Etudes sur la bière (Paris, 1876).

Peyritsch-Ueber die Laboulbeniaceen, \&c. (Sitzber. Wiener Acad., Bd. 64,

Abth. I, 1871 ; Bd. 68, Abth. I, I873; and Bd. 72, Abth. 3, 1875).

Pirotta-Sullo sviluppo della Peziza Fuckeliana (N. Giorn. Bot. Ital., xiii.).

Rathay-Ueber d. Hexenbesen d. Kirschbäume (Sitzber. Wiener Acad., Bd. 83, Abth. I).

Reess-Botan. Untersuch. ïber d. Alkoholgährungspilze (Leipzig, I870).

Reess-Zur Kenntniss d. Exoascus d. Kirschläume (Sitzber. d. Phys. Med.

Gesellsch. zu Erlangen, 1882).

Reess-Ueber den Soorpilz (ibid., 1877 and 1878 ).

Reess-Untersuch. ü. Elaphomyces granulatus (Deutsch. Naturf. u. Aerzte, Strassburg, 1885).

Reinke u. Berthold-Die Zersetzung d. Kartoffel durch Pilze (Berlin, 1879).

Schwendener-Ueber d. Entwickelung der Apothecien von Cœnogonium (Flora, I 862).

Schwendener-Ueber d. Apothecia primitus aperta u. d. Entwickel. d. Apothecien im Allgemeinen (ibid., 1864).

Sorokin-Quelques mots sur l'Ascomyces polysporus (Ann. Sc. Nat., 6 sér., Tom. iv.).

Stahl-Beiträge zur Entwickelungsgesch. d. Flechten, i. (Leipzig, 1877).

Van Tieghem-Chretomium (Comptes Rendus, 8I).

Van Tieghem-Nouv. observ. sur le développement du fruit, \&c., des Ascomyçètes. (Bull. Soc. Bot. France, xxiii., 1876). (See also Bot. Zeit. same year.)

Van Tieghem-Sur le développement du fruit des Ascodesmis (ibid.).

Van Tieghem-Nouv. observ. sur le développement du périthèce des Chætomium (ibiit.).

Van Tieghem-Sur le développement de quelques Ascomycètes (ibid., xxiv.).

Van Tieghem-Monascus, genre nouveau de l'ordre des Ascomycètes (Bull. Soc. Bot. France, 1884).

Tulasne-Fungi hypogaei (Paris, I851). 
Tulasne-Selecta Fungorum Carpologia, i.-iii. (Paris, 186I-65).

Tulasne-Rech. sur l'organisation des Onygena (Ann. Sc. Nat., 3 sér., Tom. i.).

Tulasne-Note sur l'appareil reproducteur des Lichens et des Champignons (ibid., 3 sér., Tom. xv.).

Tulasne-Mém. pour serv. à l'hist. organograph. et physiol. des Lichens (ibid., 3 sér., Tom. xvii.).

Tulasne-Discomycètes (ibid., 3 sér., Tom. xx.).

Tulasne-Mém. sur l'Ergot des Glumacées (ibid.).

Tulasne-Note sur l'appareil reprod. des Hypoxylées et des Pyrénomycètes (ibid., 4 sér., Tom. v.).

Tulasne-Nouv, observ. sur les Erysiphés (ibid., 4 sér., Tom. i.). (See also Bot. Zeit., I853.)

Tulasne-Note sur les Isaria et les Sphæria entomogènes (ibid., 4 sér., Tom. viii.).

Tulasne-De quelques Sphéries fongicoles (ibid., 4 sér., Tom. xiii.).

Tulasne-Note sur les phénomènes de copulation d. 1. Champignons (ibid., 5 sér., Tom. v.).

Tulasne-Super Friesiano Taphrinarum genere (ibid.).

Vittadini-Monographia Tuberacearum (Mediolani, I831).

Vogel-Gymnoascus uncinatus (Bot. Centralblatt, xxix.).

Wilhelm-Beitr. zur Kenntniss d. Pilzgattung Aspergillus (Diss. Berl., 1877).

Woronin-Entwickelungsgesch. d. Ascobolus pulcherrimus und einiger Pezizen

(Beitr. zur Morph. u. Physiol. d. Pilze, ii.).

Woronin-Sphæria Lemaneæ, Sordaria, \&c. (ibid., iii.).

Zopf-Zur Entwickelungsgesch. d. Ascomyceten (Chrtomium) (Nova Acta Leop., xlii.).

Zopf-Die Conidienfriichte von Fumago (ibid., xl.).

\section{Class XXI.-Uredineæ.}

The Uredineæ are a class of parasites on flowering plants and ferns. They resemble the Ascomycetes in many points, as will be seen from this short account of them. The mycele is septate and much branched, follows the intercellular spaces of the host-plants, and penetrates the cells themselves by means of short branches.

Puccinia graminis (Pers.) may be taken as a type of the course of development followed by some of the forms. Owing to the change of host involved in the course of development of this and other forms, and to the different appearances presented by succeeding stages of the organism, it was formerly supposed that these stages constituted distinct fungi. Thus no less than three form-genera (Acidium, Pers., Uredo, Pers., and Puccinia, Pers.) were established to denote the stages of the life-cycle of Puccinia graminis, the well-known corn mildew. The sporocarp (Acidium) is formed in spring on the barberry. In its 


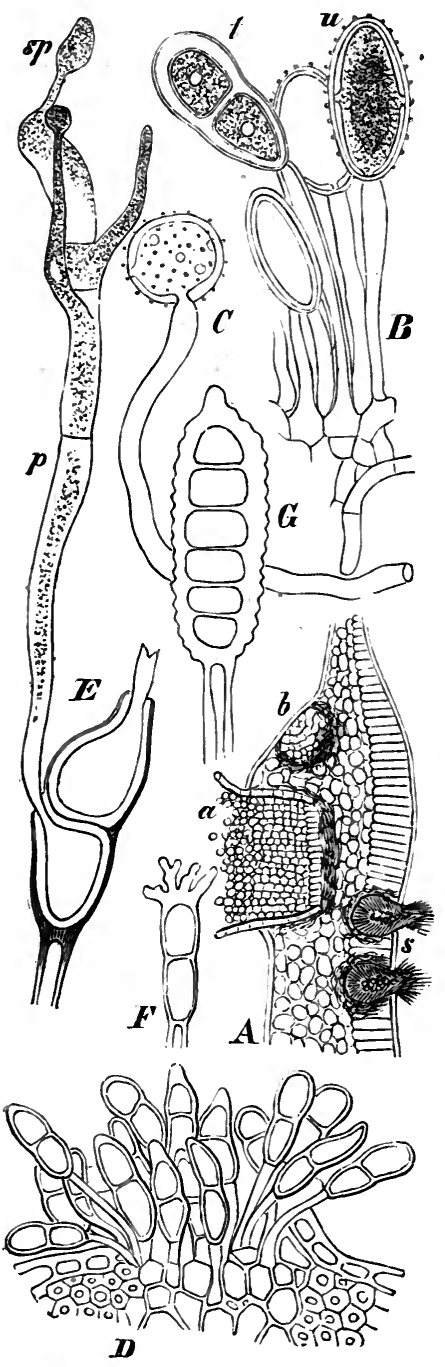

FIG. 314. $-A$, diagrammatic transverse section of barberry leaf with æcidia, $a, b$, and antherids. $s$ (slightly magnified). $B$, uredospores, $u$, and teleutospore, $t . \quad C$, germinating uredospore ( $B$ and $C \times 390)$. $D$, teleutospores. $E$, germinating teleutospore: promycele, $\phi$, and sporids, $s p(\times 400)$. $(A, B, D$, and $E$ of Puccinia graminis, $C$ of $P$. straminis Fckl., $F$ teleutospore of $P$. coronata Cord., $\times 300$ ). $G$, teleutospore of Phragmidium incrassatum Link. $(\times 300)$. $(A, F$ and $G$, after Luerssen ; $B-D$, after de Bary ; $E$, after Tulasne.) earliest stage it appears to consist of a densely interwoven mass of hyphæ situated in the subepidermal parenchyme of the leaf. This gradually increases in bulk and displaces the surrounding tissue. As it grows the hyphæ increase in size, and the shape of the whole becomes more definitely spherical. Within the base of this sphere the hymenium is developed, and consists of a continuous layer of club-shaped basids, from the summit of each of which is produced in basipetal succession a single series of acidiospores. Enclosing the sporal mass is a single layer of pseudo-parenchymatous cells arising from the margin of the hymenium, and arching over the top of the spores. The cells composing the envelope are larger than the spores, and possess thicker walls, while their clearer contents contrast with the orange-coloured spores. The enlargement of the whole body increases until the epiderm is ruptured, while the tissues of the host are pushed aside and compressed. After the rupture of the epiderm the envelope bursts at the apex, and curves back, forming the lip of a cup-shaped body; the sporal mass is farther elevated and the spores escape. These sporocarps are situated on the under surface of the leaf, but accompanying them on the upper surface there are to be found numerous flask-shaped antherids containing pollinoids produced at the apices of sterigmata, and in all points recalling 
those already described in Collema. They are orange-coloured like the sporocarps, and the pollinoids have never been known to germinate. No corresponding female sexual organ occurs in any Uredine, though the early stages of the development of the sporocarp are not sufficiently known. No such body as Woronin's hypha in Xylaria, for example, has ever been observed in the Uredineæ, and the only suggestion of a female sexual organ is to be found in the occasional occurrence in some Uredines of short obtuse hyphæ, projecting through the stomates of the host like the trichogynes of Polystigma. These may be traced, it is true, to young æcidia, but there may well be nothing more in the suggestion than the mere protrusion of mycelial hyphæ, since observations connecting such filaments with an act of fertilisation are wholly wanting. Massee ('Annals of Botany,' I888, p. 47) has recently published an account of observations of a supposed sexual process in Uredinex, involving the fertilisation of a carpogone by an antheridial branch ; but the subject stands in great need of farther investigation.

The spores from the ripe sporocarp (ai $i$ diospores) germinate only on the leaves or stems of grasses, and the germ-tubes entering by way of the stomates give rise to myceles, which attack the tissues of the host. In the course of a week or more, cushionlike masses of mycelial hyphæ situated beneath the epiderm give rise to erect basids, each of which bears a red uredospore (Uredo) at the apex. On the rupture of the epiderm the uredospores escape, and these alighting on

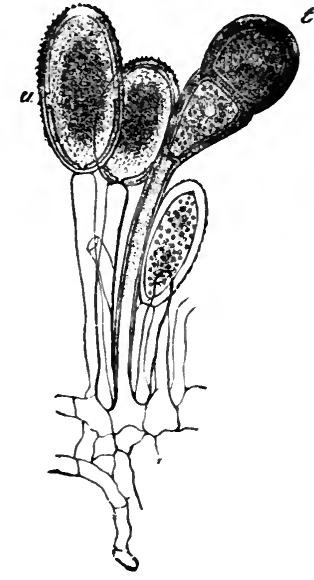

FIG. 3r5.-Puccinia graminis Pers. $t$ teleutospore; $u$, uredospores $(\times 390)$. (After Sachs.) grass plants germinate, again enter by way of the stomates, and renew the same generation. This process may and does go on indefinitely, and thus much damage is annually caused by the attack of this fungus on the corn crop.

Later on there are developed on the same mycele, first side by side with the uredospores, then gradually replacing them altogether, two-celled spores called teleutospores, and with their production the development of the fungus ceases for a period. In this condition the winter is passed. With spring they germinate, each of the two cells of the teleutospore (Puccinia) giving rise to a short promycele, the terminal cells of which bear on slender stalks a single sporid apiece. These sporids germinate in turn on the leaves of the barberry, the germ-tubes piercing the epi- 
derm, and giving rise within to the mycele which ultimately bears the sporocarps and antherids.

Gymnosporangium (DC.) represents another type of the course of development in Uredineæ. The sporocarps (corresponding to æcidia, but here denoted by the form-genus Roestelia, Reb.) appear in summer on the leaves and fruits of Pomeæ. No uredospores are formed. The next generation (teleutospores) is produced in spring on juniper in odd-shaped mucilaginous brown or yellow masses. Promyceles are formed which bear sporids, and these again set up on the leaves, \&c., of Pomeæ the sporocarp generation.

A farther reduced type is to be found in Endophyllum (Lév.). In this case the germ-tube of the spores of the sporocarp (æcidiospores) becomes a promycele, and, dividing up into several cells, each of these bears at the end of a sterigma a single sporid. The sporid on germinating renews the sporocarp generation.

Two cases of exceptional structure may be noted. In Phragmidium (Link) the sporocarps have no proper envelope, the place of the wall being taken by a circle of club-shaped paraphyses surrounding the margin of the hymenia. On the other hand the uredospores of $\mathrm{Me}$ lampsora populina (Jacq.) and of Cronartium (Pers.) are enclosed in an envelope resembling that of the sporocarp. The development of the paraphyses in the one case and of the envelope in the other requires investigation.

Besides the sporocarp-forming Uredinea there is another group known as the tremelloid Uredinea, which do not possess a sporocarp generation. These are not to be confounded with those Uredineæ in which presumably from want of investigation the sporocarps are unknown. The course of development of the tremelloid Uredineæ is perfectly well known in a number of cases (Leptopuccinieæ and Leptochrysomyxa, de By.), and consists of a teleutospore-bearing generation with commonly softer and more gelatinous spore-membranes. These teleutospores germinate as a rule at maturity and not after a period of rest. The sporids formed on the promycele produce a mycele which again bears teleutospores. Leptopuccinia malvacearum (Schroet.), L. Dianthi (Schroet.), \&c., bear the same relation in appearance, \&c., to Puccinia as Leptochrysomyxa Abietis (Ung.) bears to Chrysomyxa (Ung.), the species of which form sporocarps, uredospores, and teleutospores.

Enough has been said in this brief account to indicate a probable connection of the Uredineæ with the Ascomycetes through their sporocarps. Those forms-the tremelloid Uredineæ-in which the sporocarp generation may be presumed to have been lost, sufficiently resemble the complete types to be necessarily bound up with them; 
while on the other hand, as will be seen, they furnish a valuable link with the next class.

\section{LiteratuRE.}

De Bary-Untersuch. über die Brandpilze (Berlin, 1853).

De Bary --Rech. sur le développement de quelques Champignons parasites (Ann. Sc. Nat., sér. $4, \mathrm{xx}$.).

De Bary-Ueber Cæoma pinitorquum (Monatsber. Berl. Akad., I863).

De Bary-Neue Untersuch. über d. Uredineen (ibid., I 865, I 866).

De Bary-Ueber d. Krebs u. d. Hexenbesen d. Weisstanne (Bot. Zeit., I867).

De Bary-Æcidium abietinum (ibid., I879).

Dietel-Beitr. z. Morph. u. Biol. d. Uredinex (Bot. Centralblatt, xxxii., 1887, p. 54 ; ibid., 1888 , No. 33 ).

Farlow--The Gymnusporangia or Cedar Apples of the United States (Mem. Boston Soc. Nat. Hist., I 880).

R. Hartig-Wichtige Krankheiten der Waldbäume (Berlin, I874).

R. Hartig-Lehrbuch der Baumkrankheiten (Berlin, I882).

Léveillé-Sur la disposition méthodique des Urédinées (Ann. Sc. Nat., sér. 3, viii.). Oersted-Om Sygdomme hos Planterne, \&c. (Kjöbenhavn, I863).

Oersted-On Podisoma and Roestelia (Oversigt k. Danske Vidensk. Selskal). Forhandl., 1866 ; and K. Danske Vidensk. Selskab. Skrifter, ser. 5, vii.).

Parker-On the Morphology of Ravenelia glandulæeformis (Proc. Amer. Acad. Sc. and Arts, I886).

Rathay-Untersuch. iiber d. Spermogonien d. Rostpilze (Denkschr. d. Wien. Akad., I883, Bd. xlvi.).

M. Reess - Die Rostpilzformen d. deutsch. Coniferen (Abhandl. Nat. Gesellsch. zu Halle, Bd. xi.).

Schröter-Die Brand- u. Rostpilze Schlesiens (Abhandl. Schles. Ges. vaterland. Cultur, I869 [1872]).

Schröter-Entwickelungsges. einiger Rostpilze (Cohn, Beitr. i., Heft 3 ; ibid., ili., Heft I).

Schröter-Ueber einige amerikanische Uredineen (Hedwigia, I875).

Schroter-Beobacht. über d. Zusammengehörigkeit von Ecidium Euphorbia u. Uromyces Pisi (ilid., 1875).

Tulasne-Mém. sur les Ust'laginées et les Urédinées (Ann. Sc. Nat., sér. 3, vii. ; iliid., sér. 4 , ii.).

Ward-Researches on the Life-history of Hemileia vastatrix (Linn. Soc. Journ. Bot., xix.).

Ward-On the Morphology of Hemileia vastatrix (Quart. Journ. Micr. Sc., N.S., xxii., I 882).

R. Wolff-Acidium pini u. seine Zusammenhang mit Coleosporium Senecionis Lev. (Festschrift, Riga, I876).

In the above papers will be found references to older literature and farther memoirs on the group. For a systematic account the student is specially referred to Winter's Die Pilze Deutschlands, Oesterreichs und der Schweiz, in the new edition of Rabenhorst's Kryptogamenflora von Deutschland, \&c.; and to Plown ight's Rritish Uredineæ and Ustilagineæ (London, 1889). 


\section{Class XXII.-Basidiomycetes.}

The Basidiomycetes are a large class comprising forms of the utmost diversity in appearance, mostly saprophytes living on humus, rotten wood, or the old wood and the bark of trees. A small number are parasites. They all agree in the production of spores (basidiospores) acrogenously on basids, which are club-shaped and disposed as a rule parallel to each other, thus forming hymenia. The spores produced on one basid are two or four in number, more rarely eight, though divergences from these numbers occur. They vary in shape, but consist, except in some Tremellineæ, of a single cell. Among the hasids there commonly occur sterile hyphal branches-paraphyses. Besides these spores thus borne on definite hymenia there are also others produced more or less indefinitely on the myceles of certain members of the group, and their character will be described below. The Basidiomycetes are divided into two sub-classes, the HyMenomycétes with gymnocarpous, and the Gasteromycetes with angiocarpous fructıfication.

\section{Sub-class 1.-Hymenomycetes.}

The Hymenomycetes are characterised by the possession of a hymenium on the free exposed surface of the compound structure which bears it-the sporophore. The forms embraced in this sub-class range from very simple to highly complex structures, the latter being repre-

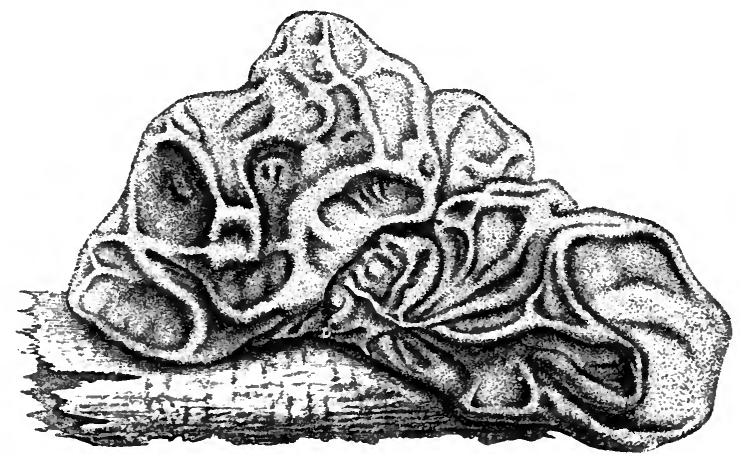

FIG. 3r6.-Tremella mesenterica Retz. (natural size). (After Tulasne.)

sented by such types as the common mushroom and the like-in slort those fungi to which the name is popularly applied.

Exobasidium Vaccinil (Woron.) may be taken as the simplest type. Its mycele is parasitic on the leaves and stems of Vaccinium vitis-idæa, 
and forms on the surface a hymenium of club-shaped basids each of which produces four basidiospores. The spores divide at maturity transversely into four cells, only the two end cells of which germinate, doubtless at the expense of the contents of the remaining two. The germtubes penetrate the epiderm of the leaf of the host, and a new mycele is formed which again bears basids. If, however, germination takes place elsewhere than on the proper host-plant, and conditions for the vegetation of the fungus be otherwise favourable, the germ-tube begins to sprout indefinitely by means of elongated sproutcells, giving rise to others only at the ends. This condition has been maintained in nutrient solutions for a considerable time, but the sprout-cells have never been observed actually to give rise to a new mycele like the one produced by the basidiospores.

The Tremellines (Tremella, Dill., Exidia, Fr.) present another simple type. They are gelatinous fungi of not very definite form, commonly of wavy outline, and are saprophytic on old and dead wood. The hymenia are formed on the surface of the gelatinous mass. The basids vary in appearance, and are usually provided with fine elongated sterigmata and reniform spores. Certain forms such as Sebacina (Tul.) and Hypochnus (Fr.) do not possess gelatinous membranes. The course of development is much the same as in Exobasidium. The germinating basidiospore gives rise under ordinary conditions to the compound sporophore again. Under other conditions, it has been observed in Dacryomyces, the germ-tubes do not grow to any great length, but produce secondary spores, or they form sprout-cells.

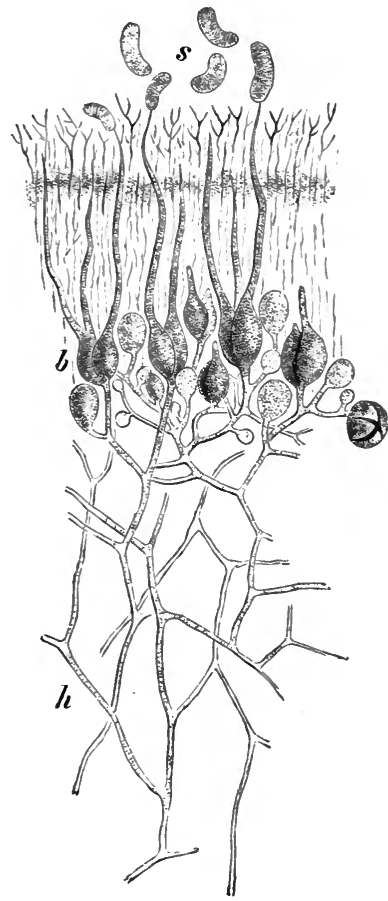

FIG. 317.-Exidia spiculusa Sommerf. Longitudinal section of portion of hymenium (much magnified). $s$, spores ; $b$, basids: $h$, hyphæ of thallus. (After Tulasne.)

The basidiospores of the same form divide transversely at maturity, usually into four cells, each of which may germinate. It should be added that on germination these secondary spores give rise to myceles. The hyphæ of such myceles, moreover, as well as those proceeding from basidiospores, sometimes give rise to tufts of rod-like cells, which in turn produce myceles. Similar phenomena have been observed in other Tremellinex. 
It is manifest therefore that in these simple types we have repeated very much the same order of things as in the tremelloid Uredineæ. It is perhaps most striking in the case of Exobasidium, from which the transition is easy to the Tremellineæ. The layer of basıds and basidiospores may be compared with the layer of teleutospores, while the transverse division

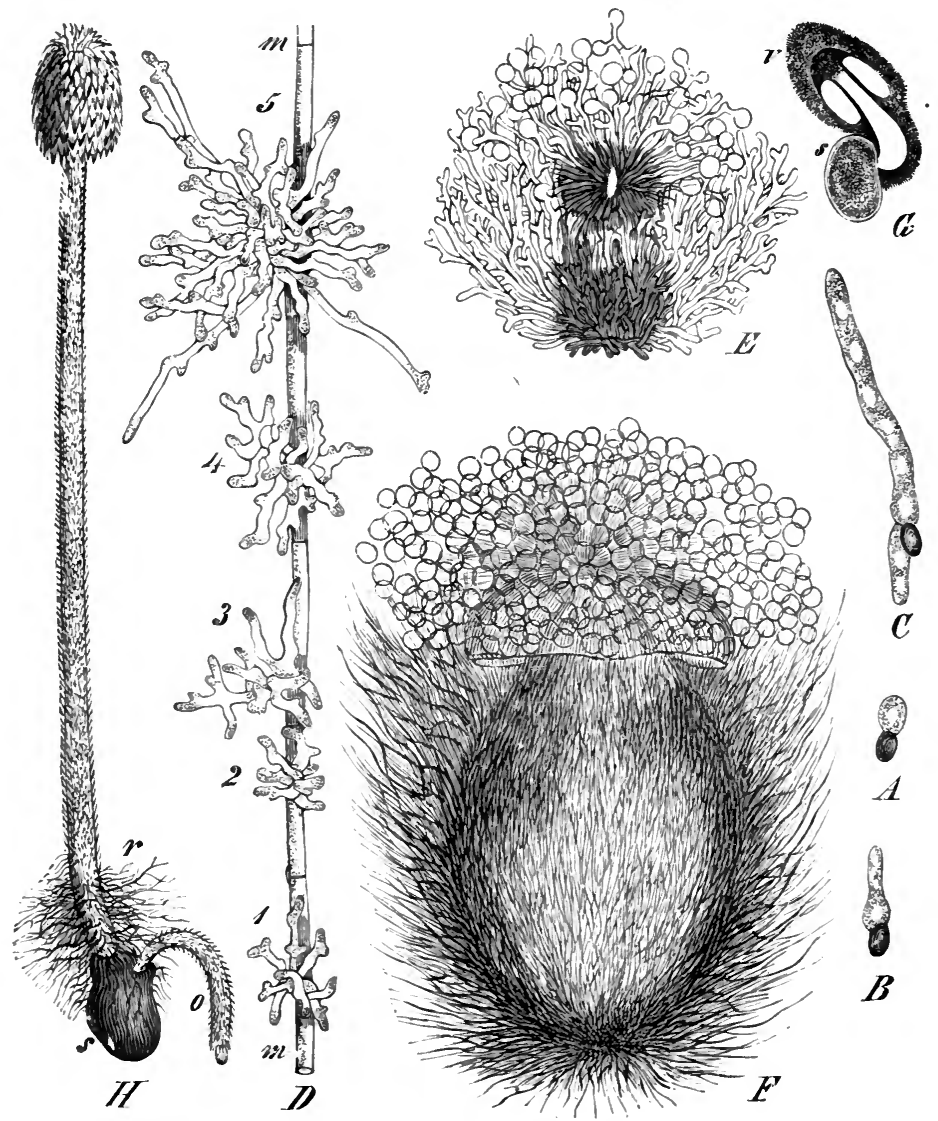

FIG. 318.-Coprinus stercorarius $\mathrm{Fr} . \quad A, B$, and $C$, germinating spore in successive stages. I) portion of mycele, $m$, with five early stages of development of fungus. $E$ and $F$, further stages. $G$, longitudinal section through germinating sclerote, $s$, with young fungus still within volva, $z$. $H$, fully developed fungus with sclerote, $s$, and rhizoids, $r$. $(A-C \times 300, D \times 200, E \times 120$, $F \times 50, G$ and $H$ natural size.) (After Brefeld.)

of the basidiospores into four cells, two of which germinate, heightens the resemblance. Farther the production of secondary spores on the short germ-tubes of basidiospores recalls the formation of sporids on the 
promyceles from teleutospores. From the T'remellineæ another easy step leads us on to the Thelephoreæ, and it may be borne in mind in this connection that certain 'Tremellineæ, as mentioned above, do not possess gelatinous membranes.

The Thelephoreæ (Corticium, Pers.) may be shortly described as recalling in point of simplicity of structure the teleutospore-layer of Uredineæ, while they approach very closely the club-shaped Hymenomycetes such as the Clavarieæ, in which the hymenium is disposed on the outer surface of erect club shaped cylindrical and often much-branched compound sporophores. Through a series of intermediate forms, the completeness of which may be recognised from a systematic study of the group, we proceed to the more perfect types of Hymenomycetes which possess sporophores of more complex structure.

In the higher forms of Hymenomycetes, the sporophore consists of a cap or pileus borne on the summit of a stalk or stipe. The mycele commonly regetates in a soil rich in humus or on old wood or the like, and though usually of loose filamentous texture it is in

Fí. 319.-Agaricus melleus L., in different stages of development on branched rhizomorph-strands. The upper portion of rhizomorph represents that formerly known as Rhizomorpha fragilis Roth, while the lower strap-shaped portion is var. subcorticalis. (After Hartig.)

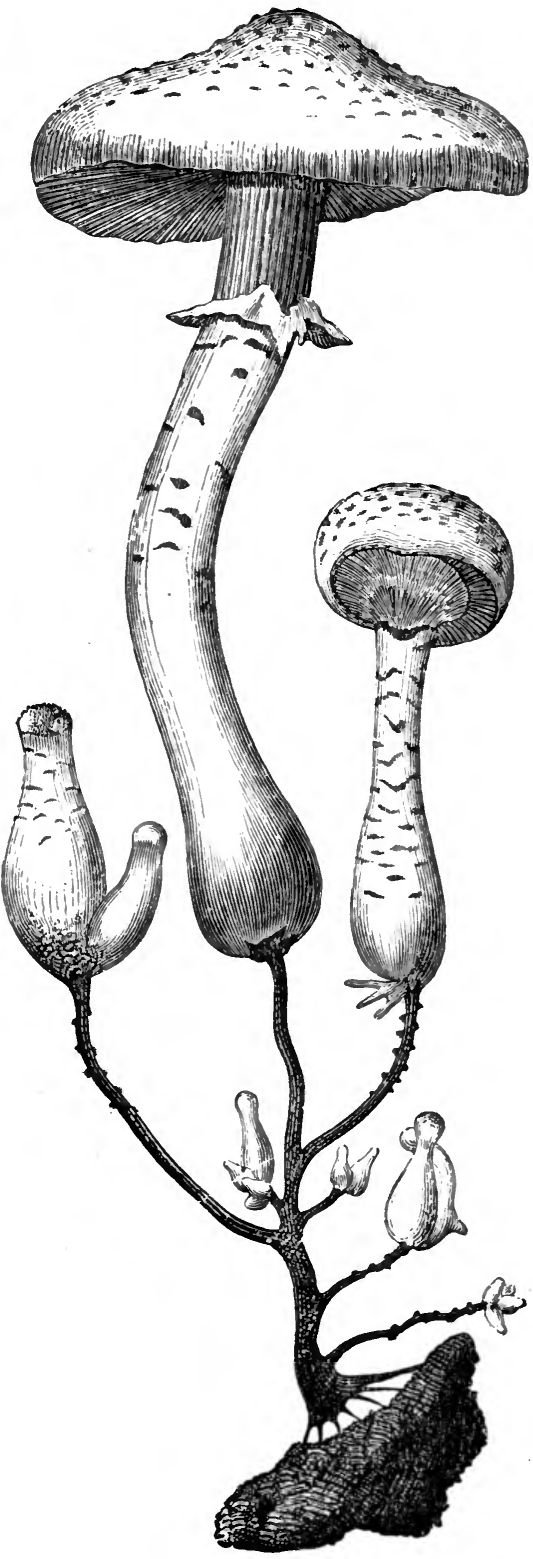


certain instances of more compact character. Such are the sclerotes which are resting states of Coprinus stercorarius (Fr.) (fig. 3I8), and the rhizomorphs of Agaricus melleus (L.) (fig. 319), composed of root-like branched strands of mycelial hyphæ, parasitic on the pine. The rhizomorphs are simply sclerotes with growing-points. From the mycele, of whatever character it be, there arises the compound sporophore by the continued apical or marginal growth of a bundle of hyphæ. It is not certain, but it may very well be, that intercalary growth also, in some

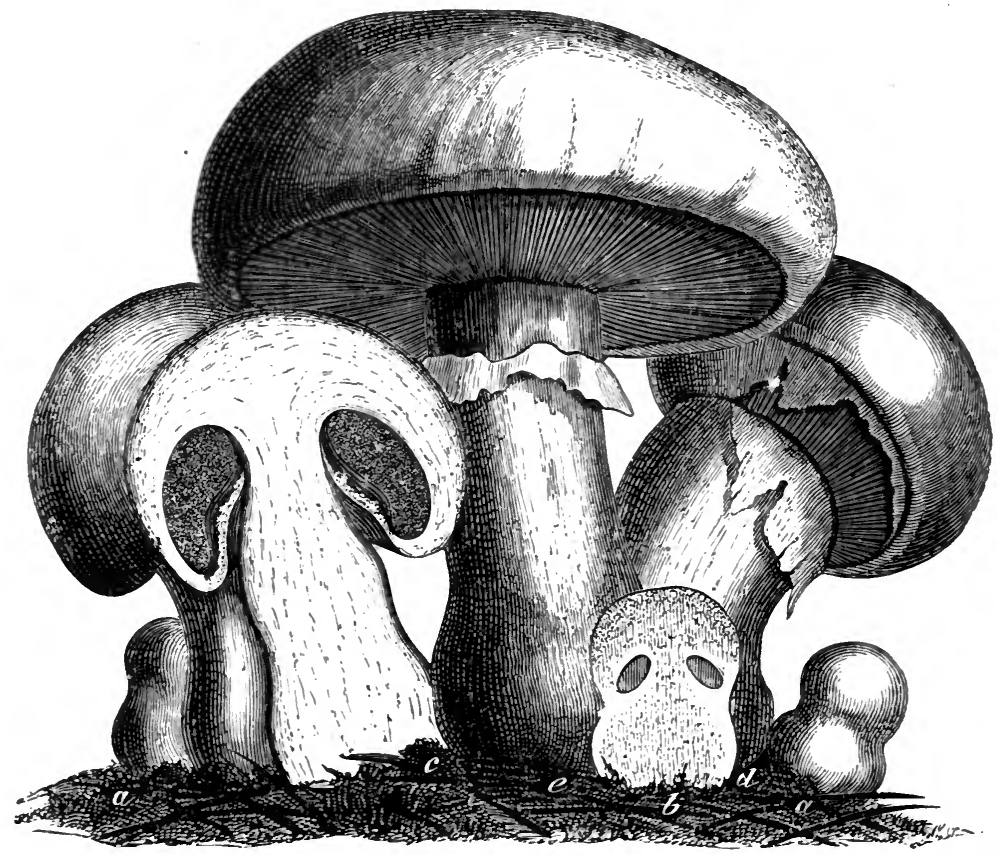

FIG. 320.-Agaricus campestris L. The common mushroom (natural size). Stages of development from $a$ to $e ; b$ and $c$ in section. (After Luerssen.)

cases at least, assists in the development. The hymenial surface, which is commonly situated on the under surface of the cap or pileus, is characterised in different genera by being spread over teeth-like projections (Hydnum, L.), radial plates in the numerous species of Agaricus (L.), concentric plates in the small genus Cyclomyces (Kze.), reticulated folds or pores (Polyporus, Mich. Boletus, L.) ; such typical characters being united by a wealth of intermediate forms. As a rule these projections are very symmetrical and of regular occurrence, and on them the chief generic characters are based in the classification of the group; 
they are termed gills or lamella in the AGARICINI, pores or tubuli in PolyPOREE, and teeth in the HYDNEE. In many of the forms the hymenium is exposed from the first ; in a series of others a membrane (velum partiale) connects the edge of the pileus all round with the stalk, and on its rupture by the extension of the pileus, part of it is left attached to the stalk, when it is termed the annulus or ring (fig. 320), though this does not occur in all cases. In a third series a membrane (velum universale or volva) (fig. 3 r 8 ) encloses the whole sporophore, pileus and stalk alike, and in the species belonging to Amanita, a sub-genus of Agaricus, both velum universale and velum partiale are present. In these latter cases, therefore, in which a

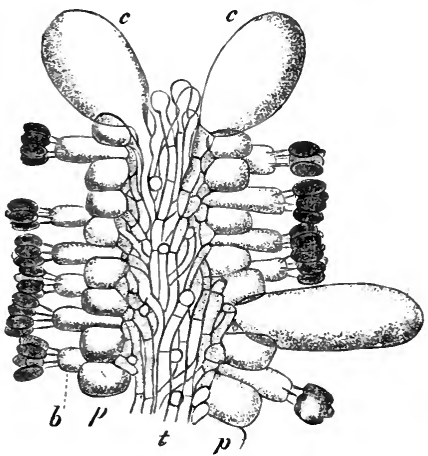

FIG. 32I.-Coprinus stercorarius Fr. Longitudinal section of the end of a gill in complete spore-bearing. $t$, trama; $p$, sterile palisade cells; $b$, basids with spores; $e$, cystids $(\times 300)$. (After Brefeld.) membrane is present, the sporophore differs from the truly gymnocarpous forms. The development of Amanita is especially noteworthy, since the gills are not developed on the free inner surface of the pileus, but during an early condition from tissue common to both stalk and pileus.

Inmediately beneath the hymenium is a layer of tissue called the sub. hymenial layer, distinguished from the rest of the tissue of the sporophore by the greater density of the ramifications of the hyphæ and by the more abundant protoplasmic contents.

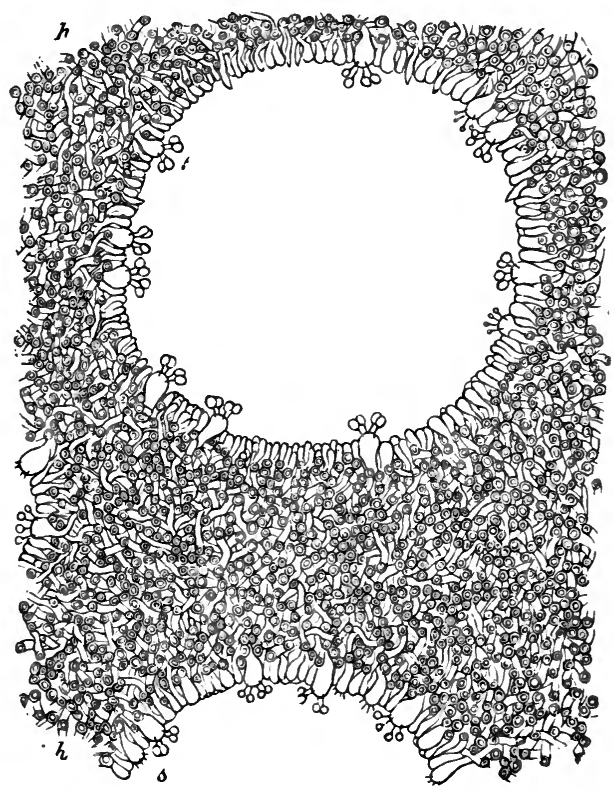

F1G. 322.-Polyporus igniarius Fr. Transverse section of the under surface. $h$, the plexus of hypha forming the walls between the pores; $s$, the hymenium $\left(x_{270}\right)$. (After Luerssen.) 
The trama is that portion of the projection which bears the subhymenial layer, and consists of hyphæ running parallel to the surface from the insertion of the projection to its margin, which in many cases is uncovered by the hymenium.

The hymenium itself consists of parallel rows of club-shaped basids surmounted by sterigmata and basidiospores. The basids are the terminations of the subhymenial hyphæ, but the latter also frequently end in sterile cells, which are termed paraphyses, from the fact that they stand in the same relation to the basids as the paraphyses do to asci. Large inflated cells, often of relatively great dimensions, called cystids,

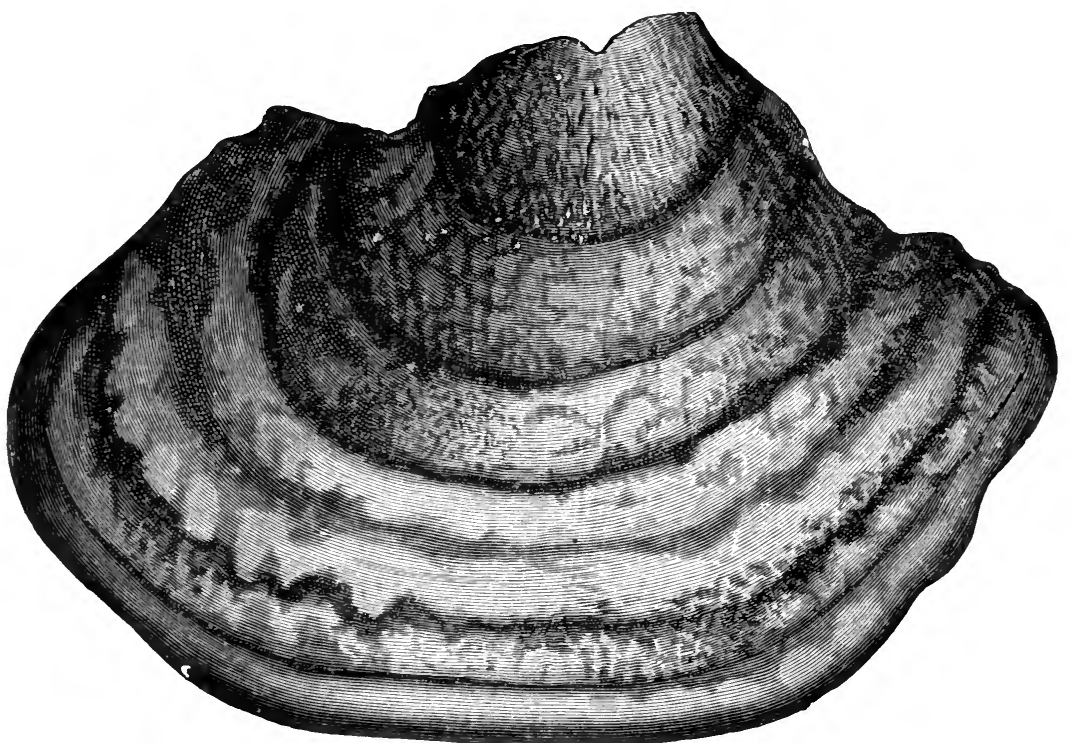

FIG. 323.-Polyporus igniarius Fr. Upper surface (half natural size). (After Luerssen.)

are frequently found emerging from the hymenial surface (fig. $32 \mathrm{I}$ ). They are very variable in form, club shaped, flask-shaped, cylindrical; pointed, hooked, or knob-shaped at the tip. They may be regarded as merely prominent hymenial hairs with the probable function of protecting the basids, or of parting the appressed lamellæ. They have been the subject of much idle speculation, and among other erroneous views they have been regarded as male organs.

In the sporophores of many Agaricini, notably of Lactarius (Fr.), laticiferous hyphae occur, which yield considerable quantities of milky, generally acrid, juice when the tissue is bruised. 


\section{Sub-class 2.-Gasteromycetes.}

The Gasteromycetes very closely resemble the Hymenomycetes in the essential points of the structure of the basids. At all events the agreement is close in this respect between the higher Hymenomycetes with cap and stalk, and the Hymenogastreæ, a section of the Gasteromycetes; while other subordinate sections, such as the Lycoperdaceæ and Phalloideæ, diverge from the Hymenogastreæ only in minor points, as, it was seen, the lower Hymenomycetes do from the higher forms. The possession of a trama with a hymenial layer on either side of it may be here noted. In the external conformation, however, of the members of the group, a great variety is displayed, and, but for the existence of numerous intermediate forms, the group would appear to lack coherence in this respect, so great is the range of variation.

The mycele is very frequently in the form of root-like strands, though there is no constancy in this respect, and the simple filamentous mycele occurs abundantly. 'The compound sporophores frequently grow to a great size in some of the sections, but the character which unites the whole is the possession of an investing membrane, the peridium, within which, and springing from it, are plates of tissue dividing the interior into chambers where the hymenium is produced.

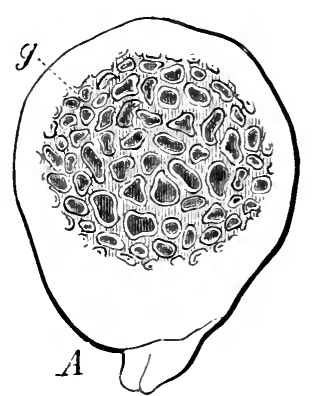

Fig. $324 .-A$, Octariana asterosperma Vitt., in section $(\times 5)$. (From luerssen after Tulasne.)

At the outset there may be noted the remarkable genus Gautieria (Vitt.), which has no peridium. The peripheral chambers are therefore exposed on the free surface. The peridia of other forms vary considerably in thickness and other characters, and a tendency exists towards excessive thickening in the basal region, which develops outwards, forming a stalk in some instances, e.g. Lycoperdon (Tourn.) ; or inwards, in which case either a cushion-like body is produced, e.g. Hymenogaster (Vitt.), or a central column, e.g. Phalloideæ. The whole chambered structure is termed the glebe.

The Hymenogastrea may be regarded as an assemblage of the simplest forms of Gasteromycetes, possessing usually the simple structure indicated, but including among its members Gautieria without a peridium, and Secotium (Kze.), a genus with a central column traversing the body of the fungus. These two forms but heighten the resemblance which it bas been remarked exists between the Hymenogastreæ and the Hymeno- 
mycetes, the one being an approach to gymnocarpous forms, and the other noteworthy in respect of its stalked and pileate appearance. De Bary, in comparing the groups, says ('Comp. Morph. and Biol,' p. 337): "If we could attribute a decisive value to the habit of the plants, we should dwell upon the great resemblance between the stalked Hymenogastreæ, like Secotium erythrocephalum ('Tul.), and a veiled Boletus. . . . But among the Polyporeæ there is a remarkable form Polyporus volvatus (Pk.), the Polyporus obvallatus (Berk. and Cooke), which considered by itself must be placed with or close to the Hymenogastreæ. Its sporophore, which lives in the bark of trees, is a hollow spherical body flattened at the poles and about the size of a hazel nut, with a thick closed wall of leathery texture; its interior surface is

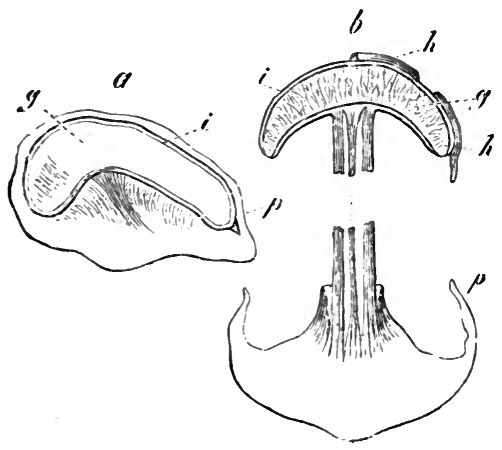

FIG. 325.- Batarrea Steveni Fr., longitudinal sections. $a$, a younger specimen, but with most of its spores ripe $b$, a mature specimen, of which only apex and base are shown. $p$ and $h$, the outer, $i$, the inner peridium; $g$, the glebe (one-third natural size). (After de Bary.)

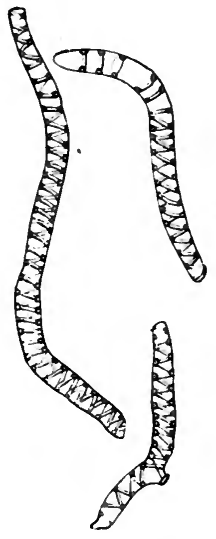

Fig. 326.-Batarrea Steveni Fr. Isolated threads of the capillitium ( $\times 390)$. (After de Bary.)

covered with the hymenium of a Polyporus on the part next the substratum, and is sterile on the opposite side.'

In the LyCOPERDACEÆ (Puff-balls) the peridia are often developed to a colossal size, and in structure they agree in the main with the Hymenogastreæ. The chief distinction lies in the existence of two kinds of hyphæ in the trama ; slender segmented hyphæ with dense protoplasmic contents, the terminal members of which compose the hymenium, and stouter hyphæ running not only in the trama, but crossing the chambers. Eventually the slender hyphæ and the hymenium disappear, leaving only the stout hyphæ, now called the capillitium, and the masses of spores between. As examples of the possession of both inner and outer peridium in this section, there may be cited Geaster (Mich.), in which the outer one 
becomes recurved after splitting longitudinaily and acquiring a stellate aspect, and Batarrea (Pers.), which possesses an axile column immediately beneath the middle of the inner peridium. It develops into a stout stalk, which raises the closed inner peridium on its summit and ruptures the outer one, which now resembles in appearance the velum universale of Hymenomycetes. In Scleroderma (Pers.) the development of the glebe is intermediate between Hymenogastreæ and Lycoperdaceæ. While the trama is disorganised, and a portion persists as a fine network together with the masses of spores, it yet forms no true capillitium.

The Nidularies, though very different in outward aspect from the
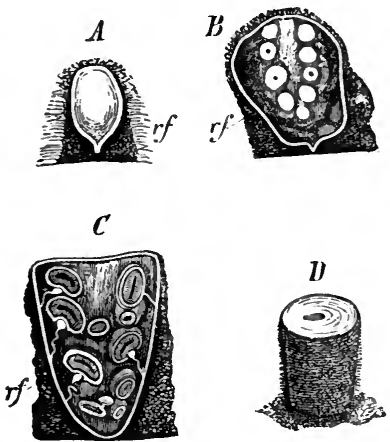

Fig. 327.-Crucibulum vulgare Tul. $A-C$, longitudinal section through ripening sporophores; stages of development in order of letters (slightly magnified). $D$, ripe sporophore in which the epiphragm is beginning to disappear (natural size). (After de Bary.)

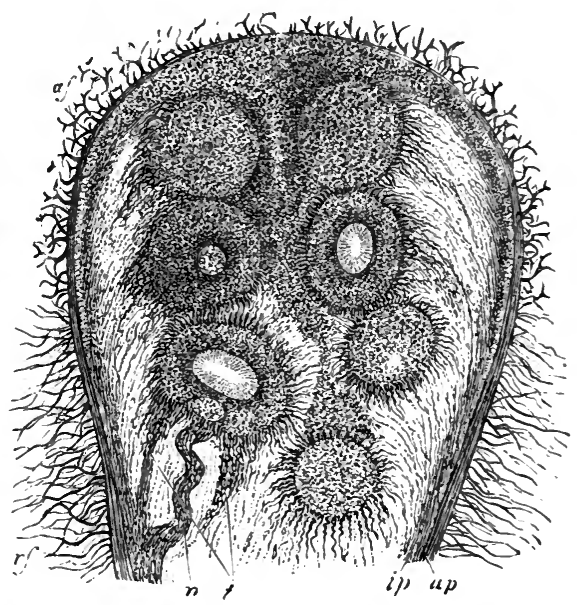

FIG. 328.-Crucibulum z'ulgare. Section through upper part of sporophore of about same age as $B$ in Fig. 327 (more highly magnified). $a p$, the outer, ip, the inner peridium; of and $a f$, its hairs; $n$, funiculus; $t$, the layer which forms a sheath round it, and belongs to a peridiolum divided through the middle. (After Sachs.)

other sections, are yet readily comparable with them. The chambers of the glebe possess very stout walls, and ultimately become separated from each other. The wall of the peridium becomes transformed into a gelatinous substance over the apical region, and on its disappearance the chambers of the glebe (peridiola) are left exposed in the interior of the bowl-shaped lower portion of the wall. Free and detached they resemble comparatively large sporanges. In Crucibulum (Tul.) a thin white membrane termed the epiphragm temporarily covers the summit (fig. 327 ).

The Phalloideæ are an assemblage of very remarkable and strange forms, in which the Basidiomycetes find their highest development. 
Great variety of external conformation exists within the group, as the student will at once recognise on viewing such members of it as Phallus (L.), Hymenophallus (Nees ab Esenb.), Clathrus (Mich.), Ileodictyon (Tul.), Aseroe (La Bill.), \&c.

Specimens of Phallus impudicus (L.) while yet enclosed within the peridium exhibit the following structure: The peridium consists of an outer white membrane and an inner white thinner one, and between these two a thick layer of tissue which has become gelatinous. Immediately within the inner membrane lies the glebe, situated in the upper capitate portion, and bounded on its inner surface by a conical membrane
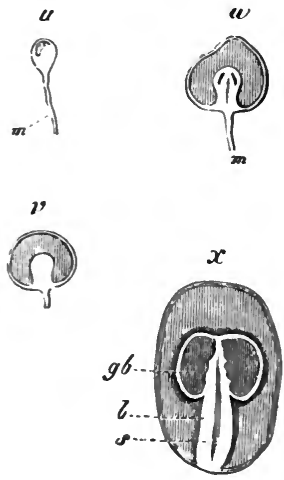

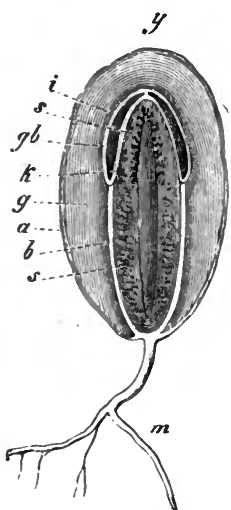

FIG. 329. - Mutinus caninus Fr. Young sporophore. $m$, mycele ; stages of development in order of letters $u-y$. $y$, a specimen with ripe spores, but before elongation of stalk. $a$, the outer wall ; $i$, the inner: $g$, gelatinous layer of peridium; $b$, the basal portion; $k$, the cone ; $s$, the stalk; $g b$, the glebe (natural size). (After de Bary.)

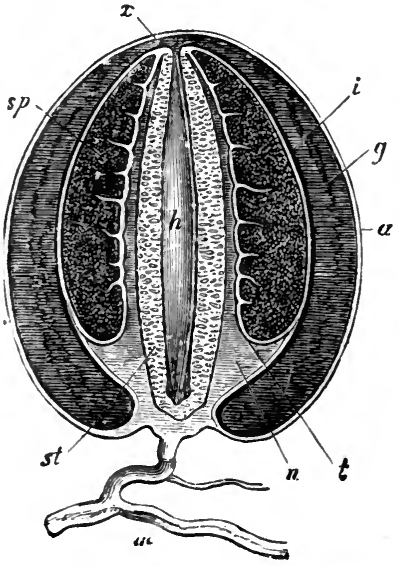

FIG. 330. - A nearly mature specimen of Phallus impudicus L. before elongation of stalk, in longitudinal section. $m$, mycele ; $a$, outer, $i$, inner wall ; $g$, gelatinous layer; st, stalk; $h$, its cavity filled with mucilage; $t$, lower margin of pileus; $s p$, glebe; $n$, the cup-shaped basal portion; $x$, the spot where the peridium bursts (twothirds natural size). (After Sachs.)

belonging to the central axis. This membrane gives off outwards into the glebe numerous walls arranged honeycomb fashion and dividing the glebe into compartments. The structure of the glebe itself recalls that of the Hymenogastreæ and Lycoperdaceæ. Below the glebe, and surrounding the base of the central axis, is a cup-shaped mass of comparatively firm tissue, in which the base of the stalk is fixed. It connects with the lower portion of the inner peridium, and sends a thin projection of tissue of less consistency upwards between the conical membrane and the stalk. The base rests on the outer layer of the peridium. The stalk itself is hollow at maturity, and is composed of air-containing 
tissue, with numerous compartnents. To scatter the spores the stalk elongates enormously, while it increases in thickness at the same time ; the peridium bursts at the apex, and the glebe is separated from the inner peridial membrane and elevated on the summit of the stalk. When the spores are scattered, the conical membrane (so-called pileus) remains with the honeycomb-like structure on its outer surface attached to the apex of the spongy stalk.

In Clathrus the development of peridium and glebe agrees with Phallus, but instead of a stalk a net-like structure serves to burst the peridium and elevate the glebe.

Such forms as Mitremyces (Nees ab Esenb.), Tulostoma

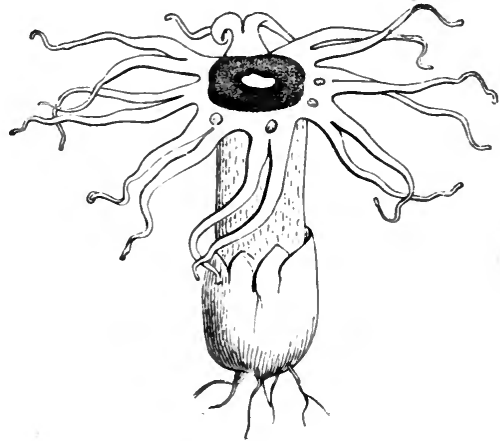

FIG. 331.-A seroe rubra Berk. Mature specimen. The peridium is attached below; the glebe is in the middle of the radiating expansion (half natural size). (From de Bary, after Berkeley.)

(Pers.), Polysaccum (DC.), and Sphærobolus (Tode) exhibit other and remarkable types of development. Though they do not properly fall under any of the sections dealt with, they may be regarded as more or less divergent from the Lycoperdaceæ.

\section{LITERATURE.}

De Bary-Zur Kenntniss einiger Agaricinen (Bot. Zeit., 1859).

Bonurden-Beobacht. u. d. Bau d. Agaricinen (Bot. Zeit., 1858).

Bunorden-Mycologische Beobacht. (Phallus, Sphærobolus) (ibid., 1851).

Bonorden-Die Gattungen Lycoperdon u. Bovista, \&c. (ibit., 1857).

Brefeld-Bot. Untersuch. ii. Schimmelpilze, iii. (Leipzig, 1877).

Brefeld--For further development of Brefeld's views on the classification, \&c., of Basidiomycetes (with much research on the lower forms) see Unters, aus dem Gesammtgebiete der Mykologie, Heft vii., I888.

Corda-Icones Fungorum Prag (1837-1854).

Eidam-Die Keinung der Sporen u. d. Entstehung d. Fruchtkörper bei d. Nidularieen (Cohn's Beiträge, ii.).

Fischer-Zur Entwick. d. Gasteromyceten (Sphærobolus, Mitremyces) (Bot. Zeit., 1884 ).

Hartig-Wichtige Krankh. d. Waldbäume (Berlin, I874).

Hartig-Die Zersetzungserscheinungen d. Holzes d. Nadelholzbäume u. d. Eiche (Berlin, 1878).

Hesse-Mikroskop. Unterscheidungsmerkmale d. typischen Lycoperdaceengenera (Pringsh., Jahrb. x.).

Hesse--Keimung d. Sporen von Cyathus striatus (ibid., x.). 
Murray-On the outer peridium of Broomeia (Journ. Linn. Soc. Bot., xx., 1884). Murray-On two new species of Lentinus, one of them growing on a large sclerotium (Trans. Linn. Soc., 1886).

Nees v. Esenbeck-Plant. mycetoid., \&c., Evolutio (Nova Acta Acad. Leop.Carol., xvi.).

Pitra-Zur Kenntniss d. Sphærobolus stellatus (Bot. Zeit., 1870).

Rossmann - Beitr. zur Entwickl. d. Phallus impudicus (Bot. Zeit., 1853).

Sachs-Morph. d. Crucibulum vulgare Tul. (Bot. Zeit., 1855, p. 833). (Omitted from index to vol. of Bot. Zeit.)

Schlechtendal-Eine neue Phalloidee, nebst Bemerkungen ii. d. ganze Familie (Linnæa, 1862).

Schlechtendal u. Müller-Mitremyces Junghuhnii (Bot. Zeit., 1844).

Schmitz-Mycologische Beobachtungen, \&c. (Linnæa, 1842).

Schmitz-Ueber Entw., Bau u. Wachstum von Thelephora sericea u. hirsuta (ilid., I 843).

Sichröter-Ueber d. Entwickl. u. d. systematische Stellung von Tulostoma (Cohn's Beiträge, ii.).

De Seynes - L'organisation des Chan De Seynes - Rech. sur 1. végétaux inférieurs, i. Des Fistulines (Paris, 1874).

Sorokin-Développement du Scleroderma verrucosum (Ann. Sc. Nat., sér. 6, iii.).

Tulasne-- Carpologia, i. (Paris, 186I).

Tulasne-Fungi Hypogai (Paris, 1851 ).

Tulasne-Obs. sur l'organisation des Tremellinées (Ann. Sc. Nat., sér. 3, xix.).

Tulasne-Nouvelles notes sur les fungi Tremellini et leurs alliés (2lid., sér. 5, xv.).

Tulasne-De la fructification des Scleroderma comparée à celle des Lycoperdon et des Bovista (ibid., sér. 2, xvii.).

Tulasne-Sur les genres Polysaccum et Geaster (ibid., sér. 2, xviii.).

Tulasne-Rech. sur l'organ. d. Nidulariées (ilid., sér. 3, i.).

Tulasne-Description d'une espèce nouvelle du genre Secotium (ilid., sér. 3, iv.).

Tulasne-See Explor. Sc, d'Algérie, p. 434 (Clathrus).

Van Tieghem - Sur le développement du fruit, \&c., des Basidiomycètes, \&c. (Bull.

Soc. Bot. France, 1876). (See also Bot. Zeit., 1876.)

Vittadini-Monographia Lycoperdineorum (Mem. Acad. Torino, r., 1842).

Woronin-Exobasidium Vaccinii (Ber. d. Naturf. Gesellsch. Freiburg, I867).

Of historical interest is -

Micheli-Nova Plant. Genera, 1729 (Phallus, Clathrus).

The student is also referred for both morphological and systematic treatises to the numerous papers of Berkeley - to be found especially in the Ann. and Mag. of Nat. Hist. and Hooker's Journal of Botany-and to his separate books; for systematic information particularly to the works of Fries, Persoon, Hoffmann (Icones Analytice Fungorum, Giessen, 186I-65), Saccardo, Sylloge, vols. v.-vii. ; and for British forms to Cooke's Handbook of British Fungi, I87 I, and to Stevenson's Hymenomycetes Britannici, I 886. 


\section{SIXTH SUBDIVISION.}

\section{MYCETOZOA.}

THE Mycetozoa are a group of organisms separated by a great gulf from the Thallophytes, but presenting certain points of resemblance to the Fungi which may here be indicated, while the amount of that resemblance and the degree of their divergence will be more fittingly estimated at the end of this chapter. Their nutrition is saprophytic, and the organs of reproduction are sufficiently like those of the Fungi to justify the use of the terms sporange, spore, swarm-spore. The vegetative body, on the other hand, differs in structure toto calo from any form of thallus. It consists of a naked protoplasmic body, either a plasmode formed by the coalescence of peculiar swarm-spores, or an aggregation of such swarm-spores. The first case is characteristic of one class, the Myxomycetes ; the second case of the other smaller class, the Acrasiex.

\section{Class XXIII.-Myxomycetes.}

The ripe spores of Myxomycetes are capable of germination at once, and inany of them retain this power for considerable periods, some for as long as several years. Most germinate at the ordinary spring or summer temperature, and in pure water, while others require a nutrient solution. The germination of the spores of Cribrarieæ and Tubulinæ has not been observed, and the failure of the attempts to procure it may be owing either to the supply of unsuitable media or to a necessity for a period of rest-more likely the former. In structure the spores resemble those of fungi, as has been said. The wall is either smooth or sculptured on the outer surface, and the protoplasm contains one, sometimes two, nuclei. The act of germination consists of the emission of a swarm-spore. The membrane opens and the protoplasm escapes with a creeping motion. This naked protoplasmic body or swarm-spore then exhibits amœboid movements, protruding and withdrawing irregular processes, becoming more or less elongated, and 
acquiring a cilium at the end of a finely pointed process. Its movements are of two kinds : a hopping movement, during which it commonly
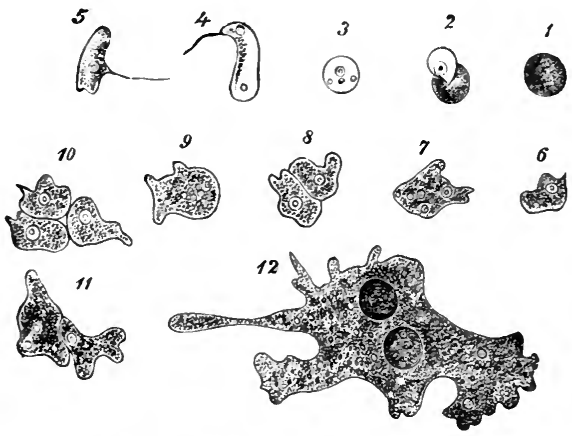

Fig. 332.-Chondrioderma difforme Rost. I, a ripe spore; 2 , the same germinating; $3-5$, swarm-spores; 6,7 , the same in amœboid state; 8, two in close contact; 9, the same coalesced ; Io, three in contact ; II, two after coalescence, the third still free; 12, young plasmode which has taken up two spores into its substance $(\times 350)$. (From Sachs, after Cienkowski.)

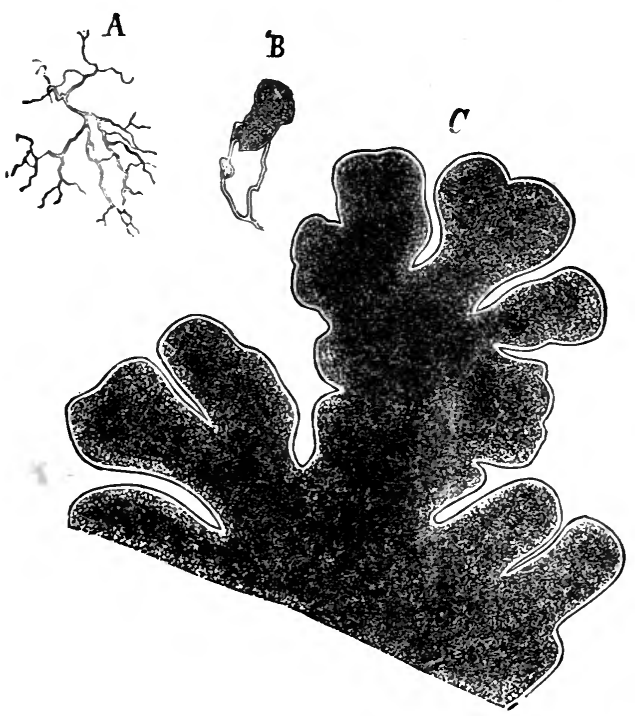

FIG. 333.-Didymium serpula Fr. $A$ and $B$, plasmodes (natural size). $C$, margin of a moving plasmode ( $x$ about 200). (After Reinke.)

ments of a huge amoboid swarm-spore without cilia. This plasmode rotates round its longitudinal axis, while the outline undulates; and a creeping movement, which takes place on a firm substratum with the cilium in advance. The creeping is also sometimes accomplished by the protrusion and retraction of pseudopodes. The same swarm-spore often moves both by hopping and by creeping alternately. After passing through this stage, during which swarm-spores multiply by simple division into two (such division taking place in some cases even before leaving the spore), the formation of plasmodes begins. The swarm-spores taking part in this process are such as have withdrawn their cilia and exhibit creeping amoboid movements. Several come into contact and coalesce, thus forming the beginning of the plasmode. Others are drawn towards it-how, no one has ever found out-and successively coalesce with it, until a comparatively large plasmode is formed with the appearance and move- 
nourishesitself and grows, acquiring, in the case of some Physareæ, great dimensions, and forming reticulated masses which may be measured by inches. Fuligo varians (Somm.) (or as it is more commonly called Athalium septicum (Fr.) or 'flowers of tan,' from its appearing during summer on tan) is such a body, but the plasmodes of other families of Myxomycetes, as well as of some Physareæ, generally remain very small in comparison with this. The appearance of the strands or branches of the plasmode (under the microscope) is that of a turbid granular mass bordered by a clearer hyaloplasm. The surface of the plasmode of Physareæ is invested with a soft shiny envelope of a substance different from protoplasm. The plasmodes of certain other forms are similarly invested with envelopes, as to the nature of which not much is known. The larger portion of the granules contained in the plasmodes of Physarea are of calcium carbonate; granules contained in other plasmodes require investigation. Nuclei are abundantly present. Many foreign bodies such as spores, diatoms, \&c., are often found included in plasmodes. Constant movement is maintained, and the most characteristic is that of the protrusion and retraction of pseudopodes. Since protrusion is commonly more active on one side than on the other, an advancing movement of the whole is thus brought about. Internal streamings, more or less copious, answer to the amceboid movements. The external causes of movements are : with reference to (I) illumination, they are negatively heliotropic ; (2) z'ater-they are positively hydrotropic, i.e., when not about to form spores they leave comparatively dry spots and move towards moist places ; (3) food - they are positively trophotropic, i.e., they move towards nutrient substances (as might be expected); (4) heat-within certain limits they move towards the warmer side of a surface unequally warmed. These movements are without reference to the direction in space in which they may

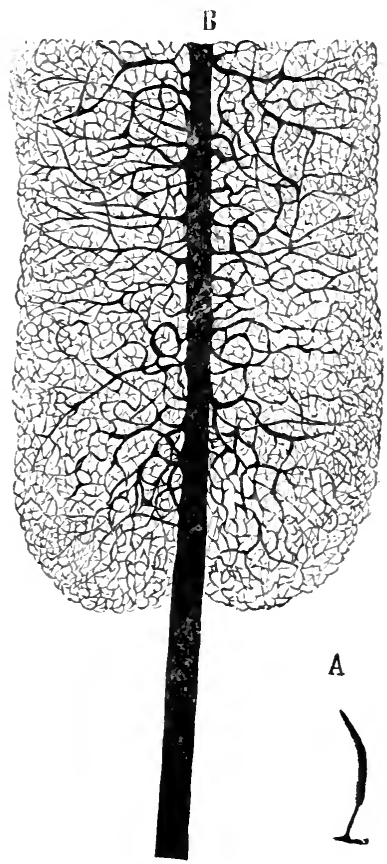

Fig. 334.-Stemonitis fusca Roth. A, sporange (natural size). $B$, capillitium ( $\times$ about 100). (After Reinke.) have to be made. It may be stated here that the process of nutrition takes place only in the amœboid states-the swarm-cell and plasmode. 
Resting states may occur at all motile stages of the life-history. Microcysts are the resting states of swarm-spores. They round themselves off, and are invested with a delicate membrane or only with a firm border. Young plasmodes similarly form thicker-walled cysts, and mature plasmodes form multicellular bodies-sclerotes.

The spores of Myxomycetes are formed either endogenously within sporanges, or on the free surface of sporophores (Ceratieæ). Sporanges are formed either by the whole plasmode becoming one, or the plasmode divides into portions, each of which becomes a sporange. Such as are situated on stalks begin as small swellings on a strand of the plasmode, and by degrees acquire their mature form as the protoplasm ascends into

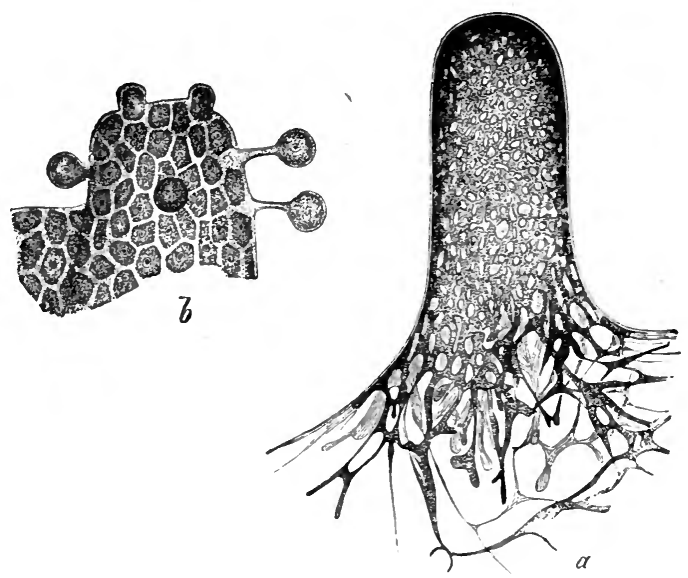

FIG. 335.- a, Ccratium hydnoides Alb. and Sch. Piece of sporophore in act of forming. $b$, Ceratium porioides Alb. and Sch. Piece of the margin of a sporophore; sporeformation beginning; two spores which subsequently become slightly ellipsoid on their stalks. $(a \times$ about $68, b \times 120$.) (After Famintzin and Woronin.)

them. While this process of formation goes on the solid contents of the plasmode are expelled. The interior of the mature sporange is either filled with spores only, or more commonly there is also present a capillitium consisting of numerous filaments traversing the cavity in all directions. They probably serve as supports to the wall of the sporange in the first instance, and may further be connected with its rupture and the dispersal of the spores.

There are only two known species of Ceratium (Link), a genus which forms free spores, i.e. not within a sporange. In this case the plasmode before spore-formation consists of a network of innumerable branches from which cylindrical processes arise. The whole protoplasm 
flows into these processes and finally breaks up into numerous polyhedral portions. Each of these portions grows outward into the form of a ball connected with the surface by a short narrow stalk. This sphere acquires a wall, and the process of spore-formation is completed.

\section{Class XXIV.-Acrasieæ.}

So far as is known the spores of Acrasieæ germinate only in nutrient solutions. The swarm-spores are never ciliated, and move only by creeping in amœboid fashion. Under unfavourable conditions they encyst themselves, and form temporary resting states. They unite in great numbers for the purpose of forming spores again, but the union never amounts to coalescence into plasmodes. They are heaped together as it were, and compose bodies of more or less definite form. In this condition each swarm-spore becomes invested with a thin membrane, though no common sporangial wall is formed. Guttulina (Cienk.) forms simple spore-heaps, but in Dictyostelium (Bref.) and Acrasis (Van Tiegh.) a stalk is formed by the swarm-spores in the centre of the mass becoming transformed into series of cells with firm walls, and up it the rest of the swarm-spores climb and form spores at the top.

\section{Doubtful Mrcetozoa.}

De Bary repudiates the attempt made by Zopf to bring together under this group an ill-assorted assemblage of lower organisms exhibiting amœboid movements. He considers such forms as Bursulla (Sorok.), Protomyxa (Hæck.), Vampyrella (Cienk.), Nuclearia (Cienk.), Monas amyli (Cienk.), Monadopsis (Klein), Pseudospora (Cienk.), Colpodella (Cienk.), and Plasmodiophora (Woron.) to be doubtful Mycetozoa. Plasmodiophora Brassicæ (Woron.), which is parasitic on the roots of Cruciferæ, on which it produces large swellings, is common. The ciliated swarm-spores penetrate into the parenchymatous tissue of such roots. The cells affected swell to a great size, and large amœboids appear in them, but it is not certain whether these are single swarmspores or small plasmodes formed by the coalescence of several. The whole protoplasmic contents of a cell then break up into spores.

\section{Affinities.}

De Bary, to whose remarkable investigations we owe the bulk of our knowledge of the Mycetozoa, considers that the group differs 
distinctly from the Fungi (and still more from other plants) 'in all such characteristics as do not belong to all organisms alike. . . . The difference would not be less decided, if the Mycetozoa were without their remarkable amœboid movements, for such movements are observed in other vegetable cells which have not a firm membrane. The characteristic mark of separation lies in the formation of plasmodes or aggregation of swarm-cells' ('Comp. Morph.', p. 443). He farther remarks that the highest forms of the group give no evidence of close affinity with yet higher organisms, and seeks for their relationship with Amœba. Guttulina, he points out, differs from such forms only by the aggregation of its spores. Guttulina protea (Fay.) (Copromyxa protea, Zopf) even forms solitary spores. This form then links the Amobæ with the more highly differentiated Acrasieæ, and these connect with the Myxomycetes. Taking together this connection with the animal kingdom, and the want of connection on the other hand with Fungi (to which they have a merely superficial resemblance) or other plants, we are justified in placing them, as de Bary does, 'outside the limits of the vegetable kingdom.'

\section{Literature of Mycetozoa.}

Baıanetzki-Influence de la lumière sur les Plasmodia des Myxonycètes (Mém. Sc.

Nat. Cherbourg, xix., p. 321).

De Bary-Die Mycetozoen (Zeitsch. f. wissensch. Zoologie, Bd. x., 1859; and 2nd edition, Leipzig, 1864).

Brefeld-Dictyostelium mucoroides (Abh. d. Senckenberg. Naturf. Gesellsch., vii.). Brefeld-Untersuch. aus der Gesammtgebiete der Mykologie (Leipzig, 1884).

Cienkowski-Zur Entwickelungsgesch. d. Myxomyceten(Pringsh. Jahrb. wiss. Bot., iii.). Cienkowski-Das Plasmodiun (ibid., iii.).

Cienkowski-Ueber einige protoplasmatische Organismen (Guttulina). See Just's Jahresber. for 1873 , p. 6r.

Cienkowski-Beitr. zur Kennt. der Monaden (Schultze's Arch. f. micros. Anat., i.). Lister-Plasmode of Badhamia and Brefeldia (Ann. of Bot., ii., 1888, p. I).

Rostafinski-Versuch eines Systems der Mycetozoen (Dissertat. Strassburg, 1873).

Rostafinski-Slucowce (Mycetozoa) (Paris, I875). A monograph admirably illustrated, but written in Polish. The system in Cooke's Myxomycetes of Great Britain (London, 1877) is adapted from Rostafinski's monograph.

Stahl--Zur Biologie der Myxomyceten (Bot. Zeit., I884).

Strasburger-Wirkung d. Lichtes und d. Wärme auf Schwärmsporen (Jena, I 878, p. 69). Strasburger-Zur Entwickgesch. d. Sporangien v. Trichia fallax (Bot. Zeit., I 884).

Van Tieghem-Sur quelques Myxomycètes à plasmode agrégé (Bull. Soc. Bot. de

France, 1880, p. 317).

Zopf-Die Schleimpilze, in Schenk's Handbuch der Botanik, iii. (1887).

For further literature see De Bary's Comp. Morph., p. 453, and Rostafinski's monograph. 


\section{SEVENTH SUBDIVISION.}

\section{PROTOPHYTA.}

Whether the Protophyta should be reckoned as a distinct subdivision from the Algæ, or only as the lowest members of that great series, is a question rather of convenience than of principle. In an ideal system of classification founded exclusively on genetic affinities, those organisms would be regarded as 'protophytes' which were the earliest heralds of the appearance of vegetable life on the surface of the globe. But, from the structure and conditions of life of such organisms, it is impossible that they can have been preserved to us in the fossil state, and it is only from the comparative simplicity or complexity in the structure of an organism that we can conjecture whether it is an archaic or a derivative form. And here, as was remarked in the Introduction, we are extremely liable to be misled if we neglect to take into account the phenomenon of the constant appearance of degeneration or retrogression in the vegetable kingdom. An organism may be simple in its structure either because it has never risen, through countless ages, above the simplicity of its primeval ancestors, or because it has fallen back from a more complicated condition. The object of the scientific systematist should be to separate, so far as possible, between these two sets of organisms, to include the former among his lowest class of protophytes, and to relegate the latter in each case to the class from which they have degenerated. But this task is attended with great difficulties, and is often well-nigh impossible. An organism may display degeneration of one set of organs, while another set manifest no such degeneration and have even continued to develop. We may take it indeed as a general law that wherever you have either the vegetative or the reproductive organs strongly developed, while the other set are very feeble or altogether wanting, you have primâ facie evidence of retrogression. But, on the other hand, degeneration may take effect in all the organs of a plant, leading to retrogression in all lines towards, it may be, the archaic form. As knowledge advances, the constant tendency will be to transfer to this class of retrogressive members of higher families forms previously regarded as protophytal. 
While the Schizophycea or chlorophyllous Protophyta approach very closely to the lowest forms of Algæ, the Schizomycetes or non-chlorophyllous Protophyta exhibit greater affinities, as de Bary has shown, with the chlorophyllous forms than with any family of Fungi. Grouping, therefore, all these lowest forms of vegetable life, whether containing chlorophyll or not, into a single subdivision of Cryptogams, it will be most convenient to discuss them under two heads, as distinct and to a certain extent parallel series.

\section{GROUP I.-SCHIZOPHYCE}

An attempt is here made to bring together those chlorophyllous; forms which, in the present state of our knowledge, we must regard as. primordial ; while others, almost equally simple in structure, have been referred to the classes of which they appear to be retrogressive members. The group now under consideration comprises the greater number of the forms of vegetable life which are unicellular, which display no true process of sexual reproduction, and which contain chlorophyll.

Limited in this sense, the Schizophyceæ may be divided into three well-marked classes, the Protococcoidea, the Diatomacea, and the Cyanophycere. In the Cyanophyceæ are included those forms in which the pure green colour of the chlorophyll is masked by a blue-green pigment dissolved in the cell-sap, an arrangement not found except in plants of the very simplest structure. The position of the Diatoms has been a subject of much controversy among systematists. They display in some respects a similarity to the Desmids ; but, for reasons given below, we are disposed to consider this resemblance as apparent rather than real, and to regard the Diatomaceæ, not as a family derived from the Desmidiaceæ by retrogression, but as a primordial type of great simplicity of structure. In the Protococcoideæ are included those forms in which the pure-green of the chlorophyll is not concealed by the blue-green colouring matter of the Cyanophyceæ, nor by the brown colouring matter of the Diatoms. It is unquestionably from them that all the higher forms of vegetable life have been derived, and the boundary line between the Protococcoideæ and the lower forms of Algæ is one that cannot be accurately laid down.

\section{LITERATURE.}

The literature of the Schizophycex is included under that of Algx, or in the works specially named when treating of the separate classes and orders. 


\section{Class XXV.-Protococcoideæ.}

In this class, the Chlorophyllophyceæ of some writers, are included those simplest forms of vegetable life in which the endochrome consists of pure chlorophyll of its natural green colour, sometimes replaced, to a larger or smaller extent, by a red pigment, but the cell-sap never pervaded, as in the Cyanophyceæ, by a soluble blue colouring-matter. The individuals are of microscopic size, and may be either motile or resting, and very commonly the same species occurs in both conditions. The motile or protococcus form is, in the lower members, strictly unicellular, consisting of chlorophyllous protoplasm either naked or invested with a very delicate coat of cellulose or of a carbohydrate nearly allied to cellulose, usually developing but little or no mucilage, and moving freely through the water by means of a pulsating vacuole and two vibratile cilia. In the resting condition the individuals are invested by a much thicker cell-wall, and have a tendency to congregate or coalesce into palmelloid families, and to enclose themselves in a common gelatinous envelope. In this state they multiply rapidly by repeated bipartition. The palmelloid form may be derived directly from the protococcoid, the protococcus-cells coming to rest, losing their cilia, and investing themselves with a thicker cell-wall of cellulose; or, in the higher members, the individual consists of a number of gonids, chlorophyllous masses of protoplasm, enclosed in a common watery hyaline envelope of mucilage, and propagation takes place by the escape of these gonids from the envelope in the form of naked biciliated zoospores or swarm-spores, closely resembling protococcus-cells, which, after going through a motile period, come to rest, lose their cilia, invest themselves with a coat of cellulose, and multiply by repeated bipartition in the palmelloid form. In some cases these swarm-spores are of two kinds, the smaller ones being conjugating zoogametes. In no case is the individual filiform and divided by transverse septa, as in the higher families of the Cyanophyceæ.

It cannot be too strongly insisted on that this class is a purely provisional one. Many of the forms at present included in it are, in all probability, nothing but stages in the development of algæ of considerably greater complexity of structure belonging to widely separated families. The external resemblance between the Protococcaceæ and the Chroococcaceæ, and the parallel series of forms in these two families, does not probably represent any genetic affinity. There is, on the other hand, an undoubted alliance with the Pandorineæ, through Chlamydococcus and Chlamydomonas, as well as with the Hydrodictyeæ and 
Siphoneæ through intermediate forms. The Protococcaceæ converge also on the boundary line between the vegetable and animal kingdoms ; and, since it has been demonstrated that the power of forming chlorophyll and starch is not of itself sufficient to determine an organism to belong to the vegetable kingdom, it is impossible to draw a hard and fast line between the Protococcaceæ and the Flagellate Infusoria, with which they are connected by such forms as Euglena and the Peridinieæ.

The Protococcoideæ are divided into two orders, the boundaries of which are very ill-defined : the Eremobice and the Protococcacece.

\section{LITERATURE.}

Ehrenberg-Die Infusionsthierchen, I 838 .

Nägeli-Neuern Algensysteme, I847, pp. 123-1 32 ; and Gattungen einzelliger Algen, 1849 .

Braun-Verjiingung in der Natur, I85I (Ray Soc. Bot. and Phys. Memoirs, I853); and Algarum unicellularum genera, 1855 .

(Also the Memoirs referred to under the separate genera, and the literature of Algæ generally.)

\section{Order i.-Eremobiæ (including Sciadiaceæ).}

In this ill-defined family, known by some writers as Characiaceæ, the limits of which are very difficult to assign, are included a number of genera distinguished from the Protococcaceæ by their greater complexity of structure. They are mostly fresh-water, but comprise also a few marine organisms, free-swimming or attached to algæ. In the larger number of genera each individual consists of a number of green protoplasmic bodies, pseudocysts or gonids - that is, masses of chlorophyllous protoplasm of defined outline but not clothed with a definite cell-wall of cellulose - sometimes of considerable size, enclosed in a common transparent hyaline envelope, which may be simple or may branch in an arborescent manner. In some genera the hyaline envelope is wanting. Multiplication takes place by simple division, or by the transformation of the gonids into zoospores, which sometimes display a differentiation into larger megazoospores and smaller microzoospores or zoogametes. Although conjugation of these gametes has hitherto been observed only in a few cases, this appears to be the earliest indication among chlorophyllous organisms of a differentiation of sexual elements; and the Eremobiæ clearly approach those algæ which multiply by conjugation through Botrydium, or through such forms as Endosphæra, Chlorochytrium, and Phyllobium, or again through Hydrodictyon. Lagerheim (Ber. Deutsch. Bot. Ges., 1884, p. 302) asserts the presence of chromatophores in Glaucocystis (Itz.). 
In the following paragraphs only the more remarkable or better known genera are described.

In Sciadium A. Br., made by some writers the type of a distinct family SCIADlACEe, the peculiar mode of germination of the zoospores gives rise to a remarkably complicated structure. Each individual consists at first of a single elongated cylindrical cell. The green protoplasmic contents of this cell break up ultimately into a number of biciliated zoospores, which are set free by the upper portion of the cell-wall becoming detached in the form of a cap. The zoospores do not, however, escape, but germinate while still attached to the mother-cell, giving rise to a cluster of smaller cylindrical cells springing from the apex of the mother-cell. This may go on until the colony consists of as many as four generations, giving the appearance of a minute branching shrub. The zoospores of each generation are smaller than those of the preceding one, and it is probable that those of the last generation, which escape altogether from the parent-cell, are conjugating zoogametes. It is pos-

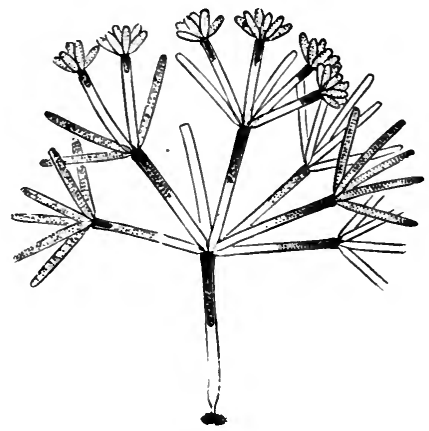

Fig. 336. -Sciadium arbuscula A. Br. (magnified).

sible that a form allied to Sciadium may have been the starting-point of the Siphonocladaceæ, with which family it shows a certain affinity, as, for example, with Valonia.

Chlorothecium Bzi. (Malpighia, I888, p. 250) occurs in the form of palmeiloid colonies with a thick and firm cell-wall on aquatic plants. From the cells of these colonies are developed zoosporanges, or rather gametanges, without any alteration of their primitive form ; from each gametange there escape from two to four swarm-spores, or occasionally only one, each provided with a single cilium and a conspicuous red pigment-spot. These swarm-spores are zoogametes, conjugating by gradual fusion. After hibernating the contents of the zygosperm break up into two masses, each of which escapes as a non-sexual zoospore, so that the zygosperm is itself a zoosporange. From these zoospores are again formed the palmelloid colonies, in which form Chlorothecium may multiply itself non-sexually without producing zoogametes.

The position of Halosphara (Schmitz, Mittheil. Zool. Stat. Neapel, 1878, p. 61 ) is very doubtful. Each individual is a minute green globe, just visible to the naked eye, as much as $0.5 \mathrm{~mm}$. in diameter, floating on the surface of the sea, and bearing an external resemblance to Volvox. 
Each cell contains a nucleus and a vacuole; the green protoplasmic contents break up ultimately into zoospores of a very peculiar form, conical, with two cilia attached to the nearly flat base, recalling those of
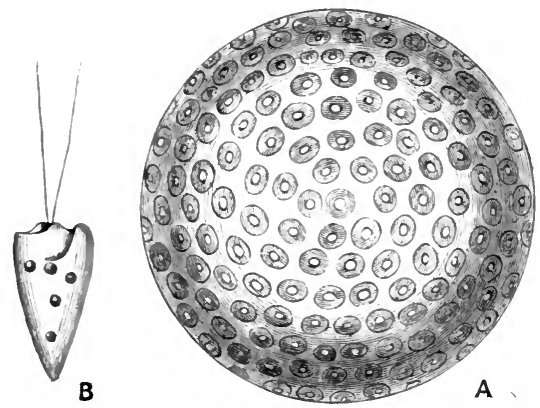

FIG. 337.-Haplosphera viridis Sichm. Globe $(\times 80)$, and zoospore ( $X$ I50). (After Schmitz.)
Hydrurus (p. 256).

In Dictyospharium Näg., which ought possibly to be placed under the Conobieæ, the free-swimming colony is composed of globular or kidneyshaped green gonids connected together by delicate threads of mucilage. New colonies are formed by repeated bipartition of the gonids, which frequently exist for a time without any enclosing cell-wall. Mis-

chococcus Näg. consists of minute globular gonids connected together in an arborescent manner and enclosed in a hyaline envelope, the whole colony attached to fresh-water algæ. Borzi (Malpighia, 1888, p. I33) describes also a palmelloid form of Mischococcus, the cells of which give birth to megazoospores with only a single cilium. The dendroidal form may spring either from these zoospores or directly from the palmella-cells; its cells also produce uniciliated swarm-spores, similar to the zoospores but smaller. They are apparently zoogametes conjuga-

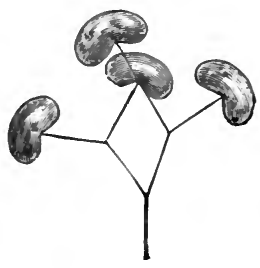

FIG. 338.-Dictyospharium reniforme Buln. ( $\times 400)$. (After Cooke.)

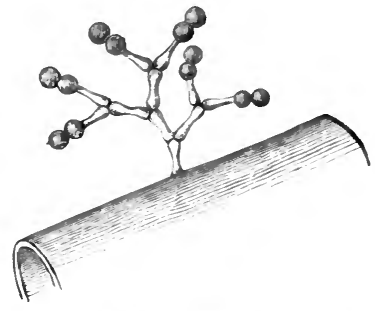

FIG. 339.-Mischocaccus confervicala Näg. $(\times 400)$. (After Cooke.)

ting to produce a biciliated zoosperm. Botrydina Bréb., found on moist ground, trunks of trees, \&c., is composed of a number of minute gonids enclosed in a pear-shaped or globular hyaline envelope, as much as $0^{\circ} \mathrm{I} \mathrm{mm}$. in diameter, and resembling Aphanocapsa among the Chroococcaceæ. It may possibly be allied to Botrydium.

Characium A. Br. is a minute green organism attached by a gelatinous stalk to algæ or other fresh-water plants, often in groups. It is 
ovate or pear-shaped, $0.02-0025 \mathrm{~mm}$. in diameter in the larger species, often apiculate or spinous at the apex. The cell-contents divide, by successive bipartitions, into zoospores, which commence swarming while still within the mother-cell, indicating an approach to Hydrodictyon. They escape through a lateral or terminal fissure. Nearly allied to Characium are Hydrocytium A. Br., also met with in fresh water, and Hydrianum Rabh., found in similar localities. In the last genus the zoospores also escape at the apex. In Apiocystis Näg. a large number of gonids are sparsely scattered through a stalked pear-shaped gelatinous envelope attached to fresh-water algæ. They occur chiefly in the periphery, and are ultimately converted into zoospores.

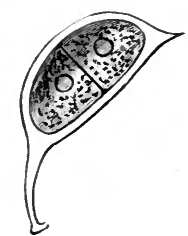

FIG. 340. - Characium ornithocephalum A. Br. $(\times 600)$. (After A. Braun.)

Codiolum A. Br. is a club-shaped marine organism, about $0^{\circ} 04 \mathrm{~mm}$. in diameter, and four to six times the length, attached to rocks or seaweeds. It is propagated by zoospores, or, according to some observers, also by resting hypnospores. Hauckia Bzì. (Nuov. Giorn. Bot. Ital.,

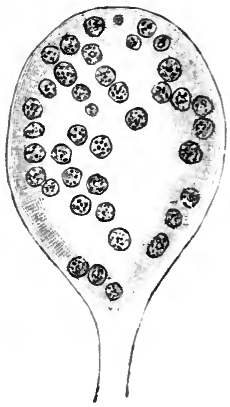

FIg. 341.-Apiocystis Brauniana Näg. ( $x$ roo). (From nature.)
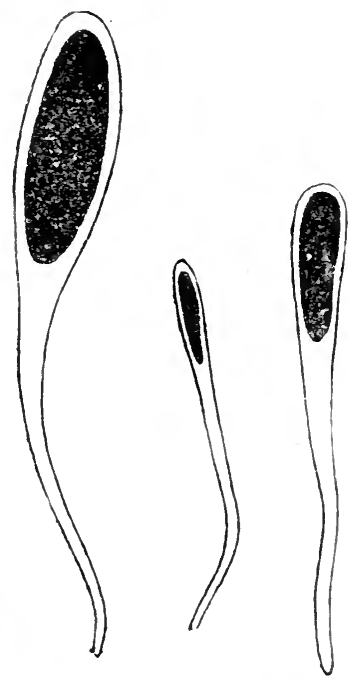

F1G. 342.-Codiolum gregarium A. Br. (magnified). (After Hauck.)

I 880, p. 290) grows on rocks exposed to the sea. The gonids are placed in pairs on a long hyaline stalk; it produces zoospores of two different sizes, but no process of conjugation has at present been observed. 
Sykidion Wright (Trans. Irish Acad., I88I, p. 27) is also a marine genus, allied to Characium and Hydrocytium; but the zoospores escape through a terminal instead of a lateral fissure.

Of free-swimming forms occurring in fresh water, Nephrocytium Näg. consists of kidney-shaped gonids enclosed

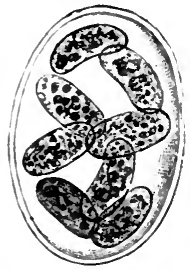

Fig. 343.-Nephrocytium Vägelii Grün. $(\times 300)$. (After Cooke.) in a hyaline envelope. Although the production of zoospores has not been detected in this genus, its position is probably here, though its true place may possibly be among the Sorastreæ. Dangeard (Bull. Soc. Linn. Normandie, i., I 888, p. 196) has observed a mode of propagation by the formation of daughter-colonies within the membrane of the parent-colony. In Ophiocytium Näg., the originally cylindrical individual becomes curved in a serpentine manner, and produced at one extremity into a hyaline spine. The zoospores escape by the detachment of the cap-like apex of the hyaline envelope.

In Hormospora Bréb. the free-swimming individual or colony consists of a very elongated straight or bent cylinder, sometimes branching, the gonids arranged in a single or double row within a dense hyaline envelope. No formation of zoospores has been observed. Cylindrocapsa (Reinsch) (see p. 227) is placed here by some authorities.

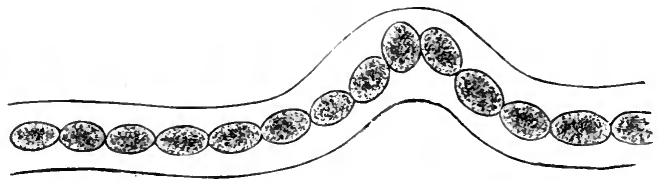

Fig. 344.-Hormospora mutabilis Bréb. $(\times$ 200). (From nature.)

Although in the majority of the genera named above only one kind of swarm-spore has hitherto been observed, it is highly probable that some or all of them produce both megazoospores and zoogametes with a sexual function.

\section{LiteratuRE.}

Fresenius-Abhandl. Senckenberg. Naturf. Gesell., iii., I856-8, p. 237. Archer-Microscop. Journ., 1866.

Zukal-Oesterr. Bot. Zeitschr., I88o, p. II.

Holmes-Journ. Linn. Soc., xviii., 1881, p. 132.

Borzl-Nuov. Giorn. Bot. Ital., 1882, p. 272; and Studi Algologici, 1883.

Lagerheim-Bot. Centralbl., xii., r882, p. 33 ; and Oefv. Vetensk. Akad. Förhandl., Stockholm, I885, p. 2 I.

Klebs-Unters. Bot. Inst. Tiibingen, i., 1883, p. 233.

Bennett-Journ. Micr. Soc., 1887, p. 9; and 1888, p. 2. 


\section{Order 2.-- Protococcacee (including Paimellaceæ).}

In this family are included a number of organisms of very simple structure, many of which occur both in the free-swimming (protococcus) and in the resting (palmella) condition. In the former state they bear a very close resemblance to the zoospores of the higher algæ. Other forms are known in one condition only, in which they have a freeswimming motion without the aid of cilia.

Protococcus Ag. is one of the commonest objects in fresh water, especially stagnant rain-water, forming masses of a bright green colour, either floating free or attached to a submerged or floating object, but destitute in this state of any spontaneous power of motion. In this palmella-condition each individual consists of a nearly spherical cell, varying between forty and fifty microns (= $\cdot 04-\cdot 05 \mathrm{~mm}$.) in diameter, which multiplies rapidly by repeated bipartition of its contents. The bright green endochrome has usually intermixed with it a larger or smaller quantity of a red pigment, the proportion varying according to the conditions of life, \&c. The change to the active condition takes place in the following way. 'The protoplasm withdraws itself from the cell-wall, and escapes in the form of an ovoid mass provided with two very long and slender vibratile cilia

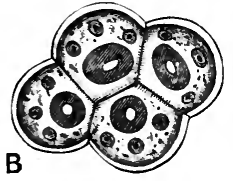

Fig. 345. - Protococcus pluvialis Ktz. $A$, motile condition ; $B$, palmella condition ( $\times 250)$. (After Cohn.) and a pulsating vacuole, by the agency of which it is driven rapidly through the water. The pulsation of this vacuole has been explained by the alternate absorption from the water, through the agency of the chlorophyll, of carbon dioxide, and the expulsion of free oxygen resulting from the process of assimilation. In some cases the contents of the mothercell do not escape as a single zoospore, but break up before escaping into eight or more smaller zoospores. The motile protococcus may be either entirely without cell-wall of cellulose, or may have a very delicate one, through orifices in which the protoplasmic cilia protrude. Some observers state that there are two kinds of zoospore in Protococcus-microzoospores and megazoospores, and that conjugation takes place between the latter; but this last statement at all events requires confịmation. After swimming about rapidly for a time in all directions with an apparently spontaneous movement, the motile protococcus comes to rest, loses its cilia, becomes encysted, or invested with a thick cell-wall of cellulose, and again enters the palmella- 
condition in the form of resting-spores, which may become dried up and retain their vitality for years as a dry powder, resuming their activity when again placed in water. McNab (Ann. \& Mag. Nat. Hist., 1883, p. 1 24) has, by the use of osmic acid and carmine, detected a nucleus in the free ciliated state of Protococcus, and also in individuals in which celldivision is going on.

When in an active condition in sunlight, Protococcus gives off into the surrounding water large quantities of oxygen, the result of the activity of its chlorophyll, thus contributing to render it habitable for animal life. The amount of the red pigment varies greatly. It is often confined to a small spot near to the point of attachment of the cilia, the 'pigment-spot,' bearing a close resemblance to the 'eye-spot' of the Flagellate Infusoria. If present in larger quantities, so as to give a red tint to the entire organism, this is known as Hæmatococcus (Ag.). In the palmella-condition this form frequently presents the structure and appearance of a blood-red incrustation on rocks and stones, when it has been described as Palmella cruenta (Ag.) and Porphyridium cruentum (Näg.). Very closely allied are the Palmella prodigiosa (Mont.) (Monas prodigiosa, Ehrb.), which forms blood-red spots on bread, potatoes, \&c., and the Palmella nivalis (Hook.) (Protococcus nivalis, Ag., Chlamydococcus nivalis, A. Br.), which, under the name of 'red snow,' frequently covers large tracts of snow in arctic and alpine regions in a very short time. Phipson (Compt. Rend., lxxxix., 1879, pp. 316, 1078) has examined the red colouring-matter of Palmella cruenta, and finds it to consist of minute globules about four microns ( $.004 \mathrm{~mm}$.) in diameter, closely resembling those of the hæmaglobin of blood, but somewhat smaller. He proposes for the pigment the name palmellin. It is soluble in water, but insoluble in alcohol, ether, and carbon bisulphide. Like hæmaglobin it contains traces of iron. Other lowly-organised snow and ice plants besides Palmella nivalis are brightly coloured, and appear to perform an important function in melting the snow by their strong absorption of the rays of heat. In addition to palmellin, Palmella contains also xanthophyll, and a small quantity of another substance of the nature of camphor and possessing a marshy odour, which Phipson calls characin, and which is present in other terrestrial and fresh-water algæ, and especially in Chara. In the hæmatococcus-condition it is sometimes impossible to detect directly the presence of chlorophyll ; but experiments by Engelmann (Rev. Internat. Sci. Biol., r882, p. 468, and Bot. Zeit., I882, p. 663) seem to show that there is always a certain amount of chlorophyll present, though it is possible that the power which Hæmatococcus undoubtedly has of decomposing carbon dioxide may be due to the presence of other substances allied to chlorophyll, but differing from it in colour. 
It is impossible to distinguish between the genera Protococcus (Ag.), Pleurococcus (Meneg.), and Palmella (Lyngb.); but it is doubtful whether Chlamydococcus (A. Br.) and Chlamydomonas (Ehrb.), which undergo much more complicated changes of form, and in some conditions very closely resemble Protococcus, have been rightly identified with it (see p. 299). Hæmatococcus Butschlii (Blockmann, Ber. Heidelberg Naturh. Ver., I886) probably belongs to Chlamydomonas. Schnetzler

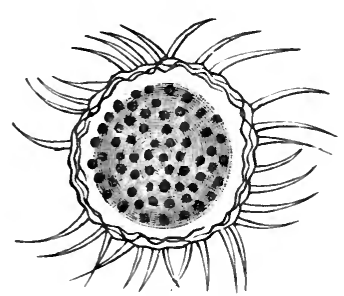

FIG. 346.-Glochiococcus anglicus Benn. $(\times 200)$. (From nature.)
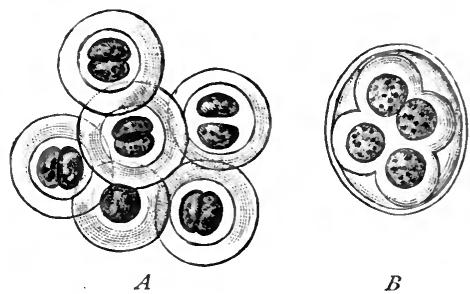

FIG. 347.-Chlorococcum gigas Grün. ( $\times 300)$. (After Cooke.)

(Bull. Soc. Vaud. Sc. Nat., I882, p. I I 5) regards Palmella uvæformis (Ktz.) as a stage in the development of a Stigeoclonium ; while Andersson identifies it with Draparnaldia.

Glochiococcus (Lagerh.) (Acanthococcus, Reinsch, Ber. Deutsch. Bot. Ges., I886, p. 237) differs from Palmella in the cell-wall, which is thick and lamellated, being in most of the species furnished with warts, spines, or other prominences. The cells, which closely resemble the zygosperms of desmids, divide into eight or sixteen daughter-cells, which remain but a short time in connection, being set free by the deliquescence of the outer membrane.

Chlorococcum (Fr.) is analogous to Chroococcus among the Chroococcaceæ. Several species are common in pools or on moist walls or rocks. In C. gigas (Grün.) the cells are as much as $0^{\circ} \mathrm{OI}-\mathrm{O}^{\circ} \mathrm{OI} 5 \mathrm{~mm}$. in diameter, and either a single cell or a colony of cells is enclosed in a very thick lamellated hyaline envelope. In Gloxocystis (Näg.), corresponding to Glœocapsa among the Cyanophyceæ, the cells are associated in families of two, four, or eight, each family being enclosed in a lamellated gela-

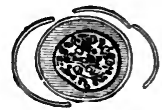

Fig. 348.-Schizochlamys gelatinosa A. Br. (x $600)$. tinous envelope, in addition to the similar envelope which encloses each cell. In Schizochlamys (A. Br.) the cells escape from the surrounding envelope by the latter splitting into two or four equal parts. Eremosphara (de By.) is a beautiful bright green globe, $O^{\circ} \mathrm{I}-O^{\circ} \mathrm{I} 5 \mathrm{~mm}$. in diameter, floating free in bog-pools, and enclosed in a thin hyaline envelope. 
Botryococcus Ktz. consists of mulberry-like masses of thick-walled cells united together into colonies, with no investing membrane, or only a very slight one; it is found in bog-pools, and is endowed with a

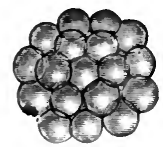

Fic. 349.-Botryococcus Braunii $\mathrm{Ktz} .\left(x_{400}\right)$.

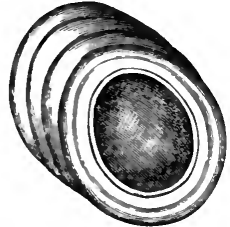

Fig. 350. - Urococcus insignis Hass. ( $x$ 400). (From nature.) rotating as well as a free-swimming motion. It has possibly a genetic affinity with the Conobieæ.

In Urococcus Hass. the endochrome is bright red, and the cellwalls throw off successive layers of mucilage, which form together a cylindrical or fusiform stalk, composed, in some species, of a large number of distinct annular segments.

Tetraspora Lk. is composed of cells associated together in large numbers in a single layer imbedded in a copious gelatinous envelope. It has no spontaneous motion, and is possibly allied to Merismopedia, and also appears to have affinities with the Ulvaceæ. Gay (Bull. Soc. Bot. France, I 886, Sess. Extraord, p. 4I) records in T. gelatinosa (Desv.) the formation of biciliated zoospores, one being produced from the contents of each cell, and afterwards becoming encysted into a resting-spore. In Palmodictyon Ktz. the gelatinous envelope is filiform and branched, and cell-division takes place chiefly in two directions only.

The position of the following genera is very uncertain. Very little is known of their mode of reproduction, and they lack the copious gelatinous envelope which is characteristic of the family generally. They are mostly but feebly endowed with spontaneous move-

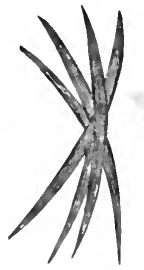

FIG. 35r.-Raphi. dium falcatum Ktz. (x 800). (From nature.) ments, and may probably be a resting condition of algæ or protophytes classed under entirely different groups.

Raphidium Ktz. includes several species very common in fresh water, and consisting of very narrow fusiform acuminate cells, usually curved, solitary Fig. 352.- Scene-
desmus obtusus Mey. ( $x$ 400). (From nature.) or joined together in bundles, the cells being in the latter case united by their middle. Cell-division takes place in one direction only.

Under the class Palmellaceæ are usually placed also the genera Scenedesmus Mey. and Polyedrium Näg., but their rank as independent organisms is exceedingly doubtful. Their probable position has already been discussed under the heads of the Sorastreæ and the Pediastreæ respectively (see pp. $3 \circ 3$ and 299). 
Reinsch unites Polyedrium with three other genera to make up a separate family, PolyedriaceÆ, belonging to Palmellaceæ.

Richter connects Glœocystis with the Chroococcaceæ, and hence genetically with higher forms of algæ. Cienkowski regards Pleurococcus, Glœocystis, and probably other genera of Protococcaceæ, as resting conditions of Chlamydomonas, or of similar organisms classed among the Cœnobieæ which multiply by conjugation. Under suitable conditions he states that they can all be made to produce biciliated zoospores with two contracting vacuoles and a nucleus. The part taken by some Protococcaceæ in the development of lichens has already been discussed on p. 3 I 8 .

\section{LITERATURE.}

Cohn-(Protococcus) Nov. Act. Akad. Cæes. Leop.-Carol., xxii., 1850, p. 605 (sce Ray Soc., Bot. and Phys. Mem., I853, p. 515).

Cienkowski-Bot. Zeit., 1865, p. 21 .

Rostafinski-(Hæmatococcus) Mém. Soc. Sc. Nat. Cherbourg, I875, p. I42.

Lagerheim-Oefv. Svensk. Vetensk. Akad. Förh., Stockholm, 1882, p. 47 ; and I 883 , p. 37 (Bot. Centralbl., xii., I882, p. 33).

Richter-Hedwigia, I880, pp. I 54, I69, I9I ; I884, p. 65 ; and I886, p. 249.

Dangeard-(Chlamydococcus) Ann. Sc. Nat., vii., 1888, p. 105.

Reinsch-(Polyedrium) Notarisia, 1888, p. 493.

\section{Class XXVI.-Diatomaceæ.}

The family of Diatoms-called by the older writers Bacillariaceæincludes a very large number of genera and species, all microscopic, some of them extremely abundant in running, stagnant (but not putrid), and salt water. The individuals are strictly unicellular, and are either free-swimming and isolated, or attached to one another in a linear series or in zigzag chains, adhering to one another by means of small annular cushions, or fixed to some solid object by a simple or compound gelatinous stalk. They are, with very few exceptions, characterised by the presence in the cell-wall of a deposit of silica, by which it becomes converted into a hard but thin and perfectly transparent shell ; and this is always invested in a thin gelatinous envelope. Some species are closely adherent to submerged plants by the whole of one side; in other cases whole colonies are enclosed in a common gelatinous envelope, which assumes the form of a simple or compound tube, flattened plate, or globular mass. This is especially the case with the marine species.

Each individual or frustule consists of two more or less symmetrical 
halves known as valves; the silicified cell-wall of the older of these halves is slightly the larger of the two, fitting on to the younger one like the lid of a cardboard box. The cell-wall is composed of an organic matrix closely allied in composition to cellulose, impregnated with silica or a compound of silica ; either of these two ingredients can

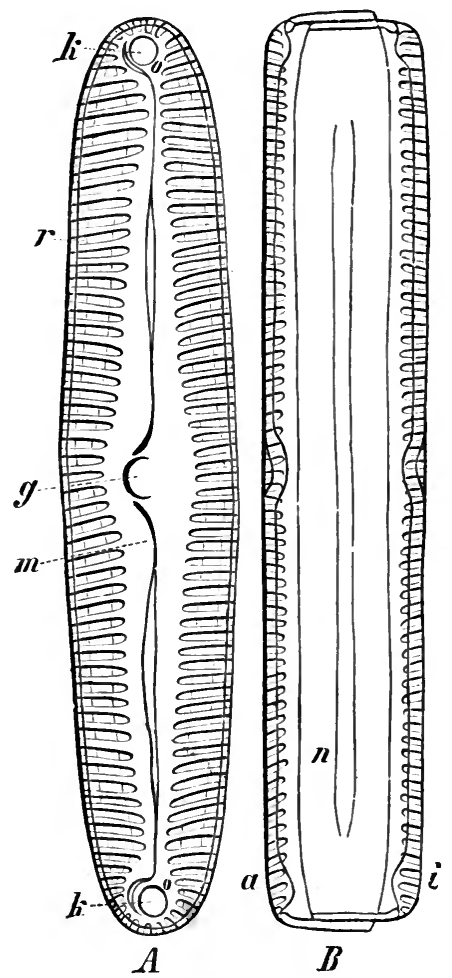

FIG. 353.- Pinnularia viridis $\mathrm{Sm}$. A, valve-view ; $B$, girdle-view (diagrammatic). $r$, furrows; $m$, raphe; $g$, central node; $k$, terminal nodules; $\boldsymbol{a}$, outer and older valve; $i$, inner valve ; $n$, secondary lines (x 80). (After Pfitzer.) be removed and the other left behind, the former by calcination, the latter by the action of hydrofluoric acid. In those species which are fixed by a gelatinous stalk, this stalk is also composed of a substance allied to cellulose. The overlapping edge of one of the two valves over the other is called the girdle or hoop; this girdle may be simple, or there may be several. In many species-and probably in all, if examined with a sufficiently high power-each valve is marked with a number of rows of very fine perforations, which, except under the very highest microscopic powers, appear as if confluent into striæ or furrows. There may be two or three sets of these apparent striæ, but they do not, as a rule, reach to the centre of the valve. So constant is the arrangement and the fineness of these striations in some of the more abundant species, that they furnish an admirable test for the definition and angular aperture of microscopic lenses. Some species of Navicula (Bory) and Pleurosigma (Sm.) are especially used for this purpose. Some marine genera in particular (Triceratium, Ehrb., Coscinodiscus, Ehrb., \&c.) are characterised by the beautiful honeycomb-like areolation of the cell-wall, due to the presence in it of actual chambers, which may or may not be covered by a thin membrane. The membrane at the bottom of these chambers is also most minutely perforated, constituting what is known as the secondary markings. In describing diatoms, the aspect in which the girdle is turned towards the observer is spoken of as the front, girdle, 
or zonal vieze; the aspect in which the surface of the valve is turned towards the observer is the side or valve view. In many diatoms the central space on the valve view not occupied by transverse striæ shows at its middle and at each end a strongly refractive thickening known as a node or nodule; and these nodules are connected with one another by a longitudinal line or rib-the raphe or suture. The primary classification of the genera of diatoms usually adopted depends on the presence or absence of this raphe.

Each diatom-cell contains a nucleus and a nucleole. The chlorophyll occurs in the form of plates or bands arranged

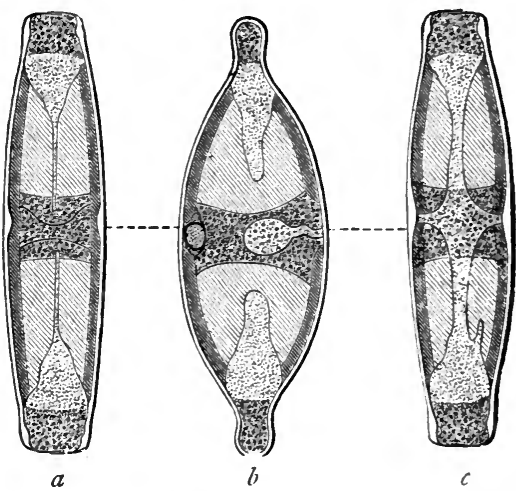

Fig. 354 A. - Anomaneis spherophora. a, $c$, girdleview ; $b$, valve-view. The endochrome-plates are shaded ( $\times 900)$. (After Pfitzer.)

with more or less symmetry, and there are usually also drops of oil, especially when conjugation is about to take place. A very few diatoms are green; but in the great majority of cases the colour of the chlorophyll is obscured by a characteristic brown pigment known as diatomin, readily soluble in alcohol, forming a brownish-yellow solution which is only slightly or not at all fluorescent. With concentrated sulphuric acid it assumes a beautiful blue-green colour. Petit (Brebissonia, I879-80, p. 8I) has very carefully investigated the chemical and physical properties of the colouring matter of diatons. $\mathrm{He}$ regards diatomin as a compound of chlorophyll and phycoxanthin, and as having

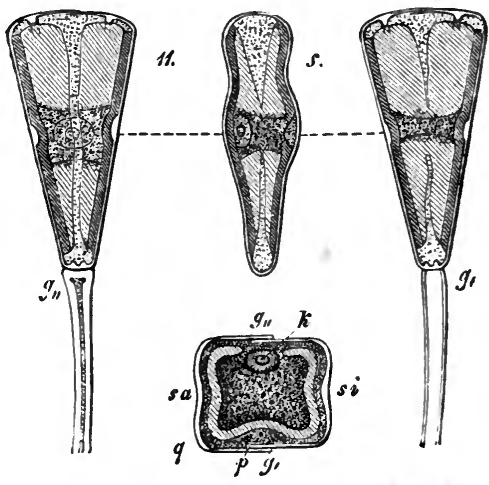

FIG. 354 B.--Gomphonema constrictum Ehrb. s, valves, side view, showing nucleus; $g_{l}, g_{\prime \prime}$, girdleviews; $q$, transverse section through middle of cell, showing silicified cell-wall, one half overlapping the other; $k$, nucleus; $p$, dense protoplasm; $g, g_{\prime \prime}$, girdle surfaces (magnified). (After Pfitzer.)

a great analogy with the chlorophyll of the higher plants, the two spectra being very similar.

Many of the solitary species of diatom, such as those belonging to 
the genus Navicula, possess. the power of propelling themselves through the water with considerable rapidity backwards and forwards in the direction of their longer axis, often with a jerking motion, or of creeping along the bottom on some submerged substance. The cause of this motion is a subject on which a large amount of attention has been bestowed. Nägeli attributed it to osmotic currents passing through the cell-wall. Ehrenberg believed that he had actually seen, in some cases, the extrusion through the raphe of vibratile cilia, in other cases of a

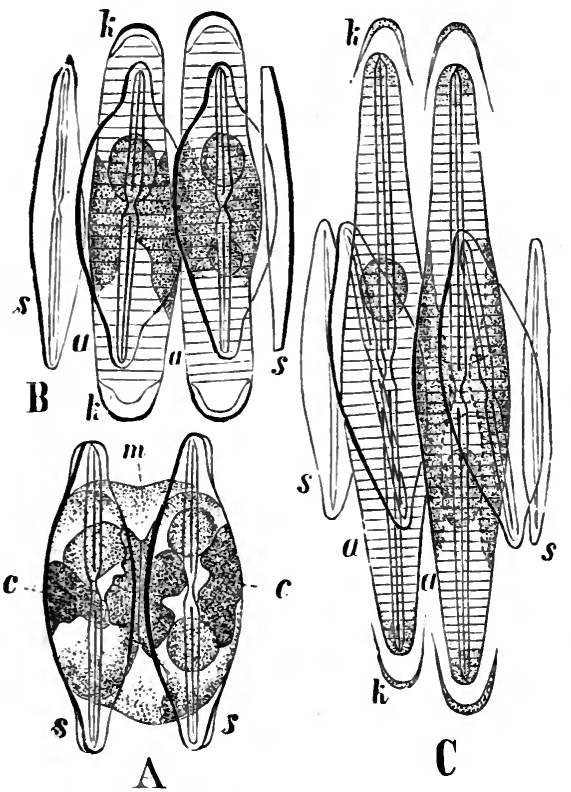

Fis. 355.- Stages in the formation of the auxospore of Frustulia saxonica Ag. $s$, valves; $m$, gelatinous envelope ; $c$, endochrome-plates; $a$, auxospore $\left(\times_{1,200}\right)$. (After Pfitzer.) 'foot' or pseudopode; but his observations have not been confirmed by others. The explanation of the motion now generally accepted is that of Schultze-that it is due to the contractility of the protoplasm which is exuded outside the cell-wall. Mereschkowsky (Bot. Zeit., I880, p. 529) states the arguments in support of the various views with regard to the causes of the motion, and sums up in favour of the theory that it is the result of osmotic currents within the siliceous cell-wall. Hallier, again (Unters. über Diatomeen, I 880 ), considers it due to a contractile layer of protoplasm, and asserts that at an early stage diatoms have no true cellwall of cellulose. Onderdonk

\section{(Microscope, 1885, p. 205) also attributes it to 'external cyclosis.'}

Diatoms have three modes of multiplication:- by simple division, by auxospores, and by a kind of conjugation which is regarded by some as sexual ; but the three modes pass gradually one into another. Simple division always commences with the bipartition of the nucleus. When it is about to commence the two valves separate from one another, the contents divide into two daughter-cells, and new siliceous valves are formed inside the old ones, and therefore necessarily smaller than they. The valves of the new individual are formed necessarily one after the other, the one formed later being smaller. The individuals produced in 
this way constantly diminish in size, until the original size is restored by the formation of an auxospore, resulting from the contents leaving the siliceous valves, which fall away from one another, and increasing in size, either by simple growth or by the coalescence of two auxospores produced in the same mother-cell. In other cases two distinct auxospores appear to be produced from the contents of a single mother-cell. The auxospore finally becomes invested in a new siliceous cell-wall. In those cases in which the process has been most carefully followed out, the auxospore does not appear to owe its origin to any process of true sexual union.

In some genera what is regarded by some as a true process of conjugation has been observed, a zygosperm being produced as the result of the coalescence of the protoplasmic contents of two different individuals. The conjugating diatoms are here placed side by side enclosed in a common gelatinous sheath; the contents of each escape by the falling apart of the two valves, and unite into a single zygosperm. In other cases two zygosperms result from the conjugation of a pair of cells. The protoplasm of each cell, as it escapes from its siliceous wall, puts out two protuberances; these meet in pairs, and the whole contents of the pair of mother-cells finally pass into the two zygosperms, which complete their development in precisely the same way as the auxospores. Buffham states (Journ.

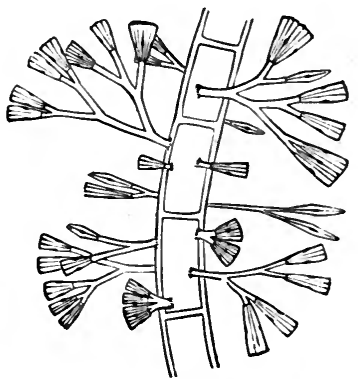

FIG. 356.-Gomphonema constrictum Ehrb. attached by gelatinous stalks to a fresh-water alga (greatly magnified).

Quek. Micr. Club, I885, p. I3 I) that in the conjugation of Rhabdomena (Ktz.) the 'male' frustule is always smaller than the 'female' frustule, and that the union is effected by the 'male' frustules attaching themselves in numbers to any part of the girdle of the 'female' frustule. De Bary and Pfitzer do not regard the fusion of the cell-contents of diatoms as in any sense a true process of sexual conjugation. De Bary (Bot. Zeit., I 858 , Supplement, p. 6r) thus summarises the four modes in which diatoms are reproduced by means of auxospores or zygosperms :--(I) Two products of conjugation are formed by the union of the contents of two distinct individuals ; (2) a similar process results in the formation of a single product of the same nature; (3) a single act of conjugation (production of auxospore) takes place between two portions of the contents of the same individual; (4) two such acts of conjugation take place simultaneously between different portions of the contents of the same individual. In all cases the formation of a new in. dividual is completed by the simple division of the product of union 
(auxospore or zygosperm) into two symmetrical halves with or without the intervention of a period of rest.

Still another mode of reproduction is described by Count Castracane and by some other observers, in Mastogloia (Thw.) and a few other genera, in the production of endogenous spores within the frustules.

It will be seen that, notwithstanding the great abundance of diatoms, some important points in their life-history still remain unsettled. On the minuter details of the modes of reproduction, the spontaneous motion of diatoms and its causes, the structure of the siliceous cell-wall, and the chemical and physical properties of diatomin, the reader is referred to the very extensive literature of the subject; only the most important memoirs are referred to below. The number of described species certainly exceeds 10,000; but this has been unduly increased by want of attention to the necessary variations in size in the same species. Not unfrequently diatoms form a gelatinous yellow scum on the surface of the water, or completely encrust submerged algæ and other water-plants; they abound on the surface of wet walls and rocks, and are not unfrequently present in the air. Some species are cosmopolitan; the marine forms are especially remarkable for their size and beauty. Various deposits found on the surface of the globe, often of very considerable thickness, known as tripoli, 'Kieselguhr,' ¿c., consist almost entirely of the fossilised siliceous shells of diatoms, and they enter largely into the composition of a variety of earths used for manufacturing purposes. In some countries, such as China, Japan, Siberia, Lapland, \&c., they form, cemented together by salts of lime, the edible earths which are mixed with meal to make a kind of flour. They occur also in large quantities in guano.

As has already been stated, the position of the Diatomaceæ in the natural system is a point on which there has been much controversy. Those who regard the mode of reproduction already described as a true process of conjugation place them in the class of Conjugatæ, near to the Desmidiaceæ, with which family they present many points of resemblance in external form, phenomena of spontaneous movement, \&c. ; and it is possible that the diatoms may be derived from the desmids by retrogressive metamorphosis. But we are, on the whole, disposed to the conclusion that they have a totally different origin; their very wide distribution in time and space, the sharp differentiation of the family, and the enormous number of species, favouring the view that they represent a comparatively small ascent from an archaic type which has never attained any higher degree of development.

Illustrative genera:-Eunotia (Ehrb.), Diatoma (DC.), Melosira (Ag.), Gomphonema (Ag.), Navicula (Bory), Rhabdonema (Ktz.), 


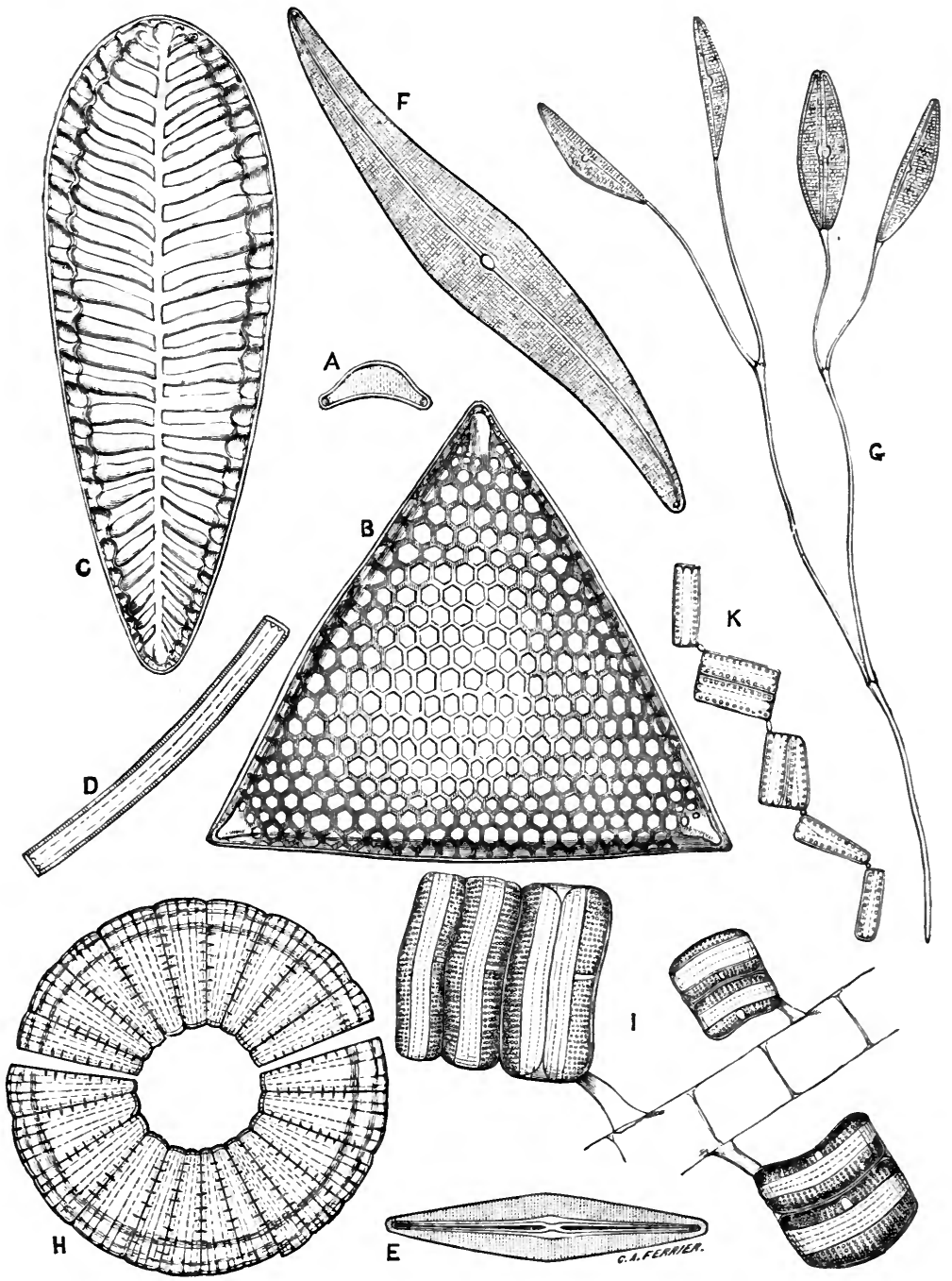

FIG. 357-Diatomaceæ: $A$, Eunotia monodon Ehrb.; B, Triceratium Favus Ehrb. ; $C$, Surirella splendida Ktz. ; D, Synedra Arcus Ktz. ; E, Navicula rhomboides Ehrb. ; $F$, Pleurosigma lacustre Sm. ; G, Cocconema lanceolatum Ehrb. ; H, Meridion constrictum Rlfs.; $I$, Achnanthes brevipes Ag. ; K, Diatuma elongatum Ag. (variously magnified). (After W. Smith.) 
Nitzschia (Hass.), Pleurosigma (W. Sm.), Achnanthes (Bory), Meridion (Leibl.), Biddulphia (Gray), Amphora (Ehrb.), Campylodiscus (Ehrb.), Cymbella (Ag.), Epithemia (Bréb.), Pinnularia (Ehrb)., Stauroneis (Ehrb.), Surirella (Turp.), Synedra (Ehrb.), Mastogloia (Thw.), Amphipleura (Ktz.), Fragillaria (Lyng.), Tabellaria (Ehrb.), Aulacodiscus (Ehrb.), Coscinodiscus (Ehrb.), I.icmophora (Ag.).

\section{LITERATURE.}

Agardh-Conspectus Diatomacearum, 1830 .

Ehrenberg-Die Infusionsthierchen, 1838 .

Kuitzing-Die kieselschaligen Bacillarien, I 844 .

Rabenhorst-Die Süsswasser-Diatomaceen Deutschlands, I 853 .

Rylands-(Marking of diatoms) Quart. Journ. Micr. Sc., I860, p. 25.

Griinow-Oesterreichische Diatomaceen, I862.

Heiberg-Kritisk Oversigt Danske Diatomaceer, 1863.

Cleve-Srenska och Norska Diatomaceer, 1868.

IV. Smith-Synopsis of British Diatomaceæ, 1872.

Hamilton L. Smith-Conspectus of the Diatomaceæ, Lens, 1873, p. 63.

Habirshaw-Catalogue of the Diatomacex, $187 \%$

Mereschkowsky - (Movements of diatoms) Bot. Zeit., 1880, p. 520.

Hallier-Untersuchungen über Diatomeen, 1880.

Brun--Diatomacées des Alpes, I880.

Van Heurck-Synopsis des Diatomacées de Belgique, I 88I.

Pfitzer-Die Bacillariaceen, in Schenk's Handbuch der Botanik, ii., I882.

Castracane-Diatonaceæ of the Challenger Expedition, I 886.

Also numerous papers by Wallich, Thwaites, Carter, Liiders, Millardet and Kraus, Schultze, Schnitz, Askenasy, Borzcow, Cox, Schaarschmidt, O. Müller, Flögel, Sichütt, Nelson and Karop, Deby, Brun, Cleve, Griinow, Janisch, F. W. Lewis, Greville, O'Meara, Petit, Gregory, Donkin, Ralfs, Walker-Arnott, Castracane, Brébisson, Kitton, Leuduger Fortmorel, Pfitzer, Rattray, Van IIeurck, Grove and Sturt, and others.

For the preparation of diatoms as microscopic objects see H. L. Smith, Lens, I873, p. 209; Kitton, Science Gossip, 1877. For detailed bibliography see Deby and Kitton, Bibliography of the Microscope, pt. 3, the Diatomaceæ, 1882.

\section{Class XXVII.-Cyanophyceæ.}

In the Cyanophyceæ or Phycochromaceæ are included all those unicellular chlorophyllous organisms in which the cell-sap is uniformly pervaded by a blue-green pigment which masks the pure green of the chlorophyll. This pigment can be separated, giving, in its aqueous solution, a beautiful blue colour in transmitted, a blood-red in reflected 
light, and is known as phycocyanin. This colour is, in a few cases, replaced by a red, and, in some Scytonemacex, by a brown endochrome, the scytonemin of Nägeli.

Although the Cyanophyceæ are described as unicellular, this term must be used with some limitation in the sense employed with respect to the Protococcoideæ, in comparison with which some of the bluegreen algæ display greater differentiation in their vegetative structure. In several families, notably the Oscillariaceæ and Rivulariaceæ, the protoplasm of the very iong filament is broken up transversely into a large number of imperfect cells known as pseudocysts, which are, however, never invested with a true cellulose cell-wall. In the Nostocaceæ, the breaking up of the filament into cells is much more complete; but even here it is doubtful whether the very thin membrane in which they are invested is composed of true cellulose. It displays the strongest tendency to deliquesce into a hyaline jelly, and, not unfrequently, as in the Scytonemaceæ and some Nostocaceæ, this gelatinous envelope becomes strongly coloured. Chromatophores with enclosed pyrenoids and nuclei are stated to have been detected in some species; while other authorities assert that neither starch nor a true nucleus is found in the Cyanophyceæ.

Multiplication by ciliated zoospores is, with a few doubtful exceptions, unknown in the Cyanophyceæ. The ordinary mode of propagation in the lower families is by simple cell-division. Quiescent restingspores or cysts, with thicker cell-walls, are also produced in several families. In the filiform orders, portions of the filament known as hormogones, consisting of a varying number of pseudocysts, become detached; these hormogones are endowed for a time with a power of spontaneous motion, after which they come to rest, and develop into new filaments. In the Oscillariaceæ this power of motion extends to the entire individual. In the Rivulariaceæ, Scytonemaceæ, and Nostocaceæ, a further differentiation is exhibited, of special cells within the filament known as heterocysts ; but their function is unknown.

The life-history of many of the Cyanophyceæ is still but imperfectly known, and their classification into families is very obscure. Some of those who have most closely investigated their structure and development are of opinion that a large number of the apparently distinct forms are but stages in the development of the same pleomorphic organism, often really belonging to a higher type. This will be further discussed under the separate families. They may be conveniently divided into two groups: the Chroococcacee, which are strictly unicellular, and the Nostochinea, embracing those families in which the aggregation of cells or pseudocysts assumes more or less of a filiform character. 


\section{Sub-class 1.-Nostochineæ.}

It is convenient to group together under this head those families of Cyanophycex, the Nostocacea, Rivulariacea, Scytonemacea, and Oscillariacee, which are characterised by the individual consisting of a cellular or pseudocellular filament, reproduced by motile hormogones, and, in some of the families, forming heterocysts.

Borzi, who has closely examined the structure and life-history of the Nostochineæ, considers that they display only a rudimentary cell-structure. The cell-wall is extremely thin, is inseparable from the contained protoplasm, and not sharply differentiated from it in its chemical reactions. The cells do not contain true starch, its place being taken, in spores and in the constituent elements of the hormogones, by a substance to which he gives the name cyanophycin-of a granular nature, apparently formed from the substance of the cell-wall, possibly a carbohydrate, and identical with the gelatinous substance of which the sheath which encloses the filaments is composed. The only indication of a nucleus is a local fragmentation and concentration of proteinaceous matter. Borzi states that in all the families of Nostochineæ the cells of a filament are in communication with one another by pores in their transverse walls, through which pass strings of protoplasm, or of a substance allied to cellulose. When heterocysts are about to be formed, this intercellular communication is suspended, and the pores are closed by a thickening of the cyanophycin or other cell-contents. In the Nostocaceæ, Scytonemaceæ, and Rivulariaceæ, the filaments are enclosed in a gelatinous sheath, which is much thinner in the Oscillariaceæ, and altogether wanting in Borzia (Cohn). This mucilaginous sheath may be continuous or septated, and may be composed of a single layer or of several ; in the latter case it not unfrequently assumes the form of a funnel at the end of the filament. Gomont differs to a certain extent from these conclusions, previous observers having, according to him, confounded the envelope proper of the cell with the mucilaginous sheath of the trichome. By the action of chromic acid he was able to separate the one from the other, and finds the very thin perfectly transparent envelope proper of the cell to possess properties intermediate between those of funguscellulose and of vegetable cutin. Bornet and Flahault call the string of cells or pseudocysts the trichome, the trichome with its envelope the filament.

When in a purely vegetative condition, all the cells of a filament are alike in form and size, and multiply by repeated bipartition. Scott and Wille have been able to demonstrate the presence of a nucleus in 
several species of Oscillaria (Bosc.) and Tolypothrix (Ktz.). The hormogones consist of a number of cells, often considerable, but usually variable in the same species. Only in a few species is the number constant, and then usually two, three, or four. Their contents are generally of a yellowish-green colour. According to Borzi, the hormogones of the Nostochineæ are of two kinds, straight and spiral. The latter kind occur only in the Oscillariaceæ, and are confined to the terrestrial species of Oscillaria, Microcoleus (Desm.), and Spirulina (Lk.). They are invested in a thin gelatinous sheath, and their movement is of a spiral nature, lasting much longer than that of the straight hormogones. These latter occur in all the families; they are not invested in a gelatinous sheath ; their motion is rectilinear and of short duration. The cells have excessively thin cell-walls, and contain abundance of cyanophycin, slightly coloured by phycocyanin. The cells of the hormogones are in communication with one another in the same way as the ordinary vegetative cells.

The spores of Nostoc and other Nostochineæ are, according to Borzi, formed as follows. The cells which become transformed into spores cease dividing transversely and increase somewhat in size. The gelification of the outer layer of the cell-walls ceases at the same time and a new cell is formed inside the old one by a process of rejuvenescence, the wall of the mother-cell ultimately disappearing altogether. The membrane of the spores thus constituted is formed out of their protoplasmic contents, and is homogeneous, without differentiation into exospore and endospore. The spore is, therefore, not homological with those of the higher Cryptogams, but is regarded by Borzi as partaking more of the nature of a cyst. Gomont, on the other hand, finds that the spores of the Nostochineæ, which are always the result of the encysting of ordinary vegetative cells, possess a distinct exospore and endospore, the former being again composed of two distinct layers, the outer of which is frequently warty or otherwise marked.

\section{Literature.}

Thuret-Mém. Soc. Sc. Nat. Cherbourg, 1857, p. 29 ; and Classification des Nostochinées, I 875 .

De Bary-Beitr. zur Kenntniss d. Nostocaceen, Flora, 1863, pp. 553 and 577.

Bornet and Thuret-Notes Algologiques, I876-1880 (especially Fasc. ii.). Borzl-Nuov. Giorn. Bot. Ital., I882, pp. 272 and 384 ; and Malpighia, 1886.

Bornet and Flahault-Ann. Sc. Nat., iii.-vii., I886-1888; and Mém. Soc. Sc. Nat. Cherbourg, 1887, p. 195 .

Gomont-Morot's Journ. de Bot., 1888, p. 43; and Bull. Soc. Bot. France, I888, p. 204. 


\section{Order I.-NOSTOCACEÆ.}

The Nostocaceæ are distinguished from all the other families of filamentous Cyanophyceæ by the less close connection with one another of the pseudocysts of which the filament is composed, giving it always more or less of a moniliform or necklace-like appearance. In most of the genera these pseudocysts are spherical or elliptical ; but in Nodularia (Mert.) they are disc-shaped, and more closely connected with one another than in the other genera. The extent to which the filaments are enveloped in mucilage varies greatly. In some genera (Nodularia) each filament is enclosed in a distinct hyaline sheath. In others (Anabæna, Bo:y, Aphanizomenon, Morr., Sphærozyga, Ag., Cỵlindrospermum, Rlfs.) this sheath is obscure or wanting ; in Aulosira (Kirch.) the filaments are either naked, or enclosed in a dry membranous sheath. In most species of Nostoc (Vauch.) a single filament or a number of filaments are enclosed in a hyaline jelly, often of considerable size and definite outline, formed from the more or less complete coalescence of the separate sheaths, which can

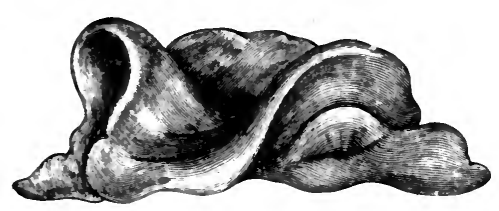

FIG. 358.-Vostoc commune L. (natural size). (After Cooke.) still sometimes be indistinctly made out. Such a jelly-like mass, which sometimes floats freely in the water of bog-pools, but is more often found on damp soil, is sometimes called a 'thallus' or ' frond.' It may vary in size from $0.2 \mathrm{~mm}$. to that of a small plum; is often of a green, violet, or blue colour, and, in the larger terrestrial species, the outer layers of the integument are more or less hardened, forming what is known as a 'periderm.'

The Nostocaceæ display no differentiation of the two extremities of filament. In nearly all the genera some of the cells are here and there replaced by heterocysts - cells incapable of further civision, of a slightly larger diameter, and with a somewhat thicker cell-wall, which is often yellow, the green protoplasmic endochrome being replaced by a watery colourless cell-sap. These heterocysts, the function of which is unknown, may be terminal, basal, or intercalary. Others of the cells, always in this case intercalary, are, in most species, replaced by resting-spores, also distinguished from the ordinary cells by their larger size and thicker cellwall, but containing a green endochrome. They are often formed more or less in connection with the heterocysts. In Cylindrospermum the terminal cells of the filaments become heterocysts, and the spores, some- 
times associated in chains, are formed immediately beneath them. The cell-wall of the resting-spores is often coloured yellow or brown, and is sometimes warty. After a period of rest they germinate by the bursting of the cell-wall and protrusion of the protoplasm. The hormogones are strings of from four to eight or twelve ordinary cells, situated between two heterocysts, which detach themselves from the rest of the filament, escape from their mucilaginous envelope, move about with a creeping motion, then come to rest, and develop into new individuals.

Bornet describes the motion of the hormogones of Nostoc as a creeping movement along a solid substratum at a rate of I $\mu$ ('०० I mm.) per second. After some hours they come to rest, large refringent globules which had previously been formed in the cells disappear, and they assume the appearance of ordinary filaments. Sometimes they
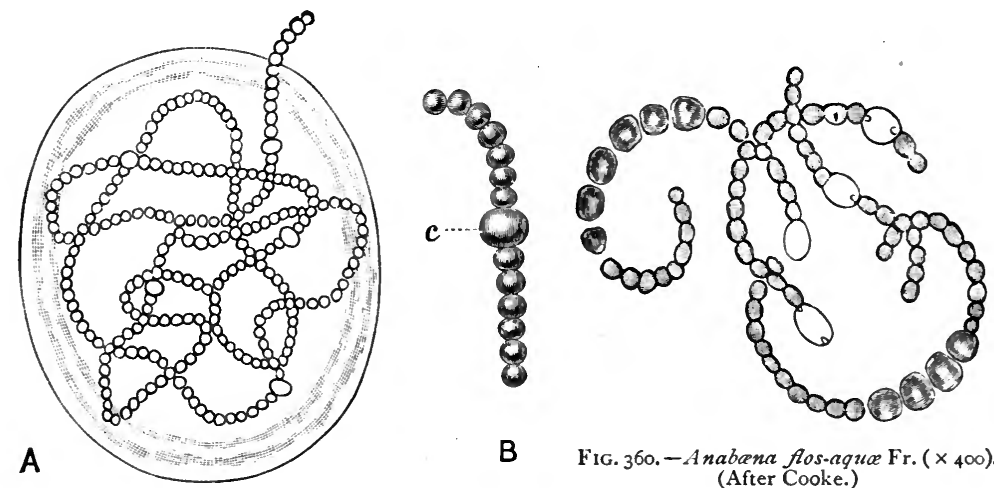

B

Fig. 360.-Anabana flos-aqua Fr. $(\times 400)$. (After Cooke.)

FIG. 359. $-N$. hyalinum Benn. $A$, 'frond' $(\times 200)$;

$B$, portion of trichome with heterocyst, $c(\times 600)$.

(From nature.)

invest themselves with a nuucilaginous sheath, and are transformed directly into spores, but usually the filament lengthens, displaying at the same time more or less sinuosity. The heterocysts do not appear at regular intervals. A new filament is thus formed altogether resembling those which spring directly from the germination of the spores. Once formed, it is subject to intermittent periods of growth, a second generation of spores, with thinner cell-walls, being sometimes formed after the first. In other cases the filament springing directly from a hormogone assumes a zigzag form, in consequence of some of the cells dividing in the transverse, others, in the longitudinal direction. In N. muscorum (Ag.) all the cells except the heterocysts are sometimes transformed into spores. The spores will occasionally germinate while still within the 'frond.' The filaments of Nostoc are ultimately serpentine, and often 
intricately interwoven, owing to the heterocysts maintaining their position when once formed, while the portions of the filament between them continue to lengthen by cell-division.

Most of the Nostocaceæ inhabit fresh, usually stagnant, water, bogpools, \&c.; a very few grow in salt water. Several species of Anabana Bory, Aphanizomenon Morr., and some other genera, frequently collect as a bright bluish-green scum on the surface of bog-pools; Aphanizomenon flos-aquæ (Rlfs.) is one of the organisms which contribute to the phenomenon know as the 'breaking of the meres.' The decay of species of Anabæna has a large share in causing the foul odour and injurious properties of stagnant water. Of the numerous species of Nostoc Vauch., a few only swim freely in water; these are usually minute with

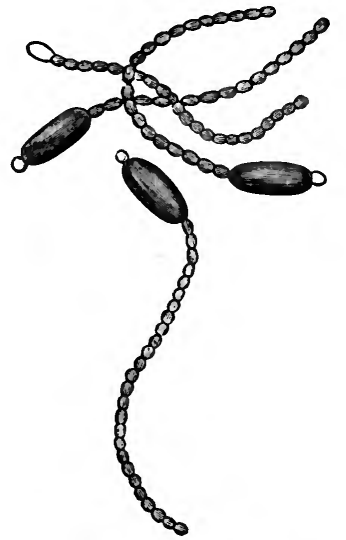

Fig. 362.-Cjlindrospermum macro. spermum $\mathrm{Ktz}$., with heterocysts and spores $(\times 400)$. (After Cooke.) a colourless 'thallus' more or less nearly spherical and distinctly lamellated, with a spontaneous power of active motion in the water. The larger number are terrestrial, growing on wet rocks, among moss on damp soil, or even on the comparatively dry ground, forming conspicuous jellylike masses, often as much as from one to two inches in diameter, usually of a green, yellow, brown, or sometimes red colour, the zomenon flos-aque Morr., with spore ( $\times$ 400). (After Cooke.) 'frond' enclosing a large number of bright bluegreen filaments (fig. 358). It is not uncommon for other chlorophyllous protophytes or algæ, the mycele of fungi, and the protoneme of mosses, to become enclosed, and even to continue growing, within their gelatinous envelope. Species of Nostoc and Anabæna are found in hot springs, and several species of the same genera are frequently to be met with within the cells of living aquatic or land plants, where they carry on an epiphytic existence (see pp. 28, I65, I7I). They occur with especial frequency in Lemna, causing yellow spots in the leaves.

Isocystis Bzi. is probably the simplest form of the Nostocaceæ. It consists of delicate moniliform filaments, which do not form colonies, but 
float freely on the surface of the water, solitary or in interwoven masses, forming but little mucilage, and destitute of heterocysts.

Hansgirg (Bot. Centralbl., xxii. and xxiii., 1885) regards the genera Nostoc, Anabæna, Cylindrospermum, and Sphærozyga as stages of development-analogous to certain zooglœa-conditions of the Schizomycetes - of various species belonging to the Oscillariaceæ, Rivulariaceæ, and Scytonemaceæ. The relationship of Nostoc with Drilosiphon will be alluded to under this last family (see p. 440). The Nostocaceæ appear also to approach the Schizomycetes through Leuconostoc (Van Tiegh.).

Among the Nostocaceæ are included, in addition to the genera already mentioned, Nodularia (Mert)., Cylindrospermum (Ktz.), Sphærozvga (Ag.), and Aulosira (Kirch.).

\section{LITERATURE.}

Meneghini - Monogr. Nostoc. Ital., 1843 .

Thuret-Mém. Soc. Sc. Nat. Cherbourg, I857, p. 23; Ann. Sc. Nat., I875, p. 372. Janczewski-Ann. Sc. Nat., I874, p. 123.

Bornet and Thuret-Notes Algol., fasc. i., pp. 2-3 ; fasc. ii., pp. 78-132.

Borzl-Flora, I878, p. 465 ; and Nuov. Giorn. Bot. Ital., 1878, p. 236.

Fischer-Beitr. zur Kenntniss der Nostocaceen, 1853.

\section{Order 2.-Rivulariacee.}

In the Rivulariaceæ-including also the Calotrichaceæ-the cells or pseudocysts of which each filament is composed are not connected together in a necklace-like form, but constitute a continuous thread divided by transverse septa which are exceedingly thin and often scarcely perceptible. Many of the species are extremely minute, the individual filaments being quite microscopic, and grow attached in tufts to a solid substratum, some water-plant or floating body, from which they radiate in a star-shaped manner, forming small green dịscs or cushions, often imbedded in copious mucilage. Each filament displays a distinct differentiation of the two apices, the distal extremity being elongated and attenuated into a hyaline hair, while at the base a portion is marked off into a more or less globular colourless basilar cell, the rudimentary celldivision being exhibited by the portion intermediate between the basilar cell and the terminal hyaline hair. The terminal hair is, according to Gomont, in perfect continuity with the rest of the true membrane of the filament, and is distinguished only by having fewer transverse septa, and by the entire absence of granular protoplasm. The outer layers of the walls of the filaments have a very strong tendency to become transformed into mucilage, from which is formed not only the copious jelly in which 
the colony is usually invested, but in most species also a separate delicate membranous sheath to each individual, often of a yellowish colour, which ultimately becomes open at the apex. In Microchæte diplosiphon (Gomont, Bull. Soc. Bot. France, I 885, p. 209) this sheath is double. The common gelatinous envelope of the colony sometimes becomes at length calcareous. In other species, which float on the surface of the water, the development of mucilage is much feebler.

The filaments of the Rivulariaceæ branch in a peculiar way. A small portion of the green tract between the basilar cell and the terminal bristle becomes rounded off, loses its endochrome, and forms a heterocyst resembling the basilar cell. This heterocyst now assumes the part of a basilar cell ; the terminal portion of the filament beyond it detaches itself, and applies itself laterally to the heterocyst,
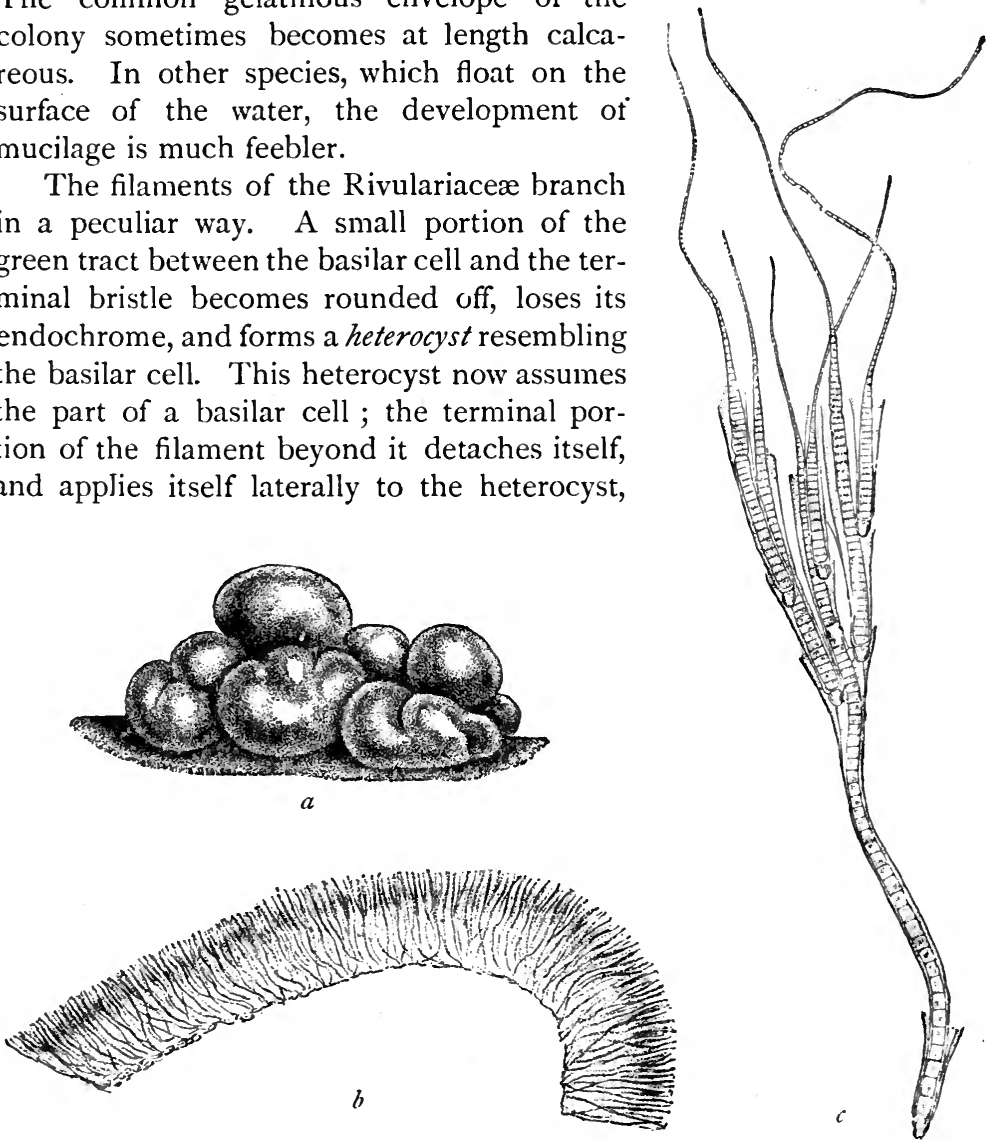

FIG. 363.-Rivularia polyotis Hauck. a, invested in its gelatinous envelope (natural size). $b$, vertical section $\left(x_{12}\right)$. $c$, filament $\left(x_{150}\right)$. (After Hauck.)

forming a 'pseudo-ramulus' or false branch; the original filament then develops a new apical portion in a direct line above the heterccyst. Heterocysts have not yet been observed in all the genera ; they sometimes occur interstitially in the filament without giving rise to a pseudoramulus; their function is obscure. The terminal hyaline bristle is of 
only temporary duration ; when it disappears it leaves the membranous sheath open at the extremity. This is especially well seen in Calothrix (Ag.).

The ordinary mode of multiplication of the Rivulariaceæ is by means of hormogones, fragments of the green portion which become detached from the rest of the filament, escape from the gelatinous envelope, move about with a creeping motion, eventually come to rest, invest themselves with a gelatinous sheath, and develop into a new filament in which the differentiation of the basal and apical extremities is soon manifested. The formation of hormogones is confined to the lower and central portions of the filament, and commences only after the disappearance of the terminal hyaline hair. 'They vary greatly in length, being composed of from two to fifty pseudocysts. When fully formed, they glide slowly out of the sheath, several often attached to one another. At the period of detachment of the hormogones the whole filament displays a slow movement ; otherwise it is quiescent, the power of motion which in the Oscillariaceæ belongs to the entire filament being in the Rivulariaceæ restricted to the hormogones. Beck (Verhandl. zool.-bot. Gesell. Wien, r886, p. 47) describes a peculiar mode of formation of the hormogones in Glœotrichia natans

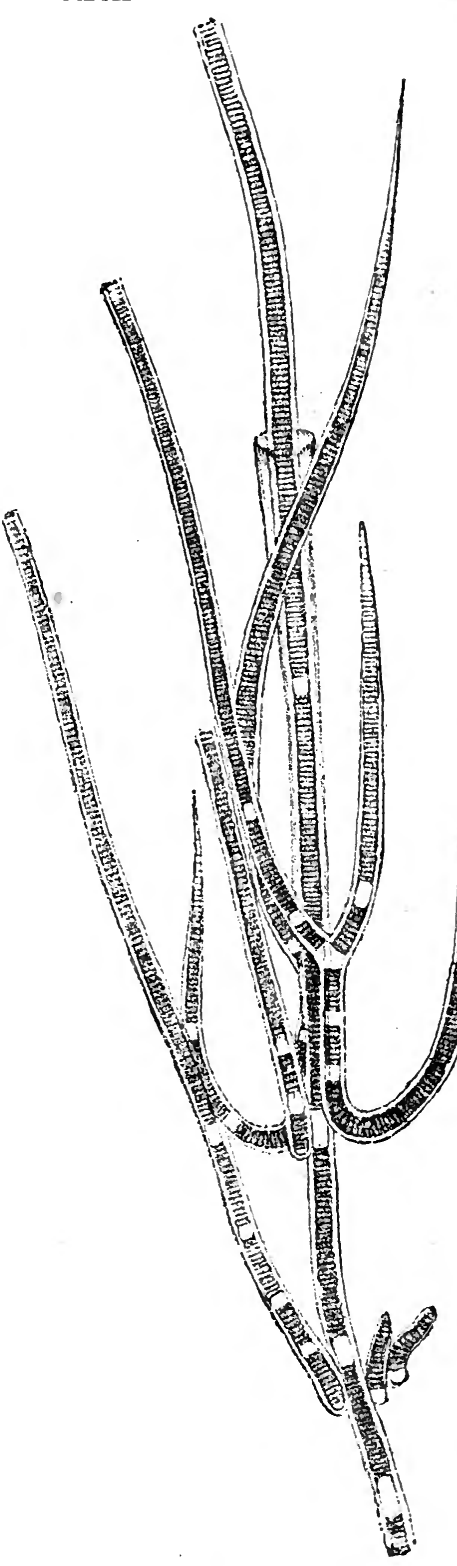

FIG. 364.-Caloth rix crustacea Thur. ( $\times$ 160). (After Bornet.) 
('Thur.) while still within the sheath, the cell-contents passing from a heterocyst into the basal cell of a hormogone.

Multiplication by quiescent resting-spores has been observed in some species of Rivulariaceæ. The lower portion of the green part of a filament immediately above the basilar cell is transformed into an elliptical thick-walled spore, which escapes from its investing membrane, and, after. a period of rest, either develops directly into a new filament, or

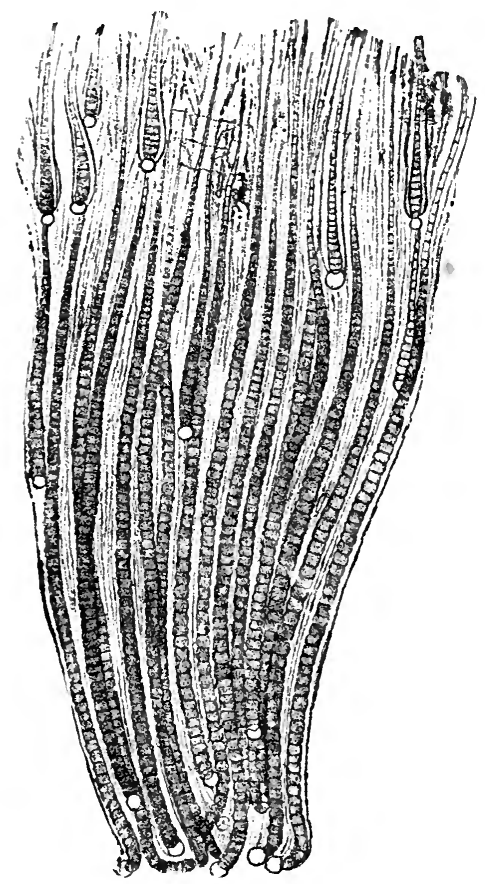

FIG. 365.-1 sactis plana Thur. ( $\times 160)$. (After Bornet.) breaks up into a number of hormogones. The spores of Glœotrichia punctulata (Thur.) are rough. Under the name 'conids' Bornet and Flahault also describe special propagative cells which become detached from the lower part of the filament.

By far the larger number of species of Rivulariaceæ grow in fresh water, especially stagnant, also on damp soil and on wet rocks. The species of the typical genus Rivularia Roth are especially abundant in both running and standing water; R. fluitans (Cohn, Hedwigia, 1878, pp. I and 33) floats free on the water, forming a bluegreen scum which enters largely into the composition of what is known as 'flos aquæ.' Some species have a red tinge. Calothrix Ag., though placed by Rabenhorst among the Scytonemaceæ, has all the characteristics of the Rivulariaceæ. The filaments of some species are comparatively thick, as much as ०.० $\mathrm{mm}$. in diameter, and are invested in a ccpious, often coloured, mucilaginous sheath. Microchate Thur. is nearly allied to Calothrix, as is Glootrichia Ag. to Rivularia. Several species of Rivularia and Ca'othrix grow in salt or brackish water, and Isactis Thur. is exclusively marine. In Hormactis Thur., which is also marine, the filaments are curved in a serpentine manner, and this character, together with the interstitial heterocysts, appears to indicate an approach to the Nostocaceæ. Other genera included in the Rivulariaceæ are L.eptochæte 
(Bzi.), Amphithrix (Ktz.), Dichothrix (Zanard.), Sacconema (Bzi.), Brachytrichia (Zan.), and Polythrix (Zan.), the last being marine.

Hansgirg (Bot. Centralblatt, xxii. and xxiii., I885) considers the genera ordinarily placed under Rivulariaceæ as being higher developments of organisms belonging to the Oscillariaceæ.

De Bary-Flora, I863, p. 577.

\section{LITERATURE.}

Bornet and Thuret - Notes Algol., fasc. i., 1876 , pp. v.-viii. ; and fasc. ii., I880, pp. $157-175$.

Bornet and Thuret-Etud. Phycol., I878, pp. I-6.

Bornet and Flahault-Ann. Sc. Nat., iii. (1886), p. 337 ; and iv. (1886), p. 34 r.

\section{ORder 3.-SCYtonemaceæ}

(including Stigonemeæ and Sirosiphoneæ).

The Scytonemaceæ resemble the Rivulariaceæ in consisting of branched filaments, often comparatively stout, enclosed, either singly or in numbers, in a mucilaginous sheath ; but differ from that family in displaying no differentiation of the two extremities. The filament terminates at each end in a large thin-walled apical cell, by the repeated division of wnich the greater part of the growth in length takes place. The filaments display no oscillation or other spontaneous motion. 'The mucilaginous sheath which invests one or more filaments is of considerable thickness, except over the apical cells, where it is very thin ; elsewhere it is generally lamellated, the lamellæ decreasing in number towards the apex, which gives the appearance of a number of funnels inserted one in another. It is often coloured by a deep yellow or brown pigment known as scytonemin, and becomes dry and pulverulent with age, but in younger filaments the sheath is sometimes altogether wanting. The filaments are not septated laterally, but the contents are divided into ' gonids' or pseudocysts, of a spherical or elliptical form, and arranged in a single row in the thinner, often in two parallel rows in portions of the thicker, filaments. These pseudocysts are at first green, but frequently become subsequently dark brown; and the filament exterior to the pseudocysts is commonly filled by endochrome coloured brown by scytonemin ; the entire plant being therefore distinguished by its brown or orange colour. In Tolypothrix (Ktz.) and Plectonema (Thur.) the filaments generally retain permanently a green colour.

The Scytonemaceæ may multiply by the individual filaments, enclosed in a common sheath, which have no genetic connection with one another, escaping separately from their sheath, and then investing themselves in a new mucilaginous envelope. But the ordinary mode of 
propagation is either by resting-spores or by hormogones. In the former case, at the end of the season of growth, the disc-shaped pseudocysts towards the end of a filament assume a roundish or ovate form, the gelatinous sheath disappears, and the spores thus formed remain for a time united together in masses. These resting-spores are capable of resisting a high degree of cold and drought ; they germinate after a period of rest, when the membrane bursts transversely. In the formation of hormogones the sheath also becomes absorbed, beginning from the apical cell, and

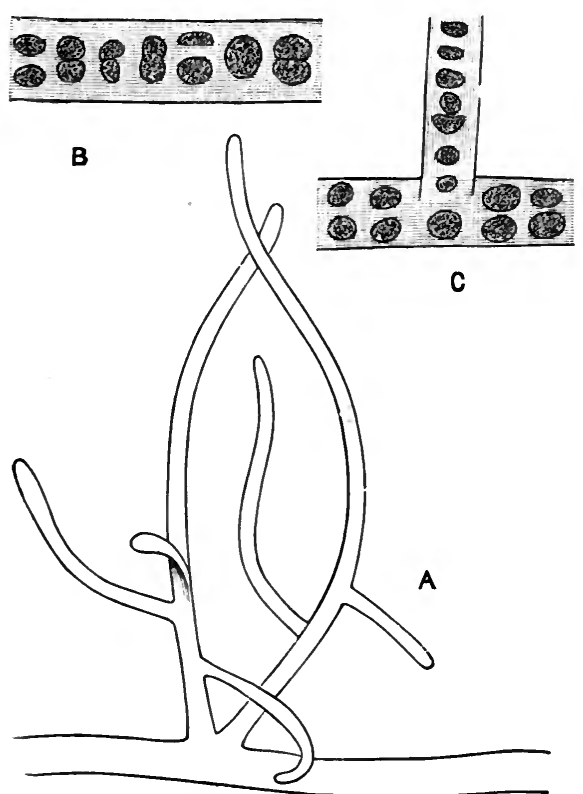

F1G. 366.-Stigonema minutum Hass. A, outline of filament $(x \mathrm{I} 00) ; B$, portion of primary filament $(\times 200)$; $C$, ditto with branch $(x 200)$. (From nature.) the filament breaks up into a number of hormogones, each consisting of many pseudocysts. In the Stigonemeæ the hormogones are formed only in the lateral branches, which contain only a single row of pseudocysts. The hormogones move slowly in the water in a straight line; in some cases an entire filament may be converted into a motile hormogone. During germination the hormogone, enclosed in a delicate transparent mucilaginous sheath, breaks up into portions of various lengths, or it becomes a new individual without breaking up ; and at this period one of the apical pseudocysts usually becomes a heterocyst.

The branching of the Scytonemaceæ takes place in two different ways, characteristic of the two sub-orders into which they are dividedthe Scytonemea and the Sirosiphonea. In the Scytonemeæ, which include the genera Scytonema (Ag.), Petalonema (Berk.), Tolypothrix (Ktz.), Plectonema (Thur.), and Drilosiphon (Ktz.), pseudo-ramuli are formed somewhat in the same way as in Rivularia, but the branches are much stouter, and stand out at right angles to the main axis. In Scytonema Ag. two contiguous pseudocysts separate at indefinite spots on the filament, and each of these then acts as the terminal pseudocyst 
to a lateral branch; the branches therefore spring in pairs at a right angle from the main axis. Thick-walled heterocysts may be formed at any spot in the filament. In Tolypothrix Ktz. the false branches spring singly from beneath heterocysts. In the Sirosiphoneæ, including Stigonema (Ag.), Sirosiphon (Ktz.), Fischera (Schw.), Capsosira (Ktz.), Hapalosiphon (Näg.), Mastigocladus (Cohn), and Mastigocoleus (I.agerh.), the formation of a false branch is preceded by a change in

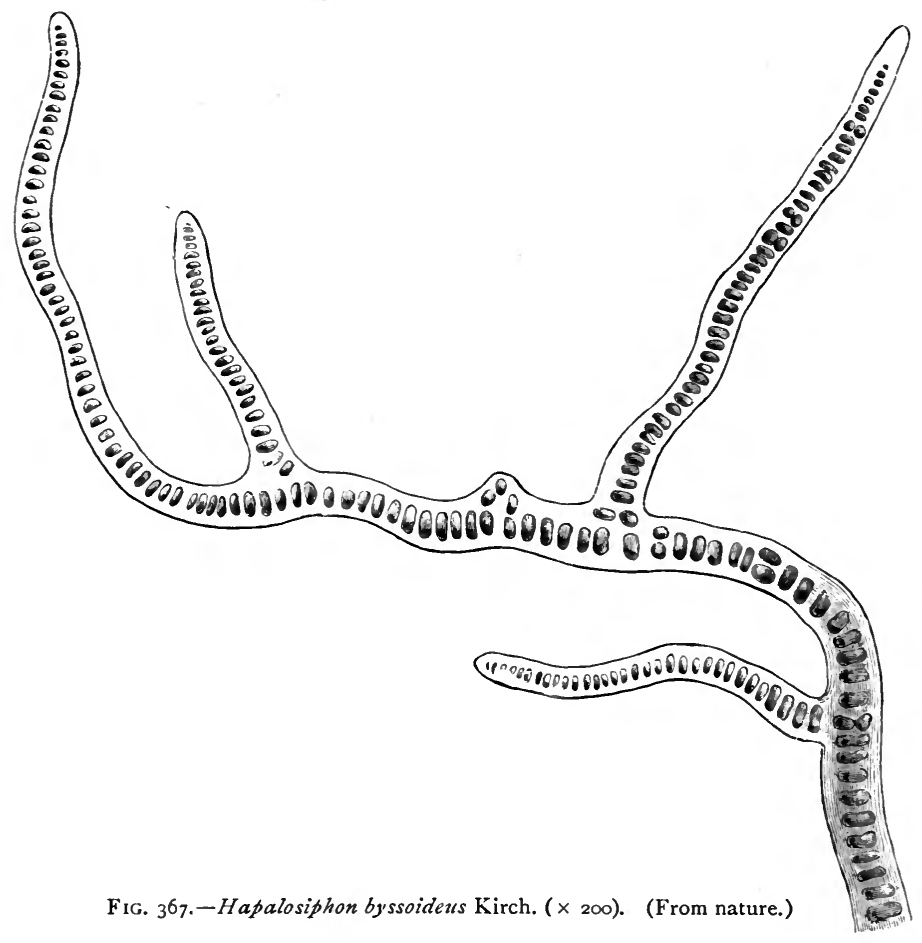

the direction of cell-division. Two or three contiguous pseudocysts in an older portion of the filament divide in a direction parallel to the axis of growth of the filament, and one of the new pseudocysts thus formed now becomes the basal pseudocyst of a lateral branch, which generally consists of a single row of pseudocysts at right angles to the axis. In Plectonema Thur. the branches protrude outside the mucilaginous sheath. Heterocysts are formed in all parts of the filament, but their function is unknown. 
Coleodesmium Bzi. appears to be one of the simplest forms of the Scytonemaceæ. No pseudo-ramuli are formed ; the filaments increase by fission only, and a number remain united in a bundle within a common envelope. Mazaa (Bornet, Bull. Soc. Bot. France, 188I, p. 287) is, on the other hand, a genus in which the development is carried to its highest point. The gelatinous 'fronds' are about $25 \mathrm{~mm}$. in diameter ; the heterocysts are borne on pedicels consisting of from one to three cells, and the whole appearance is that of a Rivularia, the filaments being immersed in a homogeneous jelly, and spreading from a central spot. No distinct sheath has been observed, nor any restingspores or hormogones. In Petalonema Berk. the mucilaginous sheath forms a kind of broad coloured wing to the filament. Mastigocoleus (Lagerheim, Notarisia, 1886 , p. 65) is a marine genus growing attached to the shells of molluscs, with both terminal and lateral heterocysts; the filament sometimes ends in a hair, as in the Rivulariaceæ. Drilosiphon Julianus Ktz., frequent on the damp walls of greenhouses, is characterised by an outer calcareous sheath, and is a remarkably pleomorphic organism. According to Zukal (Oestcrr. Bot. Zeitschr., I 883, p. 73) it forms two kinds of hormogones, and displays a kind of alternation of generations. The ordinary hormogones produce only more and more slender filaments, which gradually assume a moniliform character, and are then known as Nostoc parietinum (Rabh.). Eventually the cells of these nostoc-filaments separate, and assume the character of an Aphanocapsa, or, in other cases, become the organism known as Gloeocapsa fenestralis (Ktz.) ; or very slender filaments are produced, constituting the Leptothrix parasitica and muralis (Ktz.), which forms are distinctly connected genetically with Drilosiphon. These leptothrixfilaments may again break up into vibrio- and bacillus-forms. The second kind of hormogone has a fusiform shape, and consists usually of from four to eight pseudocysts. It may remain dormant for a time, and, on germinating, reproduces the ordinary thick filaments.

Wille (Ber. Deutsch. Bot. Gesell., I 883, p. 243) and Scott (Journ. Linn. Soc., xxiv., 1887 , p. I 88 ) have determined the presence of a cellnucleus in Tolypothrix. Wille states also that in Stigonema compactum (Kirch.) the necklace-like pseudocysts are in direct communication with one another through perforations in their cell-walls. When this species passes into the Glœocapsa-condition, the perforations disappear, in consequence of the gelification of the common sheath, and the separate cells then carry on their existence as distinct individuals. Under the name Tolypothrix amphibia, Zopf (Ber. Deutsch. Bot. (iesell., I883, p. 319) describes an organism having both an aerial and an aquatic form, the latter being a true Tolypothrix with its filaments 
enclosed in sheaths and breaking up into hormogones, from which is derived the aerial form with the nature of a Chroococcus, and dividing in three directions.

Rabenhorst and Cooke regard Stigonema, and the latter authority also Hapalosiphon, as genera of lichens; and Bornet and Flahault state that several organisms described as species of Sirosiphon and Stigonema are really lichens in a more or less advanced stage of development. Hansgirg (Oesterr. Bot. Zeitschr., I 884, and Bot. Centralbl., xxii. \& xxiii., 1885) considers the genera placed under Scytonemeæ to be the highest forms of development of various organisms hitherto mostly placed under Oscillariaceæ. In the same way, from Tolypothrix and Scytonema may arise, by further development, the corresponding forms of Hapalosiphon, Mastigocladus, Sirosiphon, Stigonema, Fischera, and other gencra usually placed under Sirosiphoneæ.

With the exception of Mastigocoleus, the Scytonemaceæ are found only in fresh water, in bog-pools, or very commonly on wet rocks or trunks of trees, or among moss. They may form mats of considerable thickness, but the individual filaments, including the sheath, seldom exceed $0^{\circ} 04-0.05 \mathrm{~mm}$. in thickness. Several Scytonemaceæ are known to enter into the composition of lichens (see fig. 279 D.)

\section{LiteratuRE.}

Bornet-Notes Algol., fasc. I, I876, pp. iv.-v. ; fasc. 2, 1880, pp. I 35-1 56. Bornet and Flahault-Ann. Sc. Nat., v., I887, p. 5 I.

\section{Order 4.-Oscillariace (including Chamesiphonace}

The Oscillariaceæ or Oscillatorieæ, in which the Lyngbyeæ are also included, consist of delicate blue-green threads, occurring singly or in large floating masses in fresh running, or more abundantly in stagnant, less often in salt, water. The filaments are cylindrical and unbranched, straight, or (Oscillaria princeps, Vauch.) with the terminal portion bent at an obtuse angle with the rest of the filament; in Spirulina (Lk.) the whole filament is coiled in a corkscrew-like manner. The filament is divided by very delicate transverse septa into disc-shaped pseudocysts ; there is no differentiation between the two extremities. The cell-wall has the property of transforming its outer layers into copious mucilage, which forms a gelatinous sheath investing either single filaments, as in Lyngbya (Ag.) and Symploca (Ktz.), or a number of filaments, as in Inactis (Ktz.) and Microcoleus (Desm.). In most species of Oscillaria (Bosc.) and Spirulina a distinct sheath is either wanting or it is extremely thin and delicate, but the filaments are often imbedded in structureless jelly. 
The blue-green colour of phycocyanin is sometimes replaced by a red or violet pigment. Scott finds a cell-nucleus in several species of Oscillaria.

The only certainly known mode of multiplication of the Oscillariaceæ is by a filament escaping from its mucilaginous

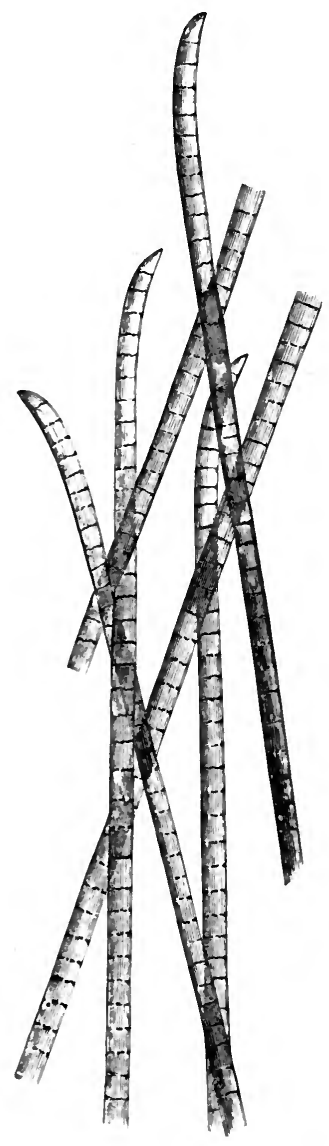

Fig. $368-$ Oscillaria tenu's Ag. $\left(\times{ }_{400}\right)$. (After Cooke.) sheath, and breaking up into hormogones, each composed of a small number of pseudocysts, which round themselves off at both ends and develop into new filaments.

The family derives its name from the oscillating or wavy motion with which the filaments are endowed. This consists in a creeping movement in the direction of the length of the filament, now backwards and now forwards, accompanied by a curvature of the filament and rotation round its own axis ; but, according to Borzi, this power of motion is limited to the reproductive period. The filaments of the Oscillariaceæ have a remarkable power of resistance to both cold and desiccation, to which they are adapted by the encysting of the filament and hardening of the mucilaginous sheath.

The movements of the Oscillariaceæ are greatly influenced by temperature and light, being much more active in warmth and sunshine than in cold and shade, but their cause is involved in considerable obscurity. Cohn (Arch. mikr. Anat., 1867, p. 48) observed that the oscillating movements take place only when the filament is in contact with a solid substratum. Siebold (Zeitschr. wiss. Zool., i 849, p. 284) states that if the water in which they grow is coloured by indigo, the particles collect round the filaments of Oscillaria up to their apex, whether they are in motion or not. Sometimes creeping spiral lines of pigment begin to be formed at both ends of the filament and meet in the middle, where the particles become heaped up into little balls ; or sometimes this begins in the middle and advances to both ends. The mode in which the particles of indigo adhere to the filament and to one another appears to indicate the excretion of mucilaginous protoplasm. 
Engelmann (Bot. Zeit., 1879, p. 49) claims to have detected this external secretion in the case of Oscillaria dubia (Ktz.). Zukal compares the motion of Spirulina to that of a growing tendril, and asserts that it is intimately connected with the growth of the filament. It consists of a slow torsion of the entire helix round its own axis, and is the result of the more rapid growth in length of the filament than of the ideal axis of growth. If the motion is suddenly interrupted, the filaments become for a moment quiescent, and then retreat towards the central point of the movement, forming a dark green lump. Hansgirg, on the other hand (Sitzber. Böhm. Gesell. Wiss., see Bot. Centralbl., xii., ı 882, p. 361), considers the twisting and nodding movements to be due, not to the growth of the filament, but to osmotic changes in the cell-contents; the separate cells exhibiting motion when the envelope itself is at rest. $\mathrm{He}$ regards the movements as of the same nature as those of the sarcode in the pseudopodes of Rhizopods and other Protozoa. The same observer states further (Bot. Zeit., I 883, p. 83I) that in the protoplasm which had escaped from the broken end of a filament of $O$. princeps, he has observed

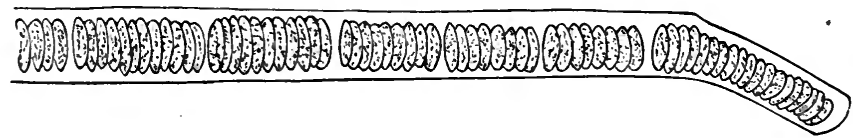

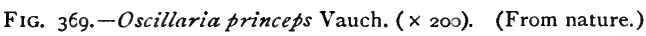

a number of amœboid cells from 9 to $12 \mu$ in diameter, nearly spherical in form, and putting out colourless pseudopodes about twice the length of the central body, and to these he attributes the motile properties of the protoplasm. He believes the cause of the oscillating motion to be that the internal protoplasm takes up water more rapidly, and consequently swells to a greater extent, than the enveloping sheath, causing the filament to move slowly backwards and forwards within the sheath. In those species in which each filament is not invested in a separate sheath, variations in the turgidity are also brought about by variations in the endosmotic and exosnotic currents. Finally Schnetzler (Arch. Sc. Phys. et Nat., I 885 , p. I64) describes the movements in O. ærugineocœrulea (Ktz.) as of six different kinds, viz. : (I) rotation of the filament or of its segments round its axis ; (2) creeping or gliding over a solid substratum ; (3) a swimming change of position in the water ; (4) rotation or flexion of the entire filament ; $(5)$ sharp tremblings or concussions ; and (6) a radiating arrangement of the entangled filaments.

Most of the species of the typical genus Oscillaria Bosc. grow in dense slimy tufts attached to other algæ or floating bodies, the filaments being not more than from 2 to $6 \mu$ in diameter; in a few species, 
such as O. princeps (Vauch.), the diameter is much greater, the separate filaments, just visible to the naked eye, floating on the surface of the water. Lyngbya Ag. is distinguished by its property of forming 'persistent cells,' the function of which is not known ; they may possibly be propagative spores. The species have a much less active motion than those of Oscillaria, and chiefly inhabit salt or brackish water. Symploca $\mathrm{Ktz}$. grows in tufts, frequently among grass with the habit of a Rivularia. In Microcoleus Desm, and Inactis Ktz. a large number of filaments are enclosed in the same gelatinous sheath.

The genera Chamæsiphon (A. Br.), Clastidium (Kirch.), Cyanocystis

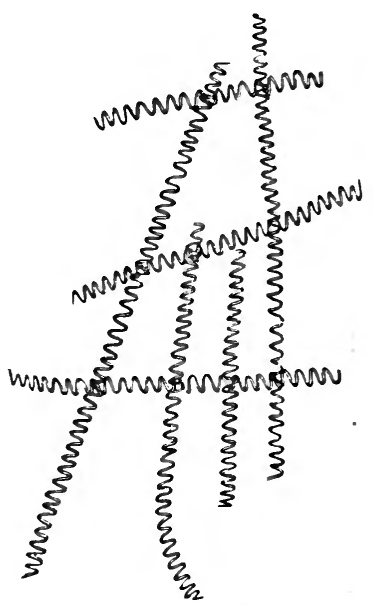

Fig. 370.-Spirulina tenuissima Ktz. $(\times 400)$. (After Cooke.) (Bzi.), and Dermocapsa (Crouan) (to which Thuret adds Xenococcus and Sphærogonium, Rostaf.) constitute Borzi's family of Chamesiphonacee, distinguished, according to that author, by the presence of coccogones, propagative cells of the nature of sporanges, in which conids are formed by repeated

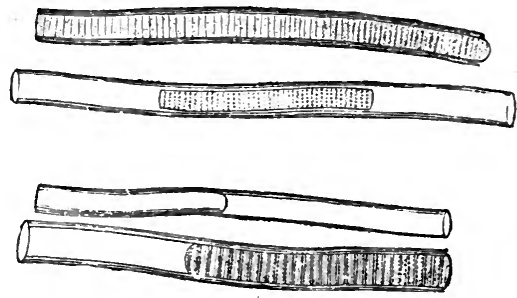

FIG. 371.-Lyngbya astuarii Liebm. ( $\times 2=0)$. (After Hauck.)

division, the usual number in each coccogone being four, eight, or sixteen. Clastidium (Jahrhft. vaterl. Naturk. Würtemberg, I 88o, p. I 35)

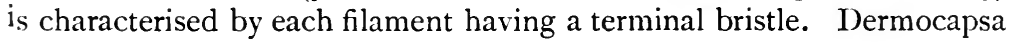
and Xenococcus are epiphytic on Catenella, Lyngbya, and other marine algæ. The former genus has been placed among both Florideæ and Fucaceæ, owing to its mode of propagation; D. violacea (Crouan) has a bright red colour.

Plaxonema Tangl (Sitzber. Akad. Wiss. Wien, r882) is a filamentous protophyte with the habit of an Oscillaria, but characterised by the presence of a disc-shaped chromatophore in the blue.green protoplasm. Under certain conditions the filaments break up into zooglœalike colonies. Borzia Cohn (Jahrber. Schles. Vaterl. Cultur, ı 883, p. 226) is a genus of Oscillariaceæ with the habit of a bacillus, consisting of 
short oblong rods, which oscillate slowly and are not enclosed in a gelatinous sheath. In B. trilocularis (Cohn) each hornogone is composed uniformly of three pseudocysts only.

Many of the Oscillariaceæ enter largely into the composition of the blue-green scum seen on the surface of stagnant ditches, \&c. Together with others of the Nostochineæ they are said to have the power of decomposing vegetable matter, and to this is largely due the foul stench of stagnant water. In addition to many species of Lyngbya a few belonging to other genera grow in salt or brackish water. Several species of Oscillaria are found in thermal springs.

The relationship of the genera of Oscillariaceæ to one another, and even to genera at present included in other families, is still very obscure. Hansgirg believes that many of the forms described as species of Chroococcus result from the breaking up of filaments of Lyngbya; while, on the other hand, most of Kützing's species of Leptothrix, and many

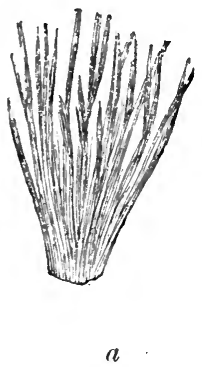

FIG. 372,-Symploca hydnoides Kt7. (a, natural size; $b, \times 200$ ). (After Hauck.) of Oscillaria, may be simply hormogones of species of Rivulariaceæ, Scytonemeæ, and Stigonemeæ, propagating by frequent divisions, and becoming invested in a more or less thick gelatinous sheath. Many species of Lyngbya may be only the young stages of development of those species of Calothrix and Scytonema to which they are found attached. Oscillaria or Lyngbya antliaria. (Hansg.) he now regards as in reality an Aphanocapsa. The same author further states that in the

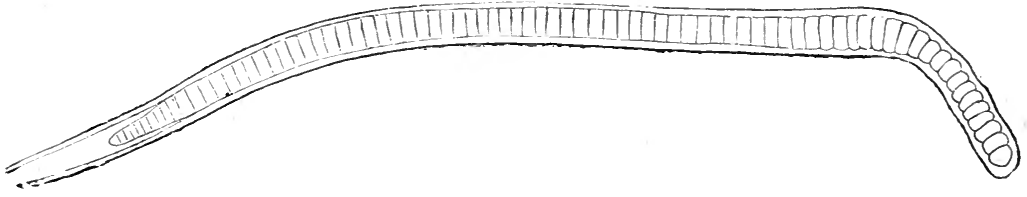

FIG. 373.-Symploca violacea Hauck ( $\times 280)$. (After Hauck.)

Lyngbyeæ and other of the higher families of Cyanophyceæ, nuclei, pyrenoids, and chromatophores occur, but only when they are in a condition of retrogression from the filiform state, and are breaking up into the unicellular condition. Under the name Chroomonas Nordstedtii Hansgirg, describes (Bot. Centralbl., xxiii., ı 885 , p. 229) a biciliated 
organism with blue-green endochrome which he regards as the swarmcell condition of a phycochromaceous alga which occurs normally in a filamentous form, probably as Oscillaria tenuis (Ag.) or O. Frölichii (Ktz.).

\section{LITERATURE.}

Fresenius-Ueb. d. Bau u. d. Leben d. Oscillarieen, 1845 . Braun-Bot. Zeit., I852, p. 395.

Bornet and Thuret-Notes Algol., fasc. 1, pp. iii. - iv. ; and fasc. 2, pp. 132-135. Zukal-Oesterr. Bot. Zeitschr., I88o, p. I I.

Hansgirg-Oesterr. Bot. Zeitschr., 1884, pp. 313 et seq. ; and Ber. Deutsch. Bot. Gesell., I 885 , p. I4.

\section{Sub-class 2 and ORDER 5.-Chroococcaceæ.}

The Chroococcaceæ share with the Schizomycetes the distinction of being among the lowest forms of vegetable life. The separate cells are always microscopic, and are filled with a blue-green or violet endochrome which owes its colour to the phycocyanin dissolved in the cell-sap ; they contain neither distinct chlorophyll-grains nor starch, nor, except in Chroodactylon (Hansg.), a distinct nucleus. The cells are either isolated. or are more often connected together

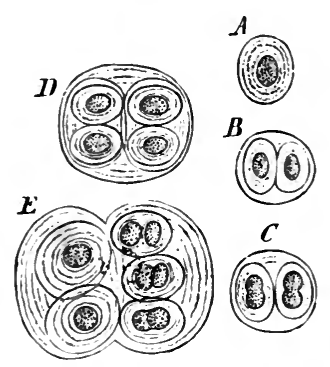

FIG. 374.- Stages in the development of Chroococcus turgidus Näg. (greatly mag. nified). (After Reinke.) into colonies by a mucus formed from the disintegration of the outer layers of the cellwall; they are never united into a filament. This gelatinous envelope is either colourless and hyaline, or of a blue, brown, or olive colour, and is often strongly lamellated. In Chroococcus (Näg.) it is homogeneous and capable of swelling greatly; in Glœocapsa (Ktz.) it is composed of two successive layers, and becomes eventually, in some species, crustaceous, and of a very dark brown or even black colour. The internal pseudocysts or gonids are never endowed with cilia, as in some Protococcacex, and are usually quiescent; but in Microcystis (Ktz.) they have a constant 'swarming' motion within the hyaline envelope. The entire organism has usually a power of slow spontaneous motion. Multiplication by swarm-spores or zoospores is unknown except in the doubtful case of Merismopedia (Mey.) (Goebel, 'Outlines of Classification,' p. 22). Resting-spores or cysts (akinetes) are formed in Glœocapsa by the cells of which a colony is composed investing themselves, while still within their common gelatinous envelope, in a rough or spiny coat of 
cellulose ; the spiny resting-spores thus formed reproduce the colony by division after a period of quiescence.

With the above exceptions the only mode of propagation in the Chroococcaceæ is by division-repeated bipartition of the cell, which may take place in one, two, or three directions. This is usually accompanied by the disappearance of the separate gelatinous envelope of each individual cell; but in Glococapsa these still remain, and as many as three or four generations of families may be enclosed within the original envelope, each surrounded by its own investment. In Chroococcus Näg. it is not unusual for the individual cells to be entirely isolated within the common envelope. In Synechococcus Näg. division takes place in one direction only, and the derivative cells remain attached to one another

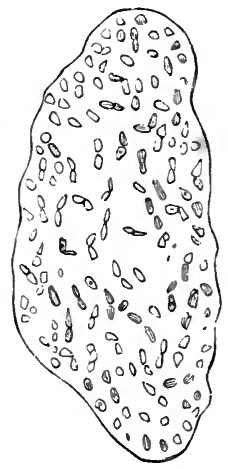

Fig. 375.-Aphanothece microscopica Näg. $(\times 70)$. (From nature.)

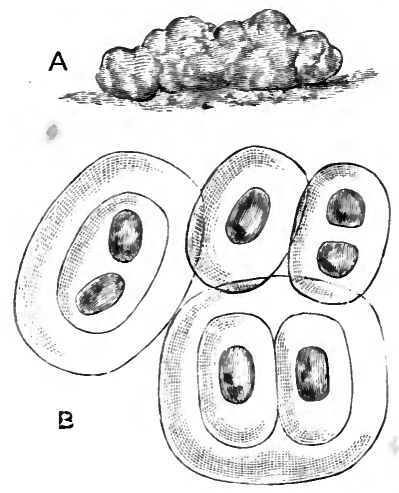

Fig. 376.-Glaothece granosa Rabh. A, gelatinous colony (magnified); $B$, cells $(\times 250)$. (After Cooke.)

in a string; but the attachment is very loose, and soon ceases. In Merismopedia, Tetrapedia Reinsch., and Gloochate Lagerh. division takes place in two directions, the result being the formation of a plate of cells, often of great regularity. In Chroococcus, Glococapsa, Glocothece Näg., Aphanocapsa Näg., Aphanothece Näg., Microcystis, and most other genera, division takes place in all three directions. In Clathrocystis Henf. the gelatinous envelope, which is of great extent, is broken up into clathrate segments. In Cxlospharium Näg., a common organism in bog-pools moving about with considerable rapidity, it is lobed at the margin, the pseudocysts appearing like blue-green projections on the surface of the globe. Chrondactylon Hansg. (Ber. Deutsch. Bot. Gesell., I 885 , p. I4) is distinguished by the formation of cell-families branching in an arborescent manner, by its distinct cell-nucleus, and 
by the star-shaped chromatophores which enclose moderately large pyrenoids. It has possibly been erroneously referred to this family.

Most of the genera and species of Chroococcaceæ grow in moist situations, as on damp rocks, where they frequently form large shining blue-green mucilaginous masses; others swim freely on the surface of bog-pools ; a few are found in salt water, attached to sea-weeds. The gonids or algal constituents of many lichens have been shown to be protophytal organisms belonging to the Chroococcaceæ. As it is highly probable that many forms at present included in the family are stages in the history of development of more highly organised protophytes, or even of algæ, their place in a final system of classification is altogether un. certain until their life-history has been more thoroughly investigated. Many are closely analogous to corresponding forms among the Protococcaceæ, as Chroococcus to Chlorococcum, Glœocapsa to Glœocystis,

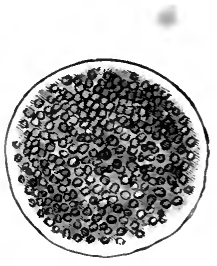

FIG. 377.-Microcystis marginata Men. $(\times 400)$. (After Cooke.)

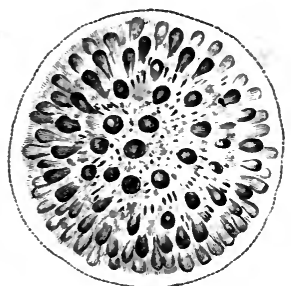

FIG. 378.-Caıospharium Kützingianum Näg. $(\times 4 \mathrm{co})$. (After Cooke.)

Aphanocapsa to Protococcus, Cœlosphærium to Botryococcus, and Merismopedia to Tetraspora; but they are probably merely parallel series of forms without any direct genetic connection. Richter, however, identifies Glœocapsa and Glœocystis.

The same observer suggests also a genetic affinity between the various genera usually included under the Chroococcaceæ of the following nature. The lowest form is the naked Aphanocapsa-condition, corresponding to Palmella among the Protococcaceæ. From this naked or only slightly encysted condition is developed the Glœecapsa- or Glœocystis-form, with several gelatinous envelopes, the Chroococcuscondition, where the investment is altogether wanting, and the cœnobeor Colosphærium-condition, where there is only a slight vesicular envelope. The Glœocapsa-form is especially adapted for exposure to air and growth upon a comparatively dry substratum; the cœnobe-type is developed in water or on a moist substratum in the air. With this is connected the cylindrical form, a higher stage, because it displays differentiation in the direction of growth, and a development towards 
the filiform condition. This cylindrical condition, when attained, is usually unstable, but becomes stable in Synechococcus. Glœocapsa may also pass into an encysted filiform condition in Sirosiphon (see p. 439). Zopf insists on the close affinity between the blue-green Schizophyceæ and the Schizomycetes. Hansgirg regards many of the forms included under Chroococcus as resulting from the breaking up of filaments of the higher Cyanophyceæ such as Lyngbya, while Glœocapsa may be derived in the same way from Stigonema, and Synechococcus from Calothrix. He believes, in fact, most if not all of the organisms hitherto included in this family to be connected, by retrogressive metamorphosis, with other more highly developed forms, and even possibly in some cases (Flora, I886, p. 291) with the protoneme of a moss. Microcystis is regarded by Richter (Hedwigia, r885, p. r8) as a resting-form of Euglena. The Chroococcaceæ, like the other Cyanophyceæ and the Protococcaceæ, enter largely into the composition of Lichens. The reader will find this subject amply treated by Bornet in his ' Recherches sur les gonidies des Lichens' (Ann. Sci. Nat., 5 Sér., xvii. and xix.).

\section{LITERATURE.}

Nägeli - Gattungen einzelliger Algen, 1849 .

Borzl-Nuov. Giorn. Bot. Ital., I878, p. 369 ; and 1879, p. 47.

Richter-Hedwigia, 1880, pp. 154, 169, 191.

Zopf-Bot. Centralbl., x., I882, p. 32 ; and Ber. Deutsch. Bot. Gesell., I883, p. 319.

Tangl-Anzeiger Akad. Wiss. Wien, I883, p. 87.

Hansgirg-Oesterr. Bot. Zeitschr., I884, pp. 313, 35I, 389; and Bot. Centralbl. xxii. and xxiii., 1885 .

\section{GROUP II. AND CLASS XXVIII.-SCHIZOMYCETES}

(BACTERIA).

Though this group has been the subject of a great deal of investigation and much speculation, it cannot be said that our knowledge of it is in due proportion to the literature. The minute size of the cells precludes an exact study of their structure. This leads to errors of determination and to confusion of forms in culture experiments, and thus renders difficult the study of the course of development. A large number of the investigators have been and are unequipped with a knowledge of natural history, and are unfitted to appreciate the significance of phenomena observed, or, in other cases, are incapable of observation of 
the kind at all. Records of the successive occurrence of different forms in the same situation have been substituted for direct observations of continuity, while errors of even grosser kind abound in the vast literature of the subject. Bacteria are the present refuge of those who believe in 'spontaneous generation,' just as higher forms of organised beings were the subject of their speculations in former times, when the instruments of investigation were less perfect.

Bacteria are either single minute cells of roundish form, or cylindrical and rod-like cells or rows of cells. As has been said, their very minute size has prevented our attaining an exact knowledge of the cellstructure. The cell-cavity is ordinarily filled with homogeneous protoplasmic contents. Chlorophyll has been discovered tingeing the protoplasm in three forms-Bacterium viride and Bacillus virens of Van Tieghem, and more faintly in Bacterium chlorinum of W. Engelmann. A red colouring matter discovered by Lankester, and named by him bacteriopurpurin, tinges the protoplasm of Beggiatoa roseo-persicina (Zopf), but though colours are often associated with masses of Bacteria, it is difficult to discern in the magnified view the exact seat of it, whether it occur in cell-contents, cell-wall, or substratum. In some forms (which do not contain chlorophyll) a substance resembling starch is found. No one has yet detected nuclei with absolute certainty. The cell-membranes are very delicate, and in such cases as Spirillum (Ehrenb.) highly elastic, but it happens to most Bacteria at one stage of their development that gelatinous outer layers are formed, which either invest single cells and cell-groups, or unite into masses large numbers of cells. A great number of Bacteria have the power of free movement. During such movement rotation takes place round the longitudinal axis, while movements of oscillation also occur in other forms. Cilia or flagella are found in some, but not all, of these moving Bacteria, and it has not been proved that they are motile organs as one might too readily infer. As a matter of fact it is not known, in many cases, whether these flagella are parts of the membrane or of the protoplasm protruded through it; and since they are not always present in motile Bacteria, they need not be regarded as essential organs of locomotion at all events.

Various growth-forms occur which were at first associated with different Bacteria and received generic names. Individual Bacteria are either roundish or in the form of straight rods, or of twisted rods. As de Bary has remarked, ' a billiard ball, a lead pencil, and a corkscrew so exactly illustrate these three chief forms,' that there is no need of models to convey instruction in this respect. The round growth-forms are termed Coccus (Micrococcus Cohn \&c.) ; the rod-like forms include those 
which have been termed Bacillus Cohn (long rods), and specially Bacterium Cohn (short rods); the shortly coiled forms are known as Vibrio Cohn; and the spiral forms have received the names of Spirillum Ehrenb., Spirochata Ehrenb., \&c., and the very elongated filiform forms are Leptothrix Ktz., Beggiatoa Trev. \&c. Involution forms are swollen bladder-like structures of irregular outline probably produced by malnutrition. These growth-forms of cells or of individuals either occur free, or in the form of filaments, or more seldom of flat surfaces or cube-like packets. Large gelatinous masses called Zoogloa, composed of numerous individuals of these growth-forms, occur in various situations such as the surfaces of fluids and solids, or they may be found suspended in fluids.
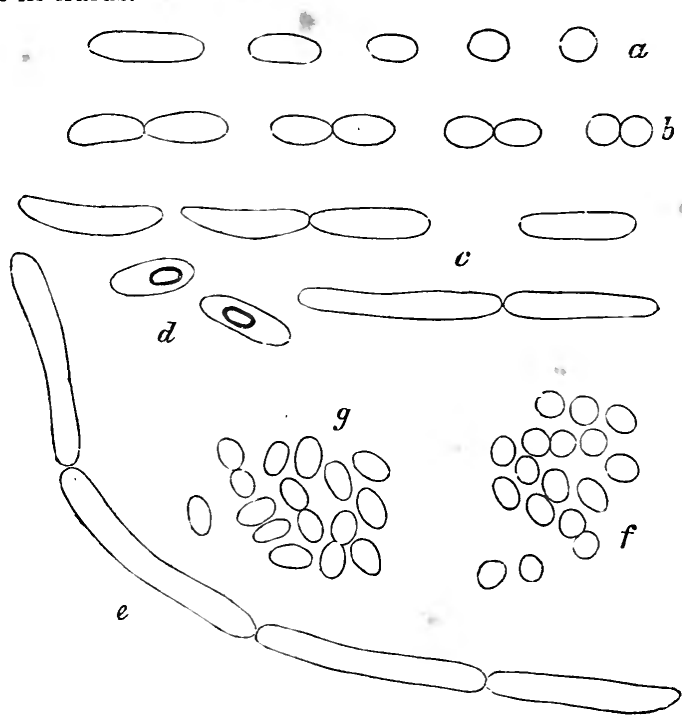

Fig. 379.-Bacillus Fitzianus Zopf. Transition forms from round cocci to rods. $d$, with spores $\left(\times_{4}, \infty\right)$. (After Buchner.)

Such forms of Bacteria are grouped into two divisions, viz. those which form their spores endogenously, the Endosporous Bacteria, and those which have no such mode of forming spores, the Arthrosporous Bacteria. This classification, which can hardly be regarded as finally satisfactory, corresponds, at all events, with the state of our knowledge of the course of development of Bacteria.

Endosporous multiplication is accomplished by the formation within a cell of a minute, granule-like body, which gradually enlarges, while the surrounding protoplasm disappears until it reaches its mature form 
within the wall of the mother-cell. The mature spore is usually a highly refringent body with definite outline, and of globular or ellipsoidal form. The formation of spores commonly takes place when the substratum yields no more nourishment, or vegetation is otherwise interrupted, and it usually occurs in most of the cells, others remaining sterile. Arthrosporous reproduction is effected by the simple separation of members which form the starting point of new growths.

The spores of Bacteria are capable of germination from maturity onwards, often for considerable periods. They withstand the operation

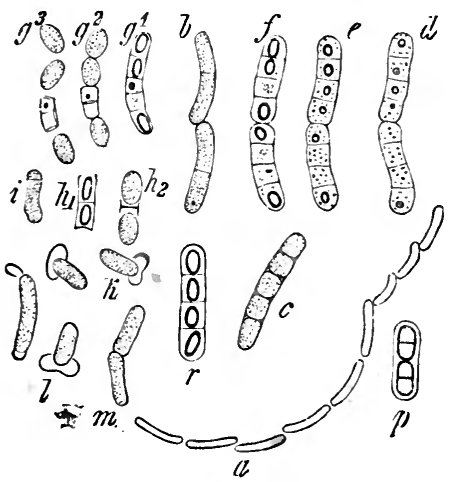

Fig. 380.-Bacillus Megaterium de By. $a$, outline of a motile chain of rods; $b$, a pair of same : $p$, a quadricellular rod after treatment with alcoholic solution of iodine; $c$, a fivecelled rod before spore-formation; $d-f$, successive stages of pair of rods while forming spores. about an hour interval between eachstate $d$ was about two o'clock afternoon, and the spores in $f$ were ripe towards evening; $r$, a quadricellular rod with ripe spores; $g^{i}$ a five-celled rod with three ripe spores placed in a nutrient solution after several days'desic. cation at $12.30 ; g^{2}$, same about $1.30 ; g^{3}$, the same about 4 o'clock; $h^{1}$, two spores with the walls of the mother-cells dried, and then placed in a nutrient solution about $11.45 ; h^{3}$, the same about $12.30 ; i, k, l$, later stages of germination; $m$, a rod formed from a spore placed eight hours before in a nutrient fluid, and in the act of splitting transversely. $(a \times$ 250, the other figures $\times 600$.) (After de Bary.) of external agencies, such as extreme degrees of temperature and the like, with varying success, many of them exhibiting astonishing endurance. Such arthrosporous forms as Beggiatoa, which vegetate in water, are probably incapable of withstanding desiccation at a very high temperature, but the spores of endosporous Bacteria possess, many of them, remarkable powers of endurance. The spores of Bacillus Anthracis (Cohn) (the cause of splenic fever) remain alive in absolute alcohol. They may be kept for at least three years in an air-dry state, and for at least one year in water, and probably for longer either in air or in water. They were found by Brefeld to withstand boiling in a nutrient solution for a quarter of an hour, the greater part of them for half an hour, a smaller number for one hour, but none for three hours. And so with the spores of other forms. The temperatures at which germination takes place, the minimum, the optimum, and the maximum, vary with different forms ; but for the most part the minimum and certainly the optimum may be said to be above the ordinary temperature of a room. Similarly the optimum temperature for vegetation is usually high, being about $30^{\circ} \mathrm{C}$., speaking very generally.

With reference to their behaviour towards the supply or exclusion of 


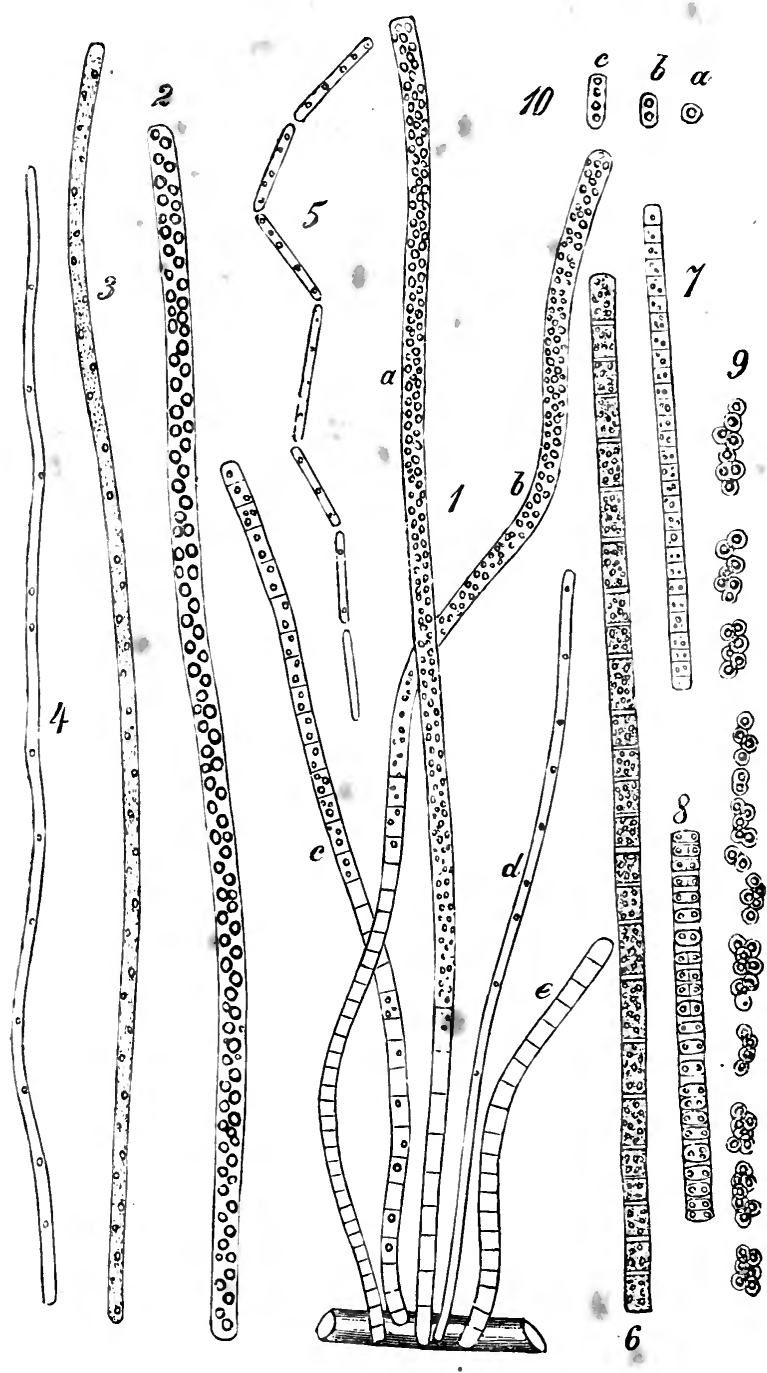

FIG. 38r.-Beggiatoa alba Trev. 1, group of filaments. 2-5, filaments of varying thickness, 5 breaking up ; small dark circles in all cases grains of sulphur; where such are abundant transverse segmentation is indistinct. $6-8$, filaments rich in sulphur showing transverse segmentation after treatment with solution of methyl violet; in 8 longitudinal division is shown (formation of cocci or spores). 9, filaments which have broken up into spores. 1o, motile spores. ( $1 \times 540$, other figures $\times$ 9o0.) (After Zopf.) 
oxygen, there is great variation among Bacteria. This variation extends from those forms, called aerobiotic by Pasteur, which require a plentiful supply of free oxygen for the purpose of vegetation (e.g. Bacillus subtilis, Cohn), to others (anaerobiotic) in which vegetation is promoted by its exclusion (e.g. Bacillus Anylobacter, Van Tiegh.). Intermediate forms occur between such extremes; and Nägeli has shown that aerobiotic forms continue to vegetate when the supply of free oxygen ceases.

Speaking in general terms, what has been said already of the mode of life of Fungi in other respects, e.g. nutritive adaptation, holds good of such Bacteria as contain no chlorophyll. They are saprophytes exciting fermentations and producing combustions of the substratum, and putrefactive processes; or parasites, though very rarely on living plants, it may very well be on account of the acid reaction. As parasites in living animals they obtain the greatest share of our interest, since, as everyone knows, it is sought to connect them with a large number of diverse diseases. That this attempt is made with the greatest rashness in many cases, on utterly insufficient data, often on the mere presence of some vaguely determined form in diseased tissues, is a scandal of medical literature. On the other hand it has been thoroughly proved in certain cases that their presence and action have the character of exciting causes of disease, and it cannot be doubted that painstaking research will bring to light numerous other instances of equal weight. Slipshod research will only retard progress in this direction. It has already done much in obscuring results, and in placing obstacles in the path. The most noteworthy feature, as de Bary has pointed out, in the parasitism of Bacteria in the living bodies of animals is their facultative parasitism-(as illustrated for example in the well-established case of Bacillus Anthracis in anthrax or splenic fever), a matter of grave importance from the medical point of view.

Among saprophytes may be mentioned Bacterium Termo (Duj.), an exceedingly abundant agent of putrefaction; Bacillus Megaterium (de By.) (fig. 380), and Beggiatoa alba (Trev.) (figs. 381, 382), the 'sewage-fungus' of engineers, found in sulphuretted waters, the effluents from manufactories and sewage-works, which has a remarkable power of extracting sulphur from the water, and storing it up in the form of minute refringent globules.

- As regards the position of Bacteria, 'to say that they are offshoots of the Fungi is to "contradict all trustworthy observations" so flatly, that the view need not be seriously discussed in this place' (de Bary, 'Comp. Morph.,' \&c., p. 474). They are only fungi in the very limited sense of their being 'thallophytes which contain no chlorophyll,' and indeed it 
has been seen that certain Bacteria do contain chlorophyll. Looking at their morphological characters, so far as these are at present known to us, it cannot be doubted that the nearest allies of the Arthrosporous Bacteria are those Protophyta, Nostocaceæ, Oscillariaceæ, Chroococcaceæ, \&c., which contain chlorophyll. Leuconostoc (Van Tiegh.) has already been mentioned (p. 433) as an intermediate form. A gap certainly exists between Arthrosporous and Endosporous forms; but so far as

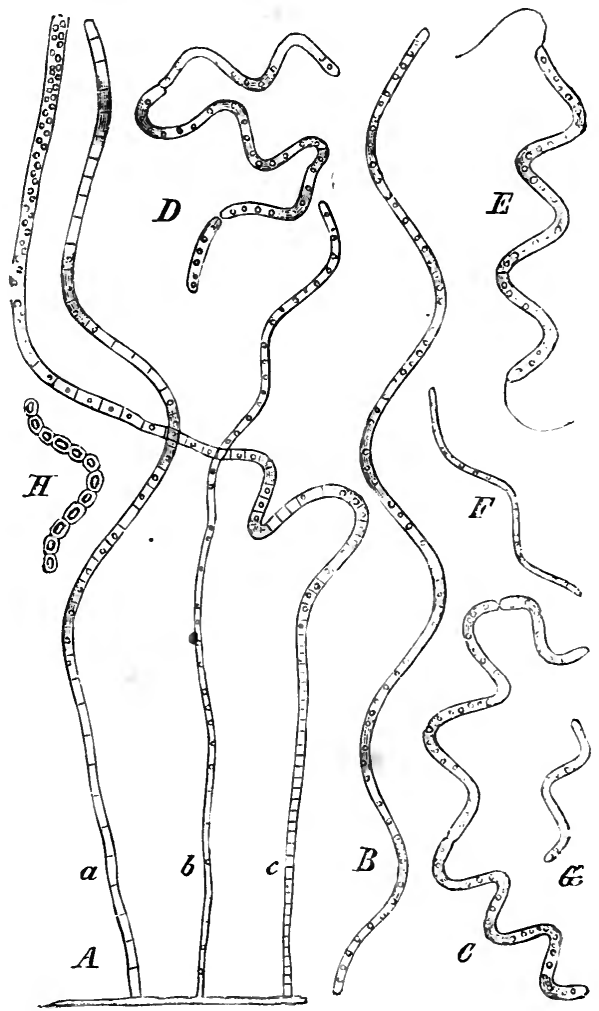

F1G. 382.-Beggiatoa alba Trev. Curved and spiral forms. $A$, attached filaments. $B-H$, portions of spiral filaments; $H$ showing separate cells, $E$ swarming ('spirillum') with a cilium at each end. Small dark circles are sulphur granules $(\times 540)$. (After Zopf.)

can be seen the latter stand nearer to the former than to any other group, and the interval which separates them may become narrower with farther knowledge. On the other side a connection appears to be indicated between Bacteria and the Flagellata; but more than this one 
can hardly say. In conclusion, and as summing the matter up, the words of de Bary ('Comp. Morph.,' \&c., p. 475) may be quoted. 'If we assume for a moment a connection between the Bacteria and the Flagellata, it is evident that as a consequence the following series of forms converge to the Flagellata : firstly, the series of Bacteria and the Nostocaceæ; secondly, that of the Mycetozoa; thirdly, that of the chlorophyllaceous Algæ, with which are connected in ascending line the main series of the vegetable kingdom and of the Fungi as one or more lateral branches.... fourthly, and lastly, the Rhizopoda and the Protozoa with the animal kingdom, which connects with these in an ascending line.'

\section{Literature.}

De Bary-Vorlesungen uiber Bacterien (Leipzig, I 885 and I886). (See English translation by Garnsey and Balfour, Oxford, I887.)

The above contains an admirable guide to the literature of the subject. (See also the same author's Comparative Morphology, \&c.)

Cornil et Babes-Les Bactéries, \&c., 2nd ed. (Paris, I886).

Crookshank-Introduction to Practical Bacteriology (London, 1886).

Duclaux - Chimie biologique (Paris, I883).

Grove-A Synopsis of the Bacteria and Yeast Fungi (London, I 884).

Klein-Micro-organisms and Disease, 3 rd ed. (London, I886).

Hueppe-Dic Formen der Bacterien (Wiesbaden, I 886).

Hueppe-Die Methoden der Bacterienforschung (Wiesbaden, I885).

Zopf-Die Spaltpilze (Breslau, I884).

The references to the vast literature of the subject in the above books will be a sufficient guide to the most ardent student. At the same time it would be unpardonable to abstain from a special reference to the labourš of Cohn, Pasteur, Koch, Lankester, Brefeld, Van Tieghem, Prazmowski, Naegeli, and Lister, since these are of fundamental importance. 


\title{
I N D E X.
}

\author{
- \\ (The figures in large type refer to Illustrations.)
}

A BI

Ahies, 3

Abjunction, 312, 275

Absidia (Van Tiegh.), 338, 339

A s̀sorbing system, 138

Acanthococcus (Lagerh.), 4I7

Acetabularia (Lmx.), 286, 251, 252

- mediterranea (Lmx.), 251, 252

Achlya (Nees ab Esenb.), 335, 346, 291, 292

- polyandra (Hildebr.), 291

- racemosa (Hildebr.), 291

Achnanthes (Bory), 426

- brevipes (Ag.), 357

Acrasiea, $401,405,406$

Acrasis (Van Tiegh.), 405

Acroblaste (Reinsch), 280

Acrocarpi, 149

Acrogynous Jungermanniacea, $16 \mathbf{1}$

Acrospore, 339, 343, 352, 361, 362, 363, 364, $365,367,368,369,370,372,373,374,376$

Acrosticheæ, 80,83

Acrostichum (L.), 85

Adder's Tonque, 100

Adiantum (L.), 85, 44, 50, 58

- capillus-Veneris (L.), 44, 50

Adventitious bud, 77, 81, 100, 49

Acidia, 384, 385, 386, 314

Acidiospore, 6, $384,385,386,314$

Ecidium (Pers.). $3_{3} 3$

Ægopodium Podagraria, 348, 349

Aerial leaf, 28, 7, 8

Aerobiotic Bacteria, 454

Athalium septicum (Fr.), 403

Agar-agar, 210

Agaricini, 393, 394, 270, 273, 318-321

Agaricus (L.), 4, 392, 393, 270, 273, 319, 320

- campestris (L.), 320

- cryophilus (Bull.), 273

- Emerici (Berk.), 316

- Gardn. ri (Berk.), 316

- igneus (Tul.), 316

- lampas (Berk.), 316

- melleus (L.), 309, 310, 3́16, 392, 270, 319

- noctilucens (Lév.), 316

- olearius (DC.), 3 r6

Agarum (Grev.), 244

Aglaozonia (Zan.), $25 \mathrm{I}$

- reptans (Ktz.), 252

Air-bladder, 232, 236, 241, 244, 206, 207, 211

\section{ANO}

Air-cavity, 102, 105, 109, 147, 167, 169, 24, 110, $112,153,154$

Akinete, 185, 258, 274, 446

Alaria (Grev.), 239, 244

- esculenta (L.), 244

Alcoholic ferment, 380

Algæ, 2, 3, 4, 184, 169-265

Algal cells of Lichens, 318, 319, 370, 279-282, 307, 308

Alsophila aculeata (Klotzsch), 57

Alteı naria (Nees ab Esenb.), 374

Alternation of generations, 16, 182, 189, 214, $263,325,440$

Amanita, 393

Anansia (Lmx.), 194, 209

Aniceba, 406

Amœboid motion, 196, 199, 21 7, 274, 284, 344, 401, 402, 403, 405, 406

Amphigaster, 160, 138, 139

Amphipleura (Ktz.), 426

Amphiroa (Lmx.), 206

Amphithecium, I45

Amphithrix (Ktz.), 437

Amphora (Ehrb.), 426

Amylum-star, 1700

Anabæna (Bory), 430, 432, 433, 360

- flos-aquæ (Fr.), 360

Anacrogynous Jungermanniaceæ, I6I

Anadyomene (Lmx.), 289

Anaerobiotic Bacteria, 454

Ancylisteæ, 4, 330, 344, 345

Ancylistes (Pfitz.), 33I

- Closterii (Pfitz.), $33^{\circ}$

Andreæa (Ehrh.), I 45, I 5o, 123, 124

- alpestris (Schmp.), 123, 124

Andreæaceæ, $136,150,123,24$

Androspore, 6, 225, 202

Aneimia (Sw.), 78, 9o, 91, 43

- Phyllitidis (Sw.), 43

Aneura (Dum.), 164

Angiopteris (Hoffm.), 9r, 94, 95, 71

- caudata (De Vriese), 71

- evecta (Hoffm.), 93

Angiosperms, 12, 13

Annularia (Brongn.), I26, 101

Annulus, 74, 78, 86, 89, 110, 122, 146, 393, 55, $56,83,110,112,319,320$

Anomœeis spherophora (Pfitz.), 354A 
ANT

Antherid, 7 (see also under Vasc. Crypt., Musc., Char., Algæe, and Fungi), 11, 30, 36, 43, 44, 65, $74,78,106,108,130,141,157,163-165,175$ 177 , 192, 199, 201-203, 208, 210, 248, 259, 286, $290,291,303-306,314$

Antheridial tube, 291

Antherozoid 7 (see also under Vasc. Crypt., Musc., Char., Alga, and Fungi), 11, 15, 17, $20,30,44,78,108,130,157,163,199,201$, $210,248,259,290$

Anthoceros (L.), 157, 165, 144, 145

- lavis (L.), 144, 145

Anthocerotex, 159, 164, 144, 145

Antipodal cells, 15

Aphanizomenon (Morr.), 430, 432, 361

- flos-aquæ (Morr.), 432, 361

Aphanocapsa (Näg), 412, 440, 445, 447448

Aphanomyces (de By.), 334, 335

Aphanothece (Näg.), 447, 375

- microscopica (Näg.), 375

Aphlebia, I 20, 92

Apical cavity, I 79

- cell, 23, 4I, 74, 90, 98, 102, 109, 156, 173, 174, I 76, I 91,2 I4, 228, 241, 437, 52, 162

- papilla, 179

Apiocystis (Näg.), 4r3, 341

- Brauniana (Näg.), 341

Aplanes Braunii (de By.), 334

Aplanospore, 185, 258, 274

Aplolepidæ, 148

A pogamy, I 1 , 52, 69, 86, 47

Apophyse, 148, 112, 124

Apospory, I I, 69, 86, 48

Apothece, 355, 356, 370, 372, 373, 308

Appendage, $378,379,312$

Appendiculæ, 363

Aquilegia, 364

Archæocalamites (Stur), r 26, 99

- radiatus (Stur), 99

Archegone, 8 (see also under Vasc. Crypt., Musc., Char., and Algæ), 4, 10, 14, 20, 29, $43,45,46,61,74,79,80,109,131,141,142$, $147,148,158,164,165,166$

Archegoniophore, 86, 61

Archespore, I $3,20,36,60,80,99$, I 1 I , I 34 , 135, 144, 146, 159, 33, 56, 110 .

Archidium (Prid.), 145, I50

Areolation, 420

Arthrocladia (Duby), 245

Arthrodonteæ, 148

Arthropity's (Göpp.), 126

Arthrosporous Bacteria, 451, 452, 455

Artotrogus (Mont.), 325

Ascobolus (Pers.), 356, 359, 360, 36r, 368, 369, $370,372,378,305$

- furfuraceus (Pers.), 305

Ascogenous hyphæ, $353,355,360,364,366,367$, $368,369,370,372,373,374,305,306,308$

Ascogone, 360

Ascomycetes, 4, 312, 353, 383, 386, 267, 268, $271,276,278,300-313$

- course of development, 36r

- homologies of the organs, 377

- (doubtful), 4, 378, 312, 313

Ascophylla (Stackh.), 235

Ascospore, 6 (see also under Ascomycetes), 268, $276,278,300,304,311,312,313$

Ascotricha (Berk.), 370

Ascus, 353 (see also under Ascomycetes), 276, 300, 303, 305, 308, 311, 312

Aseroe (La Bill.), 398, 331

- rubra (Berk.), 331

Aspergillus glaucus (Lk.), 366

Asperococcus (Lmx.), 24 I, 245, 218

- bullosus (Lmx.), 218
BAT

Aspidieæ, 83

Aspidium (Sw.), 85, 42, 55, 58

- filix-mas (Sw.), 72, 76, 77, 82, 42, 55

Asplenieæ, 83

Asplenium (L.), 69, 85, 49, 51, 56, 58

-- Adiantum-nigrum (L.), 51

- bulbiferum (Forst.)

- decussatum (Sw.), 49

- Trichomanes (L.), 56

Assimilating tissue, 138,193

Asterophyllites (Rev.), 126, 130, 101

Asterotheca (Presl), 122, 94

- Sternbergii (Stur), 94

Astromyelon (Williams.), I 26

Athyrium filix-fœemina (Bernh.). 69, 76

Atrichum undulatum (P. B.), 102, 119

Attachment-disc, 228

Aulacodiscus (Ehrb.), 426

Aulacomnion (Schw.), 149

- androgynum (Schw.), 140

Aulosira (Kirchn.), 430, 433

Auricle, 92, 161, 140

Auxiliary cell, 203

Auxospore, 6, 422, 423, 355

Azolia (Lam.), 19, 26, 31, 115, 12, 13

- caroliniana (Willd.), 13

- filiculoides (Lam.), 12

Azygosperm, 338, 340, 342, 343

Azygites (Fr.), 338

BacillariaceE, 4 I 9

Bacillus (Cohn), 440, 45 I, 379, 380

- amylobacter (Van Tiegh.), 454

- anthracis (Cohn), 452, 454

- Fitzianus (Zopf), 379

- Megaterium (de By.), 454, 380

- subtilis (Cohn), 454

- virens (Van Tiegh.), 450

Bacteria, 305, 306, 449

- conditions of vegetation, 452

- growth-forms of, 450

- mode of life, 454

- movements of, 450

- spores of, 451,452

Bacteriopurpurin, $45^{\circ}$

Bacterium (Cohn), $45 \mathrm{I}$

- chlorinum (Engelm.), 450

-- Termo (Duj.), 454

- viride (Van Tiegh.), 450

Bæomyces (Pers.), 36r

Balsamia (Vitt.), $35^{8}$

Bangia (Lyngb.), r9o, 191, 216, 193-195

- ceramicola (Chauv.), 193

-- fusco-purpurea (Lyngb.), 194, 195

Bangiaceæ, 216

Barberry, $383,384,3^{85}$

Barbula (Hedw.), 140, 147, 149, 105

Barilla, rgo

Bartramia (Hedw.), I 49

Hasal cell, 68

Basid, 312, 384, 385, 388, 389, 390, 393, 394, $275,317,321$

Basidiomycetes, 4, 306, 312, 388, 266, 270, 273, 316-331

Basidiomycetous Lichens, 319

Pasidiospore, 6, 312, 388, 389, 39o, 275, 317, $321,322,325,329$

Basilar cell, 433,365

Batarrea (Pers.), 308, 397, 325, 326

- Steveni (Fr.), 325, 326

Patrachospermeæ, 2 I I , 189-191

Batrachospermum (Bory), I9I, 211, 212, 213 , 214,189

- moniliforme (Roth), 189 
Beam, 226, 204

Beer-yeast, 268, 313

Beggiatoa (Trev.), 4, 451, 452, 381, 382

- alba (Trev.), 454, 381, 382 roseo-persicina (Zopf), 450

Biddulphia (Gray), 426

Binuclearia (Witt.), 276

Bladder-wrack, 230, 236

Blasia (Mich.), I56, I 57, I64

Blechnum (L.), 85,58

Blyttia (Endl.), I6o

Bog-mosses, I 51

Boletus (L.), 392, 396

Bonnemaisonia (Ag.), 201

Bornetia (Thur.), r94, 209

- secundiflora (Ag.), r94

Bornia (Brongn.), 126

Borzia (Cohn), 428, 444 trilocularis (Cohn), 445

Bothrodendron (L. and H.), ir6

Botrychium (Sw.), 97, 98, 99, 100, 73-75

- Lunaria (Sw.), 97, 98, 100, 73-75

Botrydiaceæ, $280,285,250$

Botrydina (Bréb.), 186, 412

Botrydium (Wallr.) I86, 284, 285, 410, 412, 250

- granulatum (Wallr.), 285,250

Botryococcus (Ktz.), r86, 4 r8, 448, 349

- Braunii (Ktz.), 349

Botryopteris (Ren.), I 22

Botrytis cinerea (Pers.), 374

Brachytrichia (Zan.), 437

Bract, I 73, 163-165

Bracteole, 173

Brake, 82

Breaking of the meres, 432

Brittle-worts, I 8 I

Brownian movement, 269

Bruckmannia (Stbg.), 127

Bryaceæ, 1 36, 146, 102-120

Bryum (L.), 145, 149, 115

- $\operatorname{argenteum}($ L.) 115

Bryopsideæ, 289

Bryopsis (Lmx.), 289, 290

Bud, I33, I8r, I96, 214, 250, 252, 162

Bulbil, 6r, 67, 176

Bulbochæete (Ag.), 188, 222, 226, 202

- setigera (Ag.), 202

Bundle-sheath, 44, rog

Bursulla (Sorok.), 405

Buxbaumia (Hall.), I49

CABbages, 326

Calamariea, I25. I 30, 96-100

Calamites, 125, 126, 97

Calamitina (Weiss.), 126, 98

Calamocladus (Schmp.), 126

Calamodendrea. 125

Calamodendron (Brongn.), 125, 126

Calamostachys (Schmp.), 125, 127

Calcareous incrustation, 181, 195, 206, 211 , 286, $304,403,440,167$

Calcium oxalate, 85,308

Callithamnion (Lyngb.). 4, 189, 19r, 194, 201, 204,180

- caudatum (Ag.), 194

- seircspermum (Griff.), 204, 180

- versicolor (Drap.), 204

Callus, 240, 244, 217

Calothrix (Ag.), 435, 436, 445, 449, 364

- crustacea (Thur.), 364

Calotrichaceæ, 433

Calypogeia (Radd.), 162, 164, 134

- Trichomanis (Cord.), 134

Calypter. 134, 144, 110, 114, 117, 131,
Campy-lodiscus (Ehrb.), 426

Canal, r43, 109

Canal-cell, 69, r 33,45

Capillitium, 358, 396, 397, 404, 326, 334

Capitulum, I77, 163

Capsella bursa-pastoris, 326

Capsosira (Ktz.), 439

Carinal canal, 106, 108

Carpogenous cells, 176, 179

Carpogone, 8, 185, 199, 359, 360, 361, 362, 363, $364,365,366,367,368,369,370,371,372,373$, $385,179,303-30 \%$

Carpomitra (Ktz.), $24 \mathrm{I}$

Carposperm, 185, 201, 203

Carpospore, 185, 201, 222, 263, 179, 199

' Carposporeæ, 3

Carpostome, 20I

'Carrageen moss,' 2 ro

Casuarina, $\mathbf{I}_{3}$

(atharinea undulata (IV. \& M.), 102

Caudex, 7 I

Caulerpa (Lmx.), 289, 256

- prolifera (Lnux.), 256

Caulerpeæ, 289, 256

Cell-cap, 222, 200

Cellulin, i 76

Central bundle, ${ }_{3} 8$

- cavity, I05, 81

-cell, 10, 14, 17, 26, 31, 69, 133, 143, x 59, 109, 158

node, 353

Ceramiaceæ, 196, 204, 172, 179-181

Ceramidium, 20I

Ceramium (Lyngb.), 204, 181

- strictum (Grev.), 181

Ceratieæ, 404

Ceratium (Lk.), 404, 335

- hydnoides (Alb. \& Sch.), 335

- porioides (Alb. \& Sch.), 335

Ceratodon (Brid.), 149

Ceratopteris thalictroides (Brongn.), 77, 8x, 52

Ceterach (Adans.), 85

Cetraria islandica (Ach.), 283

Chætangiaceæ, 2 I $\mathbf{I}$

Chætocladieæ, 339

Chætocladium (Fres.), 339, 340, 350

Chætomium (Kze.), 370

- fimeti (Fckl.), 356

Chætomorpha (Ktz.), 276

Chætopeltis (Bert.), 222

Chætophora (Schr.), 273, 275, 276

Chætophoraceæ, 222, 258, 273, 275, 279

Chætopteris (Ktz.), 249

- plumosa (Ktz.), 249

Chætostylum (Van T'iegh.), 339

Chalara Mycoderma (Cienk.), 380

Chamæsiphon (A. Br.), 444

Chamæsiphonaceæ, $44^{1}, 444$

Chantransia (Fr.), 21 I, 213, 214, 216, 190, 191

- corymbifera (Thur.), 214, 191

- virgatula (Thur.), 190

Chara (L.), 174, 175, 176, 179, 181, 182, 160$162,164,167,168$

- aspera (Willd.), i 76

- crinita (Wallr.), I8I

- fragilis (Desv.), I76, 160, 162, 164, 168

- hispida (L.), 176, 161, 167

Characeæ, 15, 173, 160-168

Characiacea, 4 Io

Characin, $18 \mathrm{r}, 4 \mathrm{I} 6$

Characium (A. Br.), 345, 412, 340

ornithocephalum (A. Br.), 340

Chareæ, I73, 182, 160-162, 164, 167, 168

Cheilanthes (Sw.), 85, 58

Chiloscyphos (Cord.), 164 
$\mathrm{CHL}$

Chlamydococcus (4. Br.), 186, 299, 300, 409, 417

nivalis (A. Br.), 416

Chlamydomonas (Ehrb.), 186, 299, 300, 409, 417,419

- Morieri (Dang.), 300

- pulvisculus (Miill.), 300

Chlamydospore, 6, 339

Cnlorochytrium (Cohn), 284, 345, 4 ro

Chlorococcum (Fr.), 41 7, 448, 347 gigas (Grün.), 4 I 7, 347

Chlorogonium (Ehrb.), 300

Chlorophyceæ, 305

Chlorophyllophyceæ, 409

Chlororufin, 279

Chlorothecium (Brzi.), 4 I I

Chlorotylium (Ktz.), 280

Choanephora (Cunn.), 340

Choironyces (Vitt.), 358

Chondria (Ag.), 209

Chondrioderma difforme (Rost.), 332

Chondrites (Sternb.), 304

Chondrus (Grev.), 208, 185

- crispus (Stackh.), 210, 185

Chorda (Stackh.), 241, 216

filum (Stackh.), 242, 216

- tomentosa (Lyngb.), 244

Chordaria (Ag.), 247, 220

flagelliformis (Ag.). 220

Chordariaceæ, 190, 247

Chromatophore, 194, 410, 427, 444, 445

Chromophyton (Wor.), 188, 257

Chroncoccaceæ, 409, 419, 427, 446, 455, 374-378

Chroococcus (Näg.), 4I 7, 44I, 445, 446, 447, $44^{8}, 449,374$

turgidus (Näg.), 374

Chroodactylon (Hansg.), 446, 447

Chroolepideæ, r87, 258, 273, 279, 247

Chroolepus (Ag.), 280, 284

- aureum (Ktz.), 280

- Iolithus (Ag.), 230

- umbrinum (Ktz.), 28o

Chroomonas Nords'edtii (Hansg.), 445

Chrysochytrium (Schroet.), 347

Chrysomyxa (Ung.), 386

Chylocladia (Grev.), 208

Chytridiaceæ, 4, 250, 344, 352, 297

- (doubtful). 347

Chytridıum (A. Br.), 4, 249, 346

Cilia (of peristome), 135, 147, 11

Cinclidium stygicum (Sw.), 120

Cingularia (Weiss), 12s, 100

- typica (Weiss), 100

Circinate vernation, 72,51

Circinella (Van Tiegh.), 339

Cladochytrieæ, $344,345,346$

Cladochytrium (Nowak.), 346, $35^{2}$

Cladonia (Hill), 36r, 279

- furcata (Hoffm.), 279

Cladophora (Ktz.), $275,276,330,243$

- gracilis (Ktz.), 243

Cladosporium herbarum (Lk.), 374

Cladostephus (Ag.), 249, 250

Clamp-connection, 306, 266

Clastidium (Kirchn.), 444

Clathrocystis (Henf.), 447

Clathrus (Mich.), 398, 399

Clavarieæ, 391

Clavicep:(TTul.), 36r, 375, 309-311

- purpurea (Tul.), 375, 309-311

Cleistocarp, 355,356

Closterium (Nitzsch), 259, 258, 269, 330, 239, 241

- Dianæ (Ehrb.), 239

- rostratum (Ehrb.), 241
COR

Clover, 364

Club-moss, 6 1

Coccidium, 2or

Coccocarpia molybdia (Pers.), 280

Coccogone, 444

Cocconema lanceolatum (Ehrb.), 357

Coccus, 45o, 379, 381

Codiolum (A. Br.), 413,342

- gregarium (A. Br.), 342

Codium (Stackh.), 289, 290

Coelastrum (Näg.), 1 86, 303, 265

- cubicum (Näg.), 265

Coloblastæ, r 86, 281

Colosphærium (Näg.), 447, 448, 378

- Kützingianum (Näg.), 378

Coemansia (Van Tiegh. and Le Mon.), 34I

Canobe, 184, 186, 291, 292, 259-265

Coleochætaceæ, I88, 190, 219, 220, 199

Coleochæte (Bréb.), r 89, 220, 199

- divergens (Prings.), 220

- pulvinata (A. Br.), 220, 199

- scutata (Bréb.), 220

- soluta (Prings.), 220

Coleodesmium (Brzi.), 440

Collateral vascular bundles, 75, 89, 98

Collema (Ach.), 321, 322, 372, $38530 \%$

- pulposum (Bernh.), 307

Collemaceæ, 322, 359, 360, 36r, 370, 372, 307 308

Collenchymatous tissue, 93

Colpodelia (Cienk.), 405

Columel, 29, 86, 135, 145, 165, 339, 351, 110, 112

Commissure, 92

Completoria complens (Lohde), 343

Compositæ, 364

Concentric vascular bundles, 18, 75, 98, 109

Conceptacle, I I, 196, 199, 207, 232, 290, 182-184, 188, 208, 209

Conducting tissue, 138 , 193

Conferva (L.), 185, 273, 274, 276

- bombycina (Ktz.), 273

Confervaceæ, $185,187,190,259,273,277,278$, 242-244

Confervites (Sch.), 304

Confervoideæ, 237

- Heterogamæ, 195, 188, 219, 199-204

- lsogamæ, 185, 186, 272, 242-247

' Conid,' 327, 436, 444

Conidiobolus utriculosus (Bref.), 343

Conidicspore, 325, 327, 309

Coniferæ, $13,310,3$

Conjugatæ, 185, 187, 258, 233-241

Conjugation, 185 (see also under Algæ, Fungi, and Schizophyceæ), 198, 222, 233238, 241, 246, 247, 252, 293-297, 299

Conjugation-tube, 346,297

'Connubium,' 263

Consortism, 318

Continuity of protoplasm, 66, 75, 192, 194, 230, $240,428,44^{\circ}$

Contractile protoplasm, 422

- (pulsating) vacuole, 257, 292, 300, 409, 415

Convolvulus, 364

Coprinus stercorarius (Fr.), 392, 318, 321

Copromyxa protea (Zopf), 406

'Copulation,' 263

Cora (Fr.), 319

Corallina (L.), 189, r94, 206, 183, 184

- officinalis (L.), 206, 183

- rubens (L.), 184

Corallinaceæ, 196, 199, 203, 206, 182-184

Coralline, I95, 206

Cordyceps (Fr.), 376 
COR

Coremium (Lk.), 3 I 2

- glaucum (Lk.), 367

Cork, 98

Cormophytes, 135, 156, 173

Corn-mildew, 383

Corpusculum, I $_{4}, 3$

Corsinia (Radd.), I6o, I66

Cortex, 173, 174, 22 r, 247, 39

Cortical lacuna, 81

- tissue, 76, 228, 242, 249, 321 , 216, 271, 311

Corticium (Pers.), 39

Coscinodiscus (Ehrb.), 420, 426

Cosmarium (Cord.), 268, 269, 270, 239

- cœlatum (Ralfs), 239

Cotyledon, 17, 28, 4I, 55, 71, 105, 8, 9, 14

Craterospermum (A. Br.), $26_{3}$

Cribrarieæ, 4 OI

Cronartium (Pers.), 386

Crouania (Ag.), 204, 172

- attenuata (Ag.), 172

Crown, I79, 164, 166

Cruciate (tetraspores), I95

Crucibulum (Tul.), 397, 327, 328

- vulgare (1ul.), 32\%, 328

Cruciferæ, 326, 327

Cruoria (Fr.), 191, 193, 2 10

Crustaceous Lichens, 32 I

Cryptogramme crispa (R. Br.), 72

Cryptonemia (Ag.), 2c8

Cryptonemiaceæ, 208

Crystalloid, 276, 288, 308

Ctenomyces (Eidam), 367

Cupule, r40, I57, I70, 155

Cupuliferce, 3 I0

Cushion, 93, I 15,87

Cutleria (Grev.), 239, 24I, 25r, 26, 227

- adspersa (de Not.), 252

- multifida (Grev.), 252, 226, 227

Cutleriaceæ, 187, 239, 251, 254, 226-229

Cyanocystis (Brzi.), 444

Cyanophyceæ, 408, 409, 426, 358-378

Cyanophycin, 428

Cyathea (Sm.), 85, 124, 59

Cyatheaceæ, 71, 73, 78, 80, 81, 85, 123, 124, 57, 59

Cycadeæ, I3, 1

Cyclomyces (Kze.), 392

Cyclopteris hibernica (Forbes), I 2 I

Cyclosis, r 75, 422, 163

Cylindrocapsa (Reinsch), 227, 4 I 4

Cylindrocapsaceæ, 228

Cylindrospernum (Ralfs), 430, 433, 362

- macrospermum (Ktz.), 362

Cymbella (Ag.), 426

Cymopolia (Lmx.), 288

Cyst, 185, 258, 264, 272, 274, 278, 427, 429, 446

Cystid, 394, 321

Cystocarp, 2or, 213, 169-171, 173, 174, 176-178, $183,184,188,189,191$

Cystopteris (Bernh.), 69, 85, 58

- bulbifera (Bernh.), 8I

- fragilis (Bernh.), 67

Cystopus (Lév.), 312, 323, 326, 327, 328, 335, 269, 275, 285, 28 (

- candidus (Lév.), 326, 269, 285

- cubicus (Lév.), 326

- Portulacæ (Lév.), 275, 287

Cystosira (Ag.), 235

Dackyomyces (Nees ab Esenb.) 389

Danæa (Sw.), 94, 95

Danæites (Göpp.), 122

Dasya (Ag.), 196, 209, 174

- elegans (Ag.), 174
ECT

Dasycladaceæ, 280, 28I, 286, 251-¿55

Dasycladus (Ag.), 287, 288, 253

- claveformis (Ag.), 253

Davallia (Sm.), 85

Davallieæ, 83

Delesseria (Grev.), 193, 208

Delesseriacex, 208

Delphinium, 364

Derbesia (Scl.), 289

Dermocapsa (Crouan), 444

- violacea (Crouan), 444

Desiccation of spores, 315,452

Desmarestia (Lmx.), 24I

Desmidiaceæ, i87, 190, 258, 259, 268, 239-241

Desmidium (Ag.), 187, 268, 239, 241

- Swartzii (Ralfs), 239, 241

Desmids, movements of, 260

Diaphragm, 31, 39, 105, 124, 125, 179, 9, 14

Diatoma (DC.), 424, 357

- elongatum (Ag.), 357

Diatomaceæ, 187, 258, 408, 419, 353-357

Diatomin, 257, 42 I

Diatoms, movements of, 422

Diatrype (Fr.), 373

Dichothrix (Zanard.), 4.37

Dicksonia (L'Hérit.), 7i, 84, 85, 42

- antarctica (Lab.), 42

Dicranum (Hedw.), 138, 149

Dictyonema (Mont.), 3 r 9

Dictyopteris (Lmx.), 254

Dict yosiphon (Grev.), 239, 24 I, 245

- hippuroides (Lyngb.), 247

Dictyosphærium (Näg.), 4 I2, 338

reniforme (Buln.), 338

Dictyostelium (Bref.), $40_{5}$

Dictyota (Lmx.), 254

Dictyotaceæ, r88, 237, 254, 230, 231

Dictyuchus (Leitg.), 334, 335

Didymium (Schrad.), 316, 353

- serpula (Fr.), 333

Dimargaris (Van Tiegh.), 34 I

Diplolepidæ, $\mathbf{1}_{4} 8$

Diploxylous bundles, I 7

Dipsacus, 364

Disc, 170, 184, 220

Discocarp, 355, 369

Discomycetes, 308, 319, 355, 356, 370

Dispira (Van Tiegh.), 34

Diverticula, 209, 187

Docidium (Bréb.), 268, 269. 239

- baculum (Bréb.), 239

Doodia (R. Br.), 85

Dothidea (Fr.), 354

Draparnaldia.(Ag.), 273, 275, 276, 4I7, 244

- glomerata (Ag.), 244

Drilosiphon (Ktz.), 433, 438, 440

- Julianus (Ktz.), $44^{\circ}$

Dry-rot, 309

Dudresnaya (Born.), r 89, 202, 204, 179

- coccinea (Crouan), l'i 9

Dulse, 2 ro

Dumontia (Lmx.), 208

Dumontiera (Nees ab Esenb.), I 7 I

Duriæa (Bor.), I 66

Durvillaa (Bory), 188, 228, 230, 235, 236

Dutch rushes, II 3

Dwarf male, 225, 201, 202

Ecklonia (Horn.), 244

Ectocarpaceæ, 187, 239, 247, 212, 221, 222

Ectocarpus (Lyngb.), 187, 239, 24 I, 247, 221, 222

- investiens (Hauck), 221

- pusillus (Griff.), 249 
ECT

Ectocarpus siliculosus (Ktz.), 249, 222

Edible earths, 424

Elachista (Duby), 247

Elaphomyceæ, 358

Elaphomyces (Nees ab Esenb.), 357, 358, 359, 367

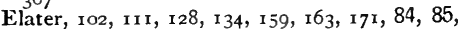
158,159

Elk's-horn-fern, 72

Embryo, 11, 13, 17, 27, 40, 56, 105, 134, 180, 27 I, 21, 45, 158

Embryo-sac, 14, 3

Embryonic vesicle, I I, I 4, 3

Emericella (Berk.), 3 I 9

Empusa (Cohn), 342, 343

- Crylli (Fres.), 343

- Muscæ (Cohn), 343

Encalypta (Schreb.), 149

Encalyptex, 148

Encysted condition, $4^{15}$

Endoclonium (Franke), 284

Endoderm, 76, 109

Endogenous spore, 424, 451, 379-381

Endophyllum (Lév.), 386

Endophytic Algæ, 222

- Fungi, 317

Endosperm, 15, 39, 20

Endosphæra (Klebs), 284, 4 Io

Endospore, 20. 47, 74, 80, 112, 134, 145, x6o, 17

Endosporous Bacteria, 45I, 452, 455

Endostome, 147

Endothecium, I45

Enteromorpha (Lk.), 217, 218, 219, 197

- intestinalis (Lk.), 197

Enterosora (Baker), 79

Entomophthora(Fres.). 342, 343

curvispora (Nowak.), 342

- ovispora (Nowak.), 342

- radicans (Bref.), 342

Entomophthoreæ, 4, 342

Entyloma (de By.), 350, 351, 352

Envelope of plasmode, 403

Envelope-tissue, 355, 360, 361, 363, 364, 366, $368,370,373,374,378,384,303-305$

Ephebe pubescens (Fr.), 281

Ephedra, II 3

Ephemerum (Hampe), i 5o, 121 serratum (Hampe), 121

Epichloe (Fr.), 361,376

Epiderm, 39, 54, 153-155

Epidermal tissue, ro, I 38, 193, 242, 216

Epiphragm, 146, 397, 112, 117, 327

Epiphytic Algæ, 237, 239, 248, 257. 444, 184, 221 Fungi, 317

Epiplasm, 354

Epispore, 20, 22, 25, 36, 47, 14, 16

Epithemia (Bréb.), 426

Equiseta cryptopora, 107

- phaneropora, 107

Equisetaceæ, 19, 20, 100, 1 24, 2, 77-86, 96-101

Equisetites (Sch.), I 24

- arenaceus (Brongn.), I 24

Equisetum (L.), เ02, х24, 2, 77-86

- arvense (L.), 106, 107, 100, х хо, 78, 79

- giganteum (L.), I $3_{3}$

- hyemale (L.), 1 10, 1 ×3, 82

limosum (L.), 109, 1х 1, 86

-.- littorale (Kuhl.), 109

maximum (Lam.), х1о, 78, 81, 83

- palustre (L.), i 10

- pratense (Ehrh.), 110

- sylvaticum (L.), 77, 80

Eremascus (Eid.), 378, 302

- albus (Eid.), 359, 36x, 302

Eremobia, r86, 410, 336-344
FON

Eremosphæra (de By.), 4x 7

Ergot, 376, 309-311

Erysiphe (Hedw.), 317, 362, 363, 367, 378

- communis (Lk.), 364

- graminis (Lév.), 364

- lamprocarpa (Lk.), 364

- Martii (Lév.) 364

- (Uncinula) spiralis (Berk. \& Curt.), ${ }_{3} 64$

Erysipheæ, 309, 359, 36o, 362, 364, 365, 378, 303

Essential air-cavity, 106

Euastrum (Ehrb.), 268, 239, 241

- pectinatum (Bréb.), 241

- rostratum (Ralfs), 239

Eucheuma spinosum (Ag.), 2 10

Eudorina'(Ehrb.), 295

Euglena, 345, 410, 449, 297

Eunotia (Ehrb.), 424, 357

- monodon (Ehrb.), 357

Eurotium (Lk.), 359, 36o, 364, 367, 378, 275, 304

- herbariorum (Lk.), 366, 275, 304

- repens (de By.), 304

Eutypa (Tul.), 373

Eusynchytrium (Schroet.), 347

Exciple, 355, 372, 308

Exidia (Fr.), 389, 317

- spiculosa (Sommerf.), 317

Exoascus (Fckl.), 379

- alnitorquus (Sad.), 380

- aureus (Sad.), 380

- deformans (Fckl.), 379

- Pruni (Fckl.), 379

Exobasidium (Woron.), 389, 390

- Vaccinii (Woron.), 388

Exospcre, 20, 47, 74, 80, х12, 134, 145, 160, 17, 20,42

Extine, x66, 325, 337. 340, 347, 349, 35x

Facultative parasites, 317, 454

- saprophytes, 317

False stomate, 107

Favella, 204, 181

Fegatella (Radd.), 168, 170, 171, 152

- conica (Cord.), 152

Female conceptacle, 232, 209

- filament, 266

- inflorescence, 151, 156

- prothallium, $15,102,103,4,79,80$

Ferment, $316,380,454$

Ferns, 64, I $19,42-76,92-95$

Fertilising-tube, 202, 211 , 179

Filament, 184,428

Filamentous Lichens, 284

Filices, 15, 16, 17, 19, 20, 21, 64, 119, 42-71, 92-95

Filmy ferns, 71, 72, 88, 62-64

Fimbriaria (Nees ab Esenb.), 171

Fischera (Schw.), 439, 441

Fissidens (Hedw.), 137, 149

Fission, 185, 270, 240

Flagellate Infusoria, 410, 416, 455, $45^{6}$

Float-corpuscle, $3 \mathbf{I}$

Floating apparatus, 31

Florideæ, 185, 188, 191, 444, 169-198

Florideæ-green, 194

'Flos-aqua,' 436

Flower, I 34, I 39, I 4 I , I 54, 104, 106, 129

'Flowering fern,' 73, 9o, 66, 67

'Flowers of tan,' 403

Foliaceous Lichens, 321

Foliose Hepaticæ, 135, 156, 160, 132-134, 137142

Fontinalis (L.), $145,149,111$

- antipyretica (L.), 111 
FOO

Foot, 1 7, 4I, 7I, 105, I44, I46, I54, 422, 14, 131

Fossil Cryptogams, I14, I 72, 183, 303, 330, 424 . 87-101

Fossombronia (Radd.), 156, 164, 135

- pusilla (Nees ab Esenb.), 135

Fovea, 50

Foveola, 51

Fragillaria (Lyngb.), 426

Fragmentation of nucleus, ${ }^{7} 6$

Frond, 72, 191, 228, 239, 24I, 242, 430, 432, 359

Frondose Hepaticæ, 135, 1 56, 135, 136, 143-159

Front view (diatoms), 420. 353, 354

Fructification, IO2, I 10, 5, 6, 77, 94, 96, 100, 101

Fruit, 180

Frullania (Radd.), 164, 139, 140

- dilatata (Nees ab Esenb.), 139

- Tamarisci (Dum.), 139

Frustule, 268, 419, 423, 353-355

Frustulia saxonica (Ag.), 355

Fruticose Lichens, 321, 283

Fucaceæ, 185, 188, 190, 228, 304, 444, 205-211

Fucoideæ, 235, 237

Fucoxanthin, 230

Fucus (L.), 188, 235, 304, 207-210

- - amylaceus,' 2 ro

- furcatus (Ag.), 228

- serratus (L.), 235, 207

- vesiculosus (L.), $232,235,236,207-210$

Fuligo varians (Somm.), 403

Funaria (L.), I 49, 103, 106, 108-110

hygrometrica (L.), 103, 106, 108-110

Fundamental tissue, ro, $76,39,53,54$

Fungi, 3, 4, 305, 266-331

- cell-contents, 307

- cell-membrane, 308

differentiation of thallıs, 309

- histological characteristics, 306

- luıninosity, 3 6

- nutrition, 316

- spores, 312

- - conditions of germination, 314

- conditions of vegetation, 316

Fungus-cellulose, 308

Funiculus, 328

Funnel, 31, 36, 15

Furrow, 100, 106, 124, 129, 420, 353

Galaxaura (Lmx.), 2 I I

Galls, 284, 347

Gametange, 272, 277, 279, 296, 349, 4II, 246, $247,260,298$

Gamete, 259, 335, 337, 338, 340, 346, 349, 350, 351, 293, 298, 299

Gasteromycetes, 309, 388, 395, 324-331

Gasteromycetous Lichen, 3 I9

Gautieria (Vitt.), 395

Geaster (Mich.), 396

Gelatine, r9o, 2 ro

Gelatinous Lichens, 32 I

Gelidiaceæ, 209

Gelidium (Lmx.), 209, 210

Geminella (Schroet.), 350

Gemma, 61, 86, 133, 140, 157, 170, 185, 196, 208, 219, 250, 105, 114

Genabea (Tul.), 357,358

Genea (Vitt.), 358

General bundle-sheath, Iog

Genuflexion, 265

Geocalycea, 162

Geocalyx (Nees ab Esenb.), r64

Germ-cell, 179

Germ-filament, 20

Germ-tube, 314, 325, 326, 327, 328, 329, 333, $35 \mathrm{I}, 352,373.385,389,390,293,299$
HAL

Gigartina (Lmx.), 208, 169

- mamillosa (Ag.), 169

Gigartinaceæ, 203, 208, 169, 185

Gills, 393, 319-321

Giraudia (D. \& S.), 239, 247, 212

- sphacelarioides (D. \& S.), 249, 212

Girdle, 420, 353, 354

Girdle-band, 268

Girdle-view (diatoms), 420, 354

Gland, 76, 67

Glaucocyst is (Itzig.), 410

Glebe, 395, 397, 398, 299, 325, 329-331

Gleichenia (Sw.), 77, 85, 60

Gleicheniaceæ, $8_{5}, 60$

Glochid, 3o, 13

Glochiococcus (Lagerh.), 4I 7, 346

- anglicus (Benn.), 346

Gloeocapsa (Ktz.), 4 7 , 440, 446, 447, 448, 449, 279

- fenestralis (Ktz.), 440

Glœochate (Lagerh.), 447

Glœocystis (Näg.), 300, 4I 7, 4I $9,44^{8}$

Gløothece (Näg.), 447, 376

- granosa (Rabh.), 376

Glœeotrichia (Ag.), 436

-- natans (Thur.), 435

- punctulata (Thur.), 4.36

Glomerule, 2 I 3

Glossopode, 50

Glycogen, 308, 355, 357

Gomphonema (Ag.), 424, 354, 356

- constrictum (Ehrb.), 354B, 356

Gonatonema (Wittr.), 26r, 263

- notabile (Wittr.), $26_{3}$

Gonatozygon (de By.), 27 I

Gongrosira (Ktz.), 284

- de Baryana (Rabenh.), 280

Gonid, 6, 322, 409, 410. 4I3, 4I 4, 437, 446, 448, $341,343,344$

Fonium (Müll.), 186, 299, 302

Gonoplasm, 325, 328

Gottschea appendiculata (Nees ab Esenb.), 133

Gracilaria (Grev.), I99, 201, 208, 178, 187

- compressa (Ag.), 178

- confervoides (Grev.), 209, 187

- lichenoides (L.), 2 10

Graphiola (Port.), 350

Grasses, 350, 364, 376, 385

Grateloupia (Ag.), 208

Griffithsia (Ag.), 199, 204

Grimmia (Ehrh.), I 49

Gulf-weed, 232, 236, 211

Gum-cell, 58, 76, 123

Guttulina (Cienk.), 405, 406

- protea (Fay.), 406

Gymnoascus (Baranet.), 359, 36o, 361, 367, 368, $369,370,378$

Gymnocarpous Lichens, 356

Gymnogramme (Desv.), I6, 67, 83, 85, 58

- leptophylla (Desv.), 65

Gymnomir rium (Nees ab Esenb.), 164

Gymnopodal shoot, 176

Gymnosperms, 12, I3, I4, 15, 52, 1, 3

Gymnosporangium (DC.), 386

Gymnostomous, 135, I 47

Gyrolith, 183

HADROME, I9

Hæmatococcus (Ag.), 4 I 6

- Butschlii (Blockm.), 4 I 7

Halidrys (Grev.), 232, 235, 206

- siliquosa (Lyngb.), 206

Halimeda (Lmx.), 289, 258

- Tuna (Lmx.), 258 
HAL

Halosphara (Schm.), 4 I I, 337

- viridis (Schm.), 337

Halymenia (Ag.), 208

Hapalocyst is mirabilis (Sorok.), 347

Hapalosiphon (Näg.), 439, 44I, $36 \%$

- byssoideus (Kirchn.), 367

Haplomitrium (Nees ab Esenb.), 156, 161

Haplospora (Kjellm.), 249

Hard Fern, 72

Hauckia (Brzi.), 4 I 3

Haustorium, 309, 323, 326, 340, 350, 362, 378, 269, 285, 296

Hawlea Miltoni (Stur), 94

Hedwigia (Ehrh.), I 49

Helicostylum (Cord.), 339

Helminthocladia (Ag.), 2 I I

Helminthocladiaceæ, I89, 21 1 , 175, 189-191

Helminthostachys (Kaulf.), 98, 99, I00

Helvella esculenta (Pers.), 278

Hepaticie, 135, I56, 132-159

Heracleum sphondylium, $34^{8}$

Hermonit is (L.), 85

Heterocyst, 427, 430, 431, 434, 438, 359, 362

Heterocism, 383

Heteromerous thallus, 320

Heterophyadic Equisetaceæ, I I 3

Heterosporous Vascular Cryptogams, 13, I5, 20, 21, 5-33

$\mathrm{H}_{1}$ bernating spores ( $\mathrm{F}$ ungi), $3 \mathrm{I}_{5}$

Hibiscus, $34^{\circ}$

Hildenbrandtia (Nard.), 19o, 191, 193, 210,211 , 188

- prototypus (Nard.), 188

- rivularis (Ag.), 2 I I

Himanthalia (Iyngb.), 228, 232, 235, 205

- lorea (Lyngb.), 'Z05

Homoiomerous thallus, $32 \mathrm{I}$

Homophyadic Equisetacex, I 13

'Honey-dew,' 376

Hookeria (Sm.), 149

Hoop, 420

Hops, 364

Hormactis (Thur.), 436

Hormidium (Ktz.), 279

Hormiscia (Aresch.), 277

Hormogone, 427, 429, 43I , 435, 438, 442, 445

Hormospora (Bréb.), 4I 4,344

- mutabilis (Bréb.), 344

Horse-tails, I00, I 3,124

House-fly, 343,378

Hyaline hair, 226, 275, 433, 199

Hyaloplasm, 403

Hyals theca (Ehrb.), 187, 268

Hybridism, 145, 235

Hydneæ, 393

Hydnobolites (Tul.), 357, $35^{8}$

Hydnocystis (Tul.), 358

Hydnotria (B. and Br.), 358

Hydnum (I ), 392

Hydrianum (Rabh.), 41 3

Hydroclathrus (Bory), 245

Hydrocytium (A. Br.), $4{ }^{1} 3$

Hydrodictyeæ, 277, 291, 296, 409260

Hydrodictyon (Roth), 186, 295, 4 Io, 41 3, 260

- utriculat um (Roth), 260

Hydrolapathum (Rupr.), 193, 196, 208, 71 sanguineum (Stackh.), 171

Hydropterideæ, 2 I

Hydrurus (Ag.), 188, 190, 256, 257, 232

- penicillatus (Ag.), 232

Hygroscopic properties, 17 I

Hymenium, 355, 357, 368, 373, 376, 384, 386 , $389,391,393,394,395,396,276,300,301,305$, 317,322

Hymenogaster (Vitt.), 395
KIE

Hymenogastrea, 395, 396, 398

Hymenomycetes, 388, 395, 266, 270, 273, 319323

Hymenophallus (Nees ab Esenb.), 398

Hymenophyllaceæ, I6, I 7, 18, 19, 64, 66, 67, $70,71,73,76,80,81,86$, 1 $21,122,61-64,93$

Hymenophyllum (L.), 86, 87, 88, 62-64 tunbridgense (Sm.), 62

Hypertrophy, 324, 326, 327

Hypha, 228, 306, 208-210, 267, 273, 281, 282, $285,300,307,308,317,322$

Hypnea (Lmx.), 209

Hypneacex, 208

Hypnosperm, 225, 227, 266, 283, 295, 296

Hypnosporange, 285

Hypnospore, 262, 281, 284, 300

Hypnum (Dill.), I 49

- populeum (Sw.), 113, 118

Hypochnus (Fr.), 389, 266

centrifugus (Tul.), 266

Hypocopra (Fckl.), $36 \mathrm{r}$

Hypodermal tissue, 107

Hypothece, 355, 360, 361, 370, 308

Hypoxylon (Bull.), 373

Hysterinea, 356

ILEODICTYON (Tul.), 398

Impotent antherids, 332

Impregnating tube, $324,332,286$

Inactis (Ktz.), 44I, 444

Indusium, 24, 29, 50, 73, 79, 86, I $21,19,32,59$, 63,93

Inflorescence, 134, 158, 170, 104, 106, 109, 131, $150,151,156,157$

Infusoria, agents in fertilisation, I 99

Innovation, $85,1_{33}, 1_{39}, 1_{5} 1,1_{57}$

Intercalary growth, $24 \mathrm{I}$

- surfact-growth, 222, 200

Internode, I02, 1 74, 81, 165, 168

Intine, $325,337,339,349,351$

Involucre, 85,94 . 1 10, 159, 165, т 7 1, 59

Involution-forms (Bacteria), 45 I

Iodine, 19o, 236, 244

'Irish moss,' 210

Isactis (Thur.), 436, 365

- plana (Thur.), 365

Isinglass, 2 ro

Isocyst is (Brzi.), 432

Isoëteæ, 21, 47, 1 19, 28-33

Isoëtes (L.), I $9,38,47,52$, I I 9, 28-33

- lacustris (L.), $28-33$

Isoëtites (Schmp.), I I9

Isogamous reproduction, 272

'Isospore,' 285

Isosporous Vascular Cryptogams, 12, 15, 20, $53,34-85$

Isthmıs, 270

JAPANESE isinglass, 210

Jungermannia (L.), 164, 132, 138, 142

- barbata (Schreb.), 138

- bicuspidata (L.), 142

nemorosa (L.), 132

Jungermanniaceæ, I 59, I60, I 72, 132-142

Kallymenia (Ag.), 208

Kaulfussia (Bl.), 78, 92, 93, 94, 95

Kelp, 190, 236, 244

Kickxella (Coem.), 34 I

Kieselguhr, 424 
LABIA т $Æ, 364$

Labium, 5 I

Laboulbenia flagellata (Peyr.), 312

Laboulbeniea, 378, 312

Lactarius (Fr.), 394

Lacuna, 105, 81

Lagenidium (Schenk), 330, $33 \mathrm{I}$

Lamella, 393, 394, 153, 273, 319-321

Lamina, 50, 230, 242

Laminaria (Lmx.), 239, 304, 215

- digitata (Lmx.), 244

- saccharina (Lmx.), 215

Laminariaceæ, 190, 230, 236, 239, 241, 242, 304, 213-217

Lamprothamnus (A. Br.), I 82

- alopecuroides (A. Br.), i 76

Lastrea (Presl), 85

Lateral conjugation, 26o, 265, 235, 238

Lathyrus, 364

Laticiferous hyphæ, 394

Laudatea (Johow), 3 I9

Laurencia (Lmx.), 209

Laver, green, 219

-- purple, 217

Leaf-sheath, 102, 105, 124, 81, 83

Leathesia (Gray), 24 I

Leiodermaria (Ren.), I I 7, 89

Leiodermarieæ, II 7, 89

Lejeunia (G. \& L.), x64

Lejolisia (Born.), 201, 209, 177

- mediterranea (Born.), 177

Lemanea (Bory), 191, 196, 2 I 4, 192

- fluviatilis (Ag.), 216

- nodosa (Ktz.), 192

Lemaneaceæ, 189, 195, 214, 192

Lemna, 432

Lenticel. 03

Lepidodendreæ, I $5_{5}, 87,88$

Lepidodendron (Sternb.), I I 5, 87, 88

Lepidophloios (Sternb.), I 16

Lepidophyllum (Brongn.), 88

Lepidostrobus (Brong1.), $115,116,88$

- Brownii (Schmp.), I 6,88

- dabadianus (Schmp.), I 16

- ornatus (Hook.), 88

Lepidozia (Dum.), I64

Leptochæte (Brzi.), 436

Leptochrysomyxa (de By.), 386

- A bietis (Ung.), 386

Leptogium microphyllum (Ach.), 307, 308

Leptome, I9

Leptophloem, ${ }_{4} 6$

Leptopuccinia Uianthi (Schroet.), ${ }_{3}^{86}$

- Malvacearum (Schroet.), 386

Leptopucciniea, 386

Leptosira (Brzi.), 280

Leptothrix (Ktz.), 4, 440, 445, $45 \mathrm{I}$

- muralis (Ktz.), 440

- parasitica (Ktz.), 440

Leptoxylem, 146

Lessonia (Bory), 244, 214

- fuscescens (Bory), 214

Leucobryum (Hampe), I38, I39, 149

Leucochytrium (Schroet.), 347

Leucodon (Schw.), r 49

Leuconostoc (Van Tiegh.), 433, 455

Liagora (Lmx.), I94, 2 I I

Lichen-fungi, $317,318,361$

Lichens, 222, 279, 318, 356, 419, 441, 448, 449, 279-284, 307, 308

- discocarpous, 370

- gymnocarpous, 356

Licmophora (Ag.), $4^{26}$

Lid-cell, $17,15^{8}$

Ligulatæ, 38,44
Ligule, $3^{8}, 44,51,31,32$

Lindsaya (Dry.), 85, 58

Lip-cell, 79, 55

Lithoderma (Aresch.), r9o, 251, 225

- fatiscens (Aresch.), 225

Lithophyllum (Phil.), 206

Lithothamnion (Phil.), 206

Liverworts, 1 $35,156,160$

Lobospira (Thur.), 254

Lomaria (Willd.), $8_{3}, 8_{5}$

- spicant (Desv.), 72

Lomentaria (Gaill.), 209

Lomentariaceæ, 209

Lophoclea (Dum.), 164

Loxsoma (R. Br.), 86, 87 , I 2 I

Iucern, 364

Luminosity of fungi, 316

Lunularia (Mich.), I 57, I 70, I7 1

Lupins, 364

Lychnothamnus (Leon.), 182

- stelliger (A. Br.), $\mathbf{1}_{76}$

Lycoperdaceæ, 395, 396, 398, 399

Lycoperdon (Tourn.), 308, 395

Lycopodiacez, I I , I 5, 16, I8, I9, 53, 34-41

Lycopodieæ, 53, 1 18, 34-39

Lycopodites (Brongn.), I 18

- Stockii (Kidst.), i 8

Lycopodium (L.), 19, 20, 53, 56, 61, 34-37, 39

- albidum (Bak.), 59

- annotinum (L.), 54, 34, 39

- cernuum (L.), 54, 6r, 35

- clavatum (L.), 56, 6i, 37

- inundatum (L.), 53

- Phlegmaria (L.), 55, I 18, 36

Lygodium (Sw.), 7 1, 77, 90, 91, 69

- palmatum (Sw.), 69

Lyngbya (Ag.), 44 I, 444, 445, 449, 371

- æstuarii (Liebm.), 371

- antliaria (Hansg.), 445

Lyngbyex, 44 r, 445

Macrocystis (Ag.), 239, 240, 244, 213, 217

- pyrifera (Ag.), 213, 217

'Macrosporange,' 7

'Macrospore,' 7

Macrosporium Sarcinula (Berk.), 374

'Macrozoospore,'?

Madotheca (Dum.), 157, 164

Male conceptacle, 233,208

'- fern,' 72

- filament, 266

- inflorescence, 104, 150, 152, 157

- prothallium, I 5, I03, 78

Mantle-cells, 36, 8o, 99, 104

IIanubrium, I75, 177, 163

Marattia (Sm.), 91 , 94, 95, 70, 71

- cicutæfolia (Kaulf.), 93, 95

Marattiaceæ, 20, 21, 64, 65, 74, 77, 78, 79, 8I, 91,121, 122, 70, 71, 94

Marchantia (L.), I57, I70, 17 I, $149.151,153-$ 159

_polymorpha (L.), 157, 149-151, 153-159

Marchantiacex, r33, r 57, r6o, 167, 149-159

Marchesettia spongioides (Hauck), 2 ro

Marsilea (L.), 33, 37, I 14 , 4, 6, 14, 15, 17, 19

- Drummondii (R. Br.), 38

- quadrifolia (L.), 34,6

- salvatrix (L.), 14, 15, 17, 19

Marsileaceæ, I2, 13 , 25, 31, 4-6, 14-19

Marsilidium (Schenk), I I 4

Martensella (Coem.), 34 I

Massaria (De Not.), 356

Massula, 25, 30, 13

Mastigobryum (Nees ab Esenb.), 164 
MAS

Mastigocladus (Cohn), 439, 44I

Mastigocoleus (Lagerh.), 439, 440, 44 I

Mastogloia (Thw.), 424, 426

Mazæa (Born.), 440

Mechanical system, I 38, I 7 I

'Medulla,' i 18, 124, 280

Medullary system, 76, 228, 242, 249, 321, 271

Megasporange, 7, 11, 22, 277, 7, 18, 19, 26, 27

Megaspore, 7, I1, 15, 20, 22, 118, 155, 7-9, 14$16,18,20,29,125$

Megazoosporange, 260

Megazoospore, 7, 218, 273, 296, 410, 196, 260

Melampsora populina (Jacq.), 386

Melanospermeæ, 235, 237

Melanospora (Cord.), 359, 36o, 370

Melobesia (Lmx.), 193, 194, 196, 206, 182, 184

- membranacea (Lmx.), 182

- Thureti (Born.), 184

Melobesiacex, I9I

Melosira (Ag.), 424

Meridion (Leibl.), 426, 357 constrictum (Ralfs), 357

Merismopedia (Mey.), 418, 446, 447, 448

Merispore, 6

Meriensia (Willd.), 77, 85

Merulius lacrymans (Fr.), 309

Mesocarpacea, $187,258,259,260,233-235$

Mesocarpus (Hass.), 260, 262, 263. 330, 233, 235

- neaumensis (Benn.), 26I parvulus (Hass.), 233

- pleurocarpus (de By.), 235

Mesoglœaceæ, 239, 247, 220

Metzgeria (Cord.), I64

Meum athamanticum, 348

Micrandres, 225, 201, 202

Micrasterias (Ag.), 268, 239

- rotata (Grev.), 239

Microchate (Thur.), 436 - diplosiphon (Gom ), 434

Micrococcus (Cohn), 450, 379

Microcoleus (Desm.), 429, 44 I, 444

Microcyst, 404

Microcystis (Ktz.), 446, 447, 449, 377

- marginata (Meneg.), 377

Microspora (Thur.), 276, 242

- floccosa (Thur.), 242

Microsporange. 7, 11, 22, 277, 7, 11, 18, 19, 26, 32,33

Microspore, 7, I1 12, 20, 22, 40, I15, I16, 155, $7,11,18,20,30,125$

Microthamnion (Näg.), 280

Microzoospore, 218, 277, 4 10

Mildew of corn, $3^{8} 3$

Mischococcus (Näg.), 412,339

- confervicola (Näg.), 339

Mitremyces (Nees ab Esenb.), 399

Mnium (L.), 138, 140, 149

Mohria (Sw.), 9o, 9r

Monadopsis (Klein), 405

Monas amyli (Cienk.), 405

Monoblepharidex, 331, 290

Monoblepharis (Cornu), 4, 33 r, 290 sphærica (Cornu), 290

Mlonoclea (Hook.), 164, 143

Forsteri (Hook.), 143

Monocleaceæ, 164,143

Monosiphonous, 192, 195

Monospora (Sol.), 196

Monostroma (Thur.), 217, 21 8, 219, 198

- bullosum (Thur.), 198

Moonwort, Ioo

Morchella (Dill.), 356

Mortierella (Coem.), 338, 339

- nigrescens (Van Tiegh.), $33^{8}$

- Rostafinskii (Bref.), 338 $\operatorname{xos}$

Musses, 135, 145

Mougeotia (de By.), 262, 264, 267, 330

calcarea (Wittr.), 262

Moulds, 366

Mucilage, 69, 220, 221 , 238, 256, 257, 263. 269, $283,298,398,248,330$

Mucilage-cell, $58,76,89,92,168,67,154$

Mucilaginous sheath, 259, 267, 268, 274, 293, $428,430,434,437,440,441$

Mucor(Mich.), 4, 307, 339, 340, 350, 381, 293, 296

- Mucedo (L.), 293, 296

- racemosus (Fres.), 339

- tenuis (Lk.), 338

Mucorea, $337,339,340$

Muccrini, 4, 308, 315, 316, 335, 341, 342, 344, $345,377,378,293-296$

Multilocular zoosporange, 187, 237, 212, 227

Multinucleatæ, 186, 280, 248-258

Musci, 1 35, 136, 102-131

Muscinea, 2, 132, 102-159

Mushroom, 3 I I, 320

Mutinus caninus (Fr.), 308, 329

Mycele, $309,337,363,366,369,375,389,275$, $293,296,303-305,318,330$

Iycetozoa, 305, 401, 456, 332-335

- doubtful, 405

Mycoidea (Cunn.), 222

- parasitica (Cunn.), 222

Mycorhiza, 310

Mylitta (Fr.), 300

Myrionema (Grev.), 24 I

Myxomycetes, 401, 406, 332-335

Myzocytium (Schenk), 330

NARDOO, 38

Navicula (Bory), 420, 422, 424, 357

- rhomboides (Ehrb.), 357

Neck, 16, 26, 39, 86. 68, 143, 179, 109, 148, 158

Neck-canal-cell, 16, 27, 39, 69, 1 59, 10

Neck-cell, 26, 68, 10

Neckera (Hedw.), 149

Nectria cinnabarina (Fr.), 267

Nemalieæ, 192, 195, 199, 2 1 1 175

Nemalion (Ag.), 21 1, 213, 175

- multifidum (Ag.), 175

Nemastoma (Ag.), 208

Nemathece, 196, 199, 202

Nematodontea, 148

Nematophycus (Carruth.), 304

Neomeris (Lmx.), 287, 254

-- Kelleri (Cram.), 287, 254

Nephrocytium (Näg.), 4I 4,343

- Nägelii (Grün), 343

Nephrodium (Rich.), 85

Nephrolepis (Sch.), 77, 85

Nereocystis (Post.), 240, 242, 244

Neutral zone, 175,163

Nidularieæ, $397,327,328$

Nitella (Ag.), 175, 176, 179, 182, 163, 165, 166

- flexilis (Ag.), 163, 165, 166

Nitelleæ, I 73, 182, 163, 165, 166

Nitophyllum (Grev.), 196, 208, 173

- punctatum (Harv.), 173

Nitzschia (Hass.), 420

Node, 102, I 73, 42 I, 165, 168

Nodularia (Mert.), 430, 433

Nodule, 421

Nostoc (Vauch.), 28, 165, 171, 429, 430, 431, $432,433,358,359$

- commune (L.), 358

- hyalinum (Benn.), 359

- muscorum (Ag.), 43I

- parietinum (Rabenh.), 440 


\section{NOS}

Nostocaceæ, $188_{5}, 427,428,430,455,456,358-362$

Nostochineæ, $186,427,428,358-373$

Nothoclæna (R. Br.), 85

Notommata, 284

Nuclei, plurality of, 186, 187, 188, 194, 272, 275, $28 \mathrm{I}, 284$

Nuclearia (Cienk.), 405

Nullipore, 206

Nummularia (Tul.), 373

Obelidiu $u$ (Nowak.), 346

Octaviana asterosperma (Vitt.), 324

'Octospore,' 217

C.dogoniaceæ, 188, 220, 222, 200-202

Cidogonium (Lk.), 222, 223, 226, 200, 201

- ciliatum (Hass.), 201

- gemelliparum (Hass.), 201

Oidium Tuckeri (Berk.), 364

Olfersia (Radd.), 8o

Oligocarpia Lindsæoides (Stur), 94

Olpidieæ, 344, 345, 346, 347

Olpidiopsis fusiformis (Cornu), 346

- Saprolegniæ (Fisch.), 346

Olpidium (A. Br.), 347

Onions, 327

Onoclea (L.), 8o, 85

Onygena (Pers.), 358, 359

Ooblastema-filament, 202, 2 I I, 215

Oogamous reproduction, 188

Oogone, 185 (see also under Algæ and Fungi), 199, 201, 202, 210, 228, 248, 249, 259, 286, 290, 291

Oomycetes, 323, 332, 285-292

Oophyte, 10, 16, 1.32, 135

Oosperm, i i (see also under Vasc. Crypt., Musc., Char., Algæ, and Fungi), 203, 210, $229,248,259,286,290,291$

Oosphere, 8 (see also underVasc. Crypt., Musc., Char., Algæ, and Fungi), 4, 10, 15, 45, 109, 148, 158, 201, 203, 210, 229, 259, 286, 291

'Oosporange,' 237

'Oospore,' 8

'Oosporeæ,' 3

Opercule, r35, 112, 117, 131

Ophiocytium (Näg.), 414

Oph1oglossaceæ, 1 3, 16, 20, 21 , 81 , 95, 1 23, 72-76

Ophioglossum (L.), 97, 98, 99, 100, 72, 76

- pedunculosum (Desv), 96

- vulgatum (L.), 98, 100, 72, 76

Orthotrichum (Hedw.), I49

Oscillaria (Bosc.), 429, 44I, 442, 443, 445, 368, 369

- ærugineo-cœrulea (Ktz.), 443

- antliaria (Hansg.), 445

- dubia (Ktz.), 443

- Frölichii (Ktz.), 446

- princeps (Vauch.), 441, 443, 444, 369

- tenuis (Ag.), 446, 368

Oscillariaceæ, $427,428,429,433,437,441,455$, 368-373

- movements of, 442

Oscillatorieæ, $44 \mathrm{I}$

Osmunda (L.), 66, 67, 75, 89, 90, 65-68

- cinnamoinea (L.), 90

- regalis (L.), 73, 90, 65-67

Osmundaceæ, $66,75,76,78,80,81,88,65-68$

Osmundites (Carruth.), 123

Ostiole, 207, 356, 182-184, 208, 209, 311

Ovulites (Lam.), 304

Oxymitra (Bisch.), I66

Pachyma (Fr.), 309

Pachyphloeus (Tul.), $35^{8}$
'PER

Padina (Adans.), 254, 230, 231

- Pavonia (Gaill.), 230, 231

Palæopteris hibernica (Schimp.), I2 I, 93

Palæostachys (Weiss), I 28

Pale, 72

Palisade-cells, 321

Palisade-parenchyme, I9

Palmella (Lyngb.), 4 I5, 417, $44^{8}$

- cruenta (Ag.), ${ }_{4} \mathrm{r} 6$

- nivalis (Hook.), 416

- prodigiosa (Mont.), $4 \mathrm{I} 6$

- uvæformis (Ktz.), 276, $4 \mathrm{I} 7$

Palmellaceæ, 257, 415, 418, 419

Palmellin, 416

Palmelloid condition, 277, 409, 4Ir, 412, +15, 246, 345

Palmodictyon (Ktz.), 418

Pandorina (Ehrb.), 186, 299, 300, 263

- morum (Ehrb.), 263

Pandorineæ, 186, 291, 299, 409, 263

Paraphyse, 55, 79, 87, 134, 142, 196, 233, 237, $244,354,355,356,358,370,371,372,373,374$, $386,388,394,36,55,106$. 208, 209, '276, 300, 305

Parasites (Fungi), 316, 317, 329, $3^{8} 3$

- (Bacteria), 454

Parasitic Algæe, 249, 280, 284

Parsley-fern, 72

Parthenogenesis, 181, 267, 333, 338

Parthenosperm, 26r, 262, 267

Parthenospore, 292

Pecopteris arborescens (Schl.), 124

Pediastreæ, 186, 190, 291, 298, 418, 261, 262

Pediastrum (Mey.), 298, 261, 262

- integrum (Näg.), 261

Pedicel, 8o

Pedicel-cell, 177, 179, 233, 369

Pellza (Lk.), 85

Pellia (Radd.), r62, r64, 136

- epiphylla (Cord.), 136

Peltate leaf, 28, 8,9

- scale, ro2, r 10, 2, 83

Pelvetia (Dcne.), 235

Penicillium (Lk.), 312, 358, 359, 360, 366, 378

- glaucum (Lk.), 3r6, 367

Penicillus (Kt $\angle$.), 289

Penium (Bréb.), 268, 241

- margaritaceum (Bréb.), 241

Perianth, I34, I4 I, 142

Pericarp, r8o, 201, 221, 263, 199

Pericentral tubes, 192

Perichæte, 134, 141, 162, 109, 129, 131

Periderm. 430

Peridiniea, 4 Io

Peridiolum, 397, 328

Peridium, 31 r, 357, 358, 395, 396, 397, 398, 399, 325, 328-331

Perigone, 142, 106

Perigyne, 159. 163, 17 1, 142, 158

Perinium, r6o

Peripheral growth, $24 \mathrm{I}$

Periphyse, 356

Periplasm, 324, 325, 327, 331, 332, 286

Peristome, 135, 147, 110-112, 114, 118

Perithece, $355,356,362,365,370,373,374,375$, $378,379,311,312$

Peronospora (Cord.), 4, 323, 326, 327, 328, 329, 378

- arborescens (de By.), 286

- calotheca (de By.), 269, 285

- densa (Rab.), 327

- Ficariz (Tul.), 327

- nivea (de By.), 327

- parasitica (de By.), 326, 327

- pygmæa (Ung.), 327 
PER

Peronospora Rumicis (Cord.), 327

- Schachtii (Fckl.), 327

- Schleideniana (Ung.), 327

- Trifoliorum (de By.), 327

- Viciæ (de By.), 327

- viticola (de By.), 327

Peronosporea, 4, 309, 312, 315, 323, 331, 332, $333,377,378,269,272,275,277,285-289$

Peronosporites (W. G. S.), 330

- antiquarius (W. G. S.), $33^{\circ}$

Persistent cell, 444

Petalonema (Berk.), 438, 440

Peyssonelia (Dcne.), 2 10

Peziza (Dill.), 356

- (Pyronema) confluens (Pers.), 369, 276, 300, 306

Phacidiace 2,36

Phæophyll, 230

Phæosporeæ, 187, 190, 230, 237, 212-232

Phæothamnieæ, 258

Phæothamnion (Lagerh.), 258, 276

Phæozoosporeæ, 237

Phalloideæ, 395, 397, 329-331

Phallus (L.), $398,399,330$

impudicus (L.), 398, 330

Phascaceæ, 136, 150, 121, 122

Phascum (L.), 140, 150

Phloem-sheath, 18, 59

Phlyctidium (A. Br.), 346

Phragma, 125

Phragmidium (Lk.), 386, 314

incrassatum (Lk.), 314

Phycochromaceæ, 426

Phycocyanin, 427, 442

Phyco-erythrin, 194, 217

Phycomyces (Kze.), 338, 339, 293 nitens (Kze.), 293

Phycomycetes, 4, 5, 323, 352, 377, 381, 285-299

Phycophæin, 230, 240,256

Phycoseris (Ktz.), 217

Phycoxanthin, 230, 421

Phyllade, 51

Phyllitis (Ktz.), 24

Phyllobium (Klebs), 284, 4 ro

Phylloglossum (Kze.), 19, 53, 56, 59, 6o, 6r, 38

- Drummondii (Kze.), 6r, 38

Phyllosiphon (Kühn), 284

Phyllotaxis, 59, 99, 106, 139, 151, 194

Phyllotheca (Brongn.), 1 24, 96

- equisetiformis, 96

Physareæ, 403

Physcia parietina (Nyl.), 279

Physiotium (Nees ab Esenb.), I6

Physma (Massal.), 372

Physoderma (Wallr.), 346

Phytophthora (de By.), 323, 327, 328, 332, 335, 272, ¿77, 289

-infestans (de By.), 314, 326, 327, 328, 272, 277, 289

omnivora (de By.), 327, 329

Pigment-spot, 223, 292, 300, 416

Pileus, 286, 391, 392, 393, 398, 399, 251, 252, $273,319,320,330$

Pilinia (Ktz.), 280

Pilobolus (Tode), 339

Pilularia (L.), 19, 33, 37, 114, 5, 16, 18

- globulifera (L.), 36, 5, 16, 18

Pinnularia (Ehrb.), 426,353

- viridis (W. Sm.), 353

Piptocephalideæ, 340, 378, 295, 296

Piptocephalis (de By.), 34o, 342, 295, 296

- Freseniana (de By, and Wor.), 295, 296

Pithophora Kewensis (Wittr.), 2 6,245

Pithophoraceæ, 187, 273, 276, 245

Pits in oogonial wall, $33^{2}$
POL

Placenta, 25, 29, 35, 8o, 86, 20 r

Placental cells, 209, 28\%

Plagiochasma (L. \& L.), 171

Plagiochila (Dum.), 164

Plantago, 364

Plasmatoparous Peronosporeæ, 327

Plasmode, 401, 402, 403, 404, 405, 406, 332, 333

- movements of, 403

- resting states of, 404

Plasmodiophora (Woron.), 405

- Brassicæ (Woron.), 405

Platycerium (L.), 83,85

- alcicorne (Desv.), 72, 77

Plaxonema (Tangl), 444

Plectonema (Thur.), 437, 438, 439

Pleomorphy of Uredinea, 383

Pleospora (Rabenh.), 361, 362, 374

- herbarum (Rabenh.), 374

Plerome-sheath, 18, 109

Pleuridium (Brid.), 150, 122

- subulatum (k abenh.), 122

Pleurocarpi, 149

Pleurocladia (A. Br.), 247

Pleurococcus, 279, 300, 417, 419

Pleurosigma (W.'Sm.), 420, 426, 357 lacustre (W. Sm.), $35 \%$

Plocamium (Lmx.), rg6, 208

- coccineum (Huds.), 209

Plumule, 4 I

Podosphæra (Kze.), 36o, 362, 378, 303

Castagnei (de By. and Wor.), 364, 303

- Kunzei (Lév.), 364

- pannosa (de By. and Wor.), 303

Pollen-grain, Ix, 12, 14,3

Pollen-sac, $r_{3}, 1$

Pollen-tube, I I, I4, 3

Pollexfenia (Harv.), 194, 209

Pollinoid, 7, 185, 198, 199, 207, 254, 360, 36r, $370,371,37^{2}, 373,374,384,385,175,179$, 182, 184, 191, 307

Polyedriaceæ, 419

Polyedrium (Näg.), 299, 418, 4 I 9

Polygonum, 364

- Hydropiper, $35 \mathbf{r}$

Polyhedra, 296, 298, 299, 262

Polyides (Ag.), 202, 209

Polyphagus (Nowak.), 314, 346, 297

Euglenæ (Nowak.), 345, 297

Polyphysa (Lmx.), 288, 255

- peniculus (R. Br.), 255

Polypodiaceæ, $64,67,75,78,79,80,81,83$, 1 21, 123, 42, 44-56, 58

Polypodiex, 83,84

Polypodium (L.), 77, 84, 85, 53, 58

- leiorhizum (Wall.), 53

Polyporea, 393, 396, 322, 323

Polyporus (Mich.), 392, 396, 322, 323

- annosus (Fr.), 316

- igniarius (Fr.), 322, 323

- obvallatus (Berk. and Cooke), 396

- sulphureus (Fr.), 316

- volvatus (Pk.), 396

Polysaccum (DC.), 399

Polysiphonia (Grev.), 192, 193, 194, 201, 209, 170

_ opaca (Zan.), 170

Polysiphonous, 192

Polyspore, 6

Polystichum angulare (Willd.), 69, 48

Polystigma (Pers.), 360, 372, 385

Polythrix (Zanard.), 437

Polytrichaceæ, ${ }_{4} 6$

Polytrichum (L.), 138, 139, 142, 148, 149, 104, $107,112,117$

- commune (L.), 104, 107, 117 
POL

Polytrichum piliferum (Schreb.), 112

Polyzonia (Suhr), 194

Pomex, 386

Pore, 154, 187

Pores of Polyporeæ, 393, 322

Porphyra (Ag.), 189, 191, 199, 216, 219

- vulgaris (L.), 217

Porphyraceæ, 189, 190, 196, 198, 199, 216, 219, 193-195

Porphyridium cruentum (Näg.), 416

Potato-disease, 328

Pottia (Ehrh.), 147, 149

Prasiola (Ag.), 217, 219

Preissia (Cord.), 169, ז70, I7 1

Primary node, iso

- root, 18o, 168

Procarp, 198, 199, 21 3, 176, 187, 192

'Proembryo,' 177, 180

'Proembryonic branch,' 176

Progametange, 349,298

Prolific cells, 276

Prolification, 69, 139, 142, 196, 289, 104, 171

Promycele, $325,328,329,337,338,350,35 \mathrm{r}$, $352,362,373,385,386,391,299,314$

Propagation, 8

Propagule, 196, 237, 250, 289, 223, 224

Prothallium, 1o, 339 (see also underVasc. Crypt. , Musc., \& (har.), 4, 8, 9, 14, 15, 20, 29, 34-36, $42,43,50,65,74,78-80,126,168$

Prothalloid branch, 176

- growth, 70, 48

Protococcaceæ, 186, 345, 409, 410, 415, 448, 345-352

Protococcoideæ, r86, 408, 409, 449, 336-352

Protococcus (Ag.), 186, 285, 409, 41 7, 448, 279, 345

- pluvialis ( $\mathrm{K}_{\mathrm{tz}}$ ), 345

Protomyces (Ung.), 4, 350, 352, 298

macrosporus (Ung.) 348,298

Protomycetaceæ, 348, 298

Protomyxa (Haeck.), 405

Protoneme, 13.3, 135, 136, 140, 214, 449, 105, 121, 125

Protophloem, 59

Protophyta, 2, 3, 4, 186, 276, 407, 336-382

Protosalvinia (Daws.), 115

Protozoa, 456

Proznosporange, 346, 297

Prunus, 364,373

Psaronieæ, 124

Psaronius (Cord.), 124, 95

Pseudo-bulbil, zo

Pseudo-cortex, 192, 212

Pseudocyst, 410, 427, 437, 44 I, 446

Pseudo-parenchyme, 249, 251, 307, 356, 358, $360,366,372,384,267$

Pseudopode, I5 I, I54, 402, 403, 422, 443, 131, 332

Pseudo-ramulus, 434, 438, 364, 366

Pseudospora (Cienk.), 405

Psilophyton (Daws.), I 9

Psiloteæ, 21, 53, 61, I I9, 40, 41

Psilotum (Sw.), 17, 18, 19, 20, 53, 6r, 63, 40

- triquetrum (Sw.), 6ז, 40

Pteris (L.), 85, 46, 47, 54, 58

- aquilina (L.), 75, 76, 77, 82, 54

- serrulata (L. fil.), 69, 46, 47

Ptilophyton (Daws.), 1 i 8

Ptilota (Ag.), r94, 204

Puccinia (Pers.), $38_{3}, 385,3^{\varepsilon 6}$

- coronata (Cord.), 314

- graminis (Pers.), $383.274,314,315$

straminis (Fckl.), 314

Puff-ball, 3ri, 396

Pulvinus, 93

\section{RHI}

Punctaria (Grev.), 187, 24 I, 245

Punctariaceæ, 239, 245

Pycnid, 362, 374

Pycnochytrium (de By.), 347

Pycnophycus (Ktz.), 235

Pycnospore, 362, 374, 375

Pyrenocarp, 355

Pyrenomycetes, 319, 355, 356, 370

Pyronema (Fckl.), 356, 359, 360, 36r, 369, 370, $372,378,276,306$

- confluens (Tul.), 276, 306

Pythium (Pringsh.), 317, 324, 329, 330, 331, 332, 335, 286

- Chlorococci (Lohde), 329

- circumdans (Lohde), 329

- de Baryanum (Hesse), 329

- entophytum (Pringsh.), 329

- Equiseti (Sad.), 329

- gracile (Schenk), 329, 286

- intermedium (de By.), 329

- proliferum (de By.), 329

- vexans (de By.), 325, 329,377

Quaternakia (Tul.), 373

RADIOLARIANS, yellow cells of, 318

Radula (Dum.), 162, 164, 137, 141

- complanata (Dum.), 137, 141

Ralfsia (Berk.), 24 I, 25 I

Ralfsiaceæ, 239, 25I, '225

Ramentum, 72

Ranunculus, 364

Raphe, 421, 353

Raphidium (Ktz.), 418, 351

— falcatum (Ktz.), 351

Reboulia (Radd.), 171

Receptacle, 8o, r7o, 232, 246, 149-151, 154, 156, 157, 205, 207, 219

Receptive spot, 69, 227

'Red snow,' 416

Rejuvenescence, 223, 274, 28 I

Renaultia (Stur), 122

Reproduction, 8

Reserve-system, I39

Resting-cell, 213, 264, 335, 339, 346, 347

Resting-sporange, 333

Resting-spore, 223, 258, 276, 278, 28I, 285, 298, $315,344,345,350,351,352,416,427,430$, $436,261,361,362$

Resting-swarm-cell, 274

Resting-zoosporange, 346

Retrogression, 4, 407, 449

Rhabdonema (Ktz.), 423, 424

Rhacophyllum adnascens (L. \& H.), 120, 92

Rhipidonema (Mattir.), 319

Rhizidieæ, 344, 345

Rhizidium (A. Br.), 346

Rhizocarpeæ, 1 8, 19, 21, 1 1 4, 4-19

Rhizoclonium (Ktz.), 276

Rhizoglossum (Presl), 99

Rhizoid, 16, 132, 139, 156, 174, 180, 222, 228, $239,241,242,273,277,282,285,332,340$, $345,346,363,14,43,50,65,102,153,168,250$, '25', ‘256, '280, 318

Rhizome, 51, 72, 81, 86

Rhizomorph, 392, 270, 319

Rhizomorpha (Roth), 309

- fragilis (Roth), 319

Rhizophore, 45

Rhizophydium (Schenk), 346

Rhizopoda, 456

Rhizopus (E.hrb.), 339, 294

- nigricans (Ehrb.), 337, 294 
RHO

Rhodomela (Ag.), 209

Rhodomelaceæ, 209, 170, 174

Rhodophyll, 194

Rhodospermex, I9I

Rhodospermin, 194

Rhodosporeæ, I9I

Rhodymenia (Grev.), 208, 186

- bifida (Ktz.), I96

- palmata (Grev.), 209

- Palmetta (Grev.), 186

Rhodymeniaceæ, 208, 171, 186

Rhytidolepidæ, II 7

Riccia (L.), 165, 166, 148

- glauca (L.), 148

Ricciacez, í6o, I65, 146-148

Ridge, 100, 106, 124, 1 29, 81

Riella (Mont.), 1 56, 159, 165, 166, 146 - helicophylla (Mont.), 146

Rivularia (Roth), 436, 363

- fluitans (Cohn), 436

- polyactis (Hauck), 363

Rivulariaceæ, $185,427,428,433 \cdot 445,363-365$

Roccella tinctoria (DC.), 284

Roestelia (Reb.), 386

Root-cap, 18, 78, 109

Root-hair, 18, 78

Rotation of protoplasm, I 75, 163

'Royal Fern,' 73, 90, 66, 67

Rozella (Cornu), 345, 347

Rumex, $3^{64}$

Russula adusta (Fr.), 308 .

Rye, 310

Rytiphlœa (Ag.), 194, 209

SACCHARoMrces (Meyen), 4, 380, 38r, 268, 313

- albicans (Reess), 380

- cerevisize (Meyen), 38o, 268, 313

- ellipsoideus (Reess), 380

- Mycoderma (Reess), 380

- Pastorianus (Reess), 380

Sacconema (Brzi.), 437

Sacheria (Sir.), 214

Saddle, 5 I

Salicaceæ, 3 ro

Salmon-disease, 332

Salvinia (L.), 17, 18, 25, 31, 7-11

- natans (I.), 7-11

Salviniaceæ, 1 2, I 3, 20. 25, I 14, 7-13

Saprolegnia (Nees ab Esenb.), 4, 332, 333. 334 $335,33^{8}, 339,346,347$

Saprolegniex, 4, 308, 312, 324, 332, 338, 347, $377,291,292$

Saprophytes, 315, 316, 317, 329, 366, 454

Sargasso Sea. 232

Sargassum (Ag.), 230, 232, 235, 211

- bacciferum (Ag.), 232, 236, 211

Scalariform conjugation, $260,265,233,234,236$, 237

- tracheide, $18,76,98$, I 23

Scenedesmus (Mey.), 303, 4x 8, 352

- obtusus (Mey.), 352

Schizæa (Sm.), 90, 9I

Schizæaceæ, 64, 80, 81, 90, 122, 43, 69

Schizochlamys (A. Br.), 4 17,348

- gelatinosa (A. Br.), 348

Schizogonium (Ktz.), 279

Schizomycetes, $433,449,379-382$

Schizoneura (Schimp.), 124

Schizophycez, 408, 336-378

Sciadiaceæ, 4 Io, 4 I I

Sciadium (A. Br.), 4 I I 336

- arbuscula (A. Br.), 336

Sclerenchyme. 75, 123, 53, 54

Scleroderma (Pers.), 397
SOR

Sclerosis, 58, 309, 39

Sclerote, 309, 310, 361, 373, 374, 376, 392, 404, $271,309,310,311,318$

Sclerotinia (F ckl.), 373

- Fückeliana (de By. and Wor.), 36r, 374

- sclerotiorum (de By.), 360, 361, 373, 374, 271

Sclerotium ('Tode), 3 ro

Scolecopteris (Stur), 122, 94

- polymorpha (Stur), 94

Scolopendrium (Sm.), 81, 85, 58

Scutiform leaf, 28, 8, 9

Scyamina (Van Tiegh.), 295

Scytonema (Ag.), 438, 441, 445, 279

Scytonemaceæ, $303,427,428,433,437,366$, 367

Scytonemeæ, 438, 44I, 445, 366, 367

Scytonemin, 427,437

Scytosiphon (Ag.), 239, 24I, 245

- lomentarium (Ag.), 246

Scytosiphonacea, 245

Seaweeds, I84, 190, 191, 235, 237

Sebacina (Tul.), 389

Secondary capitulum, i78, 163

- embryo-sac, I $_{4}, 52,3$

- growth in thickness, 49, I16, 125

- markings, 420,353

- prothallium, 39

Secotium (Kze.), 395

- erythrocephalum (Tul.), 396

Secreting system, 139

Seftenbergia (Cord.). 122, 94

- ophidermatica (Stur), 94

Seirospora Griffithsiana (Harv.), 204

Seirospore, 196, 204, 180

Selaginella (Spring), x9, 20, 38, 39, 47, 20-27

- caulescens Spr.), 20

- denticulata (Lk.), 24

- inæqualifolia (Spr.), 22, 23, 25-27

- Martensii (Spr.), 20, 21

Selaginellaceæ, 12, 13, 18, 19, 38, I 15, I30, $20-33,87-91$

Selaginelleæ, $38,39,20-27$

Selenastrum (Reiusch), r 86, 303

Seta, 134, 144, 146, 110, 112

Sewaze-fungus, 454

Sheath, 50, 428, 430, 434, 437

Shepherd's Purse, 326

Shield, I77, 163

Side-view (of diatoms), 421,354

Sieve-hypha, 244

Sieve-plate, 240, 244, 217

Sieve-tube, 18, 58, 240, 244, 217

Sigillaria, I 7 , I $8,89,91$

Sigillariostrobus, 117, I 18

Silica, 102, 107, 419, 420

Siphon, 192

Siphoneæ, 186, 280, 28r, 290, 308, 4 ro, 248, 249

Siphonocladaceæ, $186,190,279,280,281,288$, 304,41 I, 256-258

Siphonocladus (Schr.), 289

Sirogonium (Ktz.), 264, 265, 267

Sirosiphon (Ktz.), 439, 44I, 449

Sirosiphoneæ, 437, 438, 439, 44I

Solenites (L. \& H.), II9

Sorastreæ, 186, 291, 302, 414, 4 18, 264, 265

Sorastrum (Ktz.), r86, 302, 264

- spinulocum (Näg.), 264

Sordaria (Ces. and De Not.), 354, 359, 360, 370

Sorede, 319, 282

Sorophore, 37, 19

Sorosporium (Rud.), 350, 352

- Saponariæ (Rud.), $35 \mathrm{r}$ 
SOR

Sorus, 11, 20, 24, 72, 79, 94, I22, 196, 237, 244, $251,347,19,58,59,71,218$

Spatoglossum (Ktz.), 254

Special bundle-sheath, Io9

'Sperm,' 7, 8

'Sperm-cell,' 8

'Spermatia,' 7, 36o

'Spermatozoid,' 8

Spermocarp, I8o, 22 r , 165, 167, 168, 199

'Spermogone,' 7, 360

Spermothamnion (Aresch.), 209, 176

- hermaphroditum (Näg.), 176

Sphacelaria (Lyngb.), 249, 223, 224

- cirrhosa (Ag.), 223, 224

Sphacelariaceæ, 237, 239, 24 I, 249, 223, 224

Sphacele, 249, 223

Sphacelia (Lév.), 376, 309

Sphacelotheca (de By.), 352

- Hydropiperis (de By.), 350

Sphærobolus (I ode), 399

Sphærocarpus (Mich.), I6o, r66, 147

- terrestris (Sm.), 147

Sphærococcaceæ, 208, 178, 187

Sphærococcus (Stackh.), 208

Sphærogonium (Rostaf.). 444

Sphæroplea (Ag.), 227, 203, '204

- annulina (Ag.), 226, 203, 204

Sphæropleaceæ, 1 88, 220, 226, 203, 204

'Spharosp re,' 195

Sphærozyga (Ag.), 430, 433

Sphagnacea, 132, 136, 139, I42, 144, I45, I 51 125-131

Sphagnum (L.), 1 38, 156, 172, 125-131

- acutifolium (Ehrh.), 125-127, 129-131

- cymbifolium (I)ill), 128

- squarrosum (Pers.), 131

Sphenoglossum (Emm.), I I 4

Sphenophyllex, I 29, I30, 101

Sphenophyllum (Brongn.), I29, I30, 101

Sphenopteris crenata (L. \& H.), r2o, 92

Spherocrystal, 93

Sphyridium (Flot.), 36r

Spinellus fusiger (Van Tiegh.), $33^{8}$

Spiral bands, 152

Spirillum (Ehrb.), 450, 45 I, 382

Spirochæta (Ehrb.), $45 \mathrm{I}$

Spirogyra (Lk.), 4, 264, 265, 266, 267, 330, 342, 236,238

- bellis (Hass.), 238

- crassa (Ktz.), 264

- porticalis (Vauch.), 236

Spirulina (Lk.), 429, 44I, 370

- tenuissima (Ktz.), 370

Splachnidium (Grev.), 235, 236

Splachnum (B. \& S.), 149

- ampullaceum (L.), 116

Splenic fever, $45^{2}, 454$

Spongiocarpea, 209

Spongocladia (Aresch.), 276, 290

Spongodieæ, 289

Spontaneous generation, 450

- movement, 4I5, 427, 43I, 442

Sporange, 6 (see also under Vasc. Crypt., Musc., Alga, Fungi, Mycet., and Prot.), 2, $37,40,41,55,56,58-60,63,68,71,72,75,76$, $83,93,110,111,114-118,122,124,131,133$, $134,137,145,158,293,334$

- dehiscence of, 79, 94, I35, I 55, I 59, 55

Sporangiole, 339

Sporangiophore, 328, 337, 339, 287

Sporangiospore, 6

Sporangites (Daws.), I 5

Spore, 5 (see also under Vasc. Crypt., Musc., Algæ, Fungi, Mycet., and Prot.), 37, 84, 85, $158,181,245,249,272,275,303,317,318$, $332,335,361,362,379-381$
STR

Spore-sac, 147,112

Sporid, 6, 314, 350, 351, 352, 362, 373, 385, 386 $390,299,314$

Sporiferous filaments, 192

Sporocarp, I I , 353 (see also under Vasc. Crypt. Alga, and Sporocarpeæ), 5-7, 12, 18, 19 $302-305$

origin of, 359

Sporocarpea, $353,300-331$

Sporocarpon (Williams.), I 14

Sporochnacea, 245

Sporochnus (Ag.), 24 r, 246, 219 pedunculatus (Ag.), 219

Sporodinia (Lk.), 338, 339 grandis (Lk.), 337

Sporogenous tissue, 20, 46, 33

Sporogone, 1 $34,136,144,159$, I63, 107, 110, $131,142,143,145,148,156,158$

Sporophore, 309, 325, 327, 328, 336, 337, 340, $343,363,365,367,374,388,389,404,272$, $275,288,293,296,303,304,327-329,330$

Sporophore (compound), 391, 392, 393, 395, 396, 397, 398, 273, 319, 3<0 Sporophyll, 46, 51, 72, 99, г го, г16, 32, 72, 75,

Sporophyte, Io, 1 7, 132, 135, I59

Sporophytic budding, 69

Sprouting, 307, 314, 339, 352, 380, 381, 389,

Spyridia (Harv.), r93, 209

Spyridiacea, 209 .

Squamariacea, 189, 190, 191, 202, 2 10, 188

Stag's-horn-moss, 6r

Staurastrum (Mey.), 269, 270, 239, 240

Arachne (Ralfs), 239

teliferum (Ralfs), 240

Stauroneis (Ehrb.), 426

Staurospermum (Ktz.), 26o, 263, 234

- capucinum (Ktz.), 263

- gracillimun (Hass.), 234

Stemmatopteris (Cord.), I24, 95 insignis (Cord.), 124

Stemonitis fusca (Roth), 334

Stephanosphiera (Cohn), r86, 299, 301

Stephensia (Tul.), $35^{8}$

Stereocaulon ramulosum 'Ach.), 279

Sterigma, 86, 340, 367, 37o, 372, 376, 384, 386, $389,394,275,304$

Stichid, r96, 174

Stictospharia (Tul.), 373

Stigeoclonium (Ktz.), 276, 284, 4I 7

Stigma, I33, I43

Stigmaria, I $18,90,91$

- ficoides (Brongn.), I 8 8, 90

Stigmatic cell, r7, 27, r33, 143, 158, 15, 109

Stigmatoniyces (Karst.), 378

- Paeri (Peyr.), 312

Musca (Karst.), 312

Stigonema (Ag.), 439, 44 I, 449, 366

compactum (Kirchn.), 440

- minutun (Hass.), $3 € 6$

Stigonemeæ, 437, 438, 445, 366

Stipe, 230, 239, 24 I, 242, 286, 391, 319, 320

Stipule, 92, 174

Stoechospermum (Ktz.), 254

Stolon, 78, I33, I 39 Stomate, 19, 72, 78, 93, 107, 144, 160, 23, 82,

Stomium, 79, 55

Stoneworts, I 8 r

Strand-mycele, 309

Streblonema (Derb.), 239

Stroma, 35o, 352, 355, 356, 37o, 375, 311

Struthiopteris (L.); 66

- germanica (L.), 66, 69, 77

Struvea (Sond.), 289 
STY

Stylospore, 339, 362

Stypocaulon (Ktz.), 249

Subhymenial layer, 355, 368, 372, 393, 394, 305

Submerged leaf, 28, 7, 8

Subsidiary cell, 107

Sulphur, 454, 381, 382

Surirella (Turp.), 426, 357

- splendida (K tz.), 357

Suspensor, 4I, 56, 337, 338, 21, 293-296

Suture, 421

Swarm-cell, 198, 21 8, 239, 292, 196, 259, 263

Swarming motion, 446

Swarm-spore, 312, 401, 402, 405, 252, 332

Sykidion (Wright), 4I4

Symbiosis, 318

Symploca (Ktz.), 44 r, 444, 372, 373

- hydnoides (Ktz.), 372

- violacea (Hauck), 373

Synalissa symphorea (Nyl.), 279

Synange, 94, 122, 71, 94

Syncephalis (Van Tiegh.), 340

Synchytriea, 344, 345. 347

Synchytrium Taraxaci (de By.), 347

Synechococcus (Näg.), 447, 449

Synedra (Ehrb.), 426, 357

- Arcus (Ktz.), 357

Syngeneticæ, 188, 237, 256, 232

Syzygites (Ehrb.), 337

TABEllaria (Ehrb.), 426

Tangle, 244

Tannin-cell 34, 76, 92

Taonia (Ag.), 254

Tapetal cells, 2o, 25, 36, 6o, 8o, 33

Tapete, 20, 80

Targionia (Mich.), I 7 I

Targionieæ, $17 \mathrm{I}$

Tayloria (Hook.), 149

Teeth of Hydnea, 393

- - peristome, I $35,145,111$

- - sheath, 102, 105, 124, 83

Teleutospore, 6, 385, 386, 390, 391, 274, 314, 315

Terfezia (Tul.), 358

Terminal nodule (diatoms), 353

Tetmemorus (Ralfs), 268

Tetrachytrium triceps (Sorok.), 347

Tetrapedia (Reinsch), 447

Tetraphis (Hedw.), I 49

- pellucida (Hedw.), r 40, 114

Tetraspora (Lk.), 219, 418, $44^{8}$ gelatinosa (Desv.), 4 I 8

Tetrasporange, 195, 21 7, 254, 170, 172-174, 177, $182,183,186,190,230$

Tetraspore, 6, 185, 195, $217,254,195,231$

Thalassiophyllum (Post.), 244

Thalloid Hepatica, $135,156,160,135,136$, 143-159

Thallophytes, 2, 3, 4, 135, 156, 184

Thallus, 132, 184, 191, 306, 430, 432, 153, 188, $199,212,227,230,307,358$

- compound, 306

Thamnidium (Lk.), 339

Theca, 134

Thecaphora hyalina (Fingerh.), 35

- Lathyri (Kuhn), 35 I

Thelephoreæ, 39 I

Thorea (Bory), 2 I I

Thrush-fungus, 38

Tilletia (Tul.), 350, $35 \mathrm{I}$

- caries (Tul.), 315, 299

Tilopterideæ, 249 ,

Tilopteris (Ktz.), 249
UST

Tmesipteris (Berrh.. ), 6r, 63, 41

- tannensis (Bernh.), 41

Tndea (Willd.), 89, 90

$\rightarrow$ superba (Col.), 90

Tolypella (A. Br.), 182

Tolyposporium (Woron.), 35I

Tolypothrix (Ktz.), 429, 437, 438, 439, 440, 441

- amphibia (Zopf), 440

Tortula (Hedw.), 149

Trabecule, 4I, 52, I 47, 23, 32, 33, 112

Tracheide, 18, 76

Trama, 394, 395, 396, 397, 321

Traquairia (Carruth.), 1 I 4

Tree-ferns, $7 \mathrm{I}, 75,78,85,57$

Tremella (Dill.), 389

- mesenterica (Retz.), 316

Tremellinex, $343,388,389$

Tremelloid Uredineæ, 386

Trentepohlia (Mart.), 185, 280, 284, 247

- Bleischii (Rabenh.), 247

Triceratium (Ehrb.), 420,357

- Favus (Ehrb.), 357

Trichocoma (Jungh.), 3 I 9

Trichozyne, 188, 199, 219, 220, 360, 369, 370, $371,372,373,378,379,385,175,176,179$, $192,306,307$

Trichomanes (L.), 70, 71, 86, 87, 88, 61

- alatum (Sw.), 86

- pyxidiferum (L.), 86, 61

Trichome, 428,359

Trichophilus (Web.), 28o

Trichophore, 199, 176, 179

'Trichosporange,' 237

Tripoli, 424

Trochopteris (Gardn.), 91

Truffle-family, 357

Truffles, 358

Tuber, 56, I 1 2, 38, 86

一(Mich.), 357, 358

- rufum (Pico), 301

Tuberacex, 308, 357

Tuberex, 358

Tubular organ, 16 I

Tubuli of Polyporeæ, 393

Tubulinæ, 4 or

Tuburcinia (Berk.), 350, 351, 352

- Trientalis (Berk.), 352

Tulostoma (Pers.), 399

UDoteA (Lmx.), 289

Udoteaceæ, 289,258

Ulodendron (Sternb.), I 16

Ulothrix (Ktz.), 185, 277, 278, 279, 246

- implexa (Ktz.), 246

- zonata (Ktz.), 277

Ulotrichaceæ, $187,273,277,246$

Ulva (L.), 189, $217,304,196$

Ulvaceæ, 189, 190, 195, 196, 198, 217, 218, 219, 279, 418, 196-198

Umbelliferæx, 327, 348, 364

Unicellular plants, I 84, 281, 284, 286, 288, 427

Unilocular zoosporange, 187, 237, 212, 219, 220, 223

Uredineæ, 4, 312, 315, 383, 39 r, 274, 314, 315

- (tremelloid), 386, 390

Uredo (Pers.), 383,385

Uredospore, 6, 385, 386, 274, 314, 315

Urn, 134

Urococcus (Hass.), 418, 350

- insignis (Hass), 350

Urocystis (Rabenh.), 350, 35 I, 352

Urospora (Aresch.), 273, 276

Usnea barbata (Fr.), 282

Ustilagineæ, 4, 315, 349, 299 
UST

Ustilago (Pers.), $3 j^{\mathbf{I}}$

- carbo (Tul.), $35 \mathrm{I}$

- destruens (1 $1 \mathrm{ul}$.), $35 \mathrm{I}$

- Hydropiperis (. $\mathrm{chm}$ ), $35^{\circ}$

longissima (Tul.), 351

Istulina ('Tul.), 373

Vaccinium Vitis-li).ti, 388

Vagine, 1 34, 135, 144, 146 $6_{3}, 131$

Vallecular canal, 105

Valonia (Gin.), 289, +1 I, 257

- macrophysa (Kt7.), 257

Valoniaceæ, 289,257

Valve, 420, 353-355

Valve-view, 42 I, 353, 354

Vanpyrella (Cienk.), 405

Vascular bundle-sheath, 18, 76, 39

Cryptogams, 1, 2, 10, 2, 4-101 cylinder, 58, 39

Vaucheria (DC.), 186, 28 r, 283, 284, 248, 249

- dichotoma (Lyngb.), 249 - sessilis (Vauch.), 248

Veil, 50

Velum partiale, 393

- universale, 393, 397, 318

Venter, 16, 39, 68, 1 33, I +3, I 59, 109, 158

Ventral canal-cell, $16,27,40,69,143,159,45$

Verbascum, 364

Vesicle, 23, 17, 44

Vessel, 76

Vibrio (Cohn), 44o, $45 \mathrm{I}$

Vidalia (Lmx.), 194, 20,

Vine, 327 mildew, 364

Violet-stone, 280

Vittaria (Sm.), 67, 85

Volkmannia (Sternb.), 127

Volva, 393, 318

Volvocineæ, 291, 292, 259

Volvox (L.), 4, 292, 295, 259 globator (L.), 292, 209

Vorticella, rq9

WATER-BEETLES, 373

Watel-net, 296

Weissia (Hedw.), 149

'Wendungszellen,' 179,156

Whip-shaped filaments, 178,163
ZYG

Woodsia (R. Mr.), 85, 58

Woodwardia (Sm.), 85, 58 radicaus (Sm.), 78

Woronina (Cornu), 345, 347

'Woronin's hypha,' 36o, 373, 385

Wrangelia (Ag.), 209

Wrangeliacex, 209, 176, 177

Xanthinitu (Ehrb.), 269, 239

- cristatum (Bréb.), 239

Xenococcus (Rostaf.), 444

Xylaria (Hill), 360, 373, 385

$\mathrm{X}$ ylariea, 373

YEAST, 380, 268, 313,

Yeltow cells of Radiolarians, 313

ZA.MA, 1

Zanardinia (Nardo), 239, 251, 252, 228, 227 collaris (Crouan), 2¿8, 229

Zippea (Cord.), 124

Zonal view (diatoms), $42 \mathrm{I}$

Zonaria (Harv.), 254

Zonate (tetraspores), 195

Zoogamete, 185 (see also under Alyat and Prot.) , 196, 222, 246, 247, 252, 260, 263

Zooglœa, 433, 444, 45 I

Zoosphere, 252, 295, 229

Zoosporange, 220 (see also under Alyat, Fungi, and Prot.), 201, 252-255, 258, 259, 272, 277 287-289, 291, 297

Zoosporangiophore, 326, 275, 287

Zoospore, 6 (see also under Algx, Fung1, and Prot.) 199, 201, 232, 242, 259, 277, 289, 291, 292, 297

Zygnema (Ktz.), 258, 259, 264, 265, 267, 237

- pectinatum (Ag.), 237

Zygnemaceæ, 187, 258, 259, 264, 236233

Zygochytrium (Sorok.), $34 \mathrm{I}$

Zygodon (H. \& T.), x49

Zygogonium (Ktz.), 267

Zygomycetes, 4, 335, 293-299

$Z$ ygosperm, 218 (see also under $A l$ gat and Fungi), 222, 233-238, 241, 252, 263, 293-293

'Zy.gosporea,' 3

Zygosporites (Williams.), int

PRINTEI) BY

SPOTTISWOODL ANI) C(., NEW-STREET SQUARE

LONDOA 


$\therefore$ 


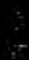

10.5.

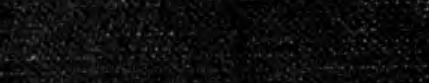

as

30.

S.7.

25:

(1)

Hos

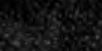

7.

asions

19.0.

(29)

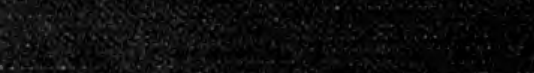

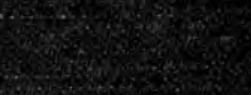

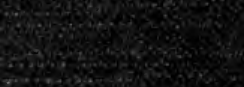

2.5.

5.5.

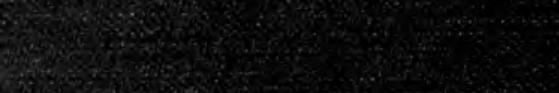

